UNITED STATES DEPARTMENT OF THE INTERIOR

Harold L. Ickes, Secretary

GEOLOGICAL SURVEY

W. C. Mendenhall, Director

Water-Supply Paper 772

\title{
STUDIES OF RELATIONS
}

OF

\section{RAINFALL AND RUN-OFF IN THE UNITED STATES}

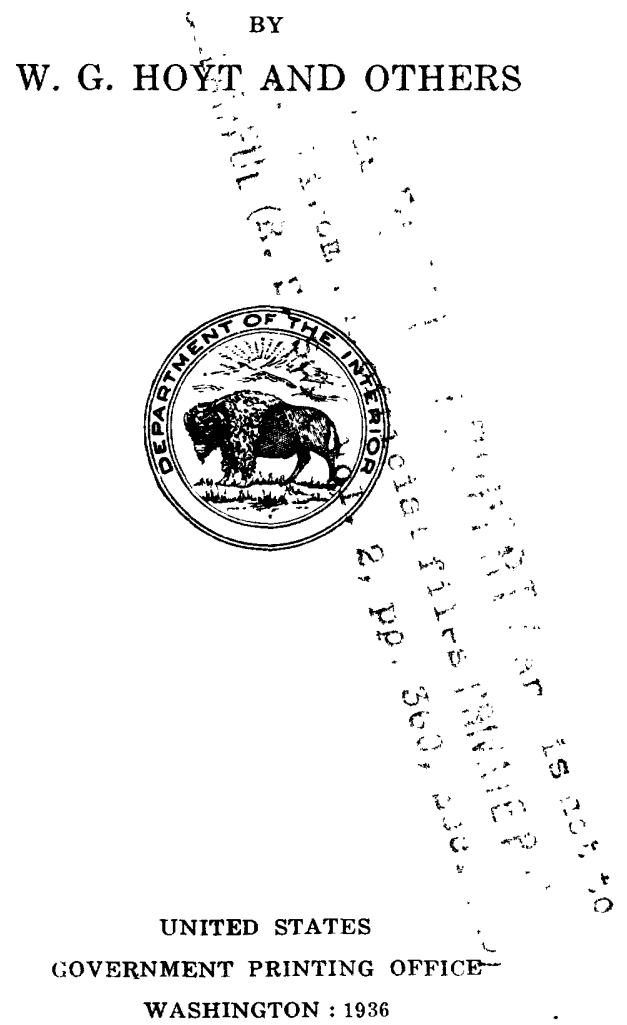

For sale by the Superintendent of Documents, Washington, D. C. - - - Price 25 cents (Paper cover) 



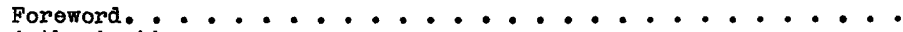
Authorization . Administration and personnel. . . . . . . . . . . . . . . Advisory coordination . . . . . . . . . . . . . . . . . . . . Acknowledgments . . . . . . . . . . . . . . . . . . . . . . . . Previous studies..... . . . . . . . . . . . . . . . . . . Alms of present study . . . . . . . . . . . . . . . . . . . . Precipitation. - * * * * * • Changes in precipitation in continental United States.... Changes in annual precipitation, by geographic provinces. . Years of high precipitation. . . . . . . . . . . . . . . Periods of high precipitation. . . . . . . . . . . . . . . Years of low precipitation . . . . . . . . . . . . . . . Periods of low precipitation . . . . . . . . . . . . . . . Changes in precipitation, by areas . . . . . . . . . ... Changes in seasonal precipitation, by geographic provinces. Changes in winter procipitation : Changes in precipitation in growing season. $\cdot$. $\cdot$. $\cdot$. Changes in fall precipitation ............... Average monthly precipitation. . . . . . . . . . . . . . Changes in temperature. . . . . . . . . . . . . . . . . . . . Changes in mun-off. . . . . . . . . . . . . . . . . . . . . . Precipitation, temperature, and run-off, by basins........ Red River Besín above Grand Forks, N. Dak. . . . . . . . . Mississippi River Basin above Keokuk, Iowa . . . . . . . Neosho River Basin above Iola, Kans. . . . . . . . . . . . Merrimack River Basin above Lawrence, Kass... . . . . . . . Jemes River Basin above Cartersville, Va... . . . . . . . . Tennesseo River Basin above Chattanooga, Tenn. . . . . . Chat tahoochee River Basin above West Point, Ga........ General accuracy of precipitation, temperature, and run-off data. Changes in rainfall, by basins. . . . . . . . . . . . . . . . .

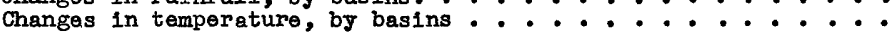
Changes in mun off, by basins. . . . . . . . . . . . . . . . . . Relations between ralnfall and mun-off. . . . . . . . . . . . Stream flow ................................... Stream-flow separation ... . . . . . . . . . . . . . . Depletion curves. . . . . . . . . . . . . . . . . . Recession curves....... . . . . . . . . . . . . . Ground-water levels and accretion . . . . . . . . . . Unit hydrographs. . . . . . . . . . . . . . . . . . Infiltration capacity and storage factors : . . . . Meteorologic factors. . . . . . . . . . . . . . . Channel storago . . . . . . . . . . . . . . . .

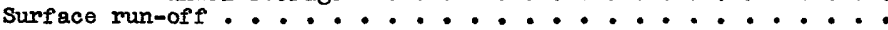
Quantitative analysis, by basins................ Unit-hydrograph anelysis of surface mun-off. . . . . . The unit hydrograph and distribution graph and their prepa-

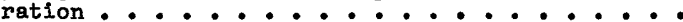
Unit hydrographs and distribution graphs by basins:. . . Muskingum River Basin above Dresden, Ohio . . . . . Wabash River Basin above Logansport, Ind. . . . . . . Embarrass River Basin above Ste. Marie, Ill... .... Skunk River Basin above Augusta, Iowa ... . . . . . Susquehanna River Basin above Towanda, $\mathrm{Pa} . .$. . . . . . Delaware River Basin above Port Jervis, N. Y. . . . . French Broad River Basin above Dandridge, Tenn. . . . Red River Basin above Denison, Tex. . : . . . . . . Summary . . . . . . . . . . . . . . . . . . . . . Appiscation of the unit-graph principle............ 
The unit-hydrograph method and storm transposition in flood problems relating to great storms in the Eastern and

Central United States, by Merrill Bernarā. . . . 218

Flood coefficients.................... 218

Storm rainfall..................... 221

Storm index ..................... . . . . . 230

Storm transposition................. 230

Storm superposition .................. 235

Delaware River Basin above Port Jervis, N. Y.... 235

French Broad River Basin above Dandridge, Tenn..: 237

Wabash River Basin above Logansport, Ind... . . . 241

Skank River Basin above Augusta, Iowa....... 241

Floods influenced by snow ............... 244

Conclusion. . . . . . . . . . . . . ..... 244

Ground-water mun-off. . . . . . . . . . . . . . . . . . 245

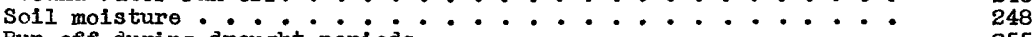

Run-off during drought periods. . . . . . . . . . . . 255

Comparis on of deficiencies in ground-rater mun-off with defi-

clencies in rainfall .............. 257

Ground-water levels . . . . . . . . . . . . . . . 269

Comparison of graphs of minimum flow.

Report of the Advisory Committee of the Section of Hydrology of

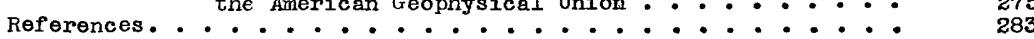

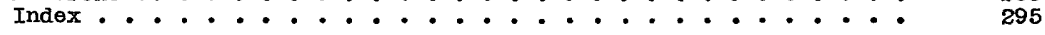

\section{ILLUSTRATIONS}

Flgure 1. Year of maximum annual precipitation at selected

2. Yong-time Weather Bureau stations - at selected Weather Bureau stations......

3. Year of minimum annual precipitation at selected long-time Weather Bureau stations - -

4. Year ending 10-year period of minimum precipitation

5. Map showing annual precipitation changes over United States..................

6. Annual and seasonal precipitation changes (Maine to

7. Annual and seasonal precipitation changes (Michigan

8. Annual and seasonal precipitation changes (Minnesota to Texas. seasonal precipitation changes (Montana

9. Annual and seasonal precipitation changes (Montana

10. Annual and seasonal precipitation changes (Washington, Oregon, Californfa). . . . . . . . .

11. Map showing annual temperature changes in United

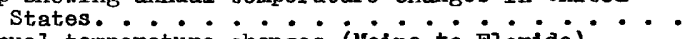

12. Annual temperature changes (Maine to Florida): :

13. Annual temperature changes (Hichigan to Iouisiana)

14. Annual temperature changes (Minnesota to Texas). .

15. Annual temperature changes (Idaho and Montana to

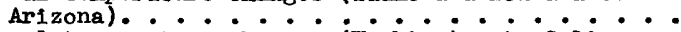

16. Annual temperature changes (Washington to cali-

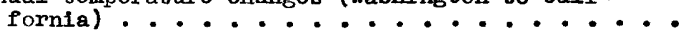

17. Map showlng annual mun-off changes in United States.

18. Base data for Red River Basin above Grand Forks, N. Dak..................

19. Base data for Mississippi River Basin above Keokuk,

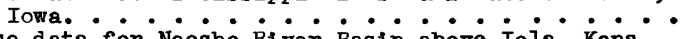

20. Base data for Neosho River Basin above Iola, Kans:

21. Base data for Merrimack River Basin above Lamrence,

22. Base data for James River Basin above Cartersvilie, Va...................... 
Figure 23. Base data for Tennessee River Basin above Chattanooga, Tenn..................

24. Base data for Chattahoochee River Basin above West

25. Ralnfall and run-of relations, Red River.: : :

26. Rainfall and mun-off relations, Mississlppi River. -

27. Rainfall and mun-off relations, Neosho River . . .

28. Rainfall and run-of relations, Merrimack River. .

29. Rainfall and run-cff relations, James River. . . .

30. Rainfall and run-off relations, Tennessee River. .

31. Rainfall and run-off relations, Chat tahoochee River:

32. Rainfall and run-off relations, combined all basins.

33. Typical unit hydrograph - Muskingum River at Dresden Ohjo....................

34. Map of Muskingum hiver Basin above Dresden, Ohio .

35. Unit hydrographs - Muskingum River at Dresden. . :

36. Unit hydrographs - Muskingum River at Dresden (con-

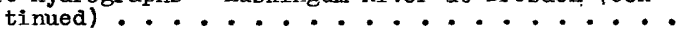

37. Unit hydrographs - Muskingum River at Tresden (continued) .................

38. Superimposed distribution graphs - Muskingum River at Dresden. . . . . . . . . . . . . .

39. Map of Wabash River Basin above Logansport, Indiana.

40. Unit hydrographs - Wabash River at Logansport. . . .

41. Unit hydrographs - Wabash River at Locansport (continued) : • . . . . . . • • . .

42. Supertmposed distribution graphs - Wabash River at

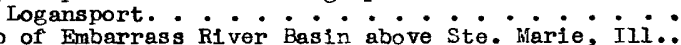

43. Map of Embarrass River Basin above Ste. Marie, Ill..

44. Unit hydrographs - Unit hydrographs - Imbarrass River at Ste. Harie (continued) .................

46. Superimposed distribution graphs - Embarrass River at ste. Harie.................

47. Map of Skunk Fiver Basin above Augusta, Iowa... -

48. Unit hydrographs - Skunk Kiver at Augusta. . . . .

49. Unit hydrographs - Skank River at Augusta (continued) ...................

50. Superimposed distribution graphs - Skcink River at

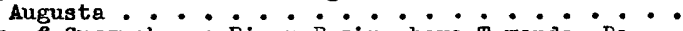

51. Map of Susquehanna River Basin above Towanda, Pa...

52. Untt hydrographs - Susquehanna River at Towanda. .

53. Unit hydrographs - Susquehanna River at Towanda (continued) .................

54. Unit hydrographs - Susquehanna kiver at Towanda (continued) .................

55. Superimposed distribution graphs - Susquehanna River at Towanda. . . . . . . . . . . . . *

56. Map of Delaware River Basir above Port Jervis, N. Y.

57. Unit hydrographs - Delaware River at Port Jervis..

58. Unit hydrographs - Delaware River at Port Jervis

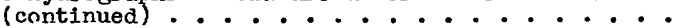

59. Unit hydrographs - Delaware River at Port Jervis (continued) .................

60. Superimposed distribution graphs - Delaware River at Port Jervis ....... . . . . . . . .

61. Map of French Broad River Basin above Landridge; Tenn. . . . . . . . . . . . . .

62. Unit hydrographs - French Broad River at Dandridge,

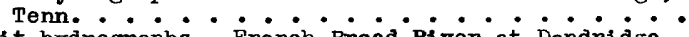

63. Unit hydrographs - French Broad River at Dondridge.

64. Unit hydrographs - French Broad River at Dandridge, Tenn. (continued) ..............

65. Superimposed distribution graphs - French Broad R1ver at Dandridge...............

66. Map of Red River Basin above Denison, Texas.: :

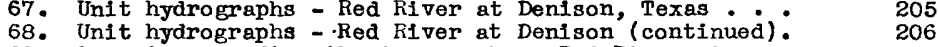

69. Superimposed distribution graphs - Red River at

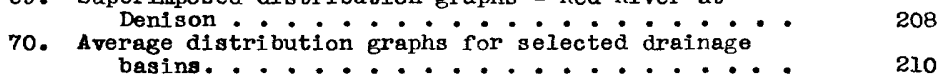

71. Flood hydrographs and fiood coefficients (c) for Muskingum River at Dresden, Ohio........ 
Figure 72. Flood hydrographs and flood coefficients (c) for

Wabash River at Logansport, Ind. • - • - . .

73. Flood hydrographs and flood coefficients (c) for Skunk River at Augusta, Iowa ..........

74. Flood hydrographs and flood coefficients (c) for Susquehanna River at Towanda, Pa......... 225

75. Flood hydrographs and flood coefficients (c) for Delaware River at Port Jervis, N. Y. . . . . .

76. Flood hydrographs and flood coefficients (c) for French Broad River at Dandridge, Tenn. . . . .

77. Flood hydrographs and flood coefficlents (c) for Red River near Denison, Texas..........

78. Flood coefficients for selected drainage basins: :

79. Map of eastern Unjted States showing storm indexes and geographic position of the centers of great

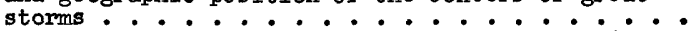

80. Map of eastern United States showing location of storm area relative to selected drainage basins. .

81. Storm of 0ct. 8-11, 1903, with relative location of Weather Bureau stations and the Delaware River Basin above Port Jervis, $N$. $Y_{\text {., }}$ in its actual position (a) and shifted to give a maximum depth of rainfail on the basin (b) . . . . . . . .

82. Pluviagraphs and hydrograph of computed fiood flow resulting from storm of oct. 8-11, 1903, in its actual position (a) and shifted so as to give a maximum average depth of rainfall on the basin position (b) . . . . . . . . . . . . .

83. Storm of July $15-16,1916$, in actual position on Frenoh Broad River Basin over Dandridge, Tenn., and resulting pluviagraph and hydrograph of computed flood flow...............

84. Storm of March 24-26; i9i3, with relative location of Weather Bureau stations superposed on Wabash River Basin above Logansport, Ind., and resulting pluviagraph and hydrograph of computed flood

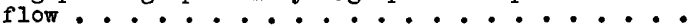

85. Storm of Aug. $25-28,1903$ with relative location of Weather Bureau stations superposed on Skunk River Basin above Augusta, Iowa and resulting pluviagraph and hydrograph of computed flood flow...

86. Observed and estimated metorologic and hydrologic data for Skunk River Basin above Augusta, Iowa..

228

229

232

87. Comparison of soil molsture changes - Skunk, Black, and Rock Rivers. . . . . • . *....

88. Ground-water levels in Piatte River vailey in Nobraska.................

89. Graphs of minimum filow: : : : : : : :

Table 1. Average annual precipitation over the United States by 5-year periods..................

2. Precipitation at iong-time Weather Bureau stations:

3. Changes in winter precipitation............

4. Changes in sumer precipitation.: : : : : : :

5. Changes in fall precipitation. . . . . . . . :

6. Changes in annual temperature by areas . . .....

7. Precipitation stations in or near Red River Basin above Grand Forks, N. Dak..............

8. Base data for Red River Bas In above Grand Forks, N. Dak. . . . . . . . .

9. Precipitation stations in or near Mississippi River Bas in above Keokuk, Iowa. . . . . . . . . .

10. Base data for Mississippi River Basin above Keokuk, Iowa. . . . . . . . . . . . . .

11. Temperature stations in or near Mississippi River Basin above Keokuk, Iowa............. 
Table 12. Precipitation stations in or near Neosho River Basin

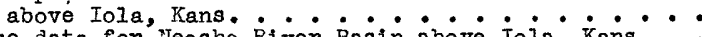

13. Base data for Neosho River Basin above Iola, Kans.

14. Precipitation stations in or near Merrimack River Basin above Lawrence, Mass............

15. Base data for lerrimack River Basin above Lawrence,

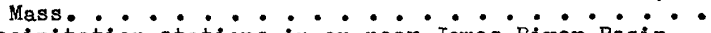

16. Precipitation stations in or near James River Basin above Cartersville, Va. ............

17. Base data for James River Basin above Cartersville,

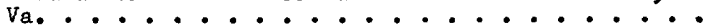

18. Precipitation stations in or near Tennessee River Basin above Chattanooga, Tenn...........

19. Base data for Tennessee River Basin above Chattanooga, Tenn. . . . . . . . . . . . ...

20. Precipitation stations in or near Chattahoochee River Basin above West Point, Ga...........

21. Base data for Chattahoochee River Basin above West Point, Ga...................

22. Basin changes in precipitation............

23. Basin changes in temperature .............

24. Basin changes in run-off . . . . . . . . . .

25. Average annual surface mun-off for typical basins. .

26. Average annual surface mun-off in Mississippi River Basin above Keokuk, Iova... . . . . . . . .

27. Typical unit-hydrograph storm - Muskingum River Basin above Dresden, Ohio .............

28. Derivation of typical distribution graph - Muskingum

29. Unit-hydrograph storms - Muskingum River Basin above Dresden, ohio ...............

30. Surface mun-off from unit storms - Muskingum River at Dresden .....................

31. Distribution graphs - Muskingum River at Dresden . .

32. Unit-hydrograph storms - Wabash River Basin above Iogansport, Ind... ...............

33. Surface run-off from unit storms - Wabash River at

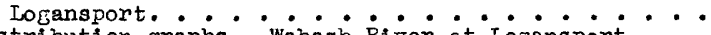

34. Distribution graphs - Wabash River at Logansport: -

35. Unit-hydrograph storms - Embarrass River Basin above Ste. Marie, Ill...................

36. Surface run-off from unit storms - Embarrass River at Ste. Marie...................

37. Distribution graphs - Embarrass River at Ste.Marie.

38. Unit-hydrograph storms - Skunk River Basin above Augusta, Iowa .................

39. Surface run-off from unit storms - Skunk River at Augusta..................

40. Distribution graphs - Skunk River at Augusta . . .

41. Unit-hydrograph storms - Susquehanna River Basin above Tovanda, Pa...................

42. Surface run-off from unit storms - Susquehanna River at Towanda..................

43. Distribution graphs - Susquehanna River at Towanda..

44. Unit-hydrograph storms - Delaware River Basin above Port Jervis, N. Y..................

45. Surface run-off from unit storms - Deiaware River at Port Jervis..................

46. Distribution graphs - Delaware River at Port Jervis.

47. Unit-hydrograph storms - French Broad River Basin above Dandridge, Tenn...............

48. Surface run-off from unit storms - French Broad River

49. Distribution graphs - French Broad River at Dandridge.

50. Unit-hydrograph storms - Red River Basin above Denison, Texas. - • • • • • • • • • • •

51. Surface run-off from unit storms - Red River at Denison ..................

52. Distribution graphs - Red River at Denison.....

53. Average distribution graphs for selected drainage basins in percent ..............

54. Development of flood coerficients for susquehanna

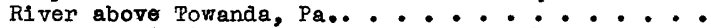

55. Flood coefficients for Delaware River at Port Jervis, N. X....................... 
Table 56. Flood coefficients for French Broad River at

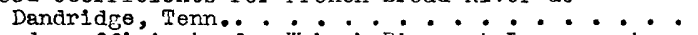

57. Flood coefflcients for Wabash River at Logansport,

Inc....................... . . . . 234

58. Flood coefficients for Skunk River at Augusta, iowa.: $\quad 235$

59. Ground-water run-off for typical basins. . . . . . . 246

60. Ground-water man-off, Upper Mississ1ppi River Basin. - 247

61. Observed and estimated meteorologic and hydrologic

62. Drought data for Red River Basin above Grand Forks,

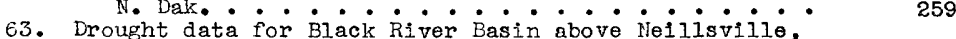

64. Drough dat for Rock River Basin above Afton, wis -262

65. Drought data for Rock River Basin above Afton, Wis... 264

66. Drought data for Mississippi River Basin above Keokuk,

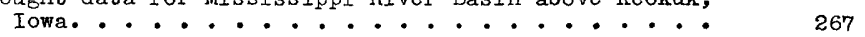


STIJDIES OF RELATIONS OF RAINFALL AND

RUN-OFF IN THE UNITED STATES

By W. G. Hoyt and others

\section{Foreword}

Human relations to the waters of the earth have developed from a simple but very significant status in the haphazard life of primeval man to a complex and often economically limiting status in connection with the present-day activities of a highly organized civilization.

The present wide scope of the uses of water for domestic supply, power development, irrigation, navigation, and recreation and the extensive human activities for protection against floods, drainage of wet lands, control of erosion, and control of pollution are generally accepted as matters of course. It is notable, nevertheless, that the severe drought, which persisted for about 5 years from 1930 to 1934 including the disastrous summer of 1934 has impressed on many people as never before the essential character and the importance of our water resources.

As a consequence the attention not only of Federal and State Governments but of the people as a whole is being turned to an evaluation of water that embraces not only its use and control in the cormon ways above mentioned but its conservation to a degree and through broad policies never before considered. Heretofore, except of course for the great interest of farmers in rain, the popular and generally recognized interest in water has tended to begin at the time when it has appeared in the surface streams or has bocome stored in the ground. But the failing streams of drought-affected regions and the disastrous erosive action of waters before they reach well-defined watercourses have notably quickened the regard for the uses and control of water at an earlier stage in the complex cycle through which it passes after its occurrence as rain. 
After precipitation, and before it finally reaches well-defined stream channels, water is subjected to the action of numerous agencies, including ground and water-surface evaporation, transpiration in plant and tree growth, infiltration and absorption by the ground, passage through the shallow storage upon 1ll-drained lands, and surface man-off through systems of trickles and streamlets. The importance of the subtractions from precipitation before it becomes stream flow may be illustrated by statement of the fact that to produce 1 pound of ary vegetable substance of a growing plant several hundred pounds of water is taken up from the soll by the roots of the plant, passes through the growing plant tissues, and then evaporates into the air from the leaf surfaces. Thus to obtain satisfactory crop yields many inches of water over the crop-producing area must be used in this way. It is evident, therefore, that in arid and semiarid regions, and indeed in humid regions in times of drought, the flow of surface streams constitutes a surprisingly small part of the water inftially falling as rain.

The conservation of even a small part of the precipitation that under present conditions does not reach the streams may be extremely desirable and important, provided it is practicable and economical. Much more trustworthy information than now avallable concerning rainfall, runof $f$, and related factors is desirable for wise planning of water conservation and utilization. There is also need for investigating those factors which are alleged to have caused some regions, within the period of apparent human occupancy, to change at least temporarily in their degree of aridity or humidity.

Early in its consideration of Public Works water projects, the Mississippi Valley Committee realized the great need for more information on the conditions affecting rainfall, mun-off, and related factors. It was recognized that to a great extent the available climatic and hydrologic data have never been adequately analyzed with a view to deducing the particular knowledge that would be helpful. Moreover, it was believed that such broad fundamental questions were largely outside the field in which private individuals and institutions could generaliy be active and hence were especially suited to investigation by an agency or agencies of the Federal Government. 
It was with an appreciation of the need and opportunity thus afforded that the present studies were undertaken. The studes were authorized and directed by the Mississippi Valley Committee of the Fmergency Administration of Public Works, now the Water Planning Committee of the National Resources Board, and the work was done by the United States Geological Survey. Most valuable and.helpful advice has been received from a special committee of the Section of Hydrology of the American Geophysical Union. The objective has been primarily the presentation of facts, generally elementery and basic, as disclosed by observed data or by their siaple analysis. It is believed that the results contained in this report present much fundamental information, an understanding of which is essential to adequate long-time planning and execution of projects for the use and control of the water resources of the country.

The Mississippi Valley Cormittee also found desirable a study of floods and, as a profect, that study was combined with the study of the relations of rainfall, run-off, and related factors. Both investigations have been carried forward concurrently with unified control and supervision, yet with the requistte independence of approach to call forth the best efforts of the separate groups at work. The results of the flood study are contained in another report to be published as Water-Supply Paper 771 .

\author{
Harlan H. Barrows \\ Herbert S. Crocker \\ GIen E. Edgerton \\ Henry S. Graves \\ Edward M. Markham \\ Charles H. Paul \\ Sherman M. Woodward \\ Harlow S. Person (acting chairman) \\ Resources Board, formerly Mississippi \\ Valley Committee of the Pederal Bmergency
}

Water Planning Committee of the National

Administration of Public Works. 


\section{Authorization}

Late in 1933 and during the first few weeks of 1934 members of the scientific staff of the Geological Survey appeared before the Mississippi Valley Committee of the Federal Fmergency Administration of Public Works to discuss certain aspects of hydrology, such as floods, droughts, and ground-water conditions, which had been found to be involved in the consideration of the numerous applications for Public Works projects in the Mississippi Valley presented to the comittee for study and recommendation. These discussions emphasized the need of studies of available hydrologic and climatologic information, with a view to determining the implications of the data with respect to various questions of planning and design and to placing such information in a form in wich it could be used and its value realized.

As a result of these conferences, the Mississippi Valley Committee recommended and obtained from the Public Works Administration late in February 1934 an allotment for studies of this character to be made in collaboration with the Geological Survey, under two headings - (1) the magnitude and frequency of floods and (2) rainfall, mun-off, and related factors Formal authorization of the studies by the Geological Survey was contained in a letter of the Federal Fmergency Administration of Public Works dated March 6, 1934.

\section{Administration and personnel}

Arrangements were made during March 1934 for the studies to be made in the water-resources branch of the Geological Survey under the general administrative supervision of N. C. Grover, chlet hydraulic engineer, and under the direct administrative supervision of R. W. Davenport, chief of the division of water utilization. W. G. Hoyt was designated as the responsible head of the studies relating to rainfall, run-off, and related factors. In order to obtain the benefit of their special training and qualifications and to furnish an experienced nucleus for a staff of investigators two engineers and one geologist of the Survey were detalled to the studies. The remainder of the personnel were made up of temporary employees appointed by the Secretary of the Interior from the list of 
applicants eligible for appointment in connection with projects of the Public Works Administration. The personnel and periods worked up to the time the report was finished, June 30,1935 , are as follows:

Regular employess:

W. G. Hoyt, hydraulic engineer, one-half time, since March 1 , 1934.

I. I. Harrolá, assistant engineer, since March 8, 1934.

R. C. Cady, funior geologist, part time, since July 1, 1934 . Temporary employees:

Merrill M. Bernard, senior engineer, Crowley, La., part time, April 1, 1934, to May 15, 1935.

A. I. Alin, junior engineer, Portland, Oreg., March 21 to May 2, 1934.

Franklin F. Snyder, junior engineer, Columbus, Ohio, since April $16,1934$.

D. M. Paul, assistant clerk, Odebolt, Iowa, since March 12, 1934.

J. Paul Bowker, assistant clerk (computer), Washington, D. C., since October 24, 1934.

C. E. Kitchin, assistant clerk (computer), Hyattsvilie, Ma., since October 25, 1934.

The division of work has been somewhat as follows:

Merrill w. Bernard has devoted his time almost exclusively to the application of the unit hydrograph and distribution graph to the analysis of flood flows and wote the discussion "The unit-hydrograph method and storm transposition in flood problems." Mr. Bernard brought to the studies a wealth of original experience in analyzing storm precipitation of high intensity and his kmowledge of the unit graph devised by L. K. Sherman and more especially the distribution graph and the pluviagraph devised by himself.

L. L. Harrold in the early part of the studies devoted a large part of his time to the study of ground-water flow, soll molsture, and related matters - subjects which he had been previously investigating. Later he carrled on and supervised work of the general computation in connection with precipitation, temperature, and run-off trends and relations.

Franklin F. Snyder, in addition to routine computation, spent a very considerable portion of his time in analyzing the fundamentals of the unit hydrograph, distribution graph, and pluviagraph, methods of presentation, and possibilities of application, and he has prepared much of the text relating to these subjects. 
R. C. Cady, as a member of the staff of the ground-water division, devoted much of his time to the determination of ground-water flow from the hydrograph of total stream flow and the study of relations between groundwater flow, water-table level, precipitation, and related factors.

Messrs. Paul, Alin, Bowker, and Kltchin have assisted in general compllations, preparation of charts, and clerical activities.

\section{Advisory coordination}

The Water Planning Committee of the National Resources Board and its predecessor the Mississippl Valley Committee malntalned contact with the studies through Prof. Sherman W. Woodward, of the University of Iowa, member of the Mississippi Valley Comnlttee, and Prof. Thorndike Saville, of New York UnIversity, executive engineer of the Water Resources section. In addition the Section of Hydrology of the American Goophysical Union, at the request of the chalrman of the Mississippi Valley Committee, appointed during May 1934 the following engineers and hydrologists as a comittee of advisers and consultants:

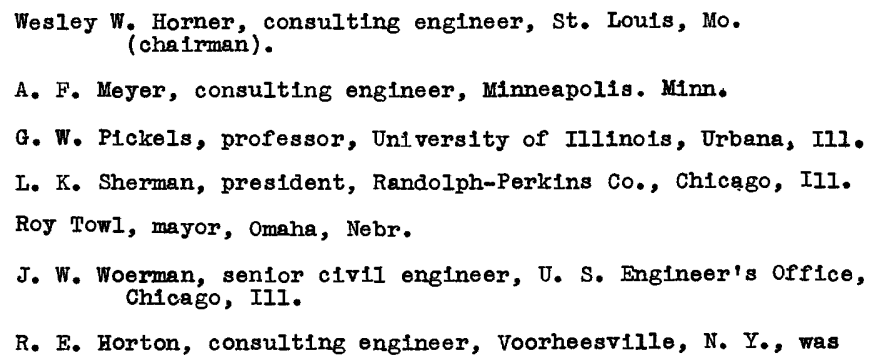
added to this advisory comittee in January 1935.

Since May 1934, some of the members of this committee have been in continuous contact with the studies, elther personaliy or through correspondence, and generous ackmowledgment is due and here given for the valuable assistance thus rendered.

Observations and recommendations of the committee of the Section of Hydrology have been freely referred to throughout the text of this report, and a statement by the committee is presented as an appendix. All compliations of records and various memoranda prepared by the Geological Survey staff have been made avallable to the committee members. The materlal has been the subject of correspondence between the committee members 
and of conferences and correspondence between certain of the members of the comittee and members of the Survey staff.

Nearly all complied records and memoranda have also been sent to each member of the Flood Protection Data Committee of the American Soclety of Civil Engineers appointed to advise in the flood studies, the membershil of which is as follows:

Gerard H. Matthes, principal engineer, office of the president, Mississippi River Cormission, Vicksburg, Miss. (chaiman).

Frederick H. Fowler, consulting engineer, San Francisco, Calif. Robert E. Horton, consulting engineer, Voorheesvill6, N. Y.

Ivan E. Houk, senior engineer, U. S. Bureau of Reclamation, Denver, Colo.

Charles $W$. Sherman, consulting englneer, Boston, Mass.

C. W. Kutz, Brigadier-General, U. S. Army (retired). Washington, D. C.

Daniel C. Walser, vice president, Charles B. Hawley Engineering Corporation, Washington, D. C.

Although this cormittee as a whole has not made definite recommendations with respect to the studies of rainfall in relation to run-off, pertinent comments have been received from individual members.

\section{Acknowledgments}

The staff engaged on the rainfall and run-off studies have received encouragement, advice, and criticism from so many sources that full acknowledgment and credit are difficult. Throughout the studies Messrs. Grover and Davenport for the water-resources branch and Professors Woodward and Saville for the Mississippi Valley Conmittee and the Water Planning Committee have been in close touch with the progress of the work and have been a continuing source of advice and encouragement. In a very large measure the methods of attacking the problems have been developed as a result of the frequent personal contacts, conferences, and exchange of correspondence with members of. the committee of the section of Hydrology, more especially its chairman, Mr. Horner, and Messrs. Sherman, Mejer, and Horton. 0. E. Meinzer, chief of the division of ground water, water-resources branch, and members of his staff have made helpful suggestions. Acknowledgment is due the U.S. Weather Bureau, the records of which have boen used freely in this report, and special aclmowledgment is due J. B. Kincer, chief, Division of Climate and Crop Weather, for his cordial and helpful cooperation. 


\section{Previous studies}

Among the first attempts in this country to determine the relations between rainfall and run-off were those made in the early 1890 's by F. H. Newell, Henry Gannett, and C. C. Babb, of the United States Geologlal Survey. On the basis of very meager rainfall and mun-off data, Newell, in the Fourteenth Annual Report (1892) of the Geological Survey, presented two curves showing the relation between mean annual precipitation and mean annual run-off - one for mountainous regions, the other for streams draining basins having broad valleys. The same report also contains rainfall and run-off maps of the United States. Henry Gannett later prepared more detailed maps of the United States, on one of which were shown lines of equal annual rainfall and on another lines of equal annual run-off. These maps had wide circulation and have been reproduced as late as 1928 (122, fig. 180).* Gannett was among the first of those in the United States to study mun-off as a residual of rainfall after losses. Maps similar to those prepared by Gannett but based on much more information have recently been prepared by the Water Resources Section of the National Resources Board and are contained in the report of the Mississippi Valley Committee of the Public Works Administration dated October 1, 1934 , and also in the report of the National Resources Board dated December 1 , 1934 (obtainable from the Superintendent of Documents, Washington).

C. C. Babb, in 1893 (3), presented curves showing monthly run-off in terms of percentage of annual run-off, the annual run-off being computed as a percentage of the annual precipitation. The jear previous, Desmond Fitzgerald presented a paper (39) in which run-off, in terms of a percentage of rainfall, is discussed.

In 1903, George W. Rafter, after many jears of study on the problem, presented a report (141) on the relation of run-off to rainfall. He discussed previous studies, including that of C. C. Vermeule in New Jersey. Vermeule (187) in an attempt to express the relation between rainfall and run-off, used a constant plus a percentage for the several months of the year and varied the relation with the mean annual temperature. Rafter presented curves showing the general relation between rainfall and run-off for

* Numbered citations in parentheses refer to the list of references at the end of this peiper. 
three periods of the year, designated by him the storage period (December to May), growing period (June to August), and replenishing period (September to November). He drew numerous general conclusions, of which one was as follows (141, p. 81): "There is no general expression giving accurately the relationship of rainfall to run-off. The run-off of a stream is affected by so many complex elements that the data are lacking for final conclusions. Every stream is in effect a law unto itself. An empirical formula may, however, be made which w11l give for some streams approximately the run-off for a series of years."

D. W. Mead in 1904 brought together in a single treatise (109), for the first time in the United States, information available as of that date on the fundamental phenomena of hydrology. These notes were superseded in 1919 by his complete textbood entitled "Hydrology, the fundamental basis of hydraulic engineering" (1II).

In $1914 \mathrm{~J}$. D. Justin (86) expressed the annual run-off by a product consistine of a coefficient (which varied with slope and mean annual temperature) multiplied by the square of the annual rainfall.

A. F. Meyer in 1915 presented a comprehensive paper entitled "Computing mun-off from rainfall and other physical data" (121), and in 1917 published his textbook "Elements of hydrology" an enlarged second edition of which was published in 1928 (122). Meyer, Iike Gannett, considered run-off a residual of rainfall after all losses had been deducted. He established curves by which the evaporation and transpiration from various drainage basins could be determined. Meyer's paper made a great advance over any previous study, in that he undertook to ascertain in rational ways the losses from precipitation after it reaches the ground, in order to determine run-off.

The technical reports of the Miami Conservancy District, publ1shed in 1921, especially part 8, "Rainfall and run-off in the Miami Valley" (72), by Ivan E. Houk, presented a great advance in the knowledge of rainfall and run-off relations. Of special interest was Houk's study of absorption rates and the distribution of stream flow into two parts surface run-off and ground-water run-off - and quantitative analysis of the hydrologic cycle.

Results of studies made by John F. Hayford concerning the relations between rainfall and run-off, under the auspices of the Carnegie Institution of Washington, were published in 1929, 4 years after his $59550-35-2$ 
death (57). The studies continued over several years and were, so far as known, the most exhaustive yet made in an attempt to express mathematically the factors Influencing dally stream flow. Hayford considered stream flow in two parts - "normal stream flow," or that portion derived from ground water, and "flood run-off," or the portion above the nomal flow. The results indicated that so many constants must be determined in connection with any drainage basin that the studies are apparently not sulted to practical application, although they are of considerable scientific Interest.

In 1932 W. T. Collins and Franklin F. Snyder, students at Oh10 State University, prepared a thesis (31) in which they derived formulas for expressing the mean monthly flow of certain ohlo streams, using a method of approach similar to that used by Professor Hayford. Reasonable agreement was reached between the computed flow and the observed flow for the particular streams and periods used in determining the several constants.

In 1932 L. K. Sherman (158) presented the 1dea that surface runoff from rainfall occurring within the same time interval, such as a day or an hour, may be expressed in untt hydrographs having equal bases on the time axis, the ordinates varying with the intensity of the rainfall.

In 1934 Merrill M. Bermard presented a paper (13) which develops certain features of the unit hydrograph and introduces the distribution graph and pluviagraph. The concepts developed by Sherman and Bernard provide a new approach to the analysis of the relation between precipitation and surface run-off.

In 1935 Robert E. Horton gave (70a) an analysis of the hydrograph describing and discussing "the natural processes involved in surface run-off quantitatively and in their natural sequence."

At the end of this report is a bibliography of papers, largely American, discussing relations between rainfall and run-off and related subjects, not incluaing references relating to precipitation or run-off of high intensity. The bibliography is not complete with respect to the extensive and valuable literature on hydrology in foreign countries. Neither is it complete with respect to many articles and discussions which have been presented in the publications of the American Geophysical Union, American Soclety of Civil Englneers, American Water Works Association, New England Water Works Assoclation, and other organizations, which can readily be found by reference to the indexes of these publications. Many of the 
authors of these papers have spent the greater part of their professional careers in a study of the intricate problems involved in the hydrologic cycle, and comments on the results of their studies would fill many volumes.

\section{Aims of present study}

The preceding brief discussion of previous studies, when read in connection with the partial bibliography, Indicates that many minds have been engaged for a period of nearly 50 jears in an attempt to determine and express the relations between rainfall and run-off. Although great progress has been made, there are many relations that still remain obscure. Early in the present study it was decided that in the light of prior investigations it was unwise to undertake a broad general study for the purpose of developing empirical formulas for expressing relations between rainfall and mean annual, monthly, or daily run-off. The study was directed, instead, along two rather definite lines of approach - (I) investigation of relations between annual and monthly precipitation, temperature, evaporation, transpiration, direct surface mun-off, ground-water run-off, and infiltration as a basis for the quantitative analysis of the hydrologic cycle over broad areas and of trends and changes therein; (2) investigation of relations between storm precipitation and direct surface run-off.

It was felt that the investigations thus outlined would be of immediate value to the Mississippi Valley Comittee and its successor the Water Planning Comittee in connection with consideration of problems involving the utilization and conservation of water and would also form a logical extension of past hydrologic studies. Such a study would not encroach on the fleld of experimental research that was being carried on by many organizations and Individuals. Rather it would be an attempt to bridge the gap between the small experimental area under controlled and simple conditions and the larger river-system areas of multiple and complex conditions.

It was hoped that the study of trends in the relations disclosed between rainfall and run-off might throw some light on perplexing questions In any broad consideration of hydrologic and climatic factors which had been presented to the Mississippi Valley Committee in the projects submitted to it for consideration and recommendation. It was also the purpose of the study to disclose weaknesses and limftations in the application of 
the hydrologic and climatologic information and thus to be valuable in connection with the improvement or extension of fact-finding services engaged in collecting these basic data.

\section{Precipitation:}

Precipitation, or rainfall, is essentially the source of all water on the earth's surface and hence is commonly considered the starting point of the hydrologic cycle. A very considerable part of the present study has therefore been devoted to the investigation of precipitation with reference to annual and seasonal changes over broad areas, as well as to the study of the relation of precipitation to stream flow. Throughout the study of changes 10-year progressive averages have been generally used, and in the various diagrams the plotted points represent the average of the figures for the 10-year perfod ending with the year for which the point is plotted. The inherent limitation as to absolute accuracy of precipitation records is recognized and has been kept in mind in an attempt to avold irrational and unsound use.

Precipitation records have been complied for the purpose of determining within reasonable limits information concerning (I) possible changes in the precipitation over the continental United States as a whole since 1881; (2) possible changes over broad geographic provinces (a) on an annual basis and (b) on a seasonal basis; (3) possible changes over typical river basins; and (4) relations between annual precipitation and annual run-off.

\section{Changes in precipitation in continental United States}

Averages of precipitation by States are available from 1881 to 1934 and are publlshed in Water-Supply Paper 680. There has been a progressive increase in the accuracy of the State averages as a result of the increase in the number of Weather Bureau stations, refinements of methods of recording, and better geographic distribution of the stations used to

* For the most recent map showing distribution of mean annual rainfall in the United States and variations from the mean togother with a discussion of precipitation in general see section III of the Report of the Water Planning Committee to the Cheimman of the National Resources Board dated November 15, 1934 (obtainable from the Superintendent of Documents, Washington, for $\$ 1.00)$. 
compute the State averages. To a greater or less extent, also, similar increases in accuracy are shown by nearly all the basic data used in the present study. The relatively less reliability of the earlier data and greater reliability of the later data should be borne in mind in connection with any conclusions that may be drawn.

Because much of the country has liad a period of deficient rainfall during the last few years the question naturally has been raised as to what changes in precipitation, if any, have taken place over the country as a whole during the last 55 years. The following table shows averages, weighted for area, of the mean annual precipitation by successive 5-year periods from 1881-85 to 1926-30 and for the 4-year period 1931-34. The figures were obtained by multiplying the mean annual precipitation computed for 5-year periods in each State by the area of the State in square miles, adding the products, and dividing the sum by the area of the United States in square miles.

Table 1.- Average annual precipitation over continental United States, by 5-year periods

(Area 3,026,719 square miles)

\begin{tabular}{|c|c|c|}
\hline $\begin{array}{l}\text { 5-year period } \\
\text { ending }\end{array}$ & $\begin{array}{l}\text { Precipitation } \\
\text { (inches) }\end{array}$ & $\begin{array}{l}\text { Variation from } \\
\text { average percent }\end{array}$ \\
\hline \multirow[t]{2}{*}{$\begin{array}{l}1885 \\
1890 \\
1895 \\
1900 \\
1905 \\
1910 \\
1915 \\
1920 \\
1925 \\
1930 \\
1934 \text { (4 years) }\end{array}$} & $\begin{array}{l}31.13 \\
28.92 \\
28.02 \\
29.07 \\
29.52 \\
29.82 \\
30.24 \\
29.21 \\
28.53 \\
29.43 \\
27.63 \\
\end{array}$ & $\begin{array}{l} \pm \quad 6.50 \\
\pm \quad 1.06 \\
=\quad 4.14 \\
\pm \quad .55 \\
\pm \quad 2.09 \\
\pm \quad 3.46 \\
\pm \quad .07 \\
\pm \quad 2.40 \\
+\quad 5.68 \\
\end{array}$ \\
\hline & Average 29.23 & \\
\hline
\end{tabular}

The computed average is probably somewhat small, owing to the inadequate distribution of stations in mountainous areas of the West. This table seems to indicate that over the United States as a whole the variation shown on the basis of 5-year periods is relatively small when compared with variations for small areas or for individual stations. That the early eighties vere, as here appears, years of extremely high precipitation is further indicated by data that follow. The early nineties and the early thirties were dry in many regions. The following study. 
by broad areas indicates that country-wide changes tend to reflect in reduced degree wider departures that occur in different localities.

Ghanges in annual precipitation, by geographic provinces

In the study of changes in precipitation by basins or States information regarding direction of change and approximate magnitude was desired, rather than information as to amounts over wide areas; therefore, precipitation stations having the longest records in each State were selected as a basis for the analysis. Table 2 lists comparative data for the stations used.

\section{Years of high precipitation}

The long-time stations listed in table 2 are shown in flgure 1 together with lines dram to a time scale showing the year of maximum annual precipitation. Only four of the 22 stations for wich records are available prior to 1850 - Hanover, N. H.; St. Paul, Mlnn.; Farmersburg, Iowa; and Clncinnati, Ohio, - recorded years of maximm precipitation prior to 1850, and only two more - Muscatine, Iowa (1851), and Santa Fe, N. Mex. (1854), - recorded years of maximum precipitation during the period 1850 to 1857. The first year in which five or more stations recorded maximum preclpitation was 1858, when such records were made at Marietta, Ohio;

Marengo and Peoria, IIl.; St. Louis, Mo.; Leavenworth, Kans.; and The Dalles, oreg. The grouping of five of these six staticns in the Central West indicates the probability that 1858 was a year of maximum precipitation in oertain parts of that region. From 1859 to 1878 few stations recorded maximum annual precipitation. There as a wide-spread distribution of stations that recorded maximum annual precipitation during the eighties. The followIng list shows years in which five or more stations recorded maxima:

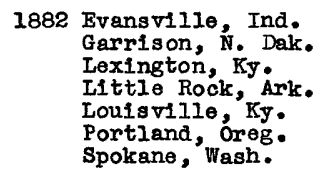

1888 Baltimore, Md.

Iynchburg, Va.

New Brunswick, N. J.

Norfolk, Va.

Richmond, Va. 
Table 2.- Preclpitation at long-time Weather Bureau stations

\begin{tabular}{|c|c|c|c|c|c|c|c|c|c|c|}
\hline \multirow{2}{*}{ Station } & \multirow{2}{*}{$\begin{array}{l}\text { Period } \\
\text { of } \\
\text { record }\end{array}$} & \multirow{2}{*}{$\begin{array}{c}\text { Average } \\
\text { annual } \\
\text { (inchos) }\end{array}$} & \multicolumn{2}{|c|}{ Maximum } & \multicolumn{2}{|c|}{ Minimum } & \multicolumn{2}{|c|}{ Maximum 10-yr. } & \multicolumn{2}{|c|}{ Minimum 10-yr. } \\
\hline & & & Year & $\begin{array}{l}\% \text { of } \\
\text { average }\end{array}$ & Tear & $\begin{array}{c}\% \text { of } \\
\text { average }\end{array}$ & $\begin{array}{l}\text { Period } \\
\text { ending }\end{array}$ & $\begin{array}{l}\text { \% of } \\
\text { average }\end{array}$ & $\begin{array}{l}\text { Period } \\
\text { onding }\end{array}$ & $\begin{array}{l}\% \text { of } \\
\text { average }\end{array}$ \\
\hline Alabama & & & & & & & & & & \\
\hline $\begin{array}{l}\text { Mobile } \\
\text { Montgomery }\end{array}$ & $\begin{array}{l}1871-1934 \\
1873-1934\end{array}$ & $\begin{array}{l}61.61 \\
51.19\end{array}$ & $\begin{array}{l}1881 \\
1929\end{array}$ & $\begin{array}{l}150 \\
153\end{array}$ & $\begin{array}{l}1904 \\
1931\end{array}$ & $\begin{array}{l}64 \\
67\end{array}$ & $\begin{array}{l}1885 \\
1924\end{array}$ & $\begin{array}{l}108 \\
109\end{array}$ & $\begin{array}{l}1910 \\
1904\end{array}$ & $\begin{array}{l}94 \\
92\end{array}$ \\
\hline $\begin{array}{l}\text { Union Springs } \\
\text { Arizong }\end{array}$ & $1868-1934$ & 50.72 & 1912 & 156 & 1927 & 59 & 1909 & 120 & 1881 & 85 \\
\hline $\begin{array}{l}\text { Phoenix } \\
\text { Univ. Arizona }\end{array}$ & $\begin{array}{l}1877-1934 \\
1868-1934\end{array}$ & $\begin{array}{r}7.78 \\
11.52\end{array}$ & $\begin{array}{l}1905 \\
1905\end{array}$ & $\begin{array}{l}254 \\
210\end{array}$ & $\begin{array}{l}1924 \\
1924\end{array}$ & $\begin{array}{l}39 \\
44\end{array}$ & $\begin{array}{l}1914 \\
1884\end{array}$ & $\begin{array}{l}161 \\
119\end{array}$ & $\begin{array}{l}3929 \\
1903\end{array}$ & $\begin{array}{l}82 \\
84\end{array}$ \\
\hline $\begin{array}{l}\text { Yuma } \\
\text { Arkansas }\end{array}$ & $1870-1934$ & 3.47 & 1905 & 329 & 1928 & 14 & 1914 & 140 & 1904 & 57 \\
\hline $\begin{array}{l}\text { Fort Smith } \\
\text { Helena } \\
\text { Little Rock } \\
\text { California }\end{array}$ & $\begin{array}{r}1878-1934 \\
1874-1934 \\
3878-1934\end{array}$ & $\begin{array}{l}38.85 \\
53.47 \\
48.38\end{array}$ & $\begin{array}{l}1890 \\
1877 \\
1882\end{array}$ & $\begin{array}{l}166 \\
151 \\
156\end{array}$ & $\begin{array}{l}1917 \\
1918 \\
1924\end{array}$ & $\begin{array}{l}51 \\
67 \\
65\end{array}$ & $\begin{array}{l}1895 \\
1886 \\
1891\end{array}$ & $\begin{array}{l}118 \\
112 \\
114\end{array}$ & $\begin{array}{l}1919 \\
1904 \\
1925\end{array}$ & $\begin{array}{l}82 \\
86 \\
90\end{array}$ \\
\hline Indio & $1878-1934$ & 3.01 & 1927 & 262 & 1894 & 0 & 1921 & 133 & 1887 & 68 \\
\hline Los Angeles & $1878-1934$ & 15.23 & 1884 & 264 & 1898 & 32 & 1893 & 134 & 1903 & 73 \\
\hline Sacramento & $1850-1934$ & 17.95 & 1884 & 194 & 1932 & 37 & 1889 & 121 & 1932 & 69 \\
\hline San Diego & $1850-1934$ & 10.30 & 1884 & 268 & 1863 & 29 & 1893 & 120 & 1865 & 74 \\
\hline San Francisco & $3850-1934$ & 22.02 & 1884 & 176 & 1917 & 41 & 1887 & 116 & $\left\{\begin{array}{l}1906 \\
1932\end{array}\right.$ & 86 \\
\hline Colorado & & & & & & & & & & \\
\hline $\begin{array}{l}\text { Denver } \\
\text { Las Animas }\end{array}$ & $\begin{array}{l}1872-1934 \\
1867-1934\end{array}$ & $\begin{array}{l}14.05 \\
12.41\end{array}$ & $\begin{array}{l}1909 \\
1923\end{array}$ & $\begin{array}{l}164 \\
172\end{array}$ & $\begin{array}{l}1911 \\
1894\end{array}$ & $\begin{array}{l}55 \\
22\end{array}$ & $\begin{array}{l}1915 \\
1915\end{array}$ & $\begin{array}{l}116 \\
121\end{array}$ & $\begin{array}{l}1904 \\
1897\end{array}$ & $\begin{array}{l}90 \\
72\end{array}$ \\
\hline $\begin{array}{l}\text { Pueblo } \\
\text { Connect1 cut }\end{array}$ & $1884-1934$ & 11.67 & 1921 & 274 & 1934 & 50 & 1923 & 116 & 1934 & 91 \\
\hline $\begin{array}{l}\text { Canton } \\
\text { Delaware }\end{array}$ & $1859-1923$ & 51.12 & 1866 & 157 & 1860 & 68 & 1872 & 117 & 1884 & 87 \\
\hline Bridgevilie & $1891-1934$ & 42.78 & 1906 & 147 & 1930 & 60 & 1911 & 108 & 1918 & 93 \\
\hline Millsboro & $1893-1934$ & 43.90 & 1934 & 144 & 1930 & 57 & $\left\{\begin{array}{l}1906 \\
1907\end{array}\right.$ & 207 & 1918 & 92 \\
\hline Floriaa & & & & & & & & & & \\
\hline $\begin{array}{l}\text { Jacksonville } \\
\text { Key West }\end{array}$ & $\begin{array}{l}1867-1934 \\
1870-1934\end{array}$ & $\begin{array}{l}49.74 \\
38.11\end{array}$ & $\begin{array}{l}1885 \\
1870\end{array}$ & $\begin{array}{l}165 \\
183\end{array}$ & $\begin{array}{l}1927 \\
1893\end{array}$ & $\begin{array}{l}61 \\
58\end{array}$ & $\begin{array}{l}1887 \\
1884\end{array}$ & $\begin{array}{l}118 \\
113\end{array}$ & $\begin{array}{l}1918 \\
1899\end{array}$ & $\begin{array}{l}84 \\
91\end{array}$ \\
\hline $\begin{array}{l}\text { St. Augustine } \\
\text { Georgia }\end{array}$ & $1877-1934$ & 47.97 & 1920 & 149 & 1911 & 66 & 1886 & 109 & 1918 & 89 \\
\hline $\begin{array}{l}\text { Atlanta } \\
\text { Augusta }\end{array}$ & $\begin{array}{l}1868-1934 \\
1869-1934\end{array}$ & $\begin{array}{l}48.27 \\
44.90\end{array}$ & $\begin{array}{l}1929 \\
1929\end{array}$ & $\begin{array}{l}140 \\
164\end{array}$ & $\begin{array}{l}1904 \\
1933\end{array}$ & $\begin{array}{l}69 \\
62\end{array}$ & $\begin{array}{l}1889 \\
1881\end{array}$ & $\begin{array}{l}117 \\
113\end{array}$ & $\begin{array}{l}1934 \\
1934\end{array}$ & $\begin{array}{l}89 \\
91\end{array}$ \\
\hline $\begin{array}{l}\text { Rome } \\
\text { Idaho }\end{array}$ & $1866-1934$ & 49.36 & 1932 & 157 & 1867 & 64 & 1920 & 114 & 1890 & 88 \\
\hline $\mathrm{B} 01 \mathrm{se}$ & $1868-1934$ & 13.10 & 1871 & 197 & 1868 & 51 & 1879 & 121 & 1933 & 86 \\
\hline Moscow & $1892-1934$ & 23.08 & 1913 & 131 & 1911 & 48 & 1903 & 102 & 1931 & 88 \\
\hline $\begin{array}{l}\text { Porthill } \\
\text { Illinois }\end{array}$ & $1890-1934$ & .02 & 1893 & 193 & 1929 & 62 & 2901 & 134 & 1931 & 101 \\
\hline Chicago & $1871-1934$ & $32 \cdot 86$ & 1883 & 140 & 1934 & 69 & 1885 & 121 & 1901 & 90 \\
\hline $\begin{array}{l}\text { Marengo } \\
\text { Peoria } \\
\text { Indiana }\end{array}$ & $\begin{array}{l}1856-1934 \\
1856-1934\end{array}$ & $\begin{array}{l}33.11 \\
34.89\end{array}$ & $\begin{array}{l}1858 \\
1858\end{array}$ & $\begin{array}{l}152 \\
153\end{array}$ & $\begin{array}{l}1901 \\
1910\end{array}$ & $\begin{array}{l}59 \\
66\end{array}$ & $\begin{array}{l}1885 \\
1884\end{array}$ & $\begin{array}{l}109 \\
111\end{array}$ & $\begin{array}{l}1904 \\
1894\end{array}$ & $\begin{array}{l}91 \\
91\end{array}$ \\
\hline $\begin{array}{l}\text { Evansville } \\
\text { Indianapolis } \\
\text { Lafayette } \\
\text { Iowa }\end{array}$ & $\begin{array}{l}1877-1934 \\
1867-1934 \\
1880-1934\end{array}$ & $\begin{array}{l}43.16 \\
39.90 \\
38.72\end{array}$ & $\begin{array}{l}1882 \\
1876 \\
1927\end{array}$ & $\begin{array}{l}164 \\
145 \\
142\end{array}$ & $\begin{array}{l}1930 \\
1934 \\
1914\end{array}$ & $\begin{array}{l}59 \\
63 \\
65\end{array}$ & $\begin{array}{l}1886 \\
1883 \\
1929\end{array}$ & $\begin{array}{l}115 \\
121 \\
107\end{array}$ & $\begin{array}{l}1933 \\
1908 \\
1919\end{array}$ & $\begin{array}{l}91 \\
91 \\
89\end{array}$ \\
\hline purbuque & $1851-1934$ & 32.90 & 1881 & 168 & 1894 & 59 & 1885 & 125 & 1910 & 87 \\
\hline Farmersburg & $1837-1930$ & 31.67 & 1849 & 169 & 1895 & 58 & & 118 & 1901 & 87 \\
\hline $\begin{array}{l}\text { Muscatine } \\
\text { Kansas }\end{array}$ & $1846-1934$ & 36.72 & 1851 & 203 & 1901 & 58 & 1858 & 130 & 1917 & 85 \\
\hline Hays & $1868-1934$ & 22.91 & 1878 & 154 & 1894 & 52 & 1905 & 116 & 1896 & 88 \\
\hline Lawrence & $1868-1934$ & 36.38 & 1915 & 142 & 1897 & 65 & 1909 & 110 & 1934 & 88 \\
\hline Ieavenworth & $1836-1934$ & 34.74 & 1858 & 172 & 1864 & 42 & 1885 & 117 & 1847 & 83 \\
\hline $\begin{array}{l}\text { Manhattan } \\
\text { Kentucky }\end{array}$ & $1858-1934$ & & 1915 & 161 & 1860 & 48 & 1911 & 116 & 1875 & 85 \\
\hline Ioxington & $1858-1934$ & $43 \cdot 35$ & 1882 & 146 & 1930 & 57 & 1888 & 116 & 1908 & 85 \\
\hline $\begin{array}{l}\text { Loulsville } \\
\text { Paduceh }\end{array}$ & $\begin{array}{l}1871-1934 \\
1882-1934\end{array}$ & $\begin{array}{l}43.26 \\
46.56\end{array}$ & $\begin{array}{l}1882 \\
1927\end{array}$ & $\begin{array}{l}131 \\
155\end{array}$ & $\begin{array}{l}1930 \\
1887\end{array}$ & $\begin{array}{l}55 \\
519\end{array}$ & $\begin{array}{l}2884 \\
1934\end{array}$ & $\begin{array}{l}315 \\
110\end{array}$ & $\begin{array}{l}1934 \\
1894\end{array}$ & $\begin{array}{l}89 \\
82\end{array}$ \\
\hline
\end{tabular}


Table 2.- Precipitation at long-time Weather Bureau stations.-Continued

\begin{tabular}{|c|c|c|c|c|c|c|c|c|c|c|}
\hline \multirow{2}{*}{ Station } & \multirow{2}{*}{$\begin{array}{l}\text { Perlod } \\
\text { of } \\
\text { record }\end{array}$} & \multirow{2}{*}{$\begin{array}{c}\text { Average } \\
\text { annual } \\
\text { (1nches) }\end{array}$} & \multicolumn{2}{|c|}{ Maximum } & \multicolumn{2}{|c|}{ Minimum } & \multicolumn{2}{|c|}{ Maximum 10-yr. } & \multicolumn{2}{|c|}{ Minjmum $10-\mathrm{yr}$} \\
\hline & & & Year & $\begin{array}{c}\% \text { of } \\
\text { average }\end{array}$ & Year & $\left|\begin{array}{c}\text { To } \\
\text { average }\end{array}\right|$ & $\begin{array}{l}\text { Period } \\
\text { ending }\end{array}$ & $\begin{array}{l}\text { क् of } \\
\text { average }\end{array}$ & $\begin{array}{l}\text { Period } \\
\text { ending }\end{array}$ & $\begin{array}{l}\text { \% of } \\
\text { average }\end{array}$ \\
\hline Iouisiana & & & & & & & & & & \\
\hline Monroe & $1886-1934$ & 51.72 & 1920 & 154 & 1899 & 63 & 1928 & 116 & 1902 & 86 \\
\hline New Orleans & $1870-1934$ & 57.46 & 1375 & 149 & 1899 & 54 & 1934 & 116 & 1899 & 82 \\
\hline $\begin{array}{l}\text { Srreveport } \\
\text { Malne }\end{array}$ & $1872-1934$ & 43.37 & 7880 & 154 & 1899 & 55 & 1885 & 128 & 1899 & 86 \\
\hline Cornish & $1857-1924$ & 46.12 & 1902 . & 137 & 1880 & 73 & 1902 & 114 & 1915 & 88 \\
\hline Gardiner & $133^{7}-1934$ & 43.00 & 1287 & 127 & 1838 & 70 & 1859 & 112 & 1914 & 90 \\
\hline Orono & $1970-1930$ & 41.80 & 1926 & 130 & 1921 & 62 & 1891 & 116 & $\left\{\begin{array}{l}1923 \\
1924\end{array}\right.$ & 89 \\
\hline Maryland & & & & & & & & & & \\
\hline Baitlmore & $1817-1934$ & $42 \cdot 56$ & $1=89$ & 146 & 1930 & 51 & 1892 & 120 & 1872 & 73 \\
\hline $\begin{array}{l}\text { Emitsburg } \\
\text { Massachusetts }\end{array}$ & $1867-1934$ & 43.86 & 1912 & 149 & 1328 & 59 & $19 \approx 0$ & 108 & 1901 & 93 \\
\hline Boston & $1818-1934$ & 40.14 & 1863 & 169 & 1922 & 68 & 1870 & 143 & 1914 & 88 \\
\hline $\begin{array}{l}\text { Lowell } \\
\text { Mi chj gen }\end{array}$ & $1826-1934$ & 41.47 & 1380 & 143 & 1914 & 67 & 1933 & 113 & 1917 & 81 \\
\hline Detroit & $1971-1934$ & 32.05 & 1880 & 149 & 1889 & 06 & 1882 & 118 & 1991 & 90 \\
\hline Lans1ng & $1364-1934$ & 31.43 & 1883 & 154 & 1930 & 59 & 1885 & 115 & 1895 & 86 \\
\hline $\begin{array}{l}\text { Marquet te } \\
\text { Minnesota }\end{array}$ & $1872-1934$ & 32.47 & 1918 & 129 & 1925 & 61 & 1884 & 105 & 1932 & 92 \\
\hline Duluth & $1871-1934$ & 27.94 & 1279 & 162 & 1910 & 65 & 1882 & 127 & 1926 & 89 \\
\hline Minneapolis & $1060-1934$ & 27.06 & $1848^{\prime}$ & 151 & 1910 & 42 & 1876 & 121 & 1934 & 97 \\
\hline $\begin{array}{l}\text { St. Faul } \\
\text { Mississ1pp1 }\end{array}$ & $1837-1933$ & 27.27 & 1849 & 132 & 1910 & 37 & 1874 & 118 & 1891 & 87 \\
\hline canton & $1983-1934$ & 49.07 & 1923 & 139 & 1924 & 59 & 1923 & 106 & 1933 & 93 \\
\hline Columbus & $\begin{array}{l}1356-1870 \\
1875-1934\end{array}$ & 53.93 & 1932 & 143 & 1904 & 67 & 1884 & 110 & 1910 & 89 \\
\hline Vicksburg & $\begin{array}{l}1840-1853 \\
1872-1934\end{array}$ & 51.93 & 1880 & 162 & 1924 & EO & 1884 & 122 & 1933 & 88 \\
\hline Missouri & & & & & & & & & & \\
\hline Hermann & $1875-1934$ & .38 .50 & 1927 & 137 & 1901 & 58 & 1929 & 107 & 1887 & 92 \\
\hline Oregon & $1856-1934$ & 35.95 & 1902 & 141 & 1910 & 59 & 1905 & 115 & 1918 & 85 \\
\hline $\begin{array}{l}\text { St. Iouis City } \\
\text { Montana }\end{array}$ & $1837-1934$ & 37.44 & 1858 & 254 & 1930 & 62 & Ir 59 & $12 a$ & 1908 & 92 \\
\hline Ag. Colloge & $\begin{array}{l}1874-1885 \\
1893-1934\end{array}$ & 18.35 & 1385 & 178 & 1934 & 57 & 1385 & 117 & 1902 & 94 \\
\hline Havre & $1880-1934$ & 13.90 & 1884 & 135 & 1905 & 49 & 1889 & 103 & 1933 & 98 \\
\hline $\begin{array}{l}\text { Miles ifty } \\
\text { Nebraska. }\end{array}$ & $1978-1934$ & 13.79 & 1879 & 165 & 1934 & 40 & 1915 & 122 & 1890 & 80 \\
\hline Bia1r & $1868-19.34$ & 29.37 & 1569 & 162 & 1934 & 61 & 1878 & 114 & 1895 & 83 \\
\hline $\begin{array}{l}\text { North Platte } \\
\text { Novada }\end{array}$ & $1875-1934$ & 18.39 & 1915 & 178 & 1931 & 54 & 1809 & 316 & 1901 & 82 \\
\hline Battle Mt. & $1870-1934$ & 6.40 & 1284 & 219 & 1318 & 38 & 1992 & 134 & 1923 & 74 \\
\hline Elko & $1870-1934$ & 9.51 & 1904 & 223 & 1072 & 11 & 1905 & 159 & 1380 & 51 \\
\hline $\begin{array}{l}\text { Imlay } \\
\text { New Hampshire }\end{array}$ & $1870-1934$ & 5.45 & 1290 & 285 & 1929 & 31 & 1927 & 130 & 1903 & 68 \\
\hline Hanover & $\begin{array}{l}1835-1855 \\
1867-1934\end{array}$ & 35.25 & 1943 & 158 & 1871 & 64 & 1851 & 127 & $1 \Omega 84$ & 83 \\
\hline $\begin{array}{l}\text { Lakeport } \\
\text { New Jersey }\end{array}$ & $1857-1932$ & 41.54 & 1888 & 133 & 1894 & 75 & 1893 & 109 & 1330 & 82 \\
\hline $\begin{array}{l}\text { New Brunsw1ck } \\
\text { New Mex1co }\end{array}$ & $1854-1934$ & 45.47 & 1889 & 135 & $\left\{\begin{array}{l}1930 \\
1932\end{array}\right.$ & 72 & 1874 & 115 & 1934 & 85 \\
\hline Ag. College & $\begin{array}{l}1851-1861 \\
1865-1934\end{array}$ & 8.57 & 1905 & 199 & 1873 & 41 & 1906 & 125 & 1880 & 83 \\
\hline San Marcial & $\begin{array}{l}1850-1862 \\
1865-1934\end{array}$ & 9.13 & 1859 & 269 & 1901 & 12 & 1884 & 123 & 1901 & 73 \\
\hline $\begin{array}{l}\text { Santa Fe } \\
\text { New York }\end{array}$ & $1850-1934$ & 14.27 & 1854 & 174 & 1917 & 35 & 1861 & 119 & 1875 & 88 \\
\hline AIbany & $1826-1934$ & 38.38 & 1871 & 148 & 1930 & 66 & 1878 & 113 & 1914 & 78 \\
\hline $\begin{array}{l}\text { New York } \\
\text { Rochester }\end{array}$ & & 42.99 & 1859 & 139 & 1835 & 67 & 1935 & 116 & & 81 \\
\hline $\begin{array}{l}\text { North Carolina } \\
\text { North }\end{array}$ & $1829-1934$ & 32.83 & 1873 & 152 & 1834 & 52 & 1878 & 118 & 1841 & 86 \\
\hline Lenoir & $1872-1934$ & 51.44 & 1901 & 159 & 1933 & 63 & 1906 & 108 & 1934 & 85 \\
\hline $\begin{array}{l}\text { Weldon } \\
\text { Wilmington }\end{array}$ & $\begin{array}{l}1872-1934 \\
1871-1934\end{array}$ & $\begin{array}{l}45.97 \\
46.93\end{array}$ & $\begin{array}{l}1891 \\
1877\end{array}$ & 130 & $\begin{array}{l}1931 \\
1909\end{array}$ & $\begin{array}{l}62 \\
59\end{array}$ & 1896 & $\begin{array}{l}113 \\
127\end{array}$ & 1934 & $\begin{array}{l}87 \\
89\end{array}$ \\
\hline & & & 1877 & 178 & 1909 & 59 & 1885 & & & \\
\hline
\end{tabular}


Table 2.- Prec1pitation at long-time Weather Bureau stations-Continued

\begin{tabular}{|c|c|c|c|c|c|c|c|c|c|c|}
\hline \multirow[b]{2}{*}{ Station } & \multirow{2}{*}{$\begin{array}{l}\text { Period } \\
\text { of } \\
\text { record }\end{array}$} & \multirow{2}{*}{$\begin{array}{c}\text { Average } \\
\text { annual } \\
\text { (1nches) }\end{array}$} & \multicolumn{2}{|c|}{ Maxinum } & \multicolumn{2}{|c|}{ IInlmum } & \multicolumn{2}{|c|}{ Yaximum 10-yr. } & \multicolumn{2}{|c|}{ Hinimum 10-yr. } \\
\hline & & & Year & $\begin{array}{c}\% \text { of } \\
\text { average }\end{array}$ & Year & $\begin{array}{c}\% \text { of } \\
\text { average }\end{array}$ & $\begin{array}{l}\text { Perlod } \\
\text { ending }\end{array}$ & $\begin{array}{c}\% \text { of } \\
\text { average }\end{array}$ & $\begin{array}{l}\text { Perlod } \\
\text { ending }\end{array}$ & $\begin{array}{c}\text { \% of } \\
\text { average }\end{array}$ \\
\hline North Dekota & & & & & & & & & & \\
\hline Devil's Lake & $\begin{array}{l}1870-1890 \\
1897-1934 \\
1870-1883\end{array}$ & 18.04 & 1921 & 141 & 1889 & 58 & 1905 & 108 & 1917 & 92 \\
\hline $\begin{array}{l}\text { Garrison } \\
\text { Ohio }\end{array}$ & $1892-1934$ & 16.38 & 1882 & 167 & 1874 & 48 & 1884 & 107 & 1877 & 86 \\
\hline $\begin{array}{l}\text { Cincinnat1 } \\
\text { Cleveland } \\
\text { Marletta } \\
\text { Toledo } \\
\text { Oklahoma }\end{array}$ & $\begin{array}{l}1835-1934 \\
1871-1934 \\
1826-1934 \\
1861-1934\end{array}$ & $\begin{array}{l}38.55 \\
33.82 \\
42.25 \\
32.03\end{array}$ & $\begin{array}{l}1847 \\
1878 \\
1858 \\
1881\end{array}$ & $\begin{array}{l}169 \\
158 \\
146 \\
144\end{array}$ & $\begin{array}{l}1901 \\
1934 \\
1930 \\
1894\end{array}$ & $\begin{array}{l}47 \\
65 \\
59 \\
67\end{array}$ & $\begin{array}{l}1855 \\
1885 \\
1891 \\
1870\end{array}$ & $\begin{array}{l}131 \\
117 \\
110 \\
123\end{array}$ & $\begin{array}{l}1903 \\
1923 \\
1901 \\
1902\end{array}$ & $\begin{array}{l}84 \\
87 \\
91 \\
87\end{array}$ \\
\hline $\begin{array}{l}\text { Lawton } \\
\text { Oklahoma City } \\
\text { Tulsa } \\
\text { Oregon }\end{array}$ & $\begin{array}{l}1871-1934 \\
1891-1934 \\
1888-1934\end{array}$ & $\begin{array}{l}31.53 \\
31.15 \\
37.40\end{array}$ & $\begin{array}{l}1905 \\
1908 \\
1915\end{array}$ & $\begin{array}{l}159 \\
167 \\
168\end{array}$ & $\begin{array}{l}1901 \\
1901 \\
1896\end{array}$ & $\begin{array}{l}51 \\
51 \\
64\end{array}$ & $\begin{array}{l}1908 \\
1927 \\
1929\end{array}$ & $\begin{array}{l}116 \\
111 \\
115\end{array}$ & $\begin{array}{l}1918 \\
1918 \\
1897\end{array}$ & $\begin{array}{l}90 \\
85 \\
87\end{array}$ \\
\hline Astoria & $1854-1934$ & 77.05 & 1933 & 148 & 1884 & 64 & $\left\{\begin{array}{l}1880 \\
1902\end{array}\right.$ & 110 & 1931 & 89 \\
\hline $\begin{array}{l}\text { Portland } \\
\text { The Dalles }\end{array}$ & $\left\{\begin{array}{l}1872-1934 \\
1853-1865 \\
1875-1034\end{array}\right.$ & $\begin{array}{l}41.62 \\
15.72\end{array}$ & $\begin{array}{l}1882 \\
1858\end{array}$ & $\begin{array}{l}162 \\
277\end{array}$ & $\begin{array}{l}1929 \\
1889\end{array}$ & $\begin{array}{l}63 \\
48\end{array}$ & $\begin{array}{l}1883 \\
1865\end{array}$ & $\begin{array}{l}134 \\
165\end{array}$ & $\begin{array}{l}1931 \\
1931\end{array}$ & $\begin{array}{l}85 \\
77\end{array}$ \\
\hline$\frac{\text { Pennsyl vanla }}{\text { Ph1ladelphia }}$ & $\left\{\begin{array}{l}1820-1934 \\
1839-1865\end{array}\right.$ & 40.41 & 1867 & 151 & 1922 & 72 & 1874 & 125 & 1886 & 91 \\
\hline $\begin{array}{l}\text { PIttsburgh } \\
\text { Rhode Is land }\end{array}$ & $1872-1934$ & 36.17 & 1890 & 140 & 1930 & 63 & 1873 & 113 & 1846 & 93 \\
\hline $\begin{array}{l}\text { Providence } \\
\text { South Carolina }\end{array}$ & $1832-1934$ & 39.19 & 1898 & 162 & 1914 & 75 & 1895 & 130 & 1918 & 90 \\
\hline $\begin{array}{l}\text { Comden } \\
\text { Charleston }\end{array}$ & $\mid \begin{array}{r}1850-1934 \\
1738-1765 \\
1832-1934\end{array}$ & $\begin{array}{l}45.56 \\
45.22\end{array}$ & $\begin{array}{l}1928 \\
1876\end{array}$ & $\begin{array}{l}183 \\
173\end{array}$ & $\begin{array}{l}1879 \\
1850\end{array}$ & $\begin{array}{l}67 \\
52\end{array}$ & $\begin{array}{l}1929 \\
1879\end{array}$ & $\begin{array}{l}119 \\
139\end{array}$ & $\begin{array}{l}1888 \\
1909\end{array}$ & $\begin{array}{l}85 \\
82\end{array}$ \\
\hline South Dakota & & & & & & & & & & \\
\hline $\begin{array}{l}\text { Huron } \\
\text { Rapid city } \\
\text { Yankton } \\
\text { Tennessee }\end{array}$ & $\begin{array}{l}1882-1934 \\
1888-1934 \\
1874-1934\end{array}$ & $\begin{array}{l}20.65 \\
17.98 \\
25.30\end{array}$ & $\begin{array}{l}1914 \\
1915 \\
1881\end{array}$ & $\begin{array}{l}146 \\
151 \\
162\end{array}$ & $\begin{array}{l}1925 \\
1931 \\
1894\end{array}$ & $\begin{array}{l}49 \\
52 \\
57\end{array}$ & $\begin{array}{l}1921 \\
1929 \\
1883\end{array}$ & $\begin{array}{l}108 \\
115 \\
114\end{array}$ & $\begin{array}{l}1934 \\
1900 \\
1934\end{array}$ & $\begin{array}{l}75 \\
79 \\
78\end{array}$ \\
\hline Ciarksvillo & 1854-1934 & 48.46 & 1919 & 152 & 1918 & 70 & 1928 & 116 & 1918 & 93 \\
\hline $\begin{array}{l}\text { Knoxvilie } \\
\text { Texas }\end{array}$ & $1871-1934$ & 47.38 & 1875 & 156 & 1930 & 71 & 1882 & 116 & 1900 & 93 \\
\hline Austin & $1856-1934$ & 34.08 & 1919 & 190 & 1917 & 46 & 1927 & 1.19 & 1912 & 82 \\
\hline $\begin{array}{l}\text { Browns vilile } \\
\text { Galveston } \\
\text { Utah }\end{array}$ & $\begin{array}{l}1871-1934 \\
1872-1934\end{array}$ & $\begin{array}{l}27.40 \\
44.77\end{array}$ & $\begin{array}{l}1886 \\
1900\end{array}$ & $\begin{array}{l}21.9 \\
175\end{array}$ & $\begin{array}{l}1917 \\
1917\end{array}$ & $\begin{array}{l}44 \\
48\end{array}$ & $\begin{array}{l}1887 \\
1882\end{array}$ & $\begin{array}{l}145 \\
119\end{array}$ & $\begin{array}{l}1902 \\
1898\end{array}$ & $\begin{array}{l}64 \\
81\end{array}$ \\
\hline$M O Q b$ & $1890-1934$ & 9.41 & $\begin{array}{l}1918 \\
1927\end{array}$ & 170 & 1898 & 46 & 1918 & 121 & 1904 & 80 \\
\hline $\begin{array}{l}\text { Salt Lake City } \\
\text { Vermont }\end{array}$ & $1874-1934$ & 16.13 & 1875 & 147 & 1890 & 64 & 1915 & 108 & $\begin{array}{l}1896 \\
1933\end{array}$ & 91 \\
\hline Burilngton & $\mid \begin{array}{l}1838-1866 \\
1872-1934\end{array}$ & 31.61 & 1897 & 138 & 1881 & 66 & 1866 & 1.12 & 1888 & 89 \\
\hline $\begin{array}{l}\text { Chelgea } \\
\text { VIrginia }\end{array}$ & $2886-1934$ & 35.78 & 1897 & 134 & 1899 & 76 & 1895 & 112 & 1917 & 89 \\
\hline $\begin{array}{l}\text { Lynchiurg } \\
\text { Norfolk } \\
\text { Richmond } \\
\text { Washington }\end{array}$ & $\begin{array}{l}1872-1934 \\
1871-1934 \\
1872-1934\end{array}$ & $\begin{array}{l}40.53 \\
44.09 \\
42.02\end{array}$ & $\begin{array}{l}1889 \\
1889 \\
1889\end{array}$ & $\begin{array}{l}150 \\
160 \\
171\end{array}$ & $\begin{array}{l}1930 \\
1930 \\
1876\end{array}$ & $\begin{array}{l}49 \\
61 \\
66\end{array}$ & $\begin{array}{l}1902 \\
1895 \\
1895\end{array}$ & $\begin{array}{l}115 \\
122 \\
117\end{array}$ & $\begin{array}{l}1930 \\
1934 \\
1885\end{array}$ & $\begin{array}{l}82 \\
83 \\
82\end{array}$ \\
\hline $\begin{array}{l}\text { Spokane } \\
\text { Walla Walla } \\
\text { West V1ratnla }\end{array}$ & $\begin{array}{l}1882-1934 \\
1873-1934\end{array}$ & $\begin{array}{l}16.62 \\
17.01\end{array}$ & $\begin{array}{l}1882 \\
1893\end{array}$ & $\begin{array}{l}156 \\
136\end{array}$ & $\begin{array}{l}1929 \\
1922\end{array}$ & $\begin{array}{l}45 \\
66\end{array}$ & $\begin{array}{l}1902 \\
1902\end{array}$ & $\begin{array}{l}111 \\
112\end{array}$ & $\begin{array}{l}1926 \\
1930\end{array}$ & $\begin{array}{l}77 \\
84\end{array}$ \\
\hline $\begin{array}{l}\text { Rowlesburg } \\
\text { WI consin }\end{array}$ & $1885-1933$ & 48.67 & 1907 & 148 & 1886 & 39 & 1914 & 115 & 1895 & 81 \\
\hline $\begin{array}{l}\text { Milwaukee } \\
\text { Wyoming }\end{array}$ & $1844-1934$ & 30.08 & 1876 & 167 & 1901 & 62 & 1878 & 118 & 1902 & 92 \\
\hline $\begin{array}{l}\text { Cheyenne } \\
\text { Lander }\end{array}$ & $\begin{array}{l}1871-1934 \\
1892-1934\end{array}$ & $\begin{array}{l}14.99 \\
12.63\end{array}$ & $\begin{array}{l}1905 \\
1923\end{array}$ & $\begin{array}{l}151 \\
171\end{array}$ & $\begin{array}{l}1876 \\
1902\end{array}$ & $\begin{array}{l}34 \\
57\end{array}$ & $\begin{array}{l}1930 \\
1924\end{array}$ & $\begin{array}{l}117 \\
118\end{array}$ & $\begin{array}{l}1882 \\
1902\end{array}$ & $\begin{array}{l}65 \\
99\end{array}$ \\
\hline
\end{tabular}




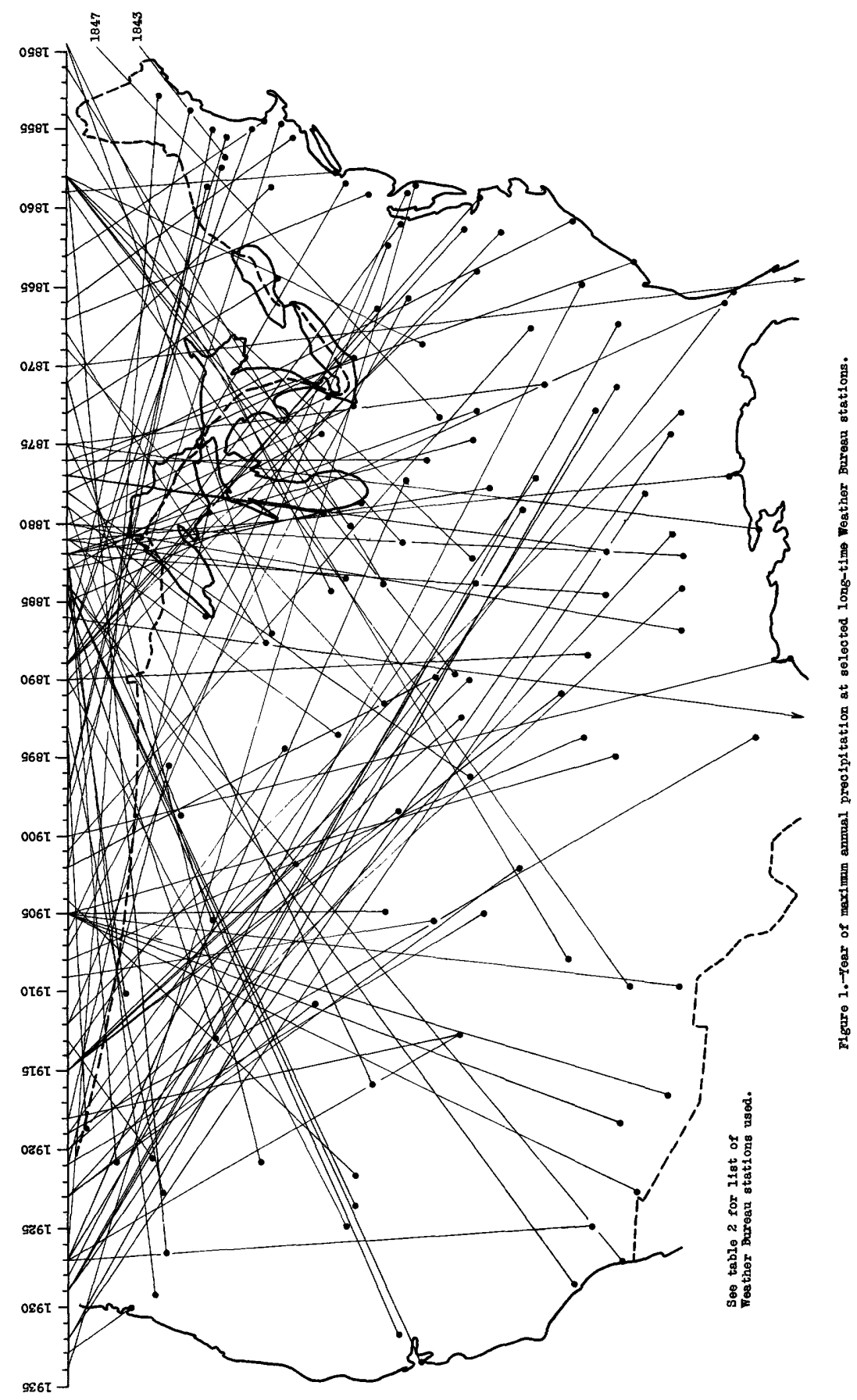


From 1890 to 1904 there are no large groups but 1905, 1915, and 1927 were outstanding wet years, five or more long-time stations having recorded maxima as follows:
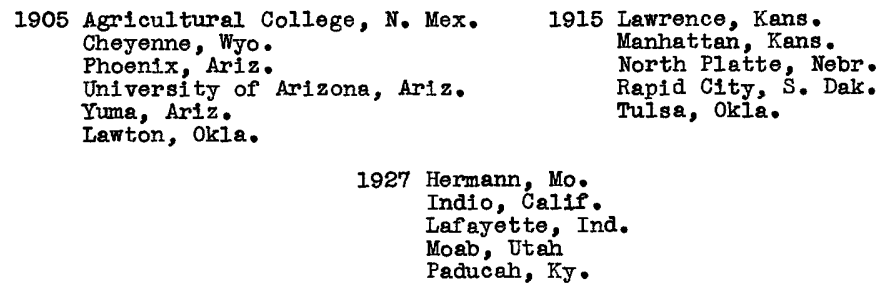

A study of the characteristics of the precipitation at each of the long-time stations for these long-time maxima would be of interest. For all the stations the average ratio of the maximum to the average annual precipitation 1s 1.66. Stations at which the ratio is over 1.80 are situated largely in the Southwest.

\section{Periods of high precipitation}

The long-time stations listed in table 2 are show in figure 2 together with a line drawn to the time scale showing the end of the 10-year period of maximum precipitation. The records for a few stations in the Middle Atlantic and New Fngland areas and a few isolated stations elsewhere show that the 10-year maximum period occurred prior to 1880. The 10-year maxima ended at the greatest number of stations during the period 1884 to 1895 and were especially confined to three 10-year periods, as follows:

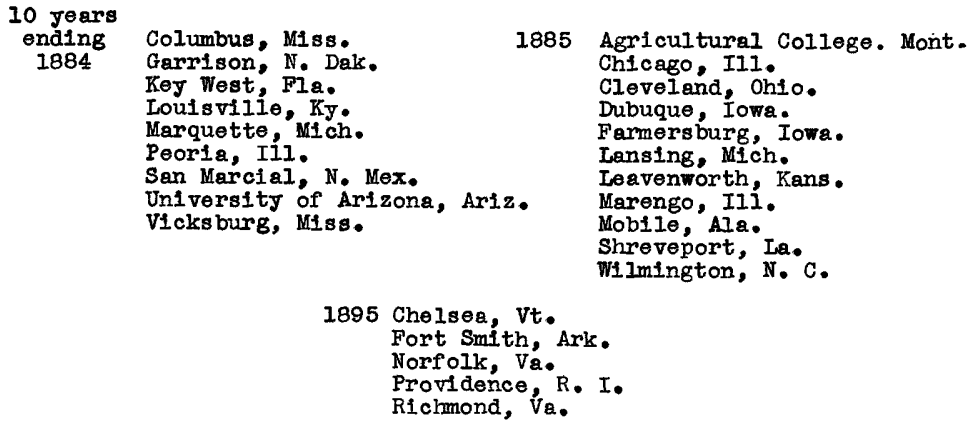

During the period 1923 to 1929 there was also a group of stations, located largely in the South and Southeast, that recorded 10-year 


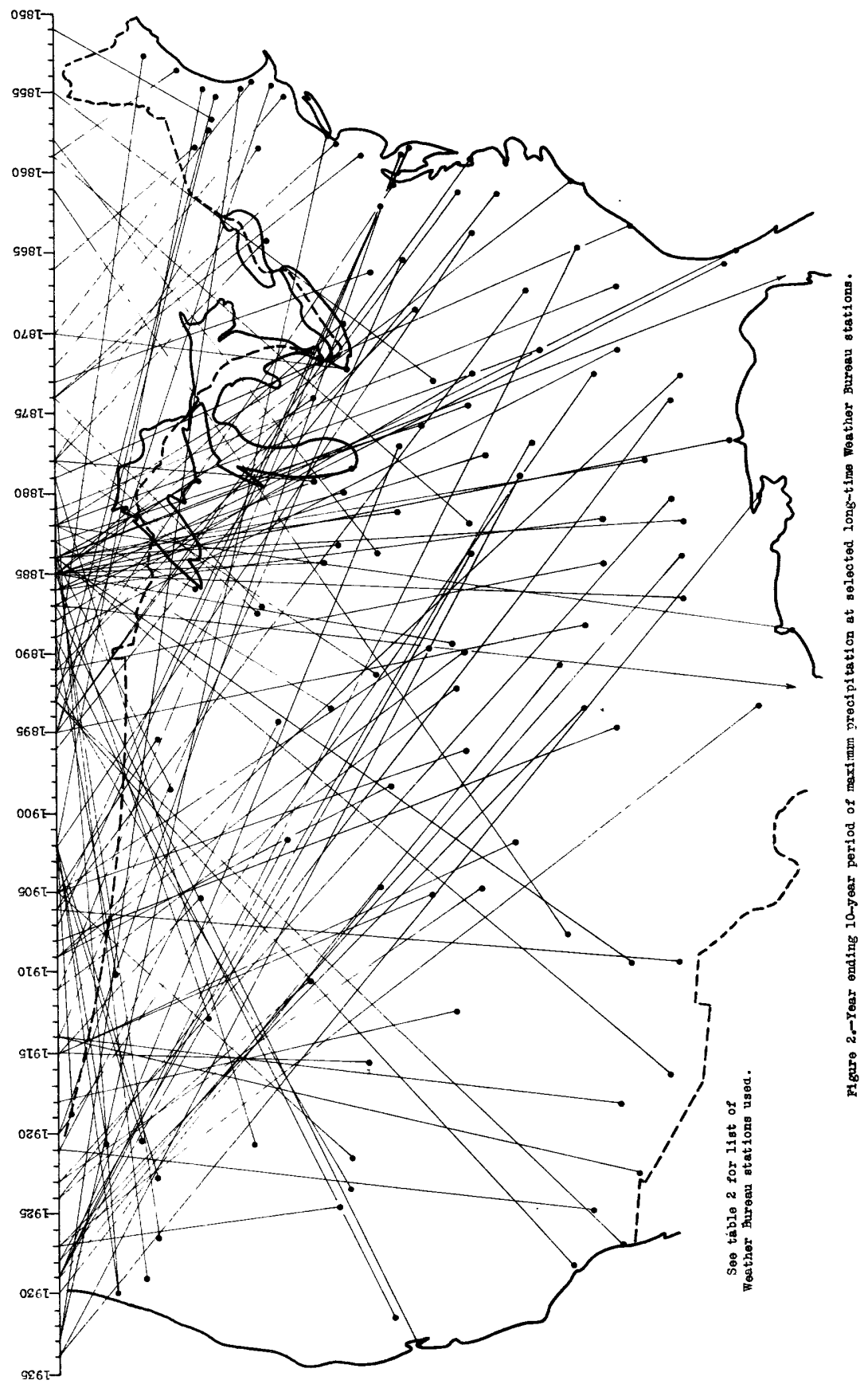


maxima. Since 19304 stations - Lowell (Mass.), New York, Paduch (Ky•), and New Orleans - heve recorded 10-year maxima.

The average ratio of the maximum 10-year period to the mean for all stations is 1.19 .

\section{Years of 10 precipitation}

The long-time atations listed in table 2 are shown plotted on figure 3 together with a line drawn to a time scale shoving the year of minimum precipitation.

Prior to $1851 \mathrm{six}$ of the 22 stations operating at that time recorded their minimum for the period of record - namely, Boston, Mass., 1822; Rochester, N. Y., 1834; New York City, N. Y., 1835; Gardiner, Maine, I838; Lowell, Mass., 1846; Charleston, S. C., 1850. These records indicate that in all probability recent droughts in certain parts of the East as regards precipitation may not have been as severe as some that occurred about a century ago.

During the 40-year period 1851 to 1890 only 23 stations recorded minimum annual precipitation. Beginning with 1894 more and more stations recorded their minima, and except in only a few jears minima were recorded at one or more stations, with the major grouping as follows:

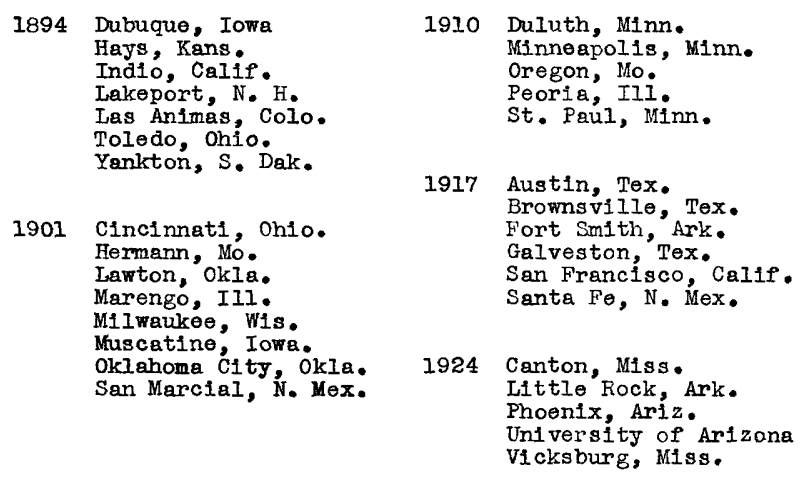




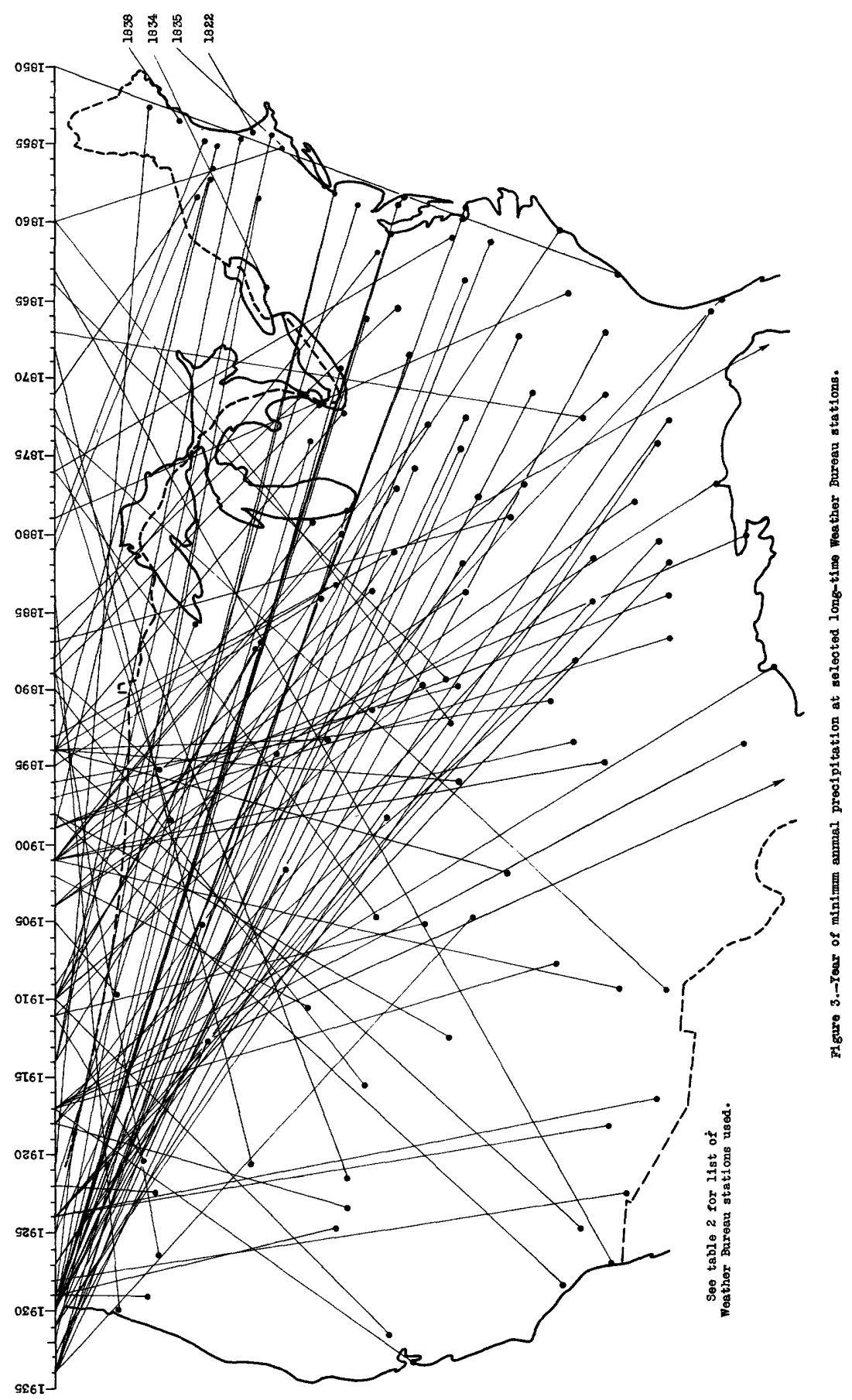




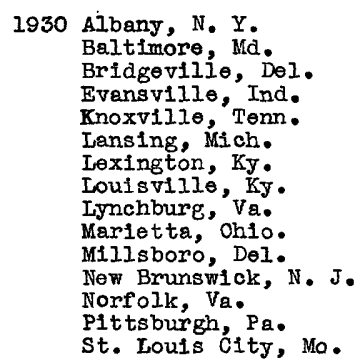

The average ratio of the annual minima for all stations to the

\section{Periods of low precipitation}

The long-time stations listed in table 2 are plotted on figure 4 together with lines drawn to the time scale showing the end of the minimum 10-year period. Four of the long-time stations recorded minimu 10-year periods prior to 1850 - New York, 1840; Rochester, N. Y., 184I; Pittsburgh, Pa., 1846; Leavenworth, Kans., 1847 - Indicating that not only were there individual years of minimum precipitation prior to 1850 but 10-year perlods as well. During the 2l-year period 1850-70 only one longtime station recorded 1ts 10-year minimum, and from 1871 to 1890 only a few scattered stations. Beginning with 1890 more and more stations recorded their 10-year minima, with an exceptionally large number during the last 4 years. outstanding 10-year periods were as follows:

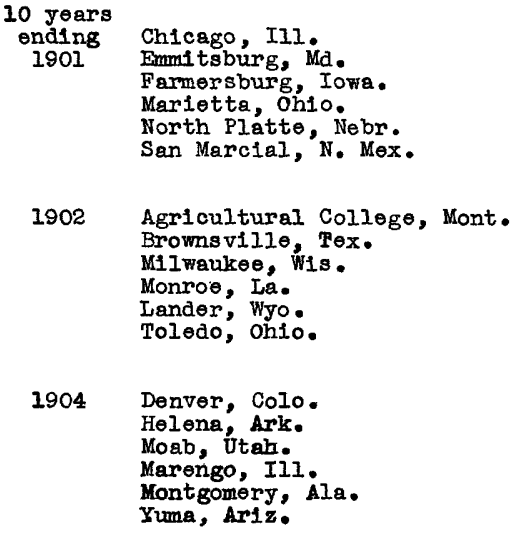




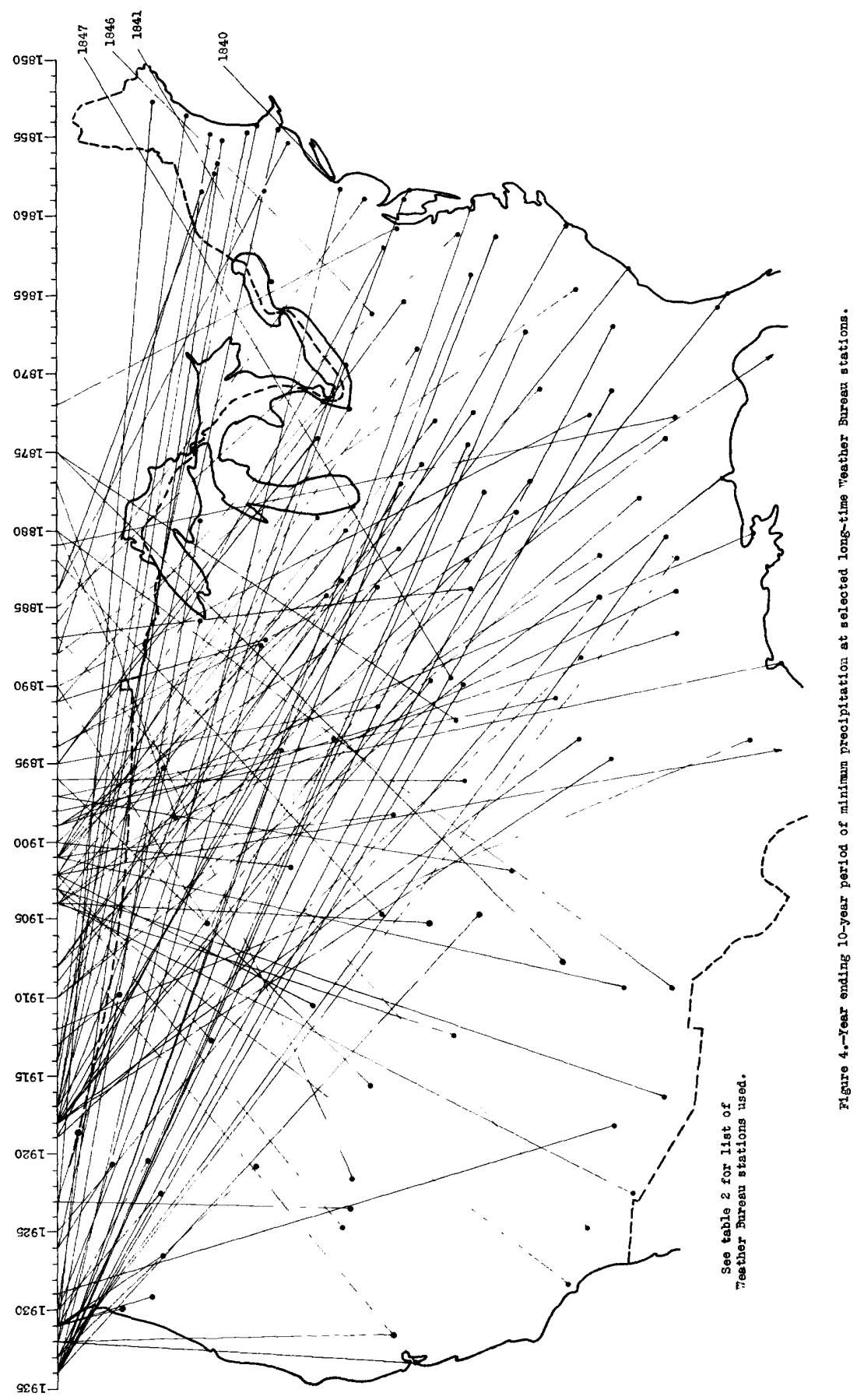



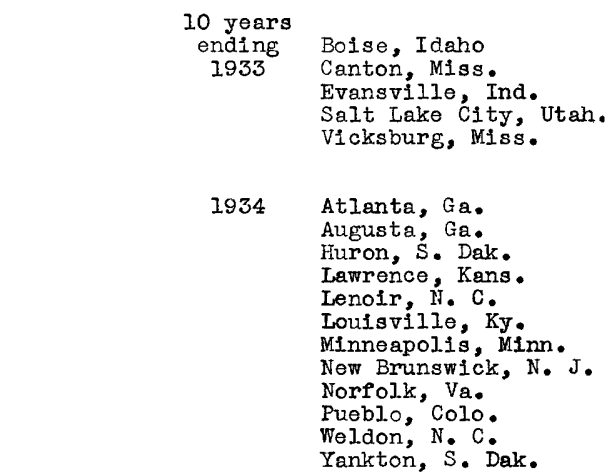

The average ratio of the 10-year minima for all stations to the average is 0.85 .

\section{Changes in precipitation, by areas}

The preceding discussion indicates that periods of either high or low precipitation occur simultaneously over large arers, and as storms over the United States are known to follow fairly well defined paths it has seemed worth while to investigate whether over large areas precipitation. trends might be related to the same general pattern. This suggested a study in the areal grouping of stations that show similar trends of rrecipitation.

The progressive 10-year averages for a number of the long-time stations listed in table 2 and for 5 additional stations were plotted and closely compared, and the stations that showed the same general type of variation were then grouped. It was found that these groups ambraced stations having much the same geographic location, as follows:

1. North Atlantic group (fig.6):

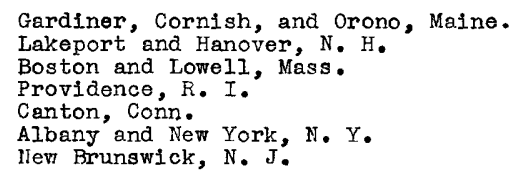

2. Middle Atlantic group (fig. 6):

Philadelphia, Pa.

Baltimore and Emmitsburg, Md.

Lynchburg, Richmond, and Norfolk, Va.

$59550-35-3$ 
3. South Atlantic group (fig. 6):

Wilmington, Lenoir, and Weldon, N. C.

Charleston and Camden, S. C.

Atlanta, Augusta, and Rome, Ga.

Jacksonville, Key West, and St. Augustine, Fla.

4. Great Lakes group (fig. 7):

Milwaukee, Wis.

Marengo, Peoria, and Chicaso, Ill.

Evansvilie, Iaf ayette, and Indianapolis, Ind.

Lansing, Detrolt, and Harquette, Mi ch.

Marietta, Cincinnati, Cleveland, and Toledo, Ohio.

Rochester, N. Y.

Pittsburgh, $\mathrm{Pa}$.

5. Tennessee River group (fig. 7):

Clarksville and Knoxville, Tenn.

Louisville, Lexington, and Paducah, Ky •

6. Gulf group (fig. 7):

Union Springs, Mobile, and Montgomery, Ala.

Vicksburg and Columbus, Miss.

New Orleans and Shreveport, La.

Helena, Fort Smith, and Little Rock, Ark.

Galvestion, Tex.

7. North Central West group (fig. 8):

St. Paul, Minn.

Muscatine and Farmersburg, Towa.

Blair and North Platte, Nebr.

Yankton and Huron, S. Dak.

Dovils Lake and Garrison, N. Dak.

8. Central West group (fig. 8):

Leavenworth, Manhattan, and Hays, Kans.

St. Louis, Oregon, and Hermann, Mo.

9. South Central West group (fig. 8):

Austin, Tex.

Tulsa, Lawton, and Oklahoma City, Okla.

10. Northwest Interior group (fig. 9):

Walla Walla and Spokane, Wash.

The Delles, Oreg.

Bolse, Idaho.

Elko and McGill, Nev.

1I. Northern and Western Plains group (fIg. 9):

Miles City and Havre, Mont.

Cheyenne and Lander, Wyo.

Pueblo, Denver, and Las Animas, Colo. 
12. Great Basin and Southwest group (f1g. 9):

Salt Lake City, Sc1p1o, and Moab, Utah. Phoenix, Yuma, and University Station, Ariz.

Santa Fe, San Marcial, Fort Wingate-McGaffey Ranger Station, and Agriculturai College, N. Mex. Ind10, Calif.

13. North Pacific coast group (fig. 10):

North Head, Wash.

Astoria, Oreg.

14. Central Pacific coast group (fig. 10):

San Francisco and Sacramento, Calif. Imlay and Thorne, Nev.

15. South Pacific coast group (fig. 10):

San Diego and Los Angeles, Calif.

The average of the progressive 10-year averages of the stations in the groups designated above is plotted on figure 5 for annual values and on figures 6 to 10 for annual and seasonal values (Decomber to April, May to Augrast, and September to November). Figures 6 to 10 also show the average precipitation by months for all the stations in each group. That portion of the graphs indicated by a dashed line represents a number of stations less than the total for the group. The figures for these points, however, were adjusted so as to be comparable with the remaining record.

That the average of the 10-year progressive averages for the group of stations shown does not represent the average precipitation over any area is of course recognized, but it is belleved to show the direction of periodic trends and the approximate magnitude of changes in each area. The trends indicated are interesting, and consideration of them may indicate areas where climatic conditions seem to be critical and where further detalled study of precipitation is desirable.

The preliminary study of 10-year progressive average annual preclpitation leads to the following deductions:

(1) The minimum 10-year period at the exceptionally long-time stations at New York City and Rochester, N. Y., Pittsburgh, Pa., and Leavenworth, Kans., ended in the 1840's (fig. 4). The minimum for any 10-year period since 1850 at these stations has been consistently above these early minima, except New Bedford, Mass. which recorded a low for the lo-hear pertod ending 1930 that was 15 percent below the minimum 10-year period prior to 1850. The early history of lakes in sections of the West indicates that in the late 1840's their beds were dry and were crossed by emigrant trails (55). Data from the records and aiaries of early settlers and travelers as complied by 


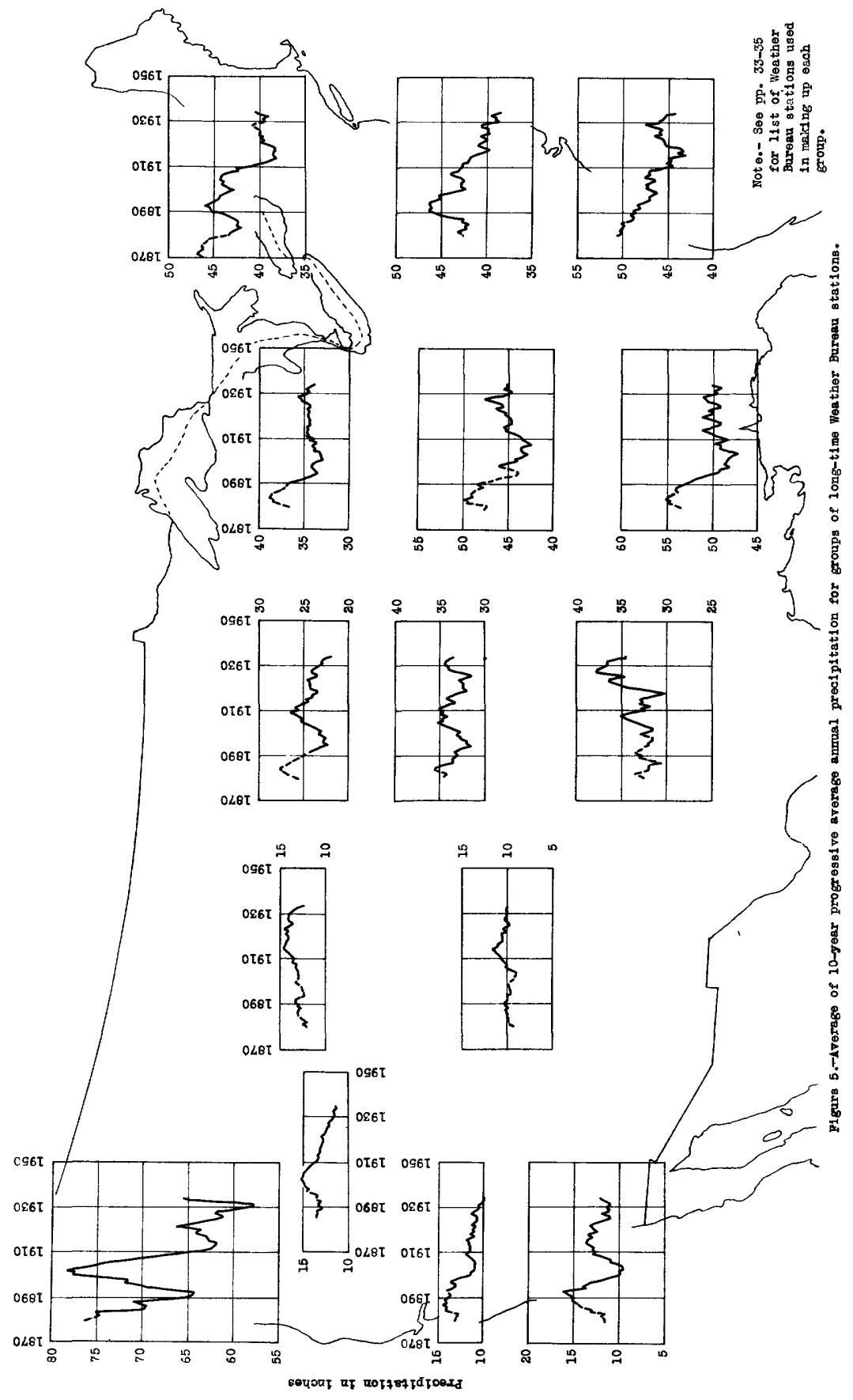



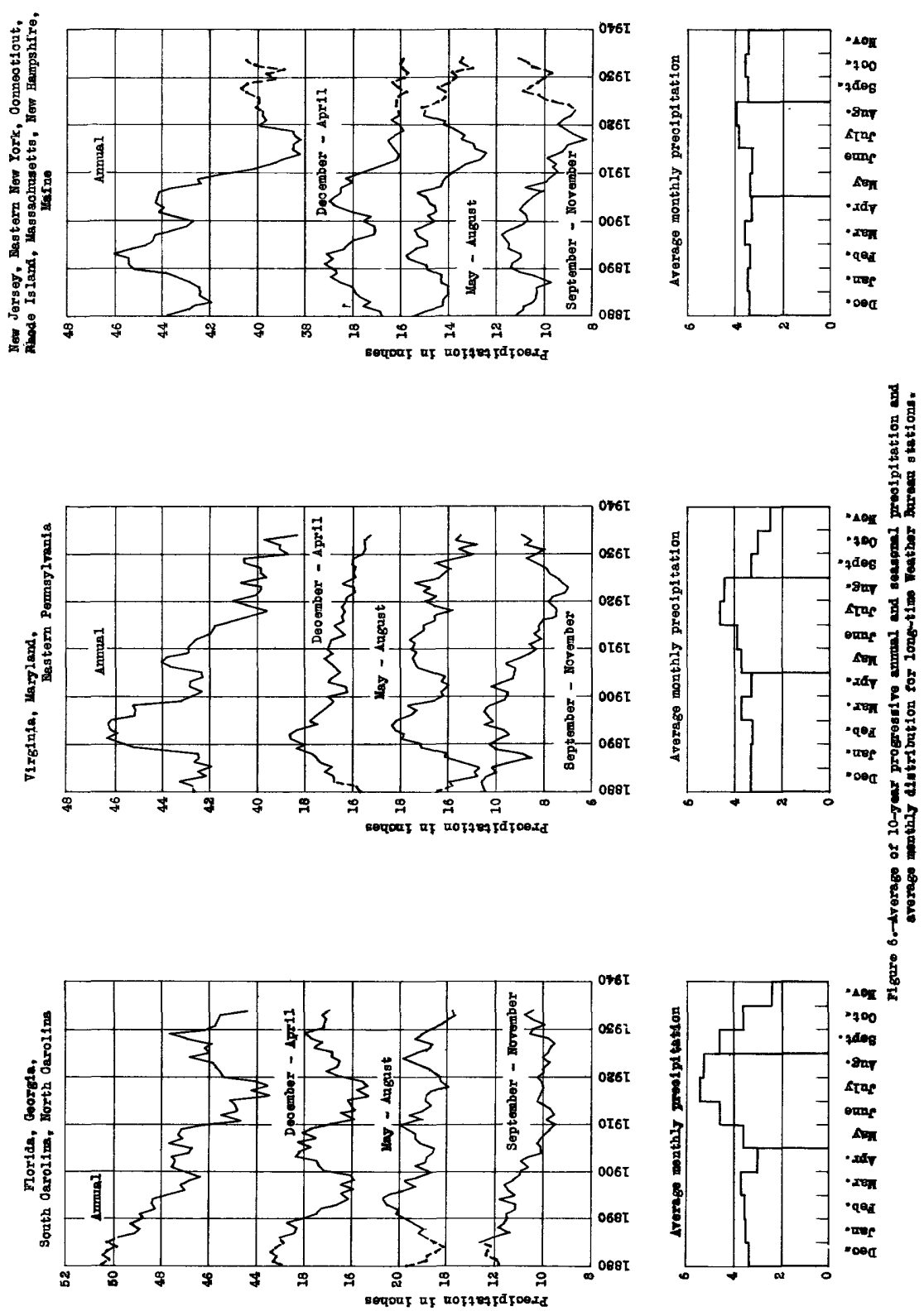

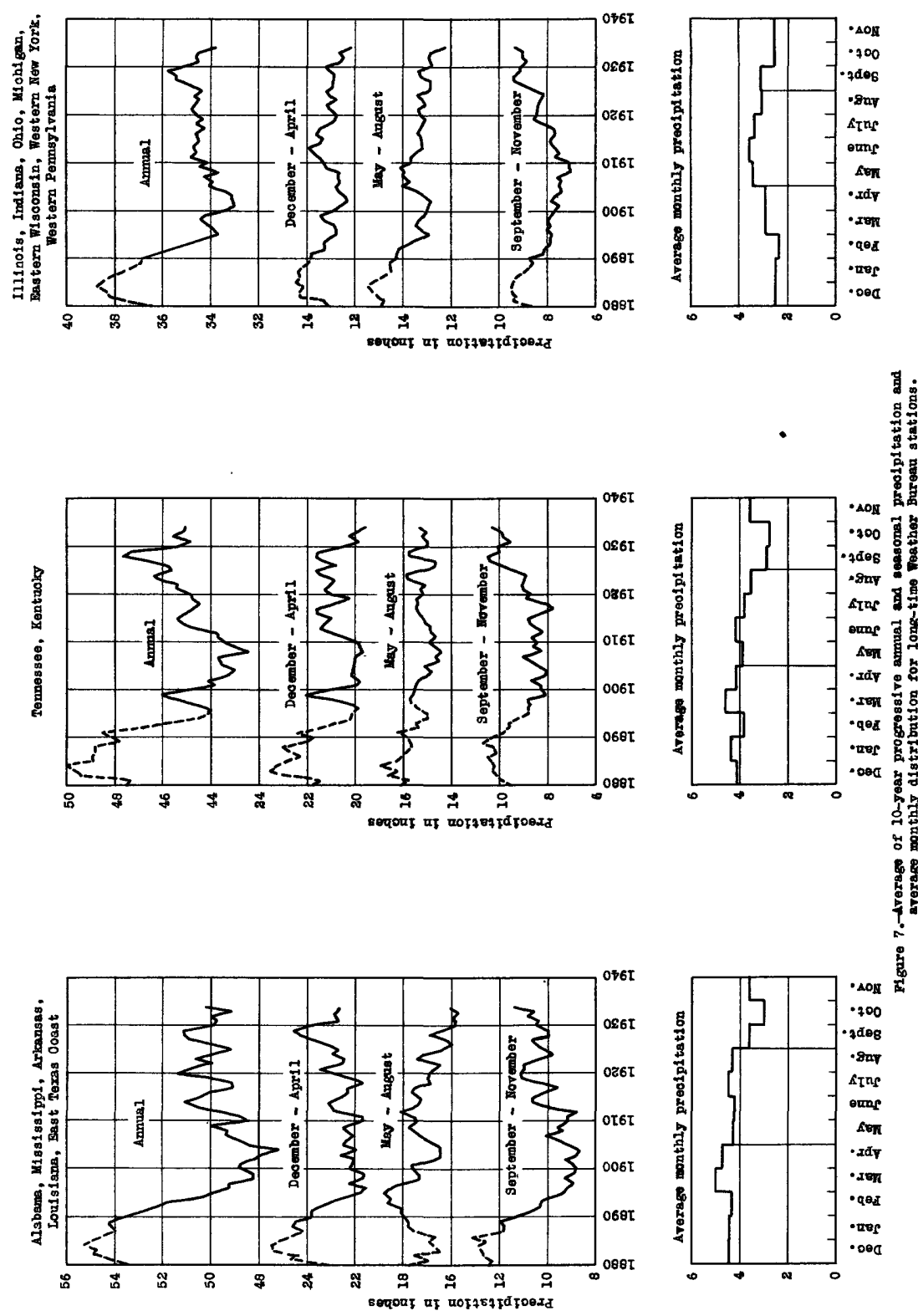

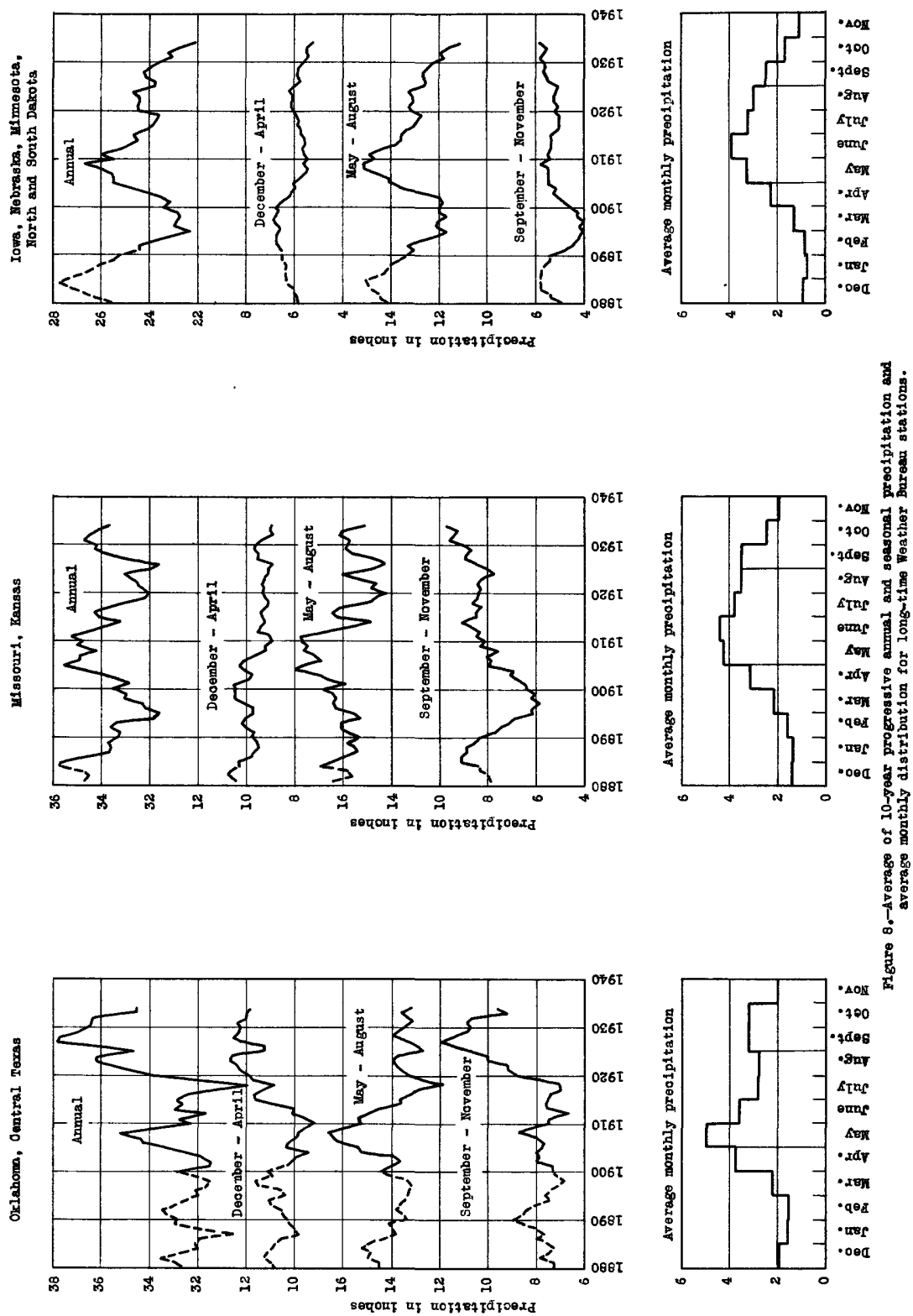

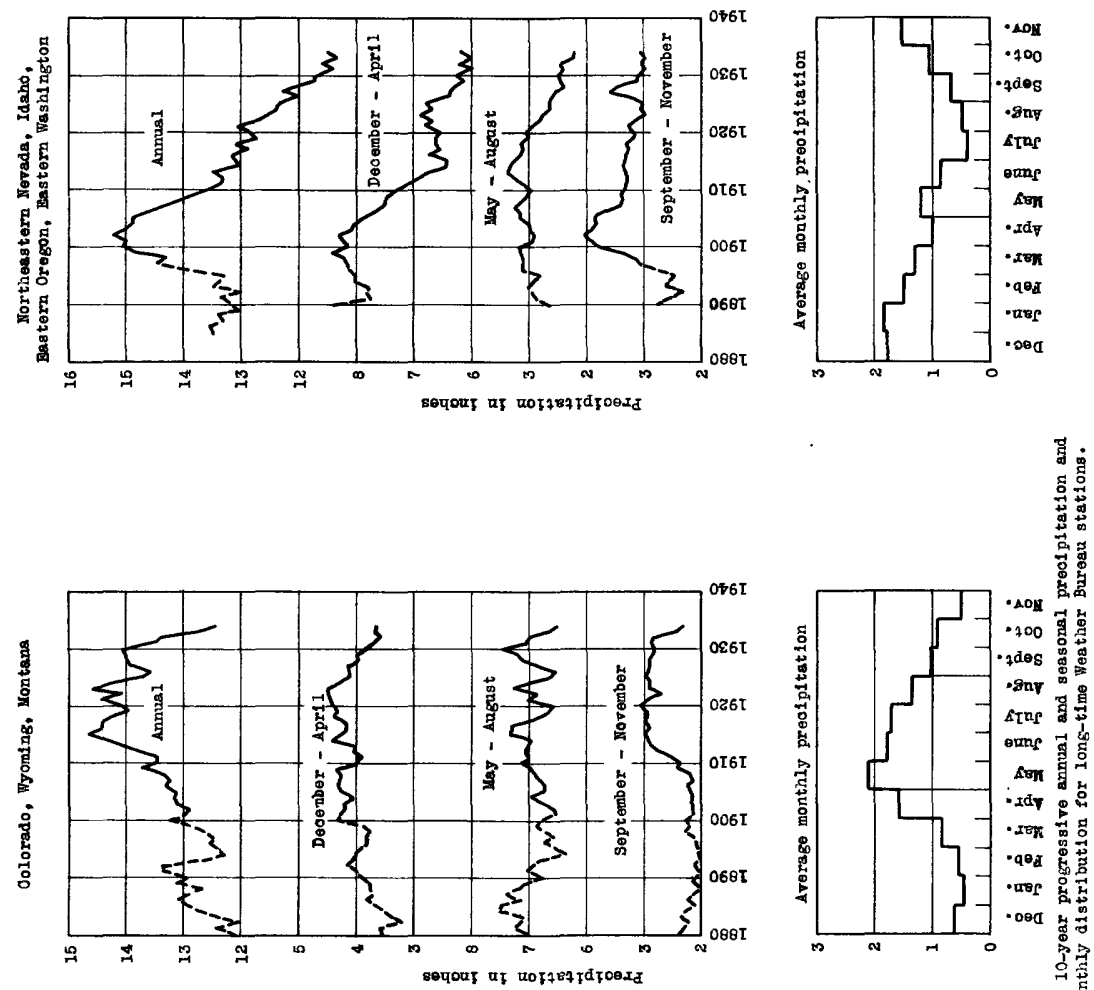

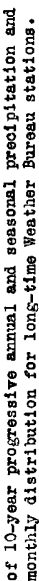
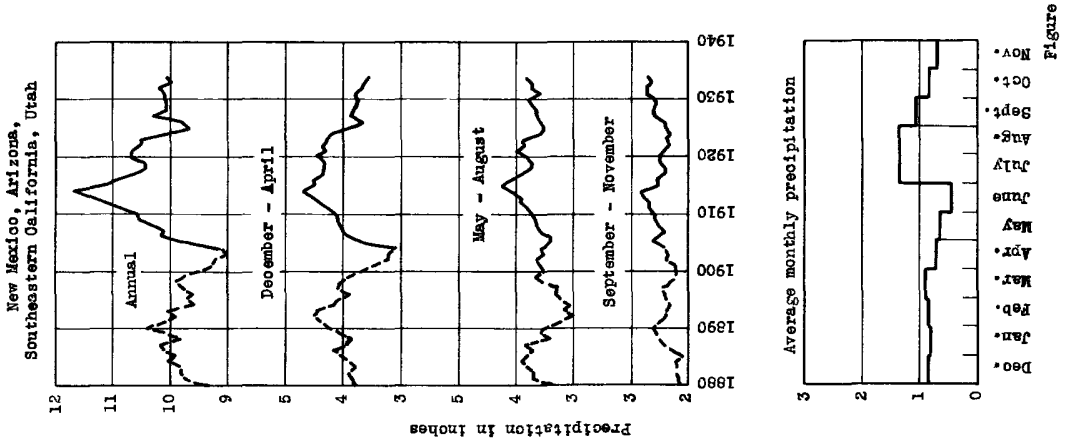

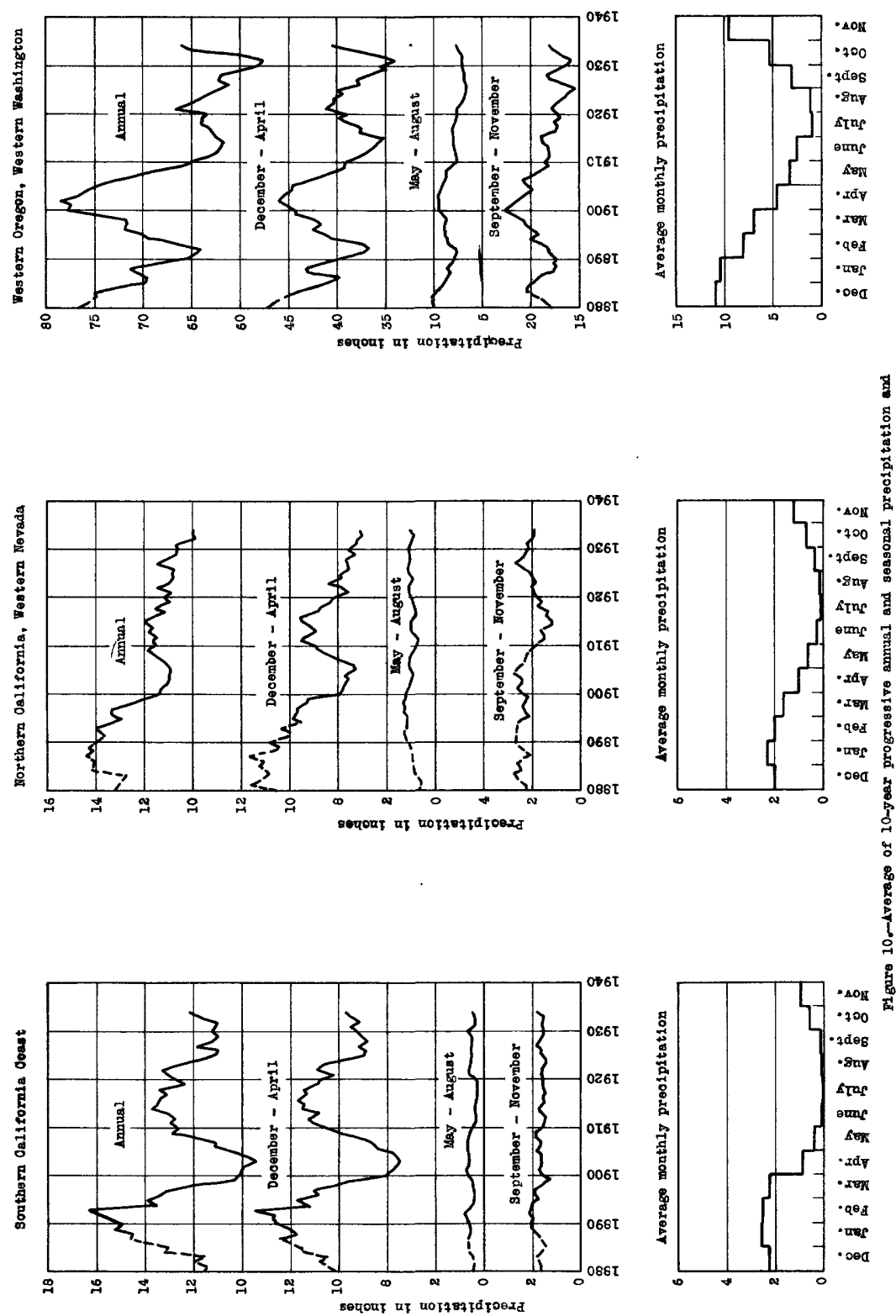
H. B. Lynch (102) Indicate a period of deficient precipitation in southern California about 1830 which has not since been surpassed. Composite treering studies in northern California indicate a 5-year perlod ending in 1850 when tree rings were prevailingly thin (18a). All these evidences seem to point to a severe drought of wide extent about the period 1830 to 1850.

(2) The trend of precipitation for the 30-year period 1850-80 seems to have been generally upward over most of the United States. During this period only a few stations registered minimum 10-year averages (fig. 4 ). On the other hand, beginning as early as 1855, maximum 10-year averages are noted (fig. 2) culminating in 10-year periods ending in 1886, when 23 out of 98 long-time stations in the United States showed maximum 10-year averages. In no other decade has there been such a grouping of maximum 10-year averages at so many stations. There seems to be little doubt that the average annual precipitation for the 5 years ending in 1885, over a very considerable part of the United States, has not been exceeded during the period 1830-1934. Other periods when in some sections maximum precipitation was recorded were 1902 for stations in the Northwest, 1914-15 for the Central West and Southwest, and 1927, 1928, and 1929 for stations in the Central West and South. These trends are clearly shown on figures 1 to 5.

(3) Beginning about 1894 more and more of the stations recorded minimum 10-year averages (fig. 4). Between 1894 and 190437 of the longtime stations recorded 10-year minima. The minima at most of the remaining stations were scattered through the 30-year period 1904-34, with the largest number culminating 10-year lows in 1930, 1931, 1933, and 1934. The long-time stations recording their minimum 10-year average in 1934 were Chicago, Cleveland, Indianapolis, Miles City, Agricultural College (Mont.), and Pueblo.

Insofar as the anmial averages of these stations are indicative of annual chanjes over the respective areas these data indicate that

(1) The persistent downward trend in annual precipitation for the last two or three decades has been generally confined to (a) the Northwest Interior, North Pacific coast, and Central Pacific coast areas, embracing Washington, Oregon, Idaho, Nevada, and central and northern California; (b) the upper Mississippi Valley, embracing parts of North and South Dakota, Nebraska, Iowa, Wisconsin, and Minnesota; and (c) the North Atlantic and Middle Atlantic areas embracing all the New England States, the eastern part of New York, and Pennsylvania, Delaware, Maryland, and Virginia. 
(2) The trend in the annual precipitation during the decade ending in 1930 was stationary or slightly upward in the Southwest, Great Basin, Northern and Western Plains, and Great Lakes area and rather decldedly upward in the South Atlantic and Tennessee River areas.

(3) Since 1930 the Northern and Western Plains area has experienced a dropping off, while the North Paciflc coast area has turned abruptiy upward.

\section{Changes in seasonal precipitation, by geographic provinces}

An examination of the seasonal changes in precipitation in certain areas indicates that they did not always correspond to the changes shown in jearly precipitation. For the purpose of examining the seasonal trends over all the areas the monthly averages of all the long-time records at stations used for the yearly trends were combined into three seasons - December to April, May to August, and September to Novernber. These three seasons correspond rather closely over the United States as a whole to the three periods found by experience to be of special significance in the study of hydrology - namely, the replenishing period, September, October, and November, when accretions to soil moisture and ground water cormonly occur; the storage perlod, December through April, when losses are at a minimum; and the growing season, May through August, when evaporation and transpiration are most active, with resulting depletion of soll moisture and minimum recharge to the ground water. As the storm tracks apparently vary by seasons, it is possible that the study of their changes by seasons will tend to disclose some of the reasons for the variations in jearly trends. Changes in seasonal precipitation may also be reflected in significant changes in seasonal run-off which are not disclosed by changes in the annual amounts.

In tables 3,4 , and 5 are shown data by seasons for each areal group of stations.

\section{Changes in winter precipitation}

The 10-year progressive averages of the precipitation for the winter season (December to April) shown in figures 6 to 10 and comperisons shown in table 3 indicate that - 
Table 3.- Precipltation, December to April, 1871-1934

\begin{tabular}{|c|c|c|c|c|c|c|c|}
\hline \multirow[b]{2}{*}{ Area * } & \multicolumn{3}{|c|}{ Average (inches) } & \multirow{2}{*}{$\begin{array}{l}\text { Ratio last } 32 \\
\text { Jears to first } \\
32 \text { years } \\
\text { (percent) }\end{array}$} & \multirow{2}{*}{$\begin{array}{c}\text { Average for } 10 \\
\text { years ending } \\
1934 \\
\text { (Inches) }\end{array}$} & \multicolumn{2}{|c|}{ Ratio last 10 years } \\
\hline & $\begin{array}{l}18^{7} / 1- \\
1934\end{array}$ & $\begin{array}{l}1871- \\
1902\end{array}$ & $\begin{array}{l}1903- \\
1934\end{array}$ & & & $\begin{array}{l}\text { To long time } \\
\text { average }\end{array}$ & $\begin{array}{c}\text { To last } 32 \\
\text { years }\end{array}$ \\
\hline $\begin{array}{r}1 \\
2 \\
3 \\
4 \\
5 \\
6 \\
7 \\
8 \\
9 \\
10 \\
11 \\
12 \\
13 \\
14 \\
15\end{array}$ & $\begin{array}{r}17.11 \\
16.54 \\
17.48 \\
13.09 \\
21.01 \\
23.32 \\
5.98 \\
9.64 \\
11.04 \\
7.25 \\
3.97 \\
3.94 \\
41.14 \\
8.86 \\
10.24\end{array}$ & $\begin{array}{r}17.92 \\
16.98 \\
18.30 \\
13.11 \\
21.25 \\
23.80 \\
6.29 \\
10.12 \\
10.48 \\
8.12 \\
3.90 \\
3.83 \\
43.60 \\
9.70 \\
10.11\end{array}$ & $\begin{array}{r}16.30 \\
16.11 \\
16.67 \\
13.07 \\
20.777 \\
22.85 \\
5.68 \\
9.16 \\
11.59 \\
6.38 \\
4.04 \\
4.04 \\
38.68 \\
8.02 \\
10.36\end{array}$ & $\begin{array}{r}91 \\
95 \\
91 \\
100 \\
98 \\
96 \\
90 \\
91 \\
111 \\
79 \\
104 \\
105 \\
89 \\
83 \\
102\end{array}$ & $\begin{array}{r}15.86 \\
15.19 \\
16.89 \\
12.1 .9 \\
19.58 \\
22.70 \\
5.22 \\
8.94 \\
11.80 \\
6.20 \\
3.65 \\
3.54 \\
40.43 \\
7.11 \\
9.76\end{array}$ & $\begin{array}{r}93 \\
92 \\
97 \\
93 \\
93 \\
97 \\
87 \\
93 \\
107 \\
86 \\
92 \\
90 \\
98 \\
80 \\
95\end{array}$ & $\begin{array}{r}97 \\
94 \\
101 \\
93 \\
94 \\
99 \\
92 \\
28 \\
102 \\
97 \\
90 \\
88 \\
105 \\
89 \\
94\end{array}$ \\
\hline
\end{tabular}

\begin{tabular}{|c|c|c|c|c|c|}
\hline \multirow[t]{2}{*}{ Area $*$} & \multicolumn{2}{|c|}{$\begin{array}{l}\text { Maximum 10-year } \\
\text { period }\end{array}$} & \multicolumn{2}{|c|}{$\begin{array}{l}\text { Minimum 10-year } \\
\text { period }\end{array}$} & \multirow{2}{*}{$\begin{array}{l}\text { Ratio last } 10 \text { jears } \\
\text { to minimum } 10 \text { years } \\
\text { (percent) }\end{array}$} \\
\hline & Inches & $\begin{array}{l}\text { Date of } \\
\text { ending }\end{array}$ & Inches & $\begin{array}{l}\text { Date of } \\
\text { ending }\end{array}$ & \\
\hline $\begin{array}{r}1 \\
2 \\
3 \\
4 \\
5 \\
6 \\
7 \\
8 \\
9 \\
10 \\
11 \\
12 \\
13 \\
14 \\
15\end{array}$ & $\begin{array}{r}19.20 \\
18.64 \\
19.38 \\
14.56 \\
23.55 \\
25.45 \\
6.92 \\
10.74 \\
12.72 \\
8.43 \\
4.48 \\
4.72 \\
46.90 \\
11.66 \\
13.55\end{array}$ & $\begin{array}{l}1891 \\
1892 \\
1883 \\
1885 \\
1883 \\
1884 \\
1897 \\
1882 \\
1923 \\
1890 \\
1922 \\
1912 \\
1880 \\
1881 \\
1893\end{array}$ & $\begin{array}{r}15.69 \\
15.19 \\
15.28 \\
17.19 \\
19.58 \\
21.45 \\
5.22 \\
8.88 \\
9.14 \\
5.98 \\
3.18 \\
3.08 \\
33.89 \\
7.00 \\
7.46\end{array}$ & $\begin{array}{l}1931 \\
1934 \\
1916 \\
1934 \\
1934 \\
1896 \\
1934 \\
1926 \\
1910 \\
1931 \\
1882 \\
1904 \\
1931 \\
1933 \\
1903\end{array}$ & $\begin{array}{l}101 \\
100 \\
111 \\
100 \\
100 \\
106 \\
100 \\
101 \\
129 \\
104 \\
115 \\
115 \\
119 \\
102 \\
131\end{array}$ \\
\hline
\end{tabular}

* Numbers correspond to those of groups 1isted on pages 33-35. 
(1) Except in the Southwest, the average winter precipitation for the last 32 years of record has been less than that for the first 32 years.

(2) Except in the South Central West area and the Northern and Western Plains area, the 10-Jear average winter precipitation in the 1880's and 1890 's was generally at a maximum.

(3) The trend is still downward in several areas, as indicated by the fact that the average for the last 10 jears is the same or nearly the same as that for the minimum 10 jears.

(4) Insofar as the few stations in the Northwest Interior area may be indicative of the winter precipitation in the adjacent mountain areas, the downward trend is critical, because the economic life of these areas depends to a considerable degree upon the winter precipitation.

Changes in precipitation in growing season

The 10-year progressive averages shown on figures 6 to 10 and comparisons shown in table 4 indicate that -

(1) Except in the Northern and Western Plains area and the Southwest, the average summer precipitation during the last 32 jears of record has been less than that for the first 32 years.

(2) Except in the southwest, the trend is generally downward, and in several areas the average for the 10 years ending in 1934 is the same or nearly the same as the minimum for the period of record.

(3) In general the percentage decrease from the first to the last 32 jears of record is comparable with the decrease in winter precipitation.

(4) The persistent downward trend is becoming critical in areas such as the upper Mississippl Valley, where the summer precipitation is so large a proportion of the total precipitation.

\section{Changes in fall precipitation}

The 10-year progressive averages show on figures 6 to 10 and comparisons shown in table 5 indicate that for the fall precipitation (September to November) -

(1) There has been a decided reversal from the winter and sumer trends. 
Table 4.- Precip1tation, May to August, 1871-1934

\begin{tabular}{|c|c|c|c|c|c|c|c|}
\hline \multirow[b]{2}{*}{ Area* } & \multicolumn{3}{|c|}{ Average (1nches) } & \multirow{2}{*}{$\begin{array}{l}\text { Rat1o last } 32 \\
\text { years to f1rst } \\
32 \text { years } \\
\text { (percent) }\end{array}$} & \multirow{2}{*}{$\begin{array}{c}\text { Average for } 10 \\
\text { years ending } \\
1934 \\
\text { (1nches) }\end{array}$} & \multicolumn{2}{|c|}{$\begin{array}{c}\text { Rat1o last io years } \\
\text { (percent) }\end{array}$} \\
\hline & $\begin{array}{l}1871- \\
1934\end{array}$ & $\begin{array}{l}1871- \\
1902\end{array}$ & $\begin{array}{l}1903 \\
1934\end{array}$ & & & $\begin{array}{l}\text { To long-time } \\
\text { average }\end{array}$ & $\begin{array}{c}\text { To last } 32 \\
\text { years }\end{array}$ \\
\hline $\begin{array}{r}1 \\
2 \\
3 \\
4 \\
5 \\
6 \\
7 \\
8 \\
9 \\
10 \\
11 \\
12 \\
13 \\
14 \\
15\end{array}$ & $\begin{array}{r}14.37 \\
16.59 \\
19.08 \\
13.56 \\
15.46 \\
17.18 \\
13.10 \\
16.10 \\
13.92 \\
2.80 \\
6.84 \\
3.63 \\
8.18 \\
.95 \\
.52\end{array}$ & $\begin{array}{r}15.04 \\
16.60 \\
19.35 \\
14.08 \\
15.73 \\
17.52 \\
13.29 \\
16.57 \\
13.98 \\
2.99 \\
6.83 \\
3.46 \\
9.02 \\
.96 \\
.60\end{array}$ & $\begin{array}{r}13.71 \\
16.58 \\
18.80 \\
13.04 \\
15.18 \\
16.84 \\
12.90 \\
15.63 \\
13.85 \\
2.60 \\
6.86 \\
3.80 \\
7.34 \\
.94 \\
.44\end{array}$ & $\begin{array}{r}91 \\
100 \\
97 \\
93 \\
96 \\
96 \\
97 \\
94 \\
99 \\
87 \\
100 \\
110 \\
81 \\
98 \\
73\end{array}$ & $\begin{array}{r}13.42 \\
15.43 \\
17.78 \\
12.33 \\
15.37 \\
16.05 \\
11.15 \\
15.11 \\
13.14 \\
2.22 \\
6.51 \\
3.84 \\
7.55 \\
1.00 \\
.45\end{array}$ & $\begin{array}{r}93 \\
93 \\
93 \\
91 \\
99 \\
93 \\
85 \\
94 \\
94 \\
79 \\
95 \\
106 \\
92 \\
105 \\
87\end{array}$ & $\begin{array}{r}98 \\
93 \\
95 \\
95 \\
101 \\
95 \\
86 \\
97 \\
95 \\
85 \\
95 \\
101 \\
103 \\
106 \\
102\end{array}$ \\
\hline
\end{tabular}

\begin{tabular}{|c|c|c|c|c|c|}
\hline \multirow[b]{2}{*}{ Area* } & \multicolumn{2}{|c|}{$\begin{array}{l}\text { Maximum 10-year } \\
\text { period }\end{array}$} & \multicolumn{2}{|c|}{$\begin{array}{l}\text { Minimum 10-year } \\
\text { perlod }\end{array}$} & \multirow{2}{*}{$\begin{array}{c}\text { Ratio last io years } \\
\text { to minimum } 10 \text { years } \\
\text { (percent) }\end{array}$} \\
\hline & Inches & $\begin{array}{l}\text { Date of } \\
\text { ending }\end{array}$ & Inches & $\begin{array}{l}\text { Date of } \\
\text { ending }\end{array}$ & \\
\hline $\begin{array}{r}1 \\
2 \\
3 \\
4 \\
5 \\
6 \\
7 \\
8 \\
9 \\
10 \\
11 \\
12 \\
13 \\
14 \\
15\end{array}$ & $\begin{array}{r}15.78 \\
18.36 \\
20.66 \\
15.49 \\
16.95 \\
18.82 \\
15.16 \\
18.00 \\
16.58 \\
3.37 \\
7.51 \\
4.23 \\
10.18 \\
1.33 \\
.80\end{array}$ & $\begin{array}{l}1893 \\
1894 \\
1894 \\
1884 \\
1884 \\
1895 \\
1908-9 \\
1904 \\
1908 \\
1913 \\
1930 \\
1915 \\
1882 \\
1892 \\
1892\end{array}$ & $\begin{array}{r}12.41 \\
14.64 \\
17.70 \\
12.33 \\
14.38 \\
15.64 \\
11.15 \\
14.21 \\
11.80 \\
2.22 \\
6.35 \\
3.03 \\
6.55 \\
.59 \\
.27\end{array}$ & $\begin{array}{l}1914 \\
1885 \\
1933 \\
1934 \\
1908 \\
1933 \\
1934 \\
1920,26 \\
1918 \\
1934 \\
1894 \\
1892 \\
1925 \\
1881-82 \\
1918\end{array}$ & $\begin{array}{l}108 \\
105 \\
100 \\
100 \\
107 \\
103 \\
100 \\
106 \\
111 \\
100 \\
102 \\
127 \\
115 \\
169 \\
167\end{array}$ \\
\hline
\end{tabular}

* Numbers correspond to those of groups I1sted on pages 33-35. 
Table 5.- Precipitation, September to November, 1871-1934

\begin{tabular}{|c|c|c|c|c|c|c|c|}
\hline \multirow[b]{2}{*}{ Area* } & \multicolumn{3}{|c|}{ Avorage (inches) } & \multirow{2}{*}{$\begin{array}{l}\text { Ratio last } 32 \\
\text { years to first } \\
32 \text { years } \\
\text { (percent) }\end{array}$} & \multirow{2}{*}{$\begin{array}{c}\text { Average for } 10 \\
\text { years ending } \\
1934 \\
\text { (Inches) }\end{array}$} & \multicolumn{2}{|c|}{$\begin{array}{c}\text { Kat1o last } 10 \text { years } \\
\text { (percent) }\end{array}$} \\
\hline & $\begin{array}{l}1871- \\
1934\end{array}$ & $\begin{array}{l}1871- \\
1902\end{array}$ & $\begin{array}{l}1903- \\
1934\end{array}$ & & & $\begin{array}{l}\text { To long-time } \\
\text { average }\end{array}$ & $\begin{array}{c}\text { To last } 32 \\
\text { years }\end{array}$ \\
\hline $\begin{array}{r}1 \\
2 \\
3 \\
4 \\
5 \\
6 \\
7 \\
8 \\
9 \\
10 \\
11 \\
12 \\
13 \\
14 \\
15\end{array}$ & $\begin{array}{r}10.41 \\
9.14 \\
10.70 \\
8.32 \\
9.21 \\
10.50 \\
5.24 \\
8.06 \\
8.40 \\
3.20 \\
2.45 \\
2.44 \\
18.42 \\
2.12 \\
1.68\end{array}$ & $\begin{array}{r}11.02 \\
10.15 \\
11.35 \\
8.31 \\
9.36 \\
10.86 \\
5.02 \\
7.40 \\
7.98 \\
3.19 \\
2.22 \\
2.32 \\
19.20 \\
2.45 \\
1.80\end{array}$ & $\begin{array}{r}9.80 \\
8.14 \\
10.04 \\
8.32 \\
9.06 \\
10.15 \\
5.46 \\
8.71 \\
8.83 \\
3.21 \\
2.68 \\
2.56 \\
17.63 \\
1.80 \\
1.57\end{array}$ & $\begin{array}{r}89 \\
80 \\
88 \\
100 \\
97 \\
93 \\
109 \\
118 \\
111 \\
101 \\
121 \\
110 \\
92 \\
74 \\
87\end{array}$ & $\begin{array}{r}11.06 \\
9.06 \\
10.49 \\
9.40 \\
10.37 \\
11.39 \\
5.90 \\
9.75 \\
9.63 \\
3.08 \\
2.33 \\
2.69 \\
18.00 \\
1.90 \\
1.80\end{array}$ & $\begin{array}{r}106 \\
99 \\
98 \\
113 \\
113 \\
108 \\
113 \\
121 \\
115 \\
96 \\
95 \\
110 \\
98 \\
90 \\
107\end{array}$ & $\begin{array}{r}113 \\
111 \\
104 \\
113 \\
114 \\
112 \\
108 \\
112 \\
109 \\
96 \\
87 \\
105 \\
102 \\
106 \\
115\end{array}$ \\
\hline
\end{tabular}

\begin{tabular}{|c|c|c|c|c|c|}
\hline \multirow[b]{2}{*}{ Area* } & \multicolumn{2}{|c|}{$\begin{array}{l}\text { Maximum 10-Jear } \\
\text { period }\end{array}$} & \multicolumn{2}{|c|}{$\begin{array}{l}\text { Minimum } 10 \text {-year } \\
\text { period }\end{array}$} & \multirow{2}{*}{$\begin{array}{c}\text { Ratio last } 10 \text { years } \\
\text { to minimum } 10 \text { jears } \\
\text { (percent) }\end{array}$} \\
\hline & Inches & $\begin{array}{l}\text { Date of } \\
\text { ending }\end{array}$ & Inches & $\begin{array}{l}\text { Date of } \\
\text { ending }\end{array}$ & \\
\hline $\begin{array}{r}1 \\
2 \\
3 \\
4 \\
5 \\
6 \\
7 \\
8 \\
9 \\
10 \\
11 \\
12 \\
13 \\
14 \\
15\end{array}$ & $\begin{array}{r}11.80 \\
10.59 \\
12.62 \\
9.52 \\
10.71 \\
13.02 \\
5.90 \\
9.75 \\
11.98 \\
4.04 \\
3.08 \\
2.83 \\
22.48 \\
2.75 \\
2.17\end{array}$ & $\begin{array}{l}1897 \\
1882 \\
1885 \\
1884 \\
1889 \\
1886 \\
1934 \\
1934 \\
1927 \\
1902 \\
1920 \\
1914 \\
1900 \\
1883 \\
1892\end{array}$ & $\begin{array}{r}8.20 \\
6.98 \\
9.49 \\
7.02 \\
7.80 \\
8.64 \\
4.04 \\
5.82 \\
6.65 \\
2.31 \\
1.99 \\
2.11 \\
15.31 \\
1.18 \\
1.28\end{array}$ & $\begin{array}{l}1917 \\
1923 \\
1910 \\
1908 \\
1917 \\
1904 \\
1897 \\
1897 \\
1912 \\
1892 \\
1893 \\
1885 \\
1925 \\
1914 \\
1899\end{array}$ & $\begin{array}{l}135 \\
130 \\
110 \\
134 \\
133 \\
132 \\
146 \\
168 \\
145 \\
133 \\
117 \\
127 \\
118 \\
161 \\
141\end{array}$ \\
\hline
\end{tabular}

* Nunbers correspond to those of groups Iisted on pages 33-35. 
(2) Except in the extreme East and the extreme Nest the average for the last 32 years has been above that for the first 32 years.

(3) Except in one area the trend is still upward, the precipitation for the last 10 jears being above the average for the last 32 years in all areas except the Northern and Western Plalns and, in General, averaging from 20 to 30 percent above the minimum 10-year average.

It is believed that the information disclosed by the study of seasonal trends indicates the great desirability for further study of the subject and the breakdown into months, especially with respect to the upward trend in fall preclpitation compared with the generally declining trend in winter and summer precipitation, in order to determine whether more exact knowledge can be developed regarding these interesting relations.

\section{Average monthly precipitation}

The graphs of average monthly precipitation shown on figures 6 to 10 are of interest in showing the marked differences in seasonal distribution. Special attention is called to the monthly distribution of rainfall in the interior States, from Missourl, Iowa, and Minnesota westward across the plains to the Rocky Mountains. The source of atmospherfe water vapor from which rainfall is derived is evaporation from oceans, lakes, creeks, rivers, swamps, and other wet or molst surfaces, and transpiration by vegetation. Mead states (111, p. 164):

The precipitation on the continental interior lands is, however, the phenornenon in which the engineers are more generally interested, and the source of this precipltation is derived most largely from molsture that obtains from the continental evaporation, from land surface, and from the surface of rivers, lakes, and swamp areas, and indirectly by the transpiration from animal and vegetable life."

There is a marked similarity between the graphs of monthly preclpitation in these areas and the known evaporation and transpiration characteristics. In this connection the unf form rainfall distribution throughout the year in the areas show for the New England States on figure 6 is of interest. The graph of preclpitation in that region bears little If any relation to the probable graph of continental evaporation and transpiration. The thought is suggested that if over broad areas air movements and alr temperatures could be taken into consideration, a study of the 
differences between the precipitation and the moisture put into the air through evaporation and transpiration might throw some light on the probable source or sources of precipitated moisture.

Such a study, if possible, would be valuable in continental areas such as the upper Kississippi River basin and the Red River Basin, where the decline in surmer precipitation has been lons continued, and where in certein instances steps are being taken to store and reterd surface run-ofi in reservolis.

\section{Changes in temperature}

Joseph B. Kincer (87) presents graphs and tables showing annual and seasonal changes in temperature recorded at several Weather Bureau stations in the United States and in foreign countries. He concludes that "the practically unanimous testimony of these graphs not only establishes the realness of these upward temperature trends but shows that they are operative on an extensive geographic scale."

As a companion to the study of changes in precipitation and a continuation of the studies by Kincer, the 10-year progressive average temperatures have been compiled for groups of stations situated in the 15 areas used in the precipitation study. Figure 11 shows the average of the 10-year progressive averages for the stations in each of 15 groups.

Figures 12 to 16 show by groups the plotting of the 10-year progressive averages for each station. The records used are those published in United States Weather Bureau Bulletin w. Since 1889 the same besis of determining the mean annual temperature has been used - nomely, the average of the daily maximum readings plus the average of the daily minimum readings livided by 2. Prior to that dete they may be on a somewhat different basis. The 10-year progressive average temperature at each station prior to 1889 was recomputed by the methods now used by the Weather Bureau and is shown by a dotted line on figures 11 to 16.

The study of temperature changes as summarized in table 6 indicates that in the country as a whole (a) the a verage temperatures for the last 32 years of record were greater than those for the preceding 32 jears; (b) the average temperature for the 10-year period ending 1934 was nearly $1.4^{\circ}$ higher than for the first 32 years of record; (c) the average temperature for the last 10 years was the maximm 10-jear average for the period of record; and (d) the average temperature for the last 10 years was $1.9^{\circ}$ above that for the 10-year period of minimum temperature, which ended, in $59550-35-4$ 


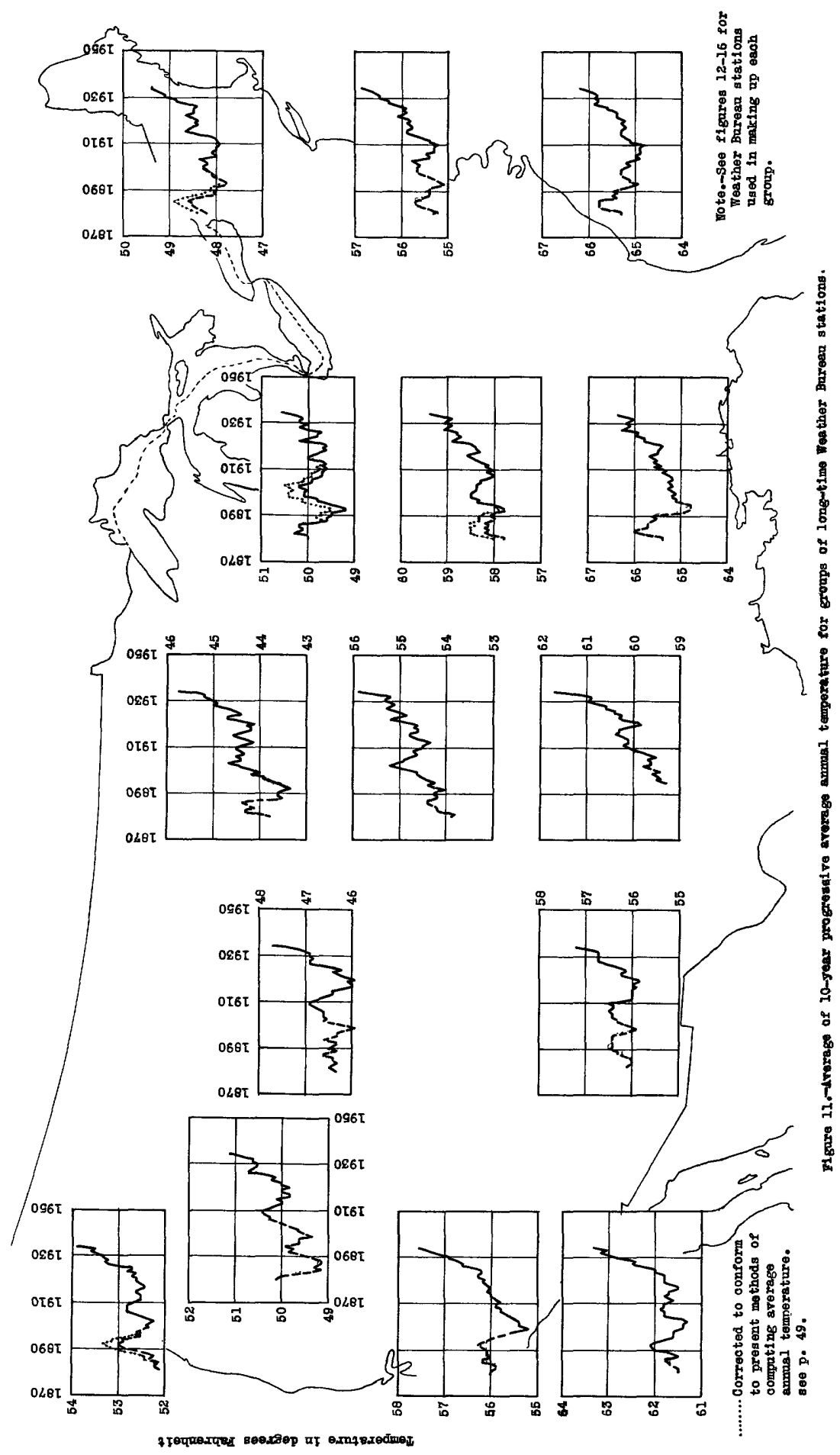



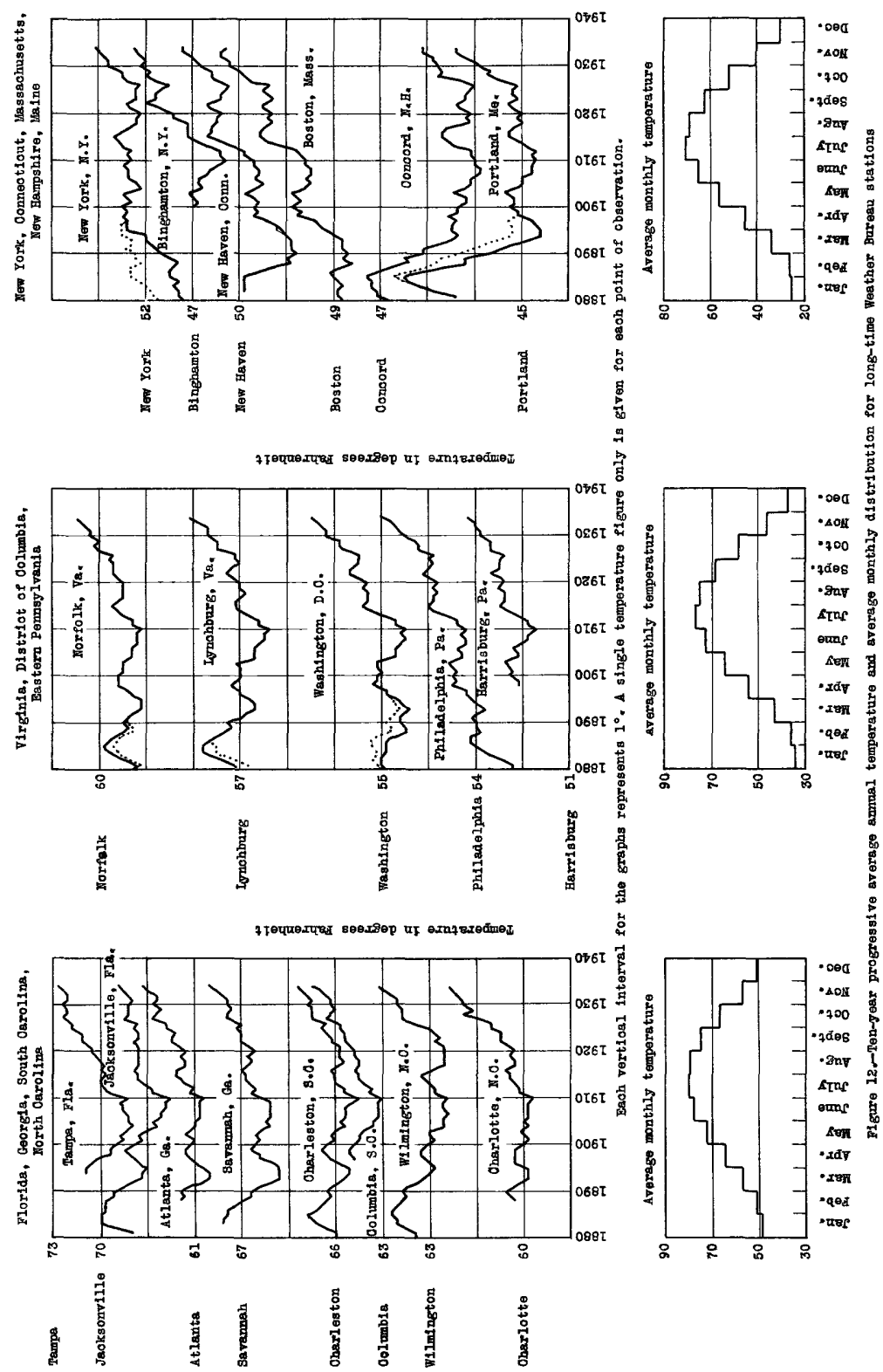


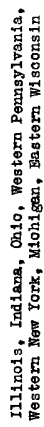
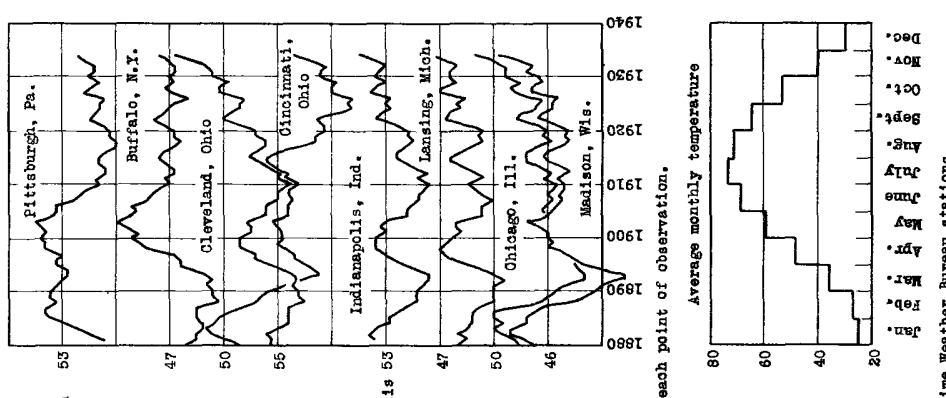

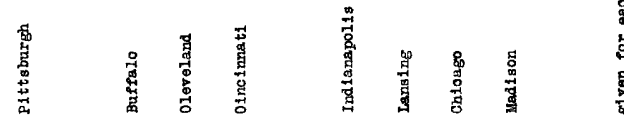

密
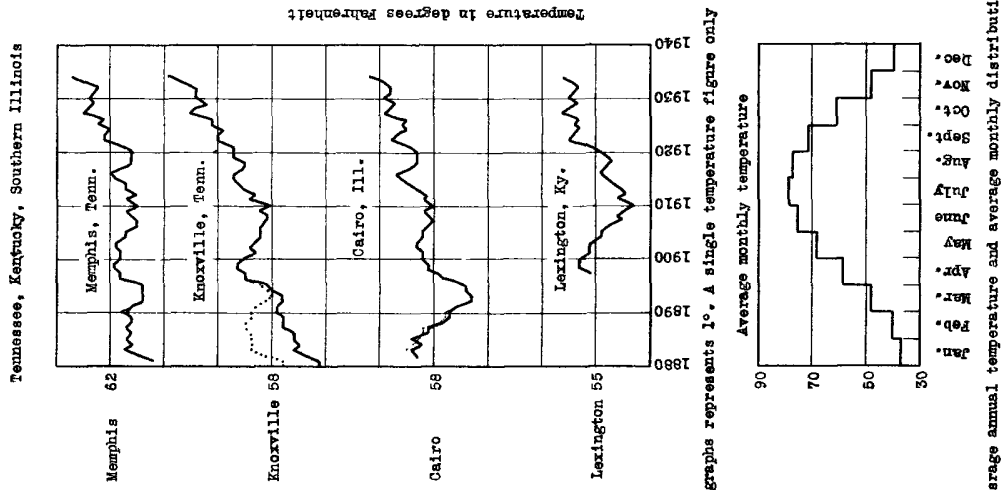

离
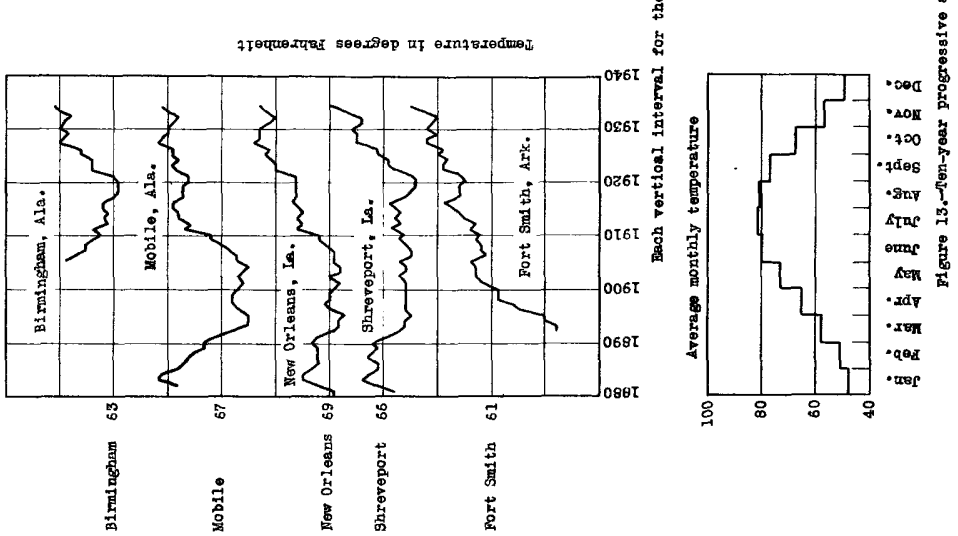

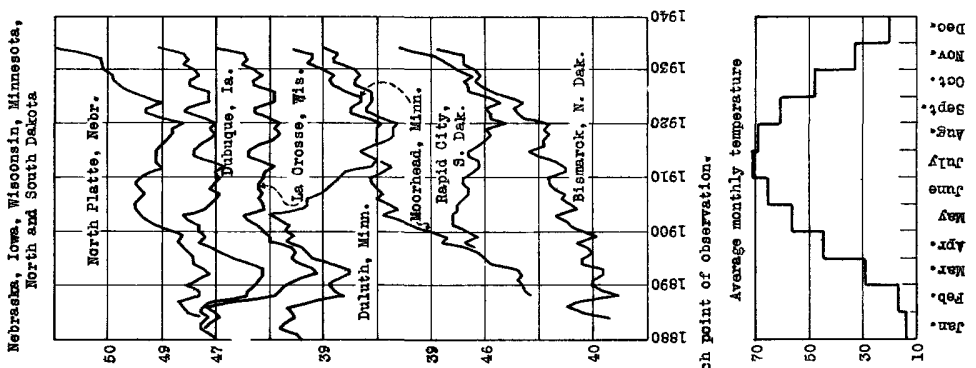
壱
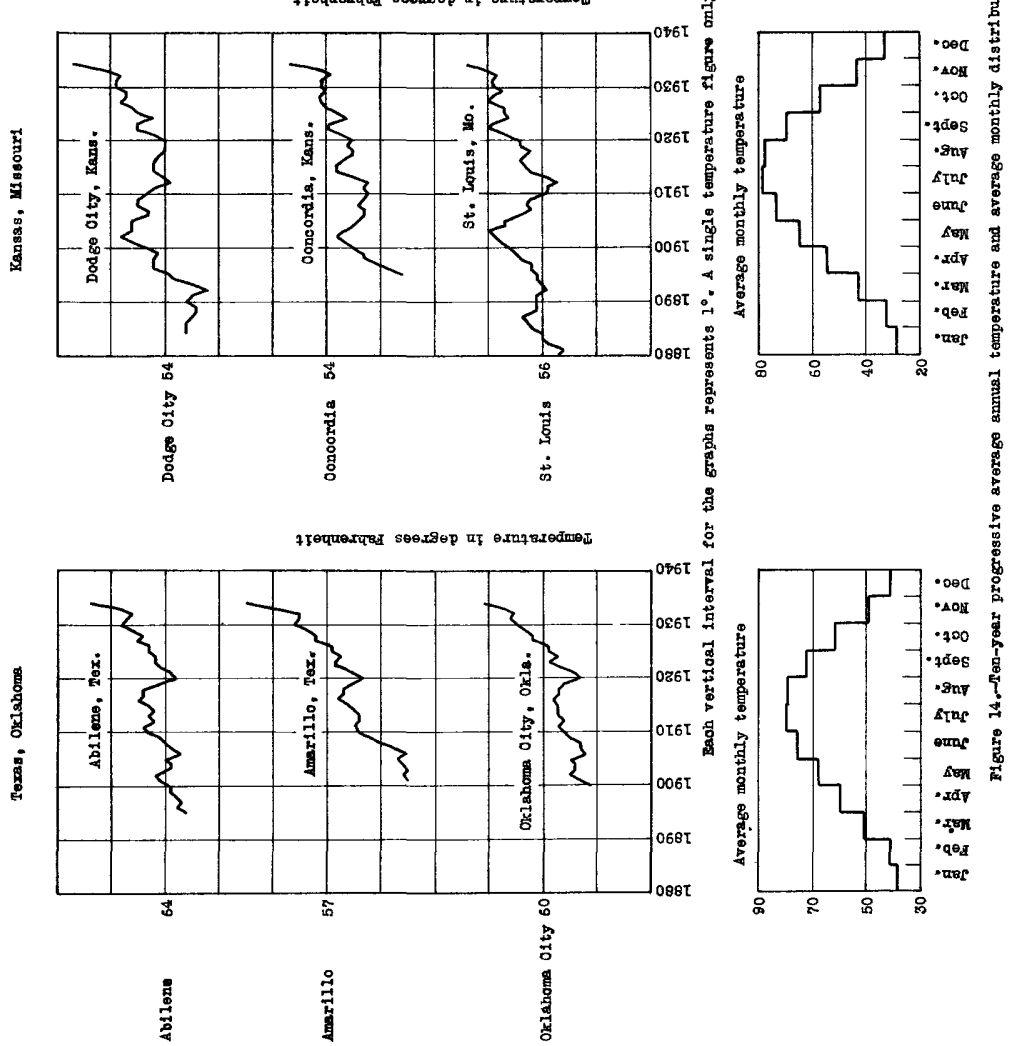

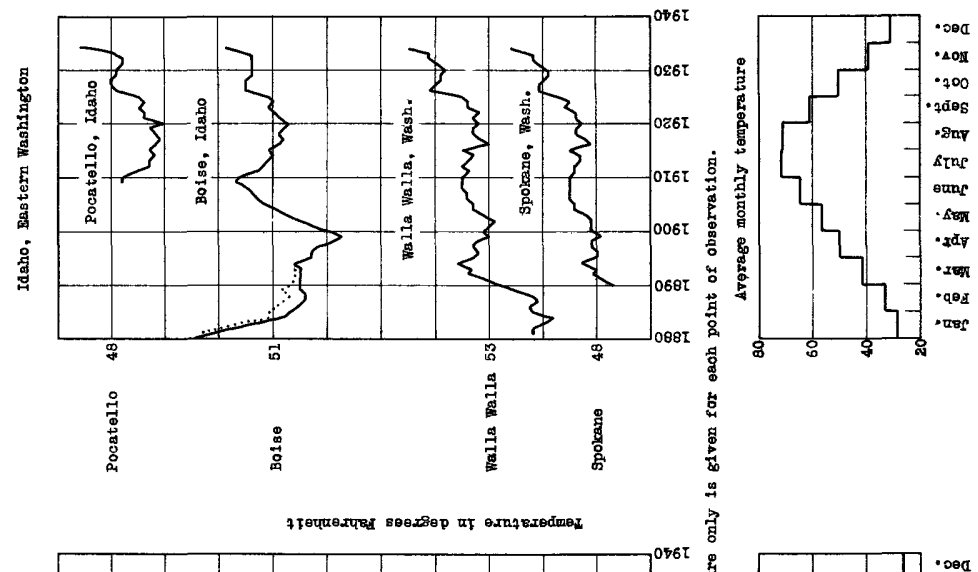

,

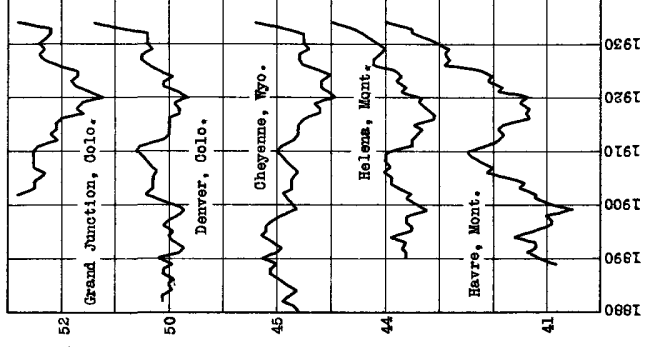

惫惫

里

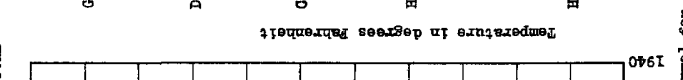

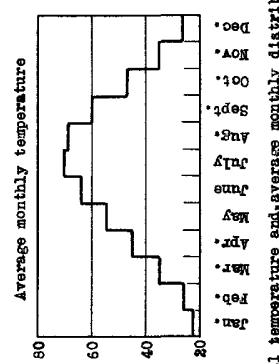

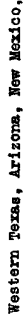

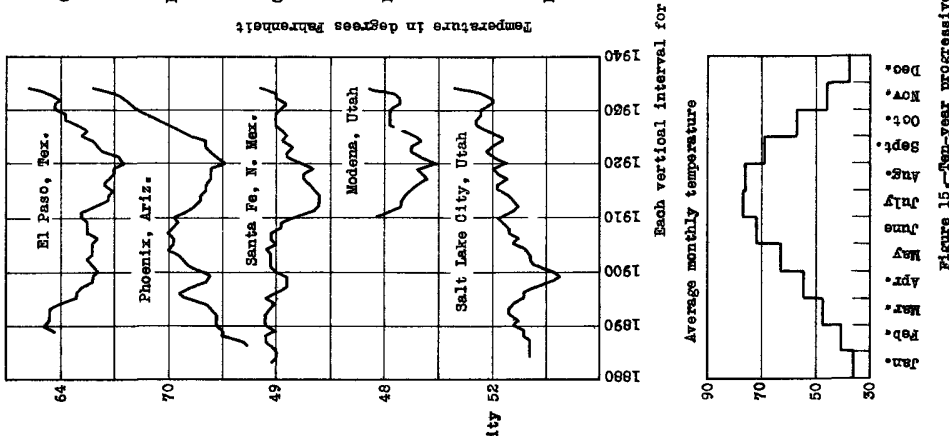

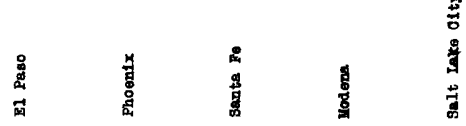



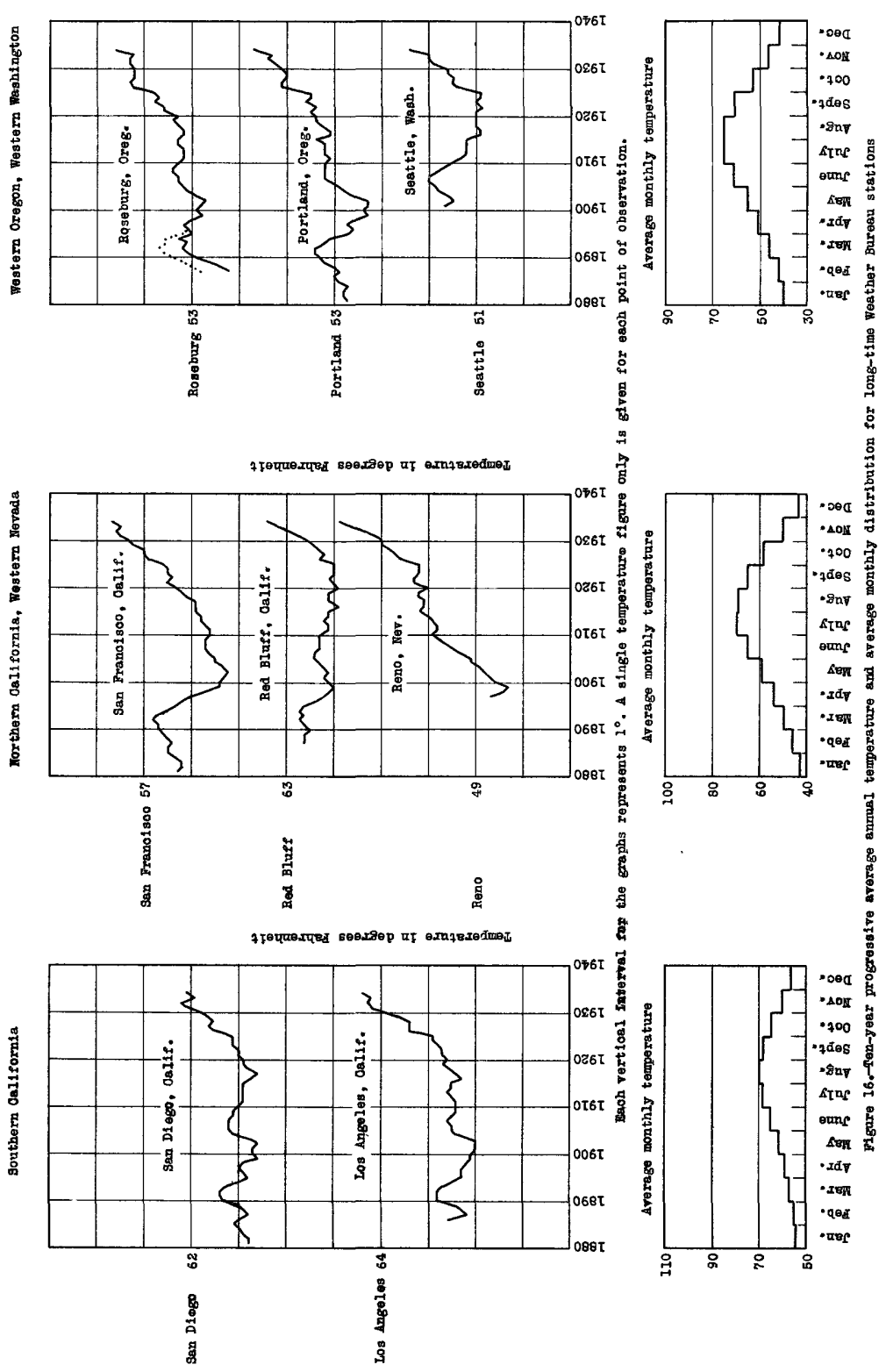
Table 6.- Anmual temperature ( ${ }^{\mathrm{F} .}$.) 1871-1934

\begin{tabular}{|c|c|c|c|c|c|c|c|}
\hline Area ${ }^{*}$ & $1871-1934$ & $\begin{array}{l}\text { Average } \\
1871-1902\end{array}$ & $1903-34$ & \multicolumn{3}{|c|}{$\begin{array}{l}\text { Increase in last half over } \\
\text { first half of perlod }\end{array}$} & $\begin{array}{l}\text { 10-year progres- } \\
\text { s1ve average } \\
\text { ending } 1934\end{array}$ \\
\hline $\begin{array}{c}1 \\
2 \\
3 \\
4 \\
5 \\
6 \\
7 \\
8 \\
9 \\
9 \\
10 \\
11 \\
12 \\
13 \\
14 \\
15 \\
15 \\
747 \\
\text { H4 }\end{array}$ & $\begin{array}{l}48.5 \\
55.7 \\
65.4 \\
50.0 \\
58.5 \\
65.7 \\
44.4 \\
54.7 \\
60.2 \\
50.1 \\
46.6 \\
56.4 \\
52.8 \\
56.0 \\
62.0\end{array}$ & $\begin{array}{l}48.3 \\
55.4 \\
65.3 \\
50.0 \\
58.3 \\
65.6 \\
44.0 \\
54.3 \\
59.8 \\
49.8 \\
46.4 \\
56.4 \\
52.6 \\
55.8 \\
61.6\end{array}$ & $\begin{array}{l}48.7 \\
56.1 \\
65.5 \\
50.1 \\
58.7 \\
65.8 \\
44.8 \\
55.1 \\
60.8 \\
50.4 \\
46.8 \\
56.5 \\
53.0 \\
56.6 \\
62.3\end{array}$ & \multicolumn{3}{|c|}{$\begin{array}{r}0.4 \\
.7 \\
.2 \\
.1 \\
.4 \\
.2 \\
.8 \\
.8 \\
1.0 \\
.6 \\
.4 \\
.1 \\
.4 \\
.8 \\
.7\end{array}$} & $\begin{array}{l}49.5 \\
56.9 \\
66.2 \\
50.6 \\
59.4 \\
66.4 \\
45.8 \\
56.0 \\
61.6 \\
51.2 \\
47.7 \\
57.2 \\
53.8 \\
57.6 \\
63.3\end{array}$ \\
\hline & \multicolumn{2}{|c|}{$\begin{array}{c}\text { Increase in last } \\
10 \text { years over }\end{array}$} & \multicolumn{2}{|c|}{ Maximum } & \multicolumn{2}{|c|}{ Minimum } & Increase in last \\
\hline Area * & $\begin{array}{l}\text { Iong-time } \\
\text { average }\end{array}$ & $\begin{array}{l}\text { First half } \\
\text { of period }\end{array}$ & $\begin{array}{l}\text { 10-year } \\
\text { average }\end{array}$ & $\begin{array}{l}\text { Date of } \\
\text { ending }\end{array}$ & $\begin{array}{l}\text { 10-year } \\
\text { average }\end{array}$ & $\begin{array}{l}\text { Date of } \\
\text { ending }\end{array}$ & $\begin{array}{l}10 \text { years over } \\
\text { minimum } 10 \text { years }\end{array}$ \\
\hline 1 & 1.0 & 1.2 & 49.5 & 1934 & 47.9 & $\begin{array}{l}1893 \\
1894 \\
1910 \\
1881 \\
1893\end{array}$ & 1.8 \\
\hline $\begin{array}{r}3 \\
4 \\
5 \\
6 \\
7 \\
8 \\
9 \\
10 \\
11 \\
12 \\
13 \\
14 \\
15\end{array}$ & $\begin{array}{r}.8 \\
.6 \\
1.9 \\
.7 \\
1.4 \\
1.3 \\
1.4 \\
1.1 \\
1.1 \\
.8 \\
1.0 \\
1.4 \\
1.3\end{array}$ & $\begin{array}{r}.9 \\
.6 \\
1.1 \\
.8 \\
1.8 \\
1.7 \\
1.8 \\
1.4 \\
1.3 \\
.8 \\
1.2 \\
1.8 \\
1.7\end{array}$ & $\begin{array}{l}66.2 \\
50.6 \\
59.4 \\
66.4 \\
45.8 \\
56.0 \\
61.6 \\
51.0 \\
47.7 \\
57.2 \\
53.8 \\
57.6 \\
63.3\end{array}$ & $\begin{array}{l}1934 \\
1934 \\
1934 \\
1934 \\
1934 \\
1934 \\
1934 \\
1934 \\
1934 \\
1934 \\
1934 \\
1934 \\
1934\end{array}$ & $\begin{array}{l}64.8 \\
49.4 \\
57.9 \\
65.0 \\
43.4 \\
53.7 \\
59.4 \\
49.2 \\
46.0 \\
55.8 \\
52.0 \\
55.2 \\
61.3\end{array}$ & $\begin{array}{r}1894 \\
1910 \\
1892 \\
1893 \\
1895 \\
1892 \\
1892 \\
1895 \\
1899 \\
1884 \\
1920 \\
1902 \\
1899 \\
1881\end{array}$ & $\begin{array}{l}1.4 \\
1.2 \\
1.5 \\
1.4 \\
2.4 \\
2.3 \\
2.2 \\
2.0 \\
1.7 \\
1.4 \\
1.6 \\
2.4 \\
2.0\end{array}$ \\
\hline
\end{tabular}

* Numbers correspond to those of groups 11sted on pages 33-35.

* Record available 1886-1934; divíded 1886-1910, 1910-34.

\# Record avallable 1874-1934; d1vided 1874-1904, 1904-34.

\#t Record available 1872-1934; divided 1872-1903, 1903-34. 
general, in the 1890's. Nearly all the stations used in the compllation of records in this report are located in cities where temperatures may be affected by conditions that do not exist in rural areas. Kincer (87) in connection with his study made a long-time comparison between three urban and three rural stations - namely, Lynchburg and Dale Enterprise, Va., Baltimore and Easton, Md., and Philadelphla and West Chester, Pa., - and found the changes at the mural stations were as pronounced as the changes at the nearby city stations. This phase of the question, however, should be given further study, because naturally if the increased temperature trends were confined entirely to urban areas they would have little significance in the problem under consideration. Further evidence that the increased temperature trends are widespread is presented by T. C. Main (103), who found by comparing 20-year progressive averages, increases of $1.0^{\circ}$ to nearly $4.0^{\circ} \mathrm{F}$. In annual temperature since about 1880 at a group of stations in Alberta and Saskatchewan. In addition to such further studies as may be necessary to determine the extent to which temperature may have increased over broad areas embracing river basins, it is especially desirable in hydrologic studies that a complete breakdown of temperature records be made by seasons and possibly by months. Kincer presents seasonal graphs on the basis of 20-year averages for the two long-time temperature records in the eastern United States. The records at New Haven, Conn., beginning with 1781, and Washington, D. C., beginning with 1817, showed that the largest changes occurred in the fall, winter, and spring and the least in the summer. A similar tendency is shown for Iowa temperature on the basis of 20-year progressive averages beginning in 1892 .

Although the temperature study outlined above is far from complete with respect to several pheses, it seems to indicate conclusively that there has been an increase in temperature over wide areas in the United states, at least since the 1890 's. It also seems reasonably certain that the increased temperatures mey have operated with the decreased precipitation to create, in certain sections of the country, a condition that is increasingly unfavorable to the maintenance of water supplies, both in surface streams and in the ground. This condition is especially acute in the upper Mississippl Valley and Red River Valley, where, as will be shown later, the average annual losses through evaporation and transpiration so nearly equal the average annual precipitation that any changs which would 
tend to increase the losses would materially affect the amount of water avallable for stream flow and for replenishment of soil moisture and ground water.

\section{Changes in mun-off}

The basins in which a detailed study of rainfall and mu-off has been made ape those of the Mississippi, Red, Merrimack, James, Chattahoochee, Tennessee, and Neosho Rivers. In addition the 10-year progressive average annual run-off for the following streams has been complied and the results plotted on figure 17 for a study in connection with the similar graphs of precipitation and temperature:

Spokane River at Spokane, Wash., 1892-1934.

Willamette River at Albany, Oreg., 1895-1934.

Kings River at Pledra, Calif., 1896-1934.

San Gabriel River near Azusa, Calif., 1896-1934.

Snake River near Moran, Wyo., 1904-1934.

Colorado River at Lees Ferry, Ariz,, 1851-1934.

The gage helghts on Lake Superior, 1869-1934, were a.Iso compiled and plotted.

The run-off records have been corrected for storage. The early records at Lees Ferry were estimated by E. C. Ie Rue (92a).

A general comparison of the change for the comparatively short run-off records with the long-time precipitation and temperature records Indicates clearly, it is belleved, that any averages based on the mun-off records available in most sections of the country might vary considerably from averages for, say, 100 years. This is a factor which naturally must be given serious consideration in connection with studies or plans based on the avallable records. 


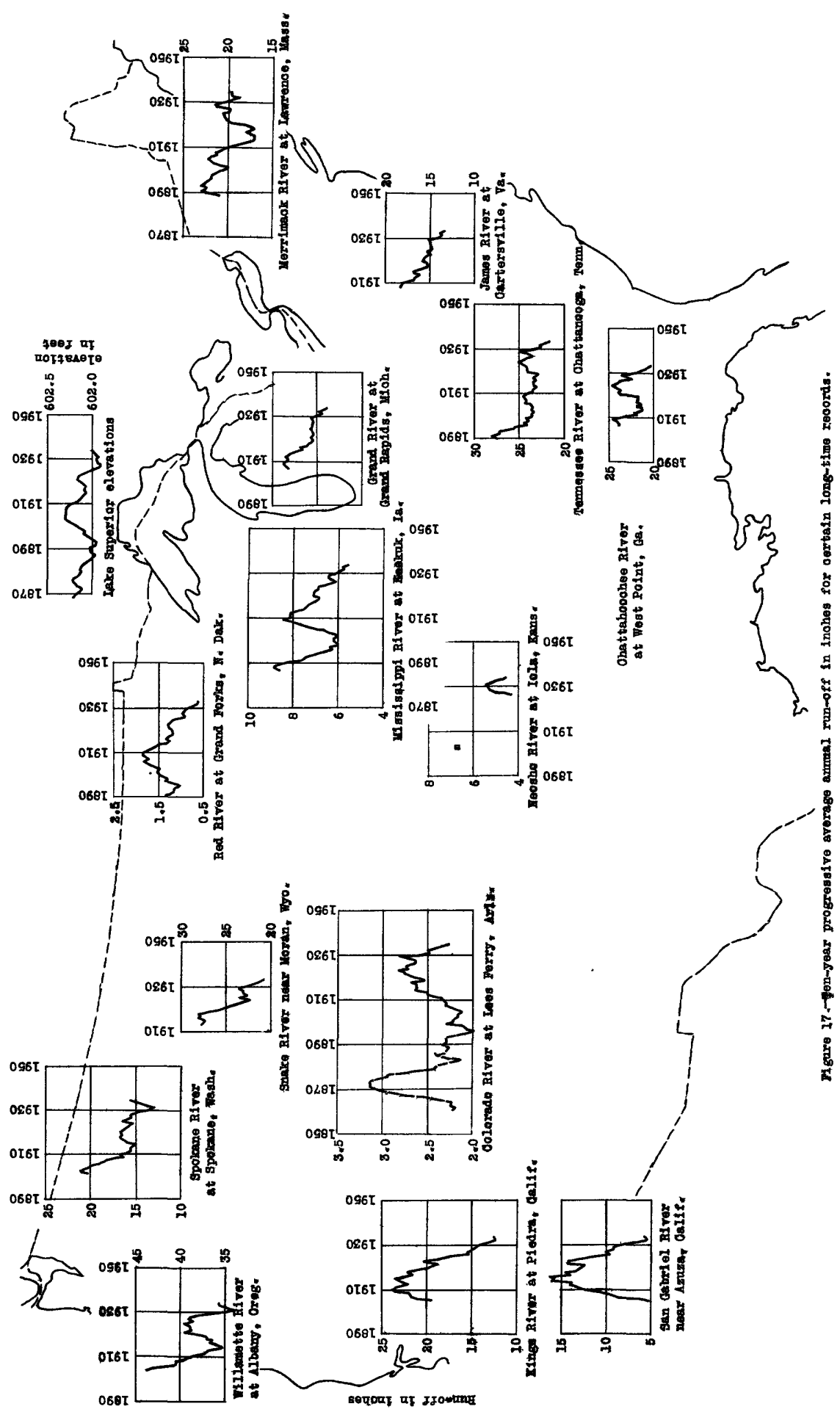




\section{Precipitation, temperature, and run-off, by basins}

The changes in the precipitation and temperature already shown by geographic provinces are qualitative rather than quantitative. In the following presentation of the changes in precipitation, temperature, and runoff, by basins, It has been the alm to determine as accurately as possible the magnitude of the several factors. As would be expected, changes within a basin correspond roughly with the changes previously indicated for the particular geographlc province or provinces in which the basin may be located.

The correlation of annual rainfall, temperature, and run-off based on long-time averages is necessarily confined to basins where (a) concurrent long-time records are available, (b) the mean annual precipitation and temperature over the entire basin and run-off from the basin have been determined with a fair degree of accuracy, (c) the run-off has not boen appreclabls changed by storage or diversion, and (d) the precipitation exceeds the combined losses resulting from evaporation and transpiration.

These requirements $11 \mathrm{~m}$ t the areas in the United States where studies of this type may be carried on. Many areas in the West cannot be studied, either because the precipitation over the basin as a whole is not accurately known or because storage and diversions are of such magnitude as to affect natural relations materlally. Iikewise in mach of the plains area the annual evaporation and transpiration so nearly equal the annual precipitation that the residual run-off approaches zero.

Records showing annual precipltation, annual temperature, and annual run-off have been made and complled for the following basins for the periods of record as indicated:

Red River Basin above Grand Forks, N. Dak., 1882-1934.

Mississippl River Basin above Keokuk, Iowa, 1878-1934.

Neosho River Basin above Iola, Kans., 1896-1903, 1918-34.

Merrimack River Basin above Lawrence, Mass., 1880-1934.

James River Basin above Carteraville, Va., 1899-1934.

Tennessee River Basin above Chattanooga, Tenn., 1881-1934.

Chattahoochee River Basin above West Point, Ga., 1897-1934.

As a basis for the preliminary study information for each basin has been compiled and is presented in tables 7 to 21. All precipitation and run-off data are stated in inches over the basin, and all figures are 
on the basis of the calendar year except those for the Merrimeck River Basin, which are on the basis of the year ending September 30 .

The precipitation, run-off, and precipitation minus run-off for each basin are presented in the form of graphs on figures 18 to 24 .

\section{Red River Basin above Grand Forks, N. Dak.}

(Drainage area, 25,500 square miles. Records avallable, 1882 - 1934)

The Ottertail River, the head of the Red River, rises in the southwest corner of clearwater county, Minn., at an altitude of about 1,550 feet, and flows south and west to Wahpeton, N. Dak., whence the Red River flows north in a continuous series of short loops, forming the boundary between North Dakota and Minnesota. The basin is very flat, the slope from the sides toward the stream for distances of 5, 10, or $20 \mathrm{miles}$ is usually only a fer feet to the mile, in places less than 2 feet to the mile, and the downward slope of the baein to the north is less than 1 foot to the mile, averaging 9 inches to the mile from Wahpeton, N. Dak., about 30 miles north of the southern boundary of the State, to Fargo, and $6 \frac{1}{2}$ inches to the mile from Fargo to Grand Forks.

Run-off.- The gage-helght record and a few discharge measurements from 1882 to 1901 were collected by the United States Corps of Engineers; since 1901 the United States Goological Survey has maintained the staff gage. The control which consists of clay and silt, shifts slightly, and the stage-discherge relations are affected by fce in winter and aquatic growths in summer.

The winter run-off prior to 1906, with the exception of 1898, 1899, and 1900, was estimated by P. T. Simons, senior drainage engineer, United states Department of Agriculture, who aleo gave a table of monthly run-off from 1882 to 1919 (163). The figures for run-off since 1919 have been taken from the water-supply papers of the United States Geological Survey. All run-off figures are on the basis of the calendar year. 
Precipitation.- The precipitation records for 1882 to 1919 were taken from the paper by Simons (163), and those for 1920 to 1923 from a compilation by E. F. Chandler (25); those for 1924 to 1934 were computed by using the arithmetic average of the station records. For the early part of the period of record, when few stations were maintained, simons calculated separately the average precipitation in each of five subdivisions of the basin and weighted these figures according to their respective areas to get the basin average. The preclpitation stations used to compute the basin average were as follows:

Table 7.- Precipitation stations in Red River Basin

above Grand Forks, N. Dak.

\begin{tabular}{|c|c|c|c|}
\hline Station & $\begin{array}{c}\text { Altitude } \\
\text { (feet) }\end{array}$ & $\begin{array}{l}\text { Period } \\
\text { of } \\
\text { record }\end{array}$ & $\begin{array}{l}\text { Mean annual } \\
\text { precipitation } \\
\text { (Inches) }\end{array}$ \\
\hline \multicolumn{4}{|l|}{ Mínnesota: } \\
\hline $\begin{array}{l}\text { Angus * } \\
\text { BemidjI * } \\
\text { Campbeli * } \\
\text { Crookstom * } \\
\text { Detrolt Lakes * } \\
\text { Fergus Falls * } \\
\text { Fosston * } \\
\text { Gonvick } \\
\text { Moorhead * } \\
\text { Redby * } \\
\text { Thief River Falls } \\
\text { Wheaton * }\end{array}$ & $\begin{array}{r}870 \\
1,400 \\
975 \\
888 \\
1,364 \\
1,210 \\
1,289 \\
1,454 \\
935 \\
1,158 \\
1,137 \\
1,018\end{array}$ & $\begin{array}{l}1920- \\
1899-1905,1912- \\
1873-80,1912- \\
1890- \\
1896- \\
1888- \\
1910- \\
1922 \\
1881- \\
1910- \\
1915- \\
1915-\end{array}$ & $\begin{array}{l}18.68 \\
23.88 \\
23.74 \\
20.92 \\
24.84 \\
23.96 \\
20.12 \\
19.83 \\
23.34 \\
21.84 \\
21.32 \\
20.75\end{array}$ \\
\hline \multicolumn{4}{|l|}{ North Dakota: } \\
\hline $\begin{array}{l}\text { Amenia * } \\
\text { Cooperstown } \\
\text { Devils Iake } \\
\text { Forman } \\
\text { Grand Forks * } \\
\text { Hillsboro * } \\
\text { Iarimore * } \\
\text { Lisbon * } \\
\text { Mcleod * } \\
\text { Maddock * } \\
\text { Manfred } \\
\text { Mayville * } \\
\text { Power } \\
\text { Sharon } \\
\text { Valley City * } \\
\text { Wahpeton * }\end{array}$ & $\begin{array}{r}954 \\
1,428 \\
1,478 \\
1,249 \\
830 \\
901 \\
1,134 \\
1,091 \\
1,075 \\
1,604 \\
1,605 \\
975 \\
1,020 \\
1,516 \\
1,245 \\
962\end{array}$ & $\begin{array}{l}1896- \\
1890-1907,1915- \\
1870-90,1897- \\
1892- \\
1892- \\
1906- \\
1893- \\
1904- \\
1912- \\
1915- \\
1903- \\
1896- \\
1892-1932 \\
1924- \\
1905- \\
1892-\end{array}$ & $\begin{array}{l}20.10 \\
17.79 \\
18.04 \\
20.72 \\
19.49 \\
20.35 \\
21.13 \\
20.82 \\
21.49 \\
16.33 \\
17.55 \\
19.88 \\
20.94 \\
19.06 \\
18.36 \\
21.52\end{array}$ \\
\hline
\end{tabular}

* Station used to compute average basin temperature.

The figures for average annual precipitation over the basin subsequent to 1900 , when from 22 to 28 stations fairly well distributed were used, should be fairly accurate. In 1882 there was on the average one station to sbout 8,500 square miles; in 1930, one to sbout 910 square miles. 
Table 8.- Precipitation, temperature, and mun-off data for

Red River Basin above Grand Forks, N. Dak.

\begin{tabular}{|c|c|c|c|c|c|c|c|c|c|c|c|}
\hline \multirow{2}{*}{ Year } & \multicolumn{3}{|c|}{$\begin{array}{l}\text { Precipitation } \\
\text { (1nches) }\end{array}$} & \multicolumn{2}{|c|}{$\begin{array}{l}\text { Temperature at } \\
\text { Moorhead, Minn. } \\
\text { (०F.) }\end{array}$} & \multicolumn{3}{|c|}{$\begin{array}{c}\text { Run-off at Grand Forks } \\
\text { (Inches) }\end{array}$} & \multicolumn{2}{|c|}{$\begin{array}{l}\text { Precipitation } \\
\text { minus run-off } \\
\text { (Inches) }\end{array}$} & \multirow{2}{*}{$\begin{array}{c}\text { Ratio } \\
\text { run-off } \\
\text { to } \\
\text { precip- } \\
\text { 1tation } \\
\text { 10-jear } \\
\text { pro- } \\
\text { gressive } \\
\text { average } \\
\text { (percent) }\end{array}$} \\
\hline & Annual & $\begin{array}{c}\text { Accumu- } \\
\text { lated }\end{array}$ & $\begin{array}{c}\text { Progres- } \\
\text { s1ve 10- } \\
\text { year } \\
\text { average }\end{array}$ & Annua 1 & $\begin{array}{l}\text { Progres- } \\
\text { sive lo- } \\
\text { year } \\
\text { average }\end{array}$ & Annual & $\begin{array}{c}\text { Accumu- } \\
\text { lated }\end{array}$ & $\begin{array}{l}\text { Progres } \\
\text { sive } 10- \\
\text { year } \\
\text { average }\end{array}$ & Annuel & $\begin{array}{l}\text { Progres- } \\
\text { stve 10- } \\
\text { year } \\
\text { average }\end{array}$ & \\
\hline $\begin{array}{r}1882 \\
83 \\
84 \\
85 \\
86 \\
87 \\
88 \\
89 \\
1890 \\
91 \\
92 \\
93 \\
94 \\
95 \\
96 \\
97 \\
98 \\
99 \\
1900 \\
01 \\
02 \\
03 \\
04 \\
05 \\
06 \\
07 \\
08 \\
09 \\
1910 \\
11 \\
12 \\
13 \\
14 \\
15 \\
16 \\
17 \\
18 \\
19 \\
1920 \\
21 \\
22 \\
23 \\
24 \\
25 \\
26 \\
27 \\
28 \\
29 \\
1930 \\
31 \\
32 \\
33 \\
34\end{array}$ & $\begin{array}{l}27.36 \\
18.74 \\
25.26 \\
18.73 \\
18.80 \\
21.77 \\
17.09 \\
15.33 \\
20.26 \\
25.62 \\
20.97 \\
20.45 \\
19.32 \\
19.55 \\
27.20 \\
22.34 \\
19.80 \\
20.63 \\
23.78 \\
26.02 \\
22.46 \\
21.77 \\
22.10 \\
26.92 \\
24.96 \\
18.48 \\
21.84 \\
22.25 \\
12.21 \\
22.17 \\
22.63 \\
19.49 \\
24.22 \\
23.06 \\
27.76 \\
13.41 \\
19.64 \\
23.02 \\
18.81 \\
22.41 \\
22.47 \\
18.84 \\
20.68 \\
22.76 \\
18.74 \\
22.49 \\
21.26 \\
15.82 \\
17.95 \\
19.67 \\
17.94 \\
16.50 \\
14.67\end{array}$ & $\begin{array}{r}27.36 \\
46.10 \\
71.36 \\
90.09 \\
108.89 \\
130.66 \\
147.75 \\
163.08 \\
183.34 \\
208.96 \\
229.93 \\
250.38 \\
269.70 \\
289.25 \\
316.45 \\
338.79 \\
358.59 \\
379.22 \\
403.00 \\
429.02 \\
451.48 \\
473.25 \\
495.35 \\
522.27 \\
547.23 \\
565.71 \\
587.55 \\
609.80 \\
622.01 \\
644.18 \\
666.81 \\
686.30 \\
710.52 \\
733.58 \\
761.34 \\
774.75 \\
794.39 \\
817.41 \\
836.22 \\
858.63 \\
881.10 \\
899.94 \\
920.62 \\
943.38 \\
962.12 \\
984.61 \\
1005.87 \\
1021.69 \\
1039.64 \\
1059.31 \\
1077.25 \\
1093.75 \\
1108.42\end{array}$ & $\begin{array}{c}- \\
- \\
= \\
= \\
\vdots \\
- \\
20.90 \\
20.26 \\
20.43 \\
19.83 \\
19.92 \\
20.76 \\
20.81 \\
21.08 \\
21.61 \\
21.97 \\
22.01 \\
22.16 \\
22.29 \\
22.56 \\
23.30 \\
23.08 \\
22.69 \\
22.90 \\
23.06 \\
21.90 \\
21.52 \\
21.53 \\
21.30 \\
21.52 \\
21.13 \\
21.41 \\
20.90 \\
20.68 \\
20.76 \\
21.42 \\
21.44 \\
21.43 \\
21.36 \\
21.01 \\
20.98 \\
20.08 \\
20.99 \\
21.15 \\
20.43 \\
20.34 \\
20.07 \\
19.62 \\
19.38 \\
18.78\end{array}$ & $\begin{array}{l}38.4 \\
34.1 \\
36.4 \\
38.0 \\
37.7 \\
36.4 \\
36.6 \\
40.2 \\
38.8 \\
38.9 \\
38.5 \\
35.0 \\
40.8 \\
38.5 \\
37.7 \\
39.2 \\
40.2 \\
39.2 \\
42.0 \\
41.5 \\
40.7 \\
38.9 \\
38.4 \\
40.1 \\
40.1 \\
37.8 \\
41.6 \\
39.6 \\
41.9 \\
39.5 \\
39.6 \\
40.7 \\
41.1 \\
41.0 \\
37.7 \\
37.4 \\
41.3 \\
40.0 \\
40.8 \\
43.0 \\
41.5 \\
41.5 \\
39.0 \\
41.2 \\
40.4 \\
39.3 \\
42.2 \\
39.0 \\
42.8 \\
45.8 \\
41.0 \\
41.7 \\
42.8\end{array}$ & $\begin{array}{c}- \\
- \\
= \\
- \\
- \\
= \\
37.6 \\
37.6 \\
37.7 \\
38.1 \\
38.2 \\
38.2 \\
38.4 \\
38.8 \\
38.7 \\
39.0 \\
39.3 \\
39.5 \\
39.9 \\
39.6 \\
39.8 \\
40.0 \\
39.9 \\
40.0 \\
40.1 \\
40.1 \\
39.9 \\
39.7 \\
39.9 \\
40.2 \\
40.3 \\
40.1 \\
40.0 \\
40.0 \\
40.0 \\
39.9 \\
40.3 \\
40.5 \\
40.5 \\
40.3 \\
40.3 \\
40.6 \\
40.8 \\
40.9 \\
40.8 \\
41.0 \\
41.3 \\
41.2 \\
41.2 \\
41.6\end{array}$ & $\begin{array}{l}3.06 \\
2.22 \\
1.56 \\
1.70 \\
1.04 \\
.56 \\
1.50 \\
.42 \\
.44 \\
.66 \\
2.04 \\
1.93 \\
1.15 \\
.45 \\
1.85 \\
3.05 \\
.89 \\
1.14 \\
1.02 \\
1.74 \\
1.72 \\
1.59 \\
2.60 \\
2.09 \\
2.46 \\
1.89 \\
1.64 \\
1.41 \\
1.27 \\
.39 \\
.47 \\
.74 \\
1.93 \\
1.57 \\
3.12 \\
1.19 \\
1.52 \\
1.18 \\
1.69 \\
.80 \\
1.27 \\
.70 \\
.38 \\
.71 \\
.64 \\
1.41 \\
1.00 \\
.80 \\
.63 \\
.18 \\
.32 \\
.21 \\
.13\end{array}$ & $\begin{array}{r}3.06 \\
5.28 \\
6.84 \\
8.54 \\
9.58 \\
10.14 \\
11.64 \\
12.06 \\
12.50 \\
13.16 \\
15.20 \\
17.13 \\
18.28 \\
18.73 \\
20.58 \\
23.63 \\
24.52 \\
25.66 \\
26.68 \\
28.42 \\
30.14 \\
31.73 \\
34.33 \\
36.42 \\
38.88 \\
40.77 \\
42.41 \\
43.82 \\
45.09 \\
45.48 \\
45.95 \\
46.69 \\
47.62 \\
49.19 \\
52.31 \\
53.50 \\
54.02 \\
55.20 \\
56.89 \\
57.69 \\
58.96 \\
59.66 \\
60.04 \\
60.75 \\
61.39 \\
62.80 \\
63.80 \\
64.60 \\
65.23 \\
65.41 \\
65.73 \\
65.94 \\
66.07\end{array}$ & $\begin{array}{l}5 \\
= \\
= \\
= \\
= \\
= \\
- \\
1.32 \\
1.21 \\
1.18 \\
1.14 \\
1.02 \\
1.10 \\
1.35 \\
1.29 \\
1.36 \\
1.42 \\
1.53 \\
1.49 \\
1.46 \\
1.60 \\
1.77 \\
1.83 \\
1.71 \\
1.79 \\
1.82 \\
1.84 \\
1.71 \\
1.58 \\
1.50 \\
1.33 \\
1.28 \\
1.34 \\
1.27 \\
1.16 \\
1.14 \\
1.18 \\
1.22 \\
1.30 \\
1.30 \\
1.24 \\
1.16 \\
.91 \\
.93 \\
.98 \\
.94 \\
.83 \\
.77 \\
.68 \\
.63 \\
.60\end{array}$ & $\begin{array}{l}24.30 \\
16.52 \\
23.70 \\
17.03 \\
17.76 \\
21.21 \\
15.59 \\
14.91 \\
19.82 \\
24.96 \\
18.93 \\
18.52 \\
18.17 \\
19.10 \\
25.35 \\
19.29 \\
18.91 \\
19.49 \\
22.76 \\
24.28 \\
20.74 \\
20.18 \\
19.50 \\
24.83 \\
22.50 \\
16.59 \\
20.20 \\
20.84 \\
10.94 \\
21.78 \\
22.16 \\
18.75 \\
23.29 \\
21.49 \\
24.64 \\
12.22 \\
19.12 \\
21.84 \\
17.12 \\
21.61 \\
21.20 \\
18.14 \\
20.30 \\
22.05 \\
18.10 \\
21.08 \\
20.26 \\
15.02 \\
17.32 \\
19.49 \\
17.62 \\
16.29 \\
14.54\end{array}$ & $\begin{array}{c}- \\
= \\
= \\
- \\
- \\
- \\
19.58 \\
19.05 \\
19.25 \\
18.69 \\
18.90 \\
19.66 \\
19.46 \\
19.79 \\
20.25 \\
20.55 \\
20.48 \\
20.67 \\
20.83 \\
20.96 \\
21.53 \\
21.25 \\
20.98 \\
21.11 \\
21.24 \\
20.06 \\
19.81 \\
19.95 \\
19.80 \\
20.19 \\
19.85 \\
20.07 \\
19.63 \\
19.52 \\
19.62 \\
20.24 \\
20.22 \\
20.13 \\
20.06 \\
19.77 \\
19.82 \\
19.177 \\
20.06 \\
20.17 \\
19.49 \\
19.51 \\
19.30 \\
18.94 \\
18.75 \\
18.18\end{array}$ & $\begin{array}{l}- \\
- \\
- \\
- \\
- \\
- \\
- \\
0 . \\
6.32 \\
5.97 \\
5.78 \\
5.75 \\
5.13 \\
5.30 \\
6.48 \\
6.12 \\
6.29 \\
6.46 \\
6.96 \\
6.72 \\
6.55 \\
7.09 \\
7.60 \\
7.93 \\
7.54 \\
7.82 \\
7.89 \\
8.40 \\
7.95 \\
7.34 \\
7.05 \\
6.19 \\
6.06 \\
6.26 \\
6.07 \\
5.60 \\
5.49 \\
5.52 \\
5.70 \\
6.07 \\
6.08 \\
5.90 \\
5.53 \\
4.53 \\
4.43 \\
4.63 \\
4.60 \\
4.07 \\
3.84 \\
3.47 \\
3.24 \\
3.19\end{array}$ \\
\hline $\begin{array}{c}\text { Total } \\
\text { Av. }\end{array}$ & $\begin{array}{r}1108.42 \\
20.91\end{array}$ & - & $=$ & $\begin{array}{r}2107.5 \\
39.8\end{array}$ & $\overline{-}$ & $\begin{array}{r}66.07 \\
1.25\end{array}$ & - & $\overline{-}$ & $\begin{array}{r}1042.35 \\
19.67\end{array}$ & $\overline{-}$ & - \\
\hline
\end{tabular}




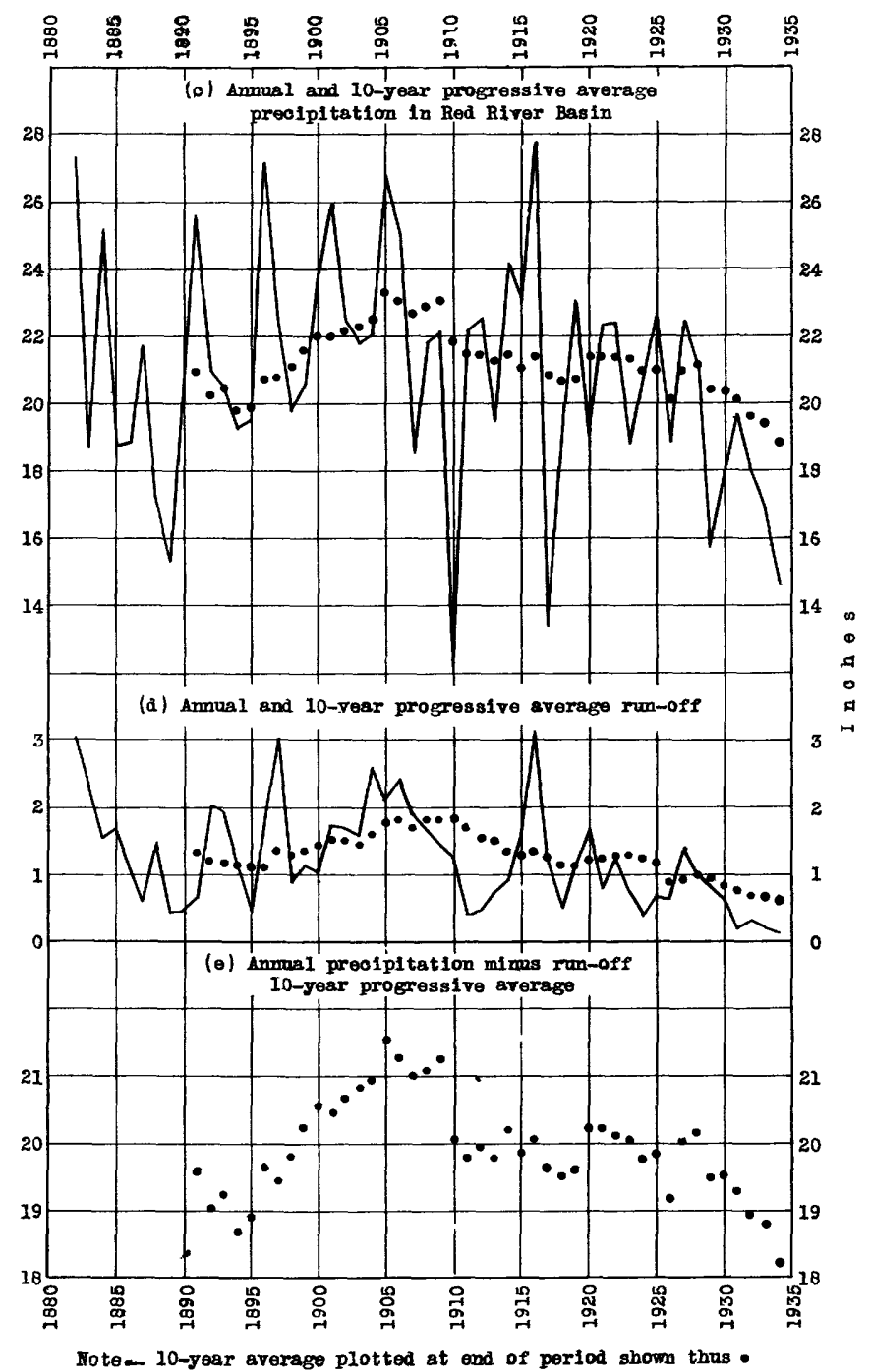

Figure 18. - Felations between rainfall and ran-off in Red River Basin above Grand Foriks, N. Dak. 
Differences in precipitation between one part of the basin and another probably result more from differences in geographic location than from differences in altitude. Such differences show a range from about 21.8 to 16.3 Inches on the basis of long-tIme averages and from about 33.8 to 17.5 inches on the basis of jearly figures. Preclpitation generally increases from west to east. The precipitation records are on the basis of the calendar year.

Temreracure.- The mean annual temperatures for the pertod of record at the stations in and adjacent to the basin were averaged and compared Wth the mean annual temperature recorded at Moorhead and found to be essentially the same. The Moorhead record of annual temperature was therefore used as an approximation of the average annual temperature for the basin. The stations in the basin averaged to compute the nomal annual temperature for the basin are indicated in the table of precipitation stations. The temperature records are on the basis of the calendar year.

\section{Mississippl River Besin above Koolruk, Iowa}

(Drainage area, 119,000 square miles. Records avallable, 1878-1934.)

The Mississippl River rises in an area of small lakes in northeastern Becker County, Minn., at about 1,570 feet above sea level, and flows in a general south and southeast course to Keokuk, Iowa. The major tributarles above Keolsuk are the Minnesota, Iowa, and skunk Rivers from the west and the St. Crolx, Chippewa, Wisconsin, and Rock Rivers from the east.

That portion of the basin above st. Paul, an area of 35,700 square miles, is for the most part relatively flat and covered with glactal drift, into which rainfall percolates rapidy. In this part of the basin there are numerous swamps and lakes. The precipitation in this area of 35,700 square miles ranges from an average of about 28 inches a year in the southeastern part to about 23 inches along the northwestern border and averages about 26.5 inches.

The middle portion of the basin, between St. Paul and Le claire, comprising 52,900 square miles, is also covered with glacial arift. The topography is rougher, however, with increasing slopes toward the river courses. The precipltation on this area averages about 31.2 inches a year. $59550-35-5$ 
The precipitation on the remainder of the Mississippi River Basin above Keokuk, comprising a V - shaped area of 30,400 square miles, covered mostly with alluvial soil, averages 33.0 inches a year.

The fall of the river for about the first 600 miles averages about 1.3 feet to the $\mathrm{mlle}$, and the fall in the lower part of the river, from St. Paul to Keokuk, averages between 0.4 and 0.5 foot to the mile. Run-off.- All the records of flow avallable for Keokuk prior to 1913 have been based on readings of a gage at the upper lock of the canal, at a place then called "Nashville," now Galland, Iowa, about 8 miles above Keokuk. The gage was founded on a rock and was read twice daily from 1878 to the time when it was drowned out by backwater from the Keokuk Dam, in 1913. The rock bed of rapids below the Nashville gage furnished an excellent control, which is permanent for all stages. Records subsequent to 1913 have been computed as the sum of the flow through the turbines and over the spillways of the power development of Keokuk. All records of flow have been computed and compiled by the Mississippi River Power Co.

There are numerous hydroelectric power developments and several storage reservoirs on the main streams and tributaries, but it is believed that their combined effect on the annual discharge is very small.

Precipitation.- The average annual precipitation ranges from about 25 to 35 inches across the basin. The estimates of annual precipitation over the basin probably increase rather rapidiy in accuracy from 1878 to 1900 and should be reasonably accurate and consistent from 1900 to date. Prior to 1900, but more especially prior to 1890 , not only were the precipitation stations few but their distribution was poor, especially in wisconsin. The number of precipitation stations avallable in determining the annual precipitation over the basin was as follows:

$\begin{array}{ll}1871-18 \text { stations } & 1910-178 \text { stations } \\ 1878-40 \text { stations } & 1920-178 \text { stations } \\ 1890-63 \text { stations } & 1930-181 \text { stations } \\ 1900-144 \text { stations } & \end{array}$

The precipitation stations used to compute the basin average were as follows: 
Table 9.- Precipitation stations in or near

Mississipp1 River Basin above Keokuk, Iowa

\begin{tabular}{|c|c|c|c|}
\hline Station & $\begin{array}{c}\text { Altitude } \\
\text { (feet) }\end{array}$ & $\begin{array}{l}\text { Period } \\
\text { of } \\
\text { record }\end{array}$ & $\begin{array}{l}\text { Mean annual } \\
\text { precipitation } \\
\text { (inches) }\end{array}$ \\
\hline \multicolumn{4}{|l|}{ Illinols: } \\
\hline $\begin{array}{l}\text { Aledo } \\
\text { Dixon } \\
\text { Elgin } \\
\text { Freeport } \\
\text { Galena } \\
\text { Galesburg }\end{array}$ & $\begin{array}{l}739 \\
696 \\
717 \\
762 \\
603 \\
758\end{array}$ & $\begin{array}{l}1901- \\
1887,1892- \\
1898-1900,1911- \\
1886-89,1909- \\
1896-1901,1928- \\
1862-71,1885-89 \\
1895-1909,1927-\end{array}$ & $\begin{array}{l}33.87 \\
33.19 \\
32.67 \\
32.69 \\
32.07 \\
35.45\end{array}$ \\
\hline $\begin{array}{l}\text { Galva } \\
\text { Geneseo }\end{array}$ & $\begin{array}{l}849 \\
639\end{array}$ & $\begin{array}{c}1865-69,1873-82,1893- \\
1873-82,1886-87 \\
1895-1908,1925-\end{array}$ & $\begin{array}{l}33.12 \\
34.55\end{array}$ \\
\hline $\begin{array}{l}\text { La Harpe } \\
\text { Marengo } \\
\text { Monmouth } \\
\text { Morrison } \\
\text { Mount Carroll } \\
\text { Oregon } \\
\text { Paw Paw } \\
\text { Rochello } \\
\text { Rockford } \\
\text { Sycamore } \\
\text { Walnut }\end{array}$ & $\begin{array}{l}691 \\
819 \\
763 \\
670 \\
817 \\
702 \\
928 \\
798 \\
720 \\
840 \\
714\end{array}$ & $\begin{array}{l}1895- \\
1856- \\
1894- \\
1896- \\
1887-91,1895- \\
1893-94,1896,1910- \\
1913- \\
1924- \\
1874- \\
1882- \\
1892-\end{array}$ & $\begin{array}{l}36.38 \\
33.11 \\
34.51 \\
34.07 \\
33.97 \\
32.17 \\
32.51 \\
36.15 \\
34.64 \\
34.63 \\
33.60\end{array}$ \\
\hline \multicolumn{4}{|l|}{ Iowa: } \\
\hline $\begin{array}{l}\text { Allison } \\
\text { Amana } \\
\text { Ames } \\
\text { Baxter } \\
\text { Belle Plaine } \\
\text { Belmond } \\
\text { Bonaparte } \\
\text { Boone } \\
\text { Britt } \\
\text { Burlington } \\
\text { Cedar Rapids } \\
\text { Charles City } \\
\text { Clinton } \\
\text { Columbus Junction } \\
\text { Davenport } \\
\text { Decorah } \\
\text { Delaware } \\
\text { Dubuque } \\
\text { Elkader } \\
\text { Fairfield }\end{array}$ & $\begin{array}{r}1,000 \\
721 \\
926 \\
993 \\
866 \\
1,181 \\
563 \\
894 \\
1,236 \\
544 \\
737 \\
1,015 \\
595 \\
595 \\
580 \\
872 \\
1,083 \\
700 \\
751 \\
780\end{array}$ & $\begin{array}{l}1914- \\
1876-1915 \\
1876- \\
1899-1932 \\
1876- \\
1909- \\
1886-89,1891- \\
1871-81,1894- \\
1876,1879-89,1897- \\
1876-82,1897- \\
1882- \\
1875- \\
1865-71,1878-- \\
1879-87,1900- \\
1871- \\
1844-46,1878-83,1892- \\
1854-58,1875-1921,1930- \\
1851- \\
1872-1920 \\
1856-59,1876-88 \\
1891-1902,1908-\end{array}$ & $\begin{array}{l}30.72 \\
33.32 \\
30.58 \\
31.73 \\
34.25 \\
32.18 \\
33.52 \\
32.88 \\
28.14 \\
36.63 \\
31.22 \\
31.49 \\
35.76 \\
34.15 \\
32.14 \\
32.96 \\
33.53 \\
32.90 \\
32.80 \\
36.21\end{array}$ \\
\hline $\begin{array}{l}\text { Fairport } \\
\text { Farmersburg } \\
\text { Fayette } \\
\text { Forest City } \\
\text { Fort Madison } \\
\text { Grinnell }\end{array}$ & $\begin{array}{r}600 \\
1,079 \\
1,003 \\
1,226 \\
522 \\
1,031\end{array}$ & $\begin{array}{l}1921-30 \\
1836-1930 \\
1888- \\
1887-89,1894- \\
1848-1918 \\
1876,1878,1880-83 \\
1888-90,1893-\end{array}$ & $\begin{array}{l}35.83 \\
31.67 \\
34.04 \\
29.33 \\
36.58 \\
34.43\end{array}$ \\
\hline $\begin{array}{l}\text { Grundy Center } \\
\text { Hampton } \\
\text { Independence } \\
\text { Iowa CIty } \\
\text { Iowa Falis } \\
\text { Keokuk } \\
\text { Lansing } \\
\text { Maquoketa }\end{array}$ & $\begin{array}{r}976 \\
1,142 \\
956 \\
733 \\
1,127 \\
614 \\
632 \\
692\end{array}$ & $\begin{array}{l}1891- \\
1877-81,1888-1915,1924-32 \\
1860- \\
1857- \\
1863-72,1892- \\
1871- \\
1896-1904,1912-32 \\
1876,1878-84,1887-90 \\
1892-93,1896-1906 \\
1914-20,1925-\end{array}$ & $\begin{array}{l}32.86 \\
33.76 \\
32.87 \\
36.22 \\
33.85 \\
32.64 \\
32.47 \\
33.62\end{array}$ \\
\hline
\end{tabular}


Table 9.- Precipitation stations in or near

Mississippi River Basin above Keokuk, Iowa--Continued

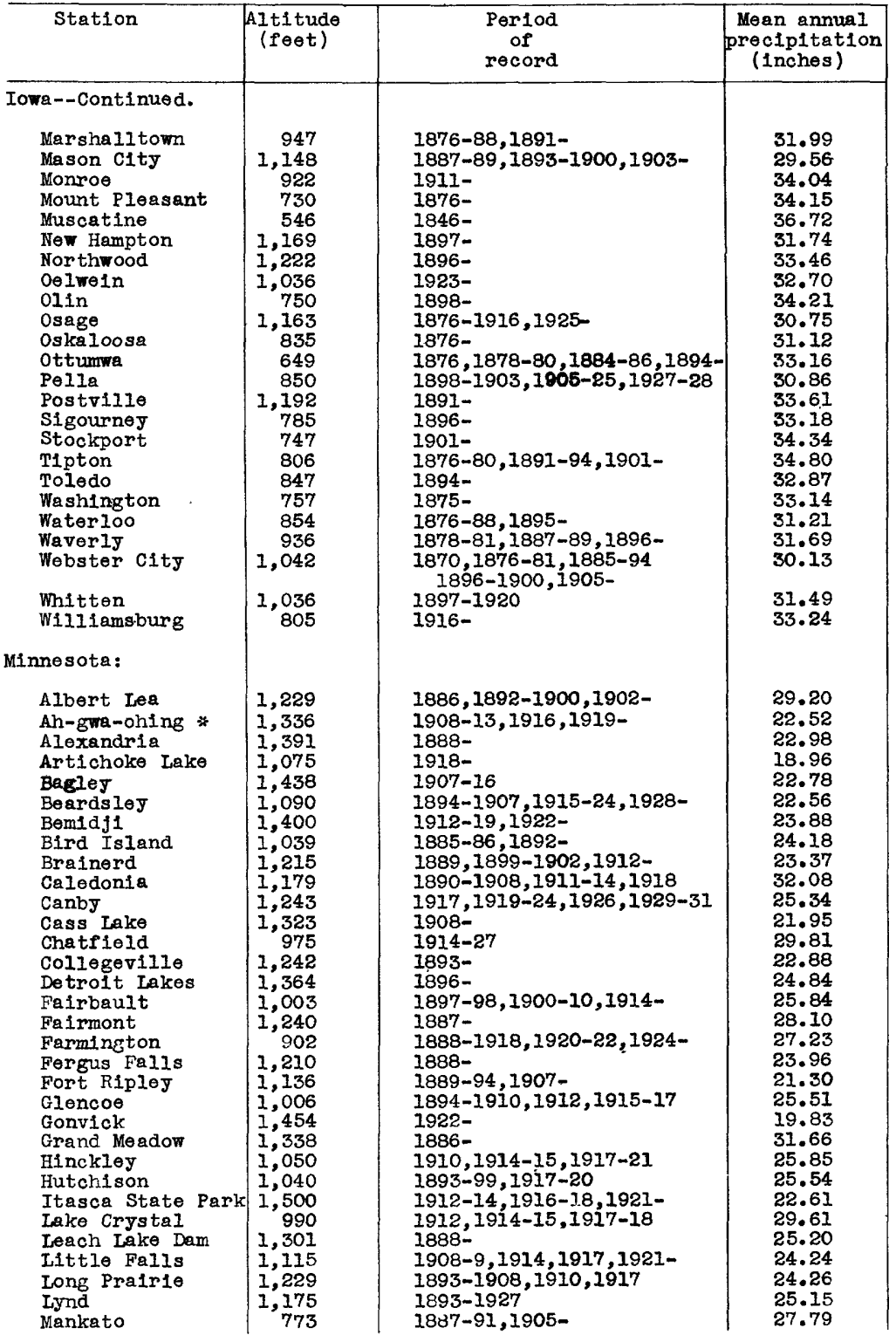

* Formerly known as State Sanitarium. 
Table 9.- Precipitation stations in or near

Mississippi River Basin above Keokuk, Iowa--Continued

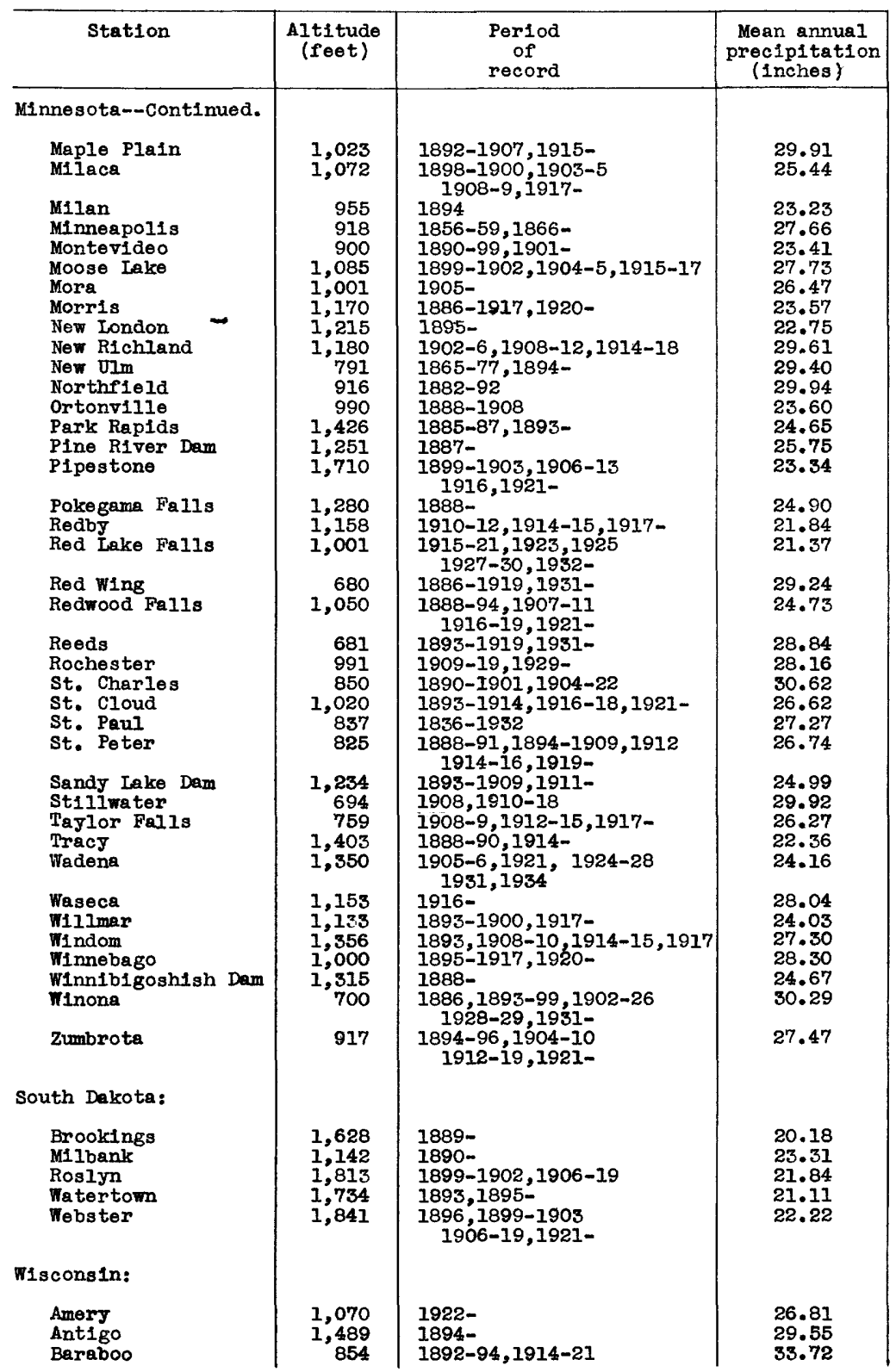


Table 9.- Precipitation stations in or near

Mississippi River Basin above Keokuk, Iowa--Continued

\begin{tabular}{|c|c|c|c|}
\hline Station & $\begin{array}{c}\text { Alt1tude } \\
\text { (feet) }\end{array}$ & $\begin{array}{l}\text { Period } \\
\text { of } \\
\text { record }\end{array}$ & $\begin{array}{l}\text { Mean annual } \\
\text { precipitation } \\
\text { (inches) }\end{array}$ \\
\hline 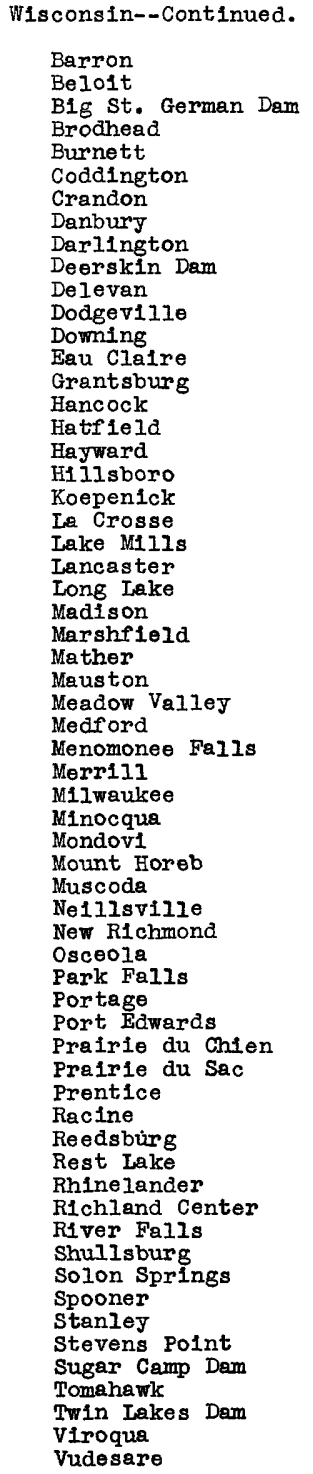 & $\begin{array}{r}1,115 \\
750 \\
1,590 \\
812 \\
880 \\
1,074 \\
1,650 \\
908 \\
867 \\
1,683 \\
920 \\
1,220 \\
983 \\
800 \\
1,095 \\
1,086 \\
973 \\
1,197 \\
980 \\
1,681 \\
714 \\
847 \\
1,060 \\
1,592 \\
974 \\
1,250 \\
962 \\
882 \\
974 \\
1,420 \\
842 \\
1,267 \\
681 \\
1,604 \\
738 \\
1,226 \\
666 \\
1,060 \\
990 \\
806 \\
1,492 \\
809 \\
969 \\
628 \\
750 \\
1,551 \\
633 \\
876 \\
1,600 \\
1,550 \\
735 \\
902 \\
1,019 \\
1,083 \\
1,104 \\
1,082 \\
1,113 \\
1,580 \\
1,450 \\
1,625 \\
1,281 \\
1,600\end{array}$ & $\begin{array}{l}1891-1921 \\
1850- \\
1910- \\
1898- \\
1904- \\
1921- \\
1891-1903,1907-19 \\
1920- \\
1901-5,1910- \\
1910- \\
1887-1903,1907-21 \\
1897-1903,1914-16 \\
1891-95,1898- \\
1891- \\
1889-90,1892- \\
1892- \\
1894- \\
1890-1923 \\
1891- \\
1891-1918,1920-24 \\
1873- \\
1891- \\
1891-1918,1921- \\
1908- \\
1869- \\
1913- \\
1903- \\
1896-1919,1924- \\
1891- \\
1890- \\
1909-15 \\
1906- \\
1841,1844-52,1854- \\
1904- \\
1908- \\
1904-20 \\
1909-19 \\
1876-86,1890- \\
1905-17 \\
1891-20 \\
1910- \\
1889- \\
1910-19 \\
1837-45,1891- \\
1908- \\
1898- \\
1897- \\
1914-19 \\
1910- \\
1908- \\
1892,1908,1920- \\
1918- \\
1906-18 \\
1906- \\
1894- \\
1903- \\
1893- \\
1910-20 \\
1913-24 \\
1910-20 \\
1890- \\
1908-17 \\
\end{array}$ & $\begin{array}{l}31.36 \\
33.18 \\
30.19 \\
33.71 \\
29.34 \\
29.90 \\
28.01 \\
26.45 \\
32.72 \\
29.82 \\
30.65 \\
31.53 \\
31.49 \\
32.63 \\
30.11 \\
30.76 \\
30.27 \\
28.69 \\
32.17 \\
31.54 \\
30.81 \\
32.84 \\
31.58 \\
29.31 \\
31.98 \\
31.47 \\
32.10 \\
31.88 \\
29.42 \\
32.98 \\
34.19 \\
30.88 \\
30.08 \\
29.71 \\
31.96 \\
34.12 \\
30.38 \\
33.26 \\
29.38 \\
30.72 \\
32.98 \\
31.15 \\
32.73 \\
30.96 \\
28.50 \\
31.99 \\
30.81 \\
32.26 \\
30.48 \\
29.67 \\
31.48 \\
29.73 \\
35.77 \\
28.19 \\
27.54 \\
33.55 \\
31.94 \\
30.03 \\
31.03 \\
27.46 \\
33.16 \\
31.72\end{array}$ \\
\hline
\end{tabular}


Table 9.- Precipitation stations in or near Mississippl River Basin above Keokuk, Iowa--Continued

\begin{tabular}{l|c|l|c|}
\hline \multicolumn{1}{|c|}{ Station } & $\begin{array}{c}\text { Altitude } \\
\text { (feet) }\end{array}$ & $\begin{array}{c}\text { Period } \\
\text { of } \\
\text { record }\end{array}$ & $\begin{array}{c}\text { Mean annual } \\
\text { precipitation } \\
\text { (inches) }\end{array}$ \\
\hline Wisconsin--Continued. & & & 32.45 \\
Watertown & 824 & $1891-$ & 31.19 \\
Waukesha & 864 & $1892-$ & 32.11 \\
Wausau & 1,247 & $1896-1900,1902-$ & 30.00 \\
West Bend & 941 & $1895-1902,1922-$ & 31.91 \\
Wejerhauser & 1,337 & $1895-96,1907-$ & 30.21 \\
Whitehali & 675 & $1891-92,1895,1897-1906$ & 31.96 \\
Williams Bay & 1,025 & $1910-17,1919-20$ & 30.19 \\
Wisconsin Dells & 900 & $1903-$ & 30.89 \\
Wisconsin Rapids & 1,036 & $1922-$ & \\
\hline
\end{tabular}

During the period 1871-77, 18 precipitation stations were used; the records for 11 stations in the southern section, controlling 26.2 percent of the area, were averaged, and those for the remaining 7 stations were weighted according to area. The figures for Twin Citles and Duluth were modifled according to their relation, during the perlod 1921-30, to the average for the stations lying within the areas controlled by Minneapolis, St. Paul, and Duluth. The same method was used for the pertod 1878-85, the records for 29 stations in the southern section, controlling 29.3 percent of the area, being averaged, and those for the remaining 11 stations welghted according to area, Twin Cities, Duluth, and Neillsville being modifled as stated above.

From 1886 to 1934 the records for the stations 1 ying within the boundaries or each State were averaged, and this average was weighted as to that part of the area of the State lying in the Mississippl River drainage basin, in percentage of the area of the basin above Keokla; from these welghted averages the average annual precipitation for the basin was determinea.

Temperature.- Seven stations with long records and well distributed over the basin were selected, and their records were averaged to determine the average annual temperature of the basin. These seven stations are Ilsted in table 11. 
Tablo 10.- Precipitation, temperature, and mu-off data for

Missisgippl River Basin above Kookuk, Iowa

\begin{tabular}{|c|c|c|c|c|c|c|c|c|c|c|c|}
\hline \multirow{2}{*}{ Year } & \multicolumn{3}{|c|}{$\begin{array}{l}\text { Precipitation } \\
\text { (Inches) }\end{array}$} & \multicolumn{2}{|c|}{$\begin{array}{c}\text { Temperature } \\
\text { (op.) }\end{array}$} & \multicolumn{3}{|c|}{$\begin{array}{c}\text { Fun-off at Kookuk } \\
\text { (Inches) }\end{array}$} & \multicolumn{2}{|c|}{$\begin{array}{l}\text { Precipitation } \\
\text { minus run-off } \\
\text { (Inches) }\end{array}$} & \multirow{2}{*}{$\begin{array}{c}\text { Ratio } \\
\text { mun-off } \\
\text { to } \\
\text { prec1p- } \\
\text { itation } \\
\text { 10-Joer } \\
\text { pro- } \\
\text { gressiro } \\
\text { averago } \\
\text { (percont }\end{array}$} \\
\hline & Annual & $\begin{array}{l}\text { Accuonu- } \\
\text { lated }\end{array}$ & $\begin{array}{c}\text { Progres } \\
\text { sive 10- } \\
\text { Jear } \\
\text { average }\end{array}$ & Annual & $\begin{array}{l}\text { Progres } \\
\text { Bive 10- } \\
\text { year } \\
\text { averago }\end{array}$ & Annual & $\begin{array}{l}\text { Accuma- } \\
\text { lated }\end{array}$ & $\begin{array}{l}\text { Progres- } \\
\text { sive 10- } \\
\text { year } \\
\text { average }\end{array}$ & Annual & $\begin{array}{l}\text { Progres- } \\
\text { sive 10- } \\
\text { Jear } \\
\text { average }\end{array}$ & \\
\hline $\begin{array}{r}1878 \\
79 \\
1880 \\
81 \\
82 \\
83 \\
84 \\
85 \\
86 \\
87 \\
88 \\
89 \\
1890 \\
91 \\
92 \\
93 \\
94 \\
95 \\
96 \\
97 \\
98 \\
99 \\
1900 \\
01 \\
02 \\
03 \\
04 \\
05 \\
06 \\
07 \\
08 \\
09 \\
1910 \\
11 \\
12 \\
13 \\
14 \\
15 \\
16 \\
17 \\
18 \\
19 \\
1920 \\
21 \\
22 \\
23 \\
24 \\
25 \\
26 \\
27 \\
28 \\
29 \\
1930 \\
31 \\
32 \\
33 \\
34\end{array}$ & 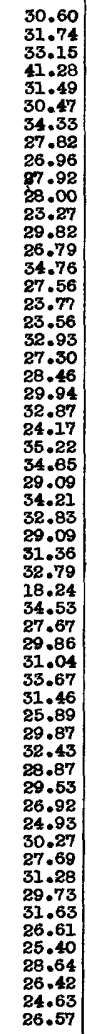 & $\begin{array}{r}30.60 \\
62.34 \\
95.49 \\
136.77 \\
168.26 \\
198.73 \\
233.06 \\
260.88 \\
287.84 \\
315.76 \\
343.76 \\
367.03 \\
396.85 \\
423.64 \\
458.40 \\
485.96 \\
509.73 \\
533.29 \\
566.22 \\
593.52 \\
621.98 \\
651.92 \\
684.79 \\
708.96 \\
744.18 \\
779.03 \\
808.12 \\
642.33 \\
875.16 \\
904.25 \\
935.61 \\
968.40 \\
986.64 \\
1021.17 \\
1048.84 \\
1078.70 \\
1109.74 \\
1143.41 \\
1174.87 \\
1200.76 \\
1230.63 \\
1263.06 \\
1291.93 \\
1321.46 \\
1348.38 \\
1373.31 \\
1403.58 \\
1431.27 \\
1462.555 \\
1492.28 \\
1523.91 \\
1550.52 \\
1575.92 \\
1604.56 \\
1630.98 \\
1655.61 \\
1682.18\end{array}$ & $\begin{array}{c}- \\
- \\
\vdots \\
- \\
- \\
37 \\
31.58 \\
31.32 \\
30.47 \\
30.14 \\
28.69 \\
29.01 \\
28.72 \\
27.67 \\
27.24 \\
27.84 \\
27.78 \\
27.82 \\
28.49 \\
28.79 \\
28.53 \\
28.68 \\
29.31 \\
29.84 \\
30.90 \\
30.89 \\
31.07 \\
31.36 \\
31.65 \\
30.19 \\
31.22 \\
30.47 \\
29.97 \\
30.16 \\
30.11 \\
29.97 \\
29.65 \\
29.50 \\
29.47 \\
30.53 \\
30.03 \\
29.95 \\
29.23 \\
29.46 \\
28.78 \\
28.79 \\
29.77 \\
29.33 \\
28.75 \\
28.40 \\
28.31 \\
27.86\end{array}$ & $\begin{array}{l}48.6 \\
45.4 \\
45.4 \\
46.0 \\
46.2 \\
42.3 \\
43.6 \\
42.6 \\
44.3 \\
43.5 \\
42.5 \\
45.7 \\
45.0 \\
45.0 \\
43.8 \\
42.5 \\
47.0 \\
44.5 \\
45.3 \\
45.0 \\
45.8 \\
44.9 \\
46.7 \\
45.9 \\
45.6 \\
44.4 \\
43.1 \\
44.6 \\
45.6 \\
43.7 \\
46.4 \\
44.6 \\
46.2 \\
46.9 \\
43.5 \\
46.1 \\
45.7 \\
45.3 \\
43.9 \\
41.4 \\
45.6 \\
45.3 \\
45.1 \\
48.4 \\
46.5 \\
45.7 \\
43.1 \\
45.3 \\
44.1 \\
44.8 \\
46.0 \\
43.3 \\
46.9 \\
50.5 \\
45.6 \\
46.8 \\
47.4\end{array}$ & $\begin{array}{c}- \\
- \\
. \\
- \\
- \\
- \\
44.8 \\
44.2 \\
44.2 \\
44.2 \\
44.1 \\
43.8 \\
43.9 \\
44.2 \\
44.4 \\
44.5 \\
44.6 \\
45.0 \\
44.9 \\
45.1 \\
45.1 \\
45.3 \\
45.5 \\
46.1 \\
45.1 \\
45.2 \\
45.0 \\
45.1 \\
45.1 \\
45.0 \\
45.0 \\
44.8 \\
45.0 \\
45.2 \\
45.3 \\
45.1 \\
44.9 \\
44.8 \\
44.9 \\
44.8 \\
45.0 \\
45.3 \\
45.3 \\
45.0 \\
45.0 \\
45.1 \\
45.4 \\
45.4 \\
45.2 \\
45.4 \\
45.6 \\
45.5 \\
45.6 \\
46.1\end{array}$ & $\begin{array}{r}6.96 \\
5.49 \\
8.59 \\
13.19 \\
10.92 \\
9.11 \\
9.34 \\
8.99 \\
7.57 \\
5.88 \\
9.61 \\
4.65 \\
6.16 \\
5.29 \\
9.07 \\
7.20 \\
5.53 \\
3.49 \\
5.41 \\
7.77 \\
4.87 \\
6.65 \\
6.55 \\
5.55 \\
7.12 \\
10.73 \\
7.49 \\
9.44 \\
9.94 \\
9.01 \\
8.19 \\
8.36 \\
4.74 \\
5.75 \\
7.10 \\
6.07 \\
5.77 \\
8.62 \\
9.41 \\
6.76 \\
5.96 \\
8.11 \\
7.56 \\
5.48 \\
6.44 \\
4.48 \\
6.03 \\
4.21 \\
6.38 \\
7.92 \\
8.17 \\
7.77 \\
4.47 \\
3.62 \\
5.04 \\
4.70 \\
3.12\end{array}$ & $\begin{array}{r}6.96 \\
12.45 \\
21.04 \\
34.23 \\
45.15 \\
54.26 \\
63.60 \\
72.59 \\
80.16 \\
86.04 \\
95.65 \\
100.30 \\
106.46 \\
111.75 \\
120.82 \\
128.02 \\
133.55 \\
137.04 \\
142.45 \\
150.22 \\
155.09 \\
161.74 \\
168.29 \\
173.84 \\
180.96 \\
191.69 \\
199.18 \\
208.62 \\
218.56 \\
227.57 \\
235.76 \\
244.12 \\
248.86 \\
254.61 \\
261.71 \\
267.78 \\
273.55 \\
282.17 \\
291.58 \\
298.34 \\
304.30 \\
312.41 \\
319.96 \\
325.44 \\
331.888 \\
336.36 \\
342.39 \\
346.60 \\
352.98 \\
360.90 \\
369.07 \\
376.84 \\
381.31 \\
384.93 \\
389.97 \\
394.67 \\
397.79\end{array}$ & $\begin{array}{l}- \\
= \\
= \\
= \\
= \\
= \\
= \\
8.60 \\
8.87 \\
8.78 \\
8.54 \\
7.75 \\
7.57 \\
7.38 \\
7.00 \\
6.44 \\
6.23 \\
6.42 \\
5.94 \\
6.14 \\
6.18 \\
6.21 \\
6.01 \\
6.37 \\
6.56 \\
7.26 \\
7.61 \\
7.74 \\
8.07 \\
8.24 \\
8.06 \\
8.08 \\
8.08 \\
7.61 \\
7.44 \\
7.36 \\
7.30 \\
7.08 \\
6.85 \\
6.83 \\
7.11 \\
7.08 \\
7.02 \\
6.86 \\
6.88 \\
6.44 \\
6.14 \\
6.26 \\
6.48 \\
6.44 \\
6.14 \\
5.95 \\
5.81 \\
5.83 \\
5.54\end{array}$ & $\begin{array}{l}23.64 \\
26.25 \\
24.56 \\
28.09 \\
20.57 \\
21.36 \\
24.99 \\
18.83 \\
19.39 \\
22.04 \\
18.39 \\
18.62 \\
23.66 \\
21.50 \\
25.69 \\
20.36 \\
18.24 \\
20.07 \\
27.52 \\
19.53 \\
23.59 \\
23.29 \\
26.32 \\
18.62 \\
28.10 \\
24.12 \\
21.60 \\
24.77 \\
22.89 \\
20.08 \\
23.17 \\
24.43 \\
13.50 \\
28.78 \\
20.57 \\
23.79 \\
25.27 \\
25.05 \\
22.05 \\
19.13 \\
23.91 \\
24.32 \\
21.32 \\
24.05 \\
20.48 \\
20.45 \\
24.24 \\
23.48 \\
24.90 \\
21.81 \\
23.46 \\
18.84 \\
20.93 \\
25.02 \\
21 . .38 \\
19.93 \\
23.45\end{array}$ & 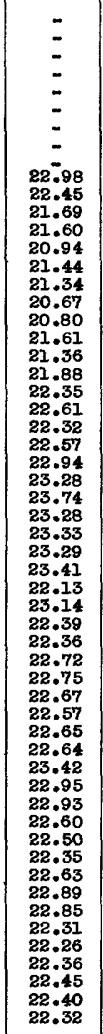 & $\begin{array}{c}- \\
- \\
- \\
- \\
= \\
- \\
27.2 \\
28.3 \\
28.8 \\
28.3 \\
27.0 \\
26.1 \\
25.7 \\
25.3 \\
23.7 \\
22.4 \\
23.1 \\
21.4 \\
21.6 \\
21.5 \\
21.8 \\
21.0 \\
21.7 \\
22.0 \\
23.2 \\
24.6 \\
24.9 \\
25.7 \\
26.1 \\
26.7 \\
25.9 \\
26.5 \\
25.4 \\
24.7 \\
24.4 \\
24.3 \\
23.9 \\
23.2 \\
23.2 \\
23.3 \\
23.6 \\
23.4 \\
23.3 \\
23.4 \\
22.4 \\
21.4 \\
21.4 \\
22.1 \\
22.4 \\
21.6 \\
21.0 \\
20.6 \\
20.6 \\
19.9\end{array}$ \\
\hline $\begin{array}{l}\text { otal } \\
\text { AV. }\end{array}$ & $\begin{array}{r}682.18 \\
29.51\end{array}$ & $=$ & & $\begin{array}{r}2573.9 \\
45.2\end{array}$ & $=$ & $\begin{array}{r}397.79 \\
6.98\end{array}$ & $\overline{-}$ & $\overline{-}$ & $\begin{array}{r}1284.39 \\
22.53\end{array}$ & $=$ & \\
\hline
\end{tabular}

- Btations used to copate average temperature over the basin are given in table 11. 


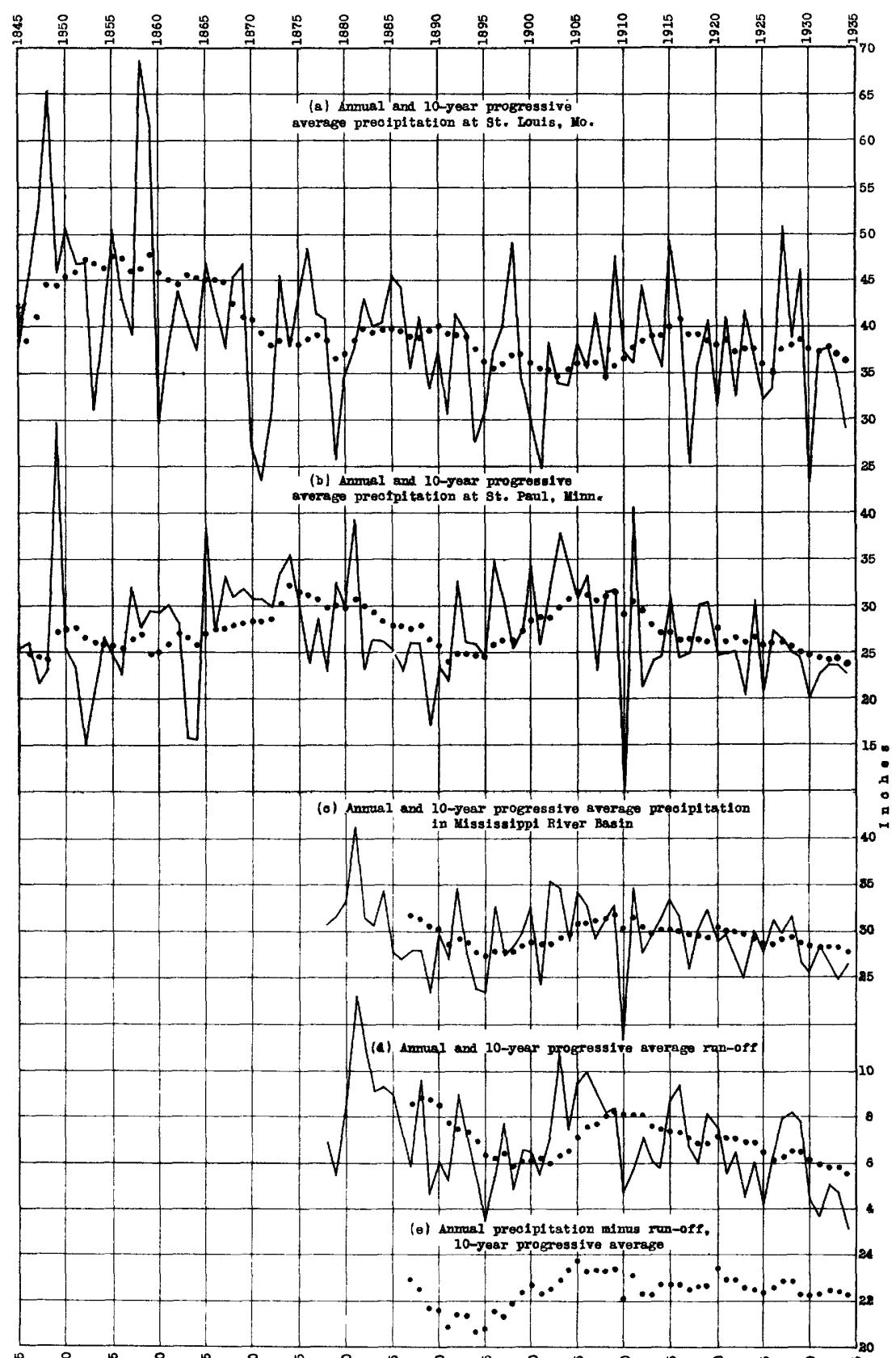

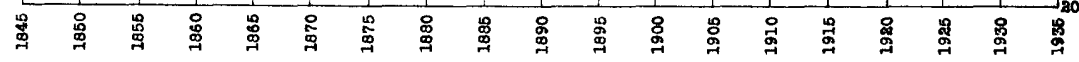

Mote.- 10-year average plotted at end of period shown thus .

Figure 19.-Relations between rainfall and run-opf in M1ssissippl River Basin above

Keokouk, Iowra. 
Table 11.- Temperature stations in or near

Mississippi River Basin above Keokuk, Iowa

\begin{tabular}{|c|c|c|c|}
\hline Station & $\begin{array}{c}\text { Altitude } \\
\text { (feet) }\end{array}$ & $\begin{array}{l}\text { Period } \\
\text { of } \\
\text { record }\end{array}$ & $\begin{array}{c}\text { Mean annual } \\
\text { temperature } \\
\text { (OF.) }\end{array}$ \\
\hline \multicolumn{4}{|l|}{ Iowa: } \\
\hline $\begin{array}{l}\text { Dubuque } \\
\text { Keokuk }\end{array}$ & $\begin{array}{l}700 \\
614\end{array}$ & $\begin{array}{l}1851- \\
1872-\end{array}$ & $\begin{array}{l}48.1 \\
52.2\end{array}$ \\
\hline \multicolumn{4}{|l|}{ Minnesota: } \\
\hline $\begin{array}{l}\text { Duluth } \\
\text { Moorhead } \\
\text { St. Paul }\end{array}$ & $\begin{array}{r}1,133 \\
935 \\
837\end{array}$ & $\begin{array}{l}1871- \\
1881- \\
1820-1932\end{array}$ & $\begin{array}{l}38.0 \\
39.2 \\
44.2\end{array}$ \\
\hline Wisconsin: & & & \\
\hline $\begin{array}{l}\text { La Crosse } \\
\text { Mrdison }\end{array}$ & $\begin{array}{l}714 \\
974\end{array}$ & $\begin{array}{l}1873- \\
1869-\end{array}$ & $\begin{array}{l}46.2 \\
45.8\end{array}$ \\
\hline
\end{tabular}

Neosho River Basin above Iola, Kans.

(Drainage area, 3,800 square miles. Records available, 1895-1903, 1918-34.)

The Neosho River rises in the north-central part of Morris County, Kans, at an altitude of about 1,500 feet, and flows in a general southeasterly direction to Iola, Kans., a distance of about 120 miles. In this distance the average fall is about 4 feet to the mile. The average width of the basin is about 30 miles. The Neosho River drains a rich agricultural territory which is in a good state of cultivation.

Run-off-- For the period October 12, 1917, to December 31, 1934, a water-stage recorder was located $2 \frac{1}{2}$ miles south and $1 \frac{1}{2}$ miles west from Iola, Allen County, half a mile below Elm Creek and 8 miles above Owl Creek. From August 1, 1895, to November 30, 1903, there was a staff gage 4 miles downstream from the present location. The drainage area for this early period as printed was 3,670 square miles; the figure 3,800 square miles was considered a correction to the original measurement.

From 1895 to 1903 the United States Geological Survey published daily gage heights, rating table, and a summary of monthly discharges. The records of dally discharge for this period are published in "Surface water of Kansas, 1895-1919," by the State of Kansas Water Comission, 1920. Since October 1917 the United States Geological Survey has published records of daily and monthly discharge. The low-water flow is regulated to a slight 
extent by dams upstream. The stage-discharge relation for the later period is practically permanent, and the records are considered good. The control for the earlier record was composed of gravel and shifted somewhat, but three to five discharge measurements were made each year to define the rating, and the records were considered falr to good. The records here used are for the calendar year.

Precipitation.- The average annual precipitation over the basin was computed by averaging the annual records at all the precipitation stations in and adjacent to the basin. These stations are listed below.

Table 12.- Precipitation stations in or near

Neosho River Basin above Iola, Kans.

\begin{tabular}{l|c|l|c|}
\hline Station & $\begin{array}{c}\text { Altitude } \\
\text { (feet) }\end{array}$ & $\begin{array}{c}\text { Period } \\
\text { of } \\
\text { record }\end{array}$ & $\begin{array}{c}\text { Mean annual } \\
\text { precipitation } \\
\text { (inches) }\end{array}$ \\
\hline Kansas: & & & 31.36 \\
Bazaar & 1,260 & $1902-3,1905-$ & 36.52 \\
Burlington * & 1,010 & $1894-$ & 30.89 \\
Council Grove & 1,234 & $1909-$ & 30.46 \\
Elmdale & 1,195 & $1925-$ & 33.17 \\
Emporia * & 1,138 & $1881-$ & 35.29 \\
Eskridge & 1,412 & $1907-$ & 31.95 \\
Hernett & 1,046 & $1906-14,1918-$ & 32.08 \\
Hesston & 1,328 & $1918-$ & 37.65 \\
Iola & 1,483 & $1923-$ & 36.39 \\
Lebo * & 1,984 & $1906-$ & 26.98 \\
Le Roy & 1,138 & $1887-$ & 31.31 \\
Lindsborg & 1,333 & $1909-$ & 30.66 \\
Marion & 1,310 & $1911-23,1930-$ & 33.27 \\
McPherson * & 1,495 & $1908-$ & 31.73 \\
Neosho Rapids & 1,092 & $1906-1889-$ & 33.99 \\
Newton * & 1,454 & $1897-$ & 35.96 \\
Osage City * & 1,081 & $1897-1912,1914-$ & \\
Yates Center & 1,068 & $1880-1921,1923-28$ & \\
\hline
\end{tabular}

* Station used in 1897 along with Yates Center.

The accuracy of the computed average precipitation probably increases rather rapidly from 1904 to 1908 and is probably good thereafter. Differences in precipitation between one part of the basin and another probably result more from differences in geographic location than from differences in altitude. Such differences showed a range from about 27.0 to 38. 0 inches on the basis of the long-time average, and the maximum range in 1912 was from about 21.1 to 47.9 inches. The records are on the basis of the calendar year. 
Table 13.- Precipitation, temperature, and mun-off data for

Noosho River Basin above Iola, Kane.

\begin{tabular}{|c|c|c|c|c|c|c|c|c|c|c|c|}
\hline \multirow{2}{*}{ Year } & \multicolumn{3}{|c|}{$\begin{array}{l}\text { Preofpitation } \\
\text { (inohes) }\end{array}$} & \multicolumn{2}{|c|}{$\begin{array}{l}\text { Temperature at } \\
\text { wi chita, Kans; } \\
\text { minus } 10 \text { (Op.) }\end{array}$} & \multicolumn{3}{|c|}{$\begin{array}{c}\text { Run-ofe at Iala } \\
\text { (Inches) }\end{array}$} & \multicolumn{2}{|c|}{$\begin{array}{l}\text { Precip1tation } \\
\text { minus run-off } \\
\text { (1nches) }\end{array}$} & \multirow{2}{*}{$\begin{array}{l}\text { Ratio } \\
\text { run-off } \\
\text { to } \\
\text { procip- } \\
\text { itation } \\
\text { I0-Jear } \\
\text { pro- } \\
\text { gressivo } \\
\text { average } \\
\text { (porcent) }\end{array}$} \\
\hline & Annual & $\begin{array}{c}\text { Acoumu- } \\
\text { latod }\end{array}$ & $\begin{array}{l}\text { Progres- } \\
\text { s1vo 10- } \\
\text { Jear } \\
\text { averago }\end{array}$ & Anmial & $\left\{\begin{array}{l}\text { Progres- } \\
\text { s1ve 10- } \\
\text { Joar } \\
\text { everage }\end{array}\right.$ & Anmial & $\begin{array}{c}\text { Aocuinu- } \\
\text { lated }\end{array}$ & $\begin{array}{l}\text { Progres- } \\
\text { s1 ve 10- } \\
\text { year } \\
\text { average }\end{array}$ & Annual & $\begin{array}{l}\text { Progres- } \\
\text { sive 10- } \\
\text { Jear } \\
\text { average }\end{array}$ & \\
\hline $\begin{array}{r}1896 \\
97 \\
98 \\
99 \\
1900 \\
01 \\
02 \\
03 \\
04 \\
05 \\
06 \\
07 \\
08 \\
09 \\
1910 \\
11 \\
12 \\
13 \\
14 \\
15 \\
16 \\
17 \\
18 \\
19 \\
1920 \\
21 \\
22 \\
23 \\
24 \\
25 \\
26 \\
27 \\
28 \\
29 \\
1930 \\
31 \\
32 \\
33 \\
34\end{array}$ & $\begin{array}{l}34.09 \\
24.76 \\
42.49 \\
32.49 \\
38.82 \\
23.66 \\
47.09 \\
40.78 \\
41.02 \\
34.85 \\
32.40 \\
33.45 \\
41 . .20 \\
39.18 \\
27.90 \\
27.71 \\
31.67 \\
28.67 \\
29.02 \\
48.74 \\
35.73 \\
24.38 \\
31.38 \\
26.84 \\
31.63 \\
28.59 \\
39.14 \\
34.75 \\
30.23 \\
29.73 \\
36.09 \\
42.94 \\
41.12 \\
34.86 \\
27.71 \\
32.26 \\
29.41 \\
25.89 \\
26.76\end{array}$ & \begin{tabular}{|r|}
34.09 \\
58.85 \\
101.34 \\
133.83 \\
172.65 \\
196.31 \\
243.40 \\
284.18 \\
325.20 \\
360.05 \\
392.45 \\
425.90 \\
467.10 \\
506.28 \\
534.18 \\
561.89 \\
593.56 \\
622.23 \\
651.25 \\
699.99 \\
735.72 \\
760.10 \\
791.42 \\
818.26 \\
849.89 \\
878.48 \\
917.62 \\
952.37 \\
982.60 \\
1012.33 \\
1048.42 \\
1091.36 \\
1132.48 \\
1167.34 \\
1195.05 \\
1227.31 \\
1256.72 \\
1282.61 \\
1309.37 \\
\end{tabular} & $\begin{array}{c}- \\
- \\
- \\
- \\
35.52 \\
- \\
36.01 \\
35.84 \\
36.71 \\
36.58 \\
37.25 \\
36.15 \\
36.56 \\
35.02 \\
33.81 \\
32.61 \\
33.99 \\
34.33 \\
33.42 \\
32.13 \\
31.20 \\
31.57 \\
31.66 \\
32.41 \\
33.01 \\
33.14 \\
31.23 \\
31.27 \\
33.13 \\
34.11 \\
34.91 \\
34.52 \\
34.88 \\
33.91 \\
33.02 \\
32.68\end{array}$ & $\begin{array}{l}57.0 \\
56.2 \\
54.6 \\
54.7 \\
56.4 \\
56.3 \\
54.7 \\
54.3 \\
55.2 \\
54.2 \\
54.5 \\
55.6 \\
56.2 \\
55.0 \\
56.4 \\
56.4 \\
53.3 \\
55.6 \\
56.3 \\
54.4 \\
54.8 \\
53.6 \\
55.4 \\
54.5 \\
54.8 \\
58.2 \\
56.2 \\
55.9 \\
53.9 \\
56.3 \\
55.1 \\
55.4 \\
56.1 \\
54.0 \\
56.2 \\
58.3 \\
55.8 \\
58.9 \\
58.7\end{array}$ & $\begin{array}{c}- \\
- \\
- \\
- \\
- \\
- \\
5 \\
55.4 \\
55.1 \\
55.1 \\
55.2 \\
55.2 \\
55.2 \\
55.3 \\
55.1 \\
55.2 \\
55.4 \\
55.4 \\
55.4 \\
55.2 \\
55.1 \\
55.1 \\
54.9 \\
55.1 \\
55.4 \\
55.4 \\
55.2 \\
55.4 \\
55.4 \\
55.6 \\
55.6 \\
55.6 \\
55.7 \\
55.7 \\
55.7 \\
56.0 \\
56.5\end{array}$ & $\begin{array}{c}4.74 \\
1.51 \\
8.01 \\
4.01 \\
5.71 \\
3.65 \\
12.27 \\
12.40 \\
= \\
= \\
= \\
= \\
= \\
= \\
= \\
= \\
= \\
= \\
= \\
2 \\
1.52 \\
4.37 \\
1.41 \\
1.79 \\
6.67 \\
5.51 \\
2.67 \\
1.95 \\
6.08 \\
11.50 \\
8.78 \\
7.08 \\
2.13 \\
2.89 \\
3.24 \\
1.37 \\
1.04\end{array}$ & $\begin{array}{c}4.74 \\
6.25 \\
14.26 \\
18.27 \\
23.98 \\
27.63 \\
39.90 \\
52.30 \\
= \\
= \\
= \\
= \\
= \\
= \\
= \\
= \\
= \\
= \\
1.52 \\
5.89 \\
7.30 \\
9.09 \\
15.76 \\
21.27 \\
23.94 \\
25.89 \\
51.97 \\
43.47 \\
52.25 \\
59.33 \\
61.46 \\
64.35 \\
67.59 \\
68.96 \\
70.00\end{array}$ & 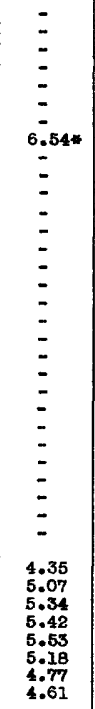 & $\begin{array}{c}29.35 \\
23.25 \\
34.48 \\
28.48 \\
33.11 \\
20.01 \\
34.82 \\
28.38 \\
= \\
= \\
= \\
= \\
= \\
= \\
- \\
= \\
= \\
29.80 \\
22.47 \\
30.22 \\
26.80 \\
32.47 \\
29.24 \\
27.56 \\
27.78 \\
30.01 \\
31.44 \\
32.34 \\
27.78 \\
25.58 \\
29.37 \\
26.17 \\
24.52 \\
25.72\end{array}$ & 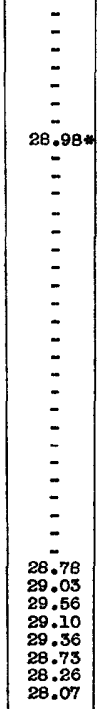 & 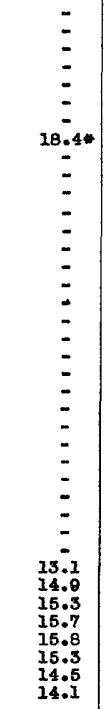 \\
\hline $\begin{array}{l}\text { Potel } \\
\text { Av. }\end{array}$ & $\begin{array}{r}1309.37 \\
33.57\end{array}$ & 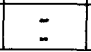 & 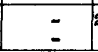 & $\begin{array}{r}2169.4 \\
55.6\end{array}$ & $=$ & $\begin{array}{r}70.007 \\
4.12^{\#}\end{array}$ & $=$ & $=$ & $\begin{array}{r}479.27^{71} \\
28.197\end{array}$ & $=$ & $\ddot{-}$ \\
\hline
\end{tabular}

* Average of B years
\# Por the period $1918-34$ 


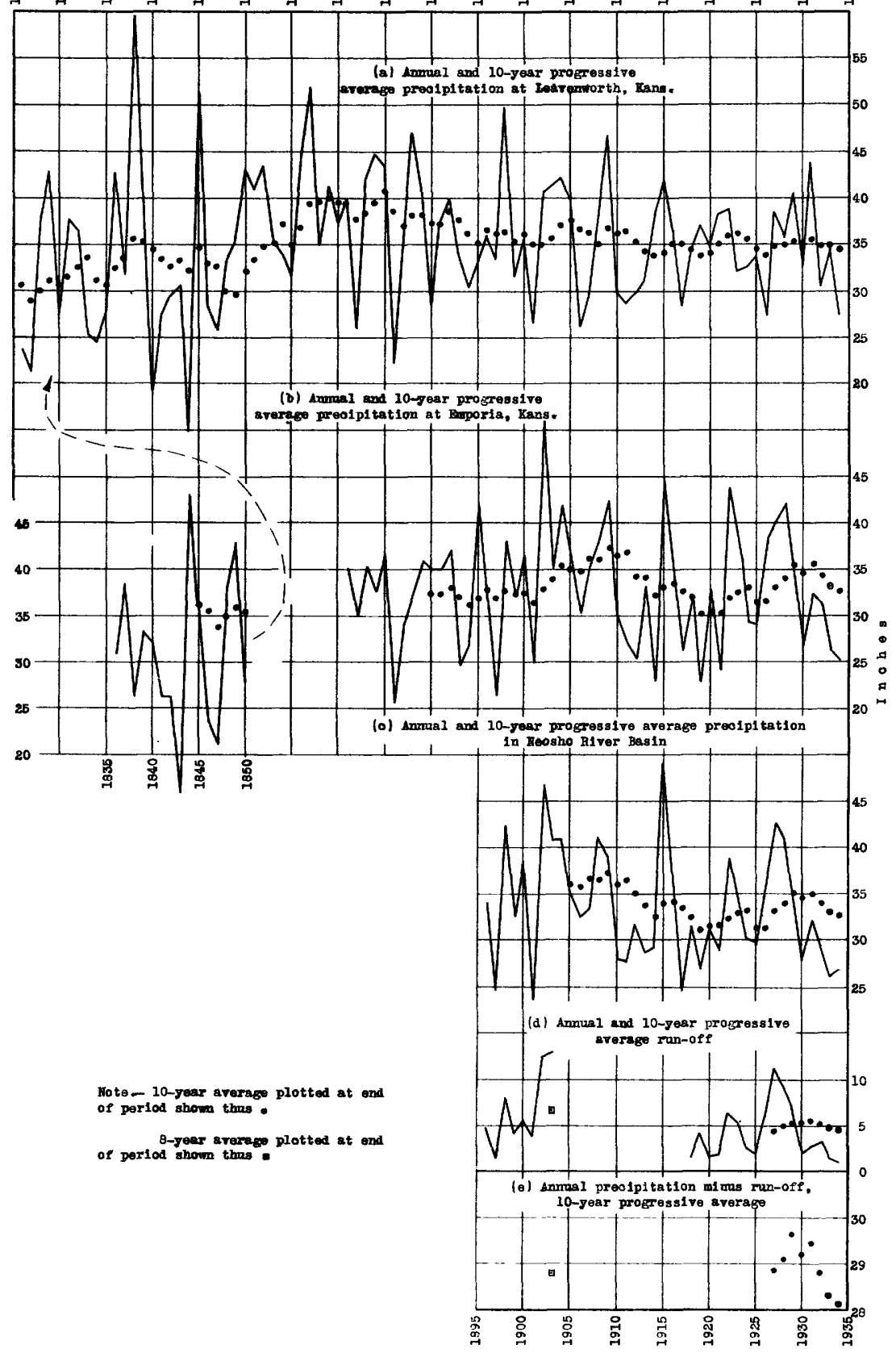

Figure 20-ilelation between rainfsll and run-off in Hoosho Rlver Besin above 
Temperature.- The normal annual temperature for the period of record of the stations in and adjacent to the basin was averaged and compared with the normal annual temperature at Wichita and was found to be about $0.8^{\circ}$ lower. The annual temperature at Wichita minus $1^{\circ}$ was taken as representative of the average annual temperature for the basin.

\section{Merrimack River Basin above Lawrence, Mass.}

(Net arainage area, 4,461 square miles. Records ava1lable, 1880-1934.)

The Merrimack River, the fourth largest stream in New England, begins at Franklin, N. H., and is formed by the junctions of the Pemigewasset and Winnepesaukee Rivers, which have drainage areas of 1,085 and 435 square miles, respectively. The Pemigewasset rises in the White Mountains of New Hampshire at an altitude of 5,000 feet and flows 70 miles south to Franklin, with an average slope of 15 feet or more to the mile. The Merrimack flows from Franklin south 40 miles to Manchester, N. H. (altitude 110 feet), then south 30 miles to Lowell, Mass. (altitude 50 feet), and then east 15 miles to Lawrence, Mass. (altitude 40 feet).

The length of the Merrimack and Pemigewasset Rivers above Lawrence is about 155 miles and the average wldth of the basin about 50 miles. The total drainage area is 4,672 square miles, which includes parts of the basins of the Nashua and Sudbury Rivers and Lake Cochituate from which water is diverted.

The upper part of the basin, in the White Mountains, is largely covered with second and third growth forest and is sparsely settled, but farther downstream the improved areas are more extensive. The topography of the White Hountain district is very rugged, with steep slopes and narrow valleys. From Franklin southward the country becomes more hilly, then rolling.

The lake and pond area amounts to 183 square miles. The largest lake is Lake Winnepesaukee, which has a water area of 72 square miles.

Run-off.- An accurate record has been kept of the flow over the dam and through the wheels and gates of the Essex Co. at Lawrence, Mass., since January 1, 1880. The flow is regulated to some extent by storage in Lake Winnepesaukee. Low-water flow is affected by operation of various power plants above Lawrence. The record is furnished by the Essex Co. and 
is considered good throughout. The records up to September 30, 1915, are revised and published in United States Geological Survey Water-Supply Paper 415. The records as here used are on the basis of the year ending September 30 .

Precipitation.- The figures for monthly and annual precipitation for the basin used here were taken from the water-supply papers. The precipitation as recorded for 1932 was the mean of 33 stations. The precipitation records as herein used are on the basis of the climatic year ending September 30. The following precipitation stations are in or adjacent to the basin.

Table 14.- Precipitation stations in or near the

Merrimack River Basin above Lawrence, Mass.

\begin{tabular}{|c|c|c|c|}
\hline Station & $\begin{array}{l}\text { Altitude } \\
\text { (feet) }\end{array}$ & $\begin{array}{l}\text { Perlod } \\
\text { of } \\
\text { record }\end{array}$ & $\begin{array}{l}\text { Mean annual } \\
\text { precipitation } \\
\text { (inches) }\end{array}$ \\
\hline \multicolumn{4}{|l|}{ Malne: } \\
\hline Hiram & 400 & $1926-29,1931-$ & 40.22 \\
\hline \multicolumn{4}{|l|}{ Massachusetts: } \\
\hline $\begin{array}{l}\text { Ashby } \\
\text { Ashland } \\
\text { Boylston } \\
\text { Clinton } \\
\text { Concord * } \\
\text { Cordavilie } \\
\text { Fitchburg * } \\
\text { Framingham } \\
\text { Groton } \\
\text { Haverhill } \\
\text { Jefferson }\end{array}$ & $\begin{array}{r}1,000 \\
227 \\
540 \\
398 \\
139 \\
250 \\
402 \\
172 \\
325 \\
50 \\
820\end{array}$ & $\begin{array}{l}1915- \\
1890- \\
1896- \\
1902- \\
1885-87,1891- \\
1894- \\
1865- \\
1876- \\
1886-1908,1913- \\
1900-30 \\
1898-1900,1902-5,1907-14 \\
1916-22,1924-\end{array}$ & $\begin{array}{l}44.93 \\
43.45 \\
45.34 \\
44.91 \\
40.61 \\
46.00 \\
41.29 \\
43.85 \\
43.34 \\
38.02 \\
47.49\end{array}$ \\
\hline $\begin{array}{l}\text { Lake Cochi tuate } \\
\text { Lawrence }\end{array}$ & $\begin{array}{r}148 \\
57\end{array}$ & $\begin{array}{l}1852-1930 \\
1856-60,1864,1866-67 \\
1869,1871-80,1885-\end{array}$ & $\begin{array}{l}45.27 \\
41.93\end{array}$ \\
\hline $\begin{array}{l}\text { Leominster } \\
\text { Loweli * } \\
\text { Princeton } \\
\text { Sterling } \\
\text { Sudbury } \\
\text { Wachusett Lake } \\
\text { Worcester * }\end{array}$ & $\begin{array}{r}540 \\
85 \\
I, 050 \\
555 \\
260 \\
880 \\
625\end{array}$ & $\begin{array}{l}1885-1932 \\
1826- \\
1885-91,1897- \\
1897- \\
1899- \\
1915- \\
1841-55,1857-62,1865-71 \\
1876-77,1882-86,1888-90 \\
1893-97,1901-\end{array}$ & $\begin{array}{l}44.08 \\
41.47 \\
45.41 \\
43.54 \\
42.34 \\
46.13 \\
42.40\end{array}$ \\
\hline
\end{tabular}

* Station used in computing temperature average for basin. 
Table 14.- Precipltation stations in or near the Merrimack River Basin above Lawrence, Mass.--Continued

\begin{tabular}{|c|c|c|c|}
\hline Station & $\begin{array}{c}\text { Altitude } \\
\text { (feet) }\end{array}$ & $\begin{array}{l}\text { Period } \\
\text { of } \\
\text { record }\end{array}$ & $\begin{array}{l}\text { Mean annual } \\
\text { precipltation } \\
\text { (Inches) }\end{array}$ \\
\hline \multicolumn{4}{|l|}{ New Hampshire: } \\
\hline $\begin{array}{l}\text { Bethlehem } \\
\text { Concord * } \\
\text { Durham } \\
\text { Franklin * } \\
\text { Glencliff * } \\
\text { Hanover * } \\
\text { Keene } \\
\text { Lakeport } \\
\text { Lincoln } \\
\text { Manchester } \\
\text { Nashua * } \\
\text { Plymouth * }\end{array}$ & $\begin{array}{r}1,440 \\
350 \\
83 \\
390 \\
1,650 \\
603 \\
550 \\
500 \\
1,200 \\
171 \\
125 \\
500\end{array}$ & $\begin{array}{l}1893- \\
1853,1857,1859- \\
1893,1895- \\
1902- \\
1910- \\
1835-55,1867- \\
1892- \\
1857-1933 \\
1921-30,1933- \\
1875- \\
1884- \\
1888-1933\end{array}$ & $\begin{array}{l}35.52 \\
37.51 \\
38.73 \\
39.50 \\
40.36 \\
35.25 \\
37.70 \\
42.42 \\
45.73 \\
38.65 \\
39.31 \\
39.16\end{array}$ \\
\hline
\end{tabular}

* Station used in computing temperature average for basin.

Temperature.- The average annual temperature for the period of record of each of the stations marked * in the preceding table was averaged and compared with the normal annual temperature at concord, N. H., and was found to agree so closely that the Concord record has been used to represent the average temperature for the basin. The temperature records as used hereln are on the basis of the calendar year.

\section{James River Basin above Cartersilile, Va.}

(Drainage area, 6,240 square miles.

Records avaliable, 1899-1934.)

The Jackson River rises on the West Virginia - Virginia State Iine, flows south $57 \mathrm{miles}$ and jolns the Cowpasture River to form the James River, which flows generally south of east for 187 miles to Cartersville, Va. The average width of the drainage basin is about $50 \mathrm{mlles}$. The western part of the basin lies in the Appelachian and Blue Ridge sections and is rugged to mountainous. The Pledmont section extends from the Blue Ridge tc the Fall Line near Rlchmond, 50 miles below Cartersville, and is characterlzed by low hills and broad valleys. Nearly half of the area consists of timber land and wood lots. The basin is primarily an agricultural area.

The Jackson River rises at an altitude of about 2,400 feet and descends to about 1,000 feet where 1t forms the James River. The James River has an average slope of 5.5 feet to the mile in the mountain section 
Tablo 15. - Precipitation, temperature, and run-orf data for

Merrimack River Basin above Lawrence, Mass.

\begin{tabular}{|c|c|c|c|c|c|c|c|c|c|c|c|}
\hline \multirow{2}{*}{$\begin{array}{c}\text { Year } \\
\text { ending } \\
\text { Sep- } \\
\text { tember }\end{array}$} & \multicolumn{3}{|c|}{$\begin{array}{c}\text { Procipitation } \\
\text { (inches) }\end{array}$} & \multicolumn{2}{|c|}{$\begin{array}{l}\text { Temperature at } \\
\text { Concord, N. H. } \\
\text { (OF.) }\end{array}$} & \multicolumn{3}{|c|}{$\begin{array}{c}\text { Run-off at Lawrence } \\
\text { (1nches) }\end{array}$} & \multicolumn{2}{|c|}{$\begin{array}{l}\text { Precipitation } \\
\text { minus run-off } \\
\text { (1nches) }\end{array}$} & \multirow{2}{*}{$\begin{array}{c}\text { Ratio } \\
\text { run-off } \\
\text { to } \\
\text { precip- } \\
\text { itation } \\
\text { lo-year } \\
\text { pro- } \\
\text { gressive } \\
\text { average } \\
\text { (percent) }\end{array}$} \\
\hline & Annual & $\begin{array}{l}\text { Accumu- } \\
\text { lated }\end{array}$ & $\begin{array}{l}\text { Progres- } \\
\text { sive } 10- \\
\text { year } \\
\text { average }\end{array}$ & Annual & $\begin{array}{c}\text { Progres- } \\
\text { sive 10- } \\
\text { year } \\
\text { everage }\end{array}$ & Annual & $\begin{array}{c}\text { Accumu- } \\
\text { lated }\end{array}$ & $\begin{array}{l}\text { Progres- } \\
\text { sive } 10- \\
\text { year } \\
\text { average }\end{array}$ & Annual & $\begin{array}{l}\text { Progres- } \\
\text { sive 10- } \\
\text { year } \\
\text { average }\end{array}$ & \\
\hline $\begin{array}{r}1880 \\
81 \\
82 \\
83 \\
84 \\
85 \\
86 \\
87 \\
88 \\
89 \\
1890 \\
91 \\
92 \\
93 \\
94 \\
95 \\
96 \\
97 \\
98 \\
99 \\
1900 \\
01 \\
02 \\
03 \\
04 \\
05 \\
06 \\
07 \\
08 \\
09 \\
1910 \\
11 \\
12 \\
13 \\
14 \\
15 \\
16 \\
17 \\
18 \\
19 \\
1920 \\
21 \\
22 \\
23 \\
24 \\
25 \\
26 \\
27 \\
28 \\
29 \\
1930 \\
31 \\
52 \\
33 \\
34 \\
\end{array}$ & $\begin{array}{l}34.57 \\
39.54 \\
44.53 \\
31.38 \\
41.61 \\
41.53 \\
45.03 \\
49.28 \\
48.59 \\
47.57 \\
51.00 \\
46.84 \\
40.94 \\
38.83 \\
33.72 \\
35.48 \\
47.34 \\
44.01 \\
46.81 \\
44.70 \\
41.20 \\
47.29 \\
47.59 \\
45.38 \\
42.10 \\
37.14 \\
39.46 \\
38.20 \\
40.90 \\
38.04 \\
34.21 \\
32.96 \\
40.06 \\
38.08 \\
38.83 \\
38.95 \\
44.91 \\
35.60 \\
40.12 \\
40.33 \\
48.34 \\
41.77 \\
49.66 \\
34 \cdot 73 \\
46.47 \\
36.23 \\
37.09 \\
42.42 \\
51.48 \\
35.91 \\
33.07 \\
42.35 \\
40.49 \\
50.31 \\
44.49\end{array}$ & $\begin{array}{r}34.57 \\
74.11 \\
118.64 \\
150.02 \\
191.63 \\
233.16 \\
278.19 \\
327.47 \\
376.06 \\
423.63 \\
474.63 \\
521.47 \\
562.41 \\
601.24 \\
634.96 \\
670.44 \\
717.78 \\
761.79 \\
808.60 \\
853.30 \\
894.50 \\
941.79 \\
989.38 \\
1034.76 \\
1076.86 \\
1114.00 \\
1153.46 \\
1191.66 \\
1232.56 \\
1270.60 \\
1304.81 \\
1337.77 \\
1377.83 \\
1415.91 \\
1454.74 \\
1493.60 \\
1538.60 \\
1574.20 \\
1614.32 \\
1654.65 \\
1702.99 \\
1744.76 \\
1794.42 \\
1829.15 \\
1875.62 \\
1911.85 \\
1948.94 \\
1991.36 \\
2042.84 \\
2078.75 \\
2111.82 \\
2154.17 \\
2194.66 \\
2244.97 \\
2289.46\end{array}$ & $\begin{array}{c}- \\
- \\
- \\
- \\
- \\
- \\
- \\
42.36 \\
44.01 \\
44.74 \\
44.38 \\
45.12 \\
44.33 \\
43.73 \\
43.96 \\
43.43 \\
43.25 \\
42.97 \\
41.99 \\
42.03 \\
42.70 \\
43.35 \\
44.19 \\
44.36 \\
43.57 \\
42.99 \\
42.40 \\
41.73 \\
41.03 \\
39.60 \\
38.84 \\
38.11 \\
37.79 \\
37.97 \\
38.51 \\
38.25 \\
38.18 \\
38.40 \\
39.82 \\
40.70 \\
41.66 \\
41.32 \\
42.09 \\
41.82 \\
41.03 \\
41.72 \\
42.85 \\
42.41 \\
40.88 \\
40.94 \\
40.02 \\
41.58 \\
41.38\end{array}$ & $\begin{array}{l}48.8 \\
48.3 \\
47.0 \\
45.2 \\
46.3 \\
44.6 \\
46.3 \\
45.9 \\
44.4 \\
47.7 \\
45.3 \\
47.0 \\
45.5 \\
41.9 \\
45.7 \\
45.7 \\
45.4 \\
45.6 \\
46.4 \\
45.0 \\
45.7 \\
45.0 \\
45.2 \\
45.3 \\
42.6 \\
44.6 \\
45.8 \\
43.8 \\
46.3 \\
45.7 \\
46.0 \\
46.1 \\
45.2 \\
47.6 \\
44.0 \\
46.9 \\
45.1 \\
43.2 \\
41.1 \\
46.4 \\
45.8 \\
47.7 \\
46.1 \\
45.2 \\
44.9 \\
45.8 \\
43.8 \\
46.3 \\
45.9 \\
45.7 \\
46.9 \\
48.0 \\
46.9 \\
46.3 \\
45.5\end{array}$ & $\begin{array}{c}- \\
- \\
- \\
- \\
- \\
- \\
- \\
46.45 \\
46.10 \\
45.97 \\
45.82 \\
45.49 \\
45.43 \\
45.54 \\
45.45 \\
45.42 \\
45.62 \\
45.35 \\
45.39 \\
45.19 \\
45.16 \\
45.50 \\
45.19 \\
45.08 \\
45.12 \\
44.94 \\
44.93 \\
45.00 \\
45.03 \\
45.14 \\
45.14 \\
45.37 \\
45.51 \\
45.74 \\
45.67 \\
45.61 \\
45.09 \\
45.16 \\
45.14 \\
45.30 \\
45.39 \\
45.15 \\
45.24 \\
45.13 \\
45.00 \\
45.31 \\
45.79 \\
45.72 \\
45.83 \\
45.86 \\
45.94 \\
46.05 \\
46.11 \\
\end{array}$ & $\begin{array}{l}17.60 \\
18.90 \\
21.63 \\
12.76 \\
20.90 \\
15.72 \\
24.58 \\
26.27 \\
25.08 \\
25.76 \\
27.42 \\
28.96 \\
16.42 \\
19.19 \\
15.75 \\
13.60 \\
22.73 \\
23.15 \\
23.14 \\
23.20 \\
19.77 \\
22.08 \\
26.05 \\
26.25 \\
19.82 \\
16.01 \\
19.98 \\
15.42 \\
23.07 \\
14.09 \\
14.98 \\
10.65 \\
19.11 \\
17.10 \\
20.09 \\
15.06 \\
24.25 \\
19.71 \\
14.49 \\
19.37 \\
25.19 \\
21.60 \\
26.34 \\
17.39 \\
21.00 \\
16.15 \\
17.06 \\
16.15 \\
31.54 \\
22.06 \\
12.58 \\
15.15 \\
16.30 \\
24.79 \\
22.60\end{array}$ & $\begin{array}{r}17.60 \\
36.50 \\
58.13 \\
70.89 \\
91.79 \\
107.51 \\
132.09 \\
158.36 \\
183.44 \\
209.20 \\
236.62 \\
265.58 \\
282.00 \\
301.19 \\
316.94 \\
330.54 \\
353.27 \\
376.42 \\
399.56 \\
422.76 \\
442.53 \\
464.61 \\
490.66 \\
516.91 \\
536.73 \\
552.74 \\
572.72 \\
588.14 \\
611.21 \\
625.30 \\
640.28 \\
650.93 \\
670.04 \\
687.14 \\
707.23 \\
722.29 \\
746.44 \\
766.15 \\
780.64 \\
800.01 \\
825 . .20 \\
846.80 \\
875.14 \\
890.53 \\
912.53 \\
928.68 \\
945.74 \\
961.89 \\
993.43 \\
1015.49 \\
1028.07 \\
1043.22 \\
1059.52 \\
1084.31 \\
1106.91 \\
\end{array}$ & $\begin{array}{c}- \\
- \\
- \\
- \\
= \\
- \\
20.92 \\
21.90 \\
22.91 \\
22.39 \\
23.03 \\
22.52 \\
22.30 \\
22.12 \\
21.81 \\
21.61 \\
21.36 \\
20.59 \\
19.90 \\
20.87 \\
21.57 \\
21.98 \\
22.22 \\
21.94 \\
21.17 \\
21.16 \\
20.25 \\
19.78 \\
18.63 \\
17.94 \\
17.02 \\
17.05 \\
16.95 \\
17.37 \\
17.80 \\
16.94 \\
17.47 \\
18.49 \\
19.59 \\
20.31 \\
20.34 \\
20.53 \\
20.64 \\
19.93 \\
19.57 \\
21.28 \\
21.55 \\
20.29 \\
19.64 \\
18.64 \\
19.38 \\
19.44\end{array}$ & $\begin{array}{l}16.97 \\
20.64 \\
22.90 \\
18.62 \\
20.71 \\
25.81 \\
20.45 \\
23.01 \\
23.51 \\
21.91 \\
23.58 \\
17.88 \\
24.52 \\
19.64 \\
17.97 \\
21.88 \\
24.61 \\
20.86 \\
23.67 \\
21.50 \\
21.43 \\
25.21 \\
21.54 \\
19.13 \\
22.28 \\
21.13 \\
19.48 \\
22.78 \\
17.83 \\
23.95 \\
19.23 \\
22.31 \\
20.95 \\
20.98 \\
18.74 \\
23.89 \\
20.76 \\
15.89 \\
25.63 \\
20.96 \\
23.15 \\
20.17 \\
23.32 \\
17.34 \\
24.47 \\
20.08 \\
20.03 \\
26.27 \\
29.94 \\
13.85 \\
20.49 \\
27.20 \\
24.19 \\
25.52 \\
21.89 \\
\end{array}$ & $\begin{array}{c}- \\
- \\
- \\
- \\
- \\
= \\
21.44 \\
22.10 \\
21.83 \\
21.99 \\
22.09 \\
21.82 \\
21.43 \\
21.84 \\
21.63 \\
21.64 \\
21.61 \\
21.40 \\
22.13 \\
21.83 \\
21.78 \\
22.21 \\
22.14 \\
21.62 \\
21.82 \\
21.23 \\
21.48 \\
21.26 \\
20.97 \\
20.91 \\
21.09 \\
20.74 \\
21.01 \\
21.14 \\
20.45 \\
21.23 \\
20.93 \\
21.33 \\
21.11 \\
21.35 \\
20.98 \\
21.56 \\
21.18 \\
21.10 \\
22.14 \\
21.57 \\
20.86 \\
20.60 \\
21.30 \\
21.39 \\
22.20 \\
21.95\end{array}$ & $\begin{array}{l}49.4 \\
49.8 \\
51.2 \\
50.5 \\
51.0 \\
50.8 \\
51.0 \\
50.3 \\
50.2 \\
49.9 \\
49.7 \\
49.1 \\
47.4 \\
48.9 \\
49.8 \\
49.8 \\
50.1 \\
50.4 \\
49.3 \\
49.9 \\
48.5 \\
48.2 \\
47.0 \\
46.2 \\
44.7 \\
45.1 \\
44.6 \\
45.1 \\
46.5 \\
44.4 \\
45.5 \\
46.4 \\
48.1 \\
48.7 \\
49.3 \\
48.7 \\
49.4 \\
48.6 \\
46.9 \\
49.7 \\
50.9 \\
49.7 \\
48.0 \\
46.6 \\
46.5 \\
47.0\end{array}$ \\
\hline $\begin{array}{r}\text { Total } \\
\text { AV. }\end{array}$ & $\begin{array}{r}2289.46 \\
41.63\end{array}$ & = & - & $\begin{array}{r}410.4 \\
45.6\end{array}$ & - & $\begin{array}{r}1106.91 \\
20.13\end{array}$ & $=$ & $=$ & $\begin{array}{r}1182.55 \\
21.50\end{array}$ & $\overline{-}$ & $=$ \\
\hline
\end{tabular}

$59550-35-6$ 


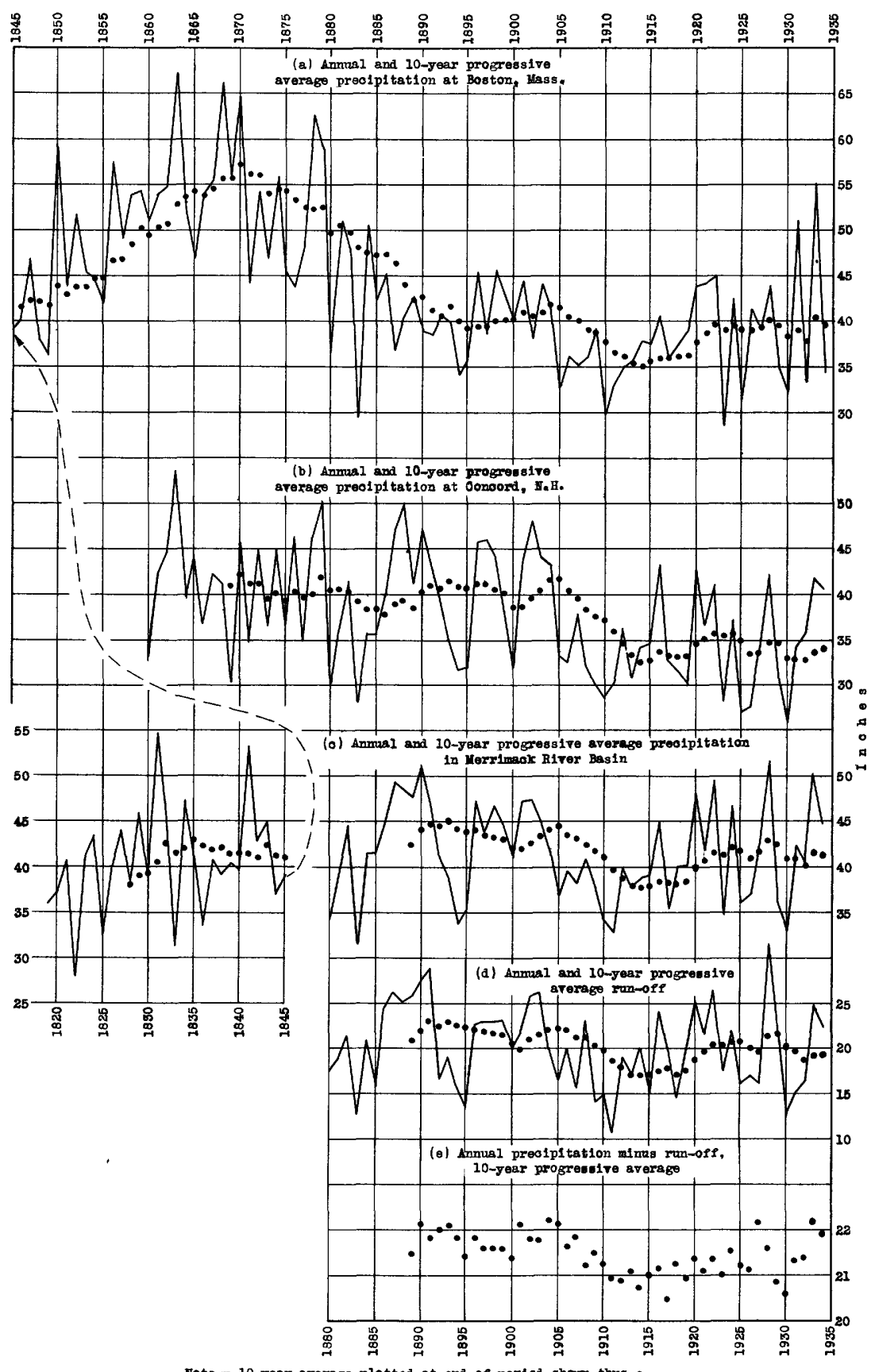

Note -10 -year average plotted at ond of period shown thus .

Floure 21.-Relations between rainfall and rum-off in Merrimack River Basin above Lawrence, Mass. 
of $88 \mathrm{mile}$ and of 2.9 feet to the mile in the piedmont section to the Fall Line.

Run-off.- The gage is located on the James River between Pemberton and Cartersville, Cumberland county, 1 mile below the mouth of the Willis R1ver. A wire gage was used from January 1899 to July 23, 1903, and a chain gage from July 24, 1903, to June 3, 1927. Since June 3, 1927, a water-stage recorder has been in operation. The daily records are fair to good prior to the installation of the water-stage recorder and good to excellent thereafter.

The flow at Cartersville is regulated to a small extent by nine hydroelectric power plants on the main stream and tributaries, the nearest of which is about $95 \mathrm{mlles}$ upstream. The only storage used is the small amount of pondage at the power developments. The records are for the calendar year.

Precipitation.- The annual precipitation over the basin was computed by averaging the annual records at all the fairly well distributed precipitation stations in and adjacent to the basin, which are listed below:

\section{Table 16.- Precipitation stations in or near}

James River Basin above Cartersville, Va.

\begin{tabular}{|c|c|l|c|}
\hline Station & $\begin{array}{c}\text { Altitude } \\
\text { (feet) }\end{array}$ & $\begin{array}{c}\text { Period } \\
\text { of } \\
\text { record }\end{array}$ & $\begin{array}{c}\text { Mean annual } \\
\text { precipitation } \\
\text { (inches) }\end{array}$ \\
\hline Virginia: & & & 41.65 \\
Blacksburg* & 2,100 & $1892-$ & 41.19 \\
Buchanan & 820 & $1893-95,1904-$ & 42.12 \\
Catawba Sanitarium & 2,100 & $1911-$ & 43.58 \\
Charlottesville & 854 & $1849,1874-78,1882-$ & 41.44 \\
Columbia & 246 & $1899-$ & 41.02 \\
Farmvilie & 316 & $1897-1906$ & 40.35 \\
Hot Springs & 2,195 & $1892-$ & 39.30 \\
Iexington & 1,060 & $1869-83,1885-86,1889-$ & 40.53 \\
Lynchburg & 681 & $1872-$ & 41.17 \\
New Canton & 300 & $1894-$ & 37.68 \\
Staunton & 1,480 & $1869-72,1890-1923,1925-$ & \\
\hline
\end{tabular}

* Station replaced by another or record discontinued prior to 1911 .

Because of the rough topography over the basin, differences in precipitation between one part of the basin and another probably result largely from differences in alt1tude. The precipitation ranges from about 37.7 to 43.6 inches on the basis of the long-time average, and in one year the range was from 29.4 to 54.1 inches. Records are on the basis of the calendar year. 
Table 17.- Precipltation, temperature, and run-off data for

James Fiver Basin above Cartersville, Va.

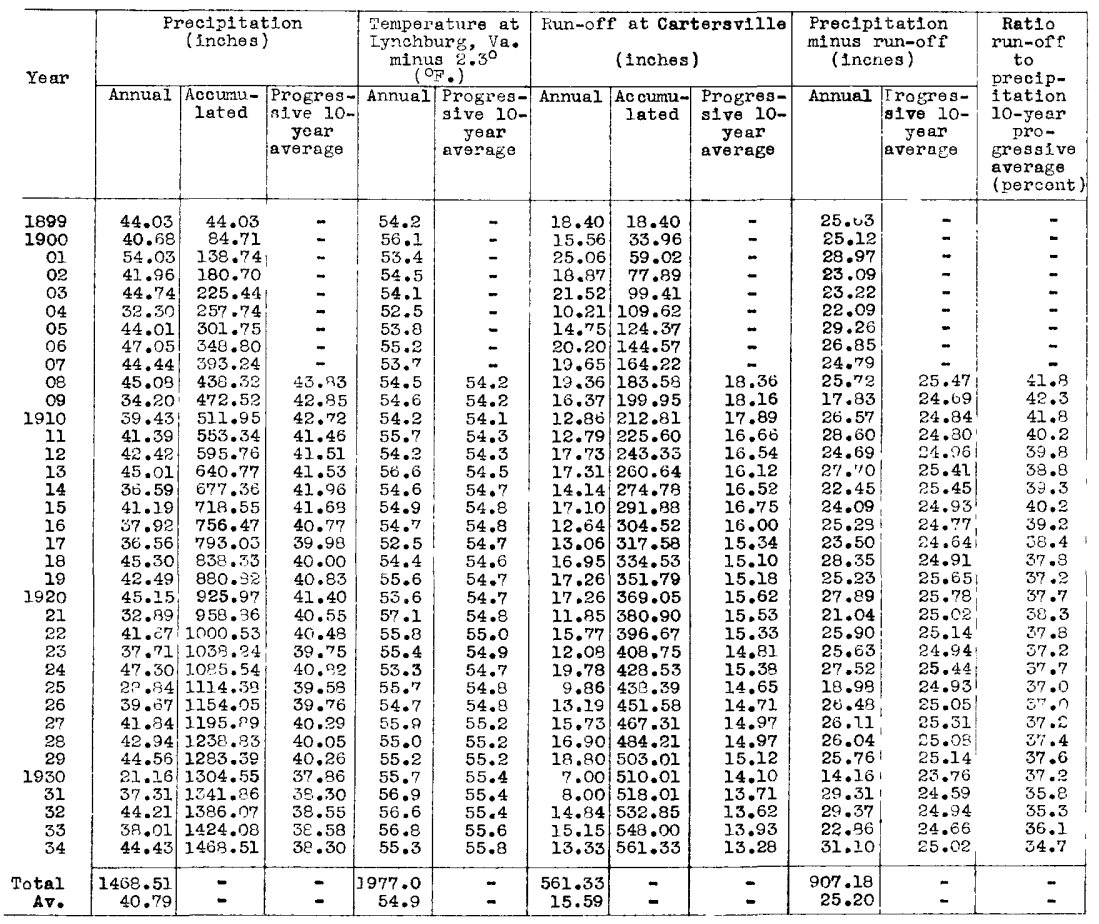




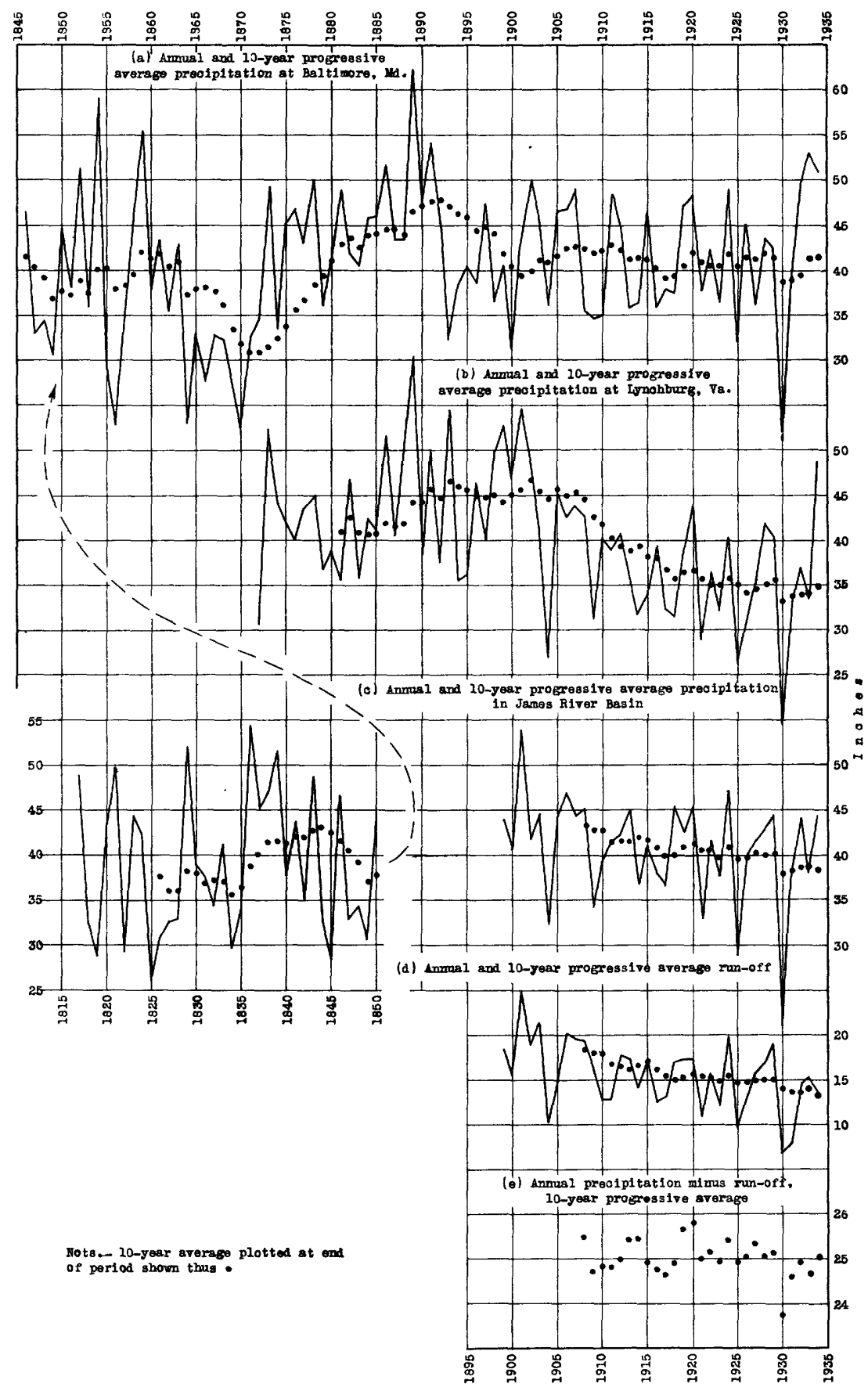

Flgare 22.-Relations betwen ralntall and ran-off in James Rirer Basin above 
Temperature.- The mean annual temperature for the period of record at the stations in and adjacent to the basin was averaged and compared with the mean annual temperature at Iynchburg and was found to be about $2.3^{\circ}$ lower. This amount was then subtracted from the figures of annual temperature at Iynchburg to arrive at the average annual temperature for the basin.

Tennessee River Basin above Chattanooga, Tenn.

The Tennessee River is formed at Knoxville, Tenn,, by the junction of the French Broad and Holston Rivers, which rise in western North Carolina and southwestern Virginia and have drainage areas of 5,140 and 3,810 square miles respectively. From Knoxville the Tennessee flows 188 miles in a southwesterly direction to Chattanooga. The hoadwater area is mountainous country, with altitudes ranging from 3,000 to 6,700 feet. At Chattanooga the altitude is about 620 feet, and the drainage area 21,400 square miles.

The river distance from Chattanooga to the head of the French Broad is about $360 \mathrm{mtles}$, and to the head of the Holston about 385 miles. The average width of the arainage basin is about 85 miles.

The average slope of the Tennessee River from Knoxville to Chattanooga is about 1.0 foot to the mile; that of the French Broad River from its mouth to a point 197 miles above is about 6.6 feet to the mile; and that of the Holston River from its mouth to a point $143 \mathrm{miles}$ above is about 2.5 feet to the mile.

Run-off.- For the period 1874 to 1913, prior to the builaing of the Hales Bar Dam, the Chattanooga gage record alone was used; from October 22, 1913, to Fobruary 28, 1915, and October 1, 1918, to January 5, 1921, the gage record at Bridgeport, Ala., was used; from March 1, 1915, to September 30, 1918, and from January 6, 1921, to June 1930 the Chattanooga gage was used, adjusted by means of the upper and lower gages at Hales Bar Iock and Dam, 33 miles below Chattanooga.

Since July 1930 gage-helght records have been obtained from a water-stage recorder just below Hales Bar Lock and Dam, where the drainage area is 22,000 square miles. 
Because the stage-discharge relation is not permanent, several rating curves were used, and the low-water records since the completion of Hales Bar Dam, in 1913, may be subject to some error owing to the indirect, method of determining the discharge. The run-off records are for the calendar year.

Precipitation.- The accuracy of the annual precipitation records. in representing the mean annual precipitation over the basin above Chattanooga is problematic. The accuracy probably increases from 1889 to 1898 and should be fairly satisfactory since 1898. Prior to 1889 the number of precipitation stations was small, but their distribution was fairly uniform over the area. The annual precipitation data prior to 1889 were weighted in relation to area represented, and those subsequent to 1889 were averaged to get the annual precipitation for the basin. The approximate number of precipitation stations used to compute the basin average is as follows:

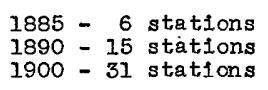

$$
\begin{aligned}
& 1910-36 \text { stations } \\
& 1920-39 \text { stations } \\
& 1930-38 \text { stations }
\end{aligned}
$$

The following is a list of stations in the basin above Chattanooga used to compute the annual precipitation:

Table 18.- Precipitation stations in or near Tennessee River Basin above Chattanooga, Tenn.

\begin{tabular}{|l|l|l|l|}
\hline Station & $\begin{array}{c}\text { Altitude } \\
\text { (feet) }\end{array}$ & $\begin{array}{c}\text { Period } \\
\text { of } \\
\text { record }\end{array}$ & $\begin{array}{c}\text { Mean annual } \\
\text { precipitation } \\
\text { (inches) }\end{array}$ \\
\hline North Carolina: & & & \\
Altapass & 2,740 & $1913-$ & 50.89 \\
Andrews & 1,800 & $1909-33$ & 62.08 \\
Ashevilile & 2,253 & $1869-78,1889-91,1893-$ & 40.28 \\
Brevard & 2,230 & $1902-34$ & 62.13 \\
Bryson City & 2,000 & $1889-$ & 54.06 \\
Cullowhee & 2,100 & $1910-$ & 43.80 \\
Hendersonville & 2,153 & $1898-$ & 60.13 \\
Highlands & 3,350 & $1879-81,1883-84,1892-$ & 81.44 \\
Hot Springs & 1,326 & $1906-$ & 43.68 \\
Jefferson & 2,900 & $1903-6,1910-$ & 48.86 \\
Linvilie & 3,800 & $1895-1906$ & 62.72 \\
Linvilie Falls & 3,300 & $1916-$ & 58.13 \\
Marshali & 1,646 & $1899-$ & 39.40 \\
Montreat & 2,600 & $1917-$ & 53.97 \\
Murphy & 1,614 & $1873-75,1877-82,1889-$ & 58.47 \\
Parker & 4,075 & $1918-$ & 50.15 \\
Waynesville & 2,756 & $1894-$ & 45.57 \\
& & &
\end{tabular}


Table 18.- Precipitation stations in or near

Tennesseo River Basin above Chattanooga, Tenn.--Continued

\begin{tabular}{|c|c|c|c|}
\hline & $\begin{array}{l}\text { Altitudo } \\
\text { (feet) }\end{array}$ & $\begin{array}{l}\text { Period } \\
\text { of } \\
\text { record }\end{array}$ & $\begin{array}{l}\text { Mean annual } \\
\text { precipitation } \\
\text { (Inches) }\end{array}$ \\
\hline \multicolumn{4}{|l|}{ Virginia: } \\
\hline $\begin{array}{l}\text { Big Stone Gap } \\
\text { Dante } \\
\text { Elk Knob } \\
\text { Marlon } \\
\text { Kendota } \\
\text { Saltville } \\
\text { Speers Ferry } \\
\text { Tennessee: }\end{array}$ & $\begin{array}{l}1,966 \\
2,000 \\
3,243 \\
2,145 \\
1,350 \\
1,770 \\
1,221\end{array}$ & $\begin{array}{l}1891-1811 \\
1917- \\
1904-19 \\
1884-1911 \\
1905- \\
1896-97,1924- \\
1896-1932\end{array}$ & $\begin{array}{l}50.66 \\
48.63 \\
48.46 \\
43.28 \\
47.81 \\
43.22 \\
49.45\end{array}$ \\
\hline $\begin{array}{l}\text { Bluff City } \\
\text { Bristol } \\
\text { Chattanooga } \\
\text { Clinton } \\
\text { Copperhill } \\
\text { Crossville } \\
\text { Dendridge } \\
\text { Decatur } \\
\text { Elizabethton }\end{array}$ & $\begin{array}{r}1,400 \\
1,757 \\
808 \\
800 \\
1,624 \\
1,820 \\
1,050 \\
850 \\
1,575\end{array}$ & $\begin{array}{l}1898- \\
1894-1908,1927-32 \\
1879- \\
1889-91,1893- \\
1914- \\
1912- \\
1905- \\
1896- \\
1869-70,1872\end{array}$ & $\begin{array}{l}44.46 \\
41.29 \\
51.61 \\
52.49 \\
54.86 \\
55.92 \\
45.84 \\
54.92 \\
44.55\end{array}$ \\
\hline Greenville & 1,581 & $\begin{array}{r}1884-1906,1916-19 \\
1921-25,1933-34\end{array}$ & 43.37 \\
\hline $\begin{array}{l}\text { Harriman } \\
\text { Jefferson City } \\
\text { Johnson City } \\
\text { Kingston } \\
\text { Knoxville } \\
\text { Loudon } \\
\text { Naryville } \\
\text { McGhee } \\
\text { Mountain City } \\
\text { Newport } \\
\text { Parksville } \\
\text { Rockwood } \\
\text { Rogersville } \\
\text { Rugby } \\
\text { Sevierville } \\
\text { Springdale } \\
\text { Tazewell } \\
\text { Tellico Plains }\end{array}$ & $\begin{array}{r}841 \\
1,117 \\
1,717 \\
751 \\
977 \\
816 \\
1,050 \\
850 \\
2,471 \\
1,100 \\
840 \\
725 \\
1,150 \\
1,410 \\
900 \\
1,058 \\
1,350 \\
1,000\end{array}$ & $\begin{array}{l}1891,1893,1895-1911 \\
1910-28 \\
1886,1896-1930 \\
1889-93,1898- \\
1854,1871- \\
1889-96,1905- \\
1883-85,1888,1898-1912 \\
1905- \\
1898-1920 \\
1892- \\
1883-1914,1925- \\
1889-97,1923-33 \\
1886- \\
1884,1889- \\
1906-30 \\
1889-1909,1911 \\
1898-1926 \\
1897-1908,1927-\end{array}$ & $\begin{array}{l}51.41 \\
45.75 \\
44.39 \\
51.42 \\
47.38 \\
50.96 \\
51.57 \\
50.15 \\
47.07 \\
44.45 \\
50.25 \\
52.35 \\
44.82 \\
55.69 \\
47.94 \\
48.63 \\
50.45 \\
53.19\end{array}$ \\
\hline
\end{tabular}

The precipitation records are on the basis of the calendar year.

Temperature.- The mean annual temperaturee for the period of record at the stations in the basin were averaged and compared with the mean annual temperature at knoxville and were found to be about $2.5^{\circ}$ lower; therefore $3^{\circ}$ was subtracted from the figures of annual temperature at Knoxville to arrive at the average annual temperature of the basin. 
Table 19.- Precipitation, tomperature, and run-off date for

Tennessee River Basin above Chattanooga, Tenn.

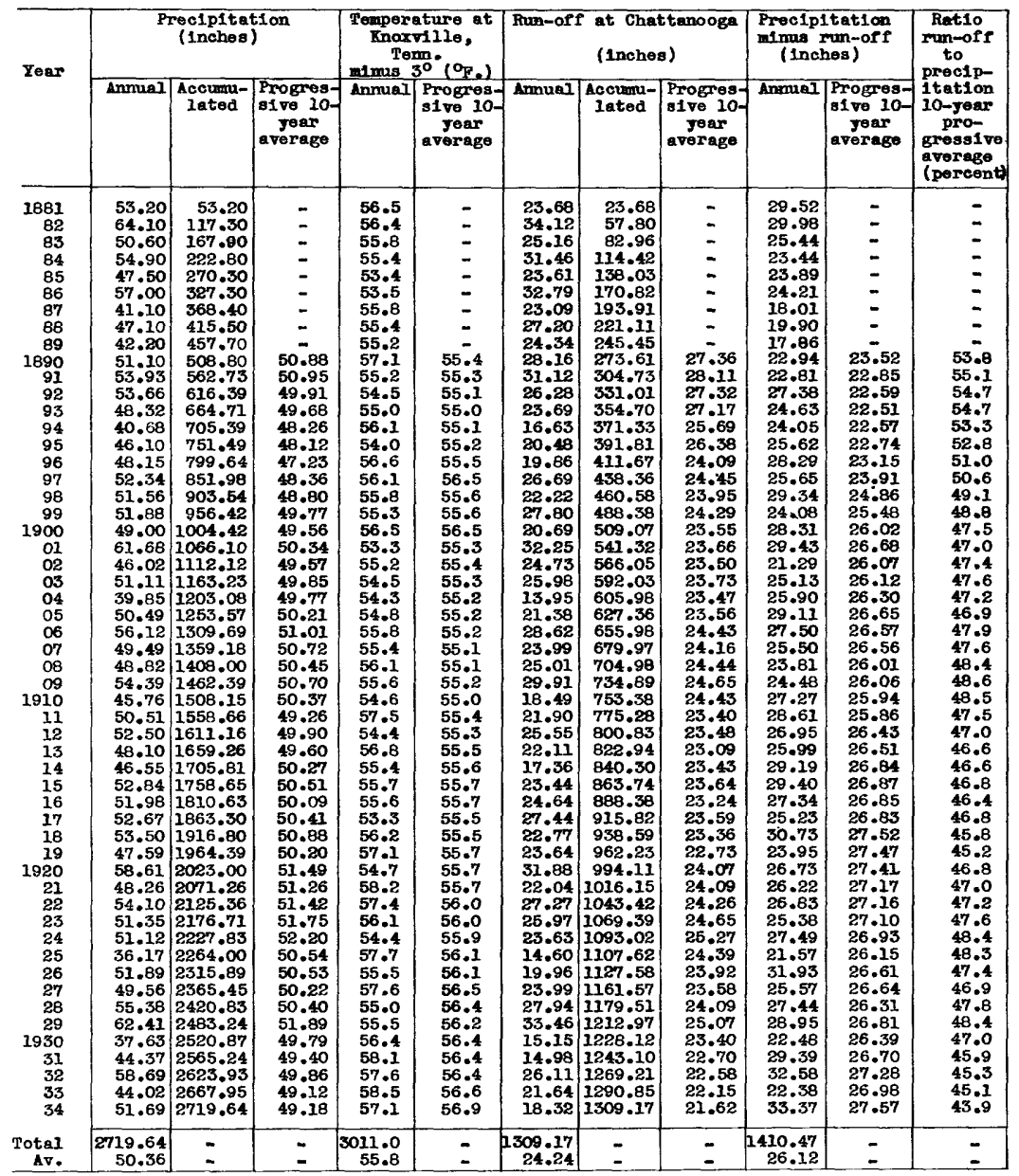




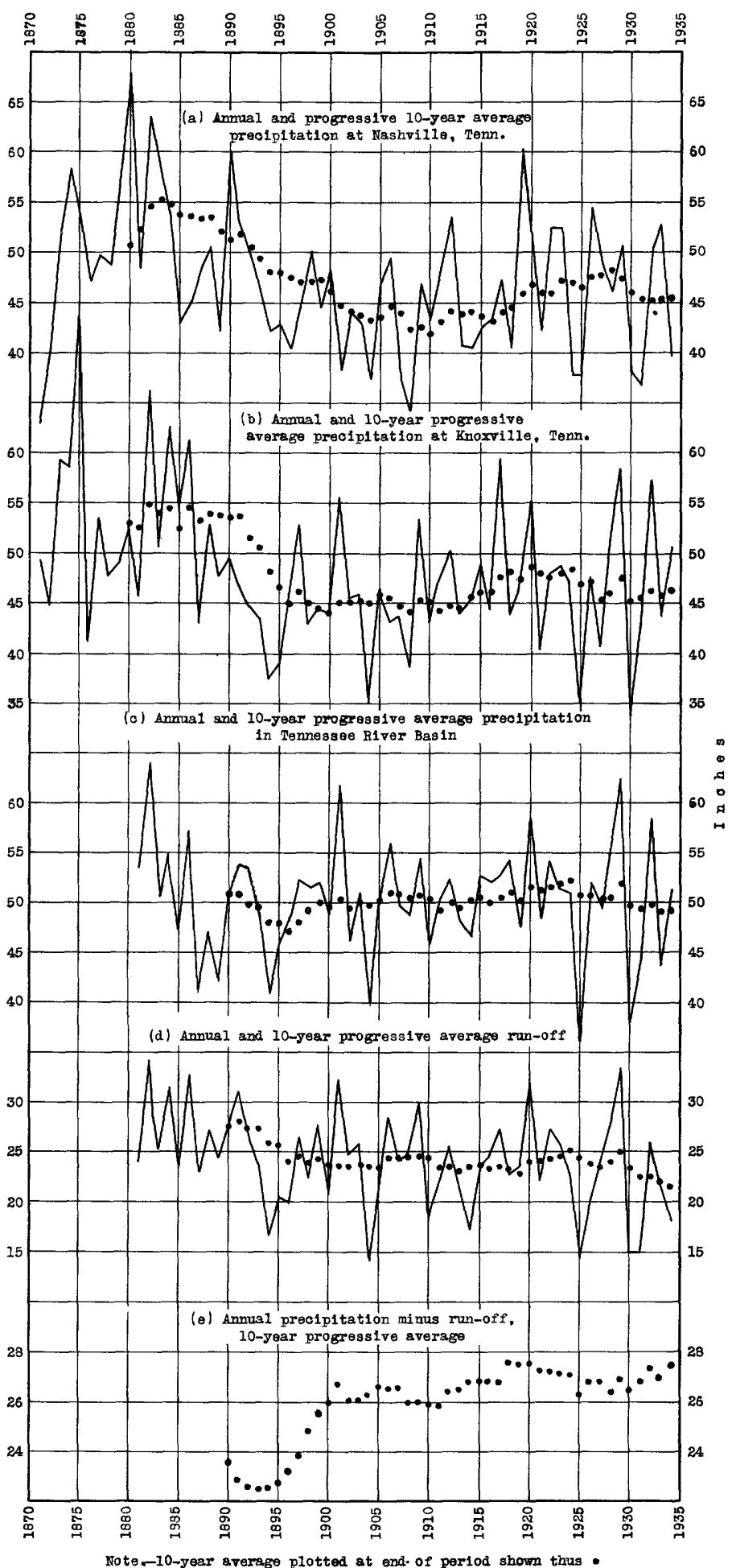

Figure 23,-Relations between ralnfall and rum-off in Tennesses River Basin above 
Chattahoochee River Basin above West Point, Ga.

(Drainage area, 3,550 square miles.

Records avallable, 1896-1934.)

The Chattahoochee River rises in the Blue Ridge in White County, Ga., at an altitude of about 4,000 feet, and flows in a southwesterly direction to West Point, Ga., on the Georgia - Alabama State line, at an altitude of about 550 feet. The length of the river above West Point is about 200 miles, and the average width of the drainage basin is 30 miles. From the lower edge of Lumpkin County down to West Point, a distance of about 145 miles, the Chattahoochee River has a fall of 484 feet, an average of about 3.3 feet to the mile.

Run-off.- The orlginal gage, established in July 1896, was a standard chain gage on the downstream handrall of the Montgomery Street Bridge In West Point, Ga. On October 20, 1912, the gage was moved 1 mile upstream, to a point opposite the city pumping plant. A staff gage (0 to 18 feet) was placed on the left bank and was read from the right bank by means of a telescope unt1l January 14, 1920, when the section 0 to 6.7 feet was moved to the right bank. Since January 26, 1925, the gage has been a continuous water-stage recorder in a concrete stilling well on the right bank 500 feet below the West Point waterworks pumping plant. The gage was read to tenths three times daily prior to the installation of the waterstage recorder. The records throughout are considered falr to good. The operation of hydroelectric power plants upstream causes slight diurnal fluctuations at West Point. The run-off figures are on the basis of the calendar year.

Precipitation.- The annual precipitation over the basin was computed by averaging the annual records at all the precipitation stations listed below, located in and adjacent to the basin. 
Table 20.- Precipitation stations in or near

Chattahoochee River Basin above West Point, Ga.

\begin{tabular}{|c|c|c|c|}
\hline & $\begin{array}{l}\text { Altitude } \\
\text { (feet) }\end{array}$ & $\begin{array}{l}\text { Period } \\
\text { of } \\
\text { record }\end{array}$ & $\begin{array}{l}\text { Mean annuel } \\
\text { precipitation } \\
\text { (Inches) }\end{array}$ \\
\hline \multicolumn{4}{|l|}{ Georgia: } \\
\hline $\begin{array}{l}\text { Atlanta } \\
\text { Canton } \\
\text { Clayton } \\
\text { Dahlonega } \\
\text { Gainesville } \\
\text { Gillsvilie } \\
\text { Lost Mountain } \\
\text { Marietta } \\
\text { Newnan } \\
\text { Norcross } \\
\text { Tallapoosa } \\
\text { Tocoa } \\
\text { West Polnt }\end{array}$ & $\begin{array}{r}1,173 \\
894 \\
2,100 \\
1,519 \\
1,254 \\
1,052 \\
1,175 \\
1,135 \\
959 \\
1,025 \\
1,150 \\
1,050 \\
620\end{array}$ & $\begin{array}{l}1859,1866,1868- \\
1879,1892- \\
1894-1920,1922- \\
1885,1894- \\
1875-86,1895- \\
1890- \\
1901-19 \\
1889-98,1920-27 \\
1895- \\
1911-32 \\
1897- \\
1892- \\
1894-\end{array}$ & $\begin{array}{l}48 \cdot 27 \\
52 \cdot 33 \\
70.07 \\
61.25 \\
54 \cdot 92 \\
51.25 \\
50.86 \\
50.20 \\
51.12 \\
51.33 \\
51.65 \\
57.98 \\
51.78\end{array}$ \\
\hline
\end{tabular}

Differences in annual precipitation between one part of the basin and another probably result largely from differences in altitude. The range shown by long-time averages is from about 48.3 to 70.1 inches; in one year the range was from 53.4 to 91.6 inches. Precipitation figures are on the basis of the calendar year.

Temperature.- The mean annual temperature for the period of record at the stations in and adjacent to the basin was averaged and compared with the mean annual temperature at Atlanta and was found to be about $0.5^{\circ}$ lower. The Atlanta record was therefore taken to represent the average temperature of the basin. Temperature figures are on the basis of the calendar year.

\section{General accuracy of precipitation, mun-off, and temperature data}

During the periods of record there has unquestionably been a gradual increase in the accuracy of the base data used. In the determination of the mean annual precipitation it has been necessary to base the average during the earlier part of the period on a fewer number of stations than were avallable during later years. The records in the earlier part of the period have generally been woighted according to area represented. For several basins comparisons were made of the relations both on an annul and on a monthly basis between the straight average of all the stations and the weighted average. In most of these comparisons the differences show were so small that the straight average has been used in general. Basin trends 
Table 21.- Precipitation, temperature, and run-off data for

Chattahoocheo River Basin above West Po1nt, Ga.

\begin{tabular}{|c|c|c|c|c|c|c|c|c|c|c|c|}
\hline \multirow{2}{*}{ Year } & \multicolumn{3}{|c|}{$\begin{array}{l}\text { Precipitation } \\
\text { (Inches) }\end{array}$} & \multicolumn{2}{|c|}{$\begin{array}{l}\text { Pemperature at } \\
\text { AtImta, Ga. } \\
\text { (OF.) }\end{array}$} & \multicolumn{3}{|c|}{$\begin{array}{c}\text { Run-off at West Point } \\
\text { (1nches) }\end{array}$} & \multicolumn{2}{|c|}{$\begin{array}{l}\text { Precipitation } \\
\text { mimus run-off } \\
\text { (1nches) }\end{array}$} & \multirow{2}{*}{\begin{tabular}{|c|} 
Ratio \\
man-off \\
to \\
precip- \\
1tation \\
10-year \\
pro- \\
gressivo \\
average \\
(percent \\
\end{tabular}} \\
\hline & Annual & $\begin{array}{l}\text { Accuma- } \\
\text { lated }\end{array}$ & $\begin{array}{l}\text { Progres- } \\
\text { sive 10- } \\
\text { Jear } \\
\text { average }\end{array}$ & Annual & $\begin{array}{l}\text { Progres- } \\
\text { st ve 10- } \\
\text { year } \\
\text { average }\end{array}$ & Anmual & $\begin{array}{l}\text { Accumu- } \\
\text { lated }\end{array}$ & $\begin{array}{l}\text { Progres- } \\
\text { sive 10- } \\
\text { year } \\
\text { average }\end{array}$ & Anmual & $\begin{array}{l}\text { Progxes- } \\
\text { sive 10- } \\
\text { year } \\
\text { average }\end{array}$ & \\
\hline $\begin{array}{r}1897 \\
98 \\
99 \\
1900 \\
01 \\
02 \\
03 \\
04 \\
05 \\
06 \\
07 \\
08 \\
09 \\
1910 \\
11 \\
12 \\
13 \\
14 \\
15 \\
16 \\
17 \\
18 \\
19 \\
1920 \\
21 \\
22 \\
23 \\
24 \\
25 \\
26 \\
27 \\
28 \\
29 \\
1930 \\
31 \\
32 \\
33 \\
34\end{array}$ & $\begin{array}{l}50.36 \\
59.42 \\
49.97 \\
63.81 \\
67.02 \\
49.05 \\
55.04 \\
36.03 \\
53.71 \\
63.75 \\
49.01 \\
52.63 \\
59.55 \\
45.05 \\
49.94 \\
66.64 \\
50.21 \\
48.64 \\
60.04 \\
50.75 \\
54.10 \\
58.02 \\
58.99 \\
70.27 \\
47.11 \\
61.17 \\
56.59 \\
51.00 \\
41.26 \\
52.27 \\
44.98 \\
57.33 \\
78.46 \\
43.76 \\
45.75 \\
72.96 \\
42.16 \\
57.47\end{array}$ & $\begin{array}{r}50.36 \\
109.78 \\
159.75 \\
223.56 \\
290.58 \\
339.63 \\
394.67 \\
430.70 \\
484.41 \\
548.16 \\
597.17 \\
649.80 \\
709.35 \\
754.40 \\
804.34 \\
870.98 \\
921.19 \\
969.83 \\
1029.87 \\
1080.62 \\
1134.72 \\
1192.74 \\
1251.73 \\
1322.00 \\
1369.11 \\
1430.28 \\
1486.87 \\
1537.87 \\
1579.13 \\
1631.40 \\
1676.38 \\
1733.71 \\
1812.17 \\
1855.93 \\
1901.68 \\
1974.64 \\
2016.80 \\
2074.27 \\
\end{array}$ & $\begin{array}{c}- \\
- \\
- \\
- \\
z \\
- \\
54.82 \\
54.68 \\
54.00 \\
54.96 \\
53.08 \\
51.38 \\
53.14 \\
52.65 \\
53.91 \\
54.55 \\
53.25 \\
53.76 \\
54.29 \\
54.24 \\
56.76 \\
56.48 \\
55.93 \\
56.57 \\
56.80 \\
54.93 \\
55.08 \\
54.17 \\
54.10 \\
56.04 \\
53.39 \\
53.26 \\
54.44 \\
53.00 \\
53.64\end{array}$ & $\begin{array}{l}61.8 \\
61.5 \\
61.6 \\
61.9 \\
59.4 \\
61.1 \\
60.1 \\
60.2 \\
60.5 \\
61.1 \\
61.7 \\
61.7 \\
61.4 \\
60.6 \\
62.9 \\
60.1 \\
61.9 \\
61.1 \\
61.4 \\
61.4 \\
59.6 \\
61.7 \\
62.2 \\
60.0 \\
63.5 \\
62.6 \\
61.4 \\
60.2 \\
63.4 \\
61.0 \\
63.2 \\
60.7 \\
61.4 \\
61.5 \\
63.0 \\
62.3 \\
63.2 \\
61.2\end{array}$ & $\begin{array}{c}- \\
- \\
= \\
- \\
= \\
- \\
- \\
60.9 \\
60.9 \\
60.9 \\
60.9 \\
60.8 \\
61.1 \\
61.0 \\
61.2 \\
61.3 \\
61.4 \\
61.4 \\
61.2 \\
61.2 \\
61.3 \\
61.2 \\
61.3 \\
61.5 \\
61.5 \\
61.4 \\
61.6 \\
61.6 \\
61.9 \\
61.8 \\
61.7 \\
61.9 \\
61.8 \\
61.8 \\
62.0 \\
62.1\end{array}$ & $\begin{array}{l}19.07 \\
20.37 \\
22.80 \\
28.85 \\
33.20 \\
26.20 \\
29.84 \\
11.57 \\
16.63 \\
28.45 \\
19.52 \\
23.06 \\
28.73 \\
17.10 \\
16.194 \\
30.14 \\
19.77 \\
13.62 \\
23.25 \\
22.21 \\
25.92 \\
20.41 \\
27.13 \\
33.46 \\
18.79 \\
28.03 \\
23.01 \\
19.07 \\
17.77 \\
18.40 \\
14.30 \\
22.08 \\
37.61 \\
17.49 \\
12.71 \\
25.65 \\
18.65 \\
17.05 \\
\end{array}$ & \begin{tabular}{|}
19.07 \\
39.44 \\
62.24 \\
91.09 \\
124.29 \\
150.49 \\
180.33 \\
191.90 \\
208.53 \\
236.98 \\
256.50 \\
279.56 \\
308.29 \\
325.39 \\
341.58 \\
371.72 \\
391.49 \\
405.11 \\
428.36 \\
450.57 \\
476.49 \\
496.90 \\
524.03 \\
557.49 \\
576.28 \\
604.31 \\
627.32 \\
646.39 \\
664.16 \\
682.56 \\
696.86 \\
718.94 \\
756.55 \\
774.04 \\
786.75 \\
812.40 \\
831.05 \\
848.10
\end{tabular} & $\begin{array}{c}\vdots \\
\vdots \\
\vdots \\
\vdots \\
\vdots \\
23.70 \\
23.74 \\
24.01 \\
24.61 \\
23.43 \\
21.73 \\
22.12 \\
21.12 \\
21.32 \\
21.98 \\
21.36 \\
22.00 \\
21.73 \\
21.57 \\
23.21 \\
23.47 \\
23.26 \\
23.58 \\
24.13 \\
23.58 \\
23.20 \\
22.04 \\
22.20 \\
23.25 \\
21.66 \\
21.05 \\
20.81 \\
20.37 \\
20.17 \\
\end{array}$ & $\begin{array}{l}31.29 \\
39.05 \\
27.17 \\
34.96 \\
33.82 \\
22.85 \\
25.20 \\
24.46 \\
37.08 \\
35.30 \\
29.49 \\
29.57 \\
30.82 \\
27.95 \\
33.754 \\
36.50 \\
30.44 \\
35.02 \\
36.79 \\
28.54 \\
28.18 \\
37.61 \\
31.86 \\
36.81 \\
28.32 \\
33.14 \\
33.58 \\
31.93 \\
23.49 \\
33.87 \\
30.68 \\
35.25 \\
40.85 \\
26.27 \\
33.04 \\
47.31 \\
23.51 \\
40.42\end{array}$ & $\begin{array}{c}- \\
- \\
\overline{-} \\
- \\
- \\
- \\
31.12 \\
30.94 \\
29.99 \\
30.35 \\
29.65 \\
29.65 \\
31.01 \\
31.54 \\
32.59 \\
32.56 \\
31.89 \\
31.76 \\
32.56 \\
32.66 \\
33.55 \\
33.01 \\
32.67 \\
32.99 \\
32.68 \\
31.35 \\
31.88 \\
32.13 \\
31.89 \\
32.79 \\
31.74 \\
32.21 \\
33.63 \\
32.62 \\
33.47 \\
\end{array}$ & $\begin{array}{c}- \\
- \\
= \\
- \\
- \\
= \\
43.2 \\
43.4 \\
44.4 \\
44.7 \\
44.2 \\
42.3 \\
41.6 \\
40.1 \\
39.5 \\
40.3 \\
40.1 \\
40.9 \\
40.0 \\
39.7 \\
40.9 \\
41.6 \\
41.6 \\
41.7 \\
42.5 \\
42.9 \\
42.1 \\
40.7 \\
41.0 \\
41.5 \\
40.6 \\
39.5 \\
38.2 \\
38.5 \\
37.6\end{array}$ \\
\hline $\begin{array}{c}\text { Total } \\
\text { Av. }\end{array}$ & $\begin{array}{r}2074.27 \\
54.59\end{array}$ & $\overline{-}$ & $\bar{z}$ & $\begin{array}{r}2335.5 \\
61.5\end{array}$ & $=$ & $\begin{array}{r}848.10 \\
22.32\end{array}$ & 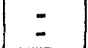 & $=$ & $\begin{array}{r}1226.17 \\
32.27\end{array}$ & $\ddot{-}$ & $\ddot{-}$ \\
\hline
\end{tabular}

* Run-off estimated for 1911 


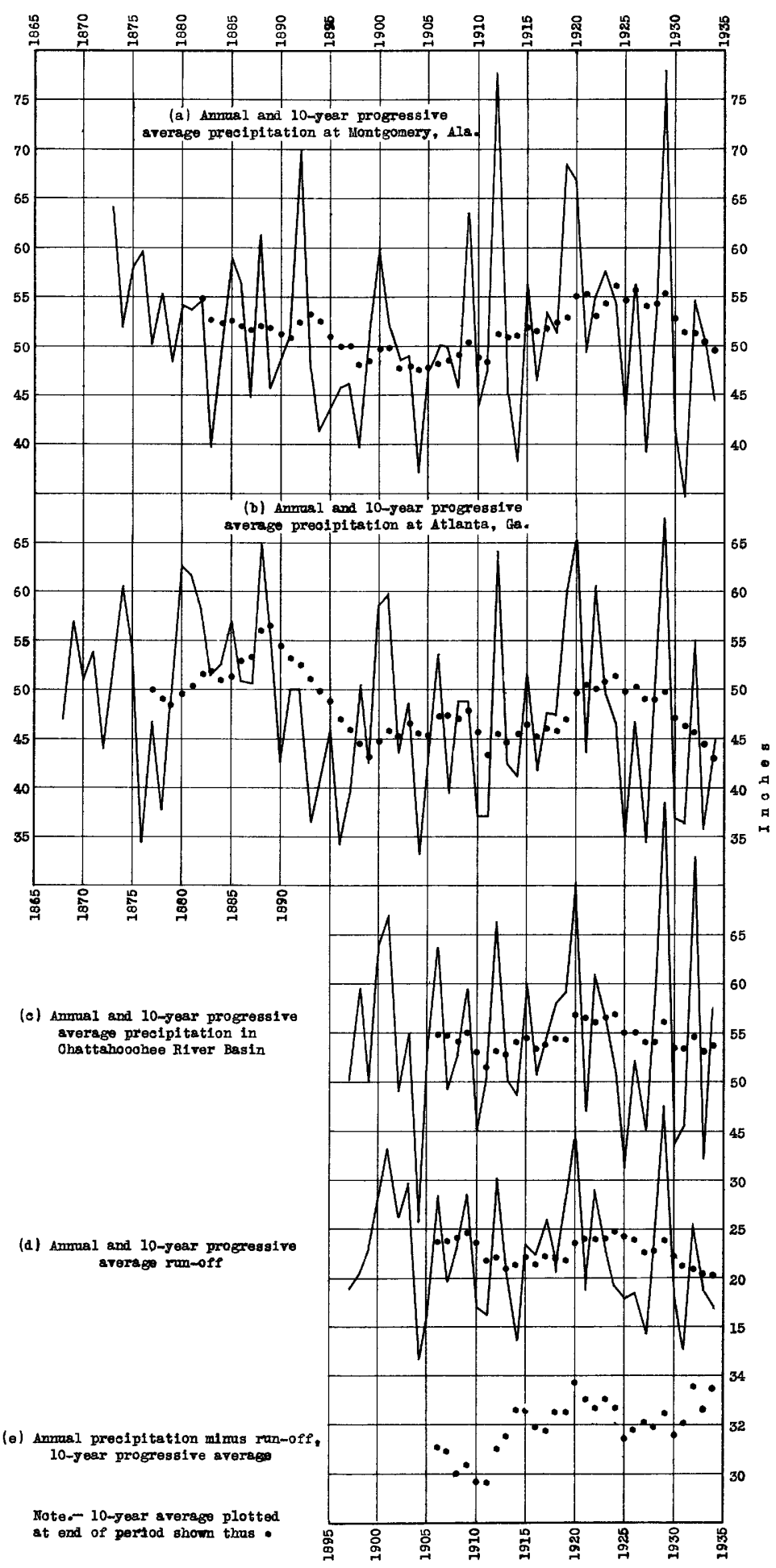

Figare 24.-Felation between rainfall and run-off in Chattahooohee River Basin above West Point, Ga. 
In the preclpitation based on all the stations can be checked against the trends show by geographic provinces, and where the data are available figures 18 to 24 8.1so show the mean annual and 10-year progressive annual precipitation for one or two long-time stations within or directiy adjacent to the basin.

Whether or not the figures given for the mean annual precipitation represent closely the amounts that fell on the basin is subject to question. For basins in which the precipltation is more a function of geographic location than of altitude the estinates of average precipitation over the basin are believed to be fairly reliable, at least for the later periods. For basins where differences in altitude as well as geographic location affect the magnitude of the precipitation the probability of errors is greater.

In general the estimates of the mean annual temperature have been based on records at a $f$ ew stations corrected to the mean by comparisons of the average for all the stations in each basin during the later part of the period with the temperature at the base station used.

With respect to the increased temperature in the later years there appears to be little doubt. There is doubt, however, as to the accuracy of the estimates of temperature increases here given. Part of the doubt rests on the belief that the indicated increase at the stations used may not be indicative of the temperatures over the basin. This phase is discussed in the section on temperature. There is also some question as to the accuracy and homogeneity of the record for the periods used. The records of the United States Weather Bureau have been used as given in Bulletin $W$ and other Weather Bureau publications for the period 1889 to 1934, during which the average temperatures have been based on the average of the average daily maxima and average daily minima. For the relatively few records prior to 1889 the figures given in Bulletin w have been corrected, where possible, to conform with the system used since 1889 . Such corrections have, in general, changed the 10-year average as complled from Bulletin $W$ by only 0.2 or $0.3^{\circ}$. Although the temperatures as given may not represent the average temperatures over the basins, especialiy in the basins having considerable differences in altitude, the indicated changes should at least be fairly representative of changes over the basins. 
So far as water stages are concerned the accuracy of the run-off records has probably increased from the beginning of the record at least up to the time when recording gages have been installed. In the matter of stage-discharge relations the accuracy probably increased from the beginning of the record up to about 1910 to 1915, when refined methods of current-meter suspension made possible more accurate determinations of depth and of velocity. In general, however, in spite of probable errors in the base data, the analyses whlch have been made disclosed fer apparent inconsistencies resulting from the data used. In view of the fact that no attempt has been made to recompute or recompile published figures, this consistency is a favorable commentary on the work of the agencles that have collected and complied the meteorologic and hydrographic data. This does not mean, however, that some of the changes in relations between rainfall and run-off that have been credited to changes in either precipitation or temperature may not be more properly credited to errors in base data or to changes not related to either rainfall or temperature.

The relations between rainfall and mun-off, shown in the tables as "ratio of run-of to precipitation", have been determaned on the basis of 10-year averages. In some basing the hydrologic cycle may be completed In a much shorter period of time, but Hayford (57) has pointed out, for the small steep Wagon Wheel Gap area in Colorado, that the stream flow on any particular day was influenced by the train of events occurring in the preceding 257 days. If such time elements are involved in a steep basin embracing a fow hundred acres, the time required to complete the cycle in all 1ts phases in basins such as the upper Hisissippi is probably measurable in years rather than months or days.

In tables 22,23 , and 24 are sumarlzed by basins the basic precipitation, temperature, and run-off data.

\section{Changes in rainfall, by basins}

Although the periods of record for the several basing are somewhat different, the presentation allows rough comparisons as between the different basins and also comparisons with the changes as given by areas. Except possibly in the Mississippi, Red, and Tennessee River basins the periods covered by concurrent precipitation, temperature, and run-off records do not embrace early years when, on the basis of long-time records, 
the precipltation was considerably higher than any included in the basin averages shown in table 22. For example, as shown in figure 21, the precipitation at Boston during the 10-year period ending 1870 was materially above any shown by subsequent periods, and a similar situation is shown with respect to other long-time stations in or near the basins studied. The averages for the Mississippl, Red, and Tennessee River basins include the high precipitation periods of the $1880^{\prime} \mathrm{s}$, and the average given may be fairly representative of a series of both high and low years. The studies indlcate clearly that averages based on records for the last 30 to 40 years In the eastern part of the United States may not embrace periods of maximum precipitation. On the other hand, there seems to be the possibility that In the plains country west of the looth merldian and also in the Great Basin area (55) records for similar periods do not cover years of prevalent droughts, as shown by the graph of the Colorado River at Lees Ferry, Ariz. (fig. 17). The tables and graphs for the basins studied furnish a convenlent record from which those interested may draw their own conclusions with respect to the magnitude of ohanges for different periods.

\section{Changes in temperature, by basins}

The temperature changes correspond with the changes previously Indicated for areas. All the basins except the Merrimacl show higher average temperatures for the last half of the record, and the average for the last 10 years was the highest for the perlod of record. The average temperature as given, in so far as it reflects the temperature over the basin, is probably too $10 \mathrm{w}$ in basins where there are marked differences in altitude. The changes indicated, however, should represent approximately the changes over the basins.

\section{Changes in run-off, by basins}

The apparent changes in run-off are consistent with the indicated changes in the precipitation and temperature. As was to be expected, the average run-off during the last half of the period of record was less than during the first half. Except in the Merrimack River Basin, where the minimum 10-year period occurred in 1918, the average run-off for the 10year period ending 1934 is the lowest for the perlod of record. For the $59550-35-7$ 
Table 22.- Average Anmual Preclpitation

\begin{tabular}{|c|c|c|c|c|c|c|c|c|}
\hline \multirow[b]{2}{*}{ Basin } & \multirow[b]{2}{*}{$\begin{array}{l}\text { Perlod of } \\
\text { record }\end{array}$} & \multicolumn{3}{|c|}{ Average (inches) } & \multirow[b]{2}{*}{$\begin{array}{l}\text { Ratio } \\
\text { leat } \\
\text { half } \\
\text { to } \\
\text { first } \\
\text { half } \\
\text { (percent) }\end{array}$} & \multirow[b]{2}{*}{$\begin{array}{c}\text { Aver- } \\
\text { age } \\
\text { for } \\
10 \\
\text { years } \\
\text { ending } \\
\text { 1934 } \\
\text { (Inches) }\end{array}$} & \multicolumn{2}{|c|}{$\begin{array}{l}\text { Ratio last } 10 \\
\text { years (percent) }\end{array}$} \\
\hline & & $\begin{array}{l}\text { Whole } \\
\text { period }\end{array}$ & $\begin{array}{l}\text { First } \\
\text { half }\end{array}$ & $\begin{array}{l}\text { Lest } \\
\text { half }\end{array}$ & & & $\begin{array}{l}\text { To } \\
\text { long } \\
\text { time } \\
\text { ev. }\end{array}$ & $\begin{array}{l}\text { To } \\
\text { firgt } \\
\text { half }\end{array}$ \\
\hline $\begin{array}{l}\text { Red } \\
\text { Mississippl } \\
\text { Neosho } \\
\text { Merrimack } \\
\text { James } \\
\text { Tennessee } \\
\text { Chattahoochee }\end{array}$ & $\begin{array}{l}1882-1934 \\
1878-1934 \\
1896-1934 \\
1880-1934 \\
1899-1934 \\
1881-1934 \\
1897-1934\end{array}$ & $\begin{array}{l}20.91 \\
29.61 \\
33.58 \\
41.63 \\
40.79 \\
50.36 \\
54.59\end{array}$ & $\begin{array}{l}21.76 \\
30.18 \\
35.00 \\
42.56 \\
42.03 \\
50.34 \\
54.20\end{array}$ & $\begin{array}{l}20.06 \\
28.84 \\
32 \cdot 16 \\
40.70 \\
39.55 \\
50.38 \\
54.98\end{array}$ & $\begin{array}{r}92 \\
96 \\
92 \\
96 \\
94 \\
100 \\
101\end{array}$ & $\begin{array}{l}18.78 \\
27.86 \\
32.68 \\
41.38 \\
38.30 \\
49.18 \\
53.64\end{array}$ & $\begin{array}{l}90 \\
94 \\
97 \\
99 \\
94 \\
98 \\
98\end{array}$ & $\begin{array}{l}86 \\
92 \\
93 \\
97 \\
91 \\
98 \\
99\end{array}$ \\
\hline
\end{tabular}

\begin{tabular}{|c|c|c|c|c|c|c|c|c|c|}
\hline \multirow[b]{2}{*}{ Besin } & \multicolumn{2}{|c|}{ Maximum year } & \multicolumn{2}{|c|}{$\begin{array}{c}\text { Maximum 10-year } \\
\text { period }\end{array}$} & \multicolumn{2}{|c|}{ Minimum year } & \multicolumn{2}{|c|}{$\begin{array}{c}\text { Minimum } 10-\text { year } \\
\text { period }\end{array}$} & \multirow[b]{2}{*}{$\begin{array}{c}\text { Ratio } \\
\text { of } \\
\text { last } \\
10 \\
\text { years } \\
\text { to } \\
\text { minimum } \\
10 \\
\text { years } \\
\text { (percent) }\end{array}$} \\
\hline & Inches & Year & Inches & $\begin{array}{l}\text { Year of } \\
\text { ending }\end{array}$ & Inches & Yoar & Inches & $\begin{array}{l}\text { Year of } \\
\text { ending }\end{array}$ & \\
\hline $\begin{array}{l}\text { Red } \\
\text { MIssissippi } \\
\text { Neosho } \\
\text { Merrimack } \\
\text { James } \\
\text { Tennessee } \\
\text { Chattahoochee }\end{array}$ & $\begin{array}{l}27.76 \\
41.28 \\
48.74 \\
61.48 \\
54.03 \\
64.10 \\
78.46\end{array}$ & $\begin{array}{l}1916 \\
1881 \\
1815 \\
1928 \\
1901 \\
1882 \\
1929\end{array}$ & $\begin{array}{l}23.30 \\
31.65 \\
37.25 \\
45.12 \\
43.83 \\
52.20 \\
56.80\end{array}$ & $\begin{array}{l}1905 \\
1909 \\
1909 \\
1893 \\
1908 \\
1924 \\
1924\end{array}$ & $\begin{array}{l}12.21 \\
18.24 \\
23.66 \\
31.38 \\
21.16 \\
36.17 \\
36.03\end{array}$ & $\begin{array}{l}1910 \\
1910 \\
1901 \\
1883 \\
1930 \\
1925 \\
1904\end{array}$ & $\begin{array}{l}18 \cdot 78 \\
27 \cdot 24 \\
31 \cdot 20 \\
37 \cdot 79 \\
37 \cdot 86 \\
47 \cdot 23 \\
51 \cdot 38\end{array}$ & $\begin{array}{l}1934 \\
1895 \\
1919 \\
1914 \\
1930 \\
1896 \\
1911\end{array}$ & $\begin{array}{l}100 \\
102 \\
105 \\
109 \\
101 \\
104 \\
104\end{array}$ \\
\hline
\end{tabular}

Table 23.- Average temperature ( $\left.O_{\cdot}\right)$

\begin{tabular}{|c|c|c|c|c|c|c|c|c|}
\hline \multirow[b]{2}{*}{ Basin } & \multirow[b]{2}{*}{$\begin{array}{l}\text { Perlod of } \\
\text { record }\end{array}$} & \multicolumn{3}{|c|}{ Avergige (inches) } & \multirow[b]{2}{*}{$\begin{array}{l}\text { Diff- } \\
\text { erence } \\
\text { lest } \\
\text { half } \\
\text { from } \\
\text { first } \\
\text { helf }\end{array}$} & \multirow[b]{2}{*}{$\begin{array}{l}\text { Aver- } \\
\text { age } \\
10 \\
\text { years } \\
\text { end- } \\
\text { Ing } \\
1934\end{array}$} & \multicolumn{2}{|c|}{$\begin{array}{l}\text { Difference last } \\
10 \text { years from }\end{array}$} \\
\hline & & $\begin{array}{l}\text { Whole } \\
\text { period }\end{array}$ & $\begin{array}{l}\text { First } \\
\text { half }\end{array}$ & $\begin{array}{l}\text { Last } \\
\text { half }\end{array}$ & & & $\begin{array}{l}\text { Whole } \\
\text { period }\end{array}$ & $\begin{array}{l}\text { Firgt } \\
\text { half }\end{array}$ \\
\hline 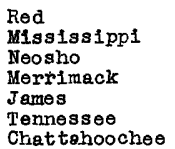 & $\begin{array}{l}1882-1934 \\
1878-1934 \\
1896-1934 \\
1880-1934 \\
1899-1934 \\
1881-1934 \\
1897-1934\end{array}$ & $\begin{array}{l}39.8 \\
45.2 \\
55.6 \\
45.6 \\
54.9 \\
55.8 \\
61.5\end{array}$ & $\begin{array}{l}38.7 \\
44.9 \\
55.4 \\
45.6 \\
54.5 \\
55.3 \\
61.2\end{array}$ & $\begin{array}{l}40.8 \\
46.5 \\
56.8 \\
45.6 \\
55.3 \\
56.3 \\
61.8\end{array}$ & $\begin{array}{l}+2.1 \\
+\quad .6 \\
+\quad .4 \\
+\quad 0.8 \\
+\quad 1.0 \\
+\quad .6\end{array}$ & $\begin{array}{l}41.6 \\
46.1 \\
56.5 \\
46.1 \\
55.8 \\
56.9 \\
62.1\end{array}$ & $\begin{array}{r}+1.8 \\
+\quad .9 \\
+\quad .9 \\
+\quad .5 \\
+\quad .9 \\
+\quad 1.1 \\
+\quad .6\end{array}$ & $\begin{array}{l}+2.9 \\
+1.2 \\
+1.1 \\
+.5 \\
+1.3 \\
+1.6 \\
+\quad .9\end{array}$ \\
\hline
\end{tabular}

\begin{tabular}{|c|c|c|c|c|c|c|c|c|c|}
\hline \multirow[b]{2}{*}{ Besin } & \multicolumn{2}{|c|}{ Maximum year } & \multicolumn{2}{|c|}{$\begin{array}{c}\text { Maximu 10-year } \\
\text { perfod }\end{array}$} & \multicolumn{2}{|c|}{ Minimum year } & \multicolumn{2}{|c|}{$\begin{array}{c}\text { Minimum } \\
\text { perfod }\end{array}$} & \multirow[b]{2}{*}{\begin{tabular}{|c|} 
Differ- \\
ence \\
lest \\
10 \\
years \\
from \\
minimum \\
10 \\
years
\end{tabular}} \\
\hline & ${ }^{\sigma_{\mathrm{F}}} \cdot$ & Year & OF. & $\begin{array}{l}\text { Year of } \\
\text { ending }\end{array}$ & OF. & Year & $\sigma_{\mathbf{F}}$ & $\begin{array}{l}\text { Year of } \\
\text { ending }\end{array}$ & \\
\hline $\begin{array}{l}\text { Red } \\
\text { Mississippl } \\
\text { Neosho } \\
\text { Merrimack } \\
\text { James } \\
\text { Tennessee } \\
\text { Chattahoochee }\end{array}$ & $\begin{array}{l}45.8 \\
50.5 \\
58.9 \\
48.8 \\
57.1 \\
58.5 \\
63.5\end{array}$ & $\begin{array}{l}1931 \\
1931 \\
1933 \\
1880 \\
1921 \\
1933 \\
1921 \\
\end{array}$ & $\begin{array}{l}41.6 \\
46.1 \\
56.4 \\
46.5 \\
55.8 \\
56.9 \\
62.1\end{array}$ & $\begin{array}{l}1934 \\
1934 \\
1934 \\
1889 \\
1934 \\
1934 \\
1934 \\
\end{array}$ & $\begin{array}{l}34 \cdot 1 \\
41 \cdot 4 \\
53.3 \\
41 \cdot 1 \\
52 \cdot 5 \\
63.3 \\
59.4\end{array}$ & $\begin{array}{l}1883 \\
1917 \\
1912 \\
1918 \\
1904 \\
1901 \\
1901\end{array}$ & $\begin{array}{l}37.6 \\
43.8 \\
54.9 \\
44.9 \\
54.1 \\
65.0 \\
60.8\end{array}$ & $\begin{array}{l}1891 \\
1892 \\
1920 \\
1908 \\
1910 \\
1893 \\
1910\end{array}$ & $\begin{array}{l}+\quad 4.0 \\
+\quad 2.3 \\
+\quad 1.6 \\
+\quad 1.2 \\
+\quad 1.7 \\
+\quad 1.9 \\
+\quad 1.3\end{array}$ \\
\hline
\end{tabular}


Table 24.- Average annual mun-off

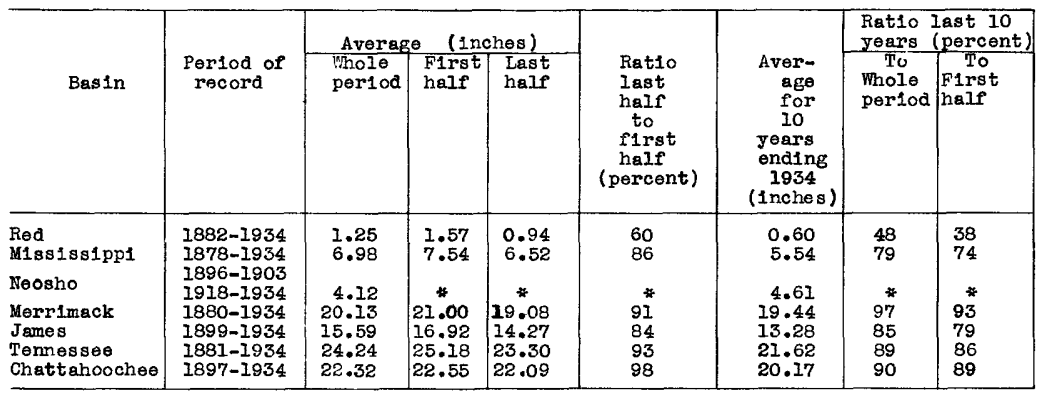

\begin{tabular}{|c|c|c|c|c|c|c|c|c|c|}
\hline \multirow[b]{2}{*}{ Basin } & \multicolumn{2}{|c|}{ Maximum year } & \multicolumn{2}{|c|}{$\begin{array}{c}\text { Maxinum I0-year } \\
\text { period }\end{array}$} & \multicolumn{2}{|c|}{ Mindmum year } & \multicolumn{2}{|c|}{$\begin{array}{l}\text { Minimum 10-year } \\
\text { period }\end{array}$} & \multirow[b]{2}{*}{$\begin{array}{c}\text { Ratio } \\
\text { of } \\
\text { last } \\
10 \\
\text { years, } \\
\text { to } \\
\text { minimum } \\
10 \\
\text { Jears } \\
\text { (percent) }\end{array}$} \\
\hline & Inches & Year & Inches & $\begin{array}{l}\text { Year of } \\
\text { ending }\end{array}$ & Inches & Year & Inches & $\begin{array}{l}\text { Year of } \\
\text { ending }\end{array}$ & \\
\hline $\begin{array}{l}\text { Red } \\
\text { Mississippi } \\
\text { Neosho } \\
\text { Merrimack } \\
\text { James } \\
\text { Temnessee } \\
\text { Chattahoochee }\end{array}$ & $\begin{array}{c}3.12 \\
13.19 \\
4 \\
31.54 \\
25.06 \\
34.12 \\
37.61\end{array}$ & $\begin{array}{c}1916 \\
1881 \\
* \\
1928 \\
1901 \\
1882 \\
1929\end{array}$ & $\begin{array}{c}1.84 \\
8.87 \\
* \\
23.03 \\
18.36 \\
28.11 \\
24.67\end{array}$ & $\begin{array}{l}1910 \\
1888 \\
* \\
1893 \\
1908 \\
1891 \\
1909\end{array}$ & $\begin{array}{c}0.13 \\
3.12 \\
* \\
10.65 \\
7.00 \\
13.95 \\
11.57\end{array}$ & $\begin{array}{l}1934 \\
1934 \\
\sharp \\
1911 \\
1930 \\
1904 \\
1904\end{array}$ & $\begin{array}{c}0.60 \\
5.54 \\
* \\
16.94 \\
13.28 \\
21.62 \\
20.17\end{array}$ & $\begin{array}{l}1934 \\
1934 \\
\$ \\
1918 \\
1934 \\
1934 \\
1934\end{array}$ & $\begin{array}{l}100 \\
100 \\
14 \\
115 \\
100 \\
100 \\
100\end{array}$ \\
\hline
\end{tabular}

* The broken record makes it impossible to presen'c comparable data. 
basins shown the period of record probably covers the minimm 10-year perlod of record except for the Neosho River Basin, where as indicated by the Leavenworth record ( $\mathrm{fig} .20$ ) a lower minimum may have occurred in 1847 or 1869; and for the James River Basin (fig. 22), where a lower minimum during the early seventies is indicated by the Baltimore record.

\section{Relations between rainfall and run-off}

The most commonly expressed relation between rainfall and munoff is the ratio obtained by dividing the run-off for a given period by the precipitation for the same period. The concept of rum-off thus conveyed is faulty and may be misleading. A sounder concept of the relation is that run-off is a residual of rainfall after the deduction of losses by evaporation and transpiration. However the ratio as commonly derived, properly considered, is of some interest and is presented for the basins studied in tables $8,10,13,15,17,19$, and 21 by 10-year progressive periods. In figures 25 to 31 are plotted the average annual precipitation against the average annial run-off for each jear covered by the period of record, and the total precipitation by 10-year periods against the total run-off for the same 10-year periods.

For the purpose of ready comparison of the relations between rainfall and run-off for the several basins, figure 32 shows to a common scale the average annual precipitation by 10-year periods plotted against the average annual run-off for the same periods. This figure is identical with similar data plotted on figures 25 to 31 with the exception of the scales. The data thus presented disclose several interesting and significant features.

On the basis of the long-time averages it appears that in the Red River Basin a change of 1 inch in annual rainfall is reflected by a change of about 0.3 inch in run-off. On the other hand, in the basins of the James, Merrimack, l'ennesse日, and Chattahoochee Rivers a change of 1 inch in rainfall is reflected by changes of 0.7 inch to 0.9 inch in runoff. In the Mississippi River Basin a change of 1 inch in rainfall is reflected by a change of about 0.5 inch in run-off.

The transpiration and evaporation as measured by "precipitation minus run-off" as givion in tables 8, 10, 13, 15, 17, 19, and 21 and shown graphically in figures 18 to 24 averages about 20 inches for the Red River 


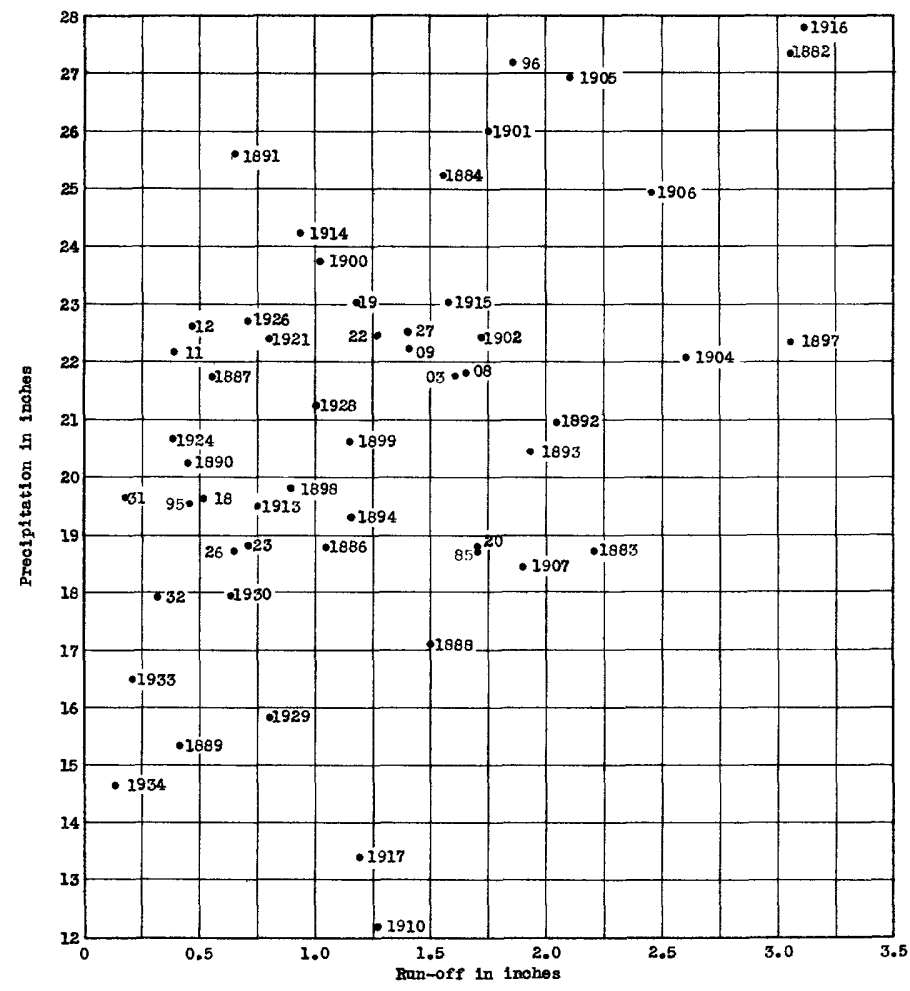

Figure 25a.-1nmal prectpitation and annual ron-off

in the Red River Bas in above Grand Forks, N.Dak.

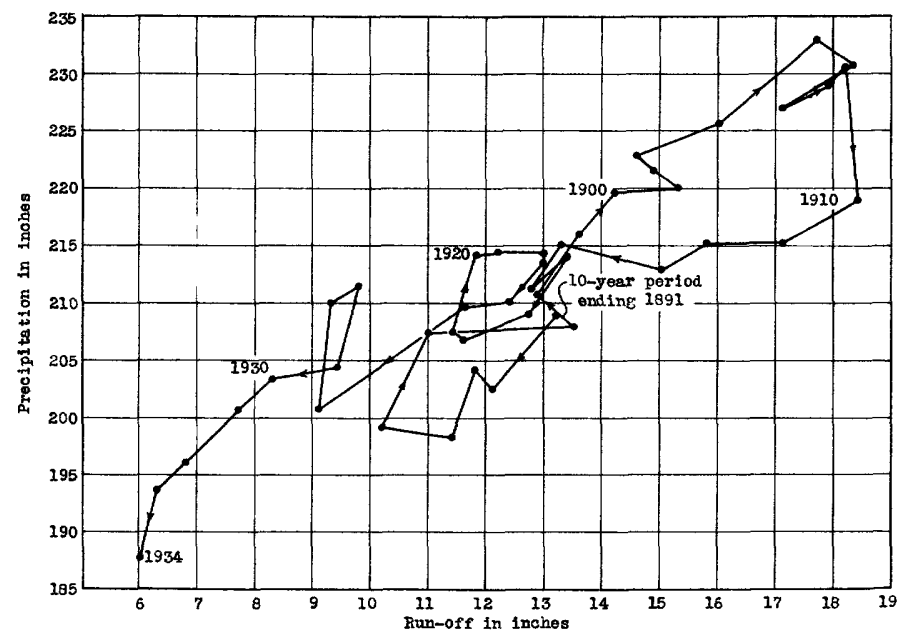

F1gure 25b.-Total preolpitation and total run-off by 10-year perlods in the Red River Besin above Grend Forks, N.Dak. 


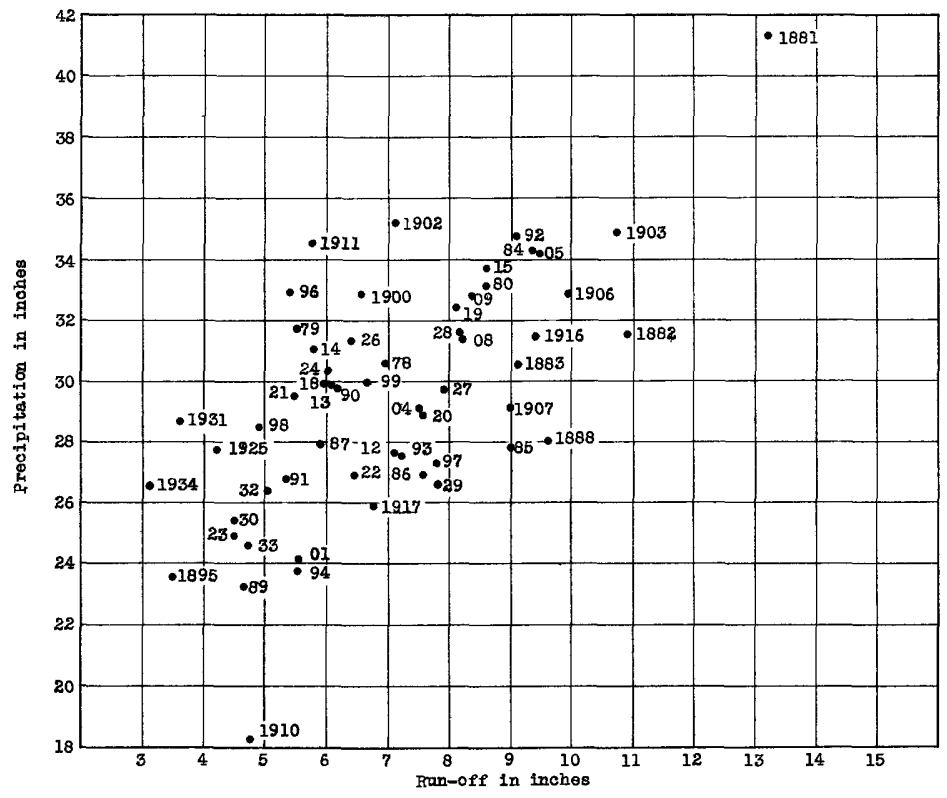

Figure 26a.-Anmual precipitation and anmual run-off in the Mississippl River Basin above Keokuk, Iows.

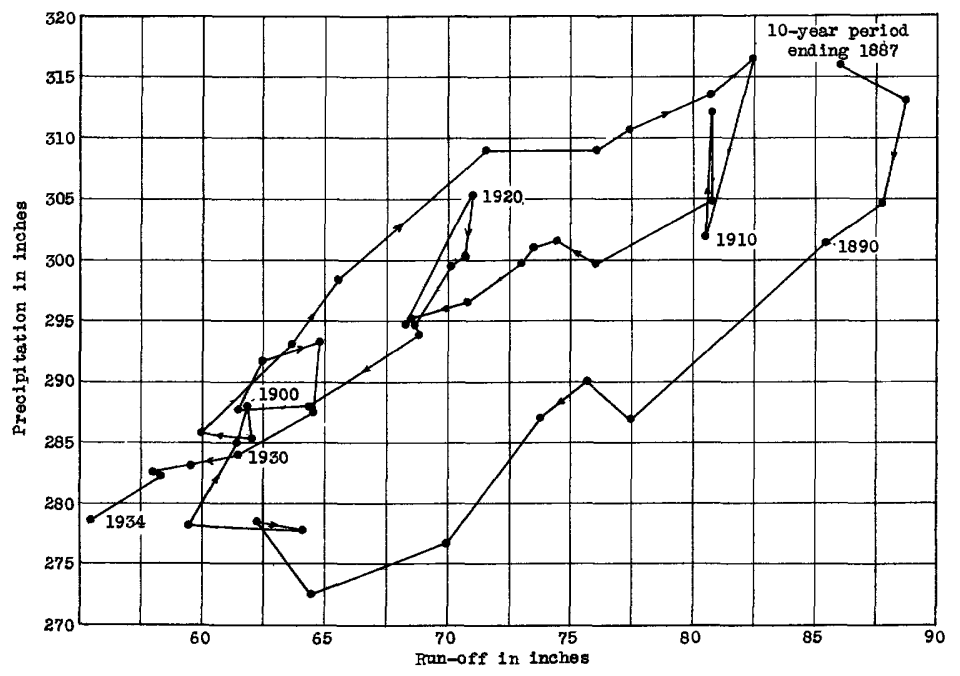

Figure 26b.-Total precipitation and total run-off by 10-year periods In the Mississippl River Basin above Keokuk, Iowa. 


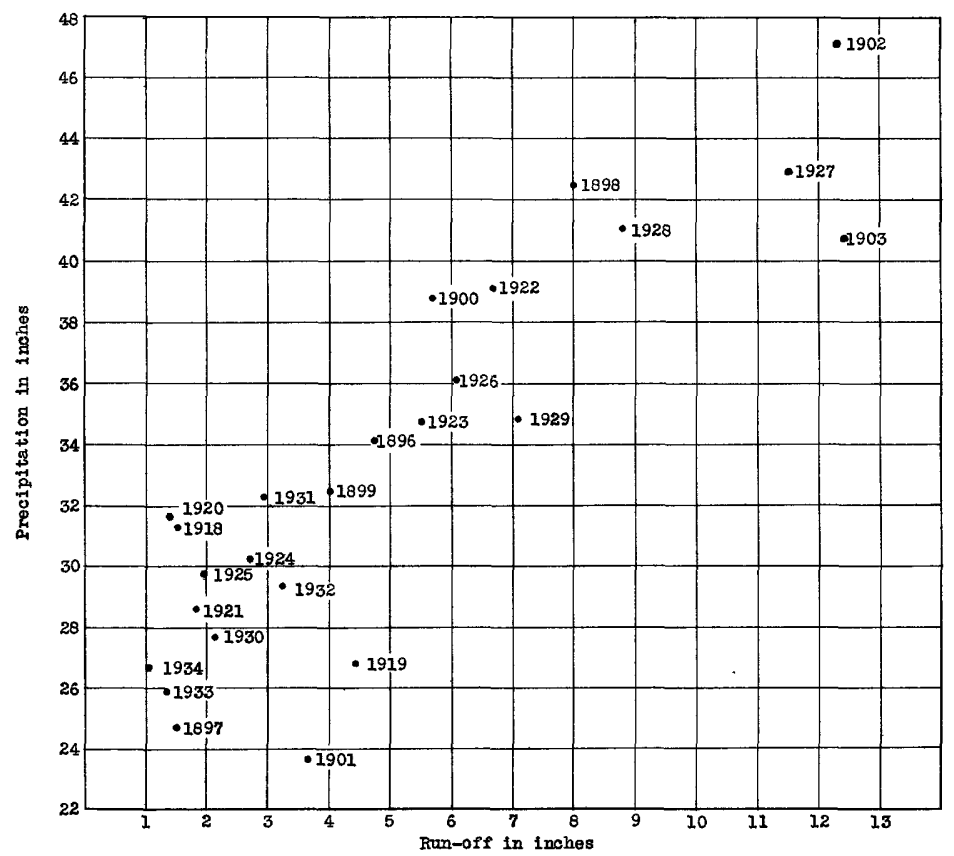

Figure 27a.-Lnnual preoipitation and annual run-off in the Neosho River Basin above Iola, Kans.

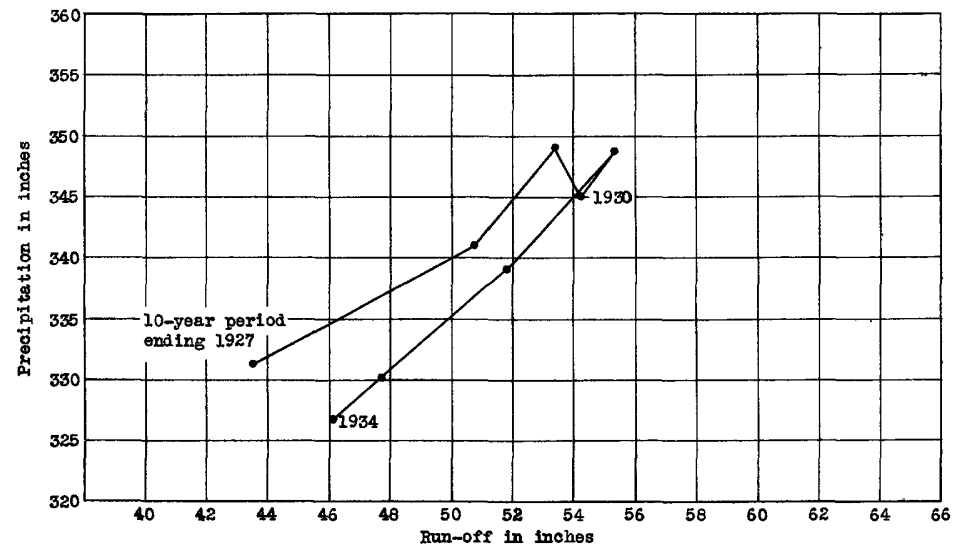

Figare 27b.-Motal precipitation and totsl run-off by 10-year periods in the Neosho River Bas in above Iola, Kans. 


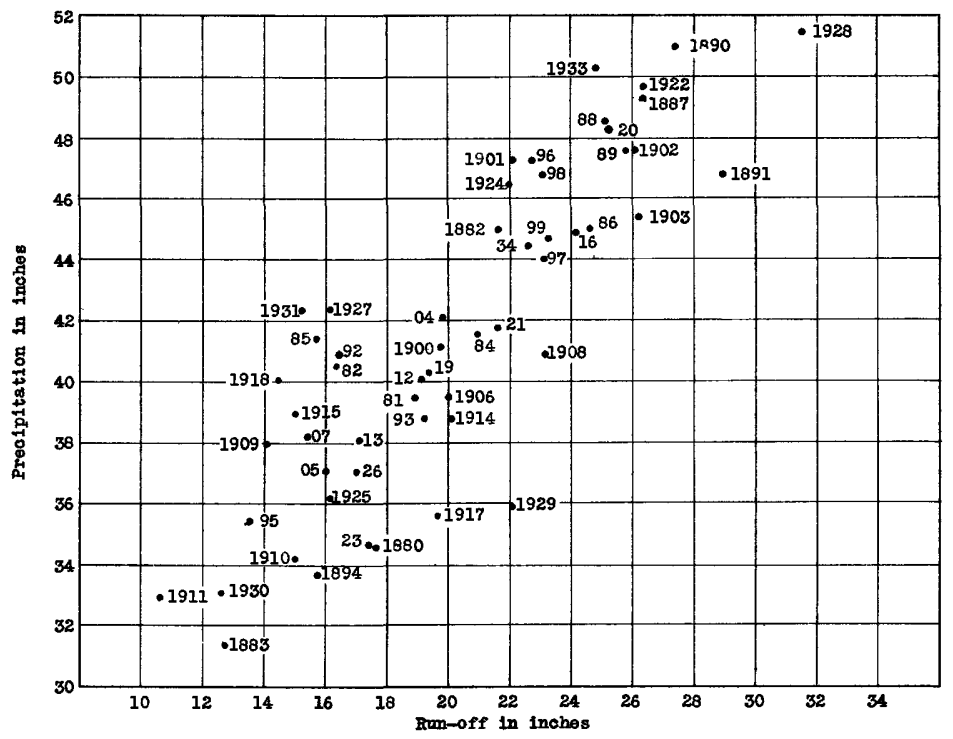

F1 gare 28a.- Anmual procipitation and annual run-off

in the Merrimack Biver Besin above Lawrence, Mass.

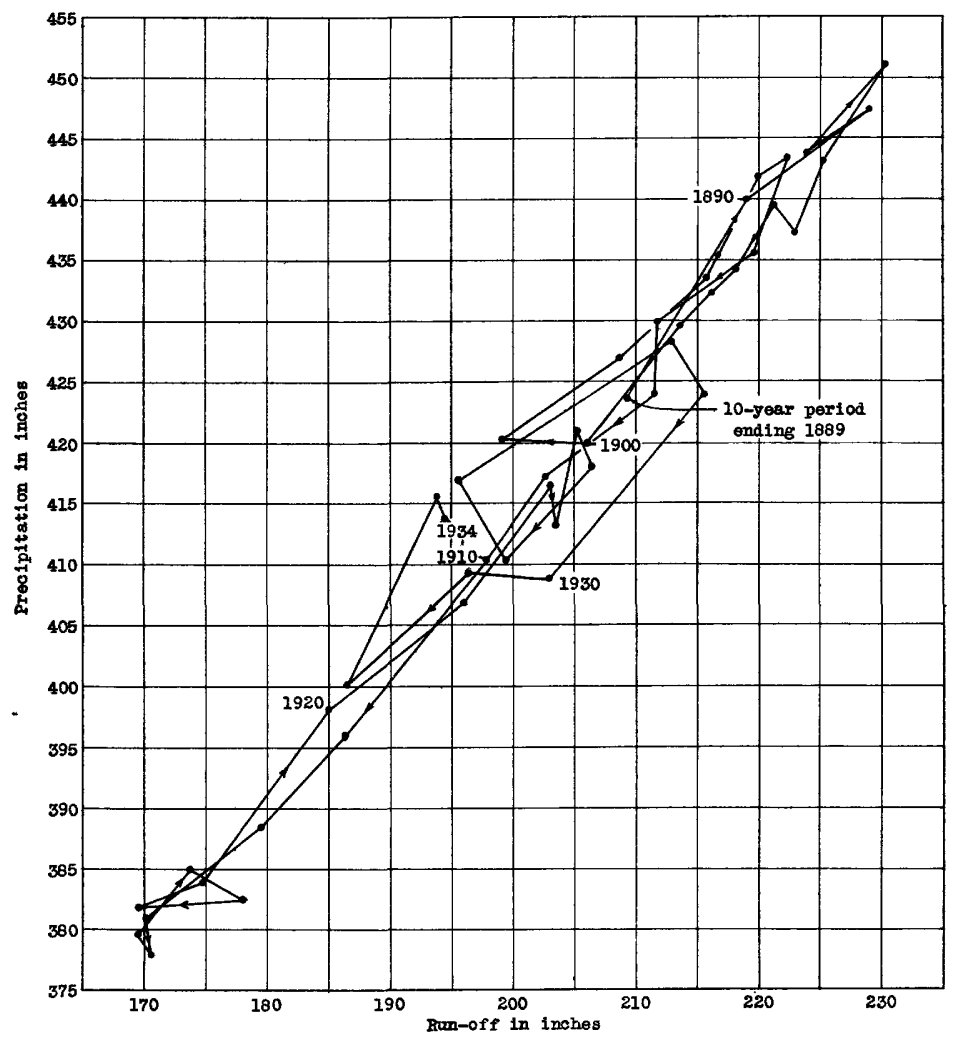

Figure 28b.-Totsl preaiptitation and tot8, r run-off by 10-year periods in the Merriasck RIver $:$. io Lewrence, Mass. 


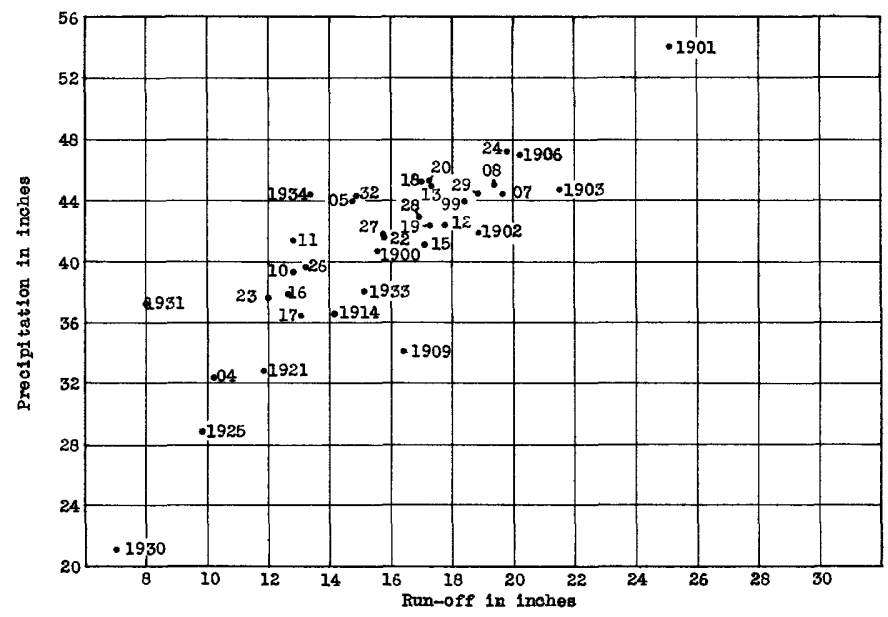

Figure 29a,-Anmal precipitation and ammal run-off in the James Riter Basin above Cartersvilie, $\nabla a$.

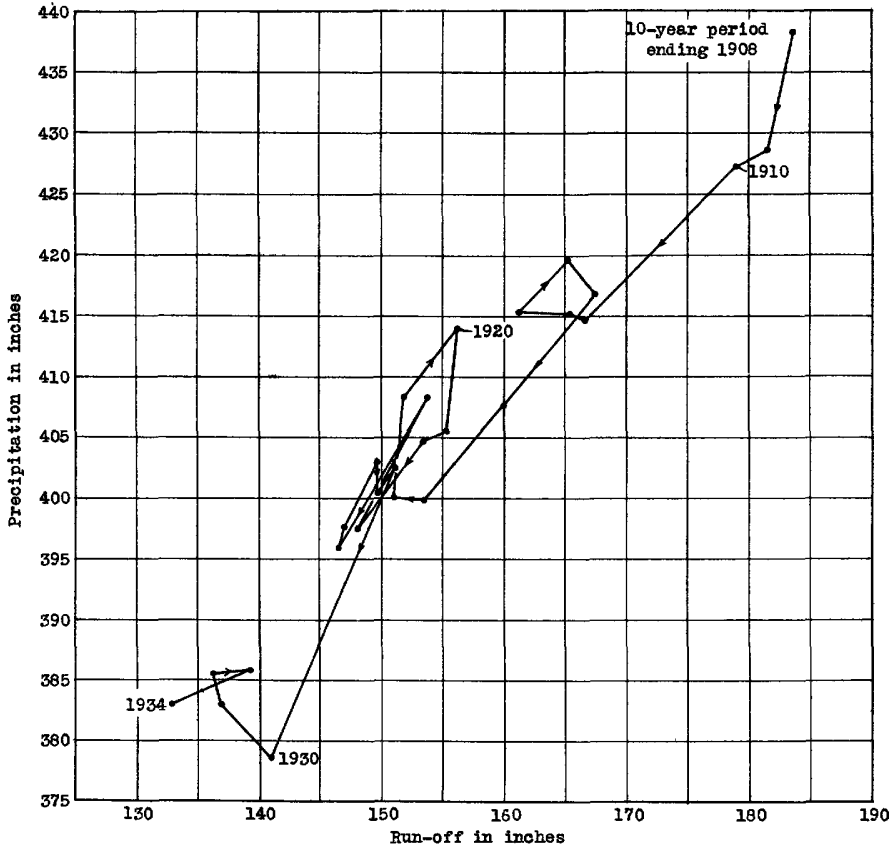

Figure 29b.-Total precipitation and total run-off by 10-year periods in the James River Basin above Cartersville, Va. 


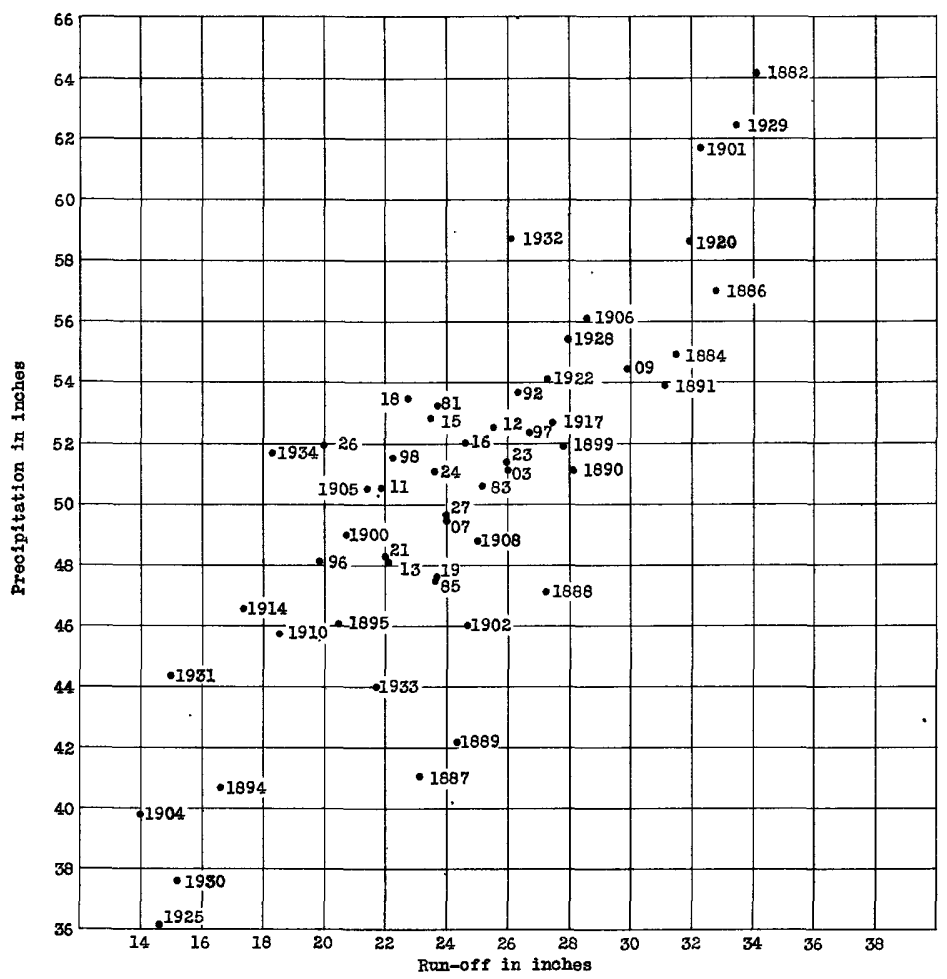

Figure 30a.-Annual precipitation and anmal run-off in the Tennesser River Besin above Chattanooge, Temm.

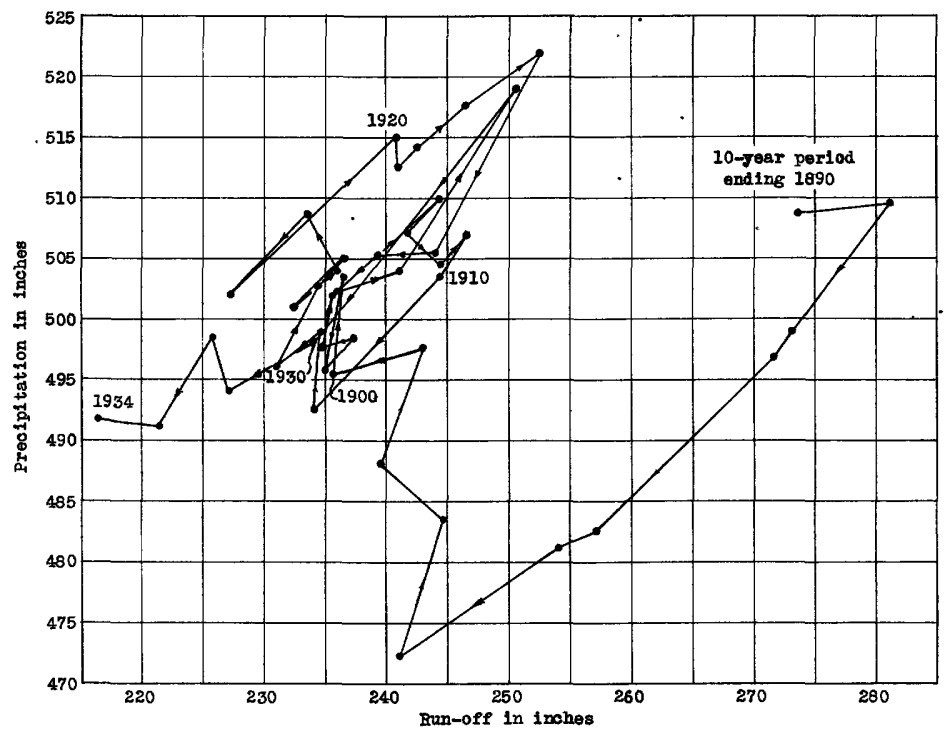

Figure 30b, - Motal precipltation and total run-off by 10-year periods in the Tennessee River Bes in above Chattanooge, Tem. 


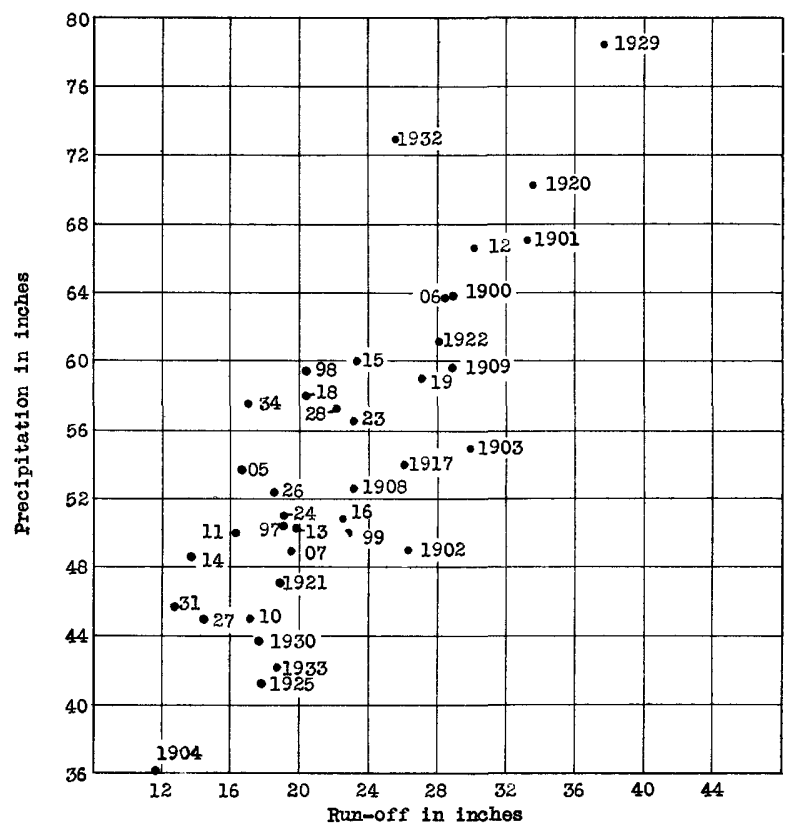

Figure 3la.-Anmual precipitation and anmual run-off

in the Chattahoochee River Basin abcre West Pcint, Ga.

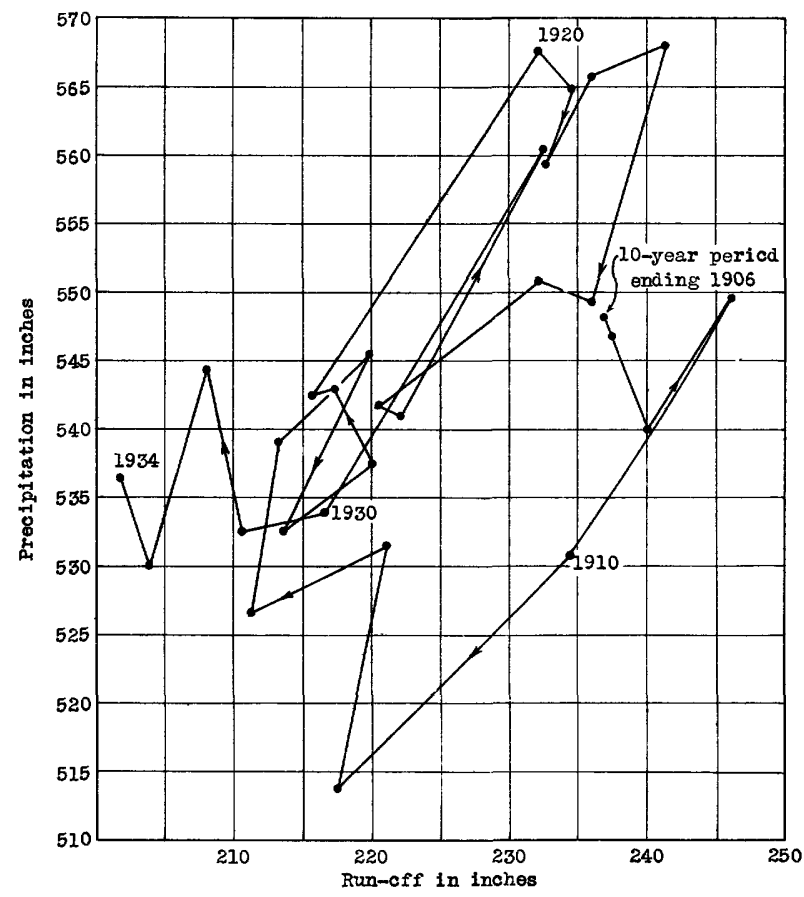

Figure 31b.-Total precipitation and tctal run-cff by 10-year periods in the Chattahoochee RIver Basin abcre West Point, Ge. 
108

RAINFALL AND RUNOFF IN THE UNITED STATES

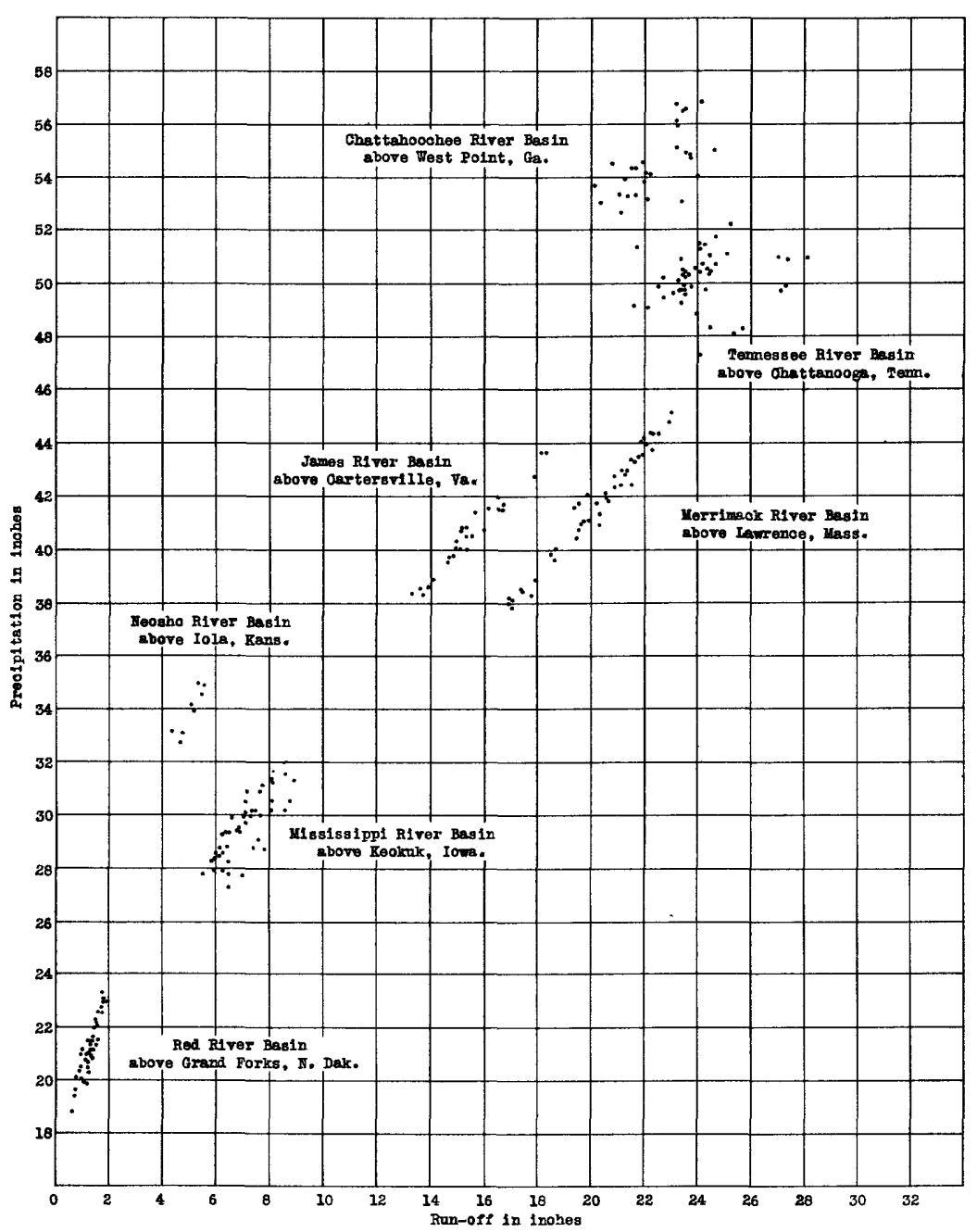

Figure 32,-10-year progressive average preolpltation and 10-year progressive average ran-off for select ted drainage basins. 
Basin, 21 inches for the Merrimack River Basin, 23 inches for the lississtppi River Basin, 25 inches for the James River Basin, 26 inches for the Tennessee River Basin, and 32 inches for the Chattahoochee River Basin. In the Red River Basin the normal loss by evaporation and transpiration is so great that the average annual run-off amounts to less than 10 percent of the average annual precipitation. The average annual precipitation during the last 10 years has apparently been less than the normal demands of transpiration and evaporation. The stream flow that has occurred under such conditions must have resulted mostly from the small amounts of surface run-off resulting from intense rainfall of short duration or melting snow which the ground could not absorb or from seepage from ground water which has escaped the demands of evaporation and transpiration. Figure 25 showing rainfall, run-off, and "precipitation minus run-off" for the Red River Basin, illustrates in a striking manner the fact that during recent years the amount of moisture avallable in this basin has not been sufficient to satisfy normal evaporation and transpiration demands and that the amount of precipitation that eventually finds its way to the stream has been declining for the last 20 or 25 years.

on the other hand, in the basins of the Merrimack, James, Tennessee, and Chattahoochee Rivers the average precipitation exceeds the normal transpiration and evaporation demands by 20 to 25 inches. There is normally in these basins a large supply of water available for replenishment of ground-water reserves and stream flow. Changes such as have occurred in the precipitation are of less vital concern than they are in areas where there is Ifttle or no surplus moisture.

The plotted relations between rainfall and run-off as shown in figures 25 to 31 indicate that except in the Neosho Basin and possibly in the Merrimack River Besin there is a tendency for the points, both annual and 10-jear total, Indicating the relation during the earlier parts of the record periods, to plot toward the right-hand side of the group of points, and for the points indicating the relation during the later parts of the record periods to plot toward the left-hand side. In other words, the relations thus presented disclose a rather decided tendency for a somewhat smaller amount of mun-off for a given amount of precipitation during the later half of the perlod than during the first half.

This apparent change in rainfall and run-off relations could have resulted from a combination of any or all of the following circumstances: 
1. The average precipitation as corpiled for the basin during the first part of the period may be less than the amount that fell on the basin, or the observed run-off may be too high. In general it is believed that in so far as the run-off records are concerned, the earlier measurements of flood flows may have had a tendency to overregister rather than underregister, and in so far as the annual averages are based on discharge measurements during high stages, they are probably an overestimate rather than an underestimate. In basins where precipitation is related to altitude the earlier precipitation records probably underestimate the precipitation over the basin. There seems to be the possibility, therefore, that at least a part of the apparent change in the indicated relations may result from errors inherent in the basic data.

2. There may have been a change either in the seasonal distribution of the rainfall or in some other of its characteristics. The preceding analysis of the seasonal precipitation for the long-time Weather Bureau stations indicates that there has been an apparent seasonal change, the fall precipitation trending upward and the winter and summer precipitation trending downward. The same tendency is noted in the seasonal analysis of precipitation by basins, the records indicating a general tendency for a larger proportion of the annual precipitation to occur in the fall during the second half of the period than during the first half. An analysis has not been made to determine whether or not there have been other changes in rainfall characteristics. Just what effect the indicated change would have on run-off is problematic.

3. Changes are supposed to have resulted from man's occupancy. The change in the relations by which less annual run-off has come from the same amount of annual precipitation appears, however, to be somewhat at variance with the opinion frequently expressed. The question arises whether cultivation has not accomplished conservation of moisture for crop production in amount sufficient to overweigh any increased surface run-off that might have been occasioned as a result of agricultural and other activities of man.

4. Increased transpiration and evaporation may have accompanied Increased temperatures. With moisture avallable an increase in temperature would increase transpiration and evaporation. The present studies, however, have not been carried to a point where the losses can be correlated with the indicated increases in temperature. 


\section{Stream flow}

It is generally understood that run-off, the portion of the precipitation that appears as flow in surface streams, occurs in two ways namely, (a) as surface run-off, or that part of the precipitation which reaches surface streams by flowing over the surface of the ground and into tributary streams, and (b) as ground-water run-off, or that part of the precipițation which before reaching surface streams has passed through the ground. Ground-water run-off is sometimes termed "seepage flow from ground water" and occasionally "base flow" or "sustalned flow."

It is axiomatic that if the greater part of the precipitation runs off the surface of a drainage basin the resulting stream flow will be erratic and irregular and will continue for only relatively short periods of time during and after rains. Little opportunity will be afforded for replenishment of ground-water reserves, and where the run-off is concentrated and erodible material is present erosion will result. On the other hand, if the greater part of the precipitation reaches the stream as seepage from ground water, stream flow will be regular and well sustained through drought periods, and ground-water reserves will be well maintained.

\section{Stream-flow separation}

In hydrologic investigations and especially in quantitative studies of factors of the hydrologic cycle, it becomes desirable to separate run-off into its surface and ground-water components. The efforts to make such separation are met with many practical difficulties and complexities. However, some progress has been made by various investigators in the development of methods of separation, and despite the recognized limitations of present knowledge, a brief account of their experience seems appropriate.

First a general contrast may be drawn between the characteristics of surface and ground-water run-off.

Ordinarily, soon after rain falls with sufficient intensity to produce a flow of water across the ground surface, surface run-off begins to appear in the channels of the stream system. Usually, where storage is negligible, not long after the rainfall ceases all such surface mun-off is in the channels of the stream system, and within a period ranging from a day or less to a month or more, depending on the size and characteristics 
of the basin, it has passed out of the stream system. The characteristics of the flow of surface run-off are related to the essential characteristics of the drainage basin and the stream system, including shape of the basin, channel velocities, etc. Many of the features of such basin characteristics are believed to be reflected by the unit hydrograph and the distribution graph, discussed elsewhere in this paper.

on the other hand, the ground-water run-off ordinarily is delayed more or less in passage through the ground, so that the part of the precipitation which takes this course is reflected in stream flow more tardily than the surface run-off, the intervening time involving weeks, months, or even longer.

A customary procedure in estimating ground-water mun-off is to present the run-off to be analyzed in the form of a hydrograph of total flow and then undertake to draw a graph to represent the ground-water component of the flow. Any flow above that indicated by the graph of groundwater run-off will then necessarily represent the surface mun-off component of the flow. In making such separation full advantage is taken of the knowledge that in general the a verage annual rate of ground-water run-off Is at least equal to the minimum daily rate of discharge of the stream. Above this discharge the determination of the ground-water run-off becomes increasingly uncertain. There is opportunity for the development of a well-defined technique for this determination, but in the absence of such technique the only recourse is to apply the best methods based on experience and science that may be avaliable.

Ivan $E$. Houk (72) made a separation between ground-water mun-off and surface run-off by drawing on the hydrograph of total stream flow "Iines representing the rate of eround-water flow .. . so as to pass through the low points only" of the hydrograph. "The endeavor was to draw the line so that the increased flow of tiles immediately after a flood that is, the drainage of the surface soil - would be included in the surface or flood run-off rather than in the ground-water run-off, since such flow acts more nearly like surface flow than like low-water flow. It was also assumed that no percolation occurs during the growing season."

Meinzer and Stearns (115), in an effort to determine the quantity of ground water that percolated into the Pomperaug River and was carried out of the basin, followed the general method used by Houk. In addition they took into account the probable time element in connection with the 
passage of the surface run-off out of the basin, and during periods of flood run-off "the curves showing the ground-water run-off were brought up somewhat to meet the descending curve that shows total run-off."

Approximately this same method was used by I. K. Sherman (158) in determining his unit graph of surface run-off. He made the separation under conditions of low ground-water flow uncomplicated by antecedent, effects.

One of the major complexities associated with the problem is the consideration of stored surface water in the drainage basin. Although on most streams a large part of the surface run-off appears at the gaging station fairly promptly after the rainfall from which it originates and is shown by a definite rise in the hydrograph of stream flow, there may be in some basins an appreciable amount of surface mun-off which is held in storage, either artificially or naturally, in lakes, ponds, reservoirs, and marshes, and which eventually appears at the gaging stations so closely associated with ground-water flow that exact differentiation would require details of information that are rarely if ever avaliable. Also the hydrograph of the peak or rise in stream flow may represent to some extent increased ground-water run-off resulting from recharge to the $z$ one $s$ of saturation and increased contributions from those zones.

In the absence of information permitting greater refinement, surface run-off is tentatively regarded in this report as that part of the total run-off that appears systematically and regularly in the stream channel as the rise directly responsive to rainfall or the melting of snow. (For classification of stream rises see 70, p. 455.) The rise probably does not include all surface water, because some of it may be materially delayed by storage in reaching the gaging station. The rise may include some ground water that has been held in ground reservoirs that feed the streams, especially after prolonged intense rainfall, with a responsiveness that is only somewhat less pronounced than that which characterizes surface run-off. This condition may occur especially in basins where perched water tables exist or in tiled areas.

Ground-water run-off as considered in this paper is the estimated seepage flow directly into the stream from the main zone of saturation and from perched water tables. (For definitions of ground-water terms see Meinzer, 113). In view of the approximations involved in the separation of ground-water and surface run-off, a ground-water graph may include some water that has been stored on the surface and may exclude $59550-35-8$ 
some ground water which in the promptness of its reaching the stream channels behaves so much like surface mun-off that it is difficult to make a distinction.

There is no question that the occurrence and movement of ground water depends on and is affected by a wide variety of topographic, geologic, and soil conditions. There is also no question that with these conditions constant for any basin, the occurrence and movement of the ground water will vary with meteorologic conditions. In a study of the problems of.separating ground-water run-off from surface run-off in a basin of material size it may therefore be desirable and necessary to take into account as many relations and as many flow characteristics as can be developed. Such relations and flow characteristics may include depletion curves, recession curves, recharge curves, unit hydrographs, infiltration and storage factors, together with the effect of meteorologic conditions. The following is a brief summary of some of the observations and methods of investigators who have attempted to ascertain the facts and truths relating to this particular phase of ground water.

\section{Depletion curves}

Samuel Hall (53) observed in connection with the recession of stream flow that in "the gently falling and lowest parts of the curve due to percolation discharge, one characteristic is the steady fall, showing not only that the rate of flow decreases but that its rate of decrease also diminishes; in other words, the curve gets flatter from day to day throughout a rainless period," and further, that after additional precipitation "not only has there been a large immediate yield, as shown by a peak, but the stream has gained in stajing power. The conclusion drawn is that new supplies of percolation water have increased the amount in storage, with result of increased discharge."

Studies of the fluctuations of the water surfaces in observed wells unaffected by pumping and below the effect of transpiration and evaporation support Hall's observations and indicate that during periods when there is no recharge the decline of the water surface in the well, or the draining out or depletion of the water in the zone of saturation in the vicinity. of the well, proceeds at a fairly uniform rate for any given stage of the water table or amount of water in ground storage. It seems 
reasonable to assume, the refore, that the seepage into the stream from the ground-water supply or the ground-water run-off should also be marked by uniformity except as affected by evaporation and transpiration.

Robert E. Horton (70, pp. 448-449) refers to early observations and presentations of depletion curves of ground-water levels by Maillet in 1903 and D. Halton Thompson in 1921 (180). The methods of these early investigators have been extended to the separation of ground water from surface run-off by Horton and others, and the theory of this separation is presented by Horton (70, pp. 446-460).

Studies of the hydrographs of some streams seem to indicate conclusively that during drought periods, when the stream flow is supplied wholly or in large part by seepage from the reservoir of ground water, the rate of decline for corresponding flow stages and climatic conditions tends to be very nearly the same. In other basins, where water-bearing formations or other conditions may be more complex, the rate in the decline of stream flow during drought periods seems to vary somewhat.

The seepage flow into the streams is supplied from an irregular and interrelated body of water in the ground. It is water that has escaped transpiration and evaporation, the effects of which in many basins are believed to be greatest in the vicinity of stream channels, where the water table is nearest the ground surface. In such localities the effects of evaporation and transpiration may vary greatly from year to year and from season to season, depending upon a variety of conditions. Some investigators have found by extensive observation that marked regularity characterizes the behavior of ground water in relation to season, temperature, and other factors. Horton (70) makes the following statement in regard to what is termed a normal depletion curve in the study of ground-water runoff:

"For streams where the ground-water level underneath the drainage basin is at a depth beyond the reach of the direct abstraction of plants or vegetation, the normal depletion curves in different years are often nearly identical throughout their common range. within the limit of error of observation and excluding the effects of barometric changes, etc., on ground-water flow. The normal depletion curves may differ to a considerable extent in different years or seasons in cases 
where there is a direct abstraction of ground water from the water table by vegetation or evaporation. Even in such cases the differences between sumerseason depletion curves in different years is often so small that for practical purposes in separating ground-water and surface run-off, an average normal depletion curve can be used."

Tomihis1 Iwasaki (82), by a detailed study of the run-off from a fairly mountainous drainage area of 156 square miles, developed a standard depletion curve and also determined the approximate relation between precipitation and the increment of ground-water and surface run-off and was thus able to build up a hydrograph of total mun-off.

It is seemingly permissible in the absence of any better method of approach to utilize in this problem the tendency to regularity that may be detected in a comparison of depletion curves, but the possibility that there may be material deviations from normal depletion curves should not be overlooked. In basins where closely comparable depletion curves can be obtained for different seasons or where the characteristics of depletion curves can be correlated to some degree with climatic or soll conditions, they seem to afford useful and valuable tools in efforts to separate ground-water run-off.

\section{Recession curves}

A recession curve, as the term is here used, is the descending limb of a hydrograph of stream flow, including both surface run-off and ground-water run-off, as it recedes from a peak downward to the point of zero surface run-off. Most streams rise more or less frequently to a flood peak and, before subsidence from it has been completed, rise to another peak. For many streams the hydrographs for the winter and early spring are characterized by peaks in such rapid succession that only rarely does the surface run-off have a chance to drain out. Such peaks make the task of drawing a ground-water hydrograph difficult and the results uncertain.

It has been observed that during periods of frequent floods the descending limbs of storm peaks become graded to a higher level than 1solated peaks occurring during periods of low flow. Through a study of the descending limbs of hydrographs of storms occurring during the summer, when 
ground water is low, it may become possible to develop a composite recession curve. Such composite curve used on the descending limb of a storm hydrograph when ground water is high seems to be valuable in locating the probable intersection of the hydrograph of surface run-off with the hydrograph of ground-water run-off. This method, like the other methods described, hos 1ts limitations. In practice it is found that the curvatures of the descending limbs during the sumer are somewhat different from those during the winter. It is also found that the descending limb of a storm peak is often affected by rainfall - that is, the rate of descent is not as rapid as the recession would be if there was no rain after the flood peak, and fitting recession curve to this descending limb results in erroneous estimates of ground-water flow.

Byron E. White (187a), in an original study of relations between rainfall and run-off when there was no snow on the ground and no freezing and thawing, definitely correlated the form and rate of recession of the recession side of the hydrograph with calendar dates and mean atmospheric temperatures. In a letter daced Apr11 29, 1935, he says: "An attempt to determine stream flow on this theory, together with some simple relations between initial flow, an imaginary instantaneous flow, and the mean rainfall on the area, which is described therein, falled to give close results, In part because of insufficient and inadequate rainfall data and in part because of insufficlent data regarding other phenomena."

Ground-water levels and accretion

The portion of the precipitation that seeps through the soll into the zone of saturation forms an increment to the ground water in the zone of saturation.

On January 1, 1935, the water surface of more than 3,000 wells was being periodically measured by the United States Geological Survey and cooperating organizations. The publication year by year of the levels thus observed, in a manner similar to the publication of the stream-flow records, is a procedure that is greatiy needed. Preliminary studies of preclpitation, accretion to the water table, and seepage from the ground-water reservolr into the stream channels have indicated that the relations are Involved. In general, information is not avallable for making an exact correlation, even where many well records are at hand. If however, 
through a study of well records or of the hydrographs of stream flow some idea can be gained of the rapidity with which accretion to the water table takes place, or the rapidity with which seepage from ground water may increase, such information will be valuable in the determination of the hydrograph of ground-water run-off.

\section{Unit hydrographs}

As described more fully in the discussion of the unit-hydrograph method of analyzing surface run-off (pp.123-133) the lengths of the bases of hydrographs of surface run-off of storms of a certain duration, such as an hour or a day, are approximately the same for any given basin. In other words, the interval between the time when the surface run-off from a l-day storm first reaches a gaging station and the time when all such surface run-off has passed the gaging station appears to be approximately the same, regardless of the storm intensity. Through a study, therefore, of the hydrographs of run-off from appropriately selected storms it is possible to determine the approximate time required for surface run-off to pass out of the basin, and hence, by a study of the hydrograph of stream flow used in conjunction with precipitation records, to determine periods when there is no appreciable surface run-off in the stream or when the hydrograph of total stream flow approximates the hydrograph of seepage flow from ground water.

Much of the information of the unit hydrograph, embodying essential features of the characteristics of the flow from surface-water run-off, Is based upon studies of flow at times when uncertainties as to groundwater run-off are relatively small. A carefully derived unit hydrograph unquestionably shows valuable information concerning the characteristics of surface run-off that seemingly may be used in an approprlate way in times of uncertainty, to learn more about the ground-water flow.

\section{Inflitration capacity and storage factors}

Robert E. Horton, a member of the Advisory Committee, has suggested that it may be possible eventually, through a knowledge of infiltration capacity, field-moisture deficiencies, and storage factors, defined by him in a recent publication (70a), to determine surface run-off and conversely ground-water run-off. 


\section{Meteorologic factors}

It is a well-known fact that during rainless periods in the autumn the flow of many springs and streams increases. This increase is usually assoclated with the end of the growing season and the decline in transpiration losses. A depletion curve of ground-water run-off loses its downward projection under such conditions, and the ground-water run-off presumably increases by an amount approximating the reduction in losses from transpiration. From studies of the relations between the decline in ground-water levels and changes in the rate of ground-water discharge, it has been observed that in certain instances a decline in water levels during a period when evaporation and transpiration are active causes a decrease in the rate of ground-water discharge noticeably smaller than that effected by the same amount of water-table lowering during a period of dormant vegetation. Although effects of other factors could be pointed out, it seems obvious that the problem of separating ground-water run-of from surface run-off requires a consideration of meteorologic conditions. Adolph F. Meyer (122) describes methods whereby meteorologic factors may be used in the determination of the amount of water avaliable for replenishment of soll molsture and recharge to ground water. A discussion of methods devised by Meyer to evaluate evaporation and transpiration losses is given on pages 250 and 251 .

\section{Channel storage}

0. E. Meinzer, of the United States Geological Survey, has suggested a method whereby ground-water run-off may be directly determined through a study of changes in channel storage. The method requires the determination of the amount of run-off that is held as channel storage at any time. It is based on the hypothesis that as soon as essentially all the direct surface run-off reaches the channel the total amount of direct surface run-off that will pass the gacing station can be calculated from the changes in channel storage. When, during a certain day in which no surface water is added to the stream system, more water is measured at the gaging station than is represented by the changes in channel storage, the excess is attributed to ground-water run-off. Field experiments are now being carried on under the direction of Meinzer to determine changes in channel storage on a small basin near Washington, D. C. 


\section{Surface run-off}

\section{Quantitative analysis, by basins}

The following tables show for typlcal basins in the United States and for major subdivisions of the Mississippl River above Keokuk, Iowa, an estimate of the mean annual surface run-off expressed in inches and as a percentage of precipitation. All figures are in general based on a 5-year annual average for the period noted and were obtained by subtracting from the total stream flow the ground-water run-off as estimated from a study of the plotted hydrograph of stream flow, using, in part, methods previously discussed. It should be clearly recognized that the estimates given are subject to error. Further refinement in the methods of determination and more exhaustive application of known factors might change the results materially. They are, however, believed to be of sufficlent accuracy to make comparisons between typical besins of a very important phase of the hydrologic cycle, and this is a primary purpose of their presentation. The figures given for the Miami River Basin, Ohlo, and for the Pomperaug River Basin, Conn., are based on general straight lines as previously outlined, and the results may not be entirely comparable with the figures given for the other basins.

Table 25.- Average annual surface run-off for typlcal basins

\begin{tabular}{|c|c|c|c|c|}
\hline \multirow[b]{2}{*}{ Basin } & \multirow[b]{2}{*}{$\begin{array}{l}\text { Procipitation } \\
\text { (Inches) }\end{array}$} & \multicolumn{3}{|c|}{ Surface run-off } \\
\hline & & Inches & $\begin{array}{l}\text { Percent of } \\
\text { total run- } \\
\text { off }\end{array}$ & $\begin{array}{l}\text { Percent of } \\
\text { precipita- } \\
\text { tion }\end{array}$ \\
\hline $\begin{array}{l}\text { Red River above } \\
\text { Grand Forks, N. Dak. } \\
\text { (1928-32) } \\
\text { Mississippi River above }\end{array}$ & 18.53 & 0.35 & 59.3 & 1.9 \\
\hline $\begin{array}{l}\text { Mississippi River above } \\
\text { Keokuk, Iowa } \\
\text { (1928-32) }\end{array}$ & 28.64 & 3.36 & 56.2 & 11.7 \\
\hline $\begin{array}{l}\text { Neosho River above } \\
\text { Io1a, Kans. } \\
\text { (1928-32) }\end{array}$ & 33.07 & 4.06 & 82.5 & 12.3 \\
\hline $\begin{array}{l}\text { Merrimack River above } \\
\text { Lawrence, Mass. } \\
\text { (1928-32\%) }\end{array}$ & 40.66 & $* 9.94$ & 50.9 & 24.5 \\
\hline
\end{tabular}

Probably too small. * Years ending September 30. 
Table 25. - Average annual surface run-off for typical basins--continued

\begin{tabular}{|c|c|c|c|c|}
\hline \multirow[b]{2}{*}{ Basin } & \multirow[b]{2}{*}{$\begin{array}{l}\text { Precipitation } \\
\text { (inches) }\end{array}$} & \multicolumn{3}{|c|}{ Surface run-off } \\
\hline & & Inches & $\begin{array}{l}\text { Percent of } \\
\text { total mun- } \\
\text { off }\end{array}$ & $\begin{array}{l}\text { Percent of } \\
\text { precipita- } \\
\text { tion }\end{array}$ \\
\hline $\begin{array}{l}\text { Tennesser River above } \\
\text { Chattanooga, Tenn. } \\
\text { (I90I-5) } \\
\text { Chattahoochee River above }\end{array}$ & 49.83 & 15.30 & 64.4 & 30.7 \\
\hline $\begin{array}{l}\text { Chattahoochee River above } \\
\text { West Point, Ga. } \\
\text { (I928-32) }\end{array}$ & 59.65 & 11.59 & 50.1 & 19.4 \\
\hline $\begin{array}{l}\text { Miami River above } \\
\text { Dayton, Ohio\# } \\
\text { (I894-19I9**) }\end{array}$ & 37.07 & 7.77 & 65.6 & 21.0 \\
\hline $\begin{array}{l}\text { Pomperaug River above } \\
\text { Bennetts Bridge, Conn. } \\
\text { (1914-16*-4) }\end{array}$ & 44.48 & 11.90 & 57.6 & 26.8 \\
\hline
\end{tabular}

\# See ref. 72.

** Years ending September 30. \#\# Seo ref. 115 .

Table 26.- Average annual surface run-off for major subdivisions of Mississippi River Basin above Keokuk

\begin{tabular}{|c|c|c|c|c|}
\hline \multirow[b]{2}{*}{ Subdivision } & \multirow[b]{2}{*}{$\begin{array}{l}\text { Precipitation } \\
\text { (inches) }\end{array}$} & \multicolumn{3}{|c|}{ Surface mun-off } \\
\hline & & Inches & $\begin{array}{l}\text { Percent of } \\
\text { total run- } \\
\text { off }\end{array}$ & $\begin{array}{l}\text { Percent of } \\
\text { precipita- } \\
\text { tion }\end{array}$ \\
\hline $\begin{array}{l}\text { Minnesota River above } \\
\text { Mankato, Minn. } \\
\text { (1930-32*) }\end{array}$ & 22.22 & 0.42 & 61.0 & 1.9 \\
\hline $\begin{array}{l}\text { Zumbro River above } \\
\text { Zumbro Falls, Minn. } \\
\text { (1931-32\%) }\end{array}$ & 26.35 & 1.70 & 48.8 & 6.5 \\
\hline $\begin{array}{l}\text { Maquoketa River above } \\
\text { Maquoketa, Iowa } \\
\text { (1931-32*) }\end{array}$ & 30.64 & 2.89 & 51.5 & 9.4 \\
\hline $\begin{array}{l}\text { La Crosse River above } \\
\text { West Salem, Wis. } \\
\text { (1928-32*) }\end{array}$ & 30.35 & 2.64 & 26.6 & 8.7 \\
\hline $\begin{array}{l}\text { Root River above } \\
\text { Houston, Minn. } \\
\text { (1931-32*) } \\
\text { K1ckapoo River above }\end{array}$ & 27.98 & 2.42 & 44.6 & 8.6 \\
\hline $\begin{array}{l}\text { Gays Mills, Wis. } \\
\text { (1928-32*) }\end{array}$ & 29.67 & 3.64 & 40.0 & 12.3 \\
\hline $\begin{array}{l}\text { Rock River above } \\
\text { Afton, Wis. } \\
\text { (I928-32*) }\end{array}$ & 29.62 & 3.63 & 49.0 & 12.3 \\
\hline $\begin{array}{l}\text { Iowa River above } \\
\text { Wapello, Iowa } \\
\text { (1928-32*) }\end{array}$ & 32.83 & 4.28 & 61.1 & 13.0 \\
\hline $\begin{array}{l}\text { St. Crolx River above } \\
\text { Rush City, Minn. } \\
\text { (1928-32*) }\end{array}$ & 25.32 & 3.76 & 51.7 & 14.8 \\
\hline
\end{tabular}

* Years ending September 30. 
Table 26.- Average annual surface run-off for major subdivisions of Mississipp1 River Basin above Keokuk--Continued

\begin{tabular}{|c|c|c|c|c|}
\hline \multirow[b]{2}{*}{ Subdivision } & \multirow[b]{2}{*}{$\begin{array}{l}\text { Precipitation } \\
\text { (inches) }\end{array}$} & \multicolumn{3}{|c|}{ Surface run-off } \\
\hline & & Inches & $\begin{array}{l}\text { Percent of } \\
\text { total run- } \\
\text { off }\end{array}$ & $\begin{array}{l}\text { Percent of } \\
\text { precipita- } \\
\text { tion }\end{array}$ \\
\hline $\begin{array}{l}\text { Pecatonica River above } \\
\text { Freeport, Ill. } \\
\text { (1928-32\%) }\end{array}$ & 31.95 & 4.77 & 47.7 & 14.9 \\
\hline $\begin{array}{l}\text { Skunk River above } \\
\text { Augusta, Iowa } \\
\text { (1928-32*) }\end{array}$ & 35.85 & 5.47 & 69.8 & 15.3 \\
\hline $\begin{array}{l}\text { Yeilow River above } \\
\text { Sprague, Wis. } \\
\text { (1928-32*) }\end{array}$ & 29.09 & 4.87 & 71.7 & 16.7 \\
\hline $\begin{array}{l}\text { Black River above } \\
\text { Neilisvilie, Wis. } \\
\text { (1928-32*) }\end{array}$ & 30.99 & 7.84 & 84.1 & 25.3 \\
\hline
\end{tabular}

* Years ending September 30.

Although basin and precipitation characteristies have not been correlated with these surface run-off estimates, in all probability they would show about the same relations as between these characteristics and flood magnitudes. In other words, the greater the intensity of the precipitation, the more impervious the soil, and the greater the basin slopes the greater will be the direct surface run-off, and vice versa. The estimates, to the extent of their accuracy, represent roughly the amount of water that would be subject to regulation and control operations relating to surface run-off. There is probably a direct relation between the magnitude of these estimates and the magnitude of erosion by water in the respective areas. 


\section{Unit-hydrograph analysis of surface run-off}

Surface run-off has been defined as that part of the precipitation which reaches surface streams by flowing over the ground and into tributary streams. Once in the stream channel, surface run-off follows the laws governing the flow of water in open channels. The discharge of surface run-off into stream channels simultaneously over basin areas results in pronounced rises in stream levels, followed by periods of decline.

The plotted graph of stream flow, which presents graphically the rises and declines of run-off, has been used by many investigators as a basis for much of the available information regarding the phenomena of surface run-off and the relation of basin characteristics to therr.

The Committee on Floods of the Boston Society of Civil Fingineers, after a study of New Ingland flood hydrographs, concluded (18) "that a flood hydrograph once determined for a given river, even for an ordinary flood, will serve as a basis for the estimation of greater flood run-off, due to the fact that the base of the flood hydrograph (or time-of-flood period) appears to be approximately constant for different floods." $\mathrm{L}$. K. Sherman (158), in 1932, presented the idea that not only was there a definite total flood period corresponding to a given rainfall for the same drainage area but that surface run-off from rainfalls occurring within the same time interval, such as a day or an hour, will produce hydrographs whose ordjnates will vary with the amount of the surface run-off. From the principles set forth by sherman the hydrograph of surface mun-off resulting from rainfall within a unit of time as a day or an hour may be called a "unit hydrograph."

Merrill M. Bernard (13), in 1934, developed certein features of the unit hydrograph, introduced added features of the distribution graph and pluviagraph, and suggested certain relations between rainfall and runoff within the storm period.

The development of unit hydrographs and distribution graphs has been based on a detalled study of the relations between rainfall and runoff as disclosed by hydrographs of stream flow, on the basis of both cumulative experience and scientific analysis. As in many other instances in the development of hydraulic science, reliance is placed to the fullest possible extent on available scientific theory, as well as on the cumulative evidence of general relations disclosed by analysis of experience or 
experiment. The use of these graphs is still largely in the experimental stage, and theoreticaliy and practically there appear to be limitations of application that have not yet been well defined. Despite a variety of difficulties, the device seems to present a tool of very considerable value for resolving to some extent the complex relations of rainfall and run-off and for advancing the science of hydrology. Consequently in the present investigations considerable time has been given to the investigation of relations between rainfall and surface mun-off as disclosed by the unit hydrograph and the distribution graph. These studies have been carried on along three lines - namely, (1) preparation of unit hydrographs for typical drainage basins, (2) general application of the unit-hydrograph method to hydraulic problems, and (3) application of the unit-hydrograph principle to flood studies.

Many rather baffling problems relating to the unit hydrograph have been encountered in these studies, and the following discussion and presentation of the underlying methods of application must be considered more or less provisional.

\section{The unit hydrograph and distribution graph and their proparation}

The terms used may be defined as follows:

A unft hydrograph is a hydrograph of surface run-off resulting from rainfall within a unit of time, as a day or an hour.

A distribution graph is a unit hydrograph of surface run-off modified to show the proportional relations of its ordinates in percentage of the total surface run-off.

In theory, at least, it would seem that the principles of the unit hydrograph deal only with surface run-off, and this discussion of the method of its preparation has been predicated on that assumption.

L. K. Sherman (I59) describes the basic hypothesis of the untt hydrograph and distribution graph and their preparation as follows:

1. The unit-hydrograph method is a procedure for determining the peak and other rates of surface run-off from a particular basin, by analogy, from an observed rainfall and the corresponding observed hydrograph of surface run-off from the same given basin.

2. The hypothesis upon which the unit-hydrograph method is based is that in a given drainage basin surface run-off from rainfall occurring 
In a unit of time will produce hydrographs of approximately equal bases, and the ordinates will vary with the intensity of the net rainfall (net rainfall being rainfall minus infiltration and other losses).

3. The first step in the application of the method to a basin is to find a hydrograph of surface mun-off due to an isolated one-day (or unit-time) rainfall from an inspection of daily rainfall and run-off records.

The average daily rates of observed flow for the run-off period are given in the United States Geological Survey water-supply papers. These dally rates of stream flow include both surface run-off and base or ground-water flow. Estimate this base flow. Subtract the base flow from each of the observed flows. Also deduct flow due to antecedent rainfall, if any. This will give the segregated flow or surface run-off due wholly to the rainfall in question. Find the percentage that each day of segregated flow bears to the total segregated flow. These figures will total 100 percent and they form the distribution graph.

Un1t hydrographs and distribution graphs have been prepared for a considerable number of rivers in the United States, and typical graphs are shown in figures 33 to 69. The problems and questions outined below have been considered in connection with their preparation. It should be stated at the beginning that the particular hydraulic problem to be solved by means of the unit-hydrograph theory determines to a great extent the technlque used in developing distribution graphs.

For the basins studied the calendar day has been used as the time unit. Basically the problem here discussed is the determination and comparison of the surface run-off resulting from the occurrence of rainfalls of 24-hour duration.

Weather Bureau records colncident with avallable run-off records are scanned, and all lsolated storms that appear from the record to have occurred within a 24-hour period are noted. These storms are then compared with the corresponding mun-off records as published in water-supply papers of the United States Geological Survey, and those storms which produced appreclable peaks in the hydrograph of total stream flow are selected as a basis for the preparation of unit hydrographs. The ideal storm would be one of 24-hours' duration colncident with the calendar day and with rainfall of uniform intensity over the basin. Storms that exactly fulfill 
these requirements seldon, if ever, occur in nature, and only approximations to the ideal can be expected.

It is not necessary to determine the average precipitation over the basin for the unit storm, to derive the resulting distribution graph. However, as an ald in studying variations in the distribution graphs, it is convenient to have at hand the recorded daily precipitation at the available stations. If the unit-hydrograph theory is applied in an intensive study of any particular basin it must be determined whether an average of the station records is satisfactory, or whether some method of weighting is required to obtain average daliy depths of precipitation over the basin. Few of the published records of the United States Weather Bureau indicate whether the recorded precipitation occurred during $I$ hour or was weIl distributed over the 24 hours. A 24-hour storm that does not synchronize with the calendar day will be recorded on two consecutive days. This lack of definite information relative to the length and time relation of storm periods is a decided handicap in analyzing surface run-off, but it is a condition that will be improved as more recording rain gages are installed.

For each unit storm, so called, a hydrograph of stream flow is plotted covering a period that will embrace as a minimum all the time involved in the surface run-off of the storm and at least a month preceding and subsequent to it. The problem now involves the determination of the surface run-off resulting from the storm. The procedure includes the determination of (a) surface run-off resulting from precipitation antecedent to the storm, (b) surface run-off resulting from subsequent precipitation, and (c) ground-water run-off resulting from antecedent precipitation and from the storm itself.

Figure 33 (graph ABCDEF) is a typical hydrograph of stream flow following three storms, the recorded precipitation of which is listed in the following table. The unit hydrograph, table 28, colum 5, is the surface flow resulting from the unit storm of June 26. 


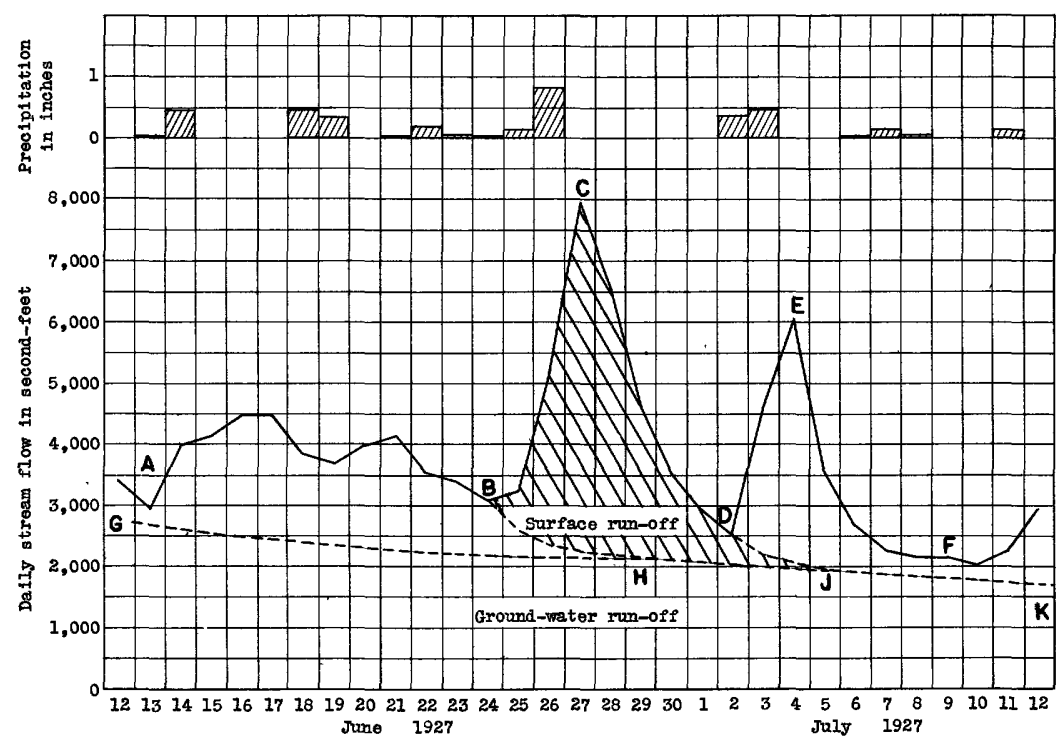

Figure 33.-Unit hydrograph for Muskingur Fiver at Dresden, Ohio.

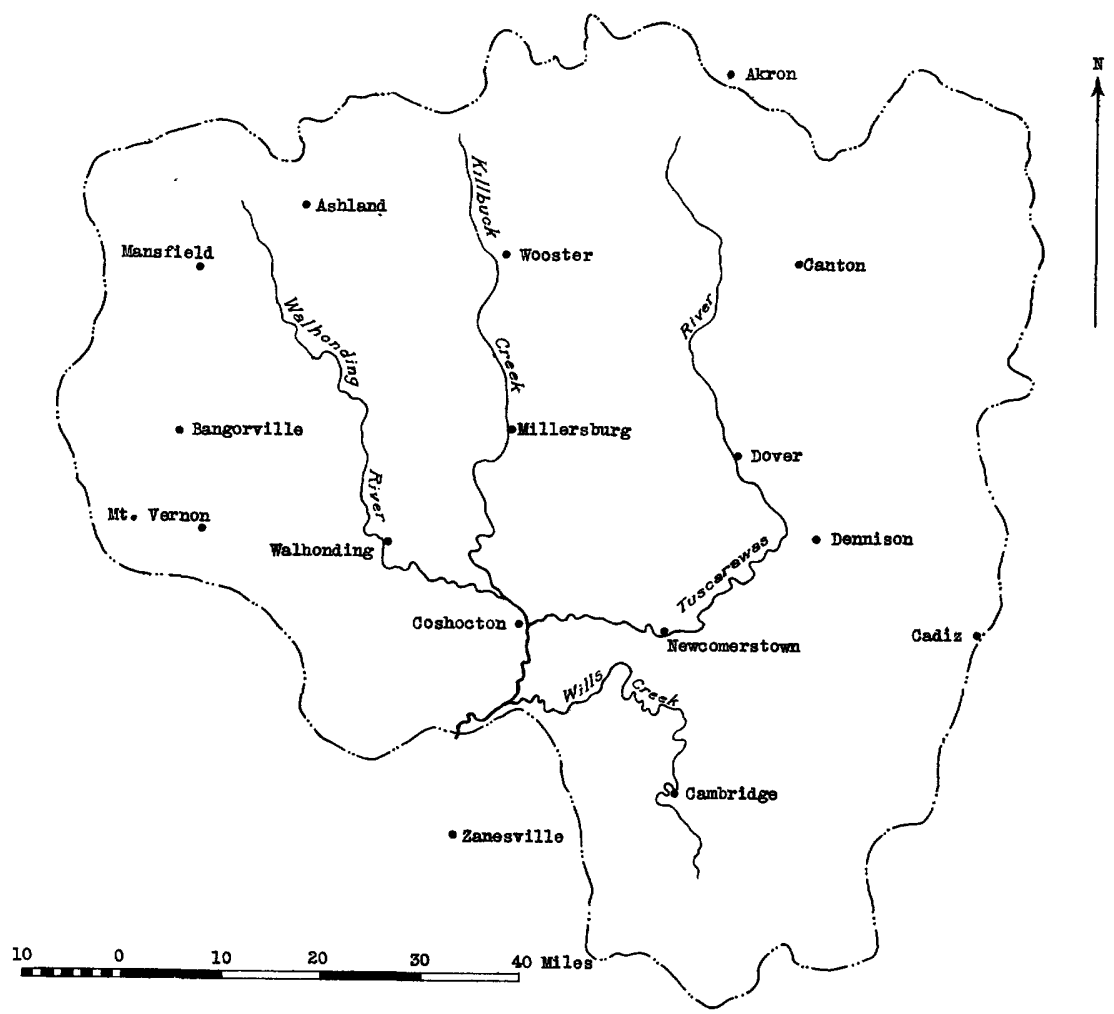


Table 27.- Typical unit-hydrograph storms in

Muskingum River Basin above Dresden, Ohio

(Precipitation in inches, measured in the afternoon except at stations marked $*$, where it was measured in the morning.)

\begin{tabular}{|c|c|c|c|c|c|c|c|c|c|c|c|}
\hline \multirow[b]{2}{*}{ Station } & \multicolumn{9}{|c|}{ June 1927} & \multicolumn{2}{|c|}{ July 1927} \\
\hline & 14 & 18 & 19 & 21 & 22 & 23 & 24 & 25 & 26 & 2 & 3 \\
\hline $\begin{array}{l}\text { Ashland } \\
\text { Bangorville } \\
\text { Canton * } \\
\text { Yansfield * } \\
\text { Wooster (no.1) } \\
\text { Cadiz } \\
\text { Cambridge } \\
\text { Coshocton * } \\
\text { Dennison } \\
\text { Dover * } \\
\text { Millersburg } \\
\text { Mount Vernon } \\
\text { Walhonding * } \\
\text { Zanesville * }\end{array}$ & $\begin{array}{l}0.20 \\
.15 \\
.33 \\
.20 \\
.18 \\
.62 \\
.80 \\
.55 \\
.60 \\
.40 \\
.29 \\
.51 \\
.55 \\
.94\end{array}$ & $\begin{array}{c}0.70 \\
1.03 \\
. \\
.56 \\
.24 \\
.82 \\
.38 \\
.20 \\
.45 \\
.12 \\
.57 \\
.85 \\
.36\end{array}$ & $\begin{array}{l}0.10 \\
.05 \\
.90 \\
.44 \\
.10 \\
. \\
.32 \\
.67 \\
.13 \\
.42 \\
- \\
.85 \\
.80\end{array}$ & $\begin{array}{c}0.05 \\
.08 \\
- \\
= \\
= \\
= \\
= \\
= \\
= \\
-\end{array}$ & $\begin{array}{l}0.22 \\
.33 \\
.13 \\
.36 \\
.20 \\
.26 \\
.12 \\
.05 \\
.75 \\
.01 \\
.16 \\
- \\
-\end{array}$ & $\begin{array}{l}0.20 \\
.05 \\
.02 \\
.31 \\
= \\
.07 \\
= \\
= \\
= \\
.02\end{array}$ & $\begin{array}{l}= \\
= \\
= \\
= \\
= \\
= \\
= \\
0 . \\
-\end{array}$ & $\begin{array}{c}0 . \overline{29} \\
- \\
\overline{-} \\
\overline{-} \\
\overline{-} \\
- \\
- \\
.60 \\
.23 \\
-\end{array}$ & $\begin{array}{r}0.78 \\
.08 \\
1.11 \\
.51 \\
.30 \\
1.32 \\
.92 \\
.75 \\
1.59 \\
1.20 \\
.39 \\
.61 \\
.95 \\
1.17\end{array}$ & $\begin{array}{c}1.20 \\
1.55 \\
- \\
\overline{.01} \\
- \\
.32 \\
- \\
- \\
.02 \\
1.10 \\
.92 \\
- \\
-\end{array}$ & $\begin{array}{r}0 . \overline{12} \\
2 . \overline{21} \\
.03 \\
.40 \\
. \overline{28} \\
1.18 \\
.06 \\
.02 \\
. \overline{4} \\
.50\end{array}$ \\
\hline Average & $\begin{array}{r}6.32 \\
.45\end{array}$ & $\begin{array}{r}6.28 \\
.45\end{array}$ & $\begin{array}{r}4.78 \\
.34\end{array}$ & .13 & $\begin{array}{r}2.59 \\
.19\end{array}$ & $\begin{array}{l}.67 \\
.05\end{array}$ & $\begin{array}{l}.33 \\
.02\end{array}$ & $\begin{array}{r}2.09 \\
.15\end{array}$ & $\begin{array}{r}11.68 \\
.83\end{array}$ & $\begin{array}{r}5.12 \\
.37\end{array}$ & $\begin{array}{r}6.22 \\
.44\end{array}$ \\
\hline
\end{tabular}

The hydrograph of ground-water run-off (graph GHJK f1g. 33) has been determined by the method described and discussed on peges 111 to 119 . The surface run-off from the storm preceding and the storm following the unit storm is determined by the downward extension (graphs BH and DJ) of the hydrograph of total stream flow until it meets the hydrograph of ground water. To the extent that the various assumptions are correct, the crosshatched area (BCDJH) represents the surface run-off from the unit storm under consideration. The figures for mean daily surface run-off are thus determined and the ratio of each daily figure to the total volume is computed. These ratios in percent constitute the dietribution graph for the particular unit storm under consideration. The following table represents the steps taken: 


\section{Table 28.- Derivation of distribution graph}

Muskingum River Basin above Dresden, Ohio

(The calendar day on which most of the rainfall occurred is denoted by $\%$ )

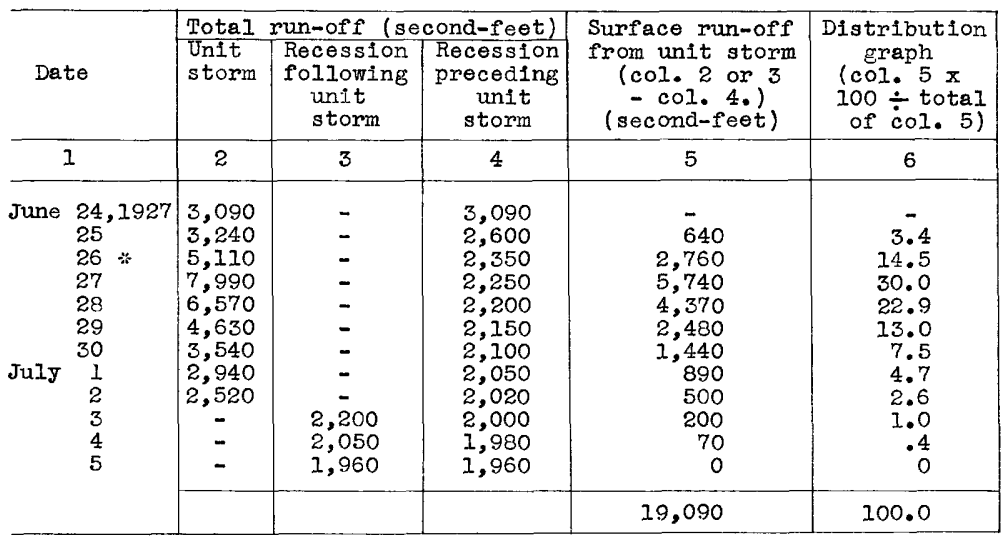

Note.- Colum 2 corresponds to graph $\mathrm{BCD}$, flgure 33 ; column 3 to graph DJ; column 4 to graph $\mathrm{BH}$; and column 5 to the cross-hatched area.

When the distribution graphs of the different unit storms considered are plotted with respect to the recorded time of the occurrence or the unit storms and with no consideration of a time unit less than 1 day, there is generally a variation in time between the day of recording of the precipitation and the peak run-off.

The average distribution graph for any basin was determined by superimposing the separate graphs to the best fit. From a study of the individual unit storms, the average time between the day of occurrence of the rain and the day of occurrence of the peak of the distribution graph was obtained; this time was then used in synchronizing the day of rain with the composite plot of all the distribution graphs.

In this connection it should be stated that the daily figures for the separate distribution graphs depend in part on the time of recording at the available precipltation stations, whereas the shape of the average distribution graph is independent. In other words, if the precipitation data to be used consist of records made at morning, afternoon, and midnight stations, the synchronization between recorded daily precipitation and resulting mean daily flows is variable.

$59550-35-9$ 
One continuous rainfall record on or near the basin aids materially in shifting recorded daily depths so as to obtain a good estimate of the precipitation occurring in any 24-hour period that has been synchronized with resulting stream flow.

The average of the peak figures on the separate graphs was used as a basis for determining the one or two peaks for the average graph, and the remaining figures for the average distribution graph were determined from the composite plot of all the graphs. This procedure was necessary, as the scattering horizontally of the peaks on the composite plat made the graphic determination of an average peak value impossible. This difficulty is eliminated where continuous-flow records rather than records of daily mean flow are available.

One of the principal causes for the variation in the time element for the basins studies is belleved to lie in the limitations of the basic information, especially with respect to time. Another suggested cause is the position of the center of the storm in the basin with relation to the gaging station. A longer elapsed time is to be expected if the storm centers at a point remote from the gaging station than if it centers at a nearer point. The stage of the river at the time of the storm may also produce a variation. If river stage is high when the unit storm occurs, it is reasonable to expect that the time of occurrence of the peak would be shorter than at a low stage.

In addition to the time variation there is appreciable difference in the percontage for the peak day. Some of this difference is due to the fixed time of beginning and ending the calendar day and is eliminated if continuous records are available. For streams that reach and maintain a high flow for lees than 24 hours, the resulting distribution-graph peak will vary as to whether the period of high flow falls within one calendar day or is divided between two days.

On the other hand, it is entirely conceivable that with continuous discharge records it would be found that owing to variations in storm centers and differences in storm intensities, as close agreement cotid not be obtained as is indicated from the observed mean daily records, which tend to obscure many important factors.

Differences in intensity and duration of the several unit storms will also modify the peak to some extent, and so will the location and movement of the center of the storm. The more remote storms have a 
greater opportunity for ironing out, thus producing flatter distribution graphs. Of course, a storm that traveled down the basin would produce the opposite effect.

Before describing problems of application of unit hydrographs and distribution graphs a general discussion based on experiences gained in the group study as well as by others seems desirable. Unquestionably the graphs have their limitations, and likewise it may be shown that some of the necessary assumptions are subject to error. The more clearly the limitations or effect of erroneous assumptions are recognized the greater the value of the graphs will be.

1. In the preparation of unit hydrographs it is necessary to separate ground-water flow from total stream flow, and because, as discussed elsewhere in this report, there seems to be no exact way that the separation can be made, it may be argued that the lack of definiteness imposes a serious limitation on the use of unit hydrographs. To overcome the limitation as far as possible, it is preferable to determine unit graphs from isolated storms that produce large surface run-off and occur when the ground-water flow is small. By so doing the probable errors in the determination of the ground-water flow are sma11, and the resulting distribution graphs are believed to represent closely the characteristics of surface run-off from that particular basin. As lnowledge of the laws governing the flow of surface water and ground water is increased, difficulties incident to their separation will become less and the accuracy of the unit hydrograph in depicting surface run-off should increase.

2. It has been pointed out that "it does not seem entirely safe to assume that the analogy between small and large floods is a rigid one." The special comittee of the Section of Hydrology of the American Geophysical Union has concluded that the validity of the unft-hydrograph theory seems strongly supported within practical limits by (a) the Eeneral agreement of distribution graphs derived under widely varying rates of rainfall and infiltration by the rainfall and run-off group - Sherman (158), Bernard (13), Smart (167), and others; (b) test by application to the recorded stream flow; (c) studies by the committee on Floods, Boston Society of Civil Engineers (18); (d) comparative analysis by Sherman (160).

3. Theoretically it would seem that, as a result of differences in channel velocities, the unit hydrograph of a 1-day storm occurring when the river is at a high stage would differ from one derived when the river 
is at a low stage. Robert $W$. Gay, of the United States Engineer Office, Zanesvillo, Ohio, who has studied the unit graph intensively in connection with Muskingum River projects, in a letter dated February 28, 1935, states: "It is probably true that as the amount of surface run-off per day increases, there are increases in hydraulic radii of the conducting channels of all sizes and corresponding increases in velocities of flow, which would tend to produce shorter run-off periods and apparently controvert to a greater or less extent the basic assumption of 'equal bases' for the graphs from varlous storms on the watershed. But before discarding the method on this ground, it must be shown that errors arising from the assumptions are sufflciently great to put this method at a disadvantage as compared with others."

The comparative analysis by Sherman (160) indicates that "the hypothesis of direct proportion of ordinates in the unlt hydrograph is not accurate for small areas involving only a few acres. The relation rapldy improves in accuracy as the area increases to 2 square miles or more. This is due to the 'Ironing out process' with the element of time."

However, W. W. Horner and F. L. Flynt (6I) found that the unithydrograph theory could be advantageously applied to areas as small as a city block. The data for such application were necessarily refined.

4. The variations in the geographic distribution of rainfall and in the intensities of 1-day storms compared with longer storms impose limitations on the duration and application of graphs. L. K. Sherman has found that "inequality of rainfall distribution over the basin does not materlally affect the accuracy of results except under extreme conditions." R. W. Gay (letter dated Febmuary 28, 1935) states that "as the path of the storm center is low down, high up, or across the center of the watershed, different graphs will result, the varlations in the graphs depending upon the ratio of maximum precipitation to average precipitation and upon the shape and topography of the watershed." Insofar as the study of large floods is concerned, the varlations in unit hydrographs are probably not serious, because storms that produce large floods have a tendency to approach unfform distribution.

5. The lack of base data, especially with regard to the time element in connection with the precipitation, is a handicap that undoubtedly will be remedied with time. Precipltation records showing the 
beginning and end of all storms and intensities are of great value in connection with unit-hydrograph studies.

6. Unit hydrographs of 1-day storms apparently cannot be obtained in basins where the infiltration capacity exceeds the rainfall or where, as a result of conditions of extreme artificial or natural storage, surface run-off may be materially delayed. Where these conditions are of such magnitude that isolated 1-day storms do not produce appreciable hydrographs of surface flow, it would seem that a time interval longer than a day would have to be used to determine distribution graphs.

These and other problems should be made the basis of much further study.

\section{Unit hydrographs and distribution graphs, by basins}

In accordance with a suggestion of the Advisory Committee of the American Geophysical Union, groups of unit hydrographs and distribution graphs have been prepared for typical basins in the central and eastern United States as follows:

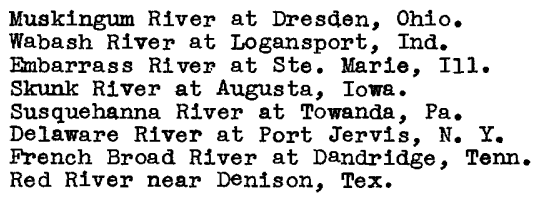

For each of these basins are given below a brief descriptive text accompanied by a map of the basin showing principal streams and the location of the Weather Bureau stations, a table showing the recorded daily rainfall at these stations during the unit storms that have been used, diagrams showing the average precipitation over the basin, hydrographs of stream flow, the estimated ground-water run-off and the distribution graph of surface run-off for the different unit storms and the superimposed distribution graphs, a table showing the distribution graph for each storm and the average distribution graph, and a table showing the approximate precipitation over the basin and the resulting surface run-off. 


\section{Muskingum River Basin above Dresden, Ohio}

The Muskingum Basin above Dresden, Ohio (fig. 34) is a fan-shaped area of 5,980 square miles. Three principal streams - the Walhonding River, Klilouck Creek, and the Tuscarawas River - flow in a southerly direction to form the Muskingum River about 18 miles above Dresden. Wills Creek enters from the east about $8 \mathrm{miles}$ above Dresden. The northern and western portions of the basin are glaciated, and the remainder has a hilly topography. The river distance from Dresden to the headwaters of the Tuscarawas River (some at altitudes above 1,200 feet) is about 120 miles, and the average gradient is about 2 feet to the mile. The headrater region of the Walhonding River (Mohican Creek) contains areas 1,400 feet or more above mean sea level, and the average gradient of the stream is about 4 feet to the mile. The zero of the gage at Dresden is 693.2 feet above mean sea level.

Daily discharges at this station have been published by the United States Geological Survey since September 1921. The original gage was a chain gage on a heavy steel eyebar suspension bridge half a mile east of Dresden. One reading was taken daily to hundredths. In August 1925 an Au recorder was installed at the same datum 70 feet below the bridge on the right bank. The records are considered good.

Normaliy about 13 United States Weather Bureau stations are avallable to determine daily rainfall for the basin. The stations are well distributed within the basin, as shown on figure 34. Table 29 gives the daily precipitation recorded at the various stations for the stoms analyzed. These storms produced the unit hydrographs at Dresden shown in figures 35,36 , and 37 .

\section{Table 29.- Typical unit-hydrograph storms in \\ Muskingum River Basin above Dresden, Ohio}

(Precipitation in inches, measured in the afternoon except at stations marked *, where it was measured in the morning.)

\begin{tabular}{l|r|r|r|c|c|c|c|c|c|c|}
\hline \multirow{2}{*}{ Station } & \multicolumn{4}{|c|}{ May 1925} & \multicolumn{7}{c|}{ June 1927} \\
\cline { 2 - 10 } & 10 & 11 & 16 & 17 & 3 & 4 & 5 & 11 & 13 & 14 \\
\hline Ashland & 0.40 & - & - & 0.45 & - & 0.90 & - & - & - & 0.20 \\
Bangorvil1e & .55 & - & 0.15 & .10 & - & 2.10 & - & - & 0.02 & .15 \\
Cadiz & .44 & 0.70 & .16 & .66 & 0.14 & 1.75 & - & - & - & .62 \\
Cambridge & .80 & .85 & .12 & .70 & .14 & .90 & - & 0.18 & - & .80 \\
Canton & - & .98 & - & .26 & - & 1.15 & 0.64 & .15 & - & .33
\end{tabular}


Table 29.- Typical unit-hydrograph storms in Muskingum River Basin above Dresden, Ohio--Continued

(Precipitation in inches, measured in the afternoon except at stations marked $*$, where it was measured in the morning.)

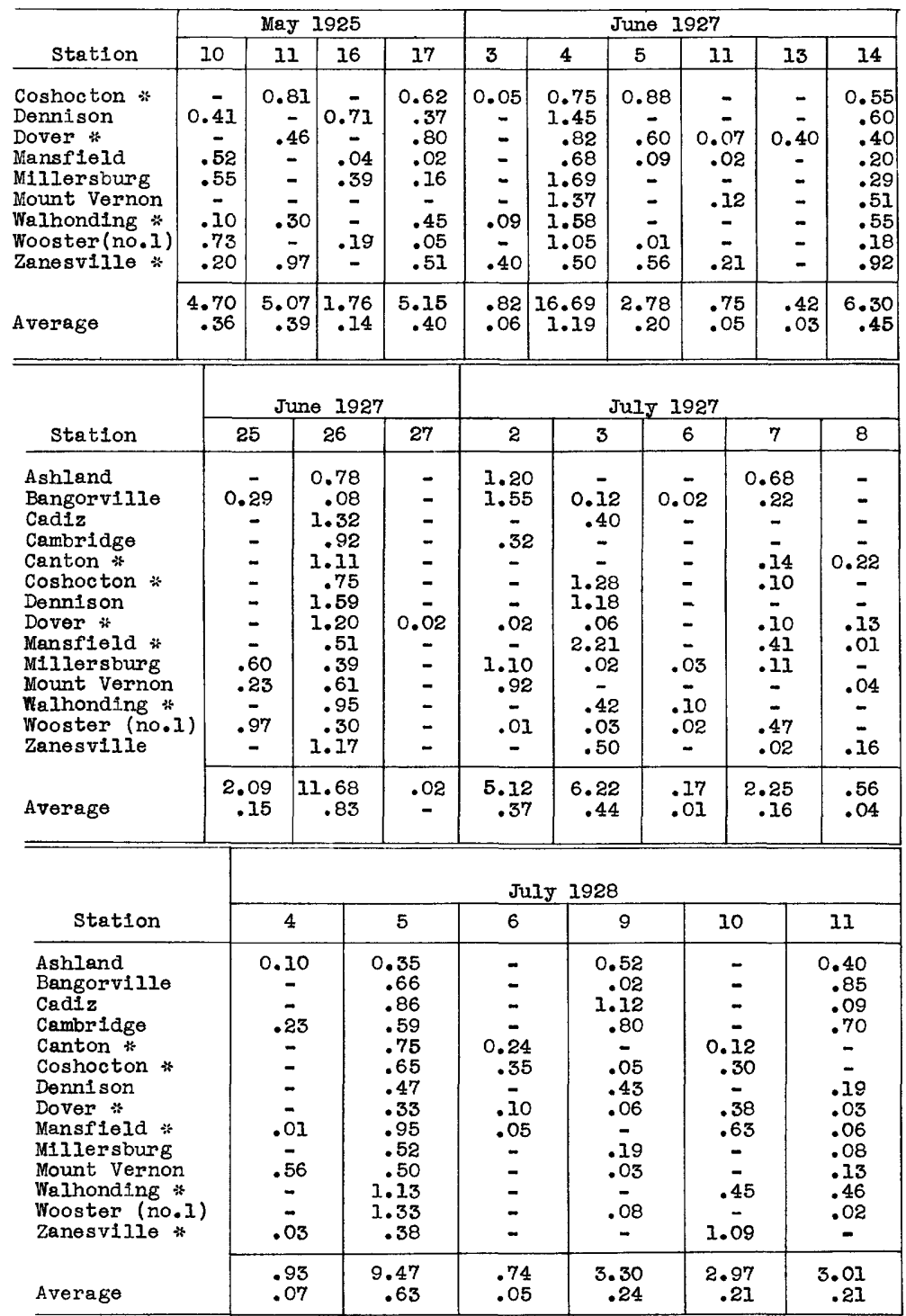


Table 29.- Typical unit-hydrograph storms in Muskingum River Basin above Dresden, Ohio--Continued

(Precipitation in inches, measured in the afternoon except at stations marked $*$, where it was measured in the morning.)

\begin{tabular}{|c|c|c|c|c|c|c|c|c|c|c|}
\hline \multirow[b]{2}{*}{ Station } & \multicolumn{10}{|c|}{ August 1928} \\
\hline & \multicolumn{2}{|r|}{4} & \multicolumn{2}{|l|}{5} & 6 & 8 & \multicolumn{2}{|r|}{10} & & 11 \\
\hline $\begin{array}{l}\text { Ashland } \\
\text { Bangorville } \\
\text { Cadiz } \\
\text { Cambridge } \\
\text { Canton * } \\
\text { Coshocton * } \\
\text { Dennison } \\
\text { Dover * } \\
\text { Mansfield * } \\
\text { Millersburg } \\
\text { Mount Vernon } \\
\text { Walhonding * } \\
\text { Wooster (no.1) } \\
\text { Zanesville * }\end{array}$ & & $\begin{array}{l}= \\
= \\
\overline{15} \\
= \\
= \\
= \\
. \\
.10 \\
.24\end{array}$ & $\begin{array}{r}1.26 \\
1.65 \\
.30 \\
.30 \\
.02 \\
.05 \\
.05 \\
- \\
.11 \\
.70 \\
1.10 \\
1.50 \\
-\end{array}$ & & $\begin{array}{l}0.10 \\
.71 \\
.79 \\
.8 \\
.17 \\
.80 \\
.80 \\
.30 \\
.30 \\
.10 \\
.32\end{array}$ & $\begin{array}{l}\bar{z} \\
\bar{z} \\
\overline{5} \\
\bar{z} \\
\bar{z} \\
\overline{-} \\
\overline{-}\end{array}$ & & $\begin{array}{c}0 . \\
.01 \\
.04 \\
- \\
.05 \\
.77 \\
\overline{26} \\
.35 \\
\overline{3} \\
. \overline{04} \\
-\end{array}$ & & $\begin{array}{l}. \\
.12 \\
- \\
. \\
31 \\
.03 \\
.26 \\
.09 \\
.12 \\
.18 \\
.50 \\
.73\end{array}$ \\
\hline \multirow[t]{3}{*}{ Average } & \multicolumn{2}{|r|}{$\begin{array}{l}.49 \\
.03\end{array}$} & \multicolumn{2}{|c|}{$\begin{array}{r}6.99 \\
.50\end{array}$} & $\begin{array}{r}4.49 \\
.32\end{array}$ & .3 & \multicolumn{2}{|r|}{$\begin{array}{r}1.52 \\
.11\end{array}$} & \multicolumn{2}{|c|}{$\begin{array}{r}2.34 \\
.17\end{array}$} \\
\hline & \multicolumn{6}{|c|}{ June 1929} & \multicolumn{4}{|c|}{ August 1929} \\
\hline & \multicolumn{2}{|l|}{7} & 8 & 12 & 13 & 14 & 22 & & 23 & 24 \\
\hline $\begin{array}{l}\text { Ashland } \\
\text { Bangorville } \\
\text { Cadiz } \\
\text { Cambridge } \\
\text { Canton. * } \\
\text { Coshocton * } \\
\text { Dennison } \\
\text { Dover * } \\
\text { Mansfield * } \\
\text { Millersburg } \\
\text { Mount Vernon } \\
\text { Newcomerstown * } \\
\text { Walhonding * } \\
\text { Wooster (no.1) } \\
\text { Zanesville * }\end{array}$ & \multicolumn{2}{|c|}{$\begin{array}{l}0 . \overline{28} \\
.51 \\
- \\
\overline{80} \\
\overline{-} \\
\overline{-} \\
.03 \\
.41 \\
\overline{-} \\
\overline{-}\end{array}$} & & $\begin{array}{l}.16 \\
.18 \\
.05 \\
- \\
= \\
= \\
.13 \\
.10 \\
= \\
.03 \\
-\end{array}$ & $\begin{array}{c}0.10 \\
= \\
.68 \\
= \\
= \\
= \\
= \\
.01 \\
= \\
.29\end{array}$ & $\begin{array}{l}0.53 \\
.26 \\
.29 \\
.35 \\
.26 \\
.50 \\
.41 \\
.27 \\
.31 \\
.22 \\
.75 \\
.70 \\
.49 \\
.23 \\
.23\end{array}$ & $\begin{array}{r}0.05 \\
.5 \\
.50 \\
.52 \\
- \\
.3 \\
= \\
. \\
.35 \\
.17 \\
.01 \\
.1 \\
.04\end{array}$ & 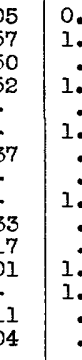 & $\begin{array}{l}.04 \\
.45 \\
.28 \\
.75 \\
.75 \\
.15 \\
.23 \\
.64 \\
.55 \\
.43 \\
.16 \\
.11 \\
.37 \\
.09 \\
.92\end{array}$ & $\begin{array}{c}\overline{-} \\
0.03 \\
\overline{10} \\
.15 \\
\overline{10} \\
.04 \\
\overline{-} \\
. \overline{14} \\
\overline{-} \\
.48\end{array}$ \\
\hline Average & $\begin{array}{r}2.0 \\
.1\end{array}$ & & & $\begin{array}{r}.65 \\
.04\end{array}$ & $\begin{array}{r}1.08 \\
.07\end{array}$ & $\begin{array}{r}5.80 \\
.39\end{array}$ & $\begin{array}{r}2.6 \\
.1\end{array}$ & 11 & $\begin{array}{r}.92 \\
.80\end{array}$ & $\begin{array}{r}1.04 \\
.07\end{array}$ \\
\hline & & & rust & & & & & גy 19 & & \\
\hline Station & 17 & 18 & 19 & 26 & 27 & 1 & 2 & 3 & 9 & 10 \\
\hline $\begin{array}{l}\text { Ashland } \\
\text { Bangorville } \\
\text { Cadiz } \\
\text { Cambridge } \\
\text { Canton * } \\
\text { Coshocton * } \\
\text { Dennison } \\
\text { Dover * } \\
\text { Mansfield * } \\
\text { Millersburg } \\
\text { Mount Vernon } \\
\text { Newcomerstown } *\end{array}$ & $\begin{array}{c}2.50 \\
= \\
= \\
= \\
= \\
= \\
= \\
= \\
=\end{array}$ & $\begin{array}{r}1.55 \\
1.01 \\
1.29 \\
1.13 \\
1.56 \\
2.20 \\
.87 \\
2.08 \\
.92 \\
2.06 \\
2.48\end{array}$ & $\begin{array}{c}= \\
\overline{-} \\
0.07 \\
= \\
= \\
\overline{-} \\
.28\end{array}$ & $\begin{array}{c}0.92 \\
.04 \\
.02 \\
- \\
.11 \\
= \\
.07 \\
.47 \\
-\end{array}$ & $\begin{array}{l}. \\
0.10 \\
.17 \\
.62 \\
.69 \\
.32 \\
.78 \\
.69 \\
.01 \\
. \\
.30\end{array}$ & $\begin{array}{c}= \\
0.72 \\
= \\
= \\
= \\
= \\
=\end{array}$ & $\begin{array}{c}1.60 \\
2.09 \\
1.80 \\
1.26 \\
- \\
.57 \\
- \\
.12 \\
1.49 \\
.57 \\
-\end{array}$ & $\begin{array}{c}\overline{-} \\
0 . \overline{05} \\
\overline{-} \\
.83 \\
2.80 \\
\overline{-} \\
1 . \overline{30} \\
1.77 \\
\overline{-} \\
1 . \overline{37}\end{array}$ & $\begin{array}{c}- \\
\overline{-} \\
0.17 \\
.07 \\
. \overline{20} \\
\overline{.02} \\
.01 \\
.05\end{array}$ & $\begin{array}{c}\overline{-} \\
0 . \overline{38} \\
- \\
= \\
\overline{10} \\
= \\
=\end{array}$ \\
\hline
\end{tabular}



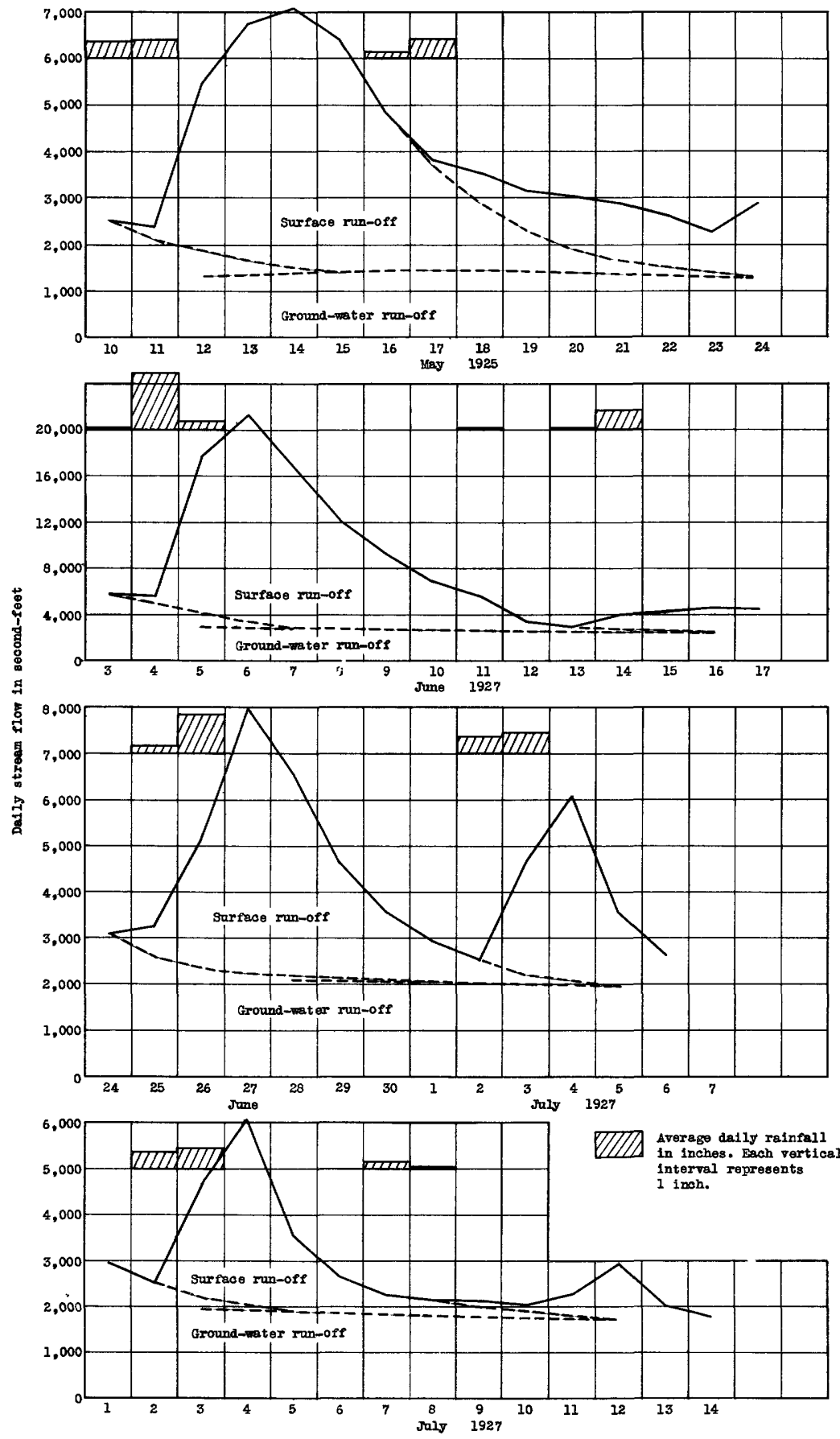

Figrare 35. Unit hydrographs for Muskingum Biver at Dresden, Ohfo. 

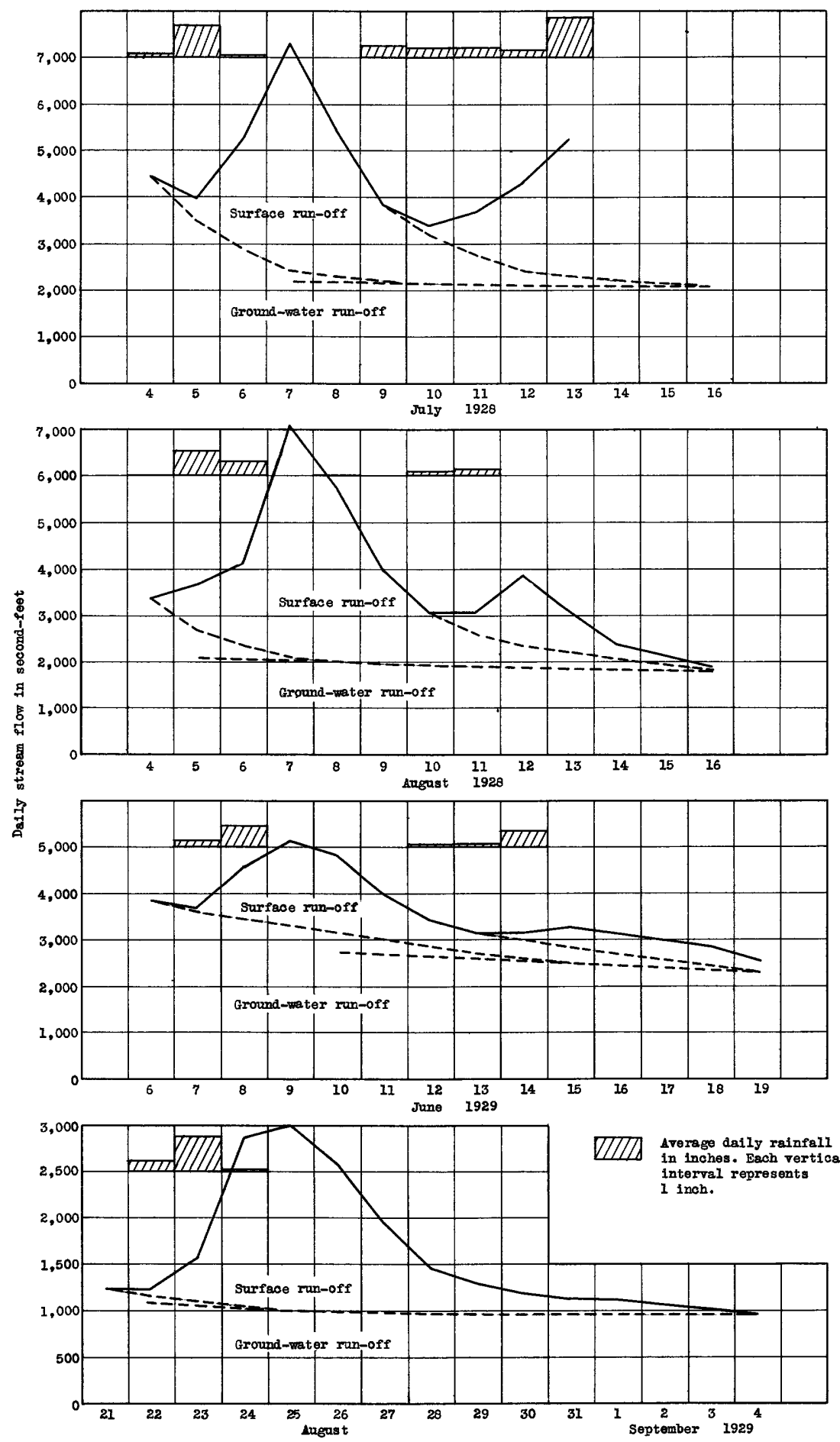

P1gare 36. -Unit hydrographs for Hhaskingum River at Dresden, Ohio. 


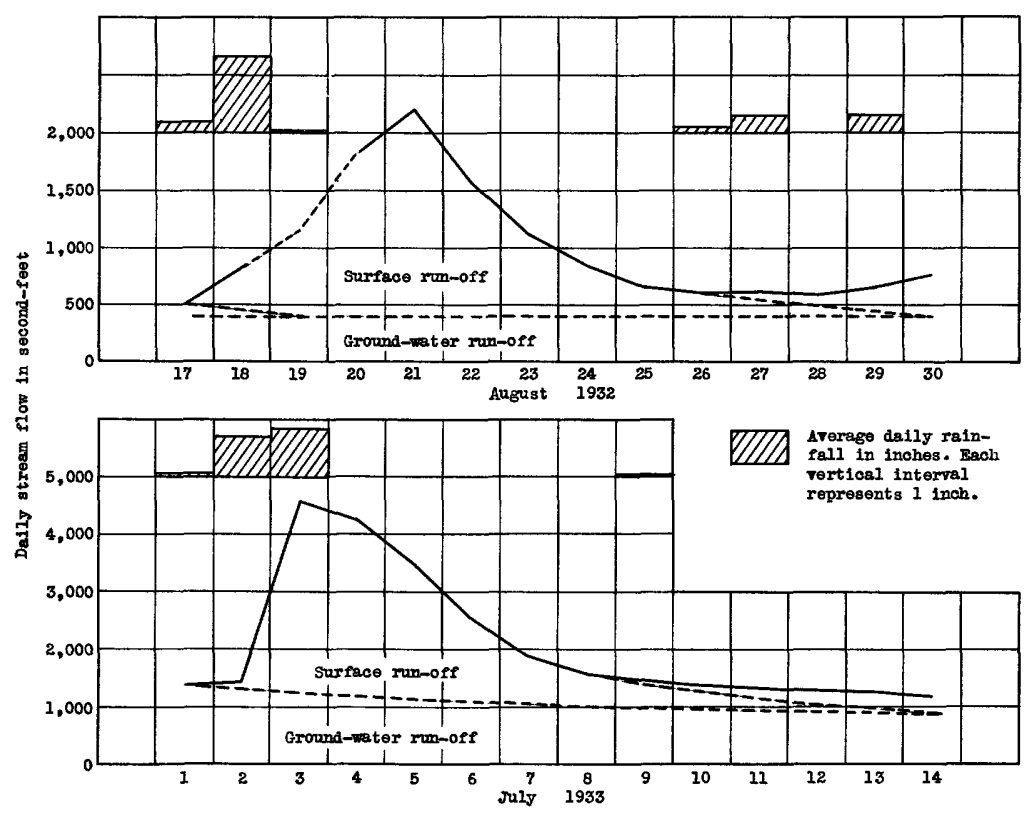

Flgare 37. - Onit hydrographs for luakingum River at Dresden, Ohio. 
Table 29.- Typical unit-hydrograph storms in Muskingum River Basin above Dresden, Ohio--Continued

(Precipitation in inches, measured in the afternoon except at stations marked *, where it was measured in the morning.)

\begin{tabular}{|c|c|c|c|c|c|c|c|c|c|c|}
\hline \multirow[b]{2}{*}{ Station } & \multicolumn{5}{|c|}{ August 1932} & \multicolumn{5}{|c|}{ July 1933} \\
\hline & 17 & 18 & 19 & 26 & 27 & 1 & 2 & 3 & 9 & 10 \\
\hline $\begin{array}{l}\text { Walhonding * } \\
\text { Wooster (no.1) } \\
\text { Zanesvilie * }\end{array}$ & $\overline{-}$ & $\begin{array}{r}0.67 \\
1.25 \\
.90\end{array}$ & $0 . \overline{0}$ & $0 . \overline{17}$ & $\begin{array}{r}0.55 \\
.03 \\
.04\end{array}$ & $\overline{-}$ & $0 . \overline{82}$ & $\begin{array}{r}2.10 \\
.87 \\
1.34\end{array}$ & $\begin{array}{c}0.03 \\
-\end{array}$ & $\frac{-}{-}$ \\
\hline Average & $\begin{array}{r}2.70 \\
.18\end{array}$ & $\begin{array}{r}19.97 \\
1.33\end{array}$ & $\begin{array}{l}.40 \\
.03\end{array}$ & $\begin{array}{r}1.80 \\
.12\end{array}$ & $\begin{array}{r}4.30 \\
.29\end{array}$ & $\begin{array}{l}.72 \\
.05\end{array}$ & $\begin{array}{r}10.32 \\
.69\end{array}$ & $\begin{array}{r}12.43 \\
.83\end{array}$ & $\begin{array}{l}.55 \\
.04\end{array}$ & $\begin{array}{l}.51 \\
.03\end{array}$ \\
\hline
\end{tabular}

The storm of May 10-11, 1925, produced the flattest unit hydrograph (and distribution graph) of the group. This is believed to be due mainly to a long light rain. The sharpest unit hydrograph, resulting from the storm of July 2-3, 1927, was the result of poor distribution of rainfal1. The greater amounts were concentrated on the Walhonding subbasin, and the resulting distribution graph at Dresden is typical of several distribution graphs that are avaliable for the Walhonding River at Pomerene. Table 30 gives the surface run-off from the unit storms with an approximation of the precipitation that caused the run-off.

\section{Table 30.- Surface run-off from unit storms, \\ Muskingum River at Dresden, Ohio}

\begin{tabular}{|c|c|c|c|}
\hline Storm & $\begin{array}{c}\text { Average of precipi- } \\
\text { tation at stations } \\
\text { (inches) }\end{array}$ & $\begin{array}{c}\text { Surface run-off } \\
\text { (inches) }\end{array}$ & $\begin{array}{c}\text { Ratio of } \\
\text { surface run- } \\
\text { off to aver- } \\
\text { age precipi- } \\
\text { tation }\end{array}$ \\
\hline May 11, 1925 & 0.75 & 0.18 & 0.24 \\
June 4, 1927 & 1.45 & .44 & .33 \\
June 26, 1927 & .98 & .12 & .12 \\
Ju1y 2, 1927 & .81 & .06 & .07 \\
Ju1y 5, 1928 & .75 & .09 & .12 \\
Aug. 5, 1928 & .85 & .10 & .09 \\
June 7, 1929 & .58 & .05 & .05 \\
Aug. 22, 1929 & 1.05 & .05 & .03 \\
Aug. 18, 1932 & 1.54 & .08 & .05 \\
July 2, 1933 & 1.57 & & \\
\hline
\end{tabular}

Table 31 gives the daliy percentages of the surface run-off for the ten distribution graphs. The first figure is the percentage for the calendar day on which most of the rainfall occurred; other figures for succeeding days. 
Table 31.- Distribution graphs for storms in

Muskingum River Besin above Dresden, Ohio

\begin{tabular}{|l|r|r|r|r|r|r|r|r|r|r|r|r|r|}
\hline May 11, 1925 & 1.0 & 12.5 & 17.8 & 19.6 & 17.5 & 11.8 & 8.1 & 5.1 & 3.1 & 1.7 & 0.9 & 0.6 & 0.3 \\
June 4, 1927 & .8 & 19.1 & 25.4 & 19.8 & 13.2 & 9.4 & 6.0 & 4.2 & 1.1 & .5 & .3 & .2 & - \\
June 26, 1927 & 3.8 & 14.2 & 29.5 & 22.4 & 12.7 & 7.4 & 5.0 & 3.1 & 1.5 & .4 & - & - & - \\
July 2, 1927 & .0 & 24.0 & 39.7 & 16.3 & 7.9 & 4.2 & 3.3 & 2.4 & 1.4 & .8 & - & - & - \\
July 5, 1928 & 3.3 & 16.1 & 32.7 & 21.2 & 10.8 & 7.1 & 4.2 & 2.0 & 1.4 & .7 & .5 & - & - \\
Aug. 5, 1928 & 6.0 & 10.9 & 30.1 & 22.7 & 12.3 & 7.0 & 4.2 & 2.8 & 2.0 & 1.3 & .7 & - & - \\
June 7, 1929 & 1.3 & 13.1 & 23.2 & 21.9 & 12.4 & 7.2 & 5.6 & 5.1 & 3.8 & 3.2 & 1.9 & 1.3 & - \\
Aug. 22, 1929 & 1.0 & 5.7 & 21.8 & 24.1 & 18.1 & 11.5 & 5.8 & 3.8 & 2.6 & 1.9 & 1.9 & 1.2 & .6 \\
Aug. 18, 1932 & 4.6 & 10.2 & 19.3 & 24.4 & 15.9 & 9.5 & 6.0 & 3.4 & 2.7 & 2.0 & 1.3 & .7 & - \\
July 2, 1933 & 1.0 & 26.0 & 24.0 & 18.3 & 11.0 & 6.5 & 4.4 & 3.3 & 2.5 & 1.7 & 0.9 & .4 & - \\
\hline
\end{tabular}

The superimposed distribution graphs are shown in figure 38. If the two distribution graphs from the storm of May 10-11, 1925, and July 23, 1927, are disregarded the range of the remaining graphs is decreased. The average distribution graph determined for the Muskingum River at Dresden is $4,15,27,21,13,8,5,3,2,1,1$ percent.

\section{Wabash River Basin above Logansport, Ind.}

The Wabash River rises in the Grand Reservoir, an artificial lake at Celina, Mercer County, Ohio, and flows in a northerly and westerly direction to Logansport, Ind., below which its direction is southwest. The Eel and the Mississinewa Rivers are the principal tributaries above Logansport. The drainage area above Logansport covers 3,830 square miles, is fan-shaped, and is about 90 miles in length and about 40 miles in average width. The length of the Wabash channel above Logansport is about 120 miles. Much of the basin is glaciated. The maximum altitude is 1,285 feet, in Randolph County, Ind.

A chain gage was established in April 1903 on the Cicott street Bridge at Logansport. The record was discontinued in July 1906. A standard chain gage was established by the State of Indiana in May 1923 at the same location, with its zero 573.8 feet above mean sea level. Records are published by the United States Geological Survey. On March 31, 1927, the Wabash HJdroelectric Co. installed an enamel staff gage on the same bridge, with its zero 2.85 feet above the zero of the State chain gage. The chain gage was read once dajly to tenths, and part of the time the staff gage readings to hundredths twice daily were furnished. The records are considered good except for periods of ice effect. 


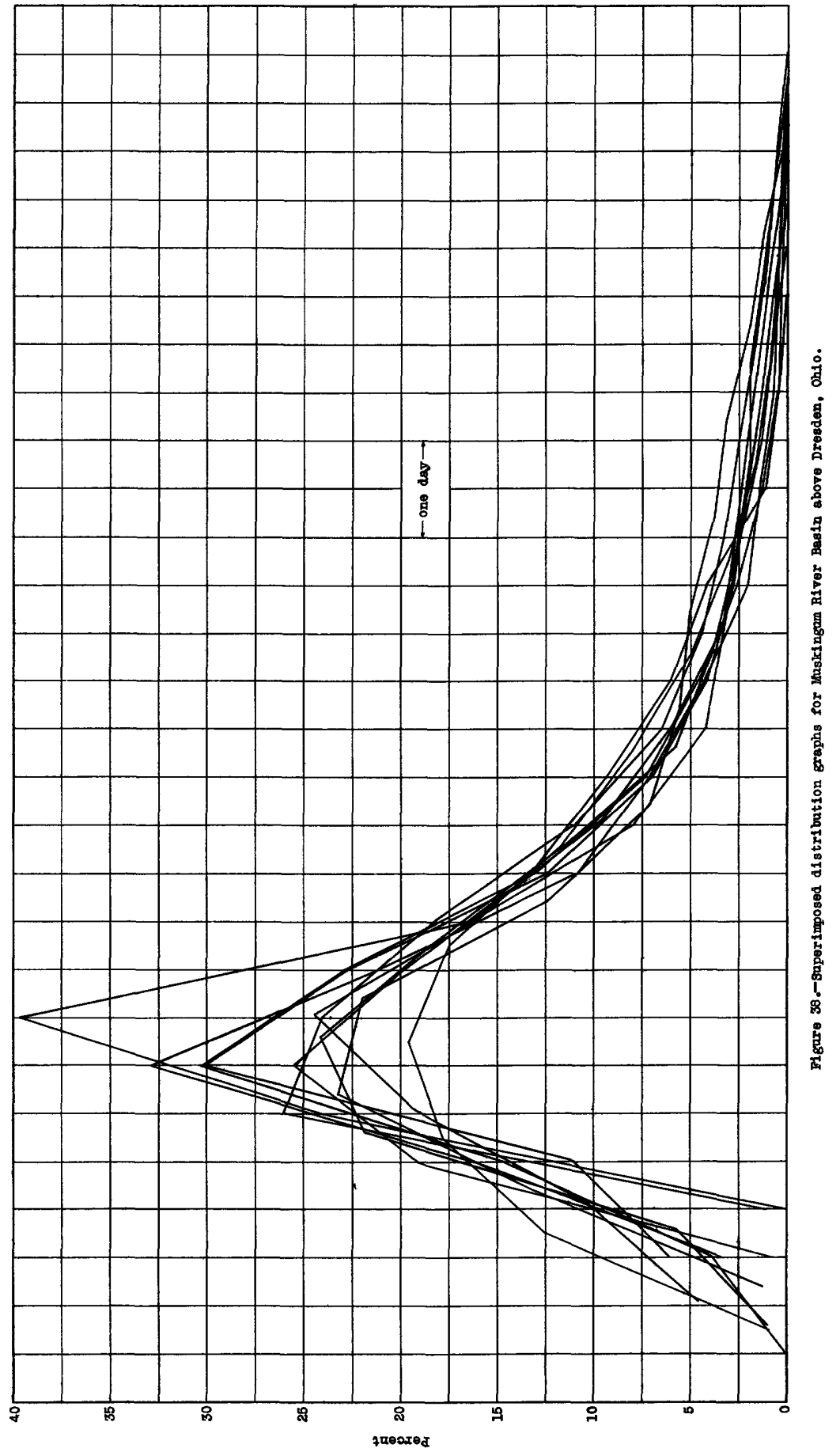


Normally about 14 stations are avallable for the determination of daliy precipitation. Figure 39 outlines the drainage basin and shows the location of the Weather Bureau stations.

Table 32 gives the daily precipitation recorded at the precipitation stations for the storms that produced the unit hydrographs shown in figures 40 and 41 .

Table 32.- Storms studied in connection with unit hydrographs for the Wabash River Basin above Logansport, Ind.

(Precipitation, in inches, measured in the afternoon except at stations marked *, where it was measured in the morning, and stations marked **, where it was measured at midnight.)

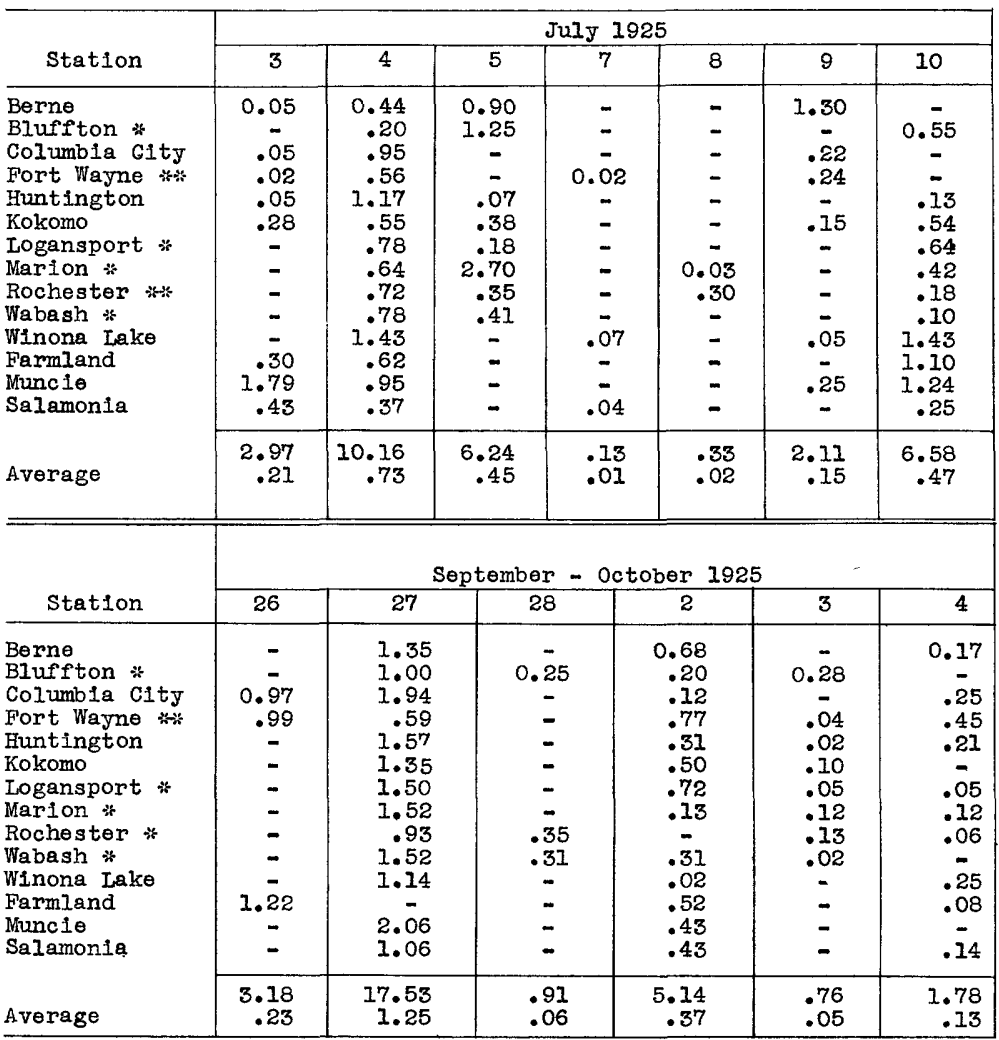


Table 32.- Storm studied in connection with unit hydrographs for the Wabash River Basin above Logansport, Ind.--Continued

(Precipitation, in inches, measured in the afternoon except at stations marked $*$, where it was measured in the morning, and stations marked **, where it was measured at midnight.)

\begin{tabular}{|c|c|c|c|c|c|c|c|c|c|c|}
\hline \multirow[b]{2}{*}{ Station } & \multicolumn{4}{|c|}{ August 1929} & \multicolumn{6}{|c|}{ August 1929} \\
\hline & \multicolumn{2}{|l|}{2} & 3 & 10 & \multicolumn{2}{|c|}{13} & 14 & 22 & \multicolumn{2}{|c|}{23} \\
\hline $\begin{array}{l}\text { Berne } \\
\text { Bluffton * } \\
\text { Columbia City } \\
\text { Fort Wayne ** } \\
\text { Huntington } \\
\text { Kokomo } \\
\text { Logansport * } \\
\text { Marion * } \\
\text { Rochester * } \\
\text { Wabash * } \\
\text { Winona Lake } \\
\text { Farmland * } \\
\text { Muncie } \\
\text { Salamonia }\end{array}$ & \multicolumn{2}{|c|}{$\begin{array}{c}0.11 \\
\overline{-} \\
1.25 \\
1.06 \\
.11 \\
.20 \\
= \\
= \\
. \\
.38 \\
.30 \\
.04\end{array}$} & $\begin{array}{r}2.04 \\
3.10 \\
2.74 \\
1.00 \\
3.82 \\
.04 \\
.58 \\
1.09 \\
1.22 \\
1.50 \\
6.25 \\
.65 \\
.54 \\
1.23\end{array}$ & $\begin{array}{r}- \\
0.02 \\
.17 \\
1.47 \\
.20 \\
.08 \\
.10 \\
1.03 \\
.01 \\
.09 \\
.16\end{array}$ & \multicolumn{2}{|c|}{$\begin{array}{c}1.03 \\
-47 \\
.38 \\
1.49 \\
= \\
= \\
= \\
.51 \\
= \\
.25\end{array}$} & $\begin{array}{c}0.41 \\
4.40 \\
.06 \\
- \\
- \\
-55 \\
1.18 \\
1.50 \\
2.00 \\
.55 \\
2.22 \\
2.07 \\
1.51\end{array}$ & $\begin{array}{c}0 . \overline{0} \\
.10 \\
-\overline{03} \\
.04 \\
\overline{-} \\
.02 \\
.09 \\
= \\
-\end{array}$ & \multicolumn{2}{|c|}{$\begin{array}{l}0.20 \\
.20 \\
.02 \\
.01 \\
.18 \\
.03 \\
.02 \\
.18 \\
.03 \\
.11 \\
.01 \\
. \\
.56 \\
.41\end{array}$} \\
\hline Average & $\begin{array}{r}3.45 \\
.25\end{array}$ & \multicolumn{2}{|c|}{$\begin{array}{r}25.80 \\
1.84\end{array}$} & $\begin{array}{r}3.33 \\
.24\end{array}$ & \multicolumn{2}{|c|}{$\begin{array}{r}4.13 \\
.30\end{array}$} & $\begin{array}{r}16.45 \\
1.18\end{array}$ & $\begin{array}{l}.34 \\
.02\end{array}$ & \multicolumn{2}{|c|}{$\begin{array}{r}1.96 \\
.14\end{array}$} \\
\hline & \multicolumn{6}{|c|}{ June - July 1931} & \multicolumn{4}{|c|}{ October 1932} \\
\hline Station & 28 & 29 & 30 & 1 & 2 & 5 & 4 & 5 & 10 & 11 \\
\hline $\begin{array}{l}\text { Berne } \\
\text { Bluffton * } \\
\text { Columbia City } \\
\text { Fort Wayne ** } \\
\text { Huntington } \\
\text { Kokomo } \\
\text { Logansport * } \\
\text { Marion * } \\
\text { Rochester * } \\
\text { Wabash * } \\
\text { Winona Lake } \\
\text { Farmland * } \\
\text { Muncie } \\
\text { Salamonla }\end{array}$ & $\begin{array}{c}0.15 \\
.07 \\
.02 \\
- \\
.06 \\
= \\
= \\
= \\
.10 \\
= \\
-\end{array}$ & $\begin{array}{r}1.42 \\
1.63 \\
.73 \\
1.07 \\
.53 \\
1.40 \\
- \\
.05 \\
.23 \\
.67 \\
.04 \\
1.00 \\
1.88\end{array}$ & $\begin{array}{c}0 . \overline{14} \\
= \\
\overline{-} \\
\overline{1 .} \\
1.26 \\
1 . \overline{09} \\
\overline{74} \\
\overline{-}\end{array}$ & $\begin{array}{c}\overline{-} \\
\overline{0} \\
0.78 \\
= \\
= \\
= \\
= \\
= \\
1.09 \\
.74\end{array}$ & $\begin{array}{c}0.07 \\
- \\
.14 \\
.33 \\
- \\
= \\
.03 \\
- \\
.07 \\
.87 \\
.04 \\
-\end{array}$ & $\begin{array}{c}0.12 \\
.22 \\
.35 \\
.79 \\
.11 \\
.28 \\
= \\
= \\
= \\
.42 \\
= \\
.26\end{array}$ & $\begin{array}{r}0.38 \\
- \\
1.32 \\
1.54 \\
1.57 \\
1.38 \\
-5 \\
1.87 \\
.76 \\
1.55 \\
.90 \\
.93 \\
.75\end{array}$ & $\begin{array}{c}1.06 \\
- \\
- \\
.09 \\
1.04 \\
- \\
= \\
.04 \\
- \\
-\end{array}$ & $\begin{array}{r}0.80 \\
.5 \\
.54 \\
.57 \\
.62 \\
.62 \\
-60 \\
.60 \\
1.22 \\
1.02 \\
1.12 \\
.95 \\
1.02\end{array}$ & $\begin{array}{c}0.03 \\
.69 \\
= \\
- \\
- \\
.86 \\
.05 \\
.71 \\
.07 \\
\overline{-} \\
.08\end{array}$ \\
\hline Average & $\begin{array}{l}.40 \\
.03\end{array}$ & $\begin{array}{r}10.65 \\
.76\end{array}$ & $\begin{array}{r}4.38 \\
.31\end{array}$ & $\begin{array}{r}2.61 \\
.19\end{array}$ & $\begin{array}{r}1.55 \\
.11\end{array}$ & $\begin{array}{r}2.55 \\
.18\end{array}$ & $\begin{array}{r}13.25 \\
.95\end{array}$ & $\begin{array}{r}2.23 \\
.16\end{array}$ & $\begin{array}{r}9.08 \\
.65\end{array}$ & $\begin{array}{r}2.49 \\
.18\end{array}$ \\
\hline
\end{tabular}

Table 33 gives the surface mun-off from the unit storms with the approximate value of the preclpitation causing the run-off. 


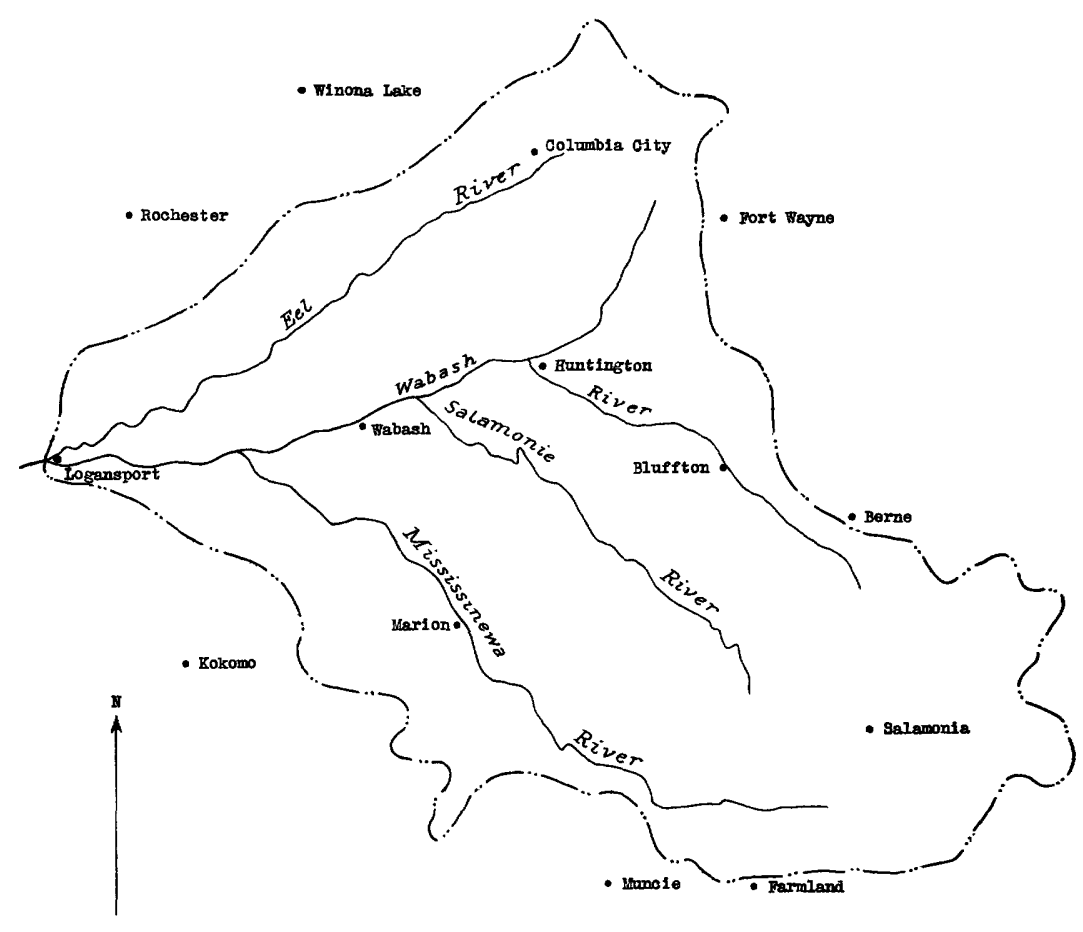

10

10

Figure 39.- Wabash River Basin above Logansport, Ind. Drainage area 3,830 square miles

$59550-35-10$ 

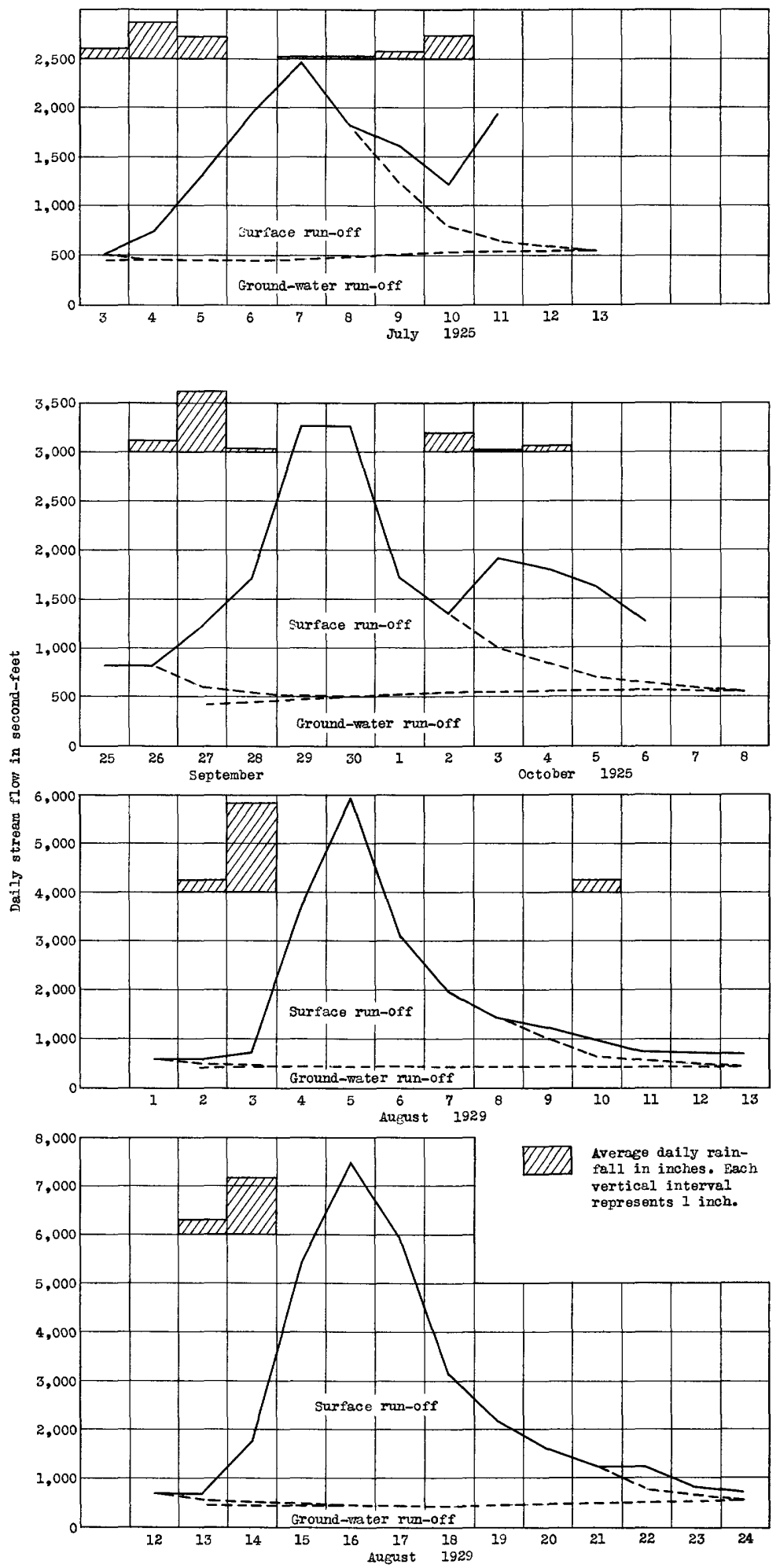

F1gure 40.-Unit hydrographs for Wabash River at Logansport, Ind. 


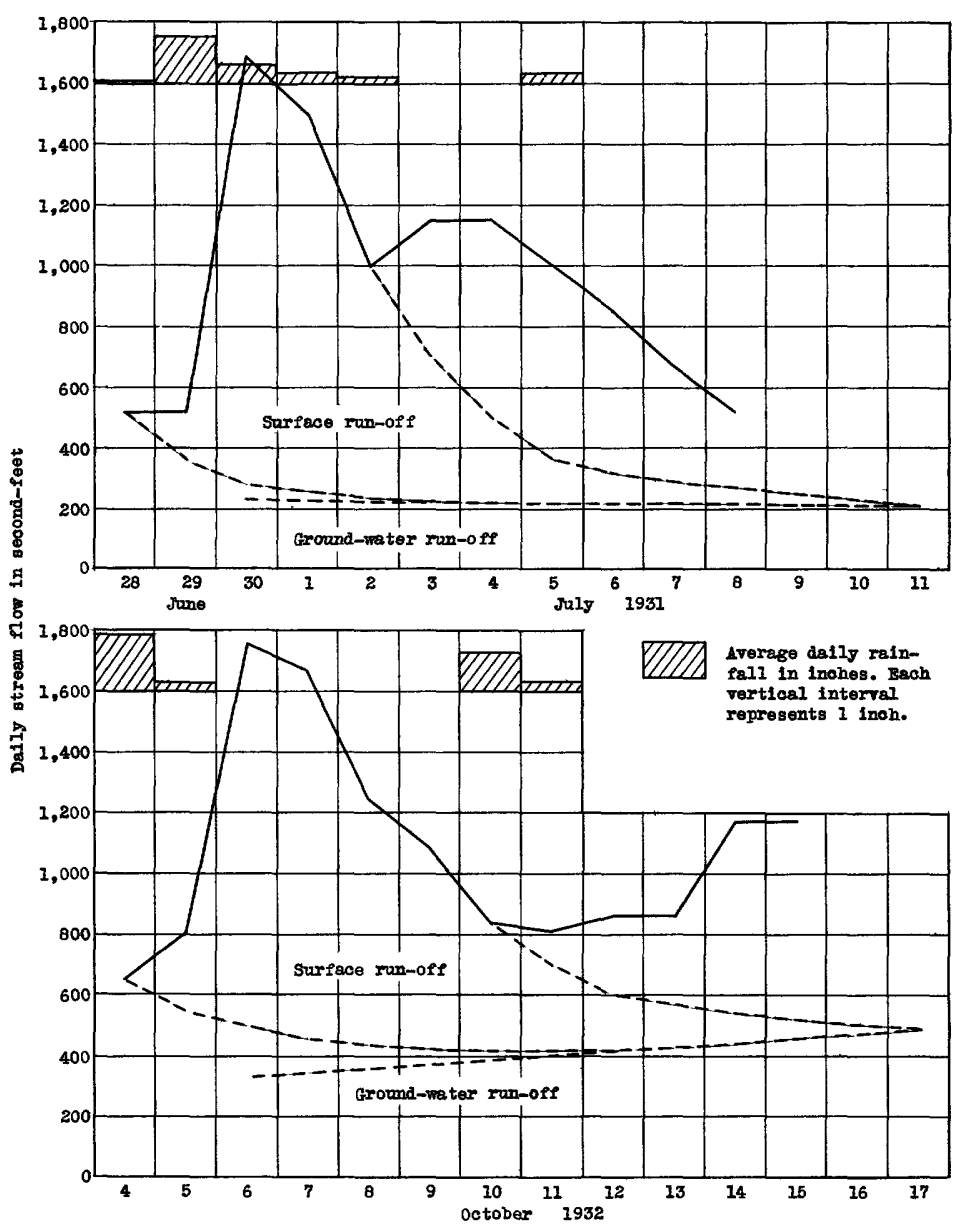

Figure 41.-Onit hydrographs for Wabesh River at Iogansport, Ind. 
Table 33.- Surface run-off from unit storms, Wabash River at Logansport, Ind.

\begin{tabular}{|c|c|c|c|}
\hline Storm & $\begin{array}{c}\text { Average of precipi- } \\
\text { tation at stations } \\
\text { (inches) }\end{array}$ & $\begin{array}{c}\text { Surface run-off } \\
\text { (inches) }\end{array}$ & $\begin{array}{c}\text { Ratio of } \\
\text { surface run- } \\
\text { off to aver- } \\
\text { age precipi- } \\
\text { tation }\end{array}$ \\
\hline July 4, 1925 & 1.39 & 0.07 & 0.05 \\
Sept. 27, 1925 & 1.54 & .10 & .06 \\
Aug. 2, 1929 & 2.09 & .15 & .07 \\
Aug. 13, 1929 & 1.48 & .25 & .17 \\
June 29, 1931 & 1.10 & .05 & .05 \\
Oct. 4, 1932 & 1.11 & .05 & .05 \\
\hline
\end{tabular}

Table 34 gives the daily percentages for the six distribution graphs, and figure 42 shows the graphs superimposed. The average distribution graph determined for the station is $3,12,27,24,14,9,5,3,-2$, 1 percent. The first figure is the percentage of surface run-off for the day on which most of the rainfall occurs; other figures for succeeding days.

\section{Table 34.- Distribution graphs for storms in \\ Wabash River Basin above Logansport, Ind.}

\begin{tabular}{l|r|r|r|r|r|r|r|r|r|r|r|r|c|}
\hline July 4, 1925 & 4.1 & 12.0 & 20.7 & 28.1 & 18.7 & 10.4 & 3.8 & 1.5 & 0.7 & - & - & - & - \\
Sept. 27,1925 & 5.9 & 11.4 & 26.7 & 26.8 & 11.6 & 7.9 & 4.4 & 2.8 & 1.3 & 0.8 & 0.4 & - & - \\
Aug. 2, 1929 & .7 & 1.5 & 21.7 & 35.9 & 17.6 & 9.9 & 6.4 & 3.7 & 1.4 & .7 & .3 & 0.2 & - \\
Aug. 13, 1929 & .4 & 4.8 & 19.5 & 27.6 & 21.6 & 10.6 & 6.6 & 4.3 & 2.8 & 1.0 & .5 & .2 & 0.1 \\
June 29, 1931 & 3.4 & 29.8 & 26.2 & 15.9 & 9.9 & 5.9 & 3.0 & 2.1 & 1.5 & 1.2 & .7 & .4 & - \\
Oct. 4, 1932 & 0 & 4.8 & 23.4 & 23.6 & 14.9 & 12.3 & 7.8 & 5.2 & 3.5 & 2.4 & 1.5 & .6 & - \\
\hline
\end{tabular}

Embarrass River Basin above Ste. Marie, III.

The Embarrass River has its source in Champaign County, I11., just south of Urbana, and flows in a general southerly diroction into the Wabash River above St. Francisville. The altitude of the divide near Urbana is 750 feet.

The basin above Ste. Marie (fig. 43) covers 1,540 square miles, is about $80 \mathrm{miles}$ long, and averages $19 \mathrm{miles}$ in width. The average gradlent for 40 miles above ste. Marie is 2 feot to the mile.

The gaging station was established in October 1909 on the kain Street Bridge at Ste. Marie. A standard chain gage was fastened to the handrail on the downstream side of the bridge and was read to hundredths once dally. No records are avallable from December 1912 to August 1914. 


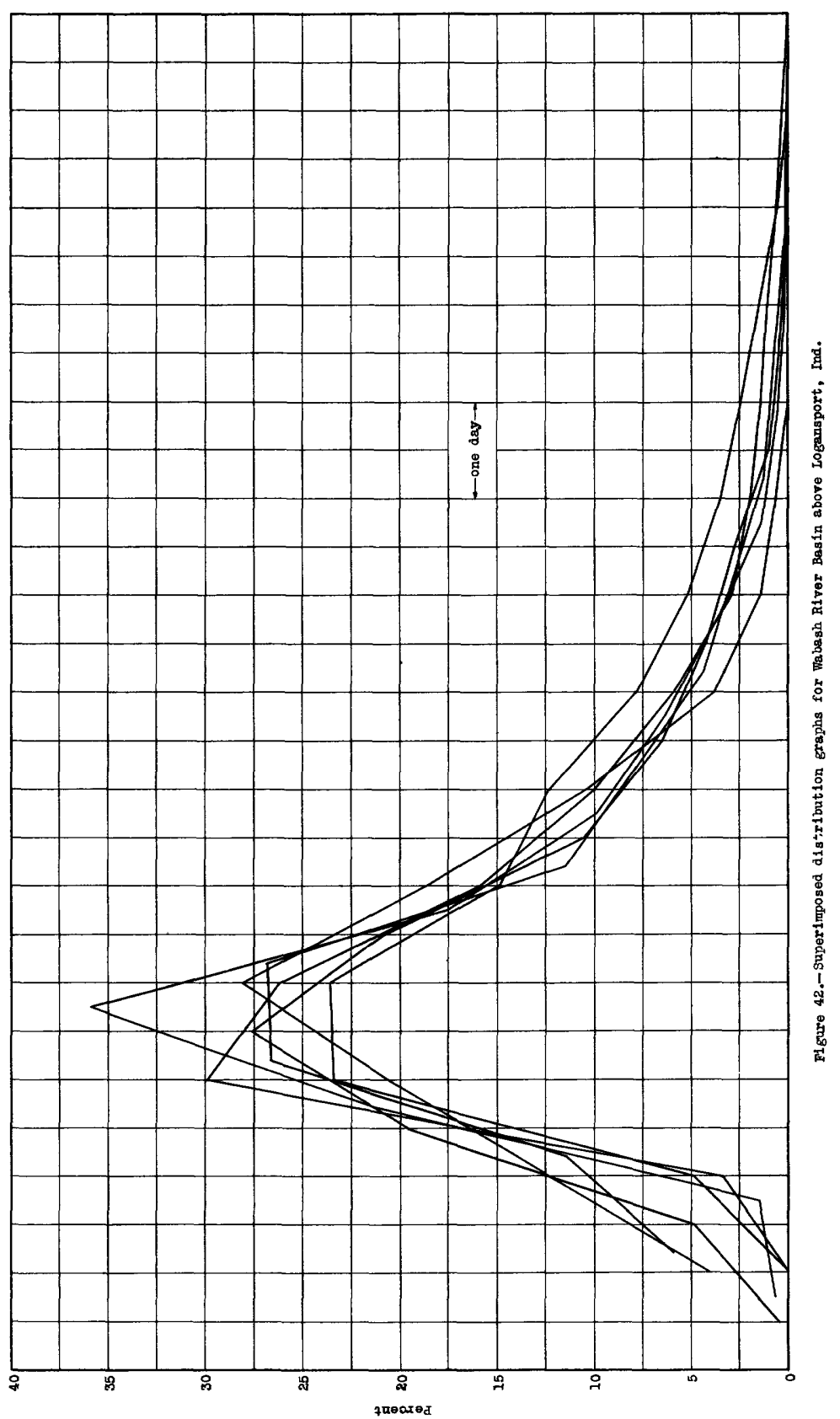


The gage was transferred to the new highway bridge in April 1925. The zero of the gage is 447.1 feet above mean sea level. The records are considered good.

Seven precipitation stations of the Unfted States Weather Bureau (see fig. 43) are generally avaliable. If the dally rainfall is to be used extensively the station records should be weighted by some method.

Table 35 gives the daily precipitation recorded at the precipitation stations for the storms that produced the unit hydrographs shown in figures 44 and 45 .

Table 35.- Storms studied in connection with unit

hydrographs, Embarrass River above Ste. Marie, I11.

(Precipitation, in inches, measured in the afternoon except at stations marked *, where it was measured in the morning.)

\begin{tabular}{|c|c|c|c|c|c|c|}
\hline \multirow[b]{2}{*}{ Station } & \multicolumn{6}{|c|}{ June - July 1918} \\
\hline & 24 & 25 & 28 & 29 & 30 & 1 \\
\hline $\begin{array}{l}\text { Casey } \\
\text { Charleston } \\
\text { Effingham * } \\
\text { Olney * } \\
\text { Paris * } \\
\text { Tuscola } \\
\text { Urbana * }\end{array}$ & $\begin{array}{c}0.04 \\
.03 \\
- \\
- \\
3.79 \\
-\end{array}$ & $\begin{array}{l}2.48 \\
2.94 \\
1.10 \\
.62 \\
2.45 \\
3.05\end{array}$ & $\begin{array}{r}1.35 \\
1.88 \\
.44 \\
.50 \\
.48 \\
1.27 \\
.64\end{array}$ & $\begin{array}{r}- \\
1.30 \\
1.38 \\
.63 \\
.87\end{array}$ & $\begin{array}{c}0.04 \\
.02 \\
- \\
- \\
.04 \\
-\end{array}$ & $\begin{array}{c}= \\
= \\
0 .\end{array}$ \\
\hline Average & $\begin{array}{r}3.86 \\
.55\end{array}$ & $\begin{array}{r}12.64 \\
1.81\end{array}$ & $\begin{array}{r}6.56 \\
.94\end{array}$ & $\begin{array}{r}4.18 \\
.60\end{array}$ & .10 & $\begin{array}{r}.26 \\
.04\end{array}$ \\
\hline & \multicolumn{6}{|c|}{ May 1920} \\
\hline Station & 11 & 12 & 13 & 16 & 17 & 18 \\
\hline $\begin{array}{l}\text { Casey } \\
\text { Charleston } \\
\text { Effingham * } \\
\text { Olney * } \\
\text { Paris * } \\
\text { Tuscola } \\
\text { Urbana * }\end{array}$ & $\begin{array}{c}0.10 \\
.08 \\
= \\
= \\
.02 \\
.04\end{array}$ & $\begin{array}{r}2.21 \\
3.12 \\
.77 \\
.33 \\
2.40 \\
3.32 \\
1.38\end{array}$ & $\begin{array}{c}- \\
0 . \overline{44} \\
.51 \\
.71 \\
\overline{-7} \\
1.04\end{array}$ & $\begin{array}{c}0.06 \\
.10 \\
= \\
= \\
.10 \\
=\end{array}$ & $\begin{array}{l}1.41 \\
1.72 \\
2.10 \\
1.95 \\
.80 \\
1.29 \\
1.15\end{array}$ & $\begin{array}{l}0.03 \\
.03 \\
.33 \\
.40 \\
.38 \\
.04 \\
.08\end{array}$ \\
\hline Average & $\begin{array}{l}.24 \\
.03\end{array}$ & $\begin{array}{r}13.53 \\
1.93\end{array}$ & $\begin{array}{r}2.70 \\
.39\end{array}$ & $\begin{array}{r}.26 \\
.04\end{array}$ & $\begin{array}{r}10.42 \\
1.49\end{array}$ & $\begin{array}{r}1.29 \\
.18\end{array}$ \\
\hline
\end{tabular}


Table 35.- Storms studied in connection with unit hydrographs, Embarrass River above Ste. Marie, Ill.--Continued

(Precipitation, in inches, measured in the afternoon except at stations marked $*$, where it was measured in the morning.)

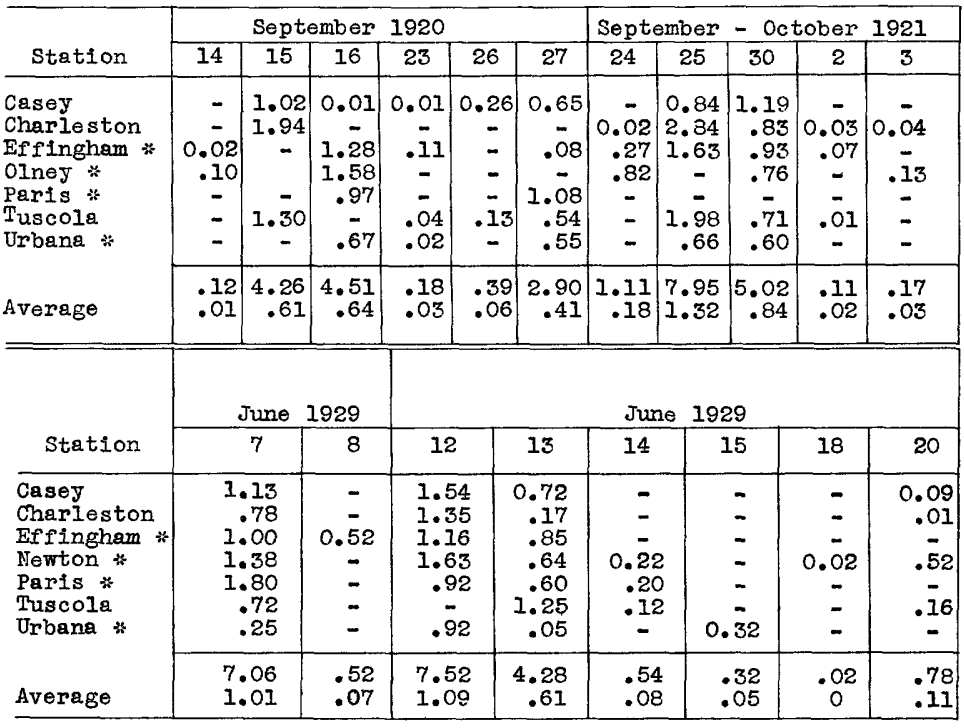

The superimposed distribution graphs for the Embarrass River above Ste. Marie (fig. 46) show an appreciable variation as a result of having one, two, or three peaks.

The storm of June 25, 1918, though of greater intensity in the upper part of the basin, which would flatten its peak, appears to have lasted about 12 hours, which would counteract the flattening effect. The result is a fairly average distribution graph.

The storm of May 12, 1920, was poorly distributed, with high intensities in the uplands and apparently about 24 hours duration. The result is a flat distribution graph.

The storms of September 15, 1920, and June 7, 1929, appear to have been short and slightly heavier on the lower part of the basin, thus giving high-peaked distribution graphs.

Table 36 gives the surface run-off from the unit storms. 


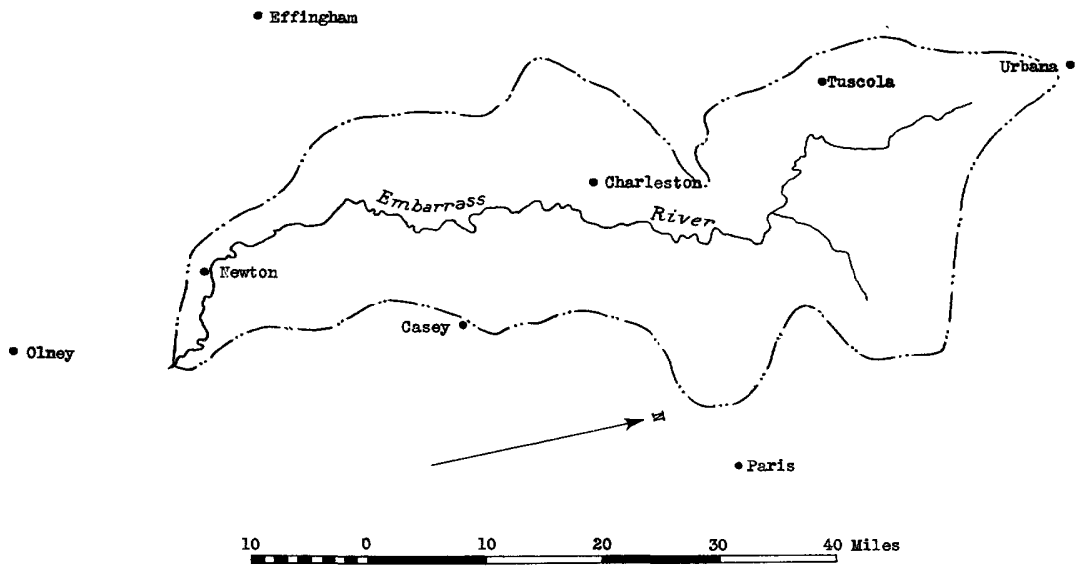

Pigtre 43.-Fmbarrass River Bes in above Ste. Marie, Ill. Drainage area 1,540 square miles 

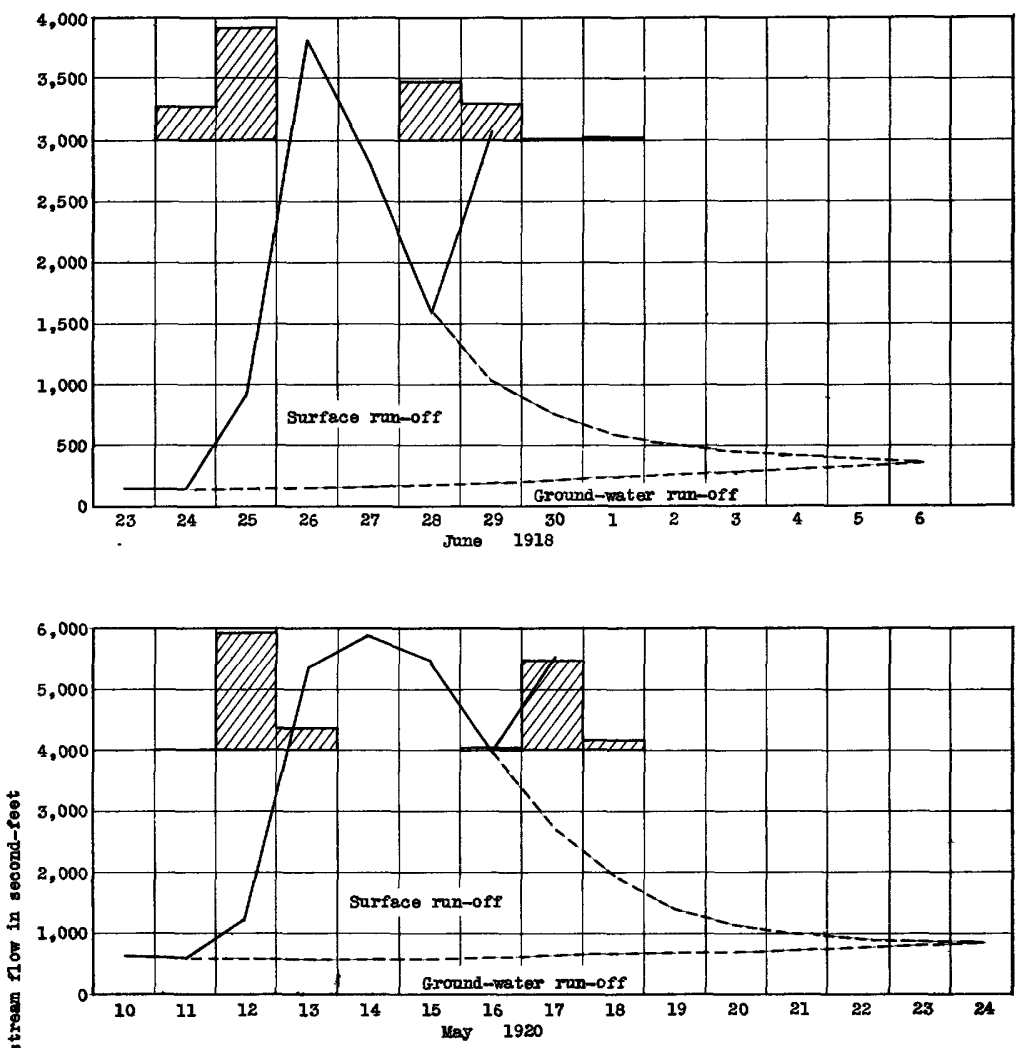

ค
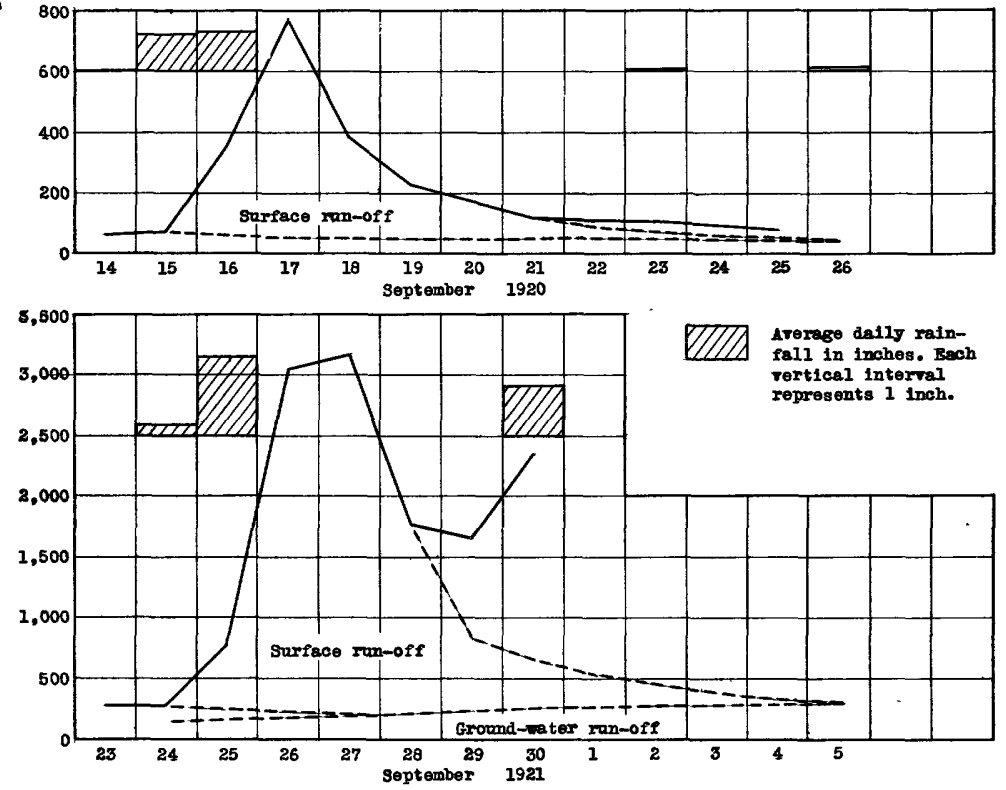

Figare 44.-Ontt hydrographs for Embarsess Biver at ste. Marle, $n 1$. 


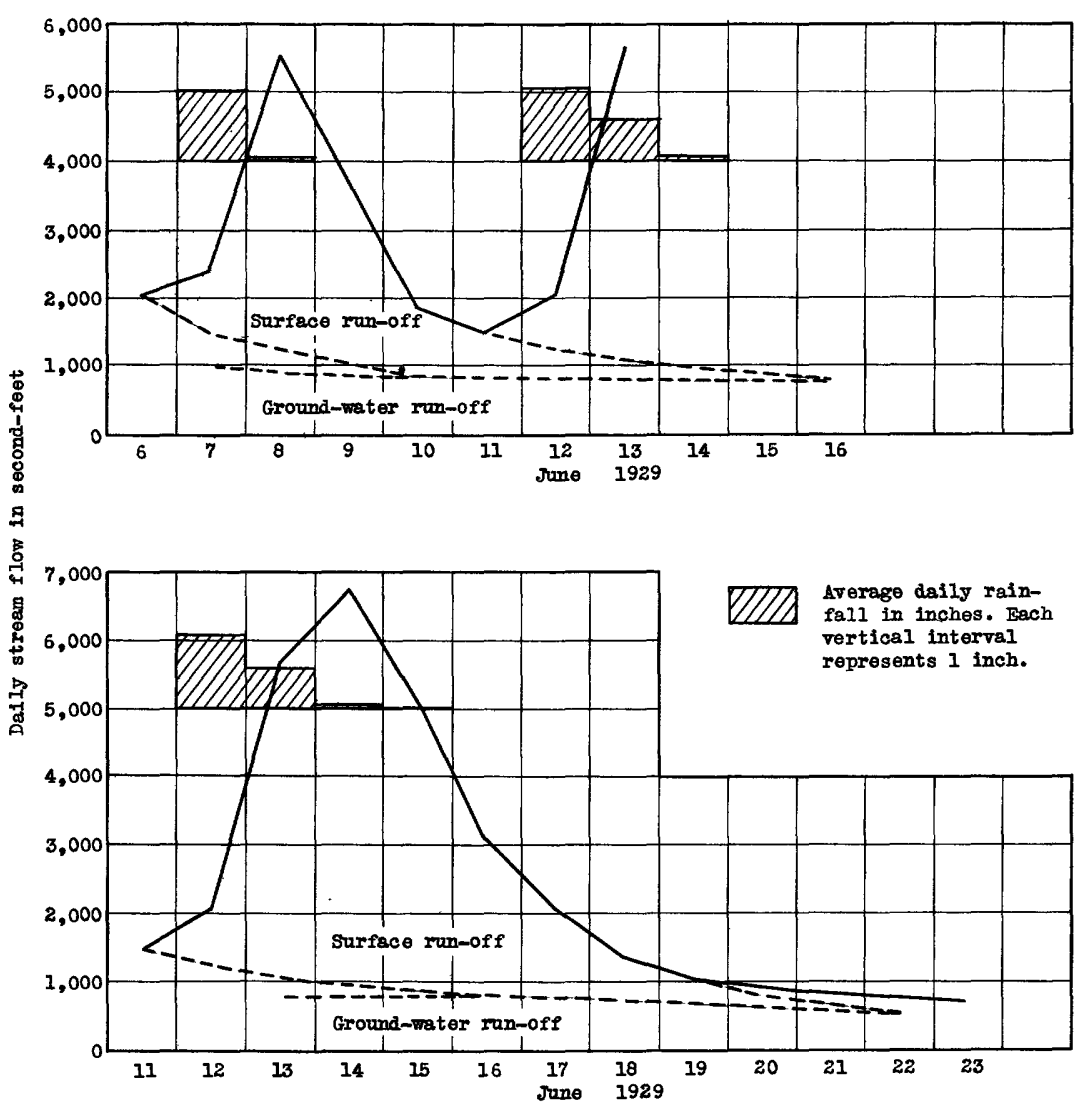

Figure 45,-Unlt hydrographs for mbarrass River at Ste. Marie, IIl. 
Table 36.- Surface run-off from unit storms,

Embarrass River at Ste. Marie, Ill.

\begin{tabular}{|c|c|c|c|c|}
\hline \multirow{2}{*}{ Storm } & \multicolumn{2}{|c|}{$\begin{array}{c}\text { Precipitation } \\
\text { (inches) }\end{array}$} & $\begin{array}{c}\text { Surface run-off } \\
\text { (Inches) }\end{array}$ & $\begin{array}{c}\text { Ratio of } \\
\text { surface run- } \\
\text { off to weighted } \\
\text { precipitation }\end{array}$ \\
\cline { 2 - 4 } & Average & $\begin{array}{c}\text { Geometrical1y } \\
\text { weighted }\end{array}$ & & 0.09 \\
June 25, 1918 & 2.36 & 2.86 & 0.26 & .21 \\
Iay 12,1920 & 2.35 & 2.79 & .58 & .03 \\
Sept. 15, 1920 & 1.26 & 1.35 & .04 & .12 \\
Sept. 25, 1921 & 1.50 & 1.89 & .23 & .25 \\
June 7, 1929 & 1.08 & .99 & .25 & .30 \\
June 12, 1929 & 1.83 & 1.66 & .49 & 49 \\
\hline
\end{tabular}

Table 37 gives the daily percentages for the six distribution graphs, and figure 46 shows the superimposed distribution graphs. An average distribution graph for the stations is $5,25,29,18,10,6,3,2$, 1, 1 percent. The first figure for each graph is the percentage of surface $r u n-o f f$ for the calendar day on which most of the rainfall occurred; other figures for succeeding days.

Table 37.- Distribution graphs for storms in

mbarrass River Basin acove Ste. Marie, III.

\begin{tabular}{l|r|r|r|r|r|r|r|r|r|r|r|r|}
\hline June 25, 1918 & 7.1 & 33.7 & 24.5 & 13.2 & 7.9 & 5.1 & 3.2 & 2.2 & 1.5 & 1.0 & 0.6 & - \\
May 12, 1920 & 2.8 & 19.8 & 22.1 & 20.3 & 14.0 & 8.8 & 5.4 & 3.0 & 1.9 & 1.0 & .6 & 0.3 \\
Sept. 15, 1920 & 0 & 16.6 & 39.9 & 18.2 & 9.7 & 6.9 & 3.9 & 2.4 & 1.3 & .8 & .3 & - \\
Sept. 25, 1921 & 5.5 & 30.1 & 31.6 & 16.5 & 6.3 & 4.1 & 2.8 & 1.8 & 1.0 & .3 & - & - \\
June 7, 1929 & 8.8 & 41.0 & 25.8 & 9.4 & 6.2 & 3.9 & 2.6 & 1.5 & .8 & - & - & - \\
June 12, 1929 & 4.0 & 22.5 & 28.5 & 20.8 & 11.4 & 6.4 & 3.1 & 1.8 & 1.0 & .5 & - & - \\
\hline
\end{tabular}

Skunk River Basin above Augusta, Iowa

The Skunk River rises at about 1,200 feet above sea level near the northeast corner of Hamilton County, Iowa, in the region of risconsin drift. The basin above Augusta (fig. 47) is 10 g and narrow and covers 4,290 square miles. The length of the stream above Augusta is about 270 miles. The basin is about 170 miles long, and the average width is 25 miles. The North Skunk River and Cedar Creok are the principal tributaries and flow in the same general direction as the main stream.

In the upper 130 miles the river drops at an average rate of 3.4 feet to the mile; the 140 miles next above the station has an average gradlent of 1.4 feet to the mile. The station at Augusta is about 12 miles 


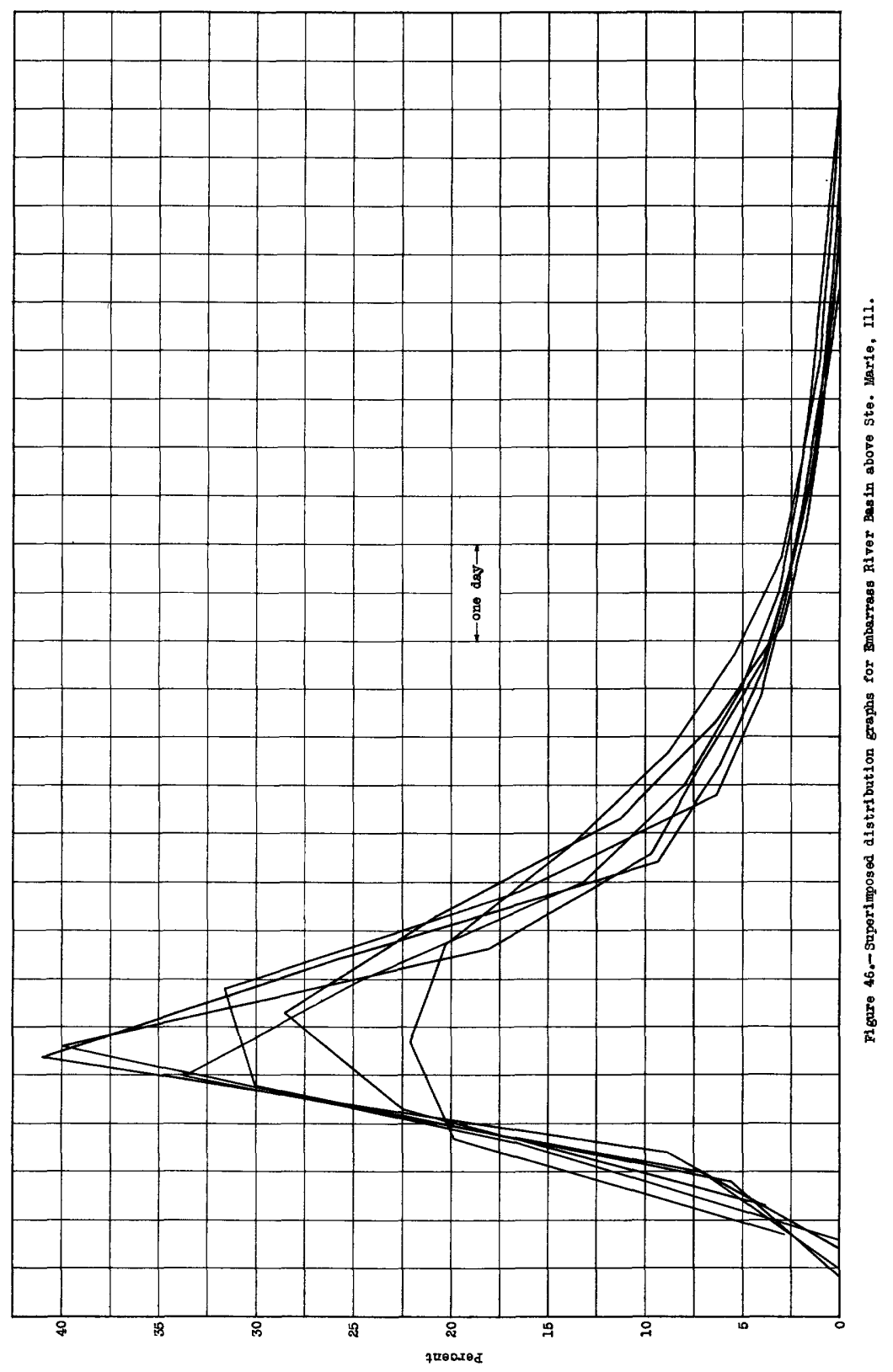


above the mouth, where the river discharges into the Mississippi River pool above the Keokuk Dam.

About 9 percent of the basin is forest, 62 percent is cultivated, and 29 percent is grass land.

The United States Geological Survey chain gage was installed on the highway bridge near Augusta in June 1915. The chain was of iron and the links gave a good deal of trovble. It was replaced by a standard copper chain in July 1915. The gage is read to half tenths once a day. The zero of the gage is 528.6 feet above sea level, Memphis datum. The records are fair with slight regulation at low stages.

Normally 14 or 15 stations are avallable for the determination of daily precipitation. Figure 47 locates the United States Weather Bureau stations on an outiline of the drainage basin.

Table 38 gives the daily precipitation recorded at the Weather Bureau stations for the storms that produced the unit hydrographs shown in figures 48 and 49.

Table 38.- Storms studied in connection with unit

hydrographs for the Skunk River Basin above Augusta, Iowe

(Precipitation, in inches, measured in the afternoon except at stations marked $*$, where it was measured in the morning.)

\begin{tabular}{|c|c|c|c|c|c|c|c|}
\hline \multirow[b]{2}{*}{ Station } & \multicolumn{7}{|c|}{ July 1924} \\
\hline & 22 & 24 & 25 & 27 & 28 & 29 & 30 \\
\hline $\begin{array}{l}\text { Ames } \\
\text { Baxter } \\
\text { Boone * } \\
\text { Grinnell } \\
\text { Monroe } \\
\text { Webster City } \\
\text { Burlington * } \\
\text { Fairfield } \\
\text { Mount Pleasant } \\
\text { Oskaloosa } \\
\text { Ottumwa } \\
\text { Sigourney } \\
\text { Stockport } \\
\text { Washington }\end{array}$ & $\begin{array}{c}\overline{-} \\
0.05 \\
- \\
- \\
\overline{92} \\
.01 \\
.67 \\
\overline{72} \\
. \overline{22} \\
.60\end{array}$ & $\begin{array}{r}0.15 \\
.30 \\
.13 \\
4.40 \\
.63 \\
.92 \\
2.27 \\
2.53 \\
3.49 \\
.75 \\
1.10 \\
2.70 \\
1.59 \\
5.80\end{array}$ & $\begin{array}{l}= \\
= \\
= \\
0 . \\
= \\
= \\
= \\
= \\
=\end{array}$ & $\begin{array}{c}0.25 \\
- \\
= \\
\overline{.04} \\
\overline{0} \\
- \\
- \\
- \\
.05 \\
-\end{array}$ & $\begin{array}{c}- \\
0.30 \\
.55 \\
.14 \\
.20 \\
.03 \\
- \\
. \overline{0} \\
.06 \\
.03 \\
.12 \\
.07\end{array}$ & $\begin{array}{r}0.16 \\
.80 \\
.54 \\
.70 \\
.73 \\
.90 \\
.59 \\
.47 \\
.59 \\
.72 \\
1.13 \\
.66 \\
1.00\end{array}$ & $\begin{array}{c}- \\
0.04 \\
- \\
- \\
.54 \\
.02 \\
.05 \\
- \\
- \\
. \\
.39 \\
.23\end{array}$ \\
\hline Average & $\begin{array}{r}4.19 \\
.30\end{array}$ & $\begin{array}{r}26.76 \\
1.91\end{array}$ & $\begin{array}{l}.42 \\
.03\end{array}$ & $\begin{array}{l}.37 \\
.03\end{array}$ & $\begin{array}{r}2.50 \\
.18\end{array}$ & $\begin{array}{r}8.99 \\
.64\end{array}$ & $\begin{array}{r}1.27 \\
.09\end{array}$ \\
\hline
\end{tabular}


Table 38.- Storms studied in connection with unit hydrographs

for the Skunk River Basin above Augusta, Iowa--Continued

(Precipitation, in inches, measured in the afternoon except at stations marked *, where it was measured in the morning.)

\begin{tabular}{|c|c|c|c|c|c|c|c|}
\hline \multirow[b]{2}{*}{ Station } & \multicolumn{7}{|c|}{ May 1927} \\
\hline & 17 & 18 & 19 & 20 & 21 & 22 & 23 \\
\hline $\begin{array}{l}\text { Ames } \\
\text { Baxter } \\
\text { Boone * } \\
\text { Grinnell } \\
\text { Monroe } \\
\text { Webster City } \\
\text { Burlington * } \\
\text { Fairfield } \\
\text { Mount Pleasant } \\
\text { Oskaloosa } \\
\text { Ottumwa } \\
\text { Sigourney } \\
\text { Stockport } \\
\text { Washington }\end{array}$ & $\begin{array}{r}1.23 \\
.19 \\
.13 \\
. \\
1.00 \\
.01 \\
.01 \\
.05 \\
= \\
.38 \\
.13\end{array}$ & $\begin{array}{r}0.66 \\
.82 \\
.04 \\
.56 \\
.63 \\
.92 \\
.03 \\
2.40 \\
1.93 \\
.36 \\
2.23 \\
.40 \\
2.56 \\
.67\end{array}$ & $\begin{array}{l}\overline{-} \\
0 . \overline{5} \\
\overline{-} \\
\overline{-} \\
2 . \overline{17} \\
\overline{-} \\
\overline{-} \\
\overline{-} \\
=\end{array}$ & $\begin{array}{c}0.76 \\
.01 \\
= \\
= \\
= \\
= \\
= \\
= \\
= \\
=\end{array}$ & $\begin{array}{c}\overline{-} \\
0.56 \\
= \\
= \\
= \\
= \\
= \\
=\end{array}$ & $\begin{array}{l}0.06 \\
.15 \\
. \\
.32 \\
.27 \\
.05 \\
.06 \\
.50 \\
.47 \\
.39 \\
.36 \\
.40 \\
.28 \\
.30\end{array}$ & $\begin{array}{r}0.92 \\
1.09 \\
.50 \\
1.18 \\
1.39 \\
1.21 \\
.64 \\
.75 \\
.29 \\
.64 \\
.08 \\
.66 \\
.19 \\
.88\end{array}$ \\
\hline \multirow[t]{3}{*}{ Average } & $\begin{array}{r}3.13 \\
.22\end{array}$ & $\begin{array}{r}14.21 \\
1.02\end{array}$ & $\begin{array}{r}2.72 \\
.19\end{array}$ & $\begin{array}{r}1.44 \\
.10\end{array}$ & $\begin{array}{r}.56 \\
.04\end{array}$ & $\begin{array}{r}3.61 \\
.26\end{array}$ & $\begin{array}{r}10.42 \\
.74\end{array}$ \\
\hline & \multicolumn{7}{|c|}{ June 1927} \\
\hline & 2 & 3 & 4 & 7 & 8 & 9 & 10 \\
\hline \multirow[t]{2}{*}{$\begin{array}{l}\text { Ames } \\
\text { Baxter } \\
\text { Boone * } \\
\text { Grinnell } \\
\text { Monroe } \\
\text { Webster City } \\
\text { Burlington * } \\
\text { Fairfield } \\
\text { Mount Pleasant } \\
\text { Oskaloosa } \\
\text { Ottumwa } \\
\text { Sigourney } \\
\text { Stoclrport } \\
\text { Washington }\end{array}$} & $\begin{array}{c}- \\
- \\
0.01 \\
.34 \\
. \\
.15 \\
.10 \\
.76 \\
.14 \\
.55 \\
.17 \\
1.20\end{array}$ & $\begin{array}{r}0.08 \\
.13 \\
.02 \\
.22 \\
.41 \\
.03 \\
.15 \\
1.50 \\
.43 \\
.19 \\
.70 \\
.72 \\
2.00 \\
.63\end{array}$ & $\begin{array}{c}- \\
0.08 \\
- \\
- \\
1.38 \\
.22 \\
1.95 \\
.03 \\
.10 \\
.08 \\
.18 \\
1.13\end{array}$ & $\begin{array}{c}0.04 \\
= \\
.16 \\
= \\
= \\
= \\
= \\
= \\
=\end{array}$ & $\begin{array}{c}0 . \overline{61} \\
\overline{-} \\
.53 \\
.55 \\
= \\
= \\
.13 \\
. \overline{06} \\
.05\end{array}$ & $\begin{array}{r}0.15 \\
.24 \\
1.14 \\
= \\
= \\
= \\
= \\
= \\
= \\
=\end{array}$ & $\begin{array}{c}0 . \overline{14} \\
. \\
.20 \\
= \\
.06 \\
.05 \\
.12 \\
.03 \\
= \\
= \\
=\end{array}$ \\
\hline & $\begin{array}{r}3.42 \\
.24\end{array}$ & $\begin{array}{r}7.21 \\
.52\end{array}$ & $\begin{array}{r}5.20 \\
.37\end{array}$ & $\begin{array}{l}.20 \\
.01\end{array}$ & $\begin{array}{r}1.63 \\
.12\end{array}$ & $\begin{array}{r}1.53 \\
.11\end{array}$ & $\begin{array}{r}.60 \\
.04\end{array}$ \\
\hline \multicolumn{8}{|c|}{ July 1928} \\
\hline \multicolumn{2}{|l|}{ Station } & 4 & 8 & & & 10 & 11 \\
\hline $\begin{array}{l}\text { Ames } \\
\text { Baxter } \\
\text { Boone * } \\
\text { Grinnell } \\
\text { Monroe } \\
\text { Webster City } \\
\text { Burlington } \\
\text { Fairfield } \\
\text { Mount Pleasa } \\
\text { Oskaloosa }\end{array}$ & & $\begin{array}{r}1.10 \\
1.17 \\
1.16 \\
1.02 \\
1.22 \\
.30 \\
.47 \\
2.12 \\
1.46 \\
1.35\end{array}$ & $\begin{array}{l}0.15 \\
.24 \\
.23 \\
.24 \\
.22 \\
.09 \\
.77 \\
.32 \\
.70\end{array}$ & & & $\begin{array}{l}0 . \overline{0} \\
.03 \\
.02 \\
.64 \\
= \\
= \\
.15 \\
.33\end{array}$ & $\begin{array}{c}- \\
0.42 \\
.03 \\
.04 \\
.07 \\
.20 \\
= \\
=\end{array}$ \\
\hline
\end{tabular}


Table 38.- Storms studied in connection with unit hydrographs

for the Skunk River Basin above Augusta, Iowa--Continued

(Precipitation, in inches, measured in the afternoon except at stations marked $*$, where it was measured in the morning.)

\begin{tabular}{|c|c|c|c|c|c|c|c|c|c|c|}
\hline \multirow{2}{*}{\multicolumn{2}{|c|}{ Station }} & \multicolumn{9}{|c|}{ July 1928} \\
\hline & & \multicolumn{2}{|r|}{4} & \multicolumn{2}{|l|}{8} & 9 & \multicolumn{2}{|c|}{10} & \multicolumn{2}{|l|}{11} \\
\hline \multicolumn{2}{|l|}{$\begin{array}{l}\text { Ottumwa } \\
\text { Sigourney } \\
\text { Stockport } \\
\text { Washington }\end{array}$} & \multicolumn{2}{|c|}{$\begin{array}{r}1.01 \\
.91 \\
1.37 \\
3.40\end{array}$} & \multicolumn{2}{|c|}{$\begin{array}{r}0.26 \\
.91 \\
.39 \\
.28\end{array}$} & $\frac{-}{.17}$ & \multicolumn{2}{|c|}{$\begin{array}{r}0.02 \\
.05 \\
.03 \\
1.08\end{array}$} & \multicolumn{2}{|l|}{$\begin{array}{c}0.07 \\
= \\
=\end{array}$} \\
\hline Average & & \multicolumn{2}{|c|}{$\begin{array}{r}18.06 \\
1.29\end{array}$} & \multicolumn{2}{|l|}{$\begin{array}{r}4.74 \\
.34\end{array}$} & $\begin{array}{l}.63 \\
.04\end{array}$ & \multicolumn{2}{|c|}{$\begin{array}{r}2.33 \\
.17\end{array}$} & \multicolumn{2}{|c|}{$\begin{array}{l}.83 \\
.06\end{array}$} \\
\hline \multirow[b]{2}{*}{ Station } & \multicolumn{5}{|c|}{ August - September 1931} & \multicolumn{5}{|c|}{ June - July 1932} \\
\hline & 30 & 31 & 1 & 2 & 3 & 25 & 26 & 27 & 1 & 3 \\
\hline $\begin{array}{l}\text { Ames } \\
\text { Baxter } \\
\text { Boone * } \\
\text { Grinnell } \\
\text { Monroe } \\
\text { Newton } \\
\text { Webster City } \\
\text { Burlington * } \\
\text { Fainfleld } \\
\text { Mount Pleasant } \\
\text { Oskaloosa } \\
\text { Ottumwa } \\
\text { Sigourney } \\
\text { Stockport } \\
\text { Washington }\end{array}$ & $\begin{array}{c}0.02 \\
.15 \\
= \\
= \\
.12 \\
= \\
.04 \\
.04 \\
= \\
= \\
=\end{array}$ & $\begin{array}{c}0 . \overline{03} \\
\overline{-} \\
1 . \overline{28} \\
.03 \\
.03 \\
\overline{11} \\
\overline{.} \\
. \overline{3} 8 \\
.04 \\
-\end{array}$ & $\begin{array}{l}0.49 \\
1.02 \\
.59 \\
1.86 \\
1.07 \\
1.72 \\
2.65 \\
3.29 \\
1.65 \\
2.99 \\
3.70 \\
2.55 \\
2.80 \\
2.10\end{array}$ & $\begin{array}{c}= \\
0 \\
0.07 \\
= \\
\overline{0} \\
= \\
= \\
= \\
=\end{array}$ & $\begin{array}{l}0.11 \\
.08 \\
.04 \\
.07 \\
.16 \\
.07 \\
- \\
.04 \\
.02 \\
.15 \\
.15 \\
.05 \\
-\end{array}$ & $\begin{array}{l}- \\
0 . \overline{62} \\
.03 \\
- \\
.05 \\
= \\
= \\
. \overline{7} \\
- \\
.65 \\
=\end{array}$ & $\begin{array}{r}0.59 \\
1.14 \\
.68 \\
.32 \\
.54 \\
.98 \\
.36 \\
.02 \\
3.25 \\
2.00 \\
5.45 \\
2.28 \\
2.55 \\
.32 \\
2.08\end{array}$ & $\begin{array}{l}0.02 \\
.12 \\
.09 \\
.65 \\
- \\
.14 \\
.03 \\
.07 \\
= \\
=\end{array}$ & $\begin{array}{l}- \\
- \\
= \\
= \\
- \\
0.16 \\
.12 \\
.12 \\
- \\
-\end{array}$ & $\begin{array}{r}0.89 \\
.89 \\
.75 \\
.72 \\
.79 \\
.77 \\
.75 \\
.11 \\
2.29 \\
1.83 \\
1.02 \\
1.67 \\
.96 \\
1.03 \\
.92\end{array}$ \\
\hline Average & $\begin{array}{l}.37 \\
.03\end{array}$ & $\begin{array}{r}1.90 \\
.14\end{array}$ & $\begin{array}{r}28.48 \\
1.90\end{array}$ & $\begin{array}{l}.16 \\
.01\end{array}$ & .94 & $\begin{array}{r}2.11 \\
.14\end{array}$ & $\begin{array}{r}22.56 \\
1.50\end{array}$ & $\begin{array}{r}1.12 \\
.07\end{array}$ & $\begin{array}{l}.40 \\
.03\end{array}$ & $\begin{array}{r}15.39 \\
1.03\end{array}$ \\
\hline
\end{tabular}

Table 39 gives the surface run-off from the unit storms and the approximate value of the precipitation that caused the run-off.

Table 39.- Surface run-off from unit storms,

Skunk River at Augusta, Iowa

\begin{tabular}{|c|c|c|c|}
\hline Storm & $\begin{array}{c}\text { Average of precipi- } \\
\text { tation at stations } \\
\text { (inches) }\end{array}$ & $\begin{array}{c}\text { Surface run-off } \\
\text { (inches) }\end{array}$ & $\begin{array}{c}\text { Ratio of } \\
\text { surface mun- } \\
\text { off to aver- } \\
\text { age precipi- } \\
\text { tation }\end{array}$ \\
\hline Ju1y 24, 1924 & 1.94 & 0.75 & 0.39 \\
May 18, 1927 & 1.43 & .34 & .24 \\
June 3, 1927 & 1.13 & .33 & .29 \\
Ju1y 4, 1928 & 1.29 & .42 & .33 \\
Aug. 31, 1937 & 2.07 & .37 & .29 \\
June 26, 1932 & 1.71 & .49 & .29 \\
\hline
\end{tabular}




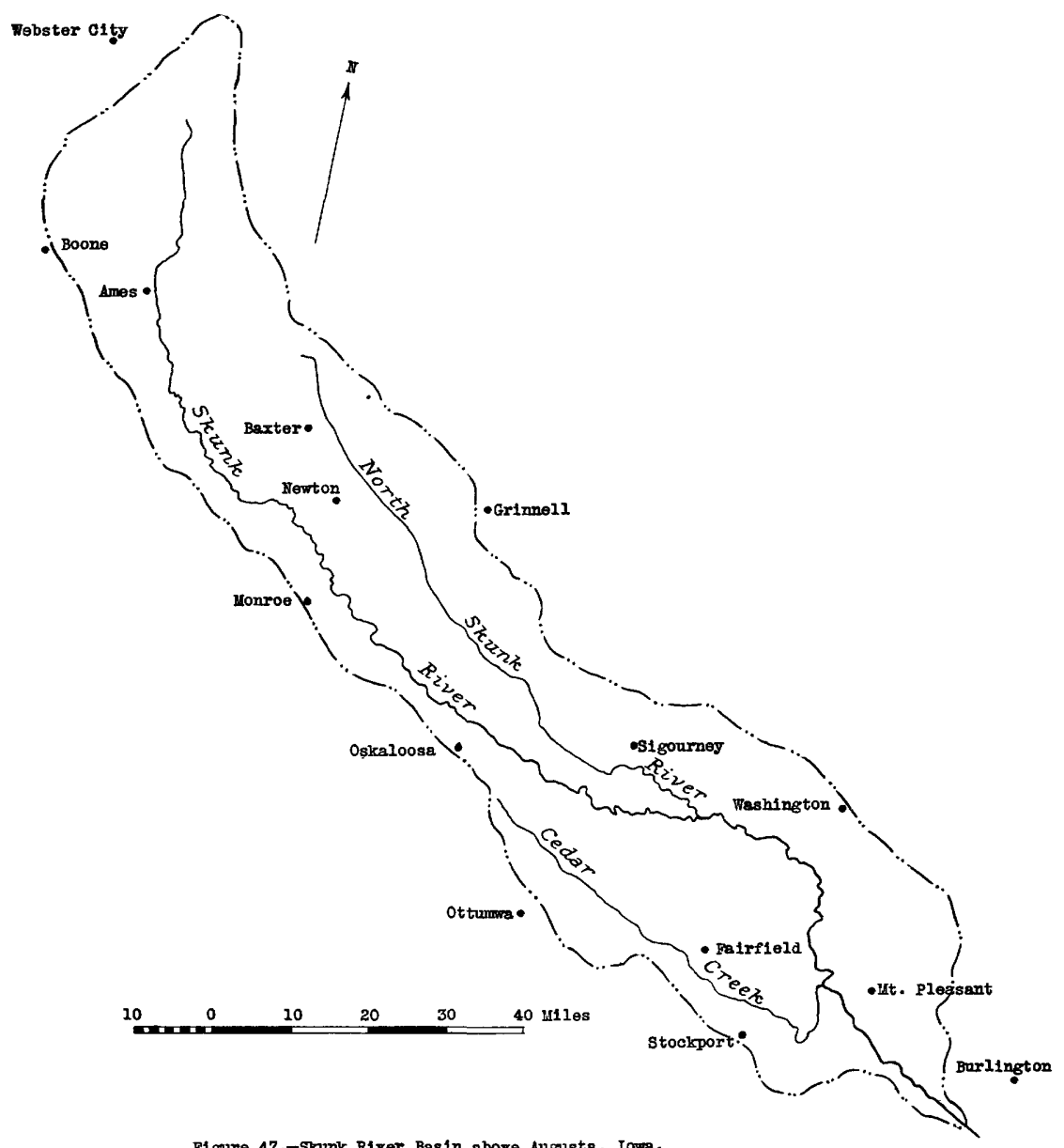

Figure 47.-Skumk River Basin above Augusta, Iowa. Drainage area 4,290 square miles 

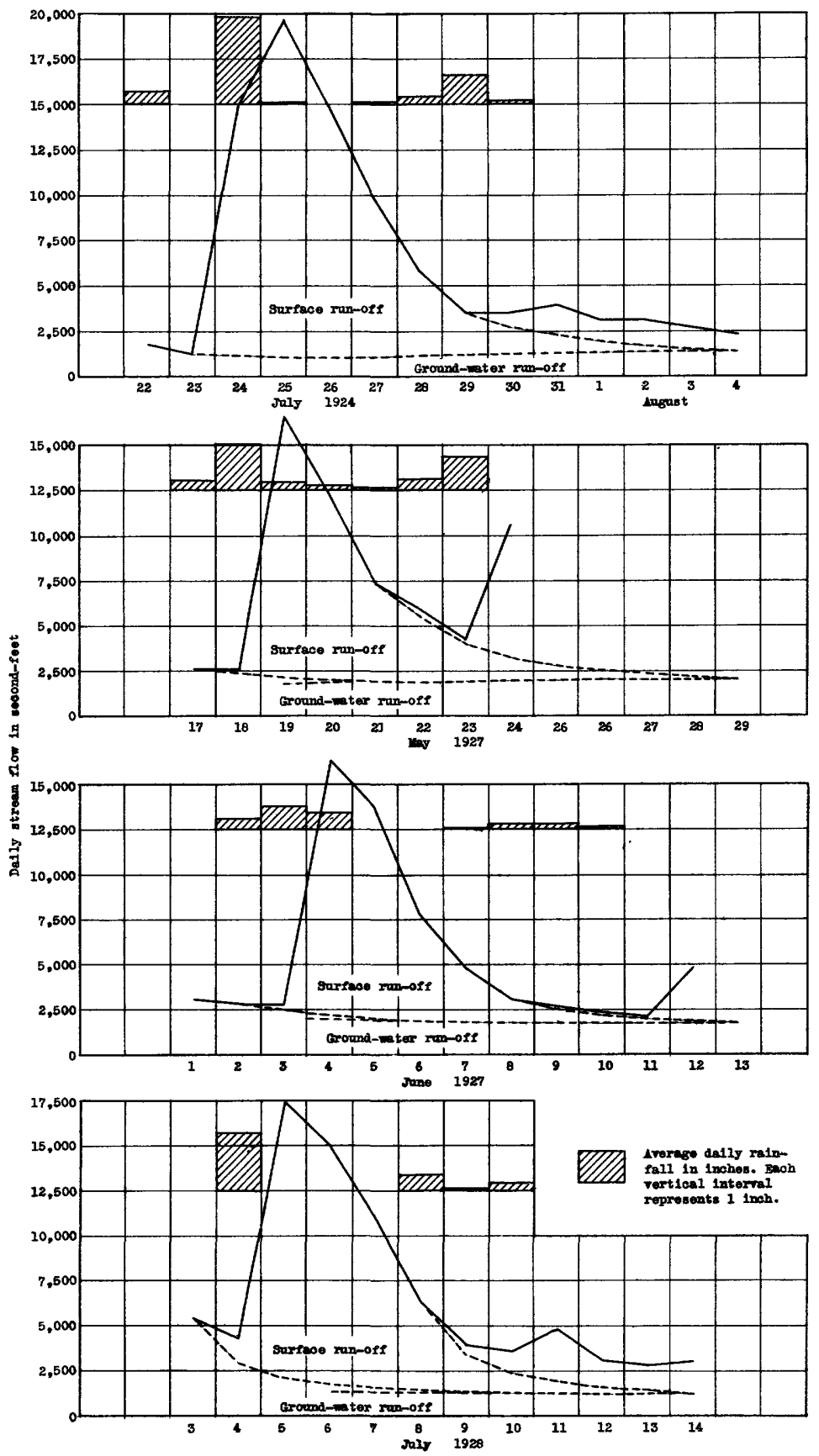

F1gare 48,-Thit hodrographs for Mank B1ver at Angusta, IOwa.

$50550-35-11$ 


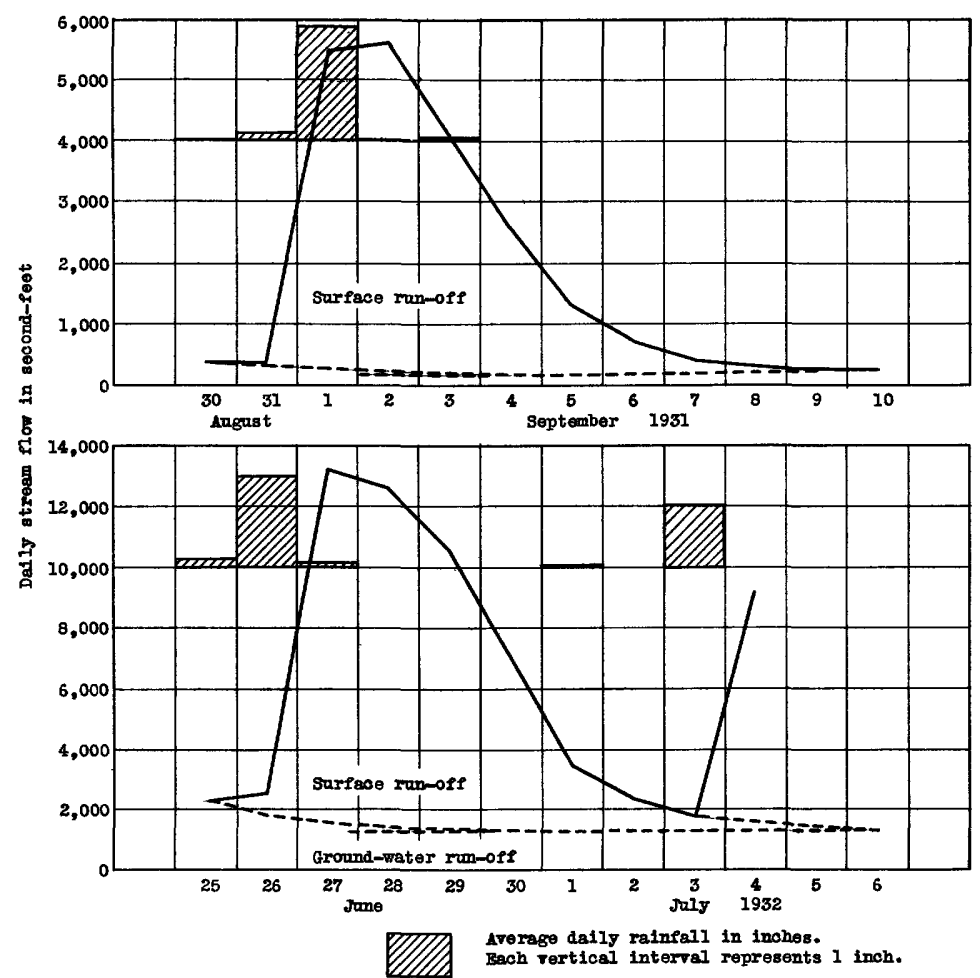

Figrare 49,-Unit hydrographs for Skomk River at Augusta, Iowa. 
Table 40 gives the daily percentages for the six distribution graphs, and figure 50 shows the graphs superimposed. The average distribution graph determined for the basin is $1,32,27,18,11,5,3,2,1$ percent. The average graph reflects the long, narrow basin and the tributary drainage. The graph rises rapidly to its peak and then tapers out gradualiy. The first figure for each distribution graph is the percentage of surface run-off for the calendar day on which most of the rainfall occurred; other figures for succeeding days.

\section{Table 40.- Distribution graphs for storms in \\ Skunk River Basin above Augusta, Iorra}

\begin{tabular}{l|r|r|r|r|r|r|r|r|r|r|r|}
\hline July 24, 1924 & 21.3 & 28.7 & 21.1 & 13.2 & 7.0 & 3.5 & 2.1 & 1.5 & 0.9 & 0.5 & 0.2 \\
May 18, 1927 & .7 & 37.2 & 26.1 & 13.8 & 9.2 & 5.3 & 3.5 & 2.0 & 1.2 & .7 & .3 \\
June 3, 1927 & .9 & 37.4 & 31.0 & 15.5 & 7.8 & 3.5 & 1.9 & 1.1 & .6 & .3 & - \\
Ju1y 4, 1928 & 2.6 & 31.6 & 27.4 & 19.4 & 10.1 & 4.2 & 2.3 & 1.4 & .7 & .3 & - \\
Aug. 31, 1931 & .4 & 27.6 & 28.4 & 20.5 & 12.6 & 5.9 & 2.7 & 1.1 & .6 & .2 & - \\
June 26, 1932 & 1.8 & 27.3 & 26.3 & 21.6 & 13.6 & 5.0 & 2.3 & 1.1 & .7 & .3 & - \\
\hline
\end{tabular}

Susquehanna River Basin above Towanda, $\mathrm{Pa}$.

The Susquehanna River rises in Otsego Lake, in the Catskill Mountains, in otsego County, N. Y., at about 1,193 feet above sea level. It flows in a southerly direction through Otsego, Chenango, and Broome Counties, N. Y., into Susquehanna County, $\mathrm{Pa}$. It then flows in a vest northwesterly direction, reenters New York, and flows westward through Broome and Tioga Counties, whence it turns south and again flows into Pennsylvania. The river distance from the State boundary to the Towanda station is about 20 miles. The Chemung River, flowing from the west and draining about 2,500 square miles, empties into the Susquehanna about 13 miles above the station. (See fig. 51.)

The drainage area above Towanda is 7,770 square miles; the length is about 170 miles, and the average width about 46 miles. The stream, drops about 500 feet in the $170 \mathrm{miles}$ above Towanda. The zero of the gage is 693.4 feet above mean sea level. The part of the basin in New York is rolling and in places broken country.

Gage heights at the stations have been observed by the United States Weather Bureau since October 1892. The Water Supply Commission of Pennsylvania, in its annual reports, has published discharge measurements and gage heights beginning January 29, 1914, and dally discharge since 


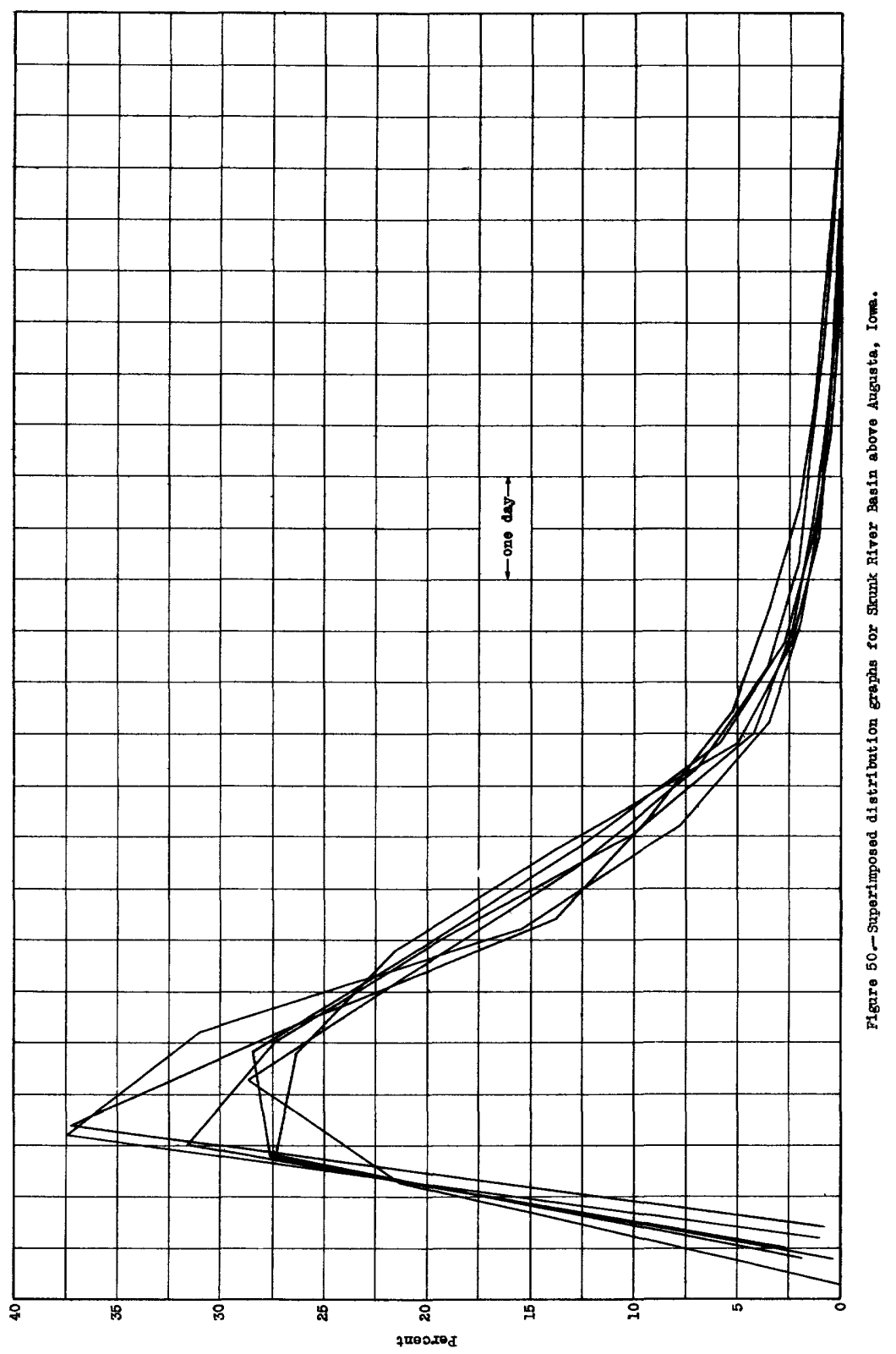


October 1918. The stage-discharge relation is probably permanent except as affected by $1 \mathrm{ce}$.

The gage is a standard chain gage attached to the downstream side of the Bridge street Bridge at Towanda and read to hundredths twice da1ly.

The United States Geological Survey has published the records for October 1918 to October 1920 and October 1931 to date. They are considered fair.

About 22 stations are normally avallable for the determination of daily rainfall. Figure 51 shows the principal drainage and the location of the precipitation stations.

Table 41 gives the daily precipitation recorded at the stations for the storms that produced the unit hydrographs shown in figures 52, 53, and 54.

Table 4l.- Storms studied in connection with unit

hydrographs for the Susquehanna River above Towanda, Pa.

(Precipitation, in inches, measured in the afternoon except at stations marked $*$, where it was measured in the morning, and stations marked **, where it was measured at midnight.)

\begin{tabular}{|c|c|c|c|c|c|c|c|}
\hline \multirow[b]{2}{*}{ Station } & \multicolumn{7}{|c|}{ October 1918} \\
\hline & 3 & 5 & 6 & 7 & 12 & 13 & 14 \\
\hline \multicolumn{8}{|l|}{ New York: } \\
\hline $\begin{array}{l}\text { Addison } \\
\text { Alfred } \\
\text { Angelica } \\
\text { Elmira } \\
\text { Haskinville } \\
\text { Bainbridge * } \\
\text { Binghamton ** } \\
\text { Cazenovia * } \\
\text { Cooperstown } \\
\text { Cortland } \\
\text { De Ruyter } \\
\text { Fishs Eddy } \\
\text { Newark Valley } \\
\text { New Berlin } \\
\text { New Lisbon } \\
\text { Norwich * } \\
\text { Oneonta } \\
\text { Roxbury } \\
\text { Sherburne * } \\
\text { Ithaca ** }\end{array}$ & $\begin{array}{l}0.30 \\
.26 \\
.11 \\
.02 \\
.79 \\
.49 \\
.14 \\
.73 \\
.20 \\
.42 \\
.59 \\
.63 \\
.40 \\
.64 \\
.58 \\
.38 \\
.38 \\
.25 \\
.03\end{array}$ & $\begin{array}{c}= \\
= \\
= \\
0.94 \\
\overline{3} 4 \\
= \\
= \\
= \\
= \\
= \\
= \\
.09\end{array}$ & $\begin{array}{r}0.88 \\
.19 \\
.15 \\
.83 \\
. . \\
1.05 \\
.25 \\
.45 \\
.04 \\
.15 \\
.46 \\
.95 \\
.80 \\
.72 \\
.32 \\
.19 \\
1.31 \\
.20 \\
.11\end{array}$ & $\begin{array}{l}0.10 \\
.14 \\
.07 \\
. \\
.38 \\
.19 \\
.01 \\
.14 \\
= \\
.36 \\
.14 \\
= \\
.01 \\
.58 \\
= \\
= \\
=\end{array}$ & $\begin{array}{l}0.15 \\
.30 \\
.27 \\
.02 \\
.23 \\
\overline{.05} \\
\overline{16} \\
.08 \\
\overline{.0} \\
.05 \\
.12 \\
\overline{.0} \\
.22 \\
.04\end{array}$ & $\begin{array}{c}- \\
0.01 \\
- \\
.09 \\
.01 \\
.02 \\
.04 \\
.07 \\
.37 \\
= \\
= \\
.11 \\
.09 \\
.10 \\
.05 \\
-\end{array}$ & $\begin{array}{l}0.05 \\
.17 \\
.15 \\
.09 \\
.12 \\
.02 \\
.03 \\
.07 \\
.06 \\
.38 \\
.14 \\
.10 \\
.07 \\
.02 \\
.15 \\
.05 \\
.23\end{array}$ \\
\hline $\begin{array}{l}\text { Pennsylvania: } \\
\text { Lawrenceville } \\
\text { Montrose } \\
\text { Towanda } \\
\text { Wellsboro } \\
\text { West Bingham }\end{array}$ & $\begin{array}{l}.58 \\
.70 \\
.70 \\
.86 \\
-\end{array}$ & $\begin{array}{l}- \\
=\end{array}$ & $\begin{array}{l}.80 \\
1.16 \\
1.01 \\
1.28 \\
1.28\end{array}$ & $\begin{array}{r}.010 \\
.08 \\
.16 \\
1.03\end{array}$ & $\begin{array}{l}. \\
.18 \\
.09 \\
.15 \\
.32\end{array}$ & $\frac{-}{.22}$ & $\begin{array}{l}. \overline{10} \\
\overline{-}\end{array}$ \\
\hline Average & $\begin{array}{r}9.39 \\
.38\end{array}$ & $\begin{array}{r}1.38 \\
.06\end{array}$ & $\begin{array}{r}13.35 \\
.53\end{array}$ & $\begin{array}{r}3.49 \\
.14\end{array}$ & $\begin{array}{r}2.43 \\
.10\end{array}$ & $\begin{array}{r}1.20 \\
.05\end{array}$ & $\begin{array}{r}2.00 \\
.08\end{array}$ \\
\hline
\end{tabular}


Table 41.- Storms studied in connection with unit hydrographs

for the Susquehanna River above Towanda, Pa.--Continued.

(Preclpitation, in inches, measured in the afternoon except at stations marked *, where it was measured in the morning, and stations marked **: where it was measured at midnight.)

\begin{tabular}{|c|c|c|c|c|c|c|c|c|c|}
\hline \multirow[b]{2}{*}{ Station } & \multicolumn{9}{|c|}{ Ju1z 1921} \\
\hline & 12 & 13 & 14 & 1 & & 16 & 19 & 20 & $2 I$ \\
\hline \multicolumn{10}{|l|}{ New York: } \\
\hline $\begin{array}{l}\text { Addison } \\
\text { Alfred } \\
\text { Angelica } \\
\text { Elmira } \\
\text { Haskinville } \\
\text { Bainbridge * } \\
\text { Binghamton ** } \\
\text { Cazenovia * } \\
\text { Cortland } \\
\text { De Ruyter } \\
\text { Morrisvilie } \\
\text { New Lisbon } \\
\text { Norwich * } \\
\text { Oneonta } \\
\text { Sherburne * } \\
\text { Ithaca ** }\end{array}$ & $\begin{array}{l}0.06 \\
.09 \\
.14 \\
.10 \\
.22 \\
= \\
= \\
.31 \\
.04 \\
.15 \\
= \\
=\end{array}$ & $\begin{array}{l}0.03 \\
.12 \\
= \\
= \\
= \\
= \\
= \\
= \\
= \\
=\end{array}$ & $\begin{array}{c}- \\
\overline{-} \\
0.56 \\
- \\
1 . \overline{14} \\
2 . \overline{40} \\
.55 \\
. \overline{40} \\
\overline{-} \\
. \overline{24}\end{array}$ & $\begin{array}{l}1: \\
1: \\
1: \\
\text { 1: } \\
\text { 1: } \\
\text { 1: } \\
\text { 1: }\end{array}$ & & $\begin{array}{c}0.05 \\
= \\
= \\
. \\
= \\
= \\
= \\
= \\
.30 \\
.64 \\
-\end{array}$ & $\begin{array}{r}1.04 \\
1.53 \\
1.25 \\
.62 \\
.73 \\
.51 \\
-\overline{0} \\
1.04 \\
.59 \\
.15 \\
.80 \\
- \\
1.24 \\
.53\end{array}$ & $\begin{array}{r}0.01 \\
.11 \\
.05 \\
.65 \\
.18 \\
.99 \\
.22 \\
.70 \\
.12 \\
1.10 \\
.70 \\
.30 \\
1.20 \\
1.20 \\
.22\end{array}$ & $\begin{array}{c}\overline{-} \\
\overline{-} \\
\overline{-} \\
0.62 \\
.58 \\
. \overline{0} \\
. \overline{26} \\
.24 \\
= \\
-\end{array}$ \\
\hline \multicolumn{10}{|l|}{ Pennsyivania: } \\
\hline $\begin{array}{l}\text { Lawrenceville } \\
\text { Montrose } \\
\text { Towanda } \\
\text { Welisboro } \\
\text { West Bingham }\end{array}$ & $\begin{array}{l}- \\
.03 \\
-\end{array}$ & $\begin{array}{l}\overline{3} 4 \\
\overline{-} \\
-\end{array}$ & $\begin{array}{l}. \\
- \\
\overline{20} \\
.\end{array}$ & \multicolumn{2}{|c|}{$\begin{array}{l}.70 \\
.22 \\
.36 \\
.09 \\
.41\end{array}$} & $=$ & $\begin{array}{l}1.40 \\
1.00 \\
.84 \\
1.14 \\
1.43\end{array}$ & $\begin{array}{l}.25 \\
.25 \\
.14 \\
.05\end{array}$ & $=$ \\
\hline Average & $\begin{array}{r}1.14 \\
.05\end{array}$ & $\begin{array}{l}.52 \\
.02\end{array}$ & $\begin{array}{r}5.89 \\
.28\end{array}$ & \multicolumn{2}{|c|}{$\begin{array}{r}19.92 \\
.95\end{array}$} & $\begin{array}{r}1.44 \\
.07\end{array}$ & $\begin{array}{r}15.84 \\
.75\end{array}$ & $\begin{array}{r}8.44 \\
.40\end{array}$ & $\begin{array}{r}1.72 \\
.08\end{array}$ \\
\hline & \multicolumn{9}{|c|}{ Apr11 1923} \\
\hline Station & 3 & 4 & 5 & 6 & 8 & 9 & 10 & 11 & 12 \\
\hline \multicolumn{10}{|l|}{ New York: } \\
\hline $\begin{array}{l}\text { Addison } \\
\text { Alfred } \\
\text { Angelica } \\
\text { Elmira } \\
\text { Haskinvilie } \\
\text { Bainbridge * } \\
\text { Binghamton } * * \\
\text { Cooperstown } \\
\text { Cortland } \\
\text { De Ruyter }\end{array}$ & $\begin{array}{c}0.10 \\
.20 \\
.07 \\
= \\
= \\
=\end{array}$ & $\begin{array}{r}0.23 \\
.21 \\
.20 \\
.89 \\
.19 \\
.22 \\
.15 \\
.03 \\
.10\end{array}$ & $\begin{array}{r}1.05 \\
1.20 \\
1.00 \\
.15 \\
.98 \\
.27 \\
.55 \\
.80 \\
1.79 \\
1.72\end{array}$ & $\begin{array}{c}\overline{-} \\
0 . \overline{0} \\
\overline{7} \\
\overline{7} \\
\overline{-} \\
.05\end{array}$ & $\begin{array}{c}0.01 \\
.03 \\
= \\
= \\
= \\
=\end{array}$ & $\begin{array}{c}- \\
- \\
0 . \\
0.02 \\
.21 \\
- \\
.03 \\
-\end{array}$ & $\begin{array}{l}0.02 \\
.14 \\
.08 \\
.10 \\
.03 \\
.20 \\
=\end{array}$ & $\begin{array}{c}0.02 \\
- \\
.02 \\
.12 \\
.06 \\
.15 \\
.06 \\
.\end{array}$ & $\begin{array}{c}0.12 \\
.17 \\
.15 \\
= \\
.26 \\
= \\
.17\end{array}$ \\
\hline
\end{tabular}


Table 41.- Storms studied in connection with unit hydrographs

for the Susquehanna River above Towanda, Pa.--Continued

(Precipitation, in inches, measured in the afternoon except at stations marked *, where it was measured in the morning, and stations marked **, where it was measured at midnight.)

\begin{tabular}{|c|c|c|c|c|c|c|c|c|c|}
\hline \multirow[b]{2}{*}{ Station } & \multicolumn{9}{|c|}{ April 1923} \\
\hline & 3 & 4 & 5 & 6 & 8 & 9 & 10 & 11 & 12 \\
\hline \multicolumn{10}{|l|}{$\begin{array}{l}\text { New York-- } \\
\text { Continued; }\end{array}$} \\
\hline $\begin{array}{l}\text { New Berlin } \\
\text { New Iisbon } \\
\text { Norwich * } \\
\text { Oneonta } \\
\text { Roxbury } \\
\text { Sherburne * } \\
\text { Ithaca ** }\end{array}$ & $\begin{array}{l}\overline{-} \\
\overline{-} \\
\overline{-} \\
0.06\end{array}$ & $\begin{array}{c}0.09 \\
.05 \\
- \\
.12 \\
1.10\end{array}$ & $\begin{array}{r}1.25 \\
.77 \\
.43 \\
1.18 \\
.75 \\
.24 \\
.49\end{array}$ & $\begin{array}{l}\overline{-} \\
0 . \overline{62} \\
\overline{10} \\
.54\end{array}$ & $\begin{array}{c}0.05 \\
- \\
\overline{10} \\
.02\end{array}$ & $\begin{array}{c}0.08 \\
= \\
= \\
.05 \\
-\end{array}$ & $\begin{array}{c}0.05 \\
= \\
= \\
=\end{array}$ & $\begin{array}{l}0.13 \\
.25 \\
.13 \\
.15 \\
.30 \\
.26 \\
.06\end{array}$ & $\begin{array}{c}-\overline{04} \\
- \\
\overline{25} \\
.14 \\
-\end{array}$ \\
\hline \multicolumn{10}{|l|}{ Pennsylvania: } \\
\hline $\begin{array}{l}\text { Lawrenceville } \\
\text { Montrose } \\
\text { Towanda } \\
\text { Wellsboro } \\
\text { West Bingham }\end{array}$ & $\begin{array}{l}- \\
\overline{-} \\
.12\end{array}$ & $\begin{array}{l}- \\
.04 \\
.23 \\
.20\end{array}$ & $\begin{array}{r}1.20 \\
.84 \\
.47 \\
1.02 \\
1.30\end{array}$ & $\begin{array}{l}= \\
=\end{array}$ & $\begin{array}{l}= \\
=\end{array}$ & $\begin{array}{l}- \\
-\end{array}$ & $\begin{array}{c} \pm \\
\overline{-} \\
.05\end{array}$ & $\begin{array}{l}\overline{-} \\
\overline{0} \\
\overline{-}\end{array}$ & $\begin{array}{l}- \\
\overline{-} \\
.15\end{array}$ \\
\hline Average & $\begin{array}{l}.55 \\
.02\end{array}$ & $\begin{array}{r}4.05 \\
.18\end{array}$ & $\begin{array}{r}19.45 \\
.88\end{array}$ & $\begin{array}{r}2.05 \\
.09\end{array}$ & .26 & $\begin{array}{l}.39 \\
.02\end{array}$ & $\begin{array}{l}.67 \\
.03\end{array}$ & $\begin{array}{r}1.73 \\
.08\end{array}$ & $\begin{array}{r}1.45 \\
.07\end{array}$ \\
\hline \multirow[b]{2}{*}{ Station } & \multicolumn{9}{|c|}{ September - October 1924} \\
\hline & \multicolumn{2}{|l|}{29} & 30 & 1 & & 2 & \multicolumn{2}{|c|}{7} & 8 \\
\hline \multicolumn{10}{|l|}{ New York: } \\
\hline $\begin{array}{l}\text { Addison } \\
\text { Alfred } \\
\text { Angelica } \\
\text { Elmira ** } \\
\text { Haskinville } \\
\text { Bainbridge * } \\
\text { Binghamton ** } \\
\text { Cooperstown } \\
\text { Cortland } \\
\text { Delhl } \\
\text { De Ruyter } \\
\text { Morrisville } \\
\text { New Berlin } \\
\text { Norwich * } \\
\text { Oneonte } \\
\text { Roxbury } \\
\text { Sherburne * } \\
\text { Ithaca ** }\end{array}$ & \multicolumn{2}{|c|}{$\begin{array}{r}2.00 \\
2.53 \\
2.10 \\
2.15 \\
.14 \\
2.04 \\
1.96 \\
3.12 \\
.30 \\
1.60 \\
.90 \\
.90 \\
.18 \\
.75 \\
.23 \\
1.90 \\
3.14\end{array}$} & $\begin{array}{l}1.57 \\
1.45 \\
1.12 \\
4.00 \\
1.56 \\
2.68 \\
2.95 \\
1.55 \\
.80 \\
4.28 \\
2.82 \\
2.30 \\
2.00 \\
3.34 \\
3.52 \\
3.30 \\
1.80 \\
1.33\end{array}$ & \multicolumn{2}{|c|}{$\begin{array}{c}0 . \overline{05} \\
.05 \\
\overline{06} \\
1.44 \\
\overline{-} \\
\overline{28} \\
\overline{-} \\
1.20 \\
1.22 \\
.25 \\
1.80 \\
-\end{array}$} & $\begin{array}{l}= \\
= \\
= \\
= \\
= \\
= \\
= \\
= \\
= \\
=\end{array}$ & \multicolumn{2}{|c|}{$\begin{array}{l}0.15 \\
.10 \\
.10 \\
.11 \\
.07 \\
.70 \\
.20 \\
.24 \\
.07 \\
.10 \\
= \\
.06 \\
.03 \\
.12\end{array}$} & $\begin{array}{c}= \\
= \\
\overline{0} \\
\overline{26} \\
\overline{-} \\
.07 \\
\overline{0} \\
.29 \\
. \overline{11} \\
\overline{-} \\
-\end{array}$ \\
\hline \multicolumn{10}{|l|}{ Pennsylvania: } \\
\hline \multirow[t]{2}{*}{$\begin{array}{l}\text { Lawrenceville } \\
\text { Montrose } \\
\text { Towanda } \\
\text { Wellsboro } \\
\text { West Bingham }\end{array}$} & \multicolumn{2}{|c|}{$\begin{array}{l}1.25 \\
1.30 \\
1.92 \\
1.95 \\
1.80\end{array}$} & $\begin{array}{l}2.90 \\
2.70 \\
2.61 \\
1.75 \\
1.30\end{array}$ & $\begin{array}{l}\overline{-} \\
\overline{-}\end{array}$ & & $\begin{array}{l}\overline{-} \\
-\end{array}$ & \multicolumn{2}{|c|}{$\begin{array}{l}.14 \\
.05 \\
.03 \\
.10\end{array}$} & $\begin{array}{l}.04 \\
.03 \\
-\end{array}$ \\
\hline & $\begin{array}{r}34.16 \\
1.49\end{array}$ & & $\begin{array}{r}53.63 \\
2.33\end{array}$ & $\begin{array}{r}6.35 \\
.29\end{array}$ & & $\begin{array}{l}.50 \\
.02\end{array}$ & $\begin{array}{r}2.0^{\circ} \\
.08\end{array}$ & & $\begin{array}{l}.88 \\
.04\end{array}$ \\
\hline
\end{tabular}


Taile 41.- Storms studied in connection with unit hydrographs

for the Susquehanna River above Towanda, Pa.--Continued

(Precipitation, in inches, measured in the afternoon except at stations marked $\%$, where it was measured in the morning, and stations marked **, where it was measured at midnight.)

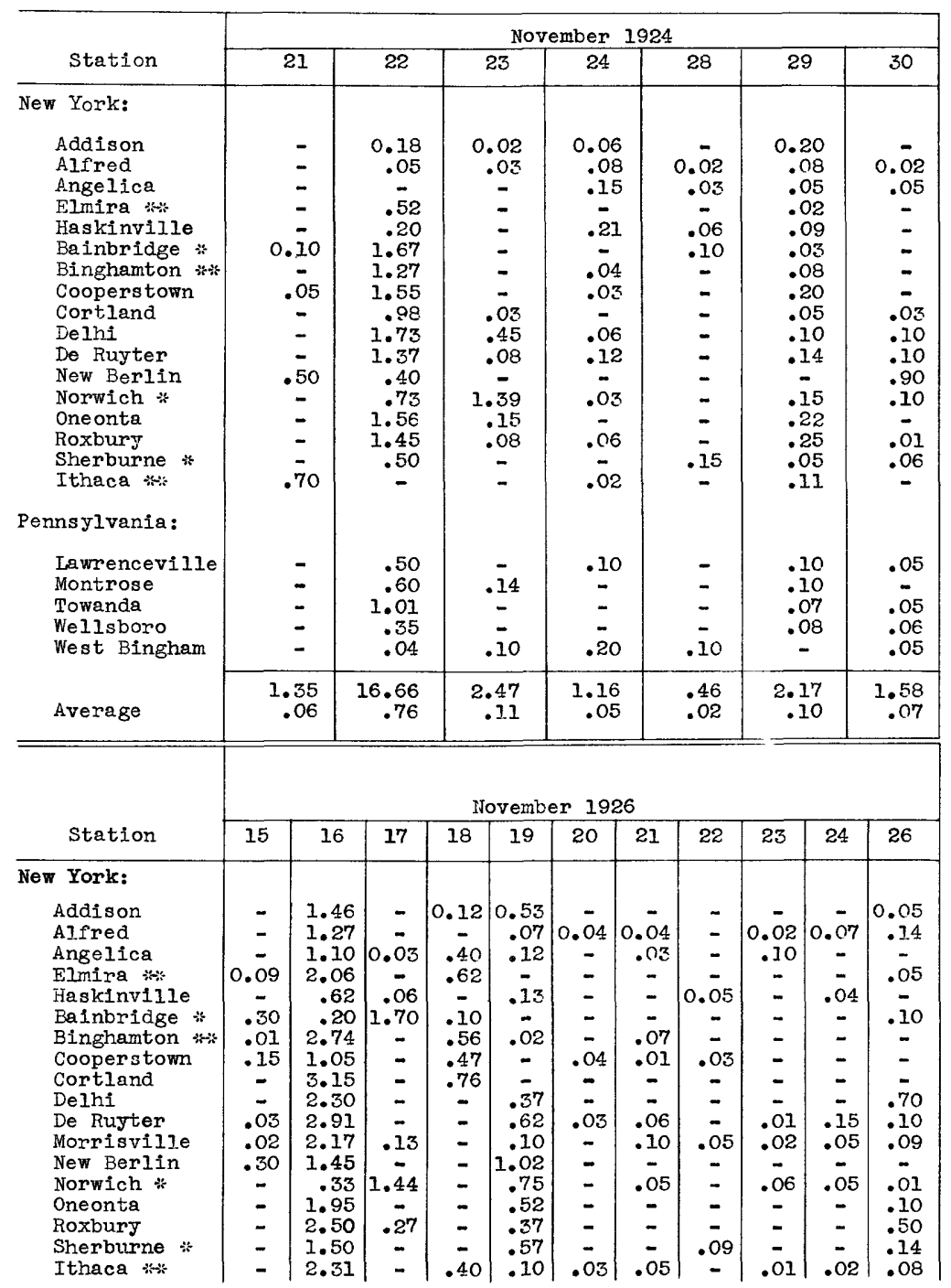


Table 41.- Storms studied in connection with unit hydrographs

for the Susquehanna River above Towanda, Pa.--Continued

(Precipitation, in inches, measured in the afternoon except at stations marked $*$, where it was measured in the morning, and stations marked **, where it was measured at midnight.)

\begin{tabular}{|c|c|c|c|c|c|c|c|c|c|c|c|}
\hline \multirow[b]{2}{*}{ Station } & \multicolumn{11}{|c|}{ November 1926} \\
\hline & 15 & 16 & 17 & 18 & 19 & 20 & 21 & 22 & 23 & 24 & 26 \\
\hline \multirow[t]{2}{*}{$\begin{array}{l}\text { Pennsylvania: } \\
\text { Iawrenceville } \\
\text { Montrose } \\
\text { Morris Run } \\
\text { Towanda } \\
\text { Wellsboro } \\
\text { West Bingham }\end{array}$} & $\begin{array}{c}- \\
0.05 \\
- \\
-\end{array}$ & $\begin{array}{l}1.65 \\
2.90 \\
3.24 \\
2.77 \\
1.75 \\
1.37\end{array}$ & $\begin{array}{c}0.15 \\
- \\
- \\
-\end{array}$ & $\begin{array}{c}- \\
- \\
0.39 \\
.13 \\
.35 \\
.30\end{array}$ & $\begin{array}{r}0.54 \\
. \\
.45 \\
.61 \\
.40 \\
-\end{array}$ & $\begin{array}{c}\overline{-} \\
0.03 \\
\overline{0} \\
\overline{0}\end{array}$ & $\begin{array}{c}- \\
\overline{-} \\
\overline{-} \\
0.05\end{array}$ & $\begin{array}{l}\overline{-} \\
\overline{-} \\
\overline{-} \\
\overline{-}\end{array}$ & $\begin{array}{c}\overline{-} \\
\overline{-} \\
\overline{-} \\
0 .\end{array}$ & $\begin{array}{l}\overline{-} \\
\overline{-} \\
\overline{-}\end{array}$ & $\begin{array}{r}0.07 \\
.14 \\
.15 \\
.15 \\
.35\end{array}$ \\
\hline & \begin{tabular}{l|l}
.95 & 4 \\
.04
\end{tabular} & $\begin{array}{r}44.75 \\
1.86\end{array}$ & $\begin{array}{r}3.78 \\
.16\end{array}$ & $\begin{array}{r}4.60 \\
.19\end{array}$ & $\begin{array}{r}7.29 \\
.30\end{array}$ & $\begin{array}{l}.22 \\
.01\end{array}$ & $\begin{array}{l}.46 \\
.02\end{array}$ & $\begin{array}{l}0.22 \\
.01\end{array}$ & $\begin{array}{l}.27 \\
.01\end{array}$ & $\begin{array}{r}0.38 \\
.02\end{array}$ & $\begin{array}{r}2.92 \\
.12\end{array}$ \\
\hline \multirow[b]{2}{*}{ Station } & \multicolumn{11}{|c|}{ October 1929} \\
\hline & 1 & & 2 & & 3 & 4 & & 7 & 8 & & 13 \\
\hline \multicolumn{12}{|l|}{ New York: } \\
\hline $\begin{array}{l}\text { Addison } \\
\text { Alfred } \\
\text { Angelica } \\
\text { Elmira ** } \\
\text { Haskinvilie } \\
\text { Binghamton ** } \\
\text { Cortland } \\
\text { Delhi } \\
\text { Morrisville } \\
\text { Norwich * } \\
\text { Oneonta } \\
\text { Roxbury } \\
\text { Sherburne } \\
\text { Ithaca *-* }\end{array}$ & $\begin{array}{l}\overline{-} \\
\overline{-} \\
\overline{-} \\
0 . \overline{26} \\
\overline{0} \\
.06 \\
\overline{14} \\
. \overline{19} \\
\overline{-}\end{array}$ & $\begin{array}{l}0 \\
6 \\
6 \\
6 \\
6 \\
6\end{array}$ & $\begin{array}{l}2.05 \\
2.00 \\
1.65 \\
3.00 \\
1.03 \\
2.99 \\
1.76 \\
2.13 \\
2.08 \\
.10 \\
2.12 \\
1.40 \\
.20 \\
2.47\end{array}$ & $\begin{array}{l}0.6 \\
1.8 \\
1.5 \\
1.5 \\
1.5 \\
0.5 \\
2.5 \\
.2\end{array}$ & $\begin{array}{l}65 \\
86 \\
37 \\
05 \\
45 \\
33 \\
26 \\
35 \\
60 \\
30 \\
27 \\
29 \\
29\end{array}$ & $\begin{array}{l}= \\
= \\
= \\
= \\
0 \\
0.07 \\
.15 \\
.11 \\
.04 \\
.40 \\
.14 \\
=\end{array}$ & & $\begin{array}{l}.08 \\
.16 \\
.22 \\
.04 \\
.20 \\
.07 \\
.58 \\
.06 \\
.48 \\
.12 \\
.04 \\
.08 \\
.02\end{array}$ & $\begin{array}{r}\overline{-} \\
= \\
\overline{-} \\
0.05 \\
.05 \\
.12 \\
.05 \\
.14 \\
-\end{array}$ & & $\begin{array}{l}0.16 \\
.12 \\
.11 \\
.04 \\
.09 \\
.09 \\
.18 \\
.04 \\
.26 \\
.07 \\
.09 \\
- \\
.16\end{array}$ \\
\hline \multicolumn{12}{|l|}{ Pennsylvania: } \\
\hline $\begin{array}{l}\text { Lawrenceville } \\
\text { Montrose } \\
\text { Morris Run } \\
\text { Towanda } \\
\text { Wellsboro }\end{array}$ & $\begin{array}{l}\overline{-} \\
\overline{-}\end{array}$ & 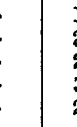 & $\begin{array}{l}1.85 \\
2.13 \\
2.52 \\
3.01 \\
2.22\end{array}$ & $\begin{array}{l}.6 \\
.4 \\
.5 \\
.8\end{array}$ & $\begin{array}{l}60 \\
47 \\
92 \\
55 \\
83\end{array}$ & $\begin{array}{l}\overline{-} \\
\overline{-}\end{array}$ & & $\begin{array}{l}10 \\
= \\
=\end{array}$ & $=$ & & $\begin{array}{l}.20 \\
.10 \\
.02 \\
.\end{array}$ \\
\hline Average & $\begin{array}{l}.65 \\
.03\end{array}$ & $\begin{array}{l}5 \\
3\end{array}$ & $\begin{array}{l}36.71 \\
1.93\end{array}$ & $\begin{array}{r}16.6 \\
.8\end{array}$ & $\begin{array}{l}62 \\
88\end{array}$ &. .91 & & $\begin{array}{l}.45 \\
.13\end{array}$ & $\begin{array}{r}.41 \\
.02\end{array}$ & & $\begin{array}{r}1.64 \\
.09\end{array}$ \\
\hline
\end{tabular}


Table 4l.- Storms studied in connection with unit hydrographs

for the Susquehanna River above Towanda, Pa.--Continued

(Precipitation, in inches, measured in the afternoon except at stations marked *, where it was measured in the morning, and stations marked ***, where it was measured at midnight.)

\begin{tabular}{|c|c|c|c|c|c|c|c|}
\hline \multirow[b]{2}{*}{ Station } & \multicolumn{7}{|c|}{ April 1930} \\
\hline & 6 & 7 & 8 & 11 & 12 & 13 & 14 \\
\hline \multicolumn{8}{|l|}{ New York: } \\
\hline $\begin{array}{l}\text { Addison } \\
\text { Alfred } \\
\text { Angelica } \\
\text { Elmira *** } \\
\text { Haskinville } \\
\text { Bainbridge * } \\
\text { Blnghamton ** } \\
\text { Cortiand } \\
\text { Delhi } \\
\text { Morrisville } \\
\text { Norwich * } \\
\text { Oneonta } \\
\text { Roxbury } \\
\text { Sherburne * } \\
\text { Ithaca * }\end{array}$ & $\begin{array}{c}0.05 \\
.07 \\
- \\
.93 \\
\overline{-} \\
1.01 \\
- \\
= \\
. \\
- \\
\overline{0} \\
.73\end{array}$ & $\begin{array}{r}1.05 \\
.56 \\
.50 \\
.30 \\
.62 \\
.81 \\
.60 \\
1.40 \\
.97 \\
1.18 \\
1.15 \\
1.18 \\
.85 \\
.96 \\
.88\end{array}$ & $\begin{array}{l}0.10 \\
.05 \\
.10 \\
.09 \\
.09 \\
.31 \\
.16 \\
.44 \\
.11 \\
.10 \\
.19 \\
.04 \\
.07 \\
.34 \\
.18\end{array}$ & $\begin{array}{c}\overline{-} \\
\overline{0} \\
\overline{0} \\
\overline{-} \\
\overline{-} \\
.04 \\
.02 \\
.20 \\
=\end{array}$ & $\begin{array}{c}\overline{-} \\
0.05 \\
- \\
. \overline{11} \\
\overline{-} \\
. \overline{25} \\
. \overline{19} \\
.12 \\
.04 \\
.07 \\
-\end{array}$ & $\begin{array}{l}0.26 \\
.03 \\
.05 \\
.20 \\
= \\
.10 \\
= \\
= \\
= \\
= \\
= \\
=\end{array}$ & $\begin{array}{l}= \\
= \\
0.05 \\
=08 \\
= \\
= \\
=\end{array}$ \\
\hline \multicolumn{8}{|l|}{ Pennsylvania: } \\
\hline $\begin{array}{l}\text { Lawrenceville } \\
\text { Montrose } \\
\text { Morris Run } \\
\text { Towanda } \\
\text { Wellsboro }\end{array}$ & $\begin{array}{l}. \\
.21 \\
.22 \\
.23 \\
.60\end{array}$ & $\begin{array}{r}.52 \\
1.30 \\
1.08 \\
1.49 \\
.40\end{array}$ & $\begin{array}{l}- \\
.08 \\
.02 \\
.02\end{array}$ & $\begin{array}{l}- \\
-\end{array}$ & $\begin{array}{l}- \\
.02 \\
-\end{array}$ & $\begin{array}{l}.10 \\
.41 \\
.30 \\
.28 \\
.25\end{array}$ & $\begin{array}{l}.40 \\
= \\
-\end{array}$ \\
\hline Average & $\begin{array}{r}4.09 \\
.20\end{array}$ & $\begin{array}{r}17.80 \\
.89\end{array}$ & $\begin{array}{r}2.40 \\
.12\end{array}$ & $\begin{array}{l}.32 \\
.02\end{array}$ & $\begin{array}{l}.85 \\
.04\end{array}$ & $\begin{array}{r}1.98 \\
.10\end{array}$ & $\begin{array}{l}.53 \\
.03\end{array}$ \\
\hline \multicolumn{8}{|c|}{ June 19} \\
\hline Station & 9 & 10 & 11 & 16 & 17 & 18 & 19 \\
\hline \multicolumn{8}{|l|}{ New York: } \\
\hline $\begin{array}{l}\text { Addison } \\
\text { Alfred } \\
\text { Angelice } \\
\text { Elmira *:* } \\
\text { Haskinville } \\
\text { Bainbridge * } \\
\text { Binghamton *** } \\
\text { Cooperstown } \\
\text { Cortland } \\
\text { Delni } \\
\text { Morrisville } \\
\text { Norwich * } \\
\text { Oneonta } \\
\text { Roxbury } \\
\text { Sherburne * } \\
\text { Ithaca ** }\end{array}$ & $\begin{array}{l}0.25 \\
.09 \\
.12 \\
.45 \\
.10 \\
.11 \\
.50 \\
.58 \\
.42 \\
.51 \\
.09 \\
.08 \\
.29 \\
.24 \\
.04 \\
.52\end{array}$ & $\begin{array}{r}1.26 \\
1.00 \\
1.50 \\
.24 \\
1.23 \\
.81 \\
.80 \\
.10 \\
.46 \\
1.02 \\
.94 \\
.75 \\
.75 \\
.60 \\
.55 \\
1.07\end{array}$ & $\begin{array}{c} \pm \\
0.04 \\
.05 \\
.44 \\
\pm \\
. \overline{0} \\
.08 \\
.25 \\
.49 \\
.02 \\
. \overline{64} \\
-\end{array}$ & $\begin{array}{r}0.26 \\
.25 \\
.15 \\
.50 \\
1.08 \\
= \\
= \\
.78 \\
.21 \\
= \\
= \\
1.09\end{array}$ & $\begin{array}{r}1.70 \\
.55 \\
.45 \\
1.80 \\
.46 \\
.78 \\
1.74 \\
1.50 \\
- \\
.27 \\
.03 \\
2.49\end{array}$ & $\begin{array}{r}0.38 \\
.50 \\
.60 \\
.01 \\
.92 \\
.08 \\
1.87 \\
.75 \\
.72 \\
.25 \\
1.16 \\
.35 \\
.03 \\
.25 \\
.32 \\
1.20\end{array}$ & $\begin{array}{l}0.04 \\
.10 \\
.03 \\
. \\
.80 \\
.05 \\
. \\
.24 \\
.21 \\
.52 \\
.97 \\
.22 \\
.12 \\
.47 \\
.05\end{array}$ \\
\hline
\end{tabular}


Table 41.- Storms studied in connection with unit hydrographs

for the Susquehanna River above Towanda, $\mathrm{Pa},-$-Continued

(Precipitation, in inches, measured in the afternoon except at stations marked $*$, where it was measured in the morning, and stations marked **, where it was measured at midnight.)

\begin{tabular}{|c|c|c|c|c|c|c|c|}
\hline \multirow[b]{2}{*}{ Station } & \multicolumn{7}{|c|}{ - June 1930} \\
\hline & 9 & 10 & 11 & 16 & 17 & 18 & 19 \\
\hline \multirow{3}{*}{$\begin{array}{l}\text { Pennsylvania: } \\
\text { Iawrenceville } \\
\text { Montrose } \\
\text { Morris Run } \\
\text { Towanda } \\
\text { Wellsboro }\end{array}$} & & & & & & & \\
\hline & $\begin{array}{r}0.22 \\
.40 \\
.20 \\
-\end{array}$ & $\begin{array}{r}.40 \\
1.60 \\
1.51 \\
.82 \\
1.55\end{array}$ & $\begin{array}{c}1.00 \\
= \\
= \\
=\end{array}$ & $\begin{array}{c}0.10 \\
.18 \\
= \\
-\end{array}$ & $\begin{array}{r}2.69 \\
1.00 \\
.18 \\
.33 \\
.32\end{array}$ & $\begin{array}{r}0.70 \\
.75 \\
.90 \\
2.02 \\
.52\end{array}$ & $\begin{array}{c}. \\
.38 \\
.01 \\
-\end{array}$ \\
\hline & $\begin{array}{r}5.21 \\
.25\end{array}$ & $\begin{array}{r}18.96 \\
.90\end{array}$ & $\begin{array}{r}3.09 \\
.15\end{array}$ & $\begin{array}{r}4.60 \\
.22\end{array}$ & $\begin{array}{r}16.29 \\
.78\end{array}$ & $\begin{array}{r}14.28 \\
.68\end{array}$ & $\begin{array}{r}4.21 \\
.20\end{array}$ \\
\hline & \multicolumn{7}{|c|}{ October 1932} \\
\hline Station & 4 & 5 & 6 & 7 & 11 & 12 & 13 \\
\hline \multicolumn{8}{|l|}{ New York: } \\
\hline $\begin{array}{l}\text { Addison } \\
\text { Alfred } \\
\text { Angelica } \\
\text { Elmire ** } \\
\text { Hasklnvilie } \\
\text { Bainbridge * } \\
\text { Binghamton ** } \\
\text { Cooperstown } \\
\text { Cortland } \\
\text { Delhi } \\
\text { Morrisville } \\
\text { Norwich * } \\
\text { Oneonta } \\
\text { Roxbury } \\
\text { Sherburne * } \\
\text { Ithaca ** }\end{array}$ & $\begin{array}{l}0.05 \\
.02 \\
.03 \\
.12 \\
.33 \\
= \\
= \\
= \\
= \\
= \\
=\end{array}$ & $\begin{array}{r}0.70 \\
.59 \\
.40 \\
2.10 \\
.60 \\
3.59 \\
.54 \\
.30 \\
.73 \\
1.48 \\
.41 \\
.60 \\
.23 \\
.30 \\
1.14\end{array}$ & $\begin{array}{l}1.96 \\
1.33 \\
1.27 \\
.49 \\
1.68 \\
2.70 \\
1.77 \\
4.85 \\
3.16 \\
5.71 \\
3.49 \\
4.04 \\
5.09 \\
6.75 \\
2.87 \\
1.28\end{array}$ & $\begin{array}{c}0.03 \\
.05 \\
- \\
.06 \\
.04 \\
.04 \\
.05 \\
.02 \\
.90 \\
.06 \\
.04 \\
.94 \\
-\end{array}$ & $\begin{array}{l}0.01 \\
.04 \\
= \\
= \\
.05 \\
.08 \\
.03 \\
. \\
.15 \\
.11 \\
.02 \\
.05 \\
.11 \\
.03\end{array}$ & $\begin{array}{l}0.20 \\
.20 \\
. \\
.20 \\
.04 \\
.02 \\
.12 \\
.46 \\
.01 \\
.08 \\
.05 \\
.08 \\
.11 \\
.02 \\
.11\end{array}$ & $\begin{array}{l}0.05 \\
.10 \\
.10 \\
= \\
= \\
= \\
= \\
.08 \\
.25 \\
= \\
.11 \\
=\end{array}$ \\
\hline Pennsylvania: & & & & & & & \\
\hline $\begin{array}{l}\text { Lawrenceville } \\
\text { Montrose } \\
\text { Morris Run } \\
\text { Towanda } \\
\text { Wellsboro }\end{array}$ & $\overline{.} . \overline{06}$ & $\begin{array}{l}.43 \\
2.20 \\
.86 \\
2.34 \\
1.05\end{array}$ & $\begin{array}{l}2.80 \\
2.25 \\
2.46 \\
2.65 \\
1.61\end{array}$ & $\begin{array}{l}\overline{-} \\
\overline{-}\end{array}$ & $\overline{-}$ & $\begin{array}{l}.10 \\
.03 \\
.04\end{array}$ & 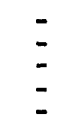 \\
\hline Average & $\begin{array}{l}.62 \\
.03\end{array}$ & $\begin{array}{r}20.59 \\
.98\end{array}$ & $\begin{array}{r}60.21 \\
2.87\end{array}$ & $\begin{array}{r}3.09 \\
.15\end{array}$ & $\begin{array}{l}.69 \\
.03\end{array}$ & $\begin{array}{r}1.87 \\
.09\end{array}$ & $\begin{array}{r}.69 \\
.03\end{array}$ \\
\hline
\end{tabular}

Table 42 gives the surface run-off from the unit storms and the approximate depth of the precipitation that caused the run-off. Figures preceded by * include run-off from melting snow. 


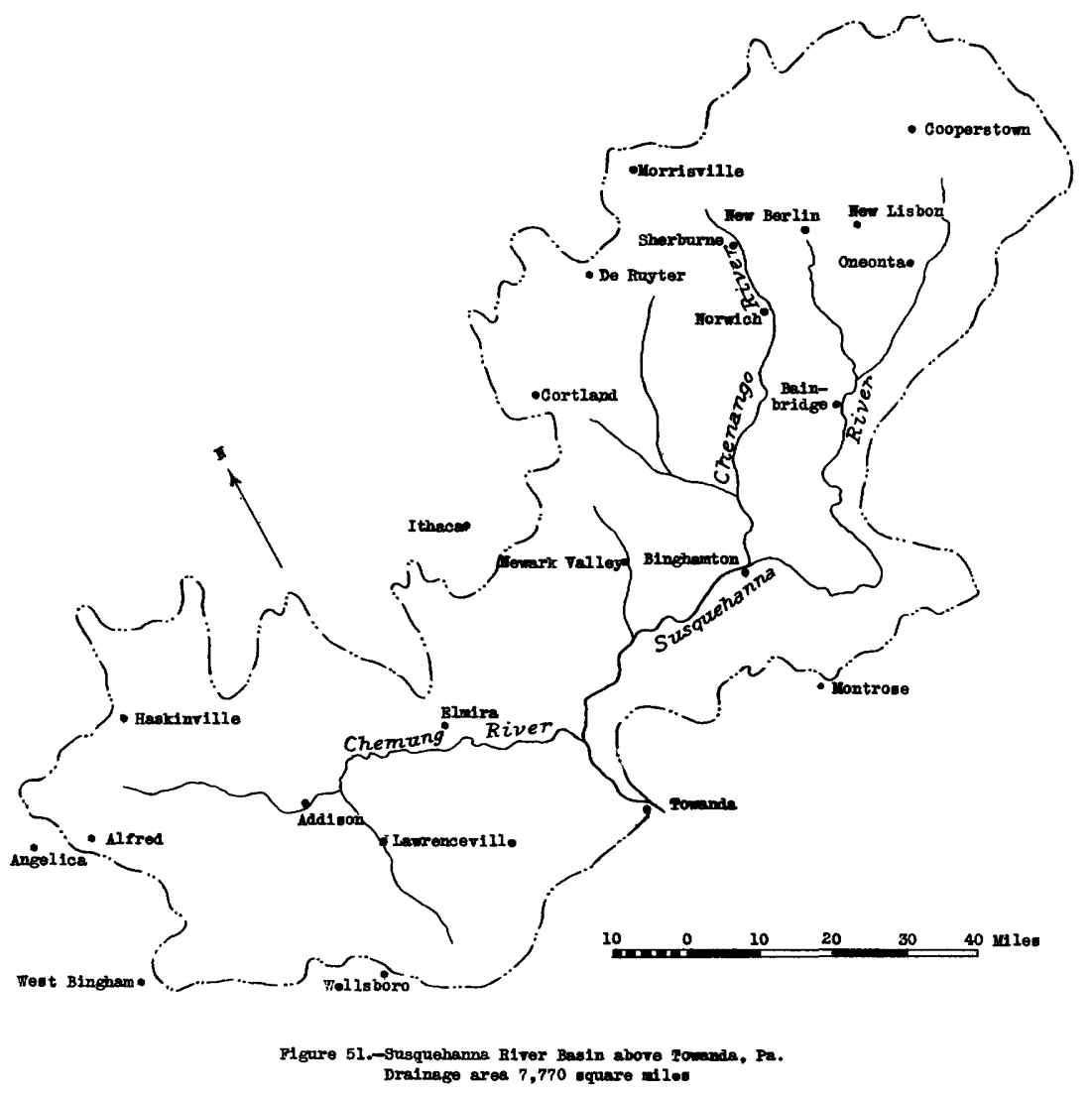



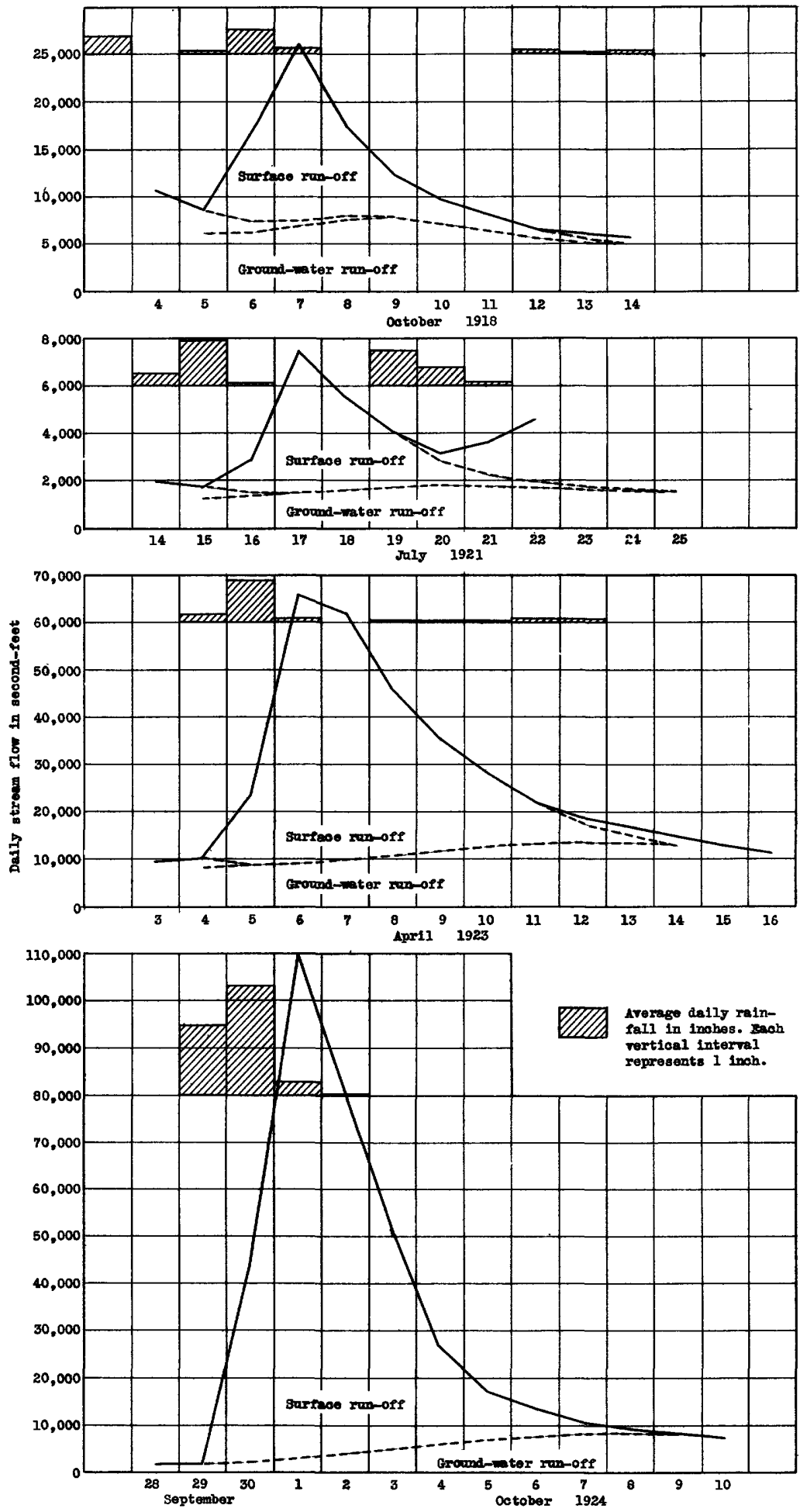

Figare 52.-Onit hyirographs for susquehams Biver at 20wanda, Pa. 

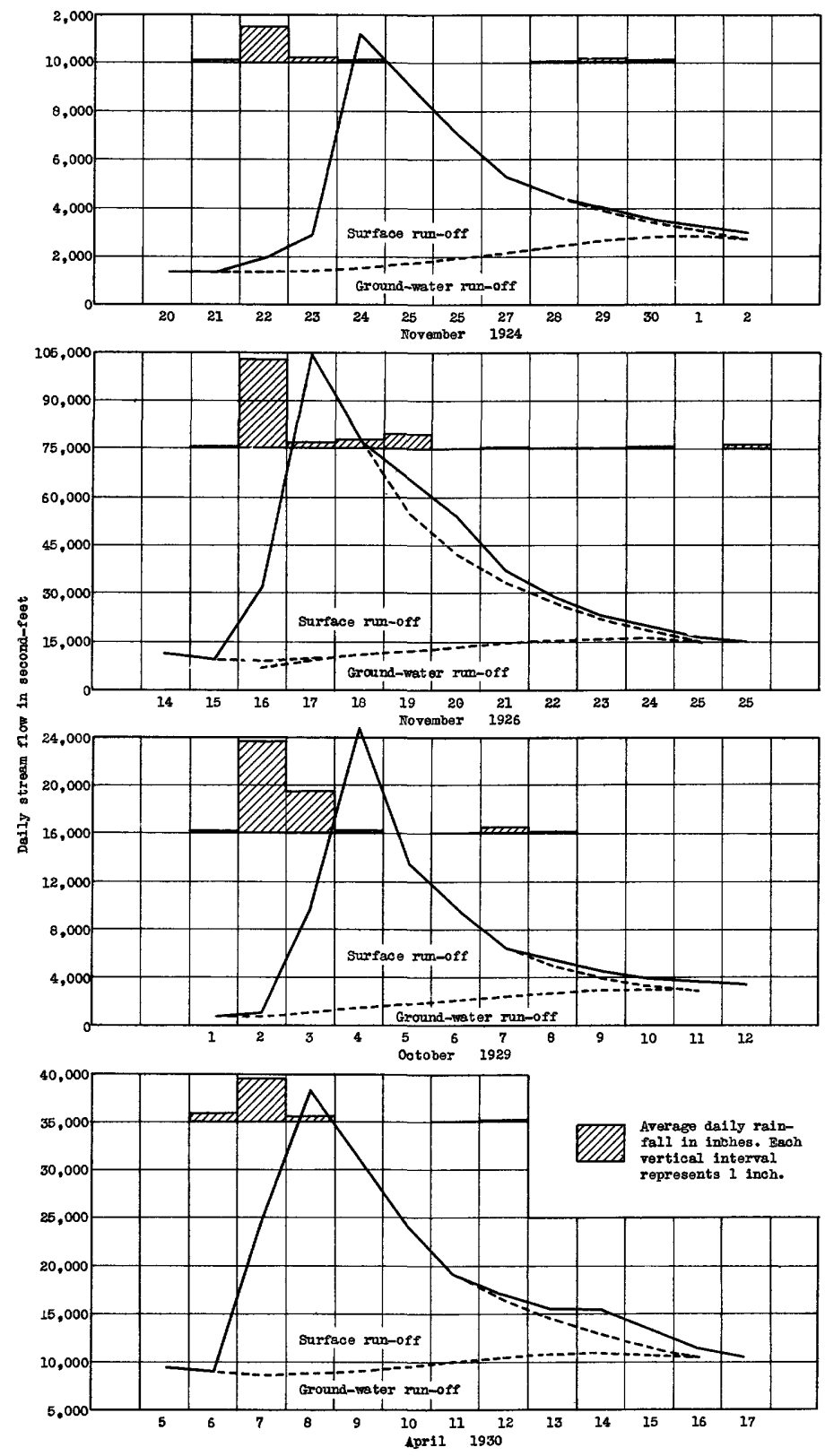

Figure 53.- Unit hydrographs for Susquehanna River at Towanda, Pa. 


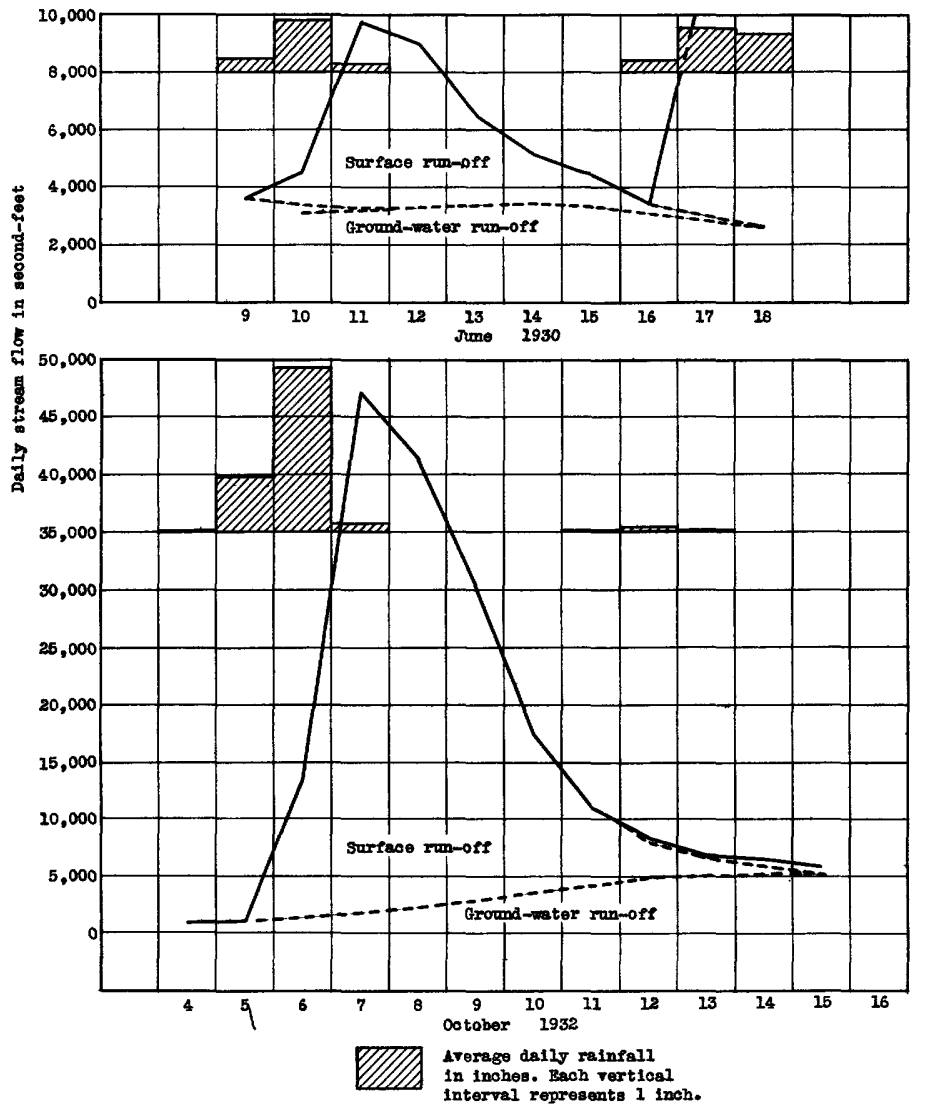

PIgare 54,-Onit hydrographs for Sesquehame RIver at Towanda, Pa. 
Table 42.- Surface mun-off from unit storms, Susquehanna River at Towanda, $\mathrm{Pa}$.

\begin{tabular}{|c|c|c|c|}
\hline Storm & $\begin{array}{c}\text { Average of precipi- } \\
\text { tation at stations } \\
\text { (inches) }\end{array}$ & $\begin{array}{c}\text { Surface run-off } \\
\text { (inches) }\end{array}$ & $\begin{array}{l}\text { Ratio of } \\
\text { surface run- } \\
\text { off to aver } \\
\text { age precipi- } \\
\text { tation }\end{array}$ \\
\hline $\begin{array}{l}\text { Cct. } 6,1918 \\
\text { July } 15,1921 \\
\text { Apr. } 5,1923 \\
\text { Sept. } 30,1924 \\
\text { Nov. } 22,1924 \\
\text { Nov. } 16,1926 \\
\text { Oct. 2, } 1929 \\
\text { Apr. } 7,1930 \\
\text { Juno } 10,1930 \\
\text { Oct. 6, } 1932\end{array}$ & $\begin{array}{l}0.73 \\
1.30 \\
1.15 \\
4.11 \\
.93 \\
2.06 \\
2.86 \\
1.21 \\
1.30 \\
4.00\end{array}$ & $\begin{array}{r}0.22 \\
.07 \\
* 1.02 \\
1.50 \\
.15 \\
* 1.42 \\
.29 \\
.50 \\
.09 \\
.71\end{array}$ & $\begin{array}{r}0.30 \\
.05 \\
.89 \\
.36 \\
.16 \\
.69 \\
.10 \\
.41 \\
.07 \\
.18\end{array}$ \\
\hline
\end{tabular}

Table 43 gives the daily percentages for the 10 distribution graphs, and figure 55 shows the graphs superimposed. The average distribution graph determined for the basin is $12,33,24,15,3,4,2,1,1$ percent. The first figure of each distribution graph is the percentage of surface run-off for the calendar day on which most of the rainfall occurred; other figures for succeeding days.

Table 43.- Distribution graphs for storms in

Susqueharna River Basin above Towanda, Pa.

\begin{tabular}{l|r|r|r|r|r|r|r|r|r|l|}
\hline Oct. 6, 1918 & \multicolumn{1}{|c|}{20.1} & 39.1 & 19.8 & 9.6 & 5.2 & 3.6 & 1.9 & 0.7 & - & - \\
July 15, 1921 & \multicolumn{1}{c|}{19.8} & 8.8 & 38.9 & 25.5 & 15.0 & 6.5 & 2.9 & 1.4 & 0.6 & 0.4 \\
Apr. 5, 1923 & 6.8 & 26.8 & 24.7 & 16.6 & 11.1 & 7.3 & 4.1 & 1.9 & .7 & - \\
Sept. 30, 1924 & 13.8 & 34.2 & 24.6 & 14.8 & 6.5 & 3.2 & 1.9 & .3 & .2 & - \\
Nov. 22, 1924 & 1.6 & 4.6 & 30.8 & 23.3 & 16.4 & 10.0 & 6.8 & 3.9 & 1.9 & .7 \\
Nov. 16, 1926 & 7.8 & 32.1 & 22.5 & 14.5 & 9.7 & 6.4 & 4.0 & 2.1 & .9 & - \\
Oct. 2, 1929 & .6 & 17.1 & 38.3 & 19.3 & 12.4 & 6.5 & 3.6 & 1.7 & .5 & - \\
Apr. 7, 1930 & 15.5 & 28.5 & 21.3 & 14.1 & 8.7 & 5.8 & 3.5 & 1.9 & .7 & - \\
June 10, 1930 & 4.5 & 33.8 & 29.3 & 16.2 & 8.7 & 4.7 & 1.6 & .7 & - & - \\
Oct.6, 1932 & 7.8 & 30.5 & 26.1 & 18.4 & 9.3 & 4.6 & 2.1 & .9 & .3 & - \\
\hline
\end{tabular}

Delaware River Basin above Port Jervis, N. Y.

The headwaters of the Delaware River lie in Delaware, Greene, and Schoharie counties, N. Y. The east branch rises at Grand Gorge, in northeasterr Delaware County. The west branch has its source in a small lake near the Schoharie and Delaware County line at an altitude of about 1,886 feet. The two branches flow in a southwesterly direction, and the main stream below their junction flows southeast. The drainage area above Port Jervis is 3,070 square miles, the length about 75 miles (river distance 


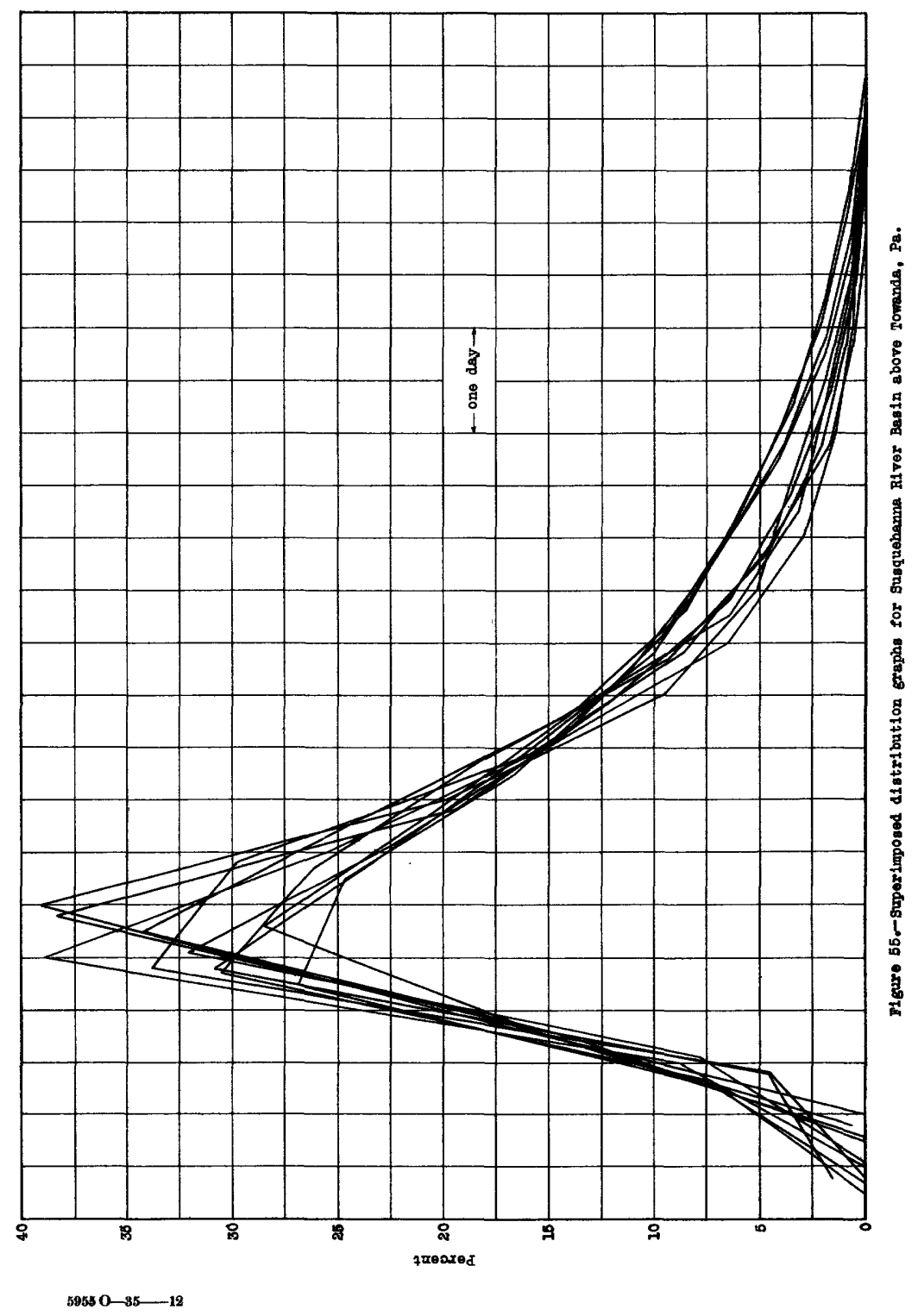


140 miles), and the average width about 41 miles. The Mongaup and Lackawaxen Rivers drain the principal subbasins. The gradient of the east and west branches above the junction is about 8 feet to the mile. From Hancock (the junction point) to Port Jervis $(75 \mathrm{mlles})$ the average gradient is about 6 feet to the mile.

The original gage, on the toll bridge at Port Jervis, was a chain established by the United States Weather Bureau in October 1904 for the purpose of flood predictions. The gage heights were supplied to the United States Geological Survey for determination of daily discharge.

A vertical and inclined staff gage was installed in June 1914. An automatic recorder was established in August 1928, about 350 feet below the bridge. The zero of the gage is 415.6 feet above mean sea level. Records are available since October 1904 and are considered good. There are large diurnal fluctuations at medium and low stages, owing to the operation of power plants on tributary streams $(12,200,000,000$ cubic feet of storage in 1930).

Eight or nine Weather Bureau stations are nomally available for the determination of daily precipitation. These stations and the principal drainage are shown in figure 56.

Table 44 gives the deily precipitation recorded at the Weather Bureau stations for the storms that produced the unit hydrographs shown in figures 57,58 , and 59 .

Table 44.- Storms considered in connection with unit hydrographs for the Delaware River Basin above Port Jervis, N. Y.

(Precipitation, in inches, measured in the afternoon except at stations marked *, where it was measured in the morning, and stations marked **, where 1t was measured at midnight.)

\begin{tabular}{|c|c|c|c|c|c|c|c|c|c|}
\hline \multirow{2}{*}{ Station } & \multicolumn{4}{|c|}{ October 1917} & \multicolumn{5}{c|}{ October 1918 } \\
\cline { 2 - 9 } & 28 & 29 & 30 & 31 & 5 & 6 & 7 & 12 & 13 \\
\hline New York: & & & & & & & & & \\
Balnbr1dge * & 0.42 & 0.24 & 1.30 & 0.57 & - & 1.05 & 0.19 & - & 0.09 \\
Beerston & .68 & .30 & 3.11 & - & - & 1.42 & - & - & - \\
Jeffersonville & - & .11 & 1.70 & - & - & 1.29 & - & 0.42 & .04 \\
Oneonta & - & - & - & - & - & .19 & - &. & .09 \\
Port Jervis & .33 & .02 & 1.59 & - & - & .54 & .14 & .09 & - \\
Roxbury & .50 & .23 & 2.40 & - & - & 1.31 & - & .22 & .10
\end{tabular}

Station at Beerston was moved to Walton after October 10, 1918. 
Table 44.- Storms considered in connection with unit hydrographs for the Delaware River Basin above Port Jervis, N. Y.--Continued

(Precipitation, in inches, measured in the afternoon except at stations marked $*$, where it was measured in the morning, and stations marked **, where it was measured at midnight;)

\begin{tabular}{|c|c|c|c|c|c|c|c|c|c|c|}
\hline \multirow[b]{2}{*}{ Station } & \multicolumn{4}{|c|}{ October 1917} & \multicolumn{6}{|c|}{ October 1918} \\
\hline & 28 & 29 & 30 & 31 & & 5 & 6 & 7 & 12 & 13 \\
\hline \multirow[t]{2}{*}{$\begin{array}{l}\text { Pennsylvania: } \\
\text { Gouldsboro * } \\
\text { Honesdale } \\
\text { Scranton } * *\end{array}$} & $\begin{array}{c}0.47 \\
.45 \\
-\end{array}$ & $0 . \overline{05}$ & $\begin{array}{l}1.80 \\
2.10 \\
2.12\end{array}$ & $\begin{array}{c}0.60 \\
- \\
-\end{array}$ & $0 . \overline{2}$ & $\overline{23}$ & $\overline{79}$ & $\overline{0 .}$ & $0 . \overline{25}$ & $\overline{-}$ \\
\hline & $\begin{array}{r}2.85 \\
.36\end{array}$ & $\begin{array}{l}.95 \\
.12\end{array}$ & $\begin{array}{r}16.12 \\
2.02\end{array}$ & $\begin{array}{r}1.17 \\
.15\end{array}$ & & $\begin{array}{l}23 \\
03\end{array}$ & $\begin{array}{r}.59 \\
.82\end{array}$ & $\begin{array}{l}.44 \\
.06\end{array}$ & $\begin{array}{l}.98 \\
.12\end{array}$ & $\begin{array}{r}0.32 \\
.04\end{array}$ \\
\hline \multirow[b]{2}{*}{ Station } & \multicolumn{6}{|c|}{ June 1922} & \multicolumn{4}{|c|}{ Apri1 - May 1923} \\
\hline & 2 & 3 & 4 & 5 & 6 & 7 & 28 & 29 & 30 & 1 \\
\hline New York: & \multirow{3}{*}{$\begin{array}{r}0.06 \\
.60 \\
.48 \\
.48 \\
.13 \\
.43\end{array}$} & \multirow[b]{2}{*}{$\begin{array}{l}1.00 \\
1.20 \\
1.81 \\
1.34 \\
1.70 \\
2.41\end{array}$} & \multirow[b]{2}{*}{$\mid \begin{array}{c}1.24 \\
- \\
- \\
- \\
-\end{array}$} & \multirow[b]{2}{*}{$\begin{array}{r}0 . \overline{0} \\
.18 \\
1.03 \\
.42 \\
.55\end{array}$} & \multirow[b]{2}{*}{$\begin{array}{c}0.18 \\
- \\
. \\
.12 \\
.02 \\
.14\end{array}$} & \multirow[b]{2}{*}{$\begin{array}{c}0.06 \\
- \\
. \\
.03 \\
-\end{array}$} & \multirow[b]{2}{*}{$\begin{array}{r}0.30 \\
.55 \\
1.52 \\
.49 \\
2.20 \\
1.28\end{array}$} & \multirow[b]{2}{*}{$\begin{array}{r}0.86 \\
.88 \\
.32 \\
.52 \\
.50 \\
1.04\end{array}$} & \multirow[b]{2}{*}{$\begin{array}{c}0 . \overline{0} \\
.11 \\
- \\
.16\end{array}$} & \multirow[b]{2}{*}{$\begin{array}{c}- \\
= \\
0.08 \\
-\end{array}$} \\
\hline $\begin{array}{l}\text { Bainbridge * } \\
\text { Jeffersonville } \\
\text { Oneonta } \\
\text { Port Jervis } \\
\text { Roxbury } \\
\text { Walton }\end{array}$ & & & & & & & & & & \\
\hline \multicolumn{10}{|l|}{ Pennsylvania: } & \\
\hline \multirow[t]{2}{*}{$\begin{array}{l}\text { Gouldsboro * } \\
\text { Hawley * } \\
\text { Scranton ** }\end{array}$} & $\begin{array}{l}.26 \\
. \overline{41}\end{array}$ & $\begin{array}{l}1.04 \\
1 . \overline{80}\end{array}$ & $\mid \begin{array}{c}1.42 \\
-\end{array}$ &. & $\begin{array}{c}.24 \\
.03\end{array}$ & $\overline{-}$ & $1 . \overline{75}$ & $\begin{array}{l}.69 \\
.87 \\
.07\end{array}$ & $\overline{.14}$ & $\begin{array}{l}.18 \\
.19 \\
.\end{array}$ \\
\hline & $\begin{array}{r}2.85 \\
.36\end{array}$ & $\begin{array}{r}12.30 \\
1.54\end{array}$ & $\begin{array}{r}2.66 \\
.33\end{array}$ & $\begin{array}{r}3.00 \\
.37\end{array}$ & $\begin{array}{l}.73 \\
.09\end{array}$ & $\begin{array}{l}.09 \\
.01\end{array}$ & $\begin{array}{r}8.09 \\
.90\end{array}$ & $\begin{array}{r}5.75 \\
.64\end{array}$ & $\begin{array}{l}.47 \\
.05\end{array}$ & $\begin{array}{l}.45 \\
.05\end{array}$ \\
\hline & \multicolumn{10}{|c|}{ September - October 1924} \\
\hline Station & \multicolumn{2}{|r|}{29} & \multicolumn{2}{|c|}{30} & \multicolumn{2}{|c|}{1} & \multicolumn{2}{|c|}{7} & \multicolumn{2}{|r|}{8} \\
\hline \multicolumn{11}{|l|}{ New York: } \\
\hline $\begin{array}{l}\text { Bainbridge } * \\
\text { Delhi } \\
\text { Jeffersonville } \\
\text { Oneonta } \\
\text { Port Jervis } \\
\text { Roxbury }\end{array}$ & \multicolumn{2}{|c|}{$\begin{array}{r}0.14 \\
.30 \\
.60 \\
.75 \\
1.02 \\
.23\end{array}$} & \multicolumn{2}{|c|}{$\begin{array}{l}2.68 \\
4.28 \\
3.80 \\
3.52 \\
4.33 \\
3.30\end{array}$} & \multicolumn{2}{|c|}{$\begin{array}{c}1.44 \\
.28 \\
- \\
= \\
.25\end{array}$} & \multicolumn{2}{|c|}{$\begin{array}{r}- \\
0.07 \\
.10 \\
.06 \\
.10 \\
.03\end{array}$} & \multicolumn{2}{|c|}{$\begin{array}{c}0.26 \\
.07 \\
- \\
. \\
.17 \\
.11\end{array}$} \\
\hline \multicolumn{11}{|l|}{ Pennsylvania: } \\
\hline $\begin{array}{l}\text { Gouldeboro * } \\
\text { Hawley * } \\
\text { Scranton ** }\end{array}$ & \multicolumn{2}{|c|}{$\begin{array}{r}.22 \\
2 . \overline{00}\end{array}$} & \multicolumn{2}{|c|}{$\begin{array}{l}4.15 \\
2.54 \\
3.33\end{array}$} & \multicolumn{2}{|c|}{$\begin{array}{c}1.72 \\
2.2 ? \\
-\end{array}$} & &.$\overline{08}$ & & $\begin{array}{l}.20 \\
.08 \\
-\end{array}$ \\
\hline Average & & $\begin{array}{l}5.26 \\
.58\end{array}$ & 31. & $\begin{array}{l}.93 \\
.55\end{array}$ & & .91 & & $\begin{array}{l}.44 \\
.05\end{array}$ & & $\begin{array}{l}.89 \\
.05\end{array}$ \\
\hline
\end{tabular}


Table 44.- Storms considered in connection with unit hydrographs fox the Delaware River Basin above Port Jervis, N. Y.--Continued

(Precipitation, in inches, measured in the afternoon except at stations marked *, where it was measured in the morning, and stations marked $* *$, where it was measured at midnight.)

\begin{tabular}{|c|c|c|c|c|c|c|c|c|}
\hline \multirow[b]{2}{*}{ Station } & \multicolumn{8}{|c|}{ October 1926} \\
\hline & 5 & 6 & 7 & & 10 & 11 & 13 & 14 \\
\hline \multicolumn{9}{|l|}{ New York: } \\
\hline $\begin{array}{l}\text { Bainbridge * } \\
\text { Delhi } \\
\text { Jeffersonville } \\
\text { Oneonta } \\
\text { Port Jervis } \\
\text { Roxbury }\end{array}$ & $\begin{array}{c}0.40 \\
- \\
.58 \\
.03\end{array}$ & $\begin{array}{l}2.00 \\
2.23 \\
1.53 \\
1.28 \\
2.00 \\
1.70\end{array}$ & $\begin{array}{l}0.10 \\
.05 \\
.03 \\
= \\
. \\
.11\end{array}$ & & $\begin{array}{l}. \\
.10 \\
.10 \\
.05 \\
.35\end{array}$ & $\begin{array}{l}= \\
= \\
=\end{array}$ & $\begin{array}{l}. . \\
0.45 \\
.18 \\
.40 \\
.03 \\
.30\end{array}$ & $\begin{array}{l}- \\
\overline{-} \\
\overline{-}\end{array}$ \\
\hline \multicolumn{9}{|l|}{ Pennsylvania: } \\
\hline $\begin{array}{l}\text { Gouldsboro * } \\
\text { Hawley * } \\
\text { Scrantion } \%\end{array}$ & $\overline{-}$ & $\begin{array}{r}1.35 \\
.93 \\
.67\end{array}$ & \multicolumn{3}{|r|}{.19} & $\begin{array}{l}.38 \\
.28 \\
-\end{array}$ & $\overline{13}$ & .15 \\
\hline Average & $\begin{array}{r}1.34 \\
.15\end{array}$ & $\begin{array}{r}13.69 \\
1.52\end{array}$ & $\begin{array}{l}.39 \\
.04\end{array}$ & \multicolumn{2}{|c|}{$\begin{array}{r}1.43 \\
.16\end{array}$} & $\begin{array}{l}.66 \\
.07\end{array}$ & $\begin{array}{r}1.49 \\
.17\end{array}$ & .31 \\
\hline & \multicolumn{3}{|c|}{ October 1927} & \multicolumn{5}{|c|}{ October 1927} \\
\hline Station & 3 & 4 & 8 & 12 & 13 & 17 & 18 & 19 \\
\hline \multicolumn{9}{|l|}{ New York: } \\
\hline $\begin{array}{l}\text { Bainbridge * } \\
\text { Delht } \\
\text { Jeffersonville } \\
\text { Oneonta } \\
\text { Port Jervis } \\
\text { Roxbury }\end{array}$ & $\begin{array}{c}- \\
0.13 \\
1.00 \\
-\end{array}$ & $\begin{array}{l}1.70 \\
2.37 \\
2.77 \\
1.74 \\
2 . \overline{85}\end{array}$ & $\begin{array}{l}0 . \\
0.41 \\
.22 \\
. \\
.15 \\
.37\end{array}$ & $\begin{array}{c}= \\
= \\
\overline{-} \\
-\end{array}$ & $\begin{array}{r}1.50 \\
.55 \\
1.80 \\
1.69 \\
1 . \overline{6}\end{array}$ & $\begin{array}{r}0.40 \\
.75 \\
.72 \\
.56 \\
1.43 \\
.36\end{array}$ & $\begin{array}{r}1.50 \\
.58 \\
1.25 \\
1.06 \\
1.70 \\
.78\end{array}$ & $\begin{array}{r}1.20 \\
1.10 \\
1.69 \\
1.41 \\
1.10 \\
1.22\end{array}$ \\
\hline \multicolumn{9}{|l|}{ Pennsylvania: } \\
\hline \multirow[t]{2}{*}{$\begin{array}{l}\text { Gouldsboro * } \\
\text { Hawley * } \\
\text { Scranton ** }\end{array}$} & $2 . \overline{60}$ & $\begin{array}{r}2.60 \\
2.82 \\
.29\end{array}$ & $\begin{array}{l}.42 \\
.41 \\
.34\end{array}$ & $1 . \overline{58}$ & $\begin{array}{r}2.18 \\
1.78 \\
.14\end{array}$ & $\begin{array}{l}.20 \\
.39 \\
.91\end{array}$ & $\begin{array}{r}1.60 \\
1.96 \\
1.85\end{array}$ & $\begin{array}{l}1.68 \\
2.32 \\
1.11\end{array}$ \\
\hline & $\begin{array}{r}3.73 \\
.41\end{array}$ & $\begin{array}{r}17.14 \\
1.90\end{array}$ & $\begin{array}{r}2.32 \\
.26\end{array}$ & $\begin{array}{r}3.56 \\
.40\end{array}$ & $\begin{array}{r}11.30 \\
1.26\end{array}$ & $\begin{array}{r}5.72 \\
.64\end{array}$ & $\begin{array}{r}11.28 \\
1.25\end{array}$ & $\begin{array}{r}11.83 \\
1.31\end{array}$ \\
\hline \multirow[b]{2}{*}{ Station } & \multicolumn{8}{|c|}{ September 1933} \\
\hline & 3 & & 4 & 6 & & 7 & 10 & 14 \\
\hline \multicolumn{9}{|l|}{ New York: } \\
\hline $\begin{array}{l}\text { Bainbridge } * \\
\text { Delhi } \\
\text { Jeffersonville } \\
\text { Oneonta } \\
\text { Port Jervis } \\
\text { Roxbury }\end{array}$ & $\begin{array}{l}0 . \overline{17} \\
.80 \\
.13 \\
.25 \\
.35\end{array}$ & $\begin{array}{l}0 . \\
1 . \\
1 . \\
1 .\end{array}$ & $\begin{array}{l}93 \\
44 \\
50 \\
44 \\
78 \\
22\end{array}$ & $\begin{array}{c}-\overline{3} \\
\overline{38} \\
.58 \\
. \overline{74}\end{array}$ & & $\begin{array}{l}04 \\
12 \\
- \\
14 \\
11 \\
25\end{array}$ & $\begin{array}{c}- \\
- \\
0.77 \\
.03\end{array}$ & $\begin{array}{r}1.12 \\
1.12 \\
.40 \\
.85 \\
.82 \\
.88\end{array}$ \\
\hline
\end{tabular}


Table 44.- Storms considered in connection with unit hydrographs

for the Delaware River Basin above Port Jervis, N. Y.--Continued

(Precipitation, in inches, measured in the afternoon except at stations marked $*$, where it was measured in the morning, and stations marked **, where it was measured at midnight.)

\begin{tabular}{|c|c|c|c|c|c|c|}
\hline \multirow{2}{*}{ Station } & \multicolumn{7}{|c|}{ September 1933 } \\
\cline { 2 - 7 } & 3 & 4 & 6 & 7 & 10 & 14 \\
\hline Pennsylvania: & & & & & & \\
Gouldsboro* & 0.02 & 2.51 & - & - & 0.45 & - \\
Hawley * & .12 & 2.84 & - & - & .36 & 0.14 \\
Scranton * & .90 & .59 & - & - & - & 1.51 \\
\cline { 2 - 7 } & 2.74 & 13.25 & 1.70 & 0.66 & 1.01 & 6.84 \\
Average & .30 & 1.47 & .19 & .07 & .11 & .76 \\
\hline
\end{tabular}

Table 45 gives the surface run-off from the unit storms and the approximate precipitation that caused the run-off.

Table 45.- Surface run-off from unit storms in

Delaware River Basin above Port Jervis, N. Y.

\begin{tabular}{|c|c|c|c|}
\hline Storm & $\begin{array}{c}\text { Average of precipi- } \\
\text { tation at stations } \\
\text { (inches) }\end{array}$ & $\begin{array}{c}\text { Surface mun-off } \\
\text { (Inches) }\end{array}$ & $\begin{array}{c}\text { Ratio of } \\
\text { surface run- } \\
\text { off to aver- } \\
\text { age precipi- } \\
\text { tation }\end{array}$ \\
\hline $\begin{array}{l}\text { Oct. } 30,1917 \\
\text { Oct. 6, } 1918 \\
\text { June } 3,1922 \\
\text { Apr. 29, } 1923 \\
\text { Sept. 30, } 1924 \\
\text { Oct. 6, 1926 } \\
\text { Oct. 4, 1927 } \\
\text { Oct. 13, } 1927 \\
\text { Sept. 4, 1933 }\end{array}$ & $\begin{array}{l}2.29 \\
.91 \\
2.23 \\
1.54 \\
4.79 \\
1.71 \\
2.31 \\
1.66 \\
1.77\end{array}$ & $\begin{array}{r}1.34 \\
.28 \\
.80 \\
.56 \\
2.01 \\
.29 \\
.31 \\
.50 \\
.52\end{array}$ & $\begin{array}{r}0.58 \\
.31 \\
.36 \\
.36 \\
.42 \\
.17 \\
.13 \\
.30 \\
.29\end{array}$ \\
\hline
\end{tabular}

Table 46 gives the daily percentages for the nine distribution graphs, and figure 60 shows the graphs superimposed. The average distribution graph determined for the basin is $6,43,24,13,7,4,2,1$ percent. The flrst figure of each distribution graph is the percentage of surface run-off for the calendar day on which most of the rainfall occurred; other figures for succeeding days. 


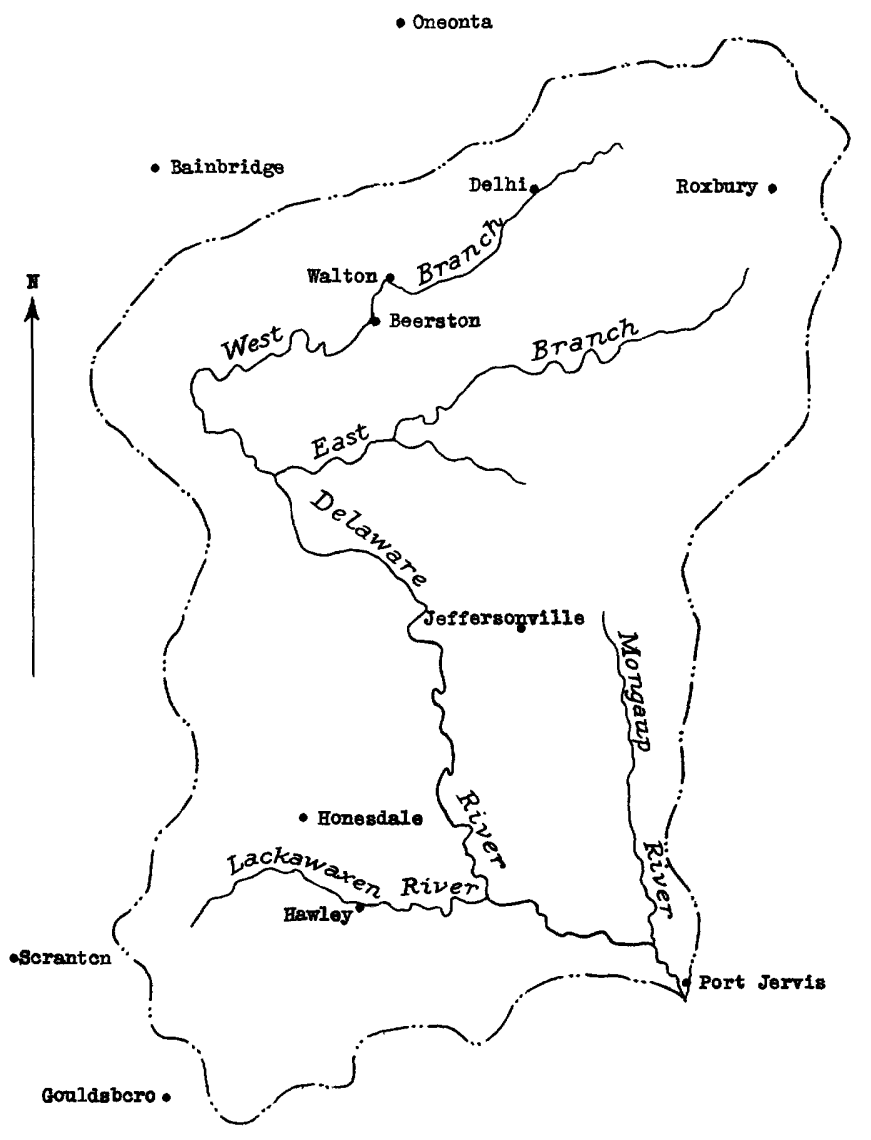

10 o

Figure 56.-Delaware River Basin above Pcrt Jervis, K. Y. Drainege aree 3,070 square miles 

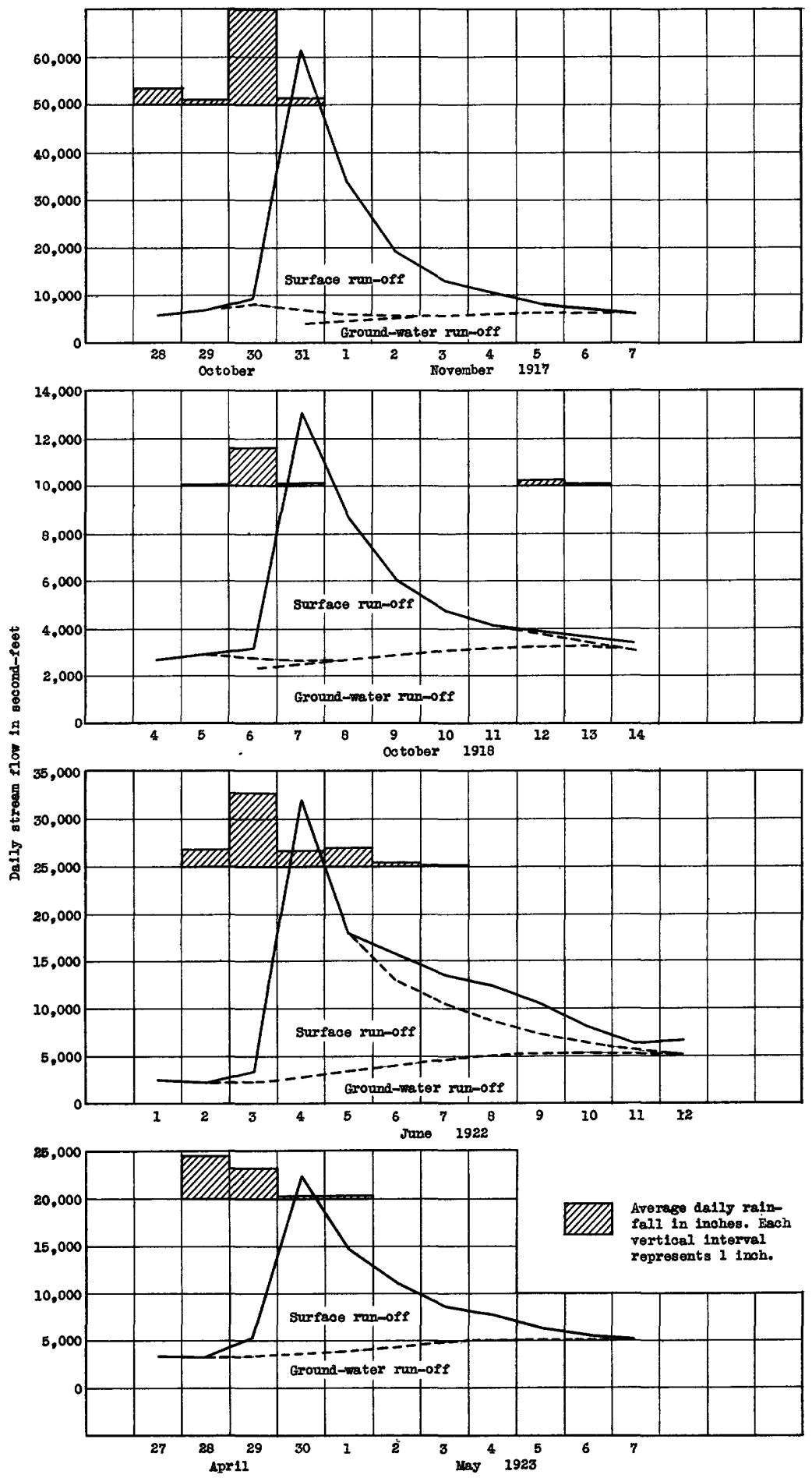

Figure 57.-Unit hydrographs for Delaware River at Port Jervis, N.Y. 

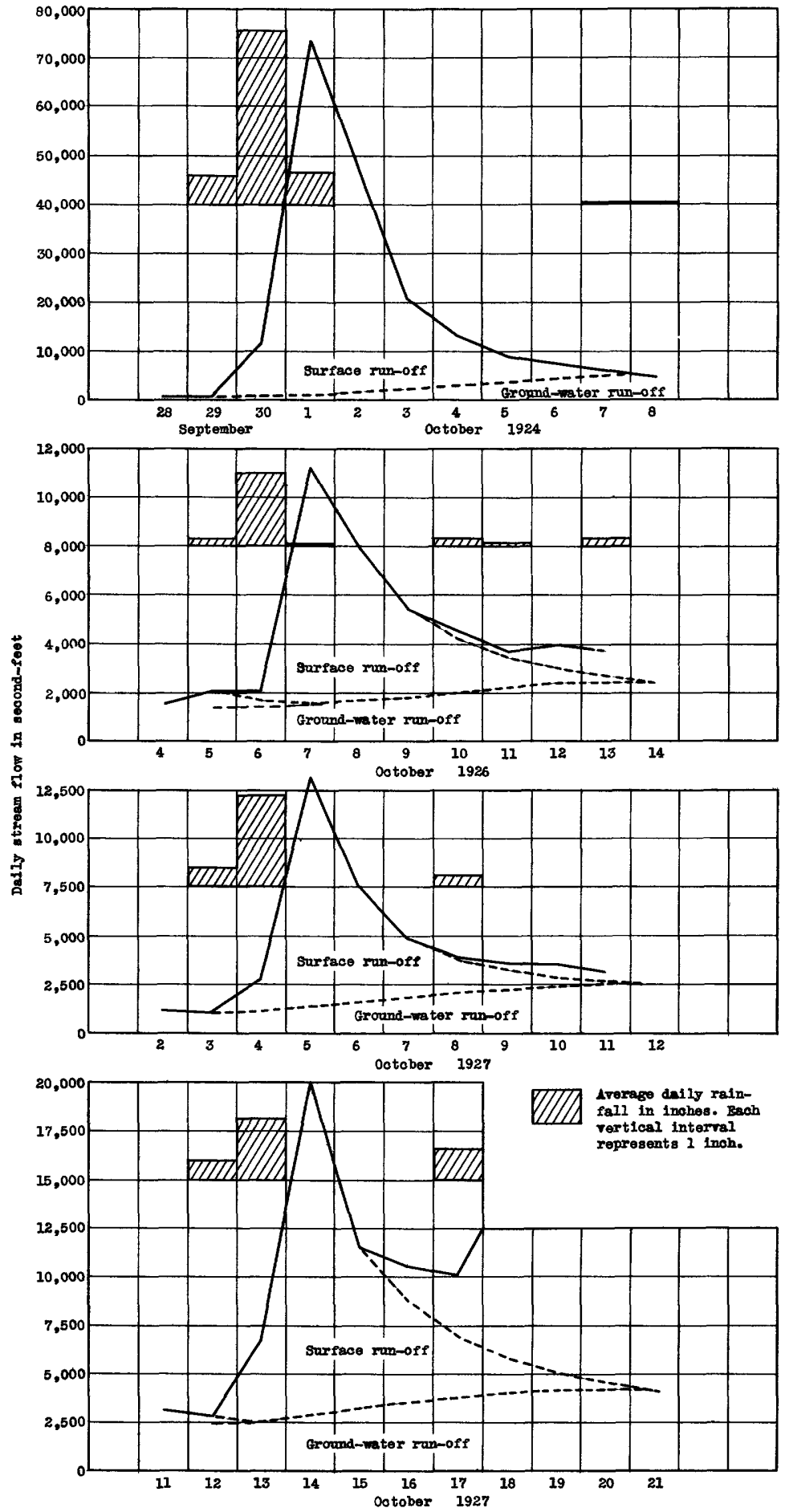

Figare 58.-Dhit hydrographs for Delamare River at Port Jervis, I.T. 


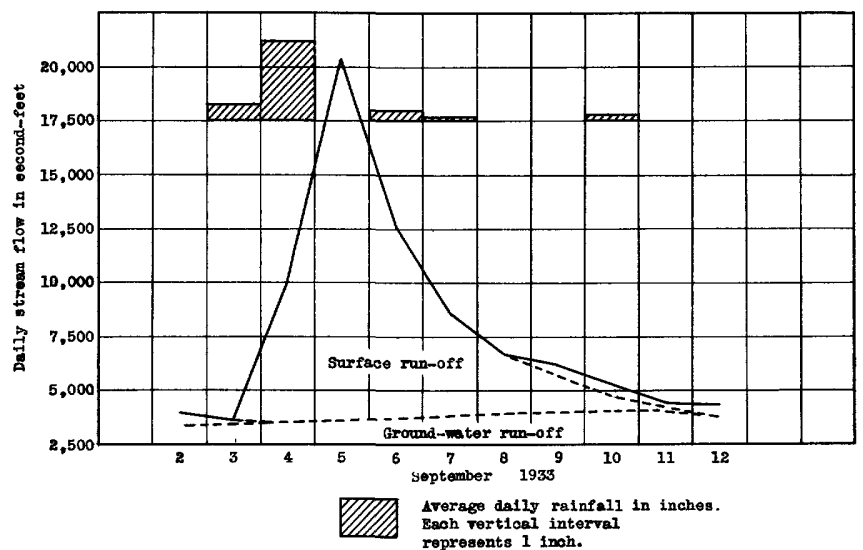

Figare 59,-Untt hydrographs for Delaware Biver at Port Jerv1s, N. Y.

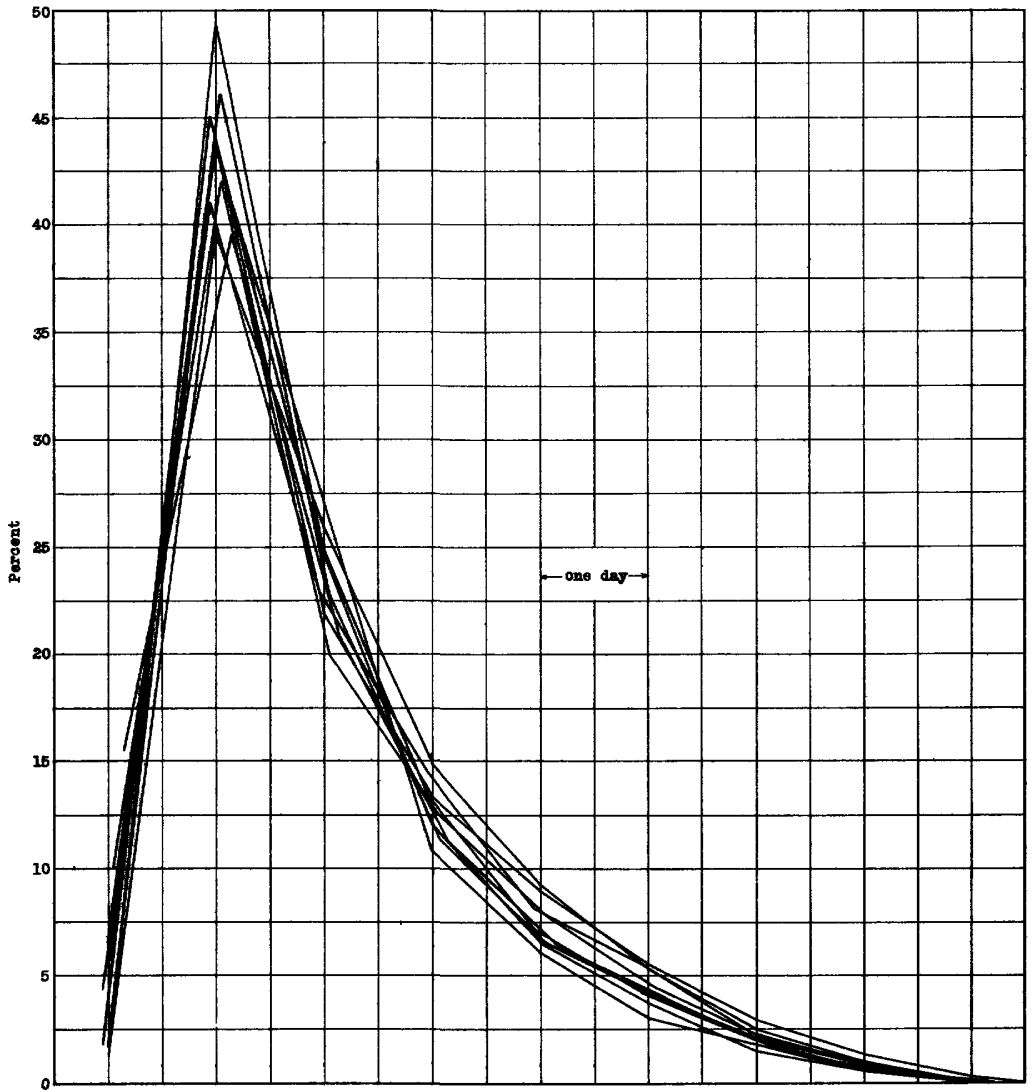

Figure 60.-Superimposed distribation graphs for Delamere B1ver Basin above Port Jervia, M.Y. 
Table 46.- Distribution graphs for storms in

Delaware River Basin above Port Jervis, N. Y.

\begin{tabular}{|c|c|c|c|c|c|c|c|c|c|}
\hline $\begin{array}{l}\text { Oct. } 30,1917 \\
\text { Oct. 6, } 1918 \\
\text { June } 3,1922 \\
\text { Apr. } 29,1923 \\
\text { Sept. 30, } 1924 \\
\text { Oct. 6, 1926 } \\
\text { Oct. 4, } 1927 \\
\text { Oct. 13, 1927 } \\
\text { Sept. 4, } 1933\end{array}$ & $\begin{array}{r}1.0 \\
1.8 \\
1.7 \\
4.4 \\
6.6 \\
1.4 \\
6.1 \\
10.0 \\
15.5\end{array}$ & $\begin{array}{l}49.4 \\
45.0 \\
43.8 \\
41.0 \\
43.7 \\
39.6 \\
46.1 \\
42.0 \\
39.5\end{array}$ & $\begin{array}{l}24.7 \\
25.5 \\
21.9 \\
23.0 \\
27.2 \\
25.9 \\
22.8 \\
20.0 \\
20.9\end{array}$ & $\begin{array}{l}12.2 \\
13.5 \\
13.4 \\
14.6 \\
10.9 \\
14.9 \\
11.5 \\
12.7 \\
11.3\end{array}$ & $\begin{array}{l}6.7 \\
7.2 \\
9.0 \\
8.1 \\
5.3 \\
9.3 \\
6.6 \\
7.8 \\
6.5\end{array}$ & $\begin{array}{l}3.8 \\
4.2 \\
5.6 \\
5.6 \\
3.1 \\
5.4 \\
4.1 \\
4.4 \\
4.0\end{array}$ & $\begin{array}{l}1.6 \\
2.1 \\
3.0 \\
2.4 \\
1.8 \\
2.5 \\
2.0 \\
2.2 \\
1.7\end{array}$ & $\begin{array}{r}0.6 \\
.7 \\
1.3 \\
.9 \\
.6 \\
1.0 \\
.8 \\
.9 \\
.6\end{array}$ & $\begin{array}{c}\overline{-} \\
0.3 \\
= \\
= \\
= \\
=\end{array}$ \\
\hline
\end{tabular}

The individual distribution graphs for the Delaware Basin when superimposed form a more uniform and compact plot than those for any of the other basins studied, although the Delaware is the most rapidly concentratIng stream and its distribution graph has the highest peaks of the group studied.

\section{French Broad River Basin above Dandridge, Tenn.}

The French Broad River rises in the Blue Ridge in Transylvania County, N. Co, near the South Carolina boundary. It first flows in a northerly direction, then northwesterly to the Tennesseo Valley, where it turns southwest.

The drainage area above Dandridge is 4,450 square miles, and the length of the river is about 150 miles. The Nolichucky and Pigeon Rivers drain the principal subbasins. The upper 50 miles of the French Broad has an average slope of 3 feet to the mile, the next $50 \mathrm{miles} 16$ feet to the mile, and the 50 miles above Dandridge 5 feet to the mile. The zero of the gage is 902.8 feet above mean sea level. About 2,800 square miles of the area drained is in North Carolina and consists of high mountainous country with several peaks above an altitude of 5,000 feet. About 50 percent of the area is forest, and the remainder is equaliy divided between crop and pasture.

The United States Geological Survey has published daily discharges at this station since October 1918. The Unfted States Weather Bureau has obtained gage heights since December 1904. The gage that was used when the Geological Survey records began was palnted (1.9 to 35.0 feet) in feet and tenths on the shoreward side of the second concrete pier of the highway briage. As the gage was difficult to read from the bank, a . rowboat was generally used in making a reading once daily. The records 
are considered fair up to 25,000 second-feet and poor above. A new gage was installed in October 1923 on the right bank; the lower part is a sloping section, and the upper part is a vertical staff gage bolted to the right-bank pier. This gage was set to a datum 0.04 foot lower than the Weather Bureau gage. The records are considered good below 30,000 secondfeet and fair above.

A water-stage recorder was installed and has been in use since october 1931. Diurnal fluctuation during low stages is caused by regulation upstream.

The records of daily stream flow are considered poor for the development of any theory connected with the unit hydrograph.

The daily precipitation was obtained by taking the average of 12 to 15 well distributed stations in or adjacent to the basin. The stations and principal drainage are shown on figure 61.

Table 47 gives the daily precipitation recorded at the Weather Bureau stations for the storms producing the unit hydrographs shown in figures 62,63 , and 64 .

Table 47.- Storms considered in connection with unit hyorographs for French Broad River Basin above Dandridge, Tenn.

(Precipitation, in inches, measured in the afternoon except at stations marked *, where it was measured in the morning, and stations marked ***, where it was measured at midnight.)

\begin{tabular}{|c|c|c|c|c|c|c|}
\hline \multirow[b]{2}{*}{ Station } & \multicolumn{6}{|c|}{ August 1921} \\
\hline & 3 & 4 & 5 & 6 & 7 & 8 \\
\hline \multicolumn{7}{|l|}{ North Carolina: } \\
\hline $\begin{array}{l}\text { Altapass } \\
\text { Asheville ** } \\
\text { Banners Elk } \\
\text { Brevard } \\
\text { Cullowhee } \\
\text { Hendersonville } \\
\text { Hot Springs } \\
\text { Marshall } \\
\text { Montreat } \\
\text { Waynesville }\end{array}$ & $\begin{array}{r}1.65 \\
.51 \\
2.60 \\
1.50 \\
1.56 \\
1.85 \\
.70 \\
-\end{array}$ & $\begin{array}{l}0.40 \\
.41 \\
.05 \\
.04 \\
.03 \\
.50 \\
. \\
.43 \\
.06 \\
.\end{array}$ & $\begin{array}{c}0 . \overline{01} \\
. \overline{75} \\
2.10 \\
.43 \\
\overline{-} \\
.02\end{array}$ & $\begin{array}{c}= \\
= \\
\overline{0} \\
\overline{0} \\
= \\
=\end{array}$ & $\begin{array}{r}0.10 \\
.49 \\
.60 \\
.20 \\
.40 \\
1.50 \\
.88 \\
.35 \\
.23 \\
.\end{array}$ & $\begin{array}{l}- \\
- \\
0.05 \\
.10 \\
.13 \\
= \\
=\end{array}$ \\
\hline \multicolumn{7}{|l|}{ Tennessee: } \\
\hline $\begin{array}{l}\text { Dandridge * } \\
\text { Greeneville * } \\
\text { Newport * } \\
\text { Rogersville * }\end{array}$ & $\begin{array}{l}.36 \\
.60 \\
.05 \\
.12\end{array}$ & $\begin{array}{r}.34 \\
1.00 \\
.22 \\
.29\end{array}$ & $\begin{array}{l}.11 \\
.04\end{array}$ & $\begin{array}{l}.19 \\
-\overline{16}\end{array}$ & $\begin{array}{l}. \overline{72} \\
- \\
-\end{array}$ & $\begin{array}{l}.24 \\
.26 \\
.45 \\
.34\end{array}$ \\
\hline Average & $\begin{array}{r}11.50 \\
.88\end{array}$ & $\begin{array}{r}3.77 \\
.29\end{array}$ & $\begin{array}{r}3.46 \\
.27\end{array}$ & $\begin{array}{l}.38 \\
.03\end{array}$ & $\begin{array}{r}5.47 \\
.42\end{array}$ & $\begin{array}{r}1.57 \\
.12\end{array}$ \\
\hline
\end{tabular}


Table 47.- Storms considered in connection with unit hydrographs

for French Broad River Basin above Dandridge, Tenn.--Continued

(Precipitation, in inches, measured in the afternoon except at stations marked *, where it was measured in the morning, and stations marked **, where it was measured at midnight.)

\begin{tabular}{|c|c|c|c|c|c|c|c|c|c|c|c|}
\hline \multirow[b]{2}{*}{ Station } & \multicolumn{11}{|c|}{ April 1922} \\
\hline & 5 & 6 & 5 & 10 & 11 & & 12 & 13 & 14 & & 15 \\
\hline \multicolumn{12}{|l|}{ North Carolina: } \\
\hline $\begin{array}{l}\text { Altapass } \\
\text { Asheville ** } \\
\text { Banners Elk } \\
\text { Brevard } \\
\text { Cullowhee } \\
\text { Hendersonville } \\
\text { Hot Springs } \\
\text { Marshall } \\
\text { Montreat } \\
\text { Waynesville }\end{array}$ & $\begin{array}{l}0 . \\
0.57 \\
.10 \\
.24 \\
.05 \\
.50 \\
.11 \\
.12 \\
.19 \\
.25\end{array}$ & $\begin{array}{r}1.30 \\
.67 \\
.36 \\
1.56 \\
.80 \\
1.51 \\
.34 \\
.70 \\
1.33 \\
.88\end{array}$ & $\begin{array}{l}30 \\
67 \\
36 \\
56 \\
30 \\
51 \\
34 \\
70 \\
33 \\
38\end{array}$ & $\begin{array}{l}= \\
= \\
= \\
= \\
= \\
\overline{-}\end{array}$ & $\begin{array}{l}0 . \overline{0} \\
.20 \\
.32 \\
.25 \\
.30 \\
.22 \\
.33 \\
-\end{array}$ & & $\begin{array}{l}\overline{-} \\
\overline{-} \\
\overline{-} \\
\overline{-} \\
= \\
-\end{array}$ & $\begin{array}{c}- \\
0 . \\
\overline{-} \\
\overline{-09} \\
= \\
=\end{array}$ & $\begin{array}{l}= \\
= \\
= \\
= \\
= \\
= \\
=\end{array}$ & & $\begin{array}{l}. \\
.19 \\
.41 \\
. \overline{10} \\
.16 \\
.74 \\
.17 \\
.14 \\
.\end{array}$ \\
\hline \multicolumn{12}{|l|}{ Tennessee: } \\
\hline $\begin{array}{l}\text { Dandridge * } \\
\text { Greeneville * } \\
\text { Newport * } \\
\text { Rogersville * }\end{array}$ & $\begin{array}{l}- \\
-\end{array}$ & \multicolumn{2}{|c|}{$\begin{array}{l}.36 \\
.30 \\
.26 \\
.83\end{array}$} & $\overline{-}$ & $\begin{array}{l}.14 \\
.10 \\
.24\end{array}$ & \multicolumn{2}{|r|}{$\begin{array}{l}.07 \\
.28 \\
.16 \\
.04\end{array}$} & $\begin{array}{l}- \\
-\end{array}$ & $\begin{array}{l}- \\
- \\
-\end{array}$ & \multicolumn{2}{|r|}{$\begin{array}{l}.30 \\
.17 \\
.65 \\
.10\end{array}$} \\
\hline Average & $\begin{array}{r}2.13 \\
.15\end{array}$ & \multicolumn{2}{|c|}{$\begin{array}{r}11.20 \\
.80\end{array}$} & $\begin{array}{l}.27 \\
.02\end{array}$ & $\begin{array}{r}2.36 \\
.17\end{array}$ & \multicolumn{2}{|r|}{.75} & $\begin{array}{l}.19 \\
.01\end{array}$ & $\begin{array}{l}.17 \\
.01\end{array}$ & \multicolumn{2}{|c|}{$\begin{array}{r}3.13 \\
.22\end{array}$} \\
\hline & \multicolumn{6}{|c|}{ September 1923} & \multicolumn{5}{|c|}{ April 1924} \\
\hline Station & 20 & 21 & 22 & 23 & 24 & 25 & 17 & 18 & 19 & 22 & 26 \\
\hline \multirow[b]{2}{*}{$\begin{array}{l}\text { North Carolina: } \\
\text { Altapass } \\
\text { Ashevilie } * * * \\
\text { Banners Elk } \\
\text { Brevard } \\
\text { Hendersonville } \\
\text { Hot Springs } \\
\text { Marshall } \\
\text { Montreat } \\
\text { Mount Mitchell } \\
\text { Waynesville }\end{array}$} & & & & & & & & & & & \\
\hline & $\begin{array}{c}- \\
= \\
\overline{-} \\
0.04 \\
.02 \\
= \\
= \\
-\end{array}$ & $\begin{array}{r}0.85 \\
.55 \\
.45 \\
- \\
4.30 \\
.70 \\
.07 \\
1.98 \\
1.10 \\
.12\end{array}$ & $\begin{array}{c}- \\
- \\
- \\
0.04 \\
- \\
- \\
. \\
. \\
-\end{array}$ & $\mid \begin{array}{c}1.25 \\
- \\
- \\
- \\
.24 \\
- \\
.23 \\
\overline{-} \\
-\end{array}$ & $\mid \begin{array}{c}1.10 \\
- \\
- \\
- \\
- \\
. \\
.18 \\
1.13 \\
.01\end{array}$ & $\begin{array}{c}0.20 \\
- \\
- \\
- \\
- \\
. \\
1.20 \\
1.20 \\
.19\end{array}$ & $\begin{array}{r}0.20 \\
.41 \\
- \\
. \\
.40 \\
.12 \\
.30 \\
.13 \\
1.57 \\
.10\end{array}$ & $\begin{array}{r}1.00 \\
.45 \\
.20 \\
2.25 \\
1.80 \\
.52 \\
.57 \\
.90 \\
- \\
1.00\end{array}$ & $\begin{array}{c}- \\
0.30 \\
= \\
= \\
= \\
= \\
-\end{array}$ & $\begin{array}{l}= \\
= \\
= \\
= \\
=\end{array}$ & $\begin{array}{r}0.45 \\
.35 \\
.70 \\
.05 \\
.10 \\
.33 \\
.35 \\
.26 \\
.55 \\
.10\end{array}$ \\
\hline \multicolumn{12}{|l|}{ Tennessee: } \\
\hline $\begin{array}{l}\text { Dandridge * } \\
\text { Elizabethton } * \\
\text { Newport * } \\
\text { Rogersville } *\end{array}$ & $\begin{array}{l}- \\
\overline{-}\end{array}$ & $\begin{array}{r}.62 \\
1.30 \\
.78 \\
.33\end{array}$ & $\begin{array}{l}\overline{-} \\
\overline{-}\end{array}$ & $\begin{array}{c}.05 \\
. \\
.42 \\
-\end{array}$ & $\begin{array}{l}- \\
\overline{-}\end{array}$ & $\begin{array}{l}- \\
\overline{-}\end{array}$ & $\begin{array}{l}- \\
- \\
-\end{array}$ & $\begin{array}{r}1.64 \\
.40 \\
1.15 \\
1.47\end{array}$ & $\begin{array}{l}.12 \\
.59 \\
.15 \\
.09\end{array}$ & $\begin{array}{r}0.05 \\
.13 \\
.09 \\
.02\end{array}$ & $\begin{array}{l}.49 \\
.27 \\
.48 \\
.25\end{array}$ \\
\hline Average & .06 & $\mid \begin{array}{r}13.15 \\
1.01\end{array}$ & $\begin{array}{l}.64 \\
.05\end{array}$ & $\begin{array}{r}2.19 \\
.17\end{array}$ & $\begin{array}{r}2.42 \\
.19\end{array}$ & $\begin{array}{r}1.79 \\
.14\end{array}$ & $\begin{array}{r}3.23 \\
.23\end{array}$ & $\left|\begin{array}{r}13.35 \\
.95\end{array}\right|$ & $\begin{array}{r}1.25 \\
.09\end{array}$ & $\begin{array}{l}.29 \\
.02\end{array}$ & $\begin{array}{r}9.73 \\
.34\end{array}$ \\
\hline
\end{tabular}


Table 47.- Storns considered in comnection with unit hydrographs

for French Broad River Basin above Dandridge, Tenn.--Continued

(Precipitation, in inches, measured in the afternoon except at stations marked *, where it was measured in the morning, and stations marked $* *$, where it was measured at midnight.)

\begin{tabular}{|c|c|c|c|c|c|c|c|c|c|}
\hline \multirow[b]{2}{*}{ Station } & \multicolumn{5}{|c|}{ October 1927} & \multicolumn{4}{|c|}{ April - May 1928} \\
\hline & 11 & 12 & 13 & 18 & 19 & 27 & 28 & 30 & 1 \\
\hline \multicolumn{10}{|l|}{ North Carolina: } \\
\hline $\begin{array}{l}\text { Asheville ** } \\
\text { Banners Elk } \\
\text { Brevard } \\
\text { Hendersonville } \\
\text { Hot Springs * } \\
\text { Linville Falls } \\
\text { Marshall * } \\
\text { Montreat * } \\
\text { Mount Mitchell } \\
\text { Waynesville }\end{array}$ & $\begin{array}{c}0.20 \\
= \\
= \\
= \\
= \\
1.02 \\
. \\
.\end{array}$ & $\begin{array}{l}1.98 \\
1.76 \\
2.50 \\
2.08 \\
.21 \\
3.93 \\
1.05 \\
1.08 \\
2.10 \\
1.15\end{array}$ & $\begin{array}{l}- \\
= \\
0.02 \\
55 \\
= \\
= \\
=\end{array}$ & $\begin{array}{l}= \\
= \\
= \\
= \\
0 . \\
=\end{array}$ & $\begin{array}{l}= \\
= \\
= \\
= \\
= \\
=\end{array}$ & $\begin{array}{r}0.97 \\
1.00 \\
1.25 \\
1.34 \\
1.05 \\
.91 \\
.70 \\
.90 \\
1.40 \\
.25\end{array}$ & $\begin{array}{c}0.20 \\
.05 \\
- \\
.52 \\
.88 \\
. \\
.15 \\
1.10 \\
.85\end{array}$ & $\begin{array}{c}0.39 \\
= \\
= \\
= \\
= \\
= \\
=\end{array}$ & $\begin{array}{l}0.02 \\
- \\
. \\
.49 \\
.30 \\
.08 \\
.35 \\
.52 \\
.52 \\
.\end{array}$ \\
\hline \multicolumn{10}{|l|}{ Tennessee: } \\
\hline $\begin{array}{l}\text { Dandridge * } \\
\text { Embreeville * } \\
\text { Newport * } \\
\text { Rogersville * }\end{array}$ & $\begin{array}{l}- \\
-\end{array}$ & $\begin{array}{l}.23 \\
.10 \\
.23 \\
.26\end{array}$ & $\begin{array}{l}.67 \\
.63 \\
- \\
.35\end{array}$ & $\begin{array}{l}- \\
-\end{array}$ & $\begin{array}{l}.19 \\
.19 \\
.\end{array}$ & $\begin{array}{l}.27 \\
.22 \\
.04 \\
.22\end{array}$ & $\begin{array}{r}.68 \\
1.03 \\
1.24 \\
.64\end{array}$ & $\begin{array}{l}- \\
-\end{array}$ & $\begin{array}{l}.11 \\
.03 \\
.14 \\
.07\end{array}$ \\
\hline Average & $\begin{array}{r}1.67 \\
.12\end{array}$ & $\begin{array}{r}18.66 \\
1.33\end{array}$ & $\begin{array}{r}2.22 \\
.15\end{array}$ & .10 & $\begin{array}{l}.81 \\
.06\end{array}$ & $\begin{array}{r}10.52 \\
.75\end{array}$ & $\begin{array}{r}7.34 \\
.52\end{array}$ & $\begin{array}{l}.64 \\
.05\end{array}$ & $\begin{array}{r}2.63 \\
.19\end{array}$ \\
\hline \multirow[b]{2}{*}{ Station } & \multicolumn{9}{|c|}{ April - May I93I } \\
\hline & \multicolumn{3}{|c|}{22} & 23 & 25 & 26 & 27 & 1 & 2 \\
\hline \multicolumn{10}{|l|}{ North Carolina: } \\
\hline $\begin{array}{l}\text { Altapass } \\
\text { Asheville ** } \\
\text { Banners Elk } \\
\text { Hendersonville } \\
\text { Hot Springs } \\
\text { Marshall * } \\
\text { Montreat * } \\
\text { Mount Mitchell } \\
\text { Waynesville }\end{array}$ & $\begin{array}{r}0 . \\
0.17 \\
1.80 \\
.32 \\
= \\
.07 \\
.77 \\
.04\end{array}$ & $\begin{array}{l}1 . \\
1 . \\
1: \\
1 . \\
1 . \\
2 . \\
2 .\end{array}$ & $\begin{array}{l}96 \\
74 \\
94 \\
74 \\
37 \\
35 \\
05 \\
25 \\
32\end{array}$ & $\begin{array}{l}\overline{-} \\
\overline{-} \\
0 . \\
=\end{array}$ & $\begin{array}{c}\overline{-} \\
\overline{0} \\
0 . \\
\overline{0} \\
.06 \\
.05\end{array}$ & $\begin{array}{l}0.05 \\
.14 \\
.30 \\
.02 \\
.48 \\
. \\
.16 \\
.30 \\
.46\end{array}$ & $\begin{array}{c}= \\
= \\
0.15 \\
= \\
=\end{array}$ & $\begin{array}{l}0.10 \\
.13 \\
- \\
.15 \\
.10 \\
- \\
.37 \\
.30\end{array}$ & $\begin{array}{l}0.03 \\
\overline{-02} \\
\overline{10} \\
.14 \\
.02\end{array}$ \\
\hline \multicolumn{10}{|l|}{ Tennessee: } \\
\hline $\begin{array}{l}\text { Dandridge * } \\
\text { Embreevilie * } \\
\text { Newport * } \\
\text { Rogersvilie * }\end{array}$ & $\begin{array}{l}- \\
\overline{-} \\
-\end{array}$ & $\begin{array}{l}1 . \\
1 .\end{array}$ & $\begin{array}{l}28 \\
98 \\
10 \\
10\end{array}$ & $\begin{array}{l}- \\
.06 \\
.05\end{array}$ & $\begin{array}{l}.16 \\
.08 \\
.10 \\
.12\end{array}$ & $\begin{array}{l}.72 \\
.28 \\
.67 \\
.45\end{array}$ & $\begin{array}{l}.08 \\
.06 \\
.01\end{array}$ & .03 & $\begin{array}{l}.04 \\
.12 \\
.06 \\
.11\end{array}$ \\
\hline Average & $\begin{array}{r}3.17 \\
.24\end{array}$ & $\begin{array}{r}20 . \\
1 .\end{array}$ & $\begin{array}{l}18 \\
55\end{array}$ & $\begin{array}{l}.21 \\
.02\end{array}$ & .61 & $\begin{array}{r}4.03 \\
.31\end{array}$ & $\begin{array}{l}.30 \\
.02\end{array}$ & $\begin{array}{r}1.21 \\
.09\end{array}$ & $\begin{array}{l}.84 \\
.06\end{array}$ \\
\hline
\end{tabular}


Table 47.- Storme considered in connection with unit hydrographs

for French Broad River Basin above Dandridge, Tenn.--Continued

(Precipitation, in inches, measured in the afternoon except at stations marked *, where it was measured in the morning, and stations marked **, where it was measured at midnight.)

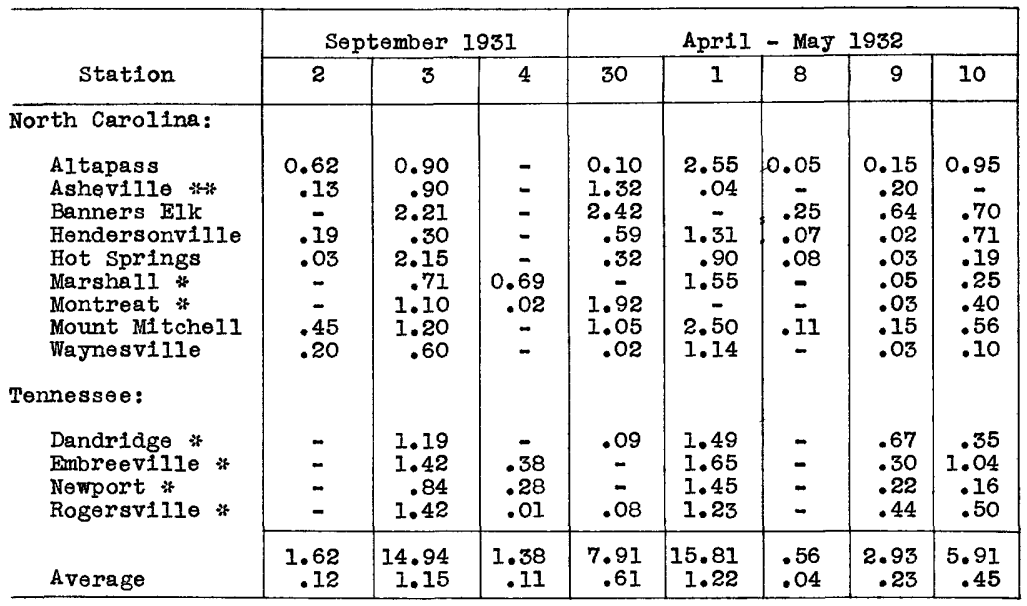

Table 48 gives the eurface run-off from the unit storms and the approximate precipitation that caused the run-off.

Table 48.- Surface run-off from unit storms in

French Broad River Basin above Dandridge, Tenn.

\begin{tabular}{|c|c|c|c|}
\hline Storm & $\begin{array}{c}\text { Average of precipi- } \\
\text { tation at etations } \\
\text { (inches) }\end{array}$ & $\begin{array}{c}\text { Surface run-off } \\
\text { (inches) }\end{array}$ & $\begin{array}{c}\text { Ratio of } \\
\text { surface run- } \\
\text { off to aver- } \\
\text { age precipi- } \\
\text { tation }\end{array}$ \\
\hline Aug. 3, 1921 & 1.44 & 0.57 & 0.40 \\
Apr. 6, 1922 & .95 & .26 & .27 \\
Sept.21, 1923 & 1.06 & .14 & .13 \\
Apr.18, 1924 & 1.27 & .50 & .13 \\
Oct. 12, 1927 & 1.60 & .45 & .35 \\
Apr. 27, 1928 & 1.27 & .49 & .27 \\
Apr. 22, 1931 & 1.81 & .27 & .20 \\
Sept.3, 3931 & 1.38 & .56 & .31 \\
Apr.30,1932 & 1.83 & & .35 \\
\hline
\end{tabular}

Table 49 gives the daily percentages for the nine distribution graphs, and figure 65 shows the graphs superimposed. The average distribution graph determined for the basin is $3,29,25,15,9,7,5,3,2,1$, 1 percent. The first figure of each dietribution graph is the percentage 
UNIT-HYDROCRAPH ANALYSIS OF SURFACE RUN-OFF

191

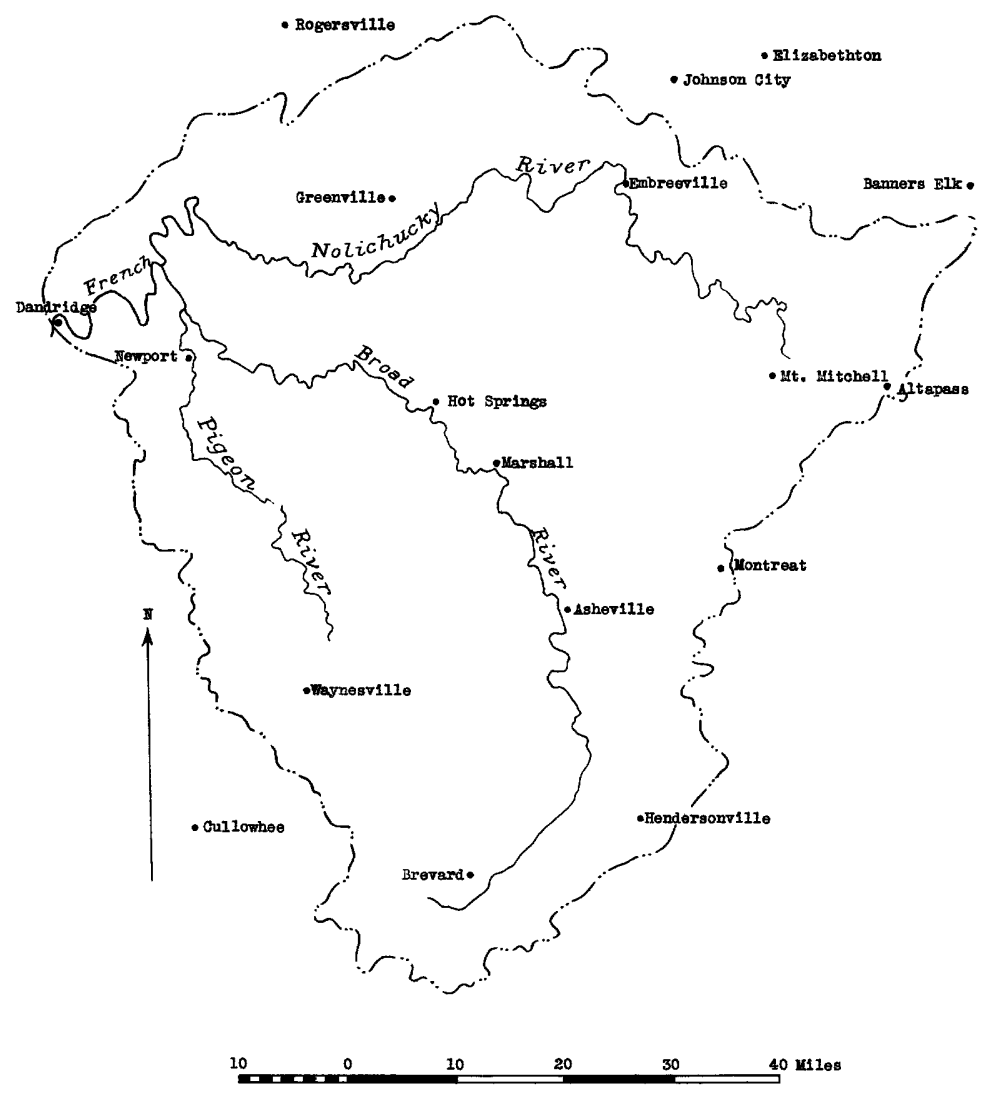

Figure 61.- Prench Broad R1ver Basin abore Dandridge, Tann. Dralnage area 4,450 square miles 

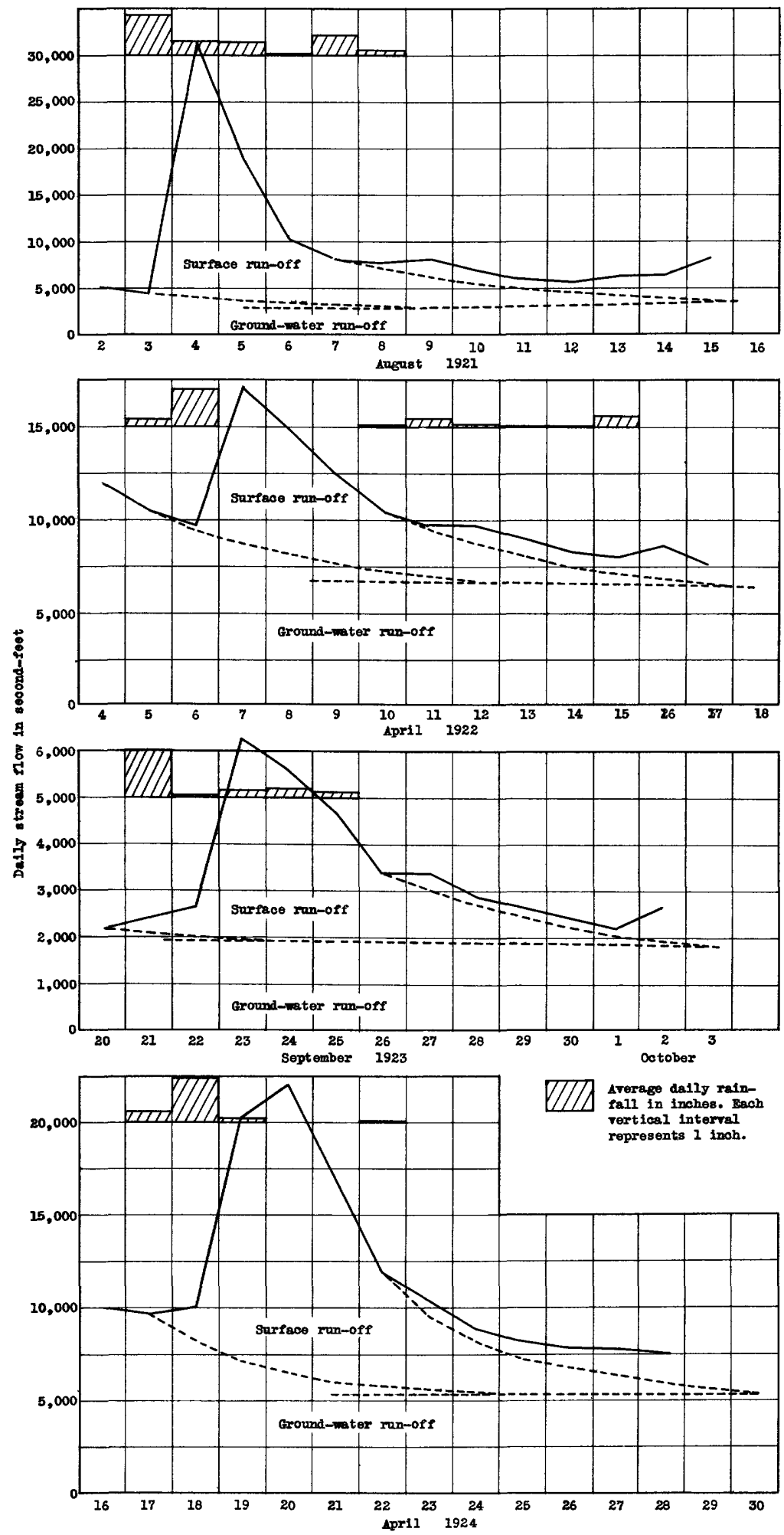

Figure 62.- Init hydrographs for Frenoh Broad Biver at Dendridge, Tenn. 

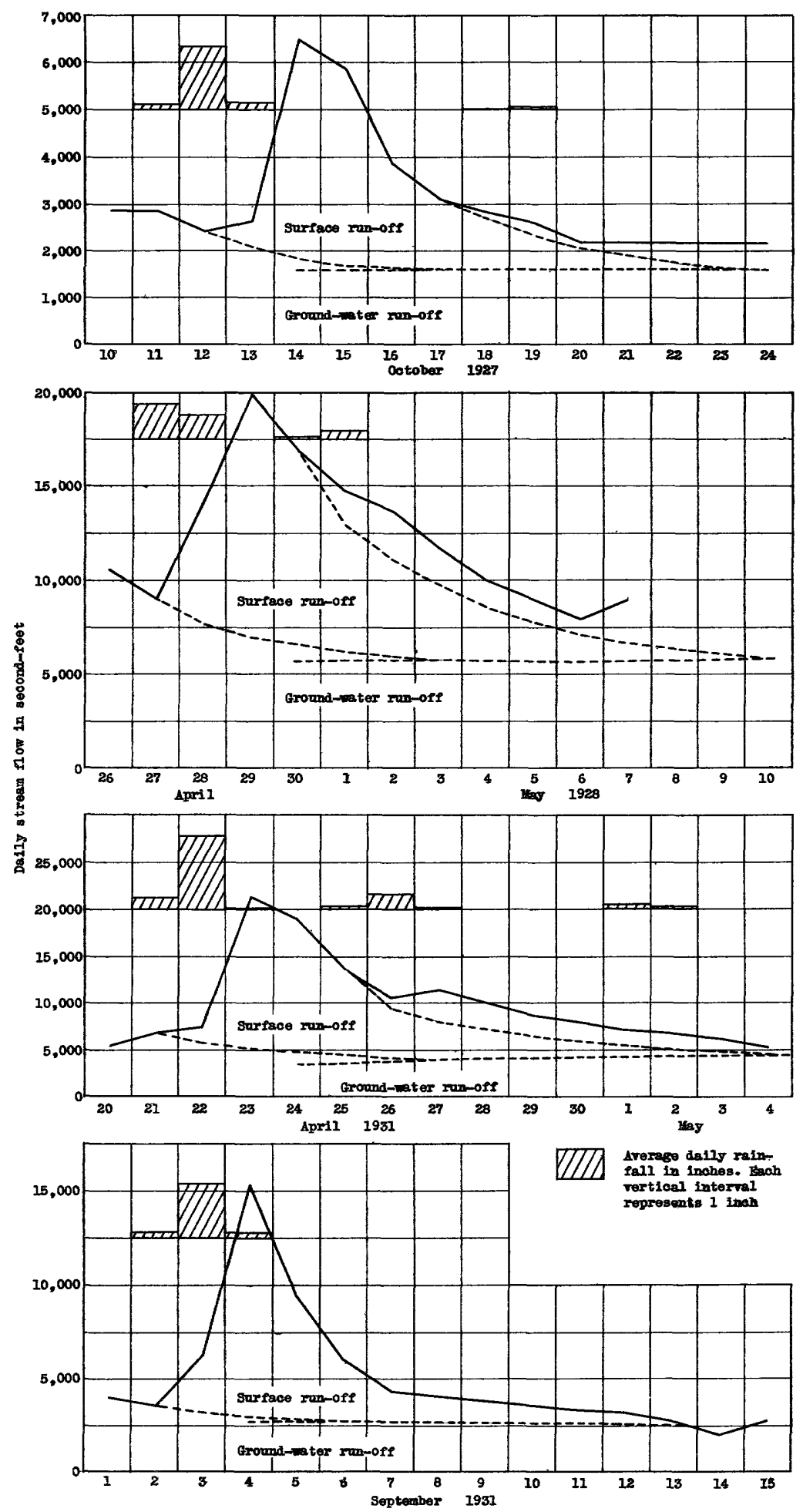


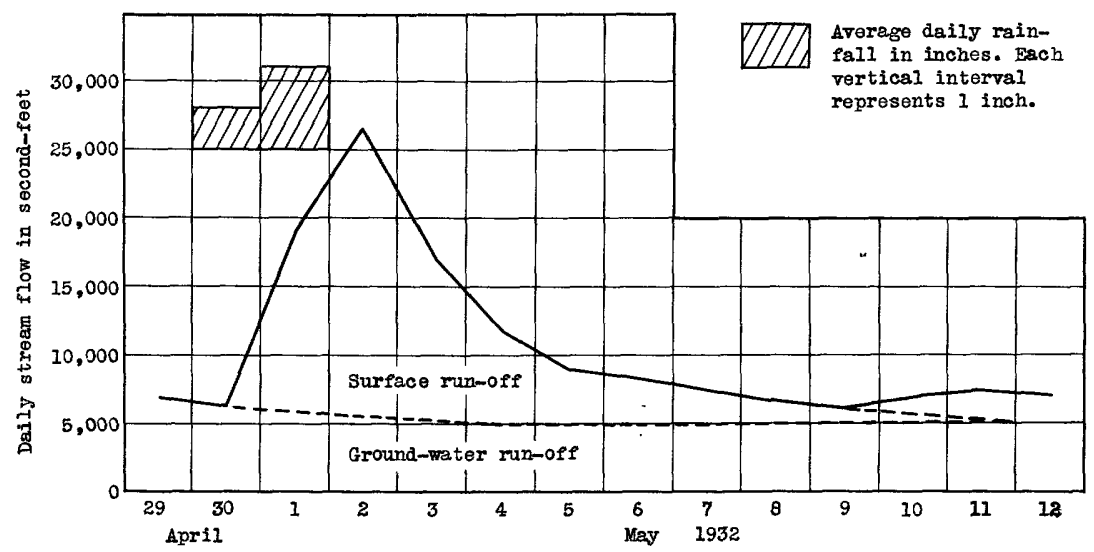

Figure 64.-Unit hydrographs for French Broad River at Dandridge. Tenn. 


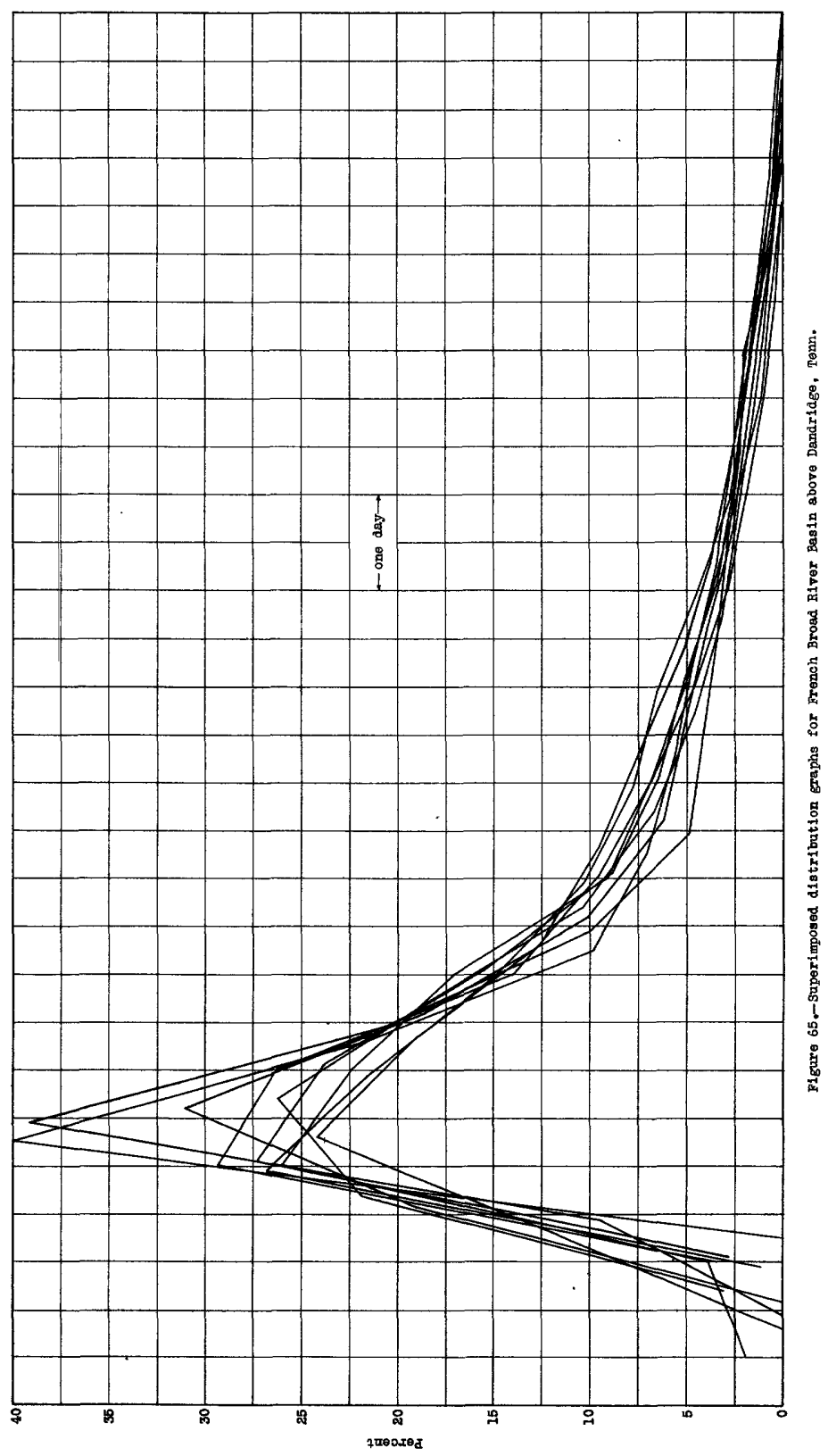


of surface run-off for the calendax day on which most of the rainfall occurred; other figures for succeeding days.

Table 49.- Distribution graphs for storns in

French Broad River Basin above Dandridge, Tenn.

\begin{tabular}{l|l|r|r|r|r|r|r|r|r|r|r|r|r|}
\hline Aug. 3, 1921 & 0 & 40.0 & 22.2 & 9.8 & 7.1 & 5.7 & 4.7 & 3.5 & 2.7 & 2.0 & 1.3 & 0.7 & 0.3 \\
Apr. 6, 1922 & 1.0 & 26.8 & 21.6 & 15.1 & 10.3 & 7.8 & 6.5 & 4.5 & 2.7 & 1.9 & 1.3 & 0.5 & - \\
Sept. 21,1923 & 1.9 & 3.8 & 26.0 & 22.4 & 17.1 & 9.1 & 6.9 & 5.1 & 3.7 & 2.3 & 1.1 & 0.6 & - \\
Apr. 18, 1924 & 3.0 & 21.9 & 26.2 & 18.5 & 10.3 & 6.7 & 4.6 & 3.2 & 2.4 & 1.7 & 1.0 & 0.5 & - \\
Oct. 12, 1927 & 0 & 3.3 & 29.3 & 26.4 & 14.0 & 9.6 & 6.9 & 4.6 & 2.9 & 1.8 & 0.9 & 0.3 & - \\
Apr. 27, 1928 & 0 & 11.8 & 24.1 & 19.2 & 12.6 & 9.6 & 7.4 & 5.3 & 3.9 & 2.7 & 1.8 & 1.2 & 0.4 \\
Apr. 22, 1931 & 2.8 & 27.3 & 23.8 & 15.5 & 8.9 & 6.5 & 5.0 & 3.5 & 2.6 & 1.9 & 1.2 & 0.7 & 0.3 \\
Sept. 3, 1931 & 9.5 & 39.1 & 20.7 & 10.0 & 4.9 & 4.2 & 3.5 & 2.9 & 2.3 & 2.1 & 0.8 & - & - \\
Apr. 30, 1932 & 0 & 19.1 & 31.0 & 18.5 & 10.1 & 6.2 & 5.1 & 3.9 & 2.5 & 1.8 & 1.2 & 0.6 & - \\
\hline
\end{tabular}

\section{Red River Basin above Denison, Tex.}

The Red River heads in eastern New Hexico at an altitude of nearly 5,000 feet and flows a little south of east across the panhandle of Texas, below which it forms the boundary between oklahoma and Texas, draining areas in both States, but mainly from the north. The drainage area above Denison is 39,400 square miles. The length of the river is roughly 550 miles; the length of the basin is about $400 \mathrm{miles}$, and the average width about 100 miles. The country is mainly rolling and hilly with some mountainous areas.

The gaging station at Denison was established in October 1923. A standard chain gage was attached to the dowstream handrail of the highway bridge $4 \frac{1}{2}$ miles northeast of Denison and is read trice daily to mandredths. The control is shifting, and the stage-discharge relation is subject to change. On October 1, 1931, the gage datum was raised 0.22 foot owing to shortening of chain. The records are considered fair, and there are no diversions.

Nomally about 35 Weather Bureau stations are available for determining daily precipitation records. These stations are shown in figure 66. Table 50 gives the daily precipitation recorded at the Weather Bureau stations for the storms producing the unit hydrographs shown in figures 67 and 68 . 


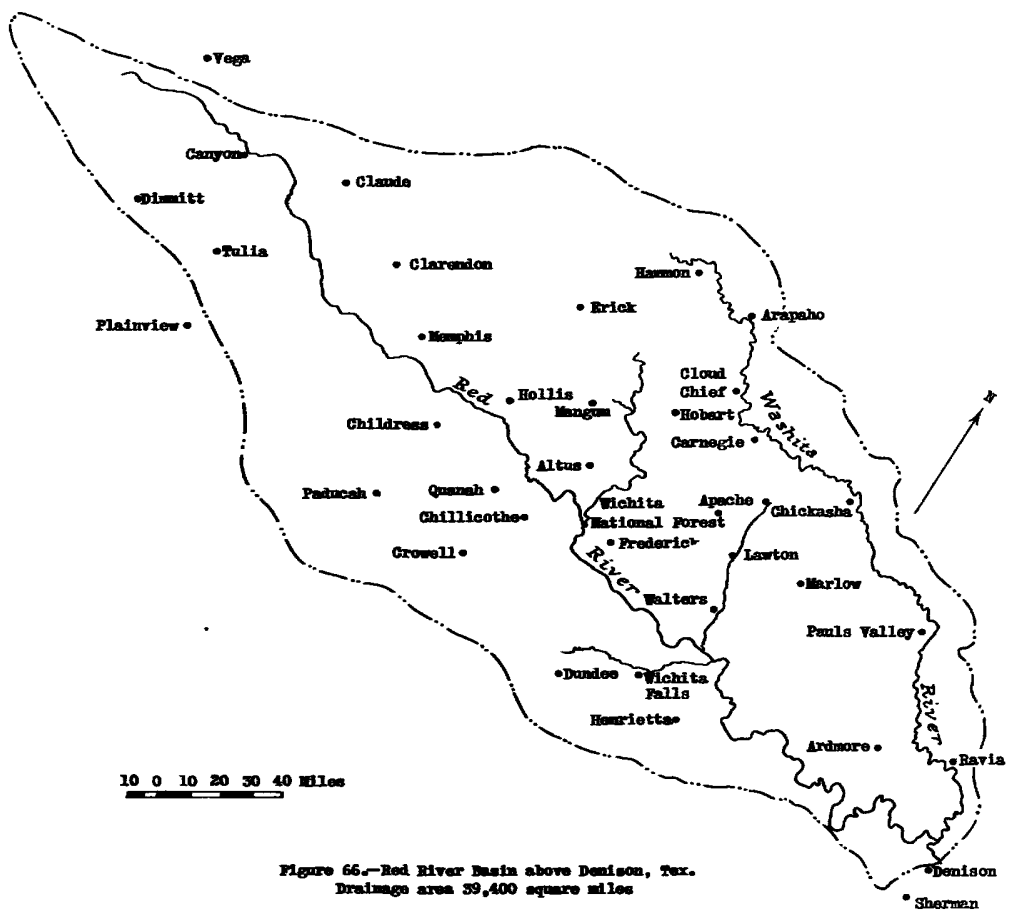


Table 50. - Storms considered in connection with unit

hydrographs for Red River Basin above Denison, Tex.

(Precipitation, in inches, measured in the afternoon except at stations marked $*$, where it was measured in the morning.)

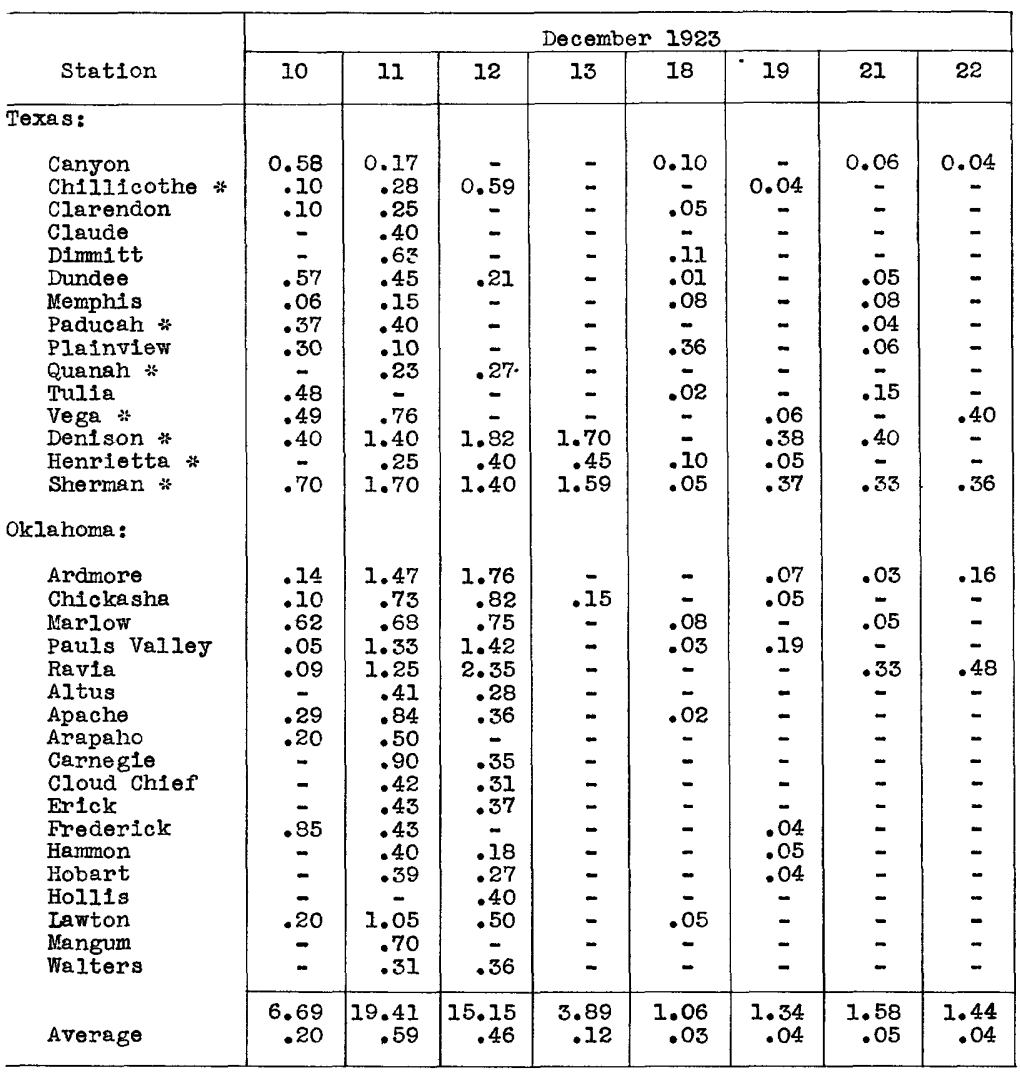


Table 50.- Storms considered in connection with unit hydrographs

for Red River Basin above Denison, Tex.--Continued

(Preclpitation, in inches, measured in the afternoon except at stations marked $*$, where it was measured in the morning.)

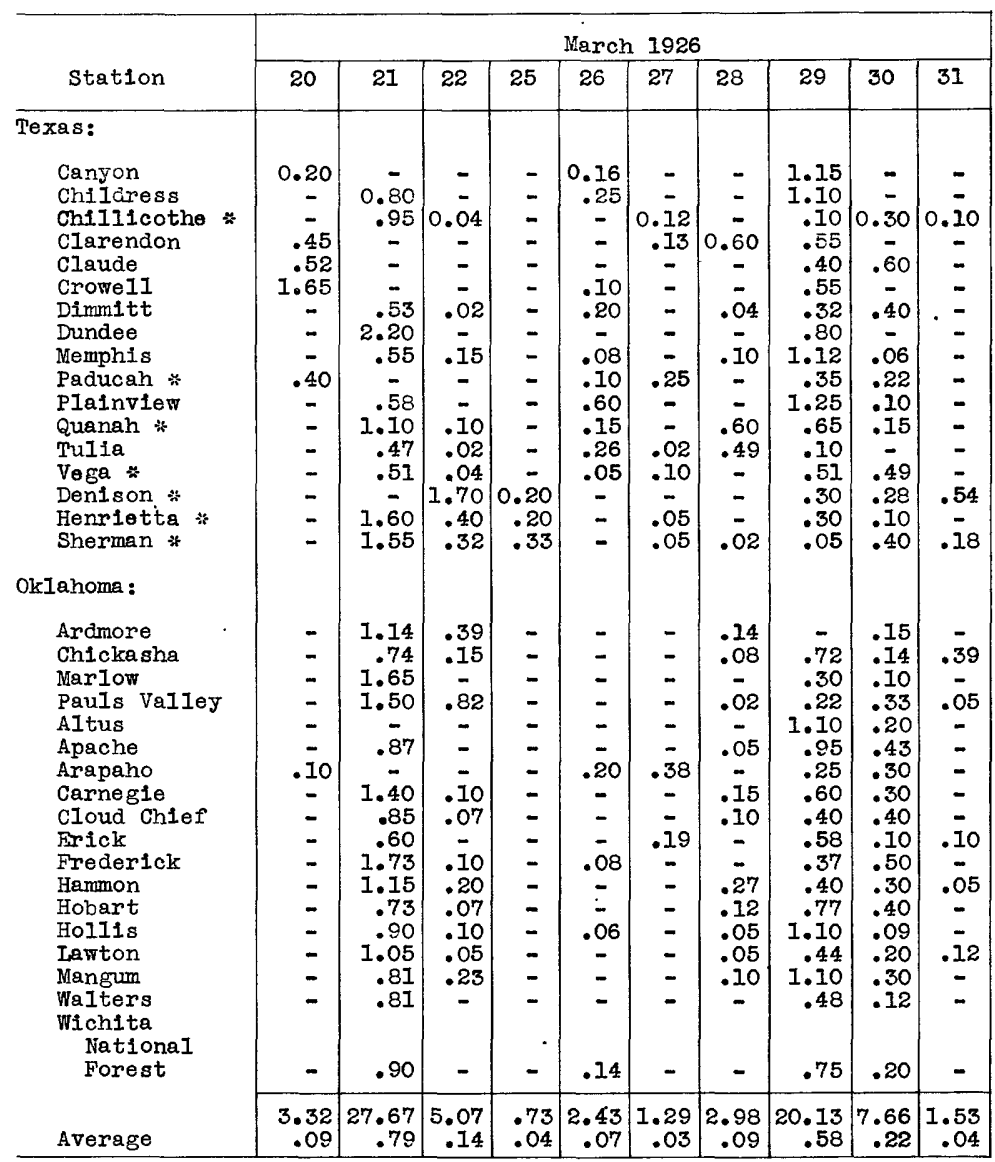


Table 50.- Storms considered in connection with unit hydrographs

for Red River Basin above Denison, Tex.--Continued

(Precipitation, in inches, measured in the afternoon except at stations marked $*$, where it was measured in the morning.)

\begin{tabular}{|c|c|c|c|c|c|c|c|c|c|}
\hline \multirow[b]{2}{*}{ Station } & \multicolumn{9}{|c|}{ March - April 1929} \\
\hline & 26 & 27 & 28 & 29 & 4 & 6 & 7 & 8 & 9 \\
\hline \multicolumn{10}{|l|}{ Texas: } \\
\hline Canyon & 1.65 & 0.35 & - & - & - & - & - & - & - \\
\hline Chilaress & - & 1.35 & 3.30 & - & - & - & - & - & - \\
\hline Chil11cothe * & .07 & .94 & 1.28 & 0.04 & $\ddot{0}$ & - & - & - & - \\
\hline $\begin{array}{l}\text { Clarendon } \\
\text { claude }\end{array}$ & .13 & 2.45 & .40 & - & 0.25 & $\overline{-}$ & - & - & $\overline{-}$ \\
\hline $\begin{array}{l}\text { Claude } \\
\text { Crowell }\end{array}$ &.$\overline{25}$ & $\begin{array}{l}1.47 \\
1.30\end{array}$ & $\begin{array}{l}.31 \\
.80\end{array}$ & $\overline{-}$ & $=$ & - & $\overline{-}$ & - & $\overline{-}$ \\
\hline Dinmitt & - & 1.89 & .32 & - & .20 & - & - & - & - \\
\hline Dundee & - & - & 1.25 & - & - & - & 0.32 & 0.24 & - \\
\hline Memphis & 1.90 & 1.65 & - & - & .05 & - & - & - & - \\
\hline Paducah * & $\begin{array}{r}1.50 \\
.04\end{array}$ & $\begin{array}{l}1.85 \\
3.21\end{array}$ & . & $=$ &.$\overline{10}$ & - & $\overline{-}$ & - & - \\
\hline Quanah * & - & 1.20 & 1.90 & - & .05 & - & - & - & - \\
\hline Vega * & - & 1.15 & .75 & .04 & .01 & - & - & $\overline{0}$ & $\overline{04}$ \\
\hline $\begin{array}{l}\text { Denison * } \\
\text { Henrietta * }\end{array}$ & $\overline{-}$ &.$\overline{80}$ & . & .03 & $\overline{-}$ & $=$ & $\ddot{-}$ & $\stackrel{03}{-}$ & $\begin{array}{c}0.04 \\
-\end{array}$ \\
\hline Sherman * & - & - & - & .27 & - & 0.02 & - & .20 & 1.67 \\
\hline \multicolumn{10}{|l|}{ Oklahoma: } \\
\hline Ardmore & - & .16 & .41 & - & - & .30 & - & .13 & .89 \\
\hline Chickasha & - & .57 & 4.79 & - & - & - & 1.36 & .09 & - \\
\hline Marlow & $=$ & .90 & $\begin{array}{l}1.55 \\
7\end{array}$ & $=$ & $\overline{-}$ & - & - & .07 & $\overline{49}$ \\
\hline $\begin{array}{l}\text { Pauls Valley } \\
\text { Altus }\end{array}$ & $1 . \overline{51}$ & 1.35 & & $=$ & $\overline{-}$ & $\overline{-}$ & $=$ & $=$ & $\stackrel{49}{-}$ \\
\hline Apache & .03 & 2.87 & 1.30 & .02 & $\overline{04}$ & - & 1.37 & .08 & - \\
\hline $\begin{array}{l}\text { Arapaho } \\
\text { Carnegle }\end{array}$ & $2 . \overline{10}$ & $\begin{array}{l}4.96 \\
1.65\end{array}$ & .04 & $\overline{-}$ & .04 & $\overline{-}$ &.$\overline{27}$ & $\overline{-}$ & $\overline{-}$ \\
\hline Cloud Chief & 2.72 & 3.10 & - & - & - & - & - & - & - \\
\hline Erick & $=$ & 3.14 & .86 & - & .01 & - & - & - & $\overline{0}$ \\
\hline $\begin{array}{l}\text { Frederick } \\
\text { Hammon }\end{array}$ & . 29 & $\begin{array}{r}.90 \\
2.20\end{array}$ & .66 & - & $\overline{-}$ & $=$ & $\because$ & $\ddot{-}$ & .05 \\
\hline Hobart & - & 3.42 & 1.87 & - & - & - & - & - & - \\
\hline Hollis & .06 & 4.54 & 1.05 & - & - & - & - & - & - \\
\hline Lawton & - & .90 & 1.70 & - & - & - & - & - & - \\
\hline Mangum & - & 1.40 & 3.50 & - & - & - & - & $\bar{n}$ & $\bar{z}$ \\
\hline \multirow{3}{*}{$\begin{array}{l}\text { Wichita } \\
\text { National } \\
\text { Forest }\end{array}$} & - & .42 & 1.02 & - & - & - & - & .17 & .34 \\
\hline & .10 & 2.00 & 1.00 & - & - & - & 1.20 & - & - \\
\hline & 11.75 & 54.89 & 32.84 & .40 & .71 & .32 & 4.52 & 1.01 & 3.48 \\
\hline Average & .35 & 1.61 & .97 & .01 & .02 & .01 & .13 & .03 & .10 \\
\hline
\end{tabular}


Table 50.- Starms considered in connection with unit hydrographs for Red River Basin above Denison, Tex.--Continued

(Precipitation, in inches, measured in the afternoon except at stations marked *, where it was measured in the morning.)

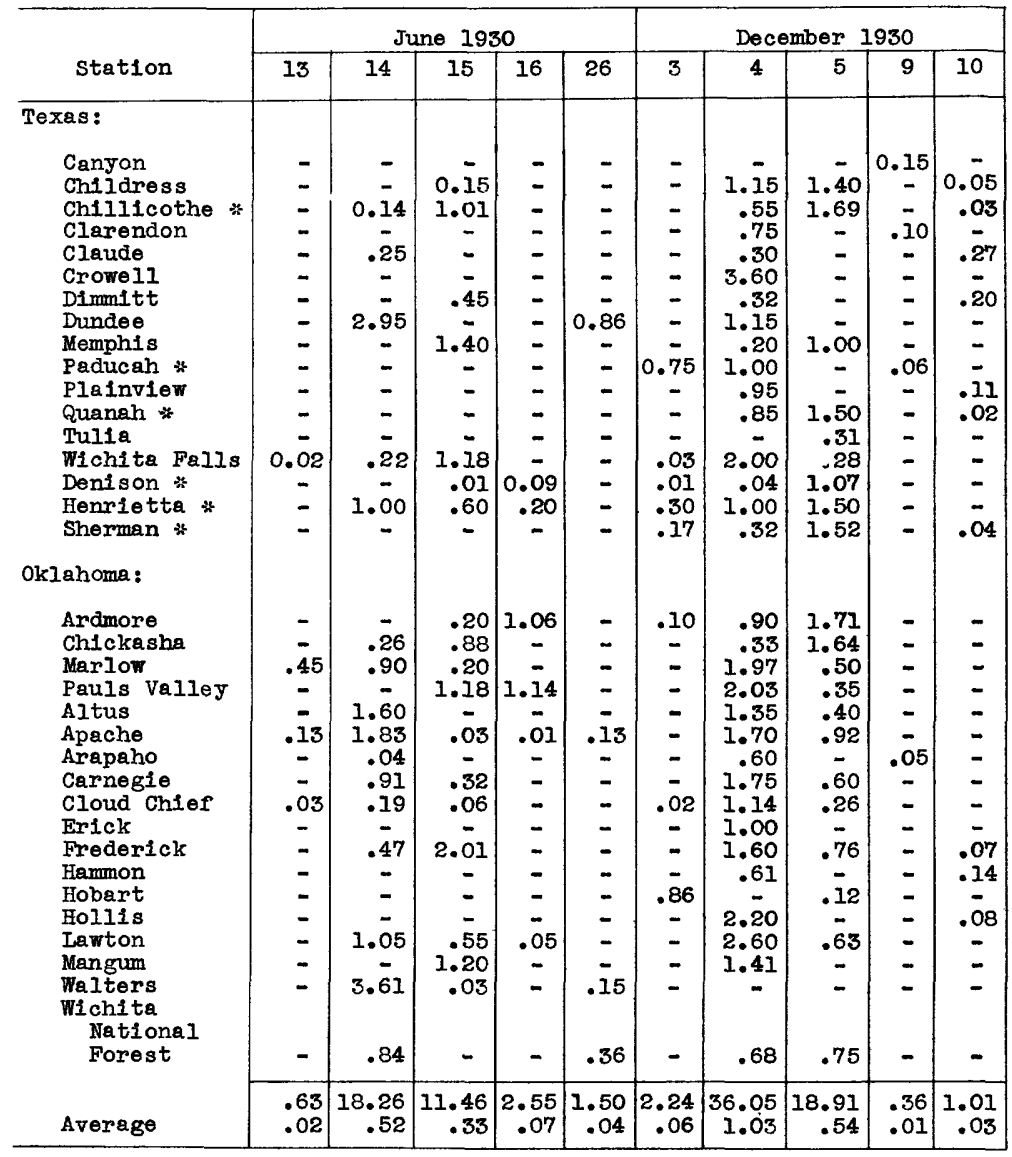


Table 50.- Storms considered in connection with unit hydrographs for Red River Basin above Denison, Tex.--Continued

(Precipitation, in inches, measured in the afternoon except at stations marked *, where it was measured in the morning.)

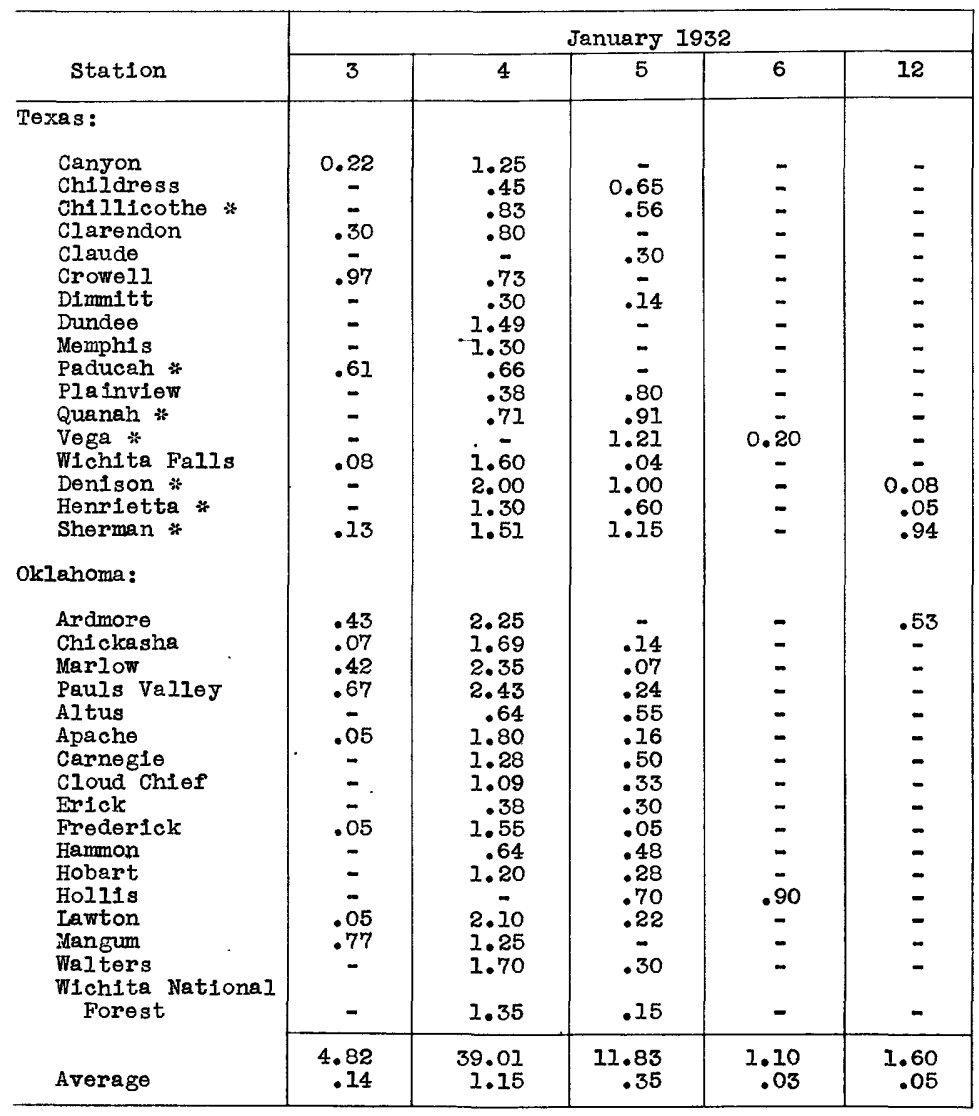


Table 50.- Storms considered in connection with unit hydrographs for Red River Basin above Denison, Tex.--Continued

(Procipitation, in inches, measured in the afternoon except at stations marked *, where it was measured in the morning.)

\begin{tabular}{|c|c|c|c|c|c|c|c|c|}
\hline \multirow[b]{2}{*}{ Station } & \multicolumn{8}{|c|}{ April 1932} \\
\hline & 17 & 18 & 19 & 21 & 22 & 23 & 26 & 27 \\
\hline $\begin{array}{l}\text { Texas: } \\
\text { Canyon } \\
\text { Childress } \\
\text { Chillicothe * } \\
\text { Clarendon } \\
\text { Claude } \\
\text { Crowell } \\
\text { Dimmitt } \\
\text { Dundee } \\
\text { Memphis } \\
\text { Paducah * } \\
\text { Plainview } \\
\text { Quanah * } \\
\text { Tulia } \\
\text { Vega } \\
\text { Wichita Falls } \\
\text { Denison * } \\
\text { Henrietta } * \\
\text { Sherman * } \\
\text { Oklahoma: } \\
\text { Ardmore } \\
\text { Chickasha } \\
\text { Marlow } \\
\text { Pauls Valley } \\
\text { Altus } \\
\text { Apache } \\
\text { Carnegie } \\
\text { Cloud Chief } \\
\text { Erick } \\
\text { Frederick } \\
\text { Haman } \\
\text { Hobart } \\
\text { Hollis } \\
\text { Lawton } \\
\text { Mangum } \\
\text { Walters } \\
\text { Wlchita } \\
\text { National } \\
\text { Forest }\end{array}$ & $\begin{array}{c}0.07 \\
= \\
= \\
= \\
= \\
= \\
= \\
= \\
= \\
= \\
= \\
-\end{array}$ & $\begin{array}{r}. \\
.13 \\
.08 \\
.19 \\
.74 \\
.28 \\
.20 \\
.12 \\
- \\
.55 \\
.07 \\
.33 \\
1.00 \\
.11 \\
1.05 \\
.25 \\
.22\end{array}$ & $\begin{array}{r}2.00 \\
.23 \\
.50 \\
.53 \\
.38 \\
1.50 \\
.80 \\
.75 \\
.45 \\
.22 \\
.44 \\
.58 \\
.13 \\
.14 \\
.40 \\
.47 \\
\\
.47\end{array}$ & 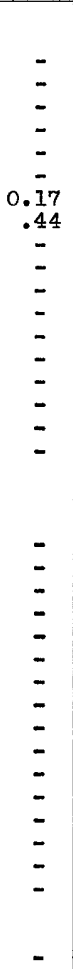 & $\begin{array}{c}0.33 \\
- \\
.75 \\
.70 \\
.65 \\
- \\
.80 \\
.61 \\
= \\
= \\
= \\
= \\
.02\end{array}$ & $\begin{array}{c}0.40 \\
.51 \\
= \\
= \\
\overline{-} \\
\overline{-} \\
- \\
.78 \\
2.95 \\
.65 \\
.08 \\
.85 \\
.90 \\
.30 \\
.81\end{array}$ & $\begin{array}{c}1.49 \\
.35 \\
= \\
.47 \\
= \\
= \\
= \\
.30 \\
.18 \\
.02 \\
= \\
= \\
= \\
= \\
= \\
-\end{array}$ & $\begin{array}{r}- \\
\overline{-} \\
1.12 \\
1.02 \\
1.15 \\
.74 \\
\overline{1} \\
1.00 \\
.88 \\
.49 \\
\overline{4} \\
= \\
= \\
= \\
-\end{array}$ \\
\hline Average & $\begin{array}{l}.34 \\
.01\end{array}$ & $\begin{array}{r}7.03 \\
.20\end{array}$ & $\begin{array}{r}10.29 \\
.29\end{array}$ & .61 & $\begin{array}{r}4.70 \\
.13\end{array}$ & $\begin{array}{r}18.56 \\
.53\end{array}$ & $\begin{array}{r}2.81 \\
.08\end{array}$ & $\begin{array}{r}9.15 \\
.26\end{array}$ \\
\hline
\end{tabular}


Table 50.- Storms considered in connection with unit hydrographs

for Red River Basin above Denison, Tex.--Continued

(Precipitation, in inches, measured in the afternoon except at stations marked *, where it was measured in the morning.)

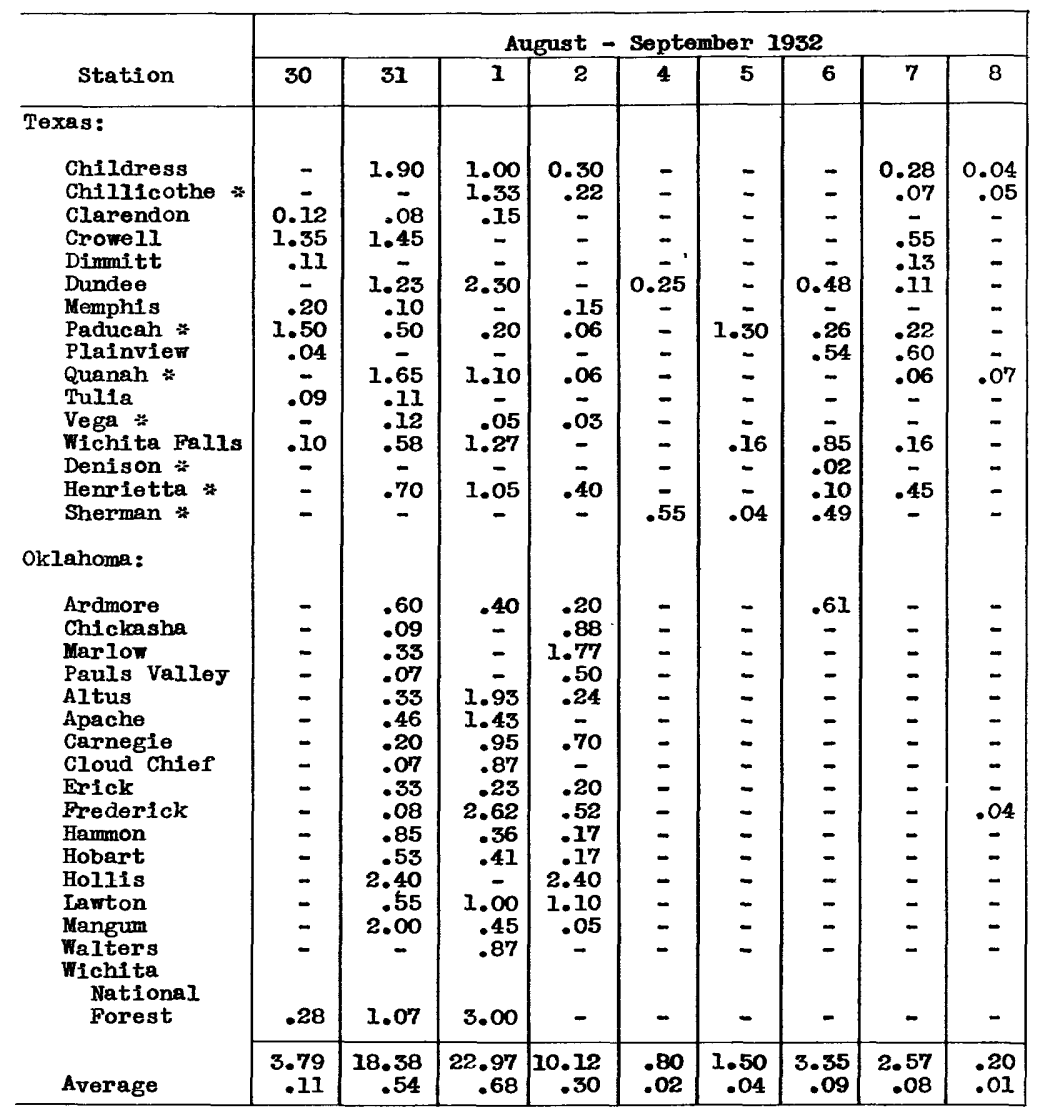

Table 51 gives the surface run-off from the unit storms and the approximate precipitation that caused the run-off. 

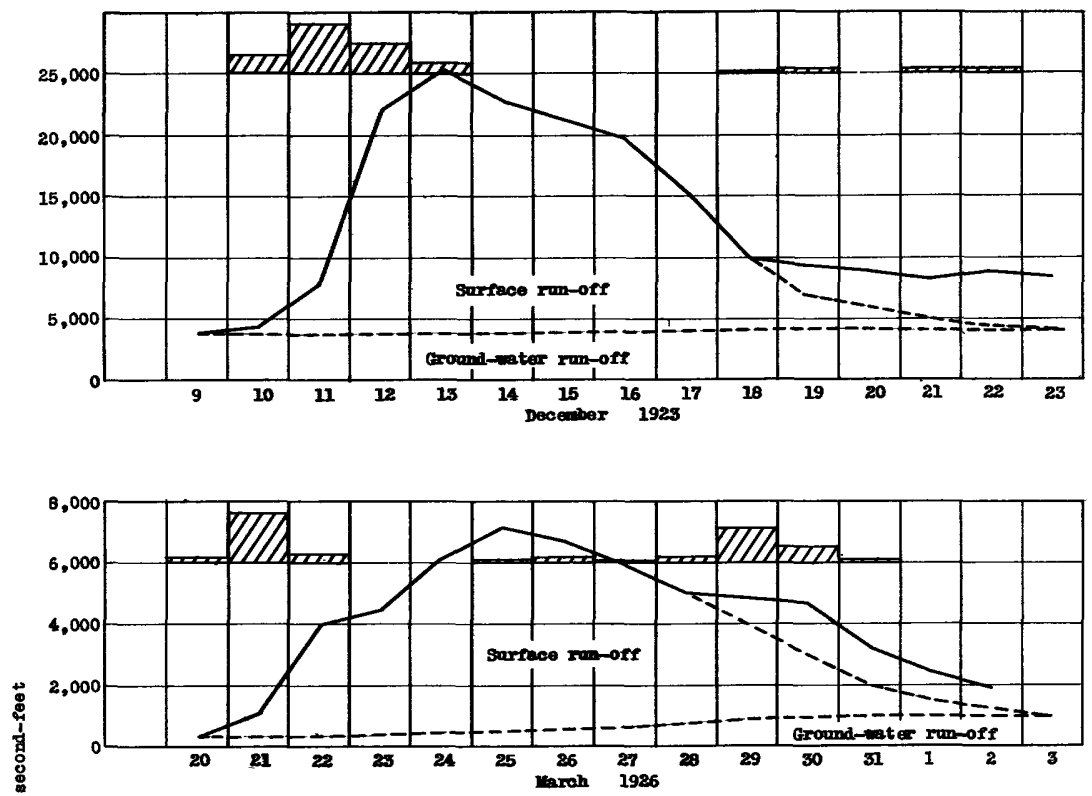

है

悬
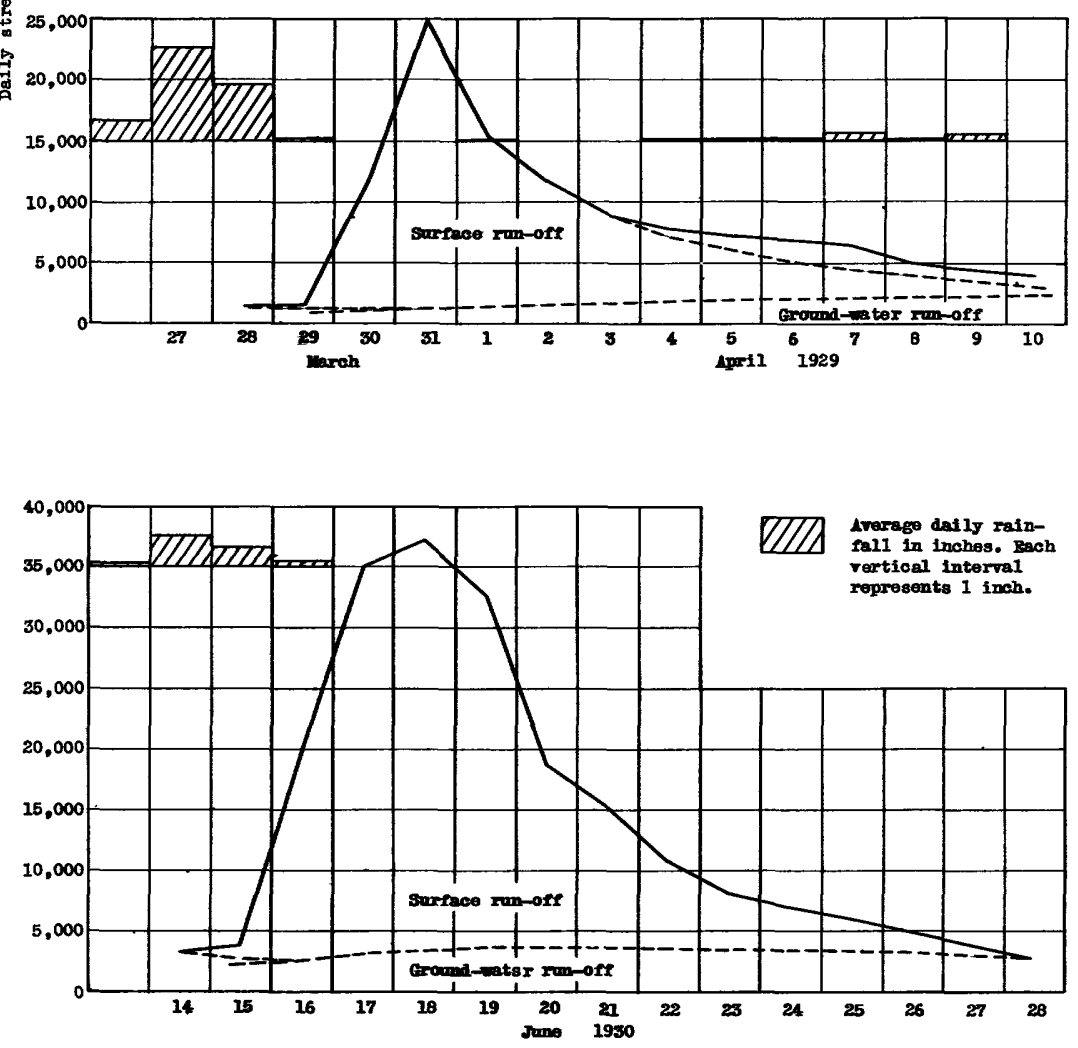

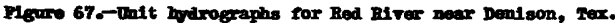



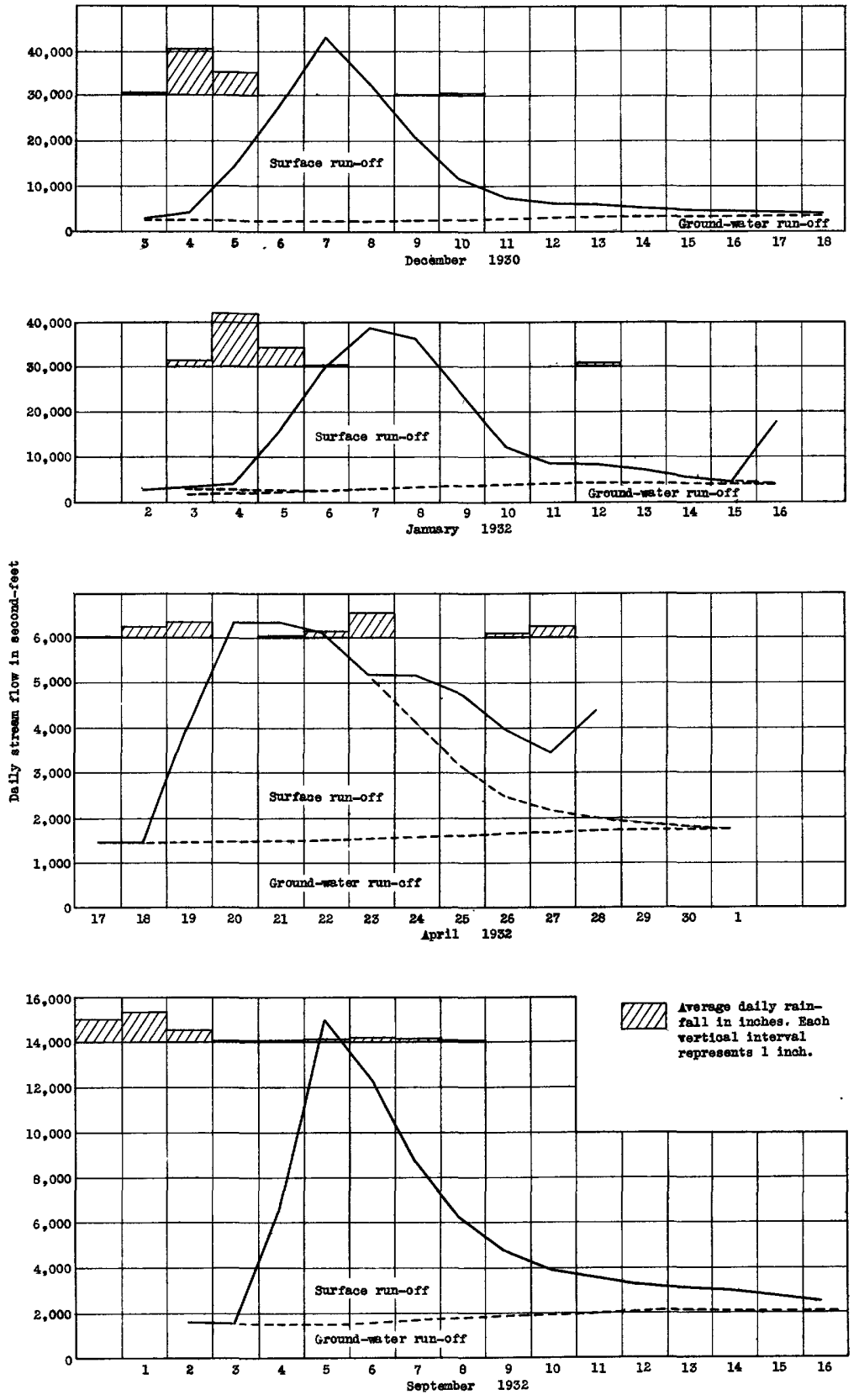

Plgure 68.-Onit hydrogrephs for Red Riter near Denlson, Tex. 
Table 51.- Surface run-off trom unit storms in

Red River Basin above Denison, Tex.

\begin{tabular}{|c|c|c|c|}
\hline Storm & $\begin{array}{c}\text { Average of precipi- } \\
\text { tation at stations } \\
\text { (1nches) }\end{array}$ & $\begin{array}{c}\text { Surface run-off } \\
\text { (Inches) }\end{array}$ & $\begin{array}{c}\text { Ratio of } \\
\text { surface run- } \\
\text { off to aver- } \\
\text { age precipi- } \\
\text { tation }\end{array}$ \\
\hline Dec. 10, 1923 & 1.37 & 0.17 & 0.08 \\
Mar. 21, 1926 & 1.02 & .04 & .04 \\
Mar. 27, 1929 & 2.94 & .08 & .03 \\
June 14, 1930 & .94 & .15 & .16 \\
Dec. 4, 1930 & 1.63 & .15 & .09 \\
Jan. 4, 1932 & 1.67 & .14 & .06 \\
Apr. 18, 1932 & 1.50 & .05 & .03 \\
Sept. 1, 1932 & 1.63 & & \\
\hline
\end{tabular}

Table 52 gives the dally percentage for the elght distribution graphs, and the graphs are superimposed in figure 69. The average distribution graph determined for the basin is $1,8,18,22,18,12,8,5,3,2$, 2, 1 percent. The flrst flgure of each distribution graph 18 the percentage of surface run-off for calendar day on which most of the rainfall occurred; other figures for succeeding days.

Table 52.- Distribution graphs for storms in Red River Basin above Denison, Tex.

\begin{tabular}{|c|c|c|c|c|c|c|c|c|c|}
\hline Storm & 1 & $\mathbf{Z}$ & \multicolumn{2}{|c|}{3} & 4 & 5 & \multirow[b]{2}{*}{$\begin{array}{c}6 \\
14.3 \\
14.2 \\
16.7 \\
18.3 \\
11.9 \\
13.8 \\
13.7 \\
13.6\end{array}$} & \multirow[b]{2}{*}{$\begin{array}{r}7 \\
13.1 \\
12.2 \\
12.0 \\
9.4 \\
5.7 \\
5.6 \\
9.5 \\
8.5\end{array}$} & \multirow[b]{2}{*}{$\begin{array}{c}8 \\
9.7 \\
9.8 \\
8.3 \\
7.2 \\
2.8 \\
3.0 \\
5.8 \\
5.5\end{array}$} \\
\hline $\begin{array}{l}\text { Dec. 10, } 1923 \\
\text { uar. 21, } 1926 \\
\text { Mar. 27, } 1929 \\
\text { June 14, } 1930 \\
\text { Dec. 4, } 1930 \\
\text { Jan. 4, } 1932 \\
\text { Apr. 18, } 1932 \\
\text { Sept. 1, } 1932\end{array}$ & $\begin{array}{l}0.4 \\
1.7 \\
0 \\
0 \\
1.0 \\
1.0 \\
0 \\
0\end{array}$ & $\begin{array}{c}3.5 \\
8.4 \\
0 \\
.6 \\
8.0 \\
8.2 \\
10.0 \\
0\end{array}$ & $\begin{array}{r}15 \\
9 \\
10 \\
17 \\
17 \\
18 \\
10\end{array}$ & & $\begin{array}{l}3.0 \\
3.1 \\
.6 \\
.9 \\
.9 \\
.1 \\
.1 \\
.14\end{array}$ & $\begin{array}{l}15.8 \\
15.3 \\
28.2 \\
21.2 \\
19.8 \\
21.5 \\
17.3 \\
21.0\end{array}$ & & & \\
\hline Storm & 8 & 10 & 11 & 12 & 13 & 14 & 15 & 16 & 17 \\
\hline $\begin{array}{l}\text { Dec. } 10,1923 \\
\text { Mar. 21, } 1926 \\
\text { Mar. 27, } 1929 \\
\text { June } 14,1930 \\
\text { Dec. 4, } 1930 \\
\text { Jan. 4, } 1932 \\
\text { Apr. 18, } 1932 \\
\text { Sept. 1, } 1932\end{array}$ & $\begin{array}{l}4.9 \\
7.2 \\
7.0 \\
4.4 \\
1.9 \\
2.7 \\
3.2 \\
4.0\end{array}$ & $\begin{array}{l}2.3 \\
4.8 \\
4.8 \\
2.8 \\
1.7 \\
1.9 \\
1.9 \\
3.1\end{array}$ & $\begin{array}{l}1.5 \\
2.3 \\
3.6 \\
2.1 \\
1.1 \\
1.0 \\
1.0 \\
2.5\end{array}$ & $\begin{array}{r}0.7 \\
1.1 \\
2.6 \\
1.7 \\
.9 \\
.3 \\
.6 \\
1.9\end{array}$ & $\begin{array}{r}2.0 \\
1.1 \\
.5 \\
.2 \\
.2 \\
1.6\end{array}$ & $\begin{array}{r}0.2 \\
1.4 \\
.4 \\
.4 \\
- \\
1.1\end{array}$ & $\begin{array}{l}- \\
0.8 \\
.3 \\
= \\
1.0\end{array}$ & $\begin{array}{l}- \\
0.5 \\
.2 \\
.5\end{array}$ & $\begin{array}{l}= \\
0.2 \\
= \\
=\end{array}$ \\
\hline
\end{tabular}

For practical application of the unit-hydrograph theory, it would seem that the drainage area of the Red River above Dentson $(39,400$ square miles) is too large to work with, except possibly ror studying floods due to heavy rainfall of wide extent. 


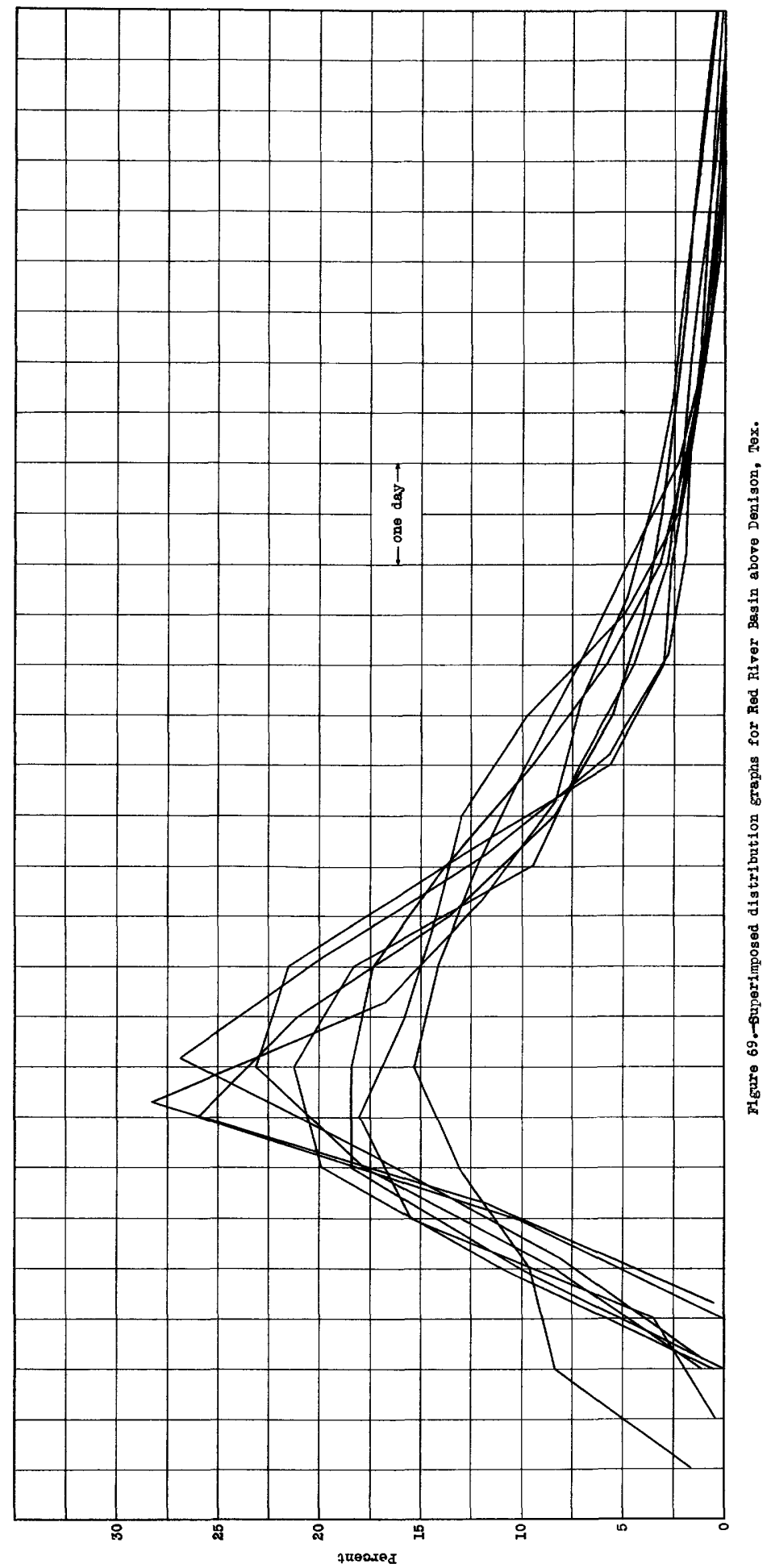


Table 53 gives the summary of the average distribution graphs for the eight basins. They are also plotted on figure 70 for graphic comparison.

Table 53.- Average distribution graphs, in percent

\begin{tabular}{l|r|r|r|r|r|r|r|r|}
\hline Day & Muskingum & Wabash & Embarrass & Skunk & Susquehanna & Delaware & $\begin{array}{l}\text { French } \\
\text { Broad }\end{array}$ & Red \\
\hline lst & 4 & 3 & 5 & 1 & 12 & 6 & 3 & 1 \\
2d & 15 & 12 & 25 & 32 & 33 & 43 & 29 & 8 \\
3d & 27 & 27 & 29 & 27 & 24 & 24 & 25 & 18 \\
4th & 21 & 24 & 18 & 18 & 15 & 13 & 15 & 22 \\
5th & 13 & 14 & 10 & 11 & 8 & 7 & 9 & 18 \\
6th & 8 & 9 & 6 & 5 & 4 & 4 & 7 & 12 \\
7th & 5 & 5 & 3 & 3 & 2 & 2 & 5 & 8 \\
8th & 3 & 3 & 2 & 2 & 1 & - & 2 & 3 \\
9th & 2 & 2 & 1 & 1 & 1 & - & 1 & 2 \\
10th & 1 & 1 & 1 & - & - & - & 1 & 2 \\
11th & 1 & - & - & - & - & - & - & 1 \\
l2th & - & - & - & - & - & &
\end{tabular}

The average distribution graphs as obtained for these basins reflect the time of occurrence, synchronization with the calendar day, and other characteristics of most of the unit storms for the respective basin. To the extent that these characteristics are different in the different basins the average distribution graphs presented in table 53 and figure 70 are not strictly comparable - that is, if a unit storm of the same duration and time of occurrence took place on all the basins simultaneously, the percentages of surface run-off on the first day from the several basins would probably not be the same as the percentages given in the table.

The general shape, however, of the various graphs on figure 70 reflects the characteristics of the different basins. No attempt has been made to correlate the graphs with the physical characteristics of the respective basins, except to note that the peak day's percentage of surfaco rum-orf varies with the lag or time between peak rainfall and resulting peak mun-off. The percentage of run-off on the peak day seems to be an Inverse exponential function of the lag, and as the lag is readily ascertainable for any basin, this foature may have significance in further stuaies.

$59550-35-14$ 


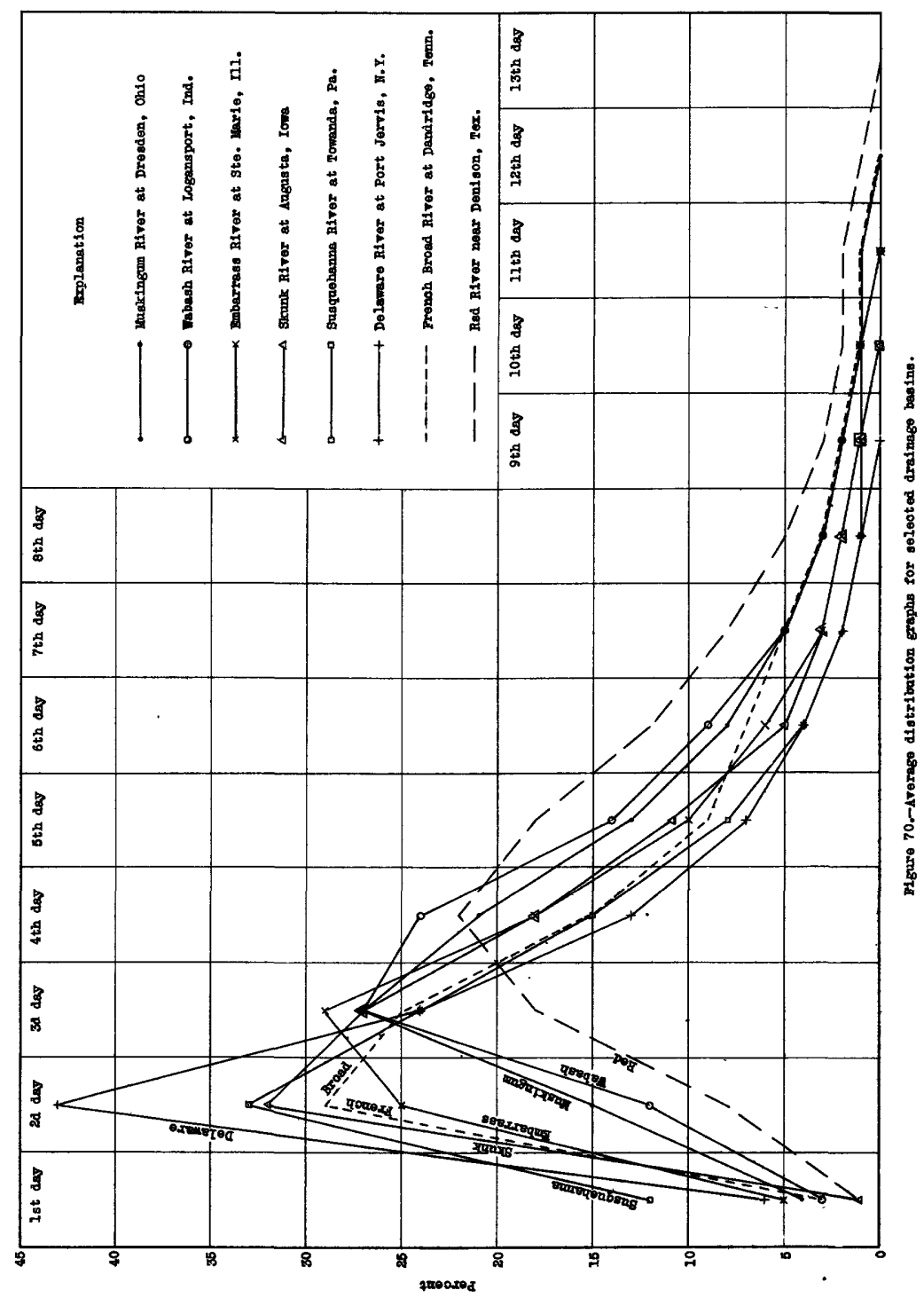




\section{Application of the unit-hydrograph principle}

In the present study the principle of the unit hydrograph has been applied by Merrill Bernard in storm transposition studies and reference is made on page 118 , to its use in studies of stream-flow separation. The principle is also being applied by several agencies, principally in connection with flood problems.

The following statement, prepared in the Special Claims Division of the United States District Engineer Office, St. Paul, Minn., Maj. Dwight F. Johns, district engineer, by W. J. Parsons, under the direction of J. A. Grant, describes briefly the use that is being made of unithydrograph principles in analyzing surface run-off in connection with operation of pools for navigation on the upper Mississippi River: With the development of operating plans for the 9-foot channel project on the upper Mississippi River, it becomes apparent that complete knowledge of the day-by-day inflow into the pools created by the several dams will be desirable. Furthermore, it appears that operation would be much improved if flood inflow from 2 to 5 days in advance could be estimated. on the main Mississipp1 River above Minneapolis and on the major tributaries there are stream gaging stations so located as to give sufficient warning of floods from the upper reaches, providing daily reports come in promptly. But the mun-off from areas below these gaging stations and the run-off from the minor tributaries where no stations are malntained will be unknown and should be estimated. Accordingly, a study has been made of the feasibility of predicting flood inflow from these areas from the rainfall. The unit-flood (term corresponds to the unit hydrograph) method introduced by Mr. Leroy K. Sherman, which distributes the run-off from each day's rain according to the composite pettern observed in actual simple floods, was recognized as a convenient method of analys1s, because of 1 ts simpliclty and because of 1ts essentially rational basis. The day-by-day nature of the desired predictions limited the study to flood flows, and no attempt was made to analyze groundwater inflow, which varies slowly over long perlod of time. The unlt-flood method appears to meet the requirements, because 
consistent unit floods have been developed for most of the tributary basins, and complex floods have been reproduced by the addition of the proper unit floods.

"Basin studies made.- Onit floods were developed for each river by reducing to a peak of 100 second-feet all recorded simple floods produced by I-day rains and such portions of complex floods as were dominated by l-day rains as the flood rose or fell away from the peak. These simple floods and portions of complex floods were averaged graphically, and a distribution diagram prepared for each stream. Although it is admitted that In this territory the total flood volume is e more uniform function of the rainfall than the peak flow (which is materially influenced by the distribution and short-time intensity of the rainfali), it is believed that this disadvantage is more than overcome by the greater number of floods made avallable when we reduce floods to one peak rather than one volume. On some streams, where only scanty records exist, no simple l-day floods have been reported, and entire reliance had to be placed on a unit flood built up from portions of complex floods.

"Flood run-off has been considered to be that portion of the hydrograph above a straight line connecting the falriy uniform flow before and after the flood. This base line for runoff generalig rises on a gradual slope. Although it is realized that the flood run-off under this assumption, includes that portion of the inflow from ground water, which responds quick1y to the rainfall, sufficient information is not avaliable to segregate thls Inflow, and the influence of abnormal groundwater conditions will be ignored. This study is Iimited to perlods of flood flow and no attempt has been made to extend the predictions into low-flow periods, when the influence of the Inflow from ground water would become important.

"Within the total area under consideration there were avaliable a total of 190 floods, produced by rainfall alone, for which daily average discharges were published by the United States Geologleal Survey and during which dally rainfall and temperature records were published by the United States Weather 
Bureau. On an average there were records of about 20 floods per stream, but in some instances only 5 to 10 were avaijable. "Rainfall-run-off relations were developed for each stream so that, in the large majority of floods, predicted values were within 20 percent of the total observed flood volumes. In these studies it was necessary to use complex as well as simple floods. the complex floods being subdivided into unit floods. The final rainfall-run-off relation was represented by a series of three curves defining a narrow belt. These maximum, mean, or minimum curves should be used as indicated by the season or the record of the preceding flood.

"Data which should be available.- The proposed plan of operation will use 25 fairly well distributed United States Weather Bureau stations, which should report daily at 8 a.m. to a central office. In addition, these stations will make immediate reports of rainfall which exceeds intensities of 1 inch in 24 hours. The stations are distributed so that at least three are in or adjacent to each drainage basin.

"It is planned to use 11 United States Goological Survey gaging stations located near the mouths of the major tributaries, which will report gage helghts dally, at 8 a.m., to the central office.

"Da1ly prediction forms.- A compllation sheet has been prepared for each tributary basin showing all pertinelt data and curves, such as the rainfall-run-off relation curves and formulae, average base flows, seasonal factors, forms for computing the average rainfall, and forms for building up flood flow from unit floods. One of these sheets should be filled out each morning during the flood season, and a predictio' prepared for the desired number of days in advance. This should be accomplished in the following order: (a) Compute the average rainfall over the river basins; (b) compute the total volume of flood run-off, using foxmula and curve; (c) distribute the total flood volume produced by each day's rainfall according to the distribution diagram; (d) estimate the base flow from the mun-off prior to the flood; and (e) obtain 
the total run-off on each day by adding the contributions from

the several sources of supply to the base flow.

"The predicted run-off should be corrected from day to day in the following manner: Compare the predicted run-off for the beginning of the day (as computed on the preceding day) with the reported mun-off. If these values differ by more than the allowable departure, compute a correction factor $C$ from the rormula

$$
C=\frac{\text { observed run-off - estimated base flow }}{\text { Estimated run-off - estimated base flow }}
$$

Daily contributions from all previous floods should then be multiplied by $C$, and the total flood run-off volume of the next unit-flood taken from the next higher curve if $c$ is more than 1 or the next lower curve if $C$ is less than 1."

The United States District Engineer office at Zanesville, Ohio, and engineers of the Muskingum Watershed Conservancy District have made use of the unit-hydrograph principle in connection with studies in the Muskingum River Basin. Engineers connected with the Tennessee Valley Authority are using the principle in studies relating to the determination of possible flood run-off and also for the purpose of forecasting run-off for a period of several days in advance. In the latter study continuous hydrologic and climatologic data are being used, whereas most of the other studies to date have been confined to daily averages.

The value of the unit-hydrograph principle in analgzing surface run-off will depend on the extent to which the principle is found applicable to areas and problems of various kinds. The principle seems especially applicable to analysis of rainfall and surface run-off that is of practical value where detailed knowledge of hydrology is important, as in (a) manipulation of storage on large systems of river development for power and water supply; (b) obtaining definite knowledge of run-off characteristics of urban areas; and (c) ana7vais of potentialities of drainage basins for producing floods and (d) forecasting flood crests.

\section{Method of application of the unit-hydrograph principle. - By}

definition, a unit hydrograph is a hydrograph of surface run-off resulting from rainfall within a unit of time, as a day or an hour, and a distribution graph is a unit hydrograph of surface run-off modified to show the proportional relations of its ordinates, in percentage of the total surface run-ott. 
If a distribution graph has been prepared for a basin by methods described in the foregoing pages and if the 24-hour depth of rainfall is known, the problem is the determination of the hydrograph of the resulting surface run-off. L. K. Sherman describes the method as follows:

"First multiply the given 24-hour rainfall depth by a coefficient (or percentage) of run-off. This will give the depth $d$ on the area in question. Multiply d by 26.89M ( $M=$ drainage area in square miles); this gives the total run-off expressed in cublc feet per second for a 24hour period. The aforesaid figure, multiplied in turn by each daily percentage of the distribution graph will give the ordinates $\mathrm{N}_{1}, \mathrm{~N}_{2}, \mathrm{~N}_{3}$, etc., for the average rate of run-off in cubic feet per second for each 24-hcur interval of the run-off period. They form the required hydrograph of runoff."

In some problems, such as that_of using the unit-nydrograph principle as a means of forecasting flood stages, on the basis of ccntinuous records rather than average rates of run-off, the unit graph as presented by Sherman in his original discussion (158), seems more adaptable than the distribution graph. The unit graph may be defined as the unit hydrograph modified so that the total surface run-off of the unit graph represents a depth of 1 inch over the drainage basin. This is accomplished by dividing the unit-hydrograph ordinates in second-feet by the total surface run-off in inches.

Merrill M. Bernard (13) uses the distribution graph to distribute total rainfall expressed either as depth in inches over the area or as flow in second-feet, which, when presented in the form of a hydrograph, shows the hypothetical stream flow if all the precipitation had appeared as surface mun-off. He designates such a hypothetical hydrograph a "pluviagraph." In the problem under consideration the given rainfall (expressed either as depth over the area or as second-feet) would have been multiplied in turn by each dally percentage of the distribution graph to form a pluviagraph, or graph of 100 percent rainfall and run-off. The pluviagraph figures are then multiplied by a coefflcient of run-off to determine the hydrograph of surface run-off.

When the surface run-off from a rain lasting several days is considered the distribution-graph percentage is applied to each day's rainfall and the results are summed as shown in table 54 . 
Regardless of whether (a) a coefflcient or percentage of run-off is applied to the recorded rainfall, (b) a deduction is made from the rainfall as recorded on the basis of infiltration loss, or (c) a coefficlent of run-off is applied to the pluviagraph, the accuracy of the hydrograph of surface run-off thus obtained will depend, as stated by Sherman, "largely on the ability of the engineer or hydrologist to determine the proper infiltration loss or coefficient of run-off. Unt1l improved quantitative or mechanical procedure is established, it is important that one who applies the simple unft-hydrograph mothods (or any rainfall method) be familiar with the basic factors affecting infiltration and rum-off."

If Sherman's mothod of approsch is followed the ongineer or hydrologist must determine the coefflclent of run-off or deductive factor to apply to the daily rainfall, so that the adjusted flgures when distributed by means of the distribution graph, or unit graph will give a hydrograph of surface run-off. In Bernard's mothod a coefficient of run-off must be selected for each storm period which, when applied to the pluviagraph of total rainfall as distributed by the distribution graph, will givs a hydrograph of surface run-off. Only surface run-off is obtained by olther mothoa.

The advisory committee of the American Geophysical Union has recommended that steps be taken to

(I) Derive and publish a set of distribution graphs for several typical basins throughout the country.

(2) Derive and publish flood hydrographs complled from possible hypothetical storms of known rainfall frequency upon the several basins.

(3) Continue the studies of flood mu-off due to actual storms in these basins and also include simflar studies on other basins. The rlood-hydrograph studies should develop the different seasonal character1st1cs.

The Plood Protection Comittee of the American Society of C1vil Fngineers has recommended that steps be taken to

(4) Compare for several besing the maximum sumface run-off from known storms with the pluviagraph figures.

(5) Compare for one basin the maximum surfacs run-off with the pluviagraph figures at soveral gaging stations for the samo storm. 
Studies in connection with recommendation No. 1 are outlined in the preceding discussion. The distribution graphs thus developed have been used by Mr. Bernard in the following section to compare the kmown surface mun-off with pluviagraph figures as recomended under No. 4 and thus arrive at probable run-off coefficients, which he has used to make estimates, in accordance with recommendation No. 2 , of the probable surface run-off that would have resulted if certain outstanding storms had centered in a critical position over certain basins. 


\section{The unit-hydrograph metnod and storm transposition}

\section{In flood problems relating to great storms in \\ the Eastern and Central United States}

By Merrill Bernard

The 1dea of superposing storms of unusual magnitude upon drainage basins for the purpose of estimating flood flow is not new. The results have not always been satisfying because of the question whether it would be physicaliy possible for the given storm to be simulated on the drainage basin and also because of the difficulty of taking into account the effect of drainage-basin characteristics on run-off when translating the records of a storm in one basin into terms of flood flow in another basin.

All flood formulas that include storm rainfall as a factor entall the 1dea of storm superpositon. Their use involves what is realiy transposition of synthotic storms to the point of application, often for great distances from the basin or basins on which the originator evolved his empirical relationships. The method herein presented involves a limited transposition of storms and the application of the unit-hydrograph principle which, through its distribution graph, gives determinate value to the effect on surface run-off of such basin characteristics as area, shape, general slope, and arrangement of stream system.

\section{Flood coefficients}

This study utilizes the approximate proportionality between the ordinates of the hydrograph of flow from surface mun-off and the ordinates of the pluviagraph, or graph of 100 percent run-off. The ratio between the greatest ordinate of the hydrograph of surface ran-off and that of the pluvlagraph is taken as the "flood coefficient." Although this ratio or "flood coefficient" is not an average coeffleient for the flood period, it. Insures agreement between the observed and computed peak values, with only a slight sacrifice in agreement between the actral and computed hrdrographs. 
The determination of the flood coefficient becomes largely a mechanical procedure after the distribution graph for the basin is made available through the various steps described on pages 124-133.*

The steps taken in the development of the coefficient for the Susquehanna River at Towanda, Pa., are 1llustrated in table 54. They are a.s follows:

(a) Compute, for the storm and flood period selected, the average dally rainfall depth over the basin. Where rainfall stations are comparatively numerous and well distributed, the arithmetic average is acceptable. Where stations a re few and poorly distributed each station record should be welghted by geometric proportioning. Average dally rainfall is listed by dato in column 2.

(b) The distribution graph of the drainage basin is listed in colwon 3.

(c) The rainfall for each day is multiplied by the items of the distribution graph and listed in a column. The product of the rainfall and the first item of the distribution graph is placed in colum 4 opposite the date on which the rainfall occurred, with the following products opposite succeoding dates. The next day's rainfall is treated in the same manner and placed in column 5, and so on. If there is rain on overy day for a long perlod, at least as many colvems are necessary for the distribution of the rainfall as there are items in the distribution graph being used. Th1s procedure is shown in columns 4 to 10.

(d) The daily increments in columns 4 to 10 are summed horizontally, and the totals are listed in column 11 as the pluviagraph values, or 100 percent run-off, expressed in inches on the drainage basin, and are converted to second-feet in colvem 12 .

(e) Observed stream flow is listed by date in column 13.

(f) Base flow, or grcund-water mu-off, is estimated from a plotted hydrograph of observed flow (see pp. 1Il-119) and listed by date in colum 14.

(g) Flow from surface mun-off (column 15) is obtained by deducting base flow from observed stream flow.

* It is to be noted that the distribution graphs used by the writer in the development of flood coefficients took silghtly different deily percentages than those presented on pages $141,148,155,163,176$, $181,190,207$, owing to minor changes and refinements of the distribution graphs in their final presentation. 


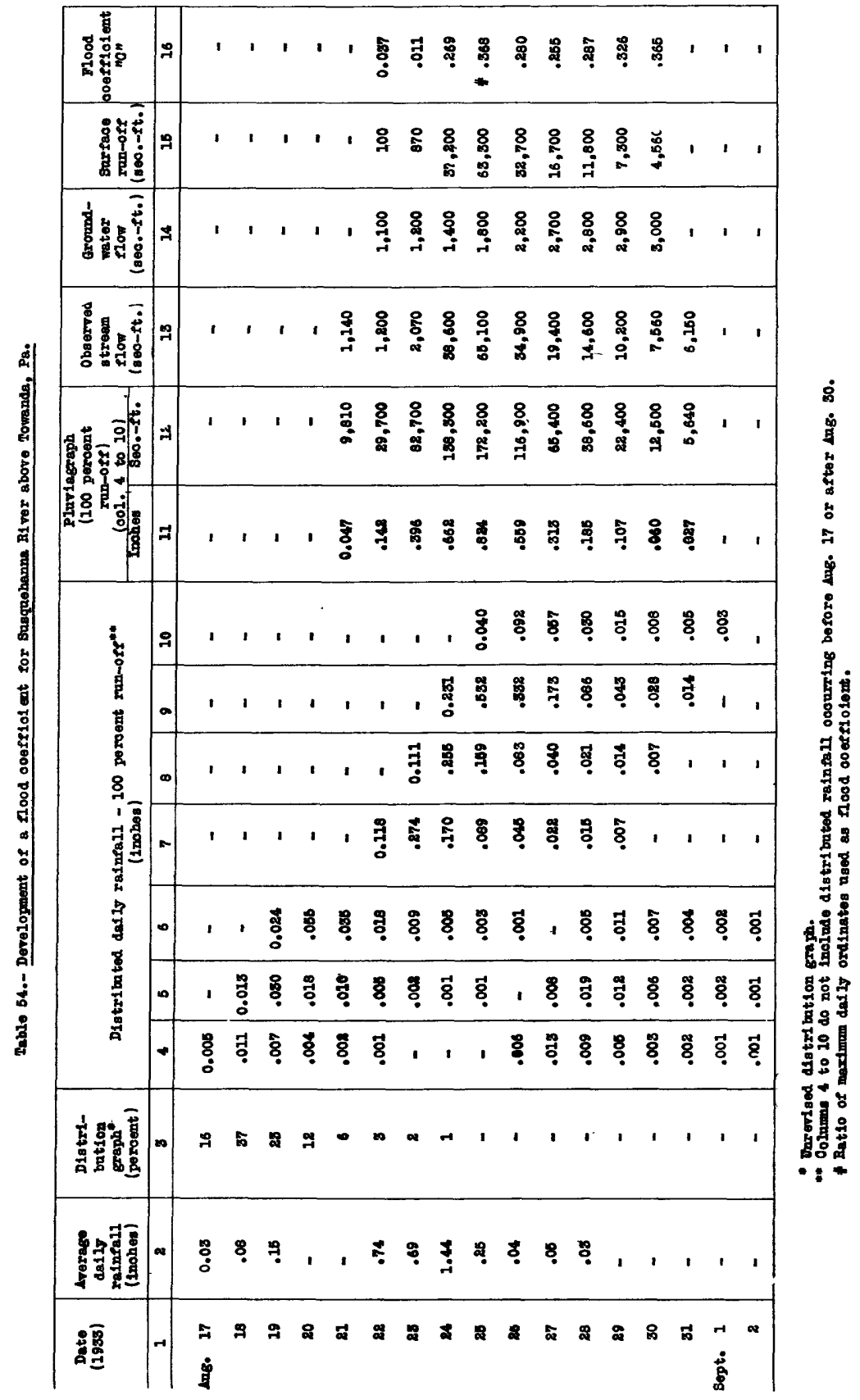


(h) The ratios of the surface rum-off to the pluviagraph are noted in columin 16. The ratio of the maximan values is taken as the flood coefficient.

On figures 71 to 77 are plotted for the maximm observed floods for selected rivers during the nominter period the observed rainfall, the distributed rainfall in the form of a pluviagraph, and the hydrograph of surface run-off. Thore is also indicated the ratio (c) between the maximum surface run-off (moximum day) and the peak pluviagraph value. A computed hydrograph of surface run-off is also ahow, obtained by moltiplying the pluviagraph value by the flood coefficient.

The flood coefficients are forud to change somewhat consistently Wth the seasons, Indicating that teuperatwre is an important factor. Other factors causing changes probably relate to differences in vegetal cover. The intensity and distribution of the rainfall within the storm period, regardiess of the season, may also affect the flood coefficient. The coefflcients of the greatest floods for the different seesons are compared graphically in flgure 78, and tholr magnitudes show, for each basin studied, a seasonal trend. Flood coefficients are not shown for the months of December, January, Fobruaxy, and March for basins where. they might be materially affected by snow ran-orf.

It was found that in most basins the particular month of the Jear having the greatest flood within the period of record was also the one of greatest monthiy run-off and always month of considerable rainfall. It was also found that, with only few exceptions, the principal phase of the flood occurred torard the middle or end of an extended wet spell, Indicating a reduction of the infiltration and absorptive capacity of the ground. Although in many basins a higher degree of saturation of the ground may have been possible, the coefficients show in flgure 78 seem the best evidence obtainable from the comparatively short records available as to what a maximom raluo might bo in a particular month or season for the selected rivers.

\section{Storm rainfall studies of the Miant Conservancy District}

In March 1913 a storm that centered in western Ohio produced a disastrous flood on the Mami River thronghout most of Its length. Corrective steps were taken almost imediately after the flood to protect the 


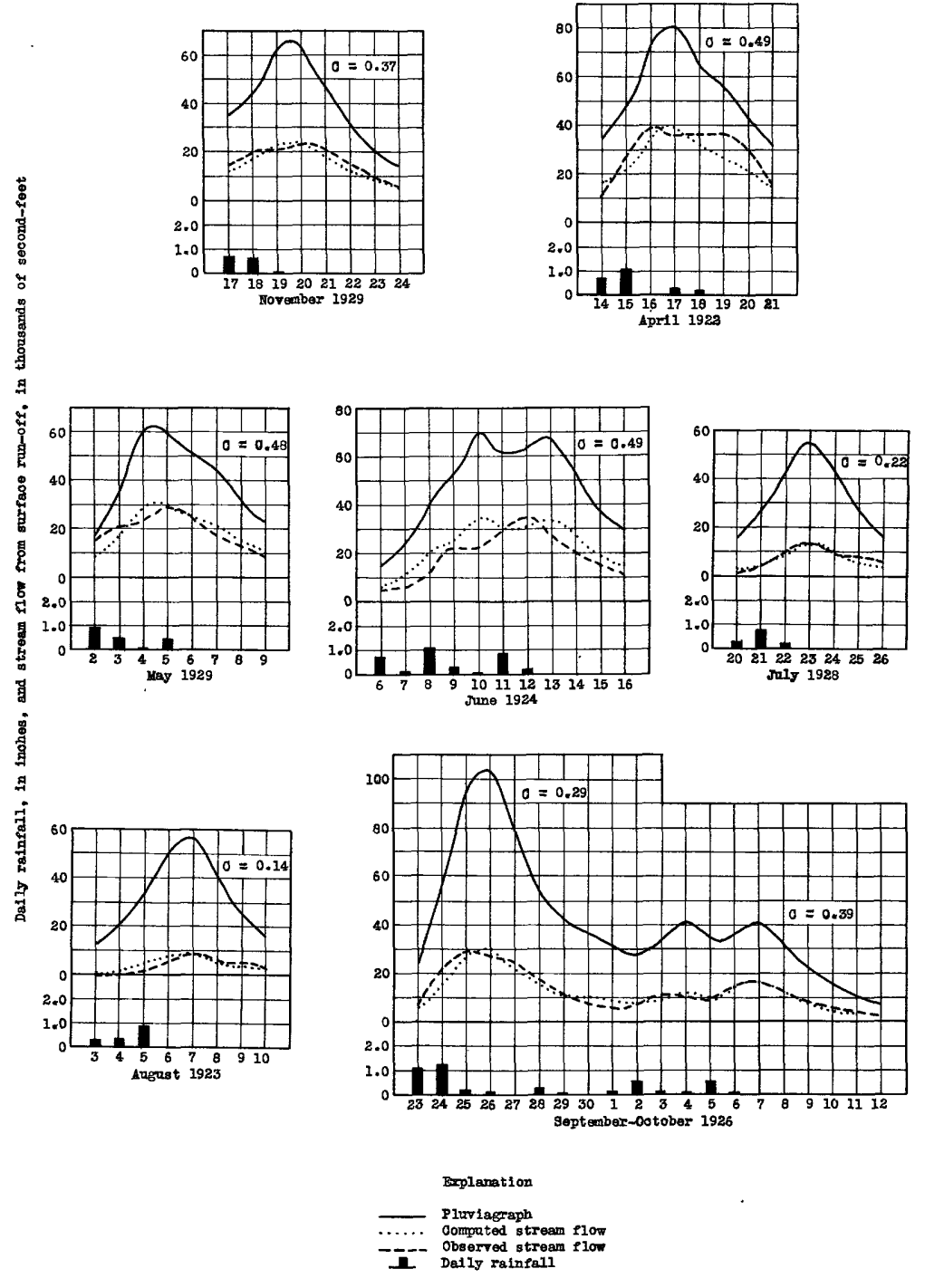

Figure 71.-Flood hydrographs and flood coefficients (c) for linskingum River at Dresden, Ohio. 


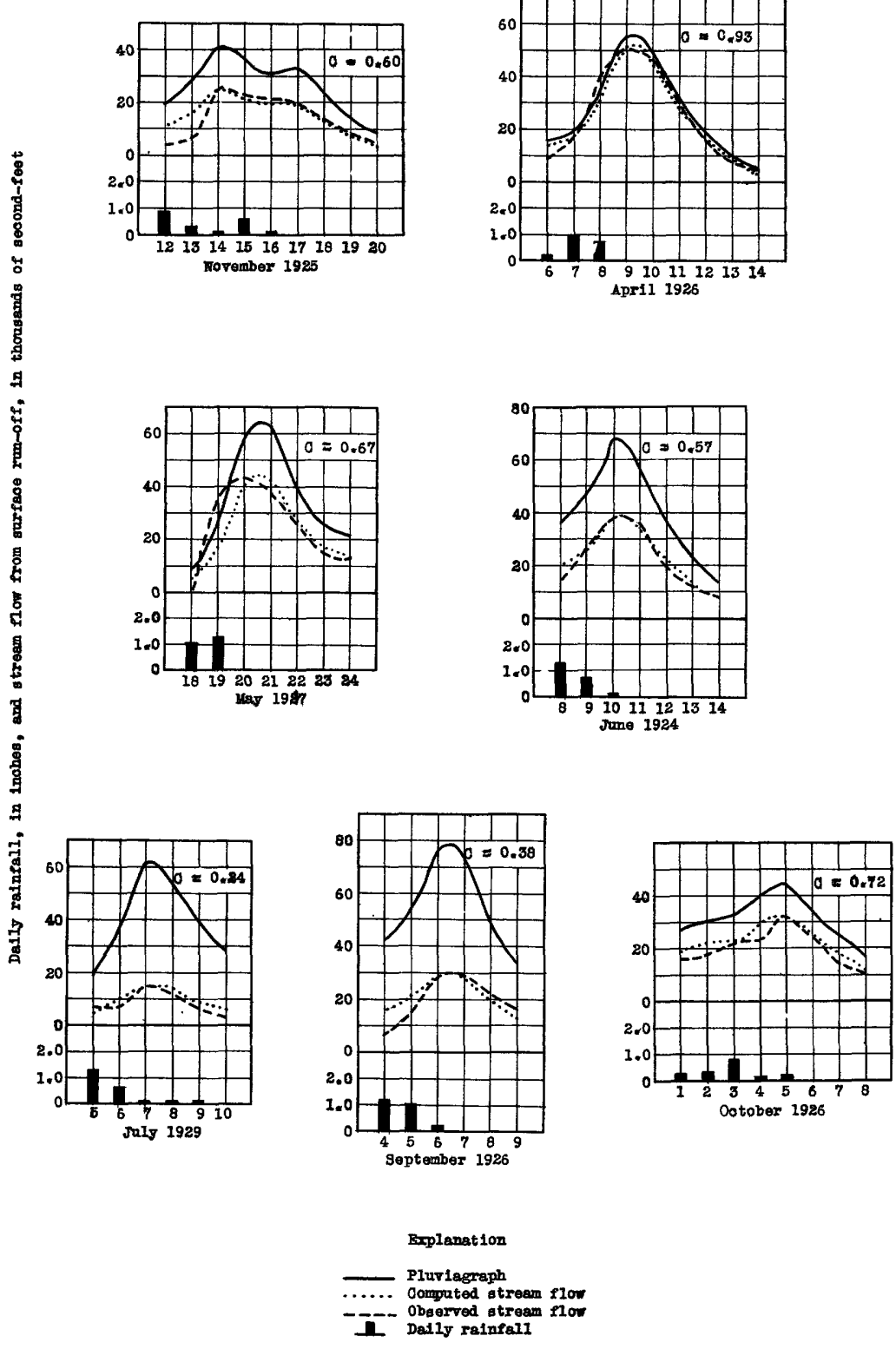

Figure 72,-Flood hydrographs and flood coefflelente (c) for Wabesh Fiver at Iogansport, Ind. 


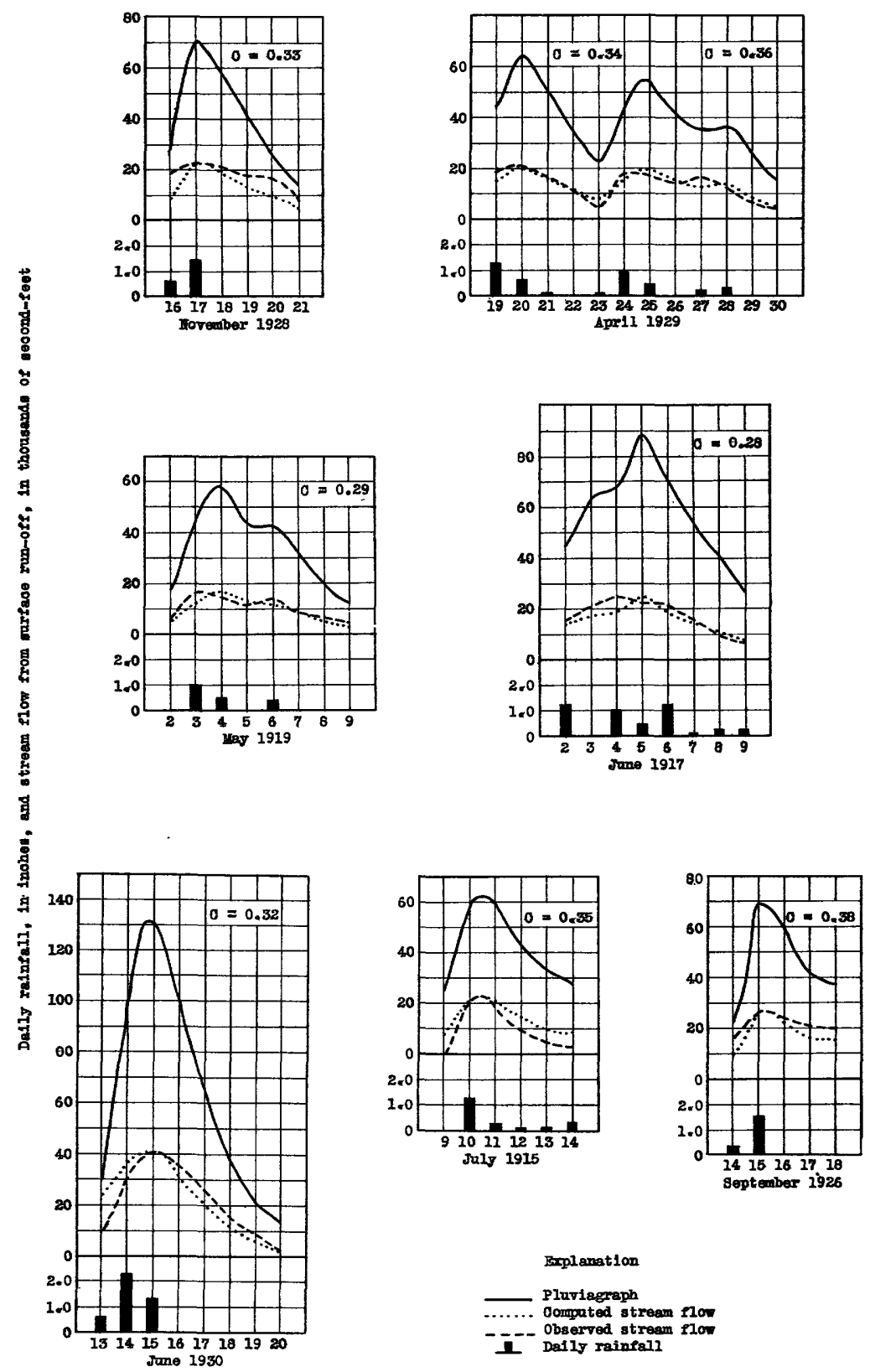

Figure 73.- Hlood hydrographs and flood coefficients (0) for Slomk Rirer at Angats, Iowe. 

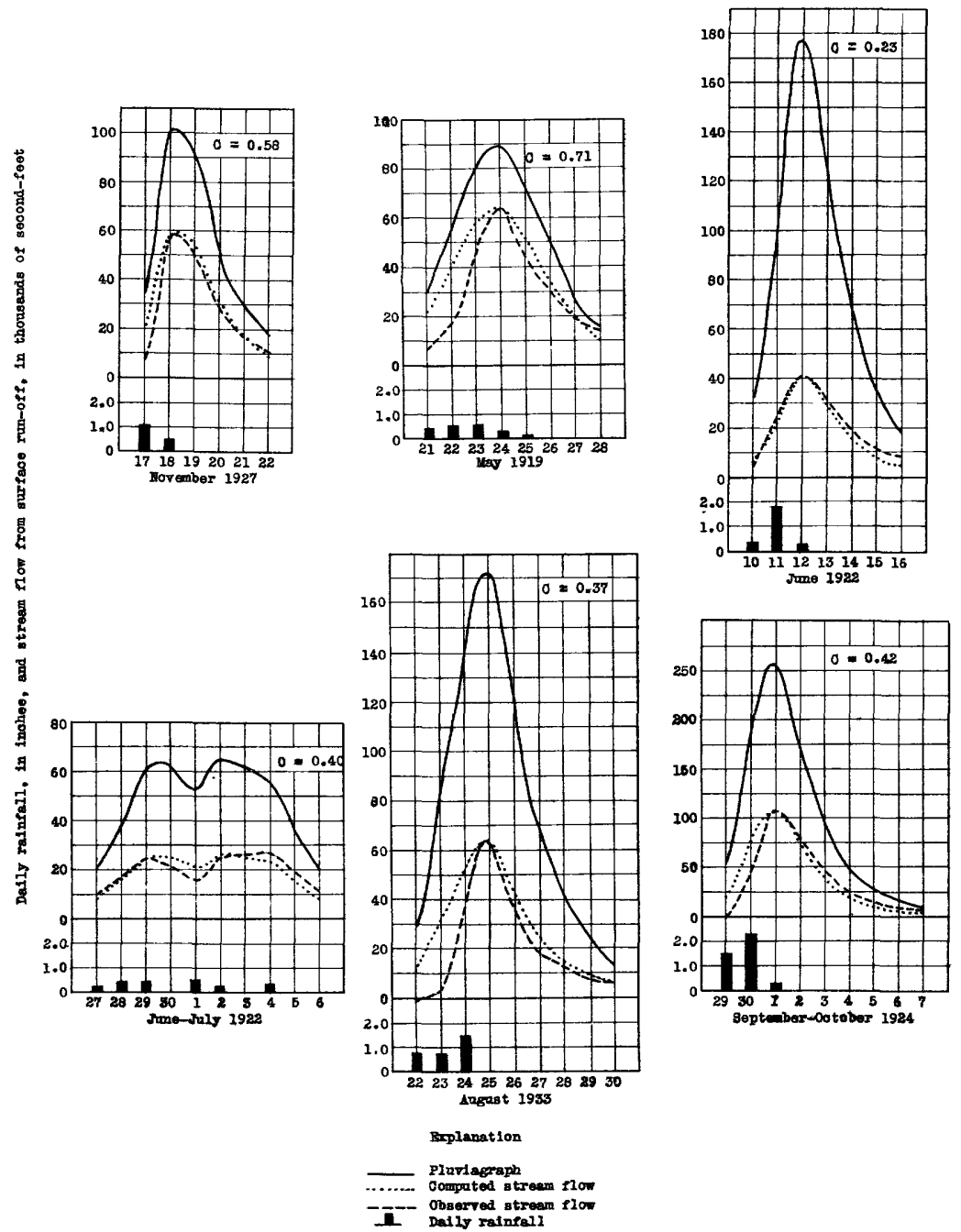

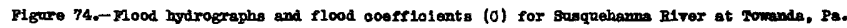



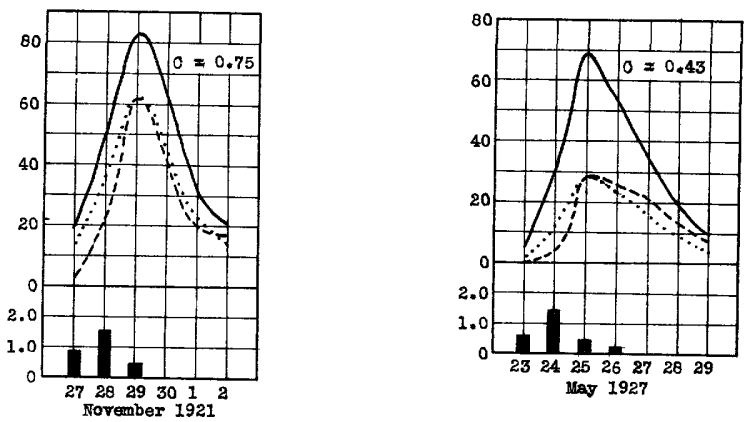

May 1927
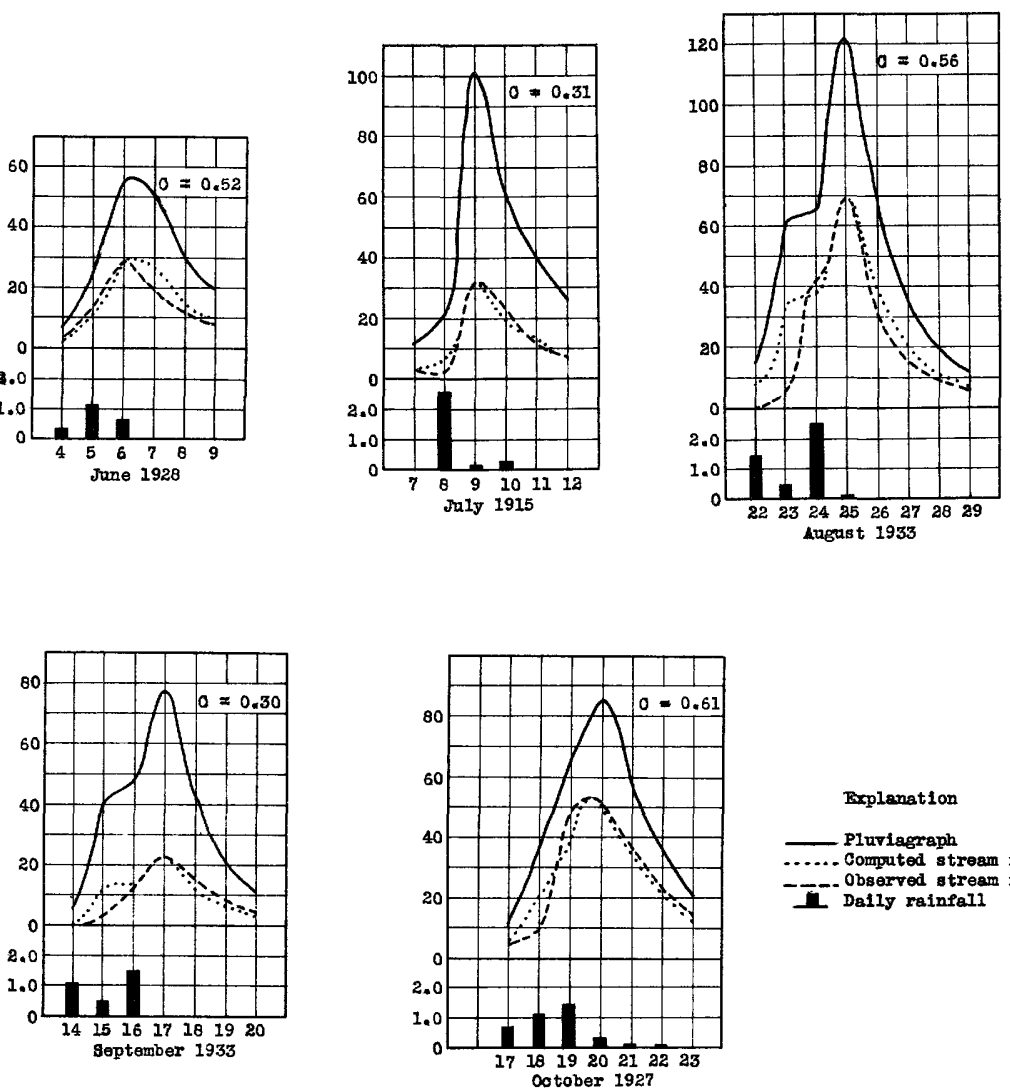

Fixplanation

Pluviagraph

Comprated strenm plow Observed stream flow

I Daily rainfall

Figure 75,-Flood hydrographs and flood coofficients (C) for Delaware River at Port Jervis, N.Y. 

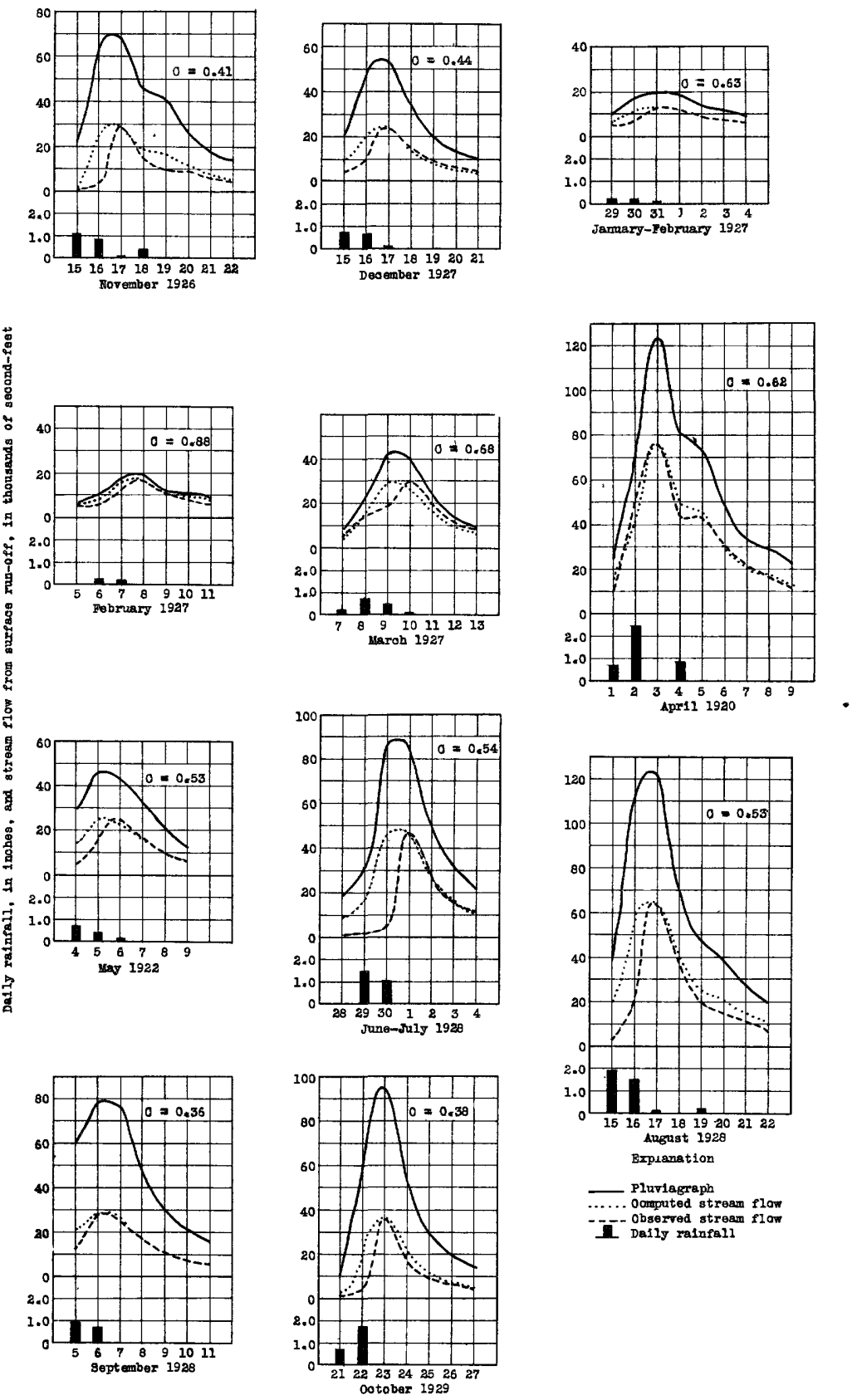

Pignre 76.-Flood hydrographs and flood oceffiofents (O) for Freneh Broad R1ver at Dandridge, Tenn. 

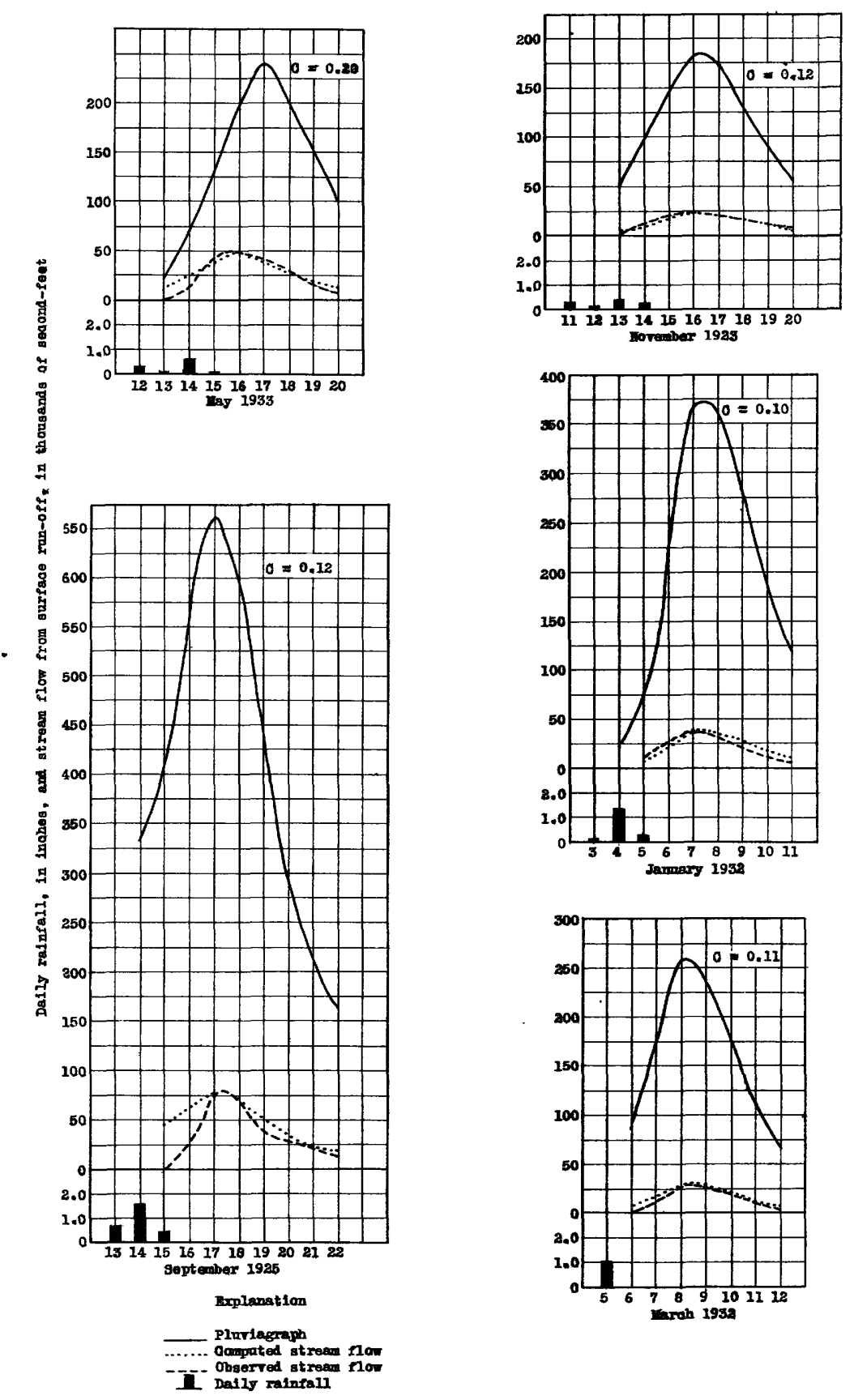

Figare 77,-Flood hodrographs and flood coefficlents (0) Sor Red Afiver noar Denison, Sex. 


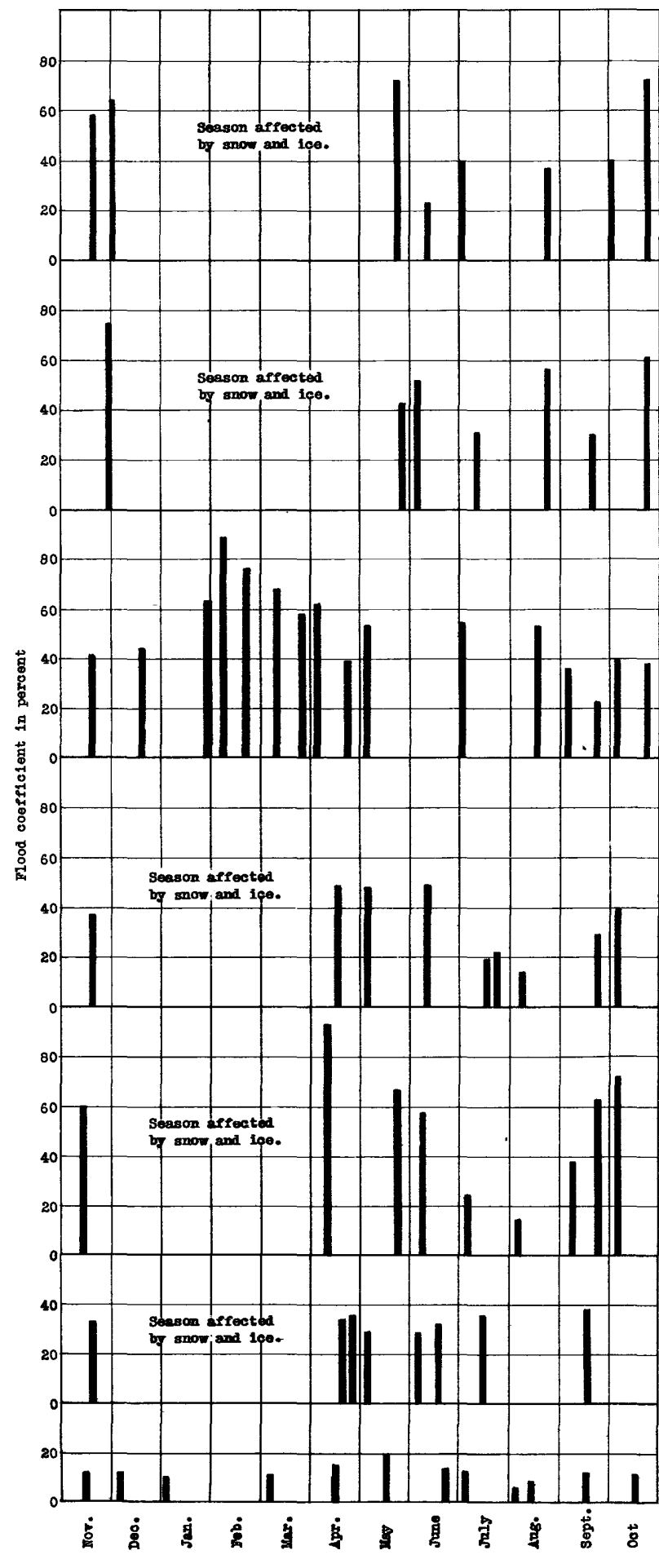

Susquehanna River

at Towanda, Pa.

Delamare River at Port Jervis, N.Y. .

French Broad River at Dandridge, Tenn.

Uhaskingum River at Dresden, Ohio.

Wabash River at togansport, in

Skamk River at sugusta, Iowa.

Rod River near Denison, Tex. 
region against a recurrence of such a catastrophe. As a preliminary to the design of adequate flood protection works for the Miami Valley, an extensive research and analysis of rainfall data was made. This analysis, covering the whole of the eastern United States and complete to 1916, was published by the Miami Conservancy District (123). This report is now in the course of revision by the Conservancy District. The storms of such areal extent that they embraced at least five preclpitation stations recording 6 inches or more of rainfall in 3 days are compared and classified on the basis of the fifth highest 3-day rainfall. This value is referred to as the storm index.

In the original report 160 notable storms were listed, plotted, and analyzed. The Conservancy District has since analyzed 90 storms occurring between 1916 and the end of 1931, making available for the present study detailed information regarding the 250 greatest storms visiting the eastern United States during the period 1892-1931.

A summarized classification of these storms is as follows:

Storm index (inches) $\begin{gathered}\text { Number of storms } \\ \text { greater than index }\end{gathered}$

$\begin{array}{rr}16 & 2 \\ 15 & 4 \\ 12 & 10 \\ 11 & 18 \\ 10 & 32 \\ 9 & 59 \\ 8 & 95 \\ 7 & 172 \\ 6 & 246\end{array}$

There is little doubt that as time passes storms will occur that will tend to increase all maxima and have the effect of moving inland charted isohyetals of excessive rainfall depths such as are presented in the isopluvial maps of the report cited (123), as well as in figure 79. This figure shows a sufficient number of storm indexes plotted at their approximate storm centers to determine the position of 1sohyetals enveloping areas having storms of equal or greater index. This illustration is noticeably similar to the isopluvial charts of the Miami Conservancy District report.

\section{Storm transposition}

The purpose of this study is to outilne a refined method of estimating flood flow from storm rainfall and to direct attention to a fuller use of available storm data. The superposed storms are not to be 
accepted as "IImiting" storms, but as actual great storms, which, having visited the vicinity, could have, with reasonable likelihood, shifted slightIy and centered in a critical position on the particular basin of interest.

An examination of figure 79 indicates that storms having indexes of 8 to 12 inches have occurred at widely different points in the central and upper Mississippl Valley. The superposition of certain storms on any basin within the region encompassed by them seems logical. Mountainous topography, however, creates an entirely different situation. Stoms centering on the windward slope of great mountain barriers cannot justifiably be shifted to basins lying on the leeward side.

Without involving questions of magnitude or frequency, valuable information may be gained by considering the superposition of a knowr. storm in a critical position on a basin. The storm selected for use should not have its center so far removed from the basin as to cast doubt on the assumption that the storm could, with reasonable probability, have centered on the basin.

The method followed superposes in a critical position upon a map of the basin the pattern of the storm, pictured as isohyetals of equal rainfall depth for the storm period. The selection of a critical position entalls the assumption of the position that would produce the greatest average depth of rainfall on the besin. As a rule this position is reasonabiy obvious. In a more detalled study the storm is centered on one or more of the subbasins having characteristics highly conducive to the production of floods. In such a study it is necessary to deal with all subbasins separately, synchronizing their flows in accordance with the indications of experience to the nearest practicable time unit. The present study considers only the position producing the greatest average depth over the basin.

The pattern or map of the storm having been fixed in critical position, the rainfall stations are treated as if the storm actualiy occurred in this locality and position. The rainfall depths are listed by date, properly weighted, and combined to give average daily rainfall over the basin throughout the storm period. All antecedent rainfall contributing surface run-off to the flood is included in the study. 


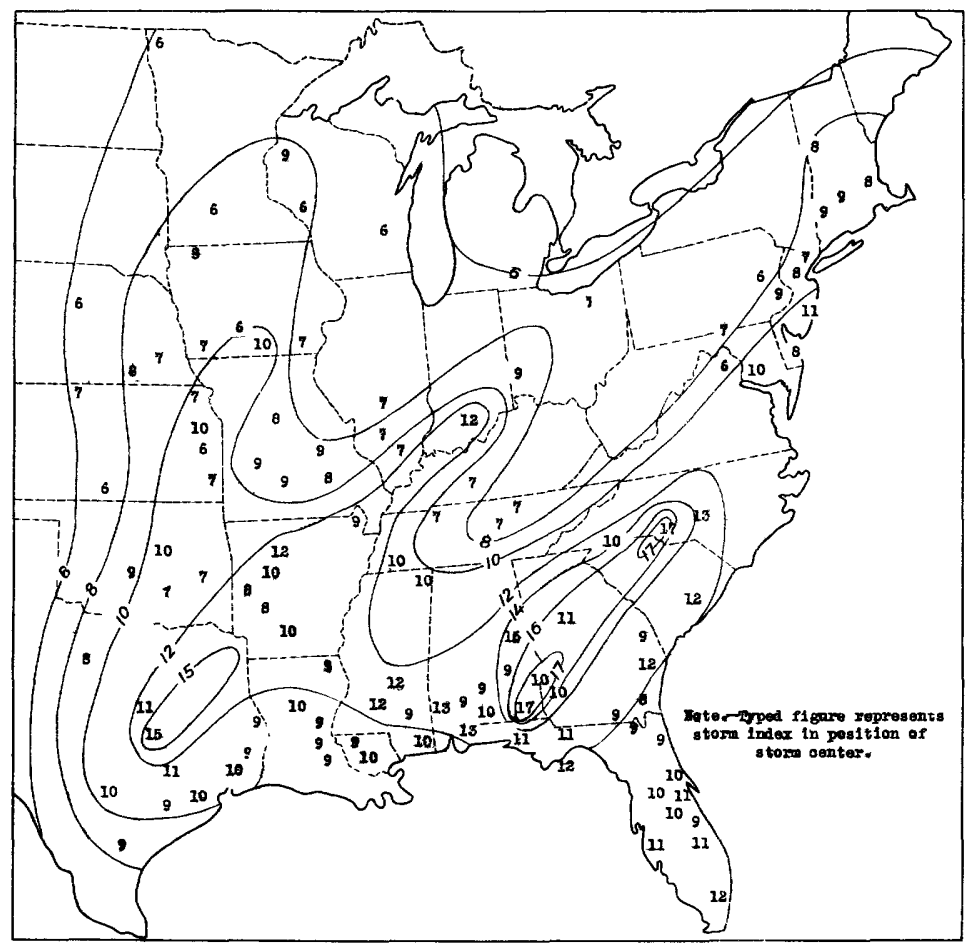

P1 gure 79 -ksp of eastern United States showing storn indexes and geographio position of the oenters of great storms. 
Figure 49 of the Miaml Conservancy report (123) shows the seasonal occurrence of the great storms embraced by the report. The 90 storms occurring since 1916 require, to some extent, revision of the chart. This can also be said of figures 50 to 57 of the report, which show the geographic position of the storms by seasons. In the northern group there were certain seasons in which it would seem, from the experience disclosed by the record, that it was practically impossible for a storm of any considerable magnitude to develop, the possible explanation being deficiency in air moisture occasioned by prevailing low temperatures.

of the seven basins analyzed, the four appearing in the table below and shown in figure 80 were selected to demonstrate the unithydrograph method of determining flood flow. The study has used the division of the year into seasons suggested in the Miami Conservancy report, the quarters beginning on November 1, February 1, May 1, and August 1. The quarters in which no qualifying storm has visited the locality are then eliminated from consideration in each basin, and it is assumed that the superposed storm could have occurred in any of the other seasons. The seasons in which, it is assumed, the superposed storm could have occurred, based on figures 50 to 57 of the Miami report, are as follows:

\section{Besin}

Delaware River French Broad River

Wabash River Skunk River

\section{Gaging station}

Port Jervis, N. $Y$.

Dandridge, Tenn.

Logansport, Ind. Augus ta, Iowa
Quarters

$3 d$ and 4 th

$3 d$ and 4 th $2 d, 3 d$, and 4 th $3 d$ and 4 th
Months

May 1 to Oct. 31

Nay 1 to Oct. 31 Feb. 1 to Oct. 31 May 1 to Oct. 31

For each of these basins the maximum flood coefficient for the season in which the storm occurred is also the maximum for any other season in which it is considered possible for the storm to have occurred. This coefficient has been used for estimating the probable surface run-off of each stom in the superposed position.

Tables 55, 56, 57, and 58 give flood coefficients for the months of probable storm occurrence in each of the four basins. 
Table 55.- Flood coefficients for Delaware River

at Port Jervis, N. Y.

\begin{tabular}{|c|c|c|c|}
\hline Date & $\begin{array}{c}\text { Maximum pluvia- } \\
\text { graph value } \\
\text { (second-feet) }\end{array}$ & $\begin{array}{c}\text { Maximum daily } \\
\text { surface run- } \\
\text { off } \\
\text { (second-feet) }\end{array}$ & $\begin{array}{c}\text { Flood } \\
\text { coefficient }\end{array}$ \\
\hline Third quarter: & & & \\
May 25, 1927 & 69,700 & 29,600 & 0.43 \\
June 6, 1928 & 55,800 & 29,200 & .52 \\
July 9, 1915 & 101,200 & 31,700 & .31 \\
Fourth quarter: & $* 121,800$ & & .56 \\
Aug. 25, 1933 & 77,500 & $* 68,500$ & .30 \\
Sept. 17, 1933 & 85,400 & 23,300 & $* 61$ \\
Oct. 20,1927 & & 51,900 & \\
\hline
\end{tabular}

* Maxima.

Table 56.- Flood coefficients for French Broad

River at Danaridge, Tenn.

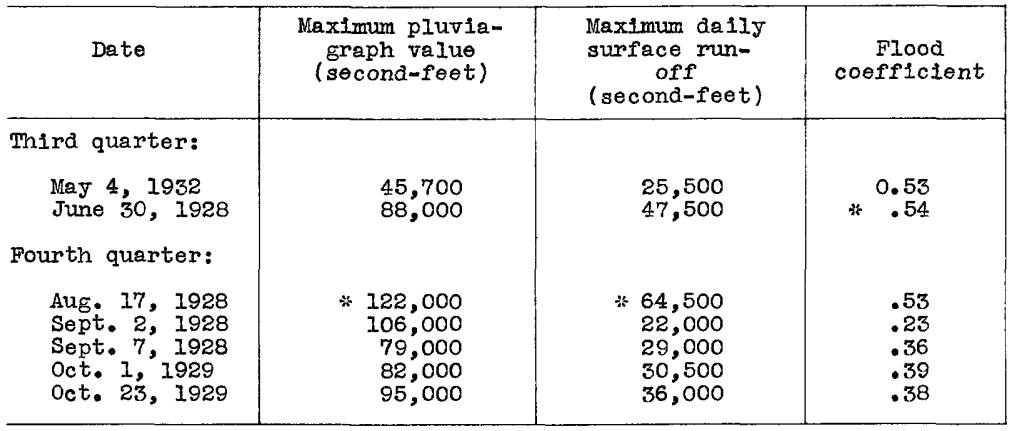

* Maxima.

Table 57.- Flood coefficients for Vabash

River at Iogansport, Ind.

\begin{tabular}{|c|c|c|c|}
\hline Dete & $\begin{array}{c}\text { Maximum pluvia- } \\
\text { graph value } \\
\text { (second-feet) }\end{array}$ & $\begin{array}{c}\text { Maximum daily } \\
\text { surface run- } \\
\text { off } \\
\text { (second-feet) }\end{array}$ & $\begin{array}{c}\text { Flood } \\
\text { coefficient }\end{array}$ \\
\hline Second quarter: & & & \\
Mar. 22, 1927 & 72,600 & $* 51,700$ & 0.77 \\
Mar. 31, 1924 & $\mathbf{5 5 , 0 0 0}$ & 35,000 & .84 \\
Apr. 8, 1926 & 54,900 & 50,800 & $* 93$
\end{tabular}

* Maxima. 
Table 57. - Flood coefficients for Wabash River

at Logansport, Ind.--Continued

\begin{tabular}{|c|c|c|c|}
\hline Date & $\begin{array}{c}\text { Maximum pluvia- } \\
\text { graph value } \\
\text { (second-feet) }\end{array}$ & $\begin{array}{c}\text { Maximum daily } \\
\text { surface run- } \\
\text { off } \\
\text { (second-feet) }\end{array}$ & $\begin{array}{c}\text { Flood } \\
\text { coefficlent }\end{array}$ \\
\hline Third quarter: & & & \\
May 21, 1927 & 63,700 & 42,700 & 0.67 \\
June 10, 1924 & 67,700 & 38,400 & .57 \\
July 6, 1929 & 61,600 & 15,000 & .24 \\
Fourth quarter: & & & .14 \\
Aug. 3, 1926 & 69,800 & 9,500 & .38 \\
Sept.3, 1926 & $* 76,600$ & 29,300 & .63 \\
Sept. 25, 1926 & 50,200 & 31,000 & .72 \\
Oct. 7, 1926 & 44,500 & 32,000 & \\
\hline
\end{tabular}

* Maxima.

Table 58.- Flood coefflclents for Skunk

River at Augusta, Iowa

\begin{tabular}{|c|c|c|c|}
\hline Date & $\begin{array}{l}\text { Maximum pluvia- } \\
\text { graph value } \\
\text { (second-feet) }\end{array}$ & $\begin{array}{l}\text { Maximum daily } \\
\text { surface run- } \\
\text { off } \\
\text { (second-feet) }\end{array}$ & $\begin{array}{c}\text { Flood } \\
\text { coefficlent }\end{array}$ \\
\hline \multicolumn{4}{|l|}{ Third quarter: } \\
\hline $\begin{array}{l}\text { May 4, } 1919 \\
\text { June } 5,1917 \\
\text { June } 15,1930 \\
\text { JuIy } 11,1915\end{array}$ & $\begin{array}{r}58,000 \\
87,500 \\
* \quad 130,500 \\
50,000\end{array}$ & $\begin{array}{r}16,500 \\
24,500 \\
* \quad 41,000 \\
20,000\end{array}$ & $\begin{array}{r}0.29 \\
.28 \\
.32 \\
.35\end{array}$ \\
\hline Fourth quarter: & & & \\
\hline Sept. 15, 1926 & 78,500 & 26,000 & $* .38$ \\
\hline
\end{tabular}

* Maxima.

\section{Storm superposition}

Figure 80 shows the outlines of the four basins and the area embraced by four major storms.

Delaware River Basin above Port Jervis, N. Y.

Storm A, of Octoker 8-11, 1903, occupled the 22d position in order of magnitude of storms over the eastern United States and ranked $3 d$ among the northern storms, with a storm 1ndex of 10.66. It centered at 


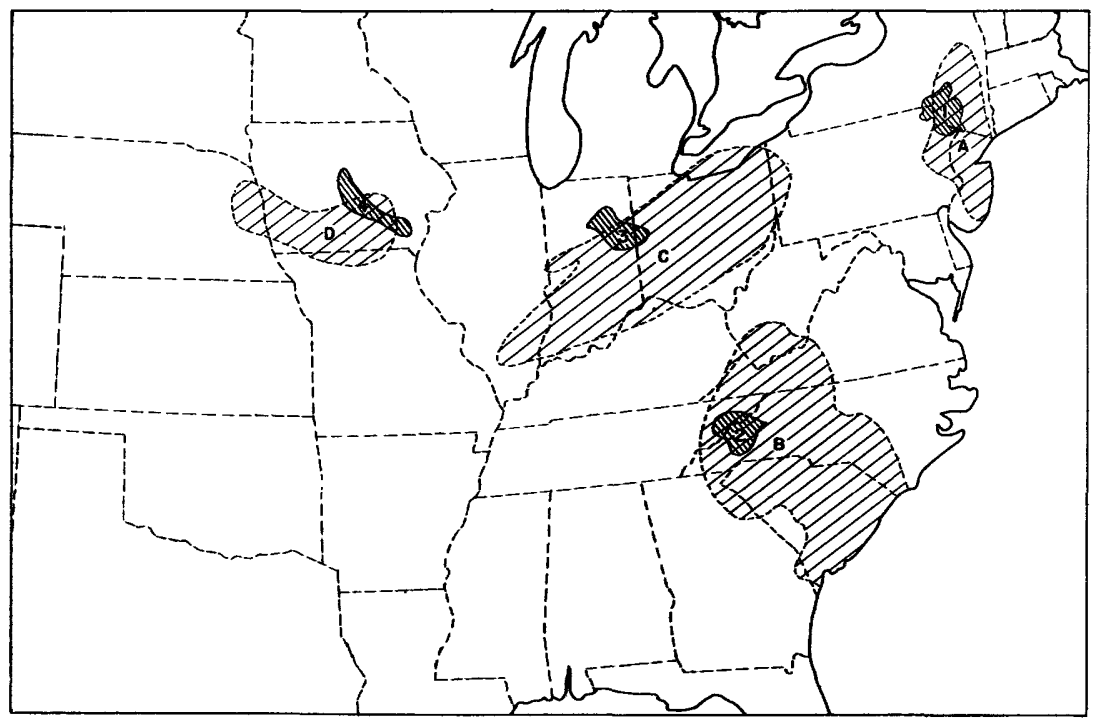

Explanation

1 Delaware Hiver Basin above Port Jervis, K.I.

2 Fremch Broad Hiver Basin above Daniridge, Temn.

3 Wabesh River Basin above Iogensport, Ini.

4 Skmk River Basin above Amgrista. To

Storm of Dtobex 8-11, 1903

B Storm of Jaly 15-16, 1916

B Storm of July 15-16, 1916
d Storm of Warch 24-26, 1913

D Storm of August 25-28, 1908

Figure 80 -llap of eastern Dnited States showing location of etorm areas relative to selected drainage basins. 
Paterson, N. J., and enveloped the Delaware Basin above Port Jervis, N. Y. An average depth of about 8 inches of rainfall fell on this basin during the storm, developing a flood peak at Port Jervis that is still the greatest of record (J. S. Geol. Survey Water-Supply Paper 726, p. 216, 1932 ). This storm is considered in the two positions shown in figure 81. Position a is that in which the storm actually occurred. The flood pluviagraph has been constructed by applying the distribution graph for the basin to the weighted dally rainfall shown in figure 82. The flood hydrograph of surface run-off shown in figure 82 has been obtained by applying a flood coefficient of 0.61 , the highest developed in the possible seasons (3d and 4th quarters, table 55) to the dafly ordinates of the pluviagraph. The computed maximum daily flow is 142,800 second-feet. This figure is consistent with the estimated instantaneous peak of about 155,000 secondfeet for this flood (U. S. Geol. Survey Water-Supply Paper 726, p. 216, 1932). The storm was next considered in position $b$, under which the greatest possible average depth of rainfall over the basin was developed. Obviously this involves the question wether it would be consistent with topographic and other controlilng conditions for this storm to occur in the transposed position. By weighting the daily rainfall at the stations in their new positions and applying the distribution graph for the basins and the same flood coefficient a maximum daily discharge of 187,000 secondfeet was computed. To the extent that the various assumptions are correct, if the storm of October 1903 had centered 80 miles to the northwest it would have produced a maximum daily discharge of 187,000 second-feet at Port Jervis.

French Broad River Basin above Dandridge, Tenn.

Storm B, of July 15-16, 1916, centered at Altapass, N. C., with one of the highest single-station 24-hour rainfall depths on record. With a storm index of 16.77 inches, it was the 2d largest of storms over the eastern United States. The excessive rainfall was confined principally to the eastward slopes of the Blue Rldge but averaged more than 5 inches over the French Broad Basin above Dandridge, Tenn. The storm's position is* shown in figure 83. The pluviagraph was based on recorded precipitation. The highest flood coefficient developed within the record period for the seasons in which it is assumed that such a storm could have occurred was 


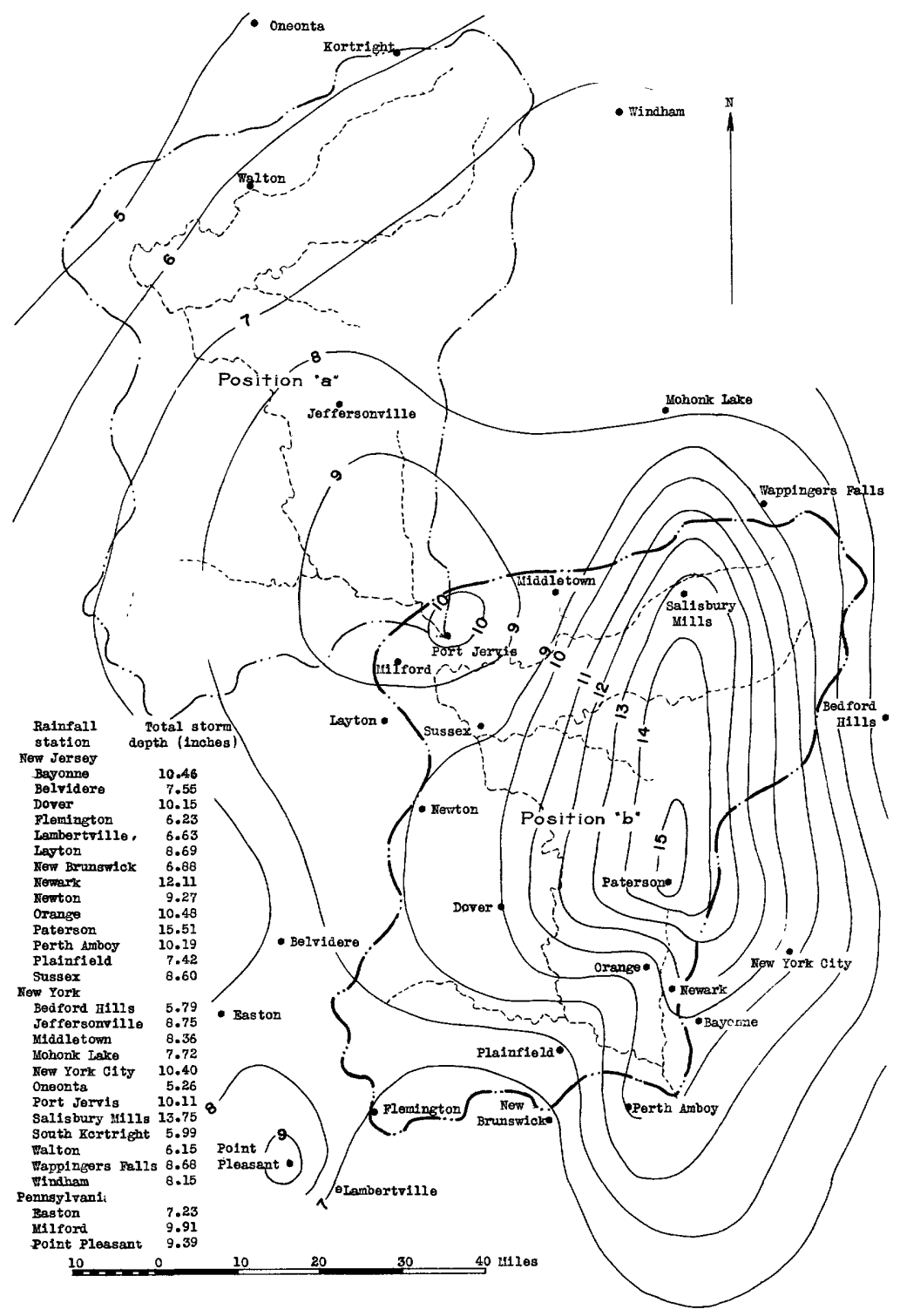

F1gure 81-Storm of 0ctober 8-11, 1903, with relative location of weather Bureau stations and the Delaware River Basin above Port Jervis, No. Y. In its actual position ("s") and
shifted so as to give a maxinum averago depth of rainfall on the basin (position "b"). 


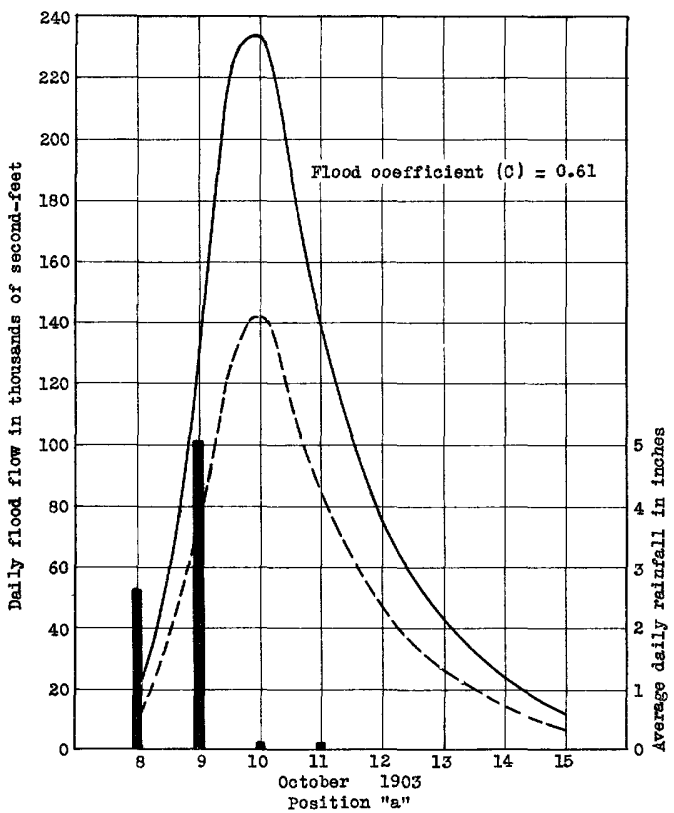

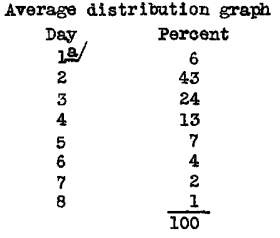

a) Day on which rainfall was recorded.

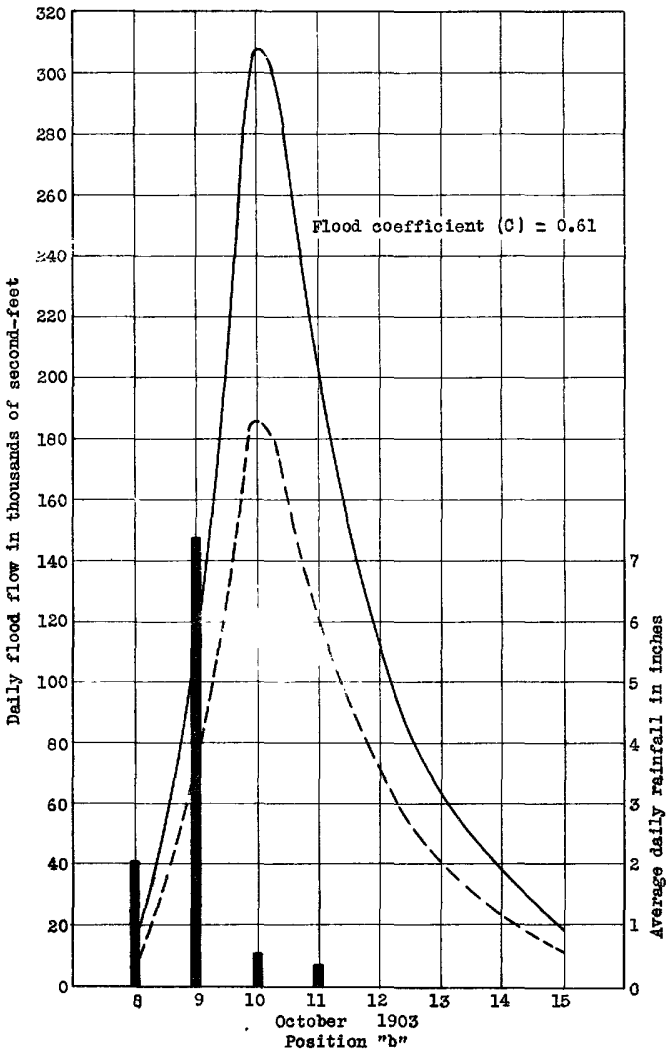

Explanation

Pluviagraph

Compated flood flow 

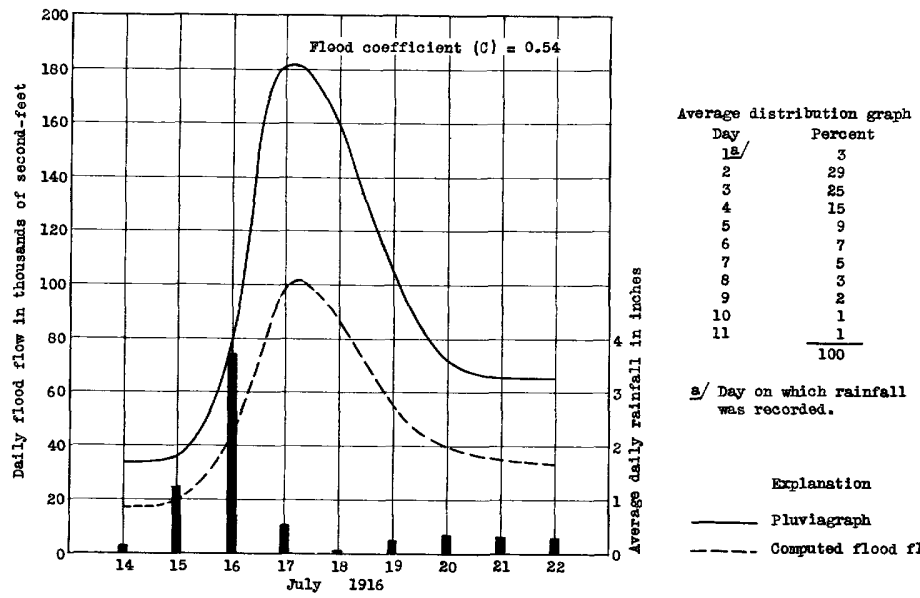
g/ Day on which rainfall

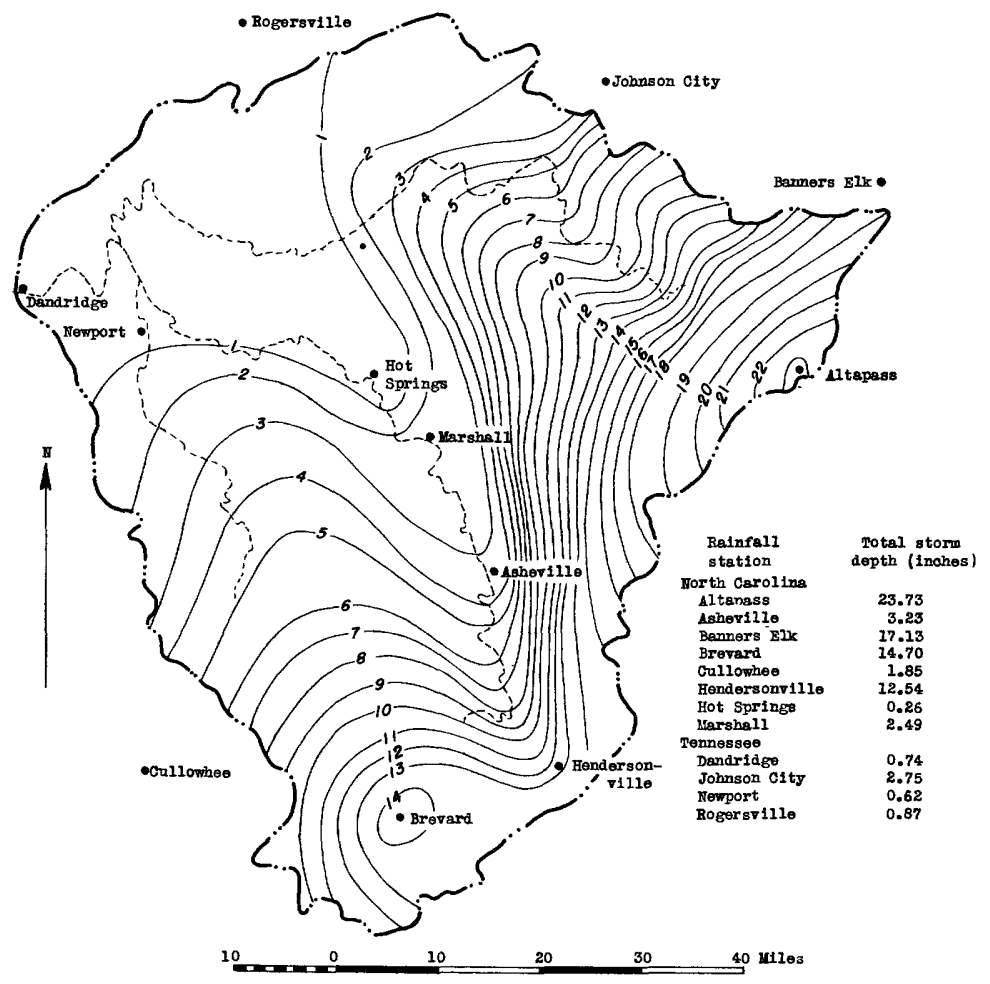

F1gure 83.-Storm of July 16-16, 1916, in 1 ts antual position on French Broad River Besin above Dendridge, Tem.. and resulting plaviegreph and hydrograph of oomputed flood flow. 
0.54. This coefficlent, applied to the pluviagraph, produced the est1mated flood hydrograph of surface flow shown in figure 83, with a maximum of 98,400 second-feet. A stage of 21.0 feet was recorded on July 17, 1916, by the United States Weather Bureau. This stage corresponds to a flow of 100,000 second-feet based on an extension of the rating curves from 16.1 feet to 21.0 feet. Because of differences in topography it is not considered feasible to center this storm on the French Broad River Basin.

Wabash RIver Basin above Logansport, Ind.

Storm C, of March 24-26, 1913, centering in eastern Indiana and western Ohio, caused the disastrous flood on the Miami River. With a storm Index of 8.98 inches, it is the 9 th largest of the northern storms. This storm has been used by various investigators to estimate probable flood discharge for many areas. By the method outlined in this study, the surface flood flow that would have resulted had this storm centered critically on the Wabash River above Logansport, Ind., has been computed and is shown graphically in figure 84. The figure also shows the storm superposed over the basin in such a position as to produce the maximum average depth of rainfall. The stations listed on the basin map are located relative to the storm and not to the basin area. The high flood coefficient, 0.93 , Is substantiated by those developed in this season on the Muskingum River above Dresden, Ohio, and a coefficlent of over 0.90 was developed during the storm of March 1913 on the Miami River above Sidney, Ohio.

Skunk River Basin above Augusta, Iowa

Flgure 85 shows storm D, of August 25-28, 1903, the 30th in order of magnitude of storms over the eastern United states and the 4 th largest of the northern storms, superposed in critical position on the Skunk River Basin above Augusta, Iowa. The maximum flood coefficient of 0.38 is applied to the computed pluviagraph to give the estimated flood hydrograph of surface run-off shown in the figure. This graph indicates a maximum daily discharge of 118,300 second-feet, or 28 second-feet per square mile.

$59550-35-16$ 


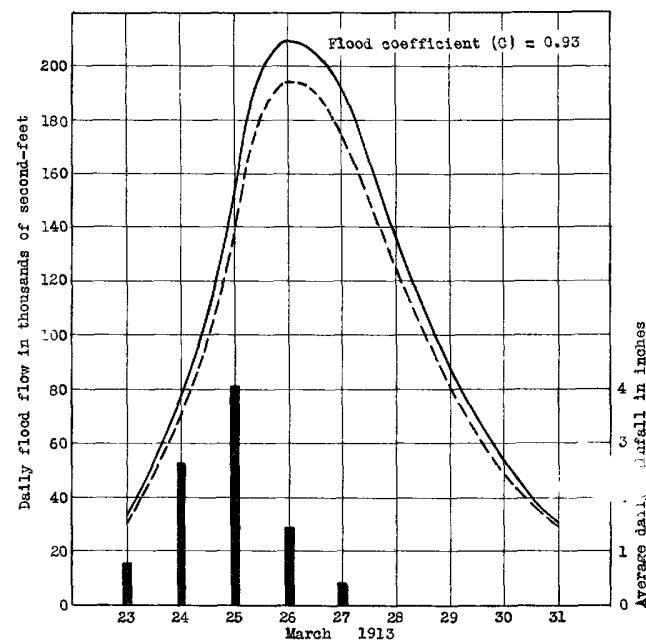

Average àistribution graph

Day

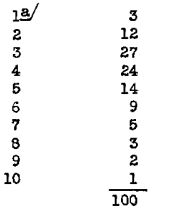

a/ Day on which rainfall wes reoorded.

Explanation Pluviagraph

Computed flood flow

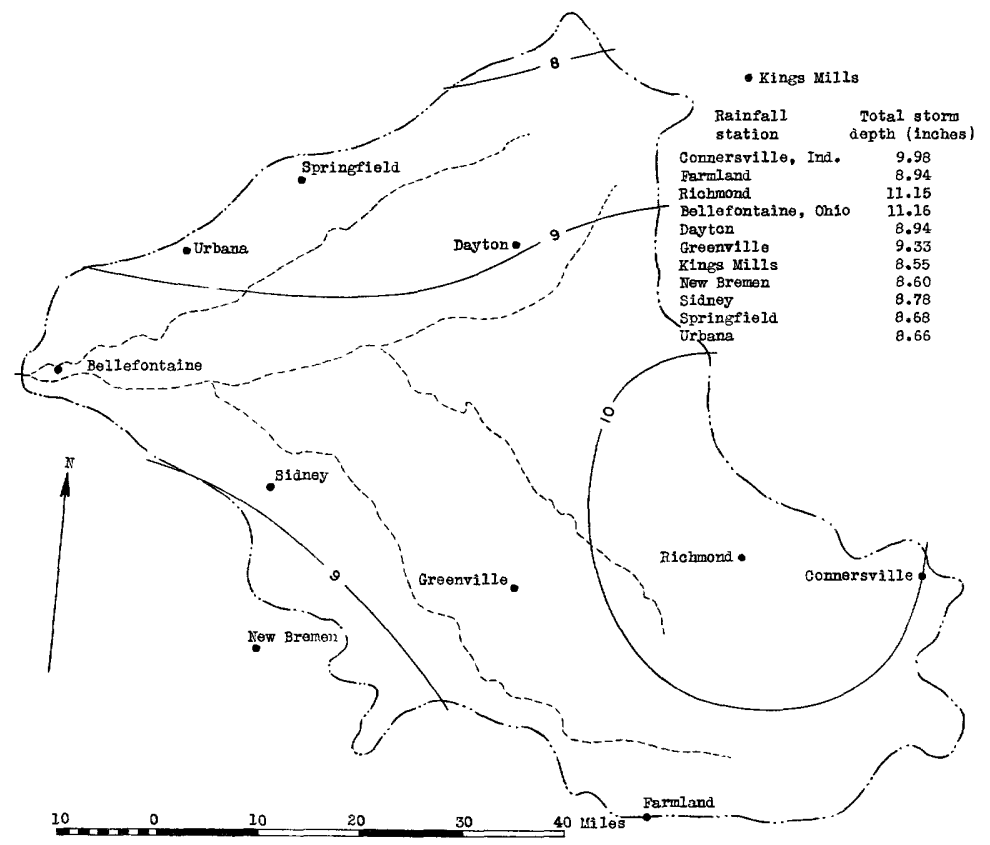

Figure 84.-Storm of Mlarch 24-26, 1913, with relat1ve location of Weather Bureau stations superposed on Wabash River Basin above Logansport, Ind., and resulting pluriagraph and hyorograph of computed flood flowe 


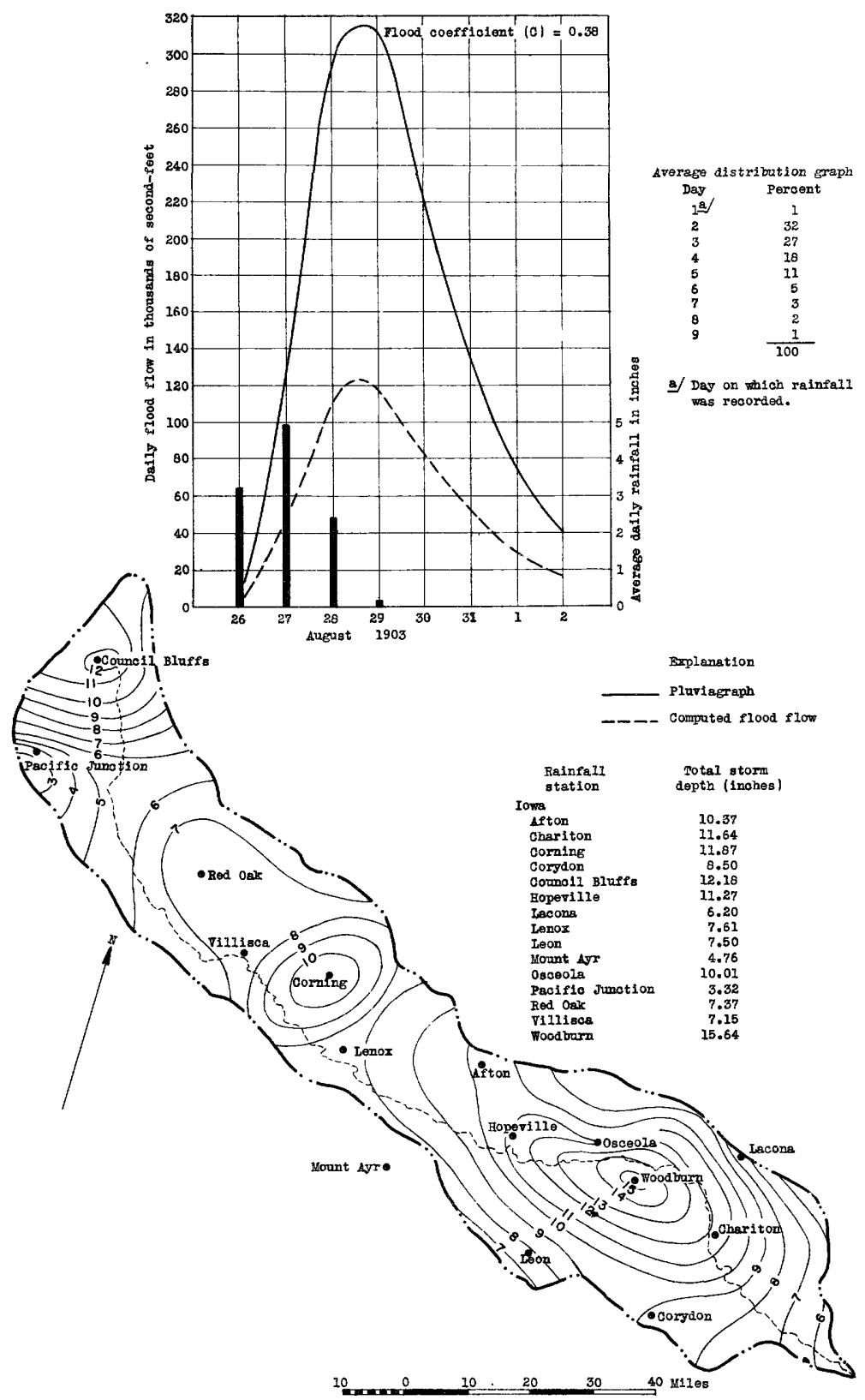

Figure 85.-Storm of Augast 25-28, 1903, with relative location of Weather Burean stations superposed an Skunk River Besin above Angesta, Iow, and resulting pluviagraph and hydrograph of oomputed flood flow. 


\section{Floods influenced by snow}

As previously stated the present study excludes an analysis of storm mun-off during winter periods, when, as a result of run-off from melted snow, appreciable floods may be produced by light rainfall accompanied by marked rises in temperature. Under these conditions the hydrograph of stream flow may show peaks exceeding peak pluviagraph values and so-crlled "flood coefficients" exceeding unity.

The analysis of several hydrographs of run-off associated with melting snow, however, has disclosed an interesting and apparently significant fact. It was found that run-off from winter rainfall, augmented by melting snow and $1 c \theta$, responded satisfactorily to the daily "proportioning" of the distribution graph developed from normal rainfalis. In other words, the run-off from the melted snow and tce seemed to be distributed in the same proportions as the mun-off from rain.

\section{Conclusion}

This special study has been intended primarily to examine the possibilities of storm superposition as a means of determining flood flow, and it is realized that further refinements may be practical and essential to the ultimate development of this method. The study is intended to direct attention to the possibility of a fuller use of available storm data, rather than to indicate that such storms are to be taken conclusively as limiting storms for their respective localities. Use of such storms as a basis for estimating flood flow should be made with caution and with appreciation of their significance, and the impression should not be created that the estimated results are necessarily to be accommodated by any contemplated design. 


\section{Ground-water mun-off}

In the preceding pages some of the problems in connection with the separation of ground-water run-off and surface run-off are discussed, together with a quantitative analysis of surface mun-off and its characteristics as disclosed by unit hydrographs. The following discussion relates to the disposal of that part of the precipitation which either is lost through evaporation and transpiration, is accumulated in the ground as soil molsture or ground water, or flows out of the basin as ground-water mun-off. The following tables show for typical basins in the United States and for major subdivisions of the Mississippl River Basin above Keokuk, Iowa, an estimate of the mean annual ground-water mun-off expressed in inches and as a percentage of "precipitation minus surface mun-off." All figuxes are, In general, 5-year annual averages and were obtained through a study of the plotted hydrographs of total stream flow, in part by methods described on pages 111-119.

As was pointed out in the discussion of the quantitative analysis of surface run-off, these estimates are subject to error. To the extent that the estimates of ground-water run-off are too large the estimates of surface run-off are too small, and vice versa. These estimates are rough approximations of the amount of infiltration that eventually reaches stream channels. They represent on an annual basis that part of the stream flow which is dependable, as compared with erratic and often destructive surface mun-off.

As noted elsewhere, the figures given for the Miami River, Ohio, and the Pomperaug Basin, Conn., are based on a general straight-line separation, and the results may not be entirely comparable with the figures given for the other basins. However, where comparisons have been made between annual estimates of ground-water run-off based on straight. lines connecting the low points of hydrographs and estimates based on other methods the differences have generally not exceeded 10 percent on an annual basis, the straight-line method giving the smaller result. 
Table 59.- Ground-water run-off for typical basins in the United States

\begin{tabular}{|c|c|c|c|c|c|}
\hline \multirow[b]{2}{*}{ Basin } & \multirow[b]{2}{*}{$\begin{array}{l}\text { Precipi- } \\
\text { tation } \\
\text { (inches) }\end{array}$} & \multirow[b]{2}{*}{$\begin{array}{l}\text { Precipi- } \\
\text { tation } \\
\text { minus } \\
\text { Surface } \\
\text { mun-off } \\
\text { (inches) }\end{array}$} & \multicolumn{3}{|c|}{ Ground-water run-off } \\
\hline & & & Inches & $\begin{array}{l}\text { Percent } \\
\text { of } \\
\text { total } \\
\text { run-off }\end{array}$ & $\begin{array}{l}\text { Percent } \\
\text { of } \\
\text { "Precipi- } \\
\text { tation } \\
\text { minus } \\
\text { Surface } \\
\text { run-off" }\end{array}$ \\
\hline $\begin{array}{l}\text { Red River above } \\
\text { Grand Forks, N. Dak. } \\
\text { (1928-32) }\end{array}$ & 18.53 & 18.18 & 0.24 & 40.7 & 1.3 \\
\hline $\begin{array}{l}\text { Msssissippi River above } \\
\text { Kookuk, Iowa } \\
\text { (1928-32) }\end{array}$ & 28.64 & 25.28 & $2 \cdot 62$ & 43.8 & 10.4 \\
\hline $\begin{array}{l}\text { Neosho River above } \\
\text { Iola, Kans; } \\
\text { (1928-32) }\end{array}$ & 33.07 & 29.01 & 0.86 & 17.5 & 3.0 \\
\hline $\begin{array}{l}\text { Merrimack River above } \\
\text { Lawrence, Mass. } \\
\text { (1928-32*) }\end{array}$ & 40.66 & 30.72 & \#\# 9.59 & 49.1 & 31.2 \\
\hline $\begin{array}{l}\text { James River above } \\
\text { Cartersvilie, Va. } \\
\text { (1928-32) }\end{array}$ & 38.04 & 31.02 & 6.09 & 46.4 & 19.6 \\
\hline $\begin{array}{c}\text { Tennessee River above } \\
\text { Chattanooga, Tenn. } \\
\text { (1901-5) }\end{array}$ & 49.83 & 34.53 & 8.44 & 35.6 & 24.5 \\
\hline $\begin{array}{l}\text { Chattahoocheo River above } \\
\text { West Point, Ga. } \\
\text { (1928-32) }\end{array}$ & 59.65 & 48.06 & 11.55 & 49.9 & 24.0 \\
\hline $\begin{array}{l}\text { Misami River above*t } \\
\text { Dayton, Ohio } \\
\text { (I894-191.9*) }\end{array}$ & 37.07 & 29.30 & 4.08 & 34.4 & 13.8 \\
\hline $\begin{array}{c}\text { Pomperaug River above\# } \\
\text { Bennetts Bridge, Conn. } \\
\text { (I9I4-16*) }\end{array}$ & 44.48 & 32.58 & 8.76 & $42 \cdot 4$ & 26.9 \\
\hline
\end{tabular}

* Years ending September 30. *t* Ref. 72 .

\# Ref. II5.

\#\# Probably too large. 
Table 60.- Ground-water run-off for major subdivisions of Mississippi River Basin above Keolruk, Iowa

\begin{tabular}{|c|c|c|c|c|c|}
\hline \multirow[b]{2}{*}{ Subdivision } & \multirow[b]{2}{*}{$\begin{array}{l}\text { Precipi- } \\
\text { tation } \\
\text { (1nches) }\end{array}$} & \multirow[b]{2}{*}{$\begin{array}{l}\text { Precipi- } \\
\text { tation } \\
\text { surface } \\
\text { run-off } \\
\text { (inches) }\end{array}$} & \multicolumn{3}{|c|}{ Ground-water run-off } \\
\hline & & & Inches & $\begin{array}{l}\text { Percent } \\
\text { of } \\
\text { total } \\
\text { run-off }\end{array}$ & $\begin{array}{c}\text { Percent } \\
\text { of } \\
\text { "Precipi- } \\
\text { tation } \\
\text { minus } \\
\text { Surf ace } \\
\text { run-of } f \text { " }\end{array}$ \\
\hline $\begin{array}{l}\text { Minnesota River above } \\
\text { Mankato, Minn. } \\
\text { (I930-32\#) }\end{array}$ & $22 \cdot 22$ & 21.80 & 0.27 & 39.0 & 1.2 \\
\hline $\begin{array}{l}\text { Black River above } \\
\text { Neilisville; Wis. } \\
\text { (1928-32*) }\end{array}$ & 30.99 & 23.15 & 1.48 & 15.9 & 6.4 \\
\hline $\begin{array}{l}\text { Skunk River above } \\
\text { Augusta, Iowa } \\
\text { (I928-32\%) }\end{array}$ & 35.85 & 30.38 & 2.37 & 30.2 & 7.8 \\
\hline $\begin{array}{l}\text { Zumbro River above } \\
\text { Zumbro Falls, Minn. } \\
\text { (I931-32*) }\end{array}$ & 26.35 & 24.65 & 7.78 & 51.2 & 7.2 \\
\hline $\begin{array}{l}\text { Yellow River above } \\
\text { Sprague, Wis. } \\
\text { (1928-32*) }\end{array}$ & 29.09 & 24.22 & 1.92 & 28.3 & 7.9 \\
\hline $\begin{array}{c}\text { Iowa River above } \\
\text { Wapelio, Iowa } \\
\text { (1928-32\%) }\end{array}$ & 32.83 & 28.55 & 2.72 & 38.9 & 9.5 \\
\hline $\begin{array}{l}\text { Maquoketa River above } \\
\text { Maquoketa, Iowa } \\
\text { (1931-32 } \$)\end{array}$ & 30.64 & 27.75 & 2.73 & 48.5 & 9.8 \\
\hline $\begin{array}{c}\text { Root River above } \\
\text { Houston, Minn. } \\
\text { (1931-32*) }\end{array}$ & 27.98 & 25.56 & 3.00 & 55.4 & 11.7 \\
\hline $\begin{array}{l}\text { Rock River above } \\
\text { Afton, Wis } \\
\text { (1928-32*) }\end{array}$ & 29.62 & 25.99 & 3.78 & 51.0 & 14.5 \\
\hline $\begin{array}{l}\text { St. Croix Ri.ver ahove } \\
\text { Rush City, Minn. } \\
\text { (1928-32\%) }\end{array}$ & 25.32 & 21.56 & 3.51 & 48.3 & 16.3 \\
\hline $\begin{array}{l}\text { Pecatonica River above } \\
\text { Freeport, Ill. } \\
\text { (1928-32*) }\end{array}$ & 31.95 & 27.18 & 5.24 & 52.3 & 19.3 \\
\hline $\begin{array}{l}\text { K1ckapoo River above } \\
\text { Gays Mills, Wis. } \\
\text { (1928-32\%) }\end{array}$ & 29.67 & 26.03 & 5.47 & 60.0 & 21.0 \\
\hline $\begin{array}{l}\text { La Crosse River above } \\
\text { West Salem, Wis. } \\
\text { (1928-32*) }\end{array}$ & 30.35 & 27.71 & 7.28 & 73.4 & 26.2 \\
\hline
\end{tabular}

* Years ending September 30. 


\section{Soll moisture}

As is shown in the quantitative analysis of ground-water munoff in tables 59 and 60 , only a relatively small part of the "precipitation minus surface run-of $f^{\prime \prime}$ eventually appears in the stream as seopage from ground-water. Although it is know that the portion which does not eventually appear as strean flow, either surface or underground, represents the amount of water that is elther evaporated or transpired, the exact processes involved are complex. One important phase of these hydrologic processes is, however, related to soil molsture and changes therein.

0 . E. Meinzer (113) defines soll water as molsture in "the part of the lithosphere, immediately below the surface, from which water is discharged into the atmosphere in perceptible quantities by the action of plants or by 3011 evaporation."

G. E. Condra (3la) defines soll molsture as "the caplilary phase of ground-water accumulation" and states that "because of its bearing on agriculture, it is perhaps our most economically important resource. There 1s drought when and where soll molsture fails during the growing season."

In addition to being one of the most important phases of the hydrologic cycle from the viewpoint of the agriculturist, it is of particwlar interest to the hydrologist. Information regarding the character1stics of changes in soil moisture is desirable in connection with the determination of run-off coefflcients for use in studies of flood, drought, and erosion problems, and in the application of methods, such as Mejer's, for computing stream flow from meterologic information.

Fleld experiments by Houk in Ohlo and by Taylor and others in California give valuable information concerning changes in soll molsture over small areas. Whether such information can be obtained over larger areas, other than through dotalled field observations, presents an interesting question. Houk, in his study of rainfall and run-off in the Mlami Valley (72), made a quantitative analyais of the components of the hydrologic cycle, month by month. He presents for the Mad RIver Valley above Wright, Ohio, for the years 1915 to 1919, graphs showing by months the rainfall, flood run-off (surface mun-off), ground-water mu-off, soll absorption, percolation and evaporation. The method used by Houk in obtaining the ground-water mun-off and the flood run-off is described on page 112, of the present report. His so-called "retention" (storage, absorption, and 
evaporation) was obtained by subtracting the run-off from the precipitation. The soil absorption was estimated on the basis of plot experiments. It was "assumed that there is a variation of 5 inches in the amount of moisture during the year; that the soll reaches its driest condition sometime late in the summer, during August or September; that it gradually fills with molsture during the months of September, October, November, and December; and that this remains saturated unt1l late in the spring, when it begins to dry out due to transpiration and increased scil evaporation. In drawIng percclation curves it was assumed that percolation ceases about the time the soil begins tc dry out in the spring and dces not begin until late in the fall, about the time the surface soll becomes saturated."

A somewhat different methcd of apprcach was used in the present study. The "precipitation minus surface mun-off" having been determined as an approximate representation of the emount of water which either is absorbed by the scil or remains on the surface in some form of storage, it is possible tc obtain, by the use of the Meyer curves of evapcration and transpiration, an approximation of the soll-molsture changes plus accretion to ground water. The cbjection may be raised that inasmuch as the ovaporation, transpiration, surface mun-off, and amount of accretion to the ground water cannot be determined accurately, the derived changes in soll moisture may have little relation to the facts. It is evident that errors in the determination of these factors may be of such magnitude as to cast doubt on the accuracy of the results. To the extent, hcwever, that the results are demonstrated tc be reasonable, as by comparison with observations relating to scil-molsture canditions, they may throw some light cn this phase of the hydrologic cycle. When the data now being collected in great quantity at the numerous projects being carried on by the Soll Conservaticn Service, Fcrest Service, United States Geological Survey, and other agencies beccme avallable, greater refinement in the methods cf quantitative analysis may be developed. A summary and brief discussion of the analyses that were made in the present study with reference to the investigation of soll molsture is given below.

The average precipitation and temperature were determined month by month over several drainage basins in the upper Mississippi Valley, from Weather Bureau records. The evaporation from water surfaces in the basins studied was assumed to be so small that it could be neglected. The evaporation from land areas and transpiration were based on curves developed by 
Adolph F. Meyer (122, 2d ed., fig. 272, p. 456, and fig. 164, p. 263), using the method described (idem, pp. 455-458) as follows:

"The author's evaporation curve.- The variation of ovaporation from land areas with changes in seasons, monthly mean temperature, and monthly mean rainfall, based on the author's study of the subject, is summarized in the evaporation curve of figure 272 .

"In the fall, when the monthiy temperature reaches $20^{\circ}$, practicaliy all the precipitation occurs as snow; consequentiy, evaporation for temperatures below $20^{\circ}$ is no longer dependent on precipitation after the ground has been covered with snow, but entirely on temperature. Full evaporation, corresponding to the given monthly temperature, is usually possible throughout the winter. After the temperature rises above $20^{\circ}$, in spring, the evaporation again depends largely on available moisture, as determined mainly by precipitation. Nevertheless, a considerable constant evaporation is still possible, irrespective of precipitation, because a certain quantity of snow and ice is almost always present on the ground while the monthly temperature ranges from $20^{\circ}$ to $35^{\circ}$. After the snow has disappeared, the re will still be a relatively large constant evaporation, irrespective of the rainfall, unless the winter precipitation has been distinctly deficient.

"A gradual reduction in the constant evaporation has been assumed for the summer. It is realized, of course, that the constant evaporation during the summer depends, in a measure, on the rainfall of each previous month. In making detalied computations of evaporation losses, the constant evaporation is readily varied by one or two tenths of an inch, In accordance with apparent variations in storage. On some watersheds, when the fall precipitation is very low and the temperature remains above $30^{\circ}$, the righthand portion of the curve is used for January and sometimes also for February - that is, when the storace is practically exhausted and there is no snow on the ground, the constant of evaporation otherwise used practicaliy vanishes, and the evaporation is entirely proportional to the rainfall. In the same way, when the fall rains are coplous and the ground-water supply is abundant, a constant of evaporation one or two tenths higher than that given by the curve may be used to advantage.

"The portions of the limiting curve belok temperatures of approximately $35^{\circ}$ represent evaporation from snow and 1.ce surfaces. At the higher temperatures the limiting curve represents values somewhat less than the evaporation from shallow water. The quantity evaporated out of each inch of rainfall becomes less and less as the monthly precipitation increases, varying more rapidiy at the lower than at the higher rates of precipitation.

"To the values of evaporation, in inches of depth per month, as taken off the curve, a coefficient must be applied to reduce these quantities to actual ovaporation from the given viatershed. This coefficient ranges from about 0.95 to 1.25 for most watersheds of the Northwest and for similar ones elsewhere. Very sandy watersheds may require a coefficient as low as 0.60 , and very impervious flat watersheds may require a coefficient in excess of 1.25. The coefficient to be used depends on topography, vegetal cover, soil, subsoil, humidity, and wind. An extremely high coefficient of evaporation (in excess of 1.25) would result from flat topography devold of vegetation, moderately pervious, shallow soll underlain with impervious eubsoll or rock, low humidity, and high wind velocity. An extremely low coefficient (less than 0.95 ) would result from rugfad topography, bare scanty soll underlain with

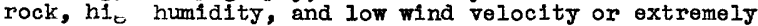
sandy soll. Between these ifmits the usual working values will be found. With a little experience, one can select coefficients for different watersheds with considerable accuracy. 
"The author's transplration curve.- The base values for total transpiration, in inches of depth, during the growing season on any given watershed, are selected with reference to the character of the vegetation and the length of the Erowing season on that watershed, giving consideration also to avallable sunshine. In the followIng computations a normal seasonal transpiration of about 9 inches has been assumed for small grains, grasses, and other agricultural crops, 8 to 12 inches for dec1duous trees, 4 1nches for evergreen trees, and 6 inches for small trees and brush. The normal monthly distribution of this total seasonal transpiration is based mainly on temperature. To obtain actual transpiration in any given month, however, the values taken from the transplration curve ( $f 1 g$. $164, p .263$ ), after being multiplied by a coefficient, must be further modifled on the basis of available molsture. Where preclpitation minus evaporation for a given month is insufficlent to meet the normal plant requirements for that month, the ground water is drawn on to a varying extent, depending on the character of the root system of the g1ven vegetation, the depth and character of the s01], and the quantity of surface-so1l storage, as determined by the preclpitation minus losses for previous months."

Although the study covered the entire period from 1916 to 1934 there is given in table 61 for the Skunk River Basin, Iowa, for the perlod October 1927 to September 1932, (I) observed precipltation over the bas In; (2) observed temperature; (3) computed transpiration over the basin; (4) computed evaporation over the basin; (5) the surface run-of determined from a study of the hydrograph of total flow; (6) "Precipitation minus surface mun-of $f^{\prime \prime}$ which in basins like this one, where the surface mun-off is rapid, represents evaporation and transpiration, a small amount of surface storage, and the infiltration month by month. In column 7 is given the difference between "Precipltation minus surface mun-off" and the total computed transpiration and evaporation. The plus sign indicates that the demands of transpiration and evaporation were less than the supply during that month and that there was elther an increase in so1l moisture or an accretion to the water table, or both, by about the amount indicated. The minus sign indlcates that the current water supply was less than the combined demands of evaporation and transpiration and that there was a draft either on soll molsture or on the ground water, or both, by about the amount indicated.

The monthly accretion to ground water (column 8) was estimated by applying the average ground-water depletion curve to the estimated hydrograph of ground-water flow at both the beginning and end of the month, and designating the area bounded by the hydrograph and the two depletion curves to the point of their intersection as "ground-water accretion" for the month under study. With these estimates (column 8) it is 
Table 61.- Observed and estimated meteorologic

and hydrologic data for Skunk River Basin above Augusta, Iovs

\begin{tabular}{|c|c|c|c|c|c|c|c|c|c|c|}
\hline Month & $\begin{array}{l}\text { Precipi- } \\
\text { tation } \\
\text { (inches) }\end{array}$ & $\begin{array}{c}\text { Pemper- } \\
\text { ature } \\
\left(\mathrm{O}_{.}\right)\end{array}$ & $\begin{array}{l}\text { Transpi- } \\
\text { ration } \\
\text { (Inches) }\end{array}$ & $\begin{array}{l}\text { Evapo- } \\
\text { ration } \\
\text { (inches) }\end{array}$ & $\begin{array}{l}\text { Surface } \\
\text { run-off } \\
\text { (Inches) }\end{array}$ & \begin{tabular}{|} 
Precipi- \\
tation \\
minus \\
surface \\
run-off \\
(inches)
\end{tabular} & $\begin{array}{l}\text { Column } 6 \\
\text { minus } \\
\text { columns } \\
3 \text { and } 4 \\
\text { (inches) }\end{array}$ & \begin{tabular}{|} 
Total \\
accretion \\
to \\
ground \\
water \\
(inches)
\end{tabular} & $\begin{array}{c}\text { Changes } \\
\text { In } \\
\text { soil } \\
\text { moisture } \\
\text { (Inches) }\end{array}$ & $\begin{array}{l}\text { Ground- } \\
\text { water } \\
\text { run-off } \\
\text { (inches) }\end{array}$ \\
\hline & 1 & 2 & 3 & 4 & 5 & 6 & 7 & 8 & 9 & 10 \\
\hline $\begin{array}{l}1927 \\
\text { Oot. } \\
\text { Nov: } \\
\text { Dec: } \\
1928\end{array}$ & $\begin{array}{l}5.08 \\
1.14 \\
1.16\end{array}$ & $\begin{array}{l}57.8 \\
41.8 \\
24.3\end{array}$ & $\begin{array}{l}1.00 \\
0 \\
0\end{array}$ & $\begin{array}{r}2.08 \\
.41 \\
.38\end{array}$ & $\begin{array}{r}0.51 \\
.04 \\
.14\end{array}$ & $\begin{array}{l}4.57 \\
1.10 \\
1.02\end{array}$ & $\begin{array}{r}1.49 \\
.69 \\
.64\end{array}$ & $\begin{array}{l}0.20 \\
0.11\end{array}$ & $\begin{array}{r}+1.29 \\
+\quad .69 \\
+\quad .53\end{array}$ & $\begin{array}{r}0.12 \\
.07 \\
.03\end{array}$ \\
\hline $\begin{array}{l}\text { Jan. } \\
\text { Feb. } \\
\text { Mar. } \\
\text { Apr: } \\
\text { May } \\
\text { June } \\
\text { July } \\
\text { Aug. } \\
\text { Sept. } \\
\text { Oct. } \\
\text { Nov. } \\
\text { Dec. } \\
\text { 1929 }\end{array}$ & $\begin{array}{l}.18 \\
2.18 \\
1.66 \\
2.61 \\
1.95 \\
6.81 \\
4.71 \\
6.54 \\
3.59 \\
3.93 \\
4.32 \\
1.17\end{array}$ & $\begin{array}{l}26.1 \\
31.0 \\
40.0 \\
46.8 \\
64.2 \\
66.7 \\
76.0 \\
74.7 \\
62.6 \\
50.5 \\
41.4 \\
31.3\end{array}$ & $\begin{array}{l}0 \\
0 \\
.05 \\
.40 \\
1.30 \\
1.50 \\
2.30 \\
2.10 \\
1.40 \\
1.00 \\
0 \\
0\end{array}$ & $\begin{array}{r}.48 \\
.83 \\
.78 \\
1.14 \\
1.20 \\
3.25 \\
2.86 \\
3.43 \\
1.86 \\
1.61 \\
1.20 \\
.30\end{array}$ & $\begin{array}{r}.21 \\
.96 \\
.24 \\
.28 \\
.09 \\
.54 \\
1.03 \\
.94 \\
.37 \\
.36 \\
1.28 \\
.85\end{array}$ & $\begin{array}{r}.03 \\
1.22 \\
1.42 \\
2.33 \\
1.86 \\
6.27 \\
3.68 \\
5.60 \\
3.22 \\
3.57 \\
3.04 \\
.32\end{array}$ & $\begin{array}{r}-.51 \\
.39 \\
.59 \\
.79 \\
-.64 \\
1.52 \\
-1.48 \\
.07 \\
-.04 \\
.096 \\
1.84 \\
.02\end{array}$ & $\begin{array}{l}0 \\
.27 \\
.21 \\
.29 \\
0 \\
.35 \\
.07 \\
.12 \\
.07 \\
.64 \\
.79 \\
0\end{array}$ & 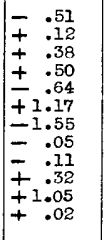 & $\begin{array}{l}.09 \\
.15 \\
.24 \\
.29 \\
.13 \\
.09 \\
.24 \\
.24 \\
.17 \\
.24 \\
.48 \\
.55\end{array}$ \\
\hline $\begin{array}{c}\text { Jan. } \\
\text { Feb: } \\
\text { Mar: } \\
\text { Apr: } \\
\text { May } \\
\text { June } \\
\text { July } \\
\text { Aug. } \\
\text { Sept. } \\
\text { Oct. } \\
\text { Nov. } \\
\text { Dec. } \\
\text { I930 }\end{array}$ & $\begin{array}{l}2.42 \\
1.25 \\
2.07 \\
5.30 \\
2.13 \\
2.70 \\
5.06 \\
2.70 \\
4.01 \\
3.34 \\
1.41 \\
.53\end{array}$ & $\begin{array}{l}13.7 \\
18.1 \\
43.4 \\
53.0 \\
59.6 \\
69.0 \\
75.7 \\
72.4 \\
64.6 \\
53.2 \\
34.6 \\
28.4\end{array}$ & $\begin{array}{l}0 \\
0 \\
.20 \\
1.00 \\
1.30 \\
1.50 \\
2.20 \\
1.60 \\
1.40 \\
.70 \\
0 \\
0\end{array}$ & $\begin{array}{r}.31 \\
.50 \\
.93 \\
2.14 \\
1.20 \\
1.72 \\
2.96 \\
1.67 \\
1.98 \\
1.31 \\
.36 \\
.16\end{array}$ & $\begin{array}{r}.12 \\
.16 \\
2.73 \\
2.18 \\
.29 \\
.15 \\
.47 \\
.16 \\
.07 \\
.07 \\
.16 \\
.02\end{array}$ & $\begin{array}{r}2.30 \\
1.09 \\
-.66 \\
3.12 \\
1.84 \\
2.55 \\
4.59 \\
2.54 \\
3.94 \\
3.27 \\
1.25 \\
.51\end{array}$ & $\begin{array}{r}1.99 \\
-1.59 \\
-1.79 \\
-.02 \\
-.66 \\
-.67 \\
-.57 \\
-.73 \\
. .56 \\
1.26 \\
.89 \\
.35\end{array}$ & $\begin{array}{l}0 \\
.11 \\
.86 \\
.76 \\
0 \\
0 \\
.12 \\
0.06 \\
.15 \\
.17 \\
0.17\end{array}$ & $\begin{array}{l}+1.99 \\
+\quad .48 \\
-2.65 \\
-\quad .78 \\
=\quad .66 \\
-\quad .67 \\
=\quad .69 \\
+\quad .73 \\
+1.11 \\
+\quad .72 \\
+\quad .35\end{array}$ & $\begin{array}{l}.21 \\
.15 \\
.36 \\
.60 \\
.55 \\
.25 \\
.14 \\
.11 \\
.07 \\
.09 \\
.14 \\
.12\end{array}$ \\
\hline $\begin{array}{l}\text { Jan. } \\
\text { Feb: } \\
\text { Mar: } \\
\text { Apr: } \\
\text { May } \\
\text { June } \\
\text { July } \\
\text { Aug. } \\
\text { Sept. } \\
\text { Oct. } \\
\text { Nov. } \\
\text { Dec. } \\
\text { l931 }\end{array}$ & $\begin{array}{r}1.69 \\
.98 \\
.99 \\
2.78 \\
3.18 \\
7.45 \\
1.20 \\
1.98 \\
2.50 \\
2.22 \\
1.94 \\
.97\end{array}$ & $\begin{array}{l}14.8 \\
37.2 \\
38.4 \\
53.3 \\
62.8 \\
71.0 \\
78.6 \\
75.6 \\
68.9 \\
52.2 \\
42.8 \\
28.0\end{array}$ & $\begin{array}{l}0 \\
0 \\
0 \\
.80 \\
1.40 \\
2.10 \\
2.30 \\
1.70 \\
1.30 \\
.50 \\
0 \\
0\end{array}$ & $\begin{array}{r}.35 \\
.59 \\
.59 \\
1.35 \\
1.75 \\
3.74 \\
1.04 \\
1.35 \\
1.46 \\
.90 \\
.60 \\
.28\end{array}$ & $\begin{array}{r}.01 \\
.59 \\
.11 \\
.13 \\
.21 \\
1.99 \\
.09 \\
.02 \\
.02 \\
.04 \\
.02 \\
.08\end{array}$ & $\begin{array}{r}1.68 \\
.39 \\
.88 \\
2.65 \\
2.97 \\
5.46 \\
1.11 \\
1.96 \\
2.48 \\
2.18 \\
1.92 \\
.89\end{array}$ & $\begin{array}{r}1.33 \\
-\quad .20 \\
.29 \\
.50 \\
-.18 \\
-\quad .38 \\
-2.23 \\
-1.09 \\
-\quad .28 \\
.78 \\
1.32 \\
.61\end{array}$ & $\begin{array}{l}0 \\
0.44 \\
0.10 \\
.25 \\
.46 \\
0 \\
0 \\
0 \\
0 \\
0 \\
0\end{array}$ & $\begin{array}{l}+1.33 \\
=\quad .64 \\
+\quad .29 \\
\pm \quad .40 \\
-\quad .43 \\
=.84 \\
-2.23 \\
-1.09 \\
-\quad .28 \\
+\quad .78 \\
+1.32 \\
+\quad .61\end{array}$ & $\begin{array}{l}.07 \\
.19 \\
.26 \\
.14 \\
.21 \\
.23 \\
.17 \\
.04 \\
.02 \\
.02 \\
.01 \\
.01\end{array}$ \\
\hline $\begin{array}{l}\text { Jan. } \\
\text { Feb: } \\
\text { Mar: } \\
\text { Apr: } \\
\text { May } \\
\text { June } \\
\text { JuIy } \\
\text { Aug. } \\
\text { Sept. } \\
\text { Oct. } \\
\text { Nov. } \\
\text { Dec. } \\
\text { I932 }\end{array}$ & $\begin{array}{l}.59 \\
.18 \\
2.45 \\
3.30 \\
3.08 \\
4.05 \\
3.61 \\
3.56 \\
7.21 \\
4.19 \\
5.96 \\
2.84\end{array}$ & $\begin{array}{l}31.4 \\
36.8 \\
36.2 \\
52.3 \\
58.4 \\
76.5 \\
80.2 \\
74.6 \\
72.4 \\
59.0 \\
48.8 \\
37.1\end{array}$ & $\begin{array}{l}0 \\
0 \\
0 \\
.70 \\
1.20 \\
2.20 \\
2.40 \\
1.90 \\
2.10 \\
1.10 \\
. .40 \\
0 .\end{array}$ & $\begin{array}{r}.54 \\
.42 \\
.94 \\
1.51 \\
1.56 \\
2.48 \\
2.41 \\
2.10 \\
3.50 \\
1.77 \\
1.62 \\
.72\end{array}$ & $\begin{array}{l}.01 \\
.03 \\
.05 \\
.37 \\
.04 \\
.38 \\
.22 \\
.05 \\
.40 \\
.29 \\
1.55 \\
1.07\end{array}$ & $\begin{array}{r}.58 \\
.16 \\
2.39 \\
2.93 \\
3.04 \\
3.67 \\
3.39 \\
3.51 \\
6.81 \\
3.90 \\
4.41 \\
1.77\end{array}$ & $\begin{array}{r}.04 \\
-.26 \\
1.45 \\
.72 \\
.28 \\
-1.01 \\
-1.42 \\
-\quad .49 \\
1.21 \\
1.03 \\
2.39 \\
1.05\end{array}$ & $\begin{array}{l}0 \\
.08 \\
.05 \\
.20 \\
0 \\
.08 \\
.0 \\
0 \\
.12 \\
.20 \\
1.01 \\
.30\end{array}$ & $\begin{array}{l}+.04 \\
-1.35 \\
+1.41 \\
+\quad .52 \\
+\quad .28 \\
-1.09 \\
-1.42 \\
-1.49 \\
+1.09 \\
+1.83 \\
+1.38 \\
+\quad .75\end{array}$ & $\begin{array}{l}.01 \\
.04 \\
.04 \\
.11 \\
.08 \\
.08 \\
.05 \\
.02 \\
.04 \\
.16 \\
.20 \\
.59\end{array}$ \\
\hline $\begin{array}{l}\text { Jan. } \\
\text { Feb: } \\
\text { Mar: } \\
\text { Aps: } \\
\text { May } \\
\text { June } \\
\text { July } \\
\text { Aug. } \\
\text { Sept. }\end{array}$ & $\begin{array}{l}1.56 \\
.75 \\
1.53 \\
1.49 \\
4.03 \\
6.95 \\
4.70 \\
7.93 \\
1.45\end{array}$ & $\begin{array}{l}30.0 \\
34.0 \\
29.7 \\
50.3 \\
64.0 \\
74.2 \\
77.4 \\
73.8 \\
65.0\end{array}$ & $\begin{array}{l}0 \\
0 \\
0 \\
.50 \\
1.50 \\
2.20 \\
2.50 \\
2.20 \\
1.50\end{array}$ & $\begin{array}{r}.70 \\
.55 \\
.70 \\
.83 \\
2.13 \\
3.66 \\
2.90 \\
3.90 \\
.85\end{array}$ & $\begin{array}{r}1.53 \\
.28 \\
.38 \\
.08 \\
.41 \\
.84 \\
.75 \\
.92 \\
.01\end{array}$ & $\begin{array}{r}.03 \\
.47 \\
1.15 \\
1.41 \\
3.62 \\
6.11 \\
3.95 \\
7.01 \\
1.44\end{array}$ & $\begin{array}{r}-.67 \\
-\quad .08 \\
.45 \\
.08 \\
-.01 \\
.025 \\
-1.45 \\
-.91 \\
-.91\end{array}$ & $\begin{array}{l}.33 \\
.53 \\
. .33 \\
0 . \\
.33 \\
. .34 \\
0.40 \\
0^{.40}\end{array}$ & $\begin{array}{ll}-1.00 \\
\overline{ } & .61 \\
+ & .12 \\
\pm & .08 \\
\pm & .34 \\
= & .09 \\
-1.45 \\
+ & .51 \\
- & .91\end{array}$ & $\begin{array}{l}.49 \\
.45 \\
.52 \\
.40 \\
.32 \\
.30 \\
.31 \\
.17 \\
.16\end{array}$ \\
\hline
\end{tabular}


possible to correct the figure shown in column 7 to show the changes in soil moisture only. This amount is shown in column 9. The estimated ground-water run-off is listed in column 10. These data show quantitatively some of the factors in the hydrologic cycle.

Figure 86 shows graphically for the Skunk River Basin for the period October 1926 to September 1932, by months, the rainfall, temperature, evaporation, transpiration, surface run-off, ground-water run-of and changes in soil moisture. These changes have been accumulated for the replenishing and storage period, which has been taken as the period from September 1 through April 30, and for the growing period, from May 1 through August 31. These inaicated changes in soil moisture are the plus or minus differences between precipitation and the sum of the evaporation, transpiration, surface run-off, and accretion to ground water. The graph either represents the accumulated errors in the determination of these items or is an approximate representation of the changes in soil moisture.

Although various steps in the method of analysis are open to criticism, in that they are not subject to an exact mathematical solution, the results seem reasonable and represent, at least in a general way, the average magnitude of several elements of the hydrologic cycle in the Skunk River Basin.

A comparison was made between the computed changes in so1l moisture and the general summary of concurrent climatologic conditions for this basin as reported by the Weather Bureau. A summary of the outstanding results is given below:

(1) Beginning about May 1, there is an indicated depletion in soll molsture that generally continues through August. Years in which the indicated depletion is more than about 4 inches, or months in which such depletion is excessive, are described by the Weather Bureau as drought periods, so far as vegetative growth is concerned.

(2) Months during the growing season when either no net change or an Increase instead of a decrease in soll moisture is indicated are Invariably described by the Weather Bureau as generally cool, wet months in which cultivation was difficult on account of wet solis and crop growth was generalij retarded.

(3) In general, beginning with the heavy september rains, there is an apparent increase in soil moisture. Fall months that ao not show 


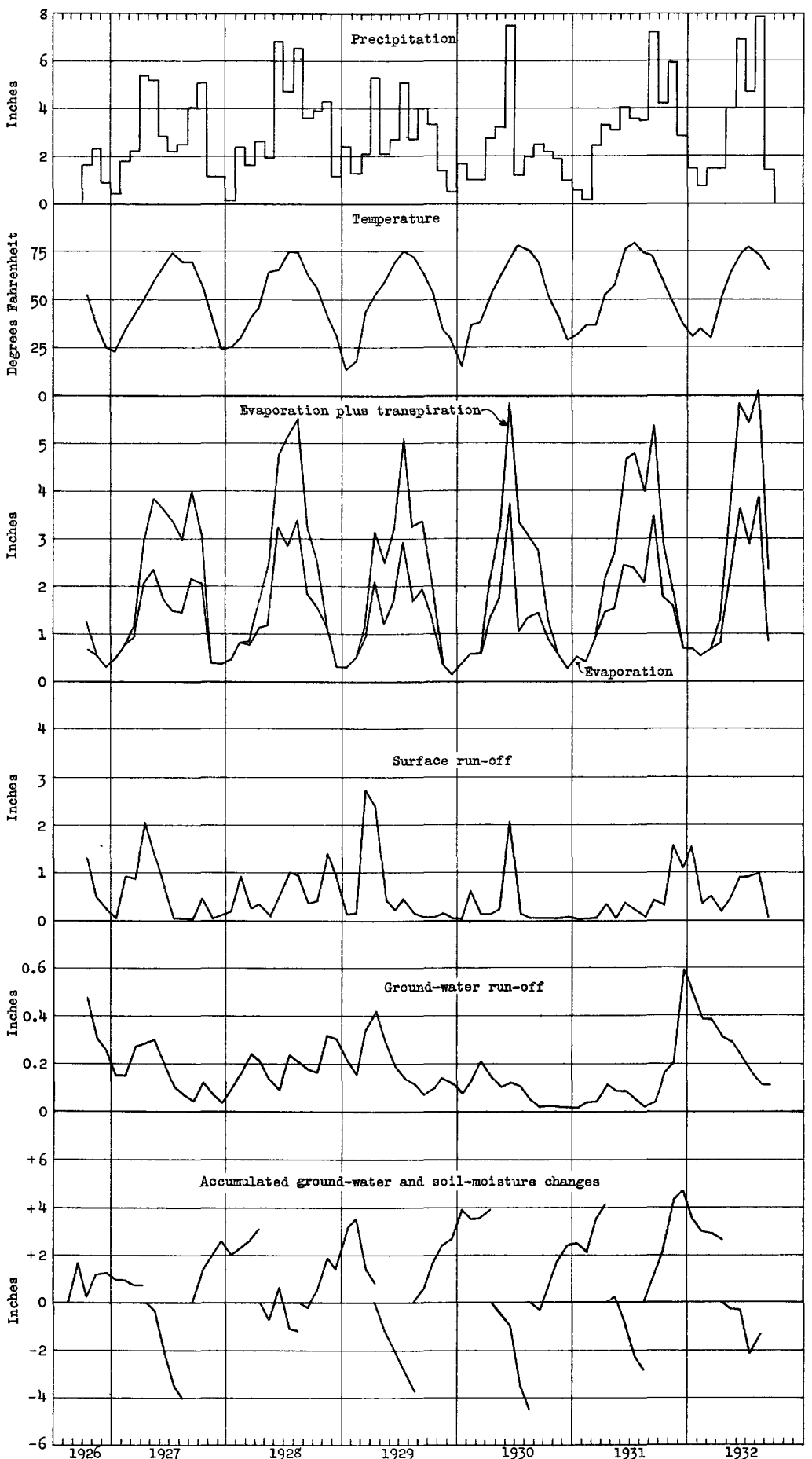

Figure 86.-Observed and estimated meteorologic and hydrologic data for Skunk River Basin above Augusta, Iowa, 1926-32. 
such trends are described by the Weather Bureau as being unusually warm and dry.

(4) Spring months in which an unusual amount of soil moisture is shown to have accumlated are described by the Weather Bureau as being cool and wet and accompanied by delayed planting.

Studies simllar to that already outlined for the Skunk River Basin were made on the Black River and Rock RIver Basins, in Wisconsin. In figure 87 the computed changes in soll moisture for these three basins were plotted against the precipitation and temperature on a monthly basis, and a comparison showed a considerable degree of uniformity. Although no great amount of accuracy is claimed for these curves, they illustrate a phase of the hydrologic cycle that is of the greatest importance to the farmers and are believed to represent roughly the information that would be obtained if the combined experience of successful farmers in this area were translated into specific data.

These curves are especially notable as indicating that in the areas studied with the surface run-off taken into consideration, an average monthly precipitation of $6 \frac{1}{2}$ to 7 inches is required during July to hold the soll moisture constant. An examination of the Weather Bureau records indicates that when this amount of precipitation occurs in July, the surface soil is generally too wet for satisfactory cultivation. Consequently, from the viewpoint of the farmer the most satisfactory conditions would seem to prevail when normal drafts on soil moisture occur, providing drying of the surface soil sufficient to permit cultivation.

\section{Run-off during drought periods}

From the beginning of climatic records in the United States until about 1930 widespread droughts were infrequent, the major droughts in the humid areas having occurred during 1894, 1895, 1901, and 1910. During 1930, however, there was one of the most widespread droughts on record, followed by deficient precipitation over extensive areas in 1931, 1932, and 1934. These droughts have naturally raised questions as to their effect and as to what can be done to provide against losses from their recurrence.

In conformity with the suggestions of the advisory committee of the American Geophysical Union, only preliminary studies have been made of run-off during drought periods and its relations with rainfall 


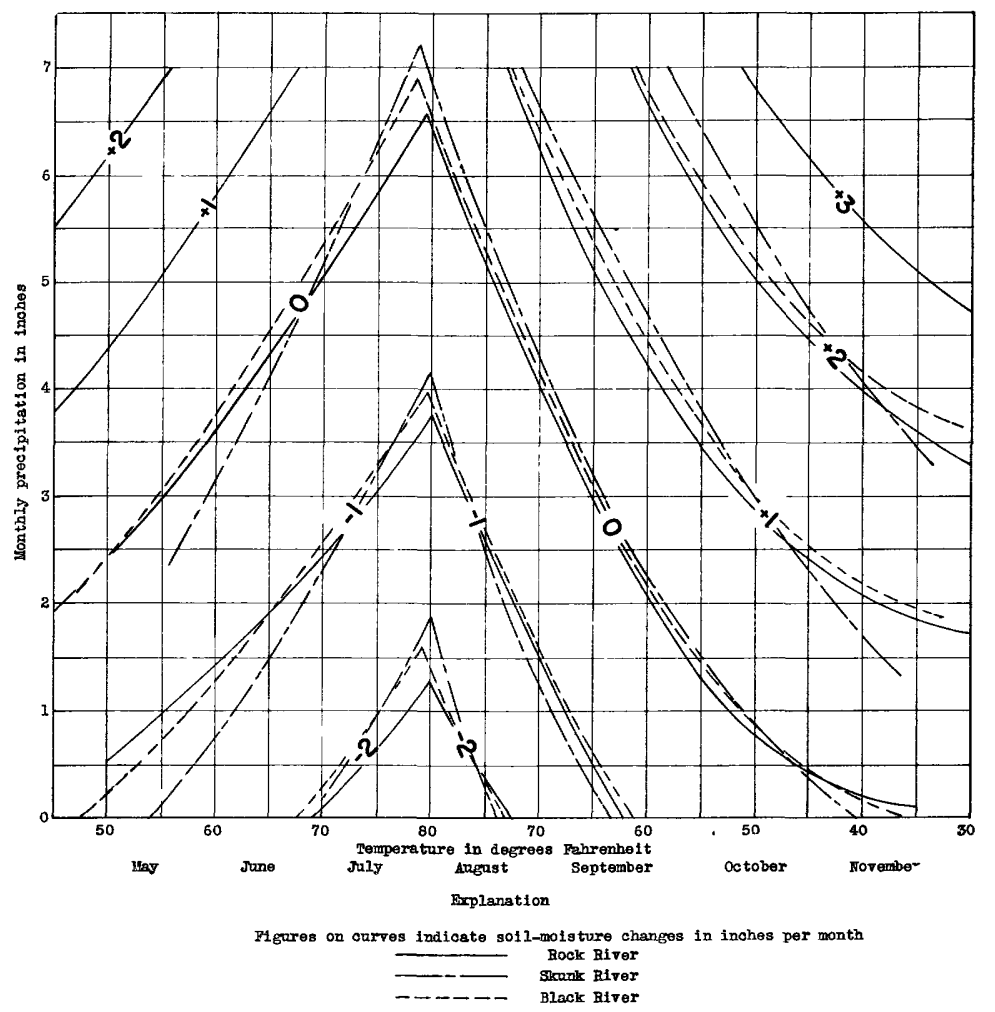

F1gure 87. - Fstimated relations between mean monthly precipitation, temperature, and soil-molsture ohanges in inohes per month in Rock, Srounk, and Black River Basins. 
or deflciency of rainfall. These studies have included (a) comparison of deficiencies in run-off, which during such drought periods is largely ground-water run-off, with deficiencies in rainfall and excesses in temperature, and (b) plotting of hydrographs of the annual minimum stream flow for periods of record on representative streams.

\section{Comparison of deficiencies in}

\section{ground-water run-off with deficlencies in rainfall}

The study of deficiencies in ground-water run-off compared with deficiencies in rainfall was based on the assumption that if two severe droughts of equal intensity have occurred many years apart and at the same season of the year, the minimum flow, being supplied mainly from ground water, would be less and the rate of decline of the stream flow greater in the later drought if there had been a material lowering of the water table in the drainage basin during the intervening period. On ths other hand, it was assumed that if for fairly comparable drought conditions as respects rainfall and temperature there was an indication that the decline in stream flow was no more rapid and the minimum contribution of ground water to the stream no less in the later drought, the state of depletion of the ground-water supply was probably no more severe. Although during drought periods it seems well established that stream flow in basins with no artificial storage is supplied in a large part by seepage from ground water, no exact correlation seems possible between the groundwater conditions considered in detall over large areas and the seepage flow therefrom appearing in the stream.

Ground-water experts agree that when the water table in a basin is high the seepage flow from the ground water will tend to be greater than when it is low, and vice versa. It appears, therefore, that if the minimum stream flow of a region is found to be the lowest in many jears, it may be inferred that the water table is probably also correspondingly low. As the relation between ground-water mun-off and the ground-water conditions as marked by water levels in wells is complex and not well defined, deductions as to ground-water conditions from a study of low-water run-off are necessarily qualitative and at present, at least, more or less open to question. In this connection the following quotation from the report of Devid G. Thompson, chalman of the Committee on Underground Water of the Section of Hydrology of the American Geophysical $59550-30-17$ 
Union (179a), is of value in calling the attention of hydrologists and others to the complexities of ground water:

"Only those who have studied in detail the flucturtions of the groundwater levels and the factors producing them appreciate the errors that may result from inadequate observations and erroneous interpretations. Although much detailed information has been gathered in regard to fluctuations of ground-water levels, and some of it is in print, comparatively few hydrologists appear to be informed on the subject, to know the variety of factors that produce fluctuations or the complexity of the resulting ground-water movements. There is littio realization of the magnitude or rapidity of fluctuations that may result from seasonal or secular differences in rainfall, from differences in geologic conditions, in relief, and depth at which the water lies, from differences in artesian and nonartesian conditions, from heavy pumpage in highly permeable formations or small witharavals for domestic use in poorly permeable formations, and from changes in atmospheric pressure and other factors. The variety of fluctuations of the groundwater levels that have been revealed by automatic recorders installed on wells during the past 15 years has been amazing, and such records serve to emphasize the fact that conclusions as to secular changes in groundwater levels based on any information except actual measurements in wells may be quite erroneous."

A comparison has been made between the run-off, rainfall, and temperature during drought periods on the Red River at Grand Forks, N. Dak.; the Black River at Neillsville, Wis.; the Rock River at Afton, Wis.; the Skunk River at Augusta, Iova; and the Mississippi River at Keokuk, Iowa. Several different methods of analyzing the run-off and the precipitation, or lack of it, during drought periods were tried, and a comparison was made of the deficiencies in rainfall and mun-off and excess in temperature - factors that seem to be the most illuminating. In tables 62 to 66 are given the observed precipitation, temperature, and run-off for each month during drought per1ods, together with the averages and departures for each basin. The tables also show, so far as possible, the estimated ground-water flow for each period of drought.

Table 62 gives data for the Red River Basin for three outstanding drought perlods, 1889-90, 1910-13, and 1929-31. During the f1rst drought a deficiency of 5.05 inches in precipitation accumulated in 5 consecutive months, and by the end of 14 months the accumulation had reached a total of 8.79 inches. In 5 consecutive months of the second drought a def1clency of 5.77 inches had accumulated, and for the remainder of the drought the precipitation averaged a little more than the general average. In the third drought a deficlency of 5.68 inches had accumulated in 4 consecutive months; at the end of 16 months had reached a total of 8.60 inches, and at 
Table 62.- Drought data for Red River Basin above Grand Forks, N. Dak.

\begin{tabular}{|c|c|c|c|c|c|c|c|c|c|c|}
\hline \multirow{2}{*}{ Month } & \multicolumn{3}{|c|}{$\begin{array}{c}\text { Temperature } \\
\text { at Moorhead, M1nn. }\left({ }^{\circ} \mathrm{F} .\right)\end{array}$} & \multirow{2}{*}{$\begin{array}{l}\text { over } \\
\text { For } \\
\text { month }\end{array}$} & \multicolumn{2}{|c|}{$\begin{array}{l}\text { Precipitation } \\
\text { the basin (Inches) }\end{array}$} & \multicolumn{3}{|c|}{$\begin{array}{l}\text { Run-off } \\
\text { at Grand Forks (Inches) }\end{array}$} & \multirow{2}{*}{$\begin{array}{l}\text { Est1mated } \\
\text { ground- } \\
\text { water } \\
\text { run-off } \\
\text { (1nches) }\end{array}$} \\
\hline & For & Average & Departure & & Averago & Departure & $\begin{array}{l}\text { For } \\
\text { month }\end{array}$ & Averago & Departure & \\
\hline $\begin{array}{l}1889 \\
\text { April } \\
\text { May } \\
\text { June } \\
\text { JuIy } \\
\text { August } \\
\text { September } \\
\text { October } \\
\text { November } \\
\text { December } \\
1890\end{array}$ & $\begin{array}{l}45.2 \\
52.0 \\
63.7 \\
66.8 \\
68.6 \\
54.3 \\
43.6 \\
24.8 \\
20.0\end{array}$ & $\begin{array}{l}40.6 \\
55.1 \\
64.4 \\
68.1 \\
66.1 \\
58.2 \\
44.5 \\
27.1 \\
17.5\end{array}$ & $\begin{array}{l} \pm \quad 4.6 \\
=3.1 \\
=\quad .7 \\
=2.3 \\
=3.9 \\
=2.9 \\
+8.5\end{array}$ & $\begin{array}{l}1.09 \\
1.89 \\
1.18 \\
2.32 \\
2.11 \\
3.68 \\
.02 \\
.24 \\
.52\end{array}$ & $\begin{array}{l}1.72 \\
2.69 \\
3.68 \\
2.98 \\
2.57 \\
2.04 \\
1.31 \\
.80 \\
.60\end{array}$ & 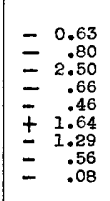 & $\begin{array}{l}0.09 \\
.05 \\
.03 \\
.03 \\
.02 \\
.02 \\
.02 \\
.02 \\
.02\end{array}$ & $\begin{array}{l}0.29 \\
.18 \\
.14 \\
.13 \\
.07 \\
.06 \\
.06 \\
.05 \\
.04\end{array}$ & $\begin{array}{l}=0.20 \\
=\quad .13 \\
=\quad .11 \\
=\quad .10 \\
=\quad .04 \\
=\quad .04 \\
=\quad .03 \\
\quad .02\end{array}$ & $\begin{array}{l}\overline{-} \\
\overline{-} \\
\overline{-} \\
\overline{-}\end{array}$ \\
\hline $\begin{array}{l}\text { January } \\
\text { February } \\
\text { March } \\
\text { April } \\
\text { May } \\
\text { June } \\
\text { JuIy } \\
\text { August } \\
\text { September } \\
\text { October } \\
\text { November } \\
\text { Decomber }\end{array}$ & $\begin{array}{r}-.9 \\
4.8 \\
18.2 \\
44.6 \\
48.0 \\
67.6 \\
69.2 \\
62.7 \\
54.6 \\
44.8 \\
32.6 \\
18.8\end{array}$ & $\begin{array}{r}3.8 \\
8.1 \\
22.7 \\
40.6 \\
55.1 \\
64.4 \\
68.1 \\
66.1 \\
58.2 \\
44.5 \\
27.1 \\
11.5\end{array}$ & $\begin{array}{l}-4.7 \\
=\quad 3.3 \\
+\quad 4.5 \\
+\quad 4.0 \\
+\quad 7.1 \\
+\quad 3.2 \\
+\quad 3.1 \\
=3.6 \\
+\quad .3 \\
+\quad 5.5 \\
+\quad 7.3\end{array}$ & $\begin{array}{r}.32 \\
.39 \\
.30 \\
.59 \\
1.26 \\
5.37 \\
2.35 \\
2.77 \\
1.88 \\
2.54 \\
.24 \\
.17\end{array}$ & $\begin{array}{r}.56 \\
.59 \\
.75 \\
1.72 \\
2.69 \\
3.68 \\
2.98 \\
2.57 \\
2.04 \\
1.31 \\
.80 \\
.60\end{array}$ & $\begin{array}{lr}= & .24 \\
= & .20 \\
= & .45 \\
= & 1.13 \\
= & 1.43 \\
+ & 1.69 \\
= & .63 \\
= & .20 \\
\overline{+} & .16 \\
= & .23 \\
-\quad .56 \\
& .43\end{array}$ & $\begin{array}{l}.02 \\
.02 \\
.02 \\
.08 \\
.04 \\
.06 \\
.05 \\
.03 \\
.02 \\
.03 \\
.04 \\
.03\end{array}$ & $\begin{array}{l}.03 \\
.03 \\
.09 \\
.29 \\
.18 \\
.14 \\
.13 \\
.07 \\
.06 \\
.06 \\
.05 \\
.04\end{array}$ & $\begin{array}{ll}= & .01 \\
= & .01 \\
= & .07 \\
= & .21 \\
= & .08 \\
=\quad .08 \\
=\quad .04 \\
=\quad .04 \\
=\quad .03 \\
=\quad .01\end{array}$ & $\begin{array}{l}\overline{-} \\
\overline{-} \\
\overline{-} \\
\overline{-} \\
\overline{-}\end{array}$ \\
\hline $\begin{array}{l}1910 \\
\text { June } \\
\text { July } \\
\text { August } \\
\text { September } \\
\text { October } \\
\text { November } \\
\text { December } \\
1911\end{array}$ & $\begin{array}{l}69.1 \\
71.4 \\
65.4 \\
57.7 \\
50.4 \\
24.0 \\
11.8\end{array}$ & $\begin{array}{l}64.4 \\
68.1 \\
66.1 \\
58.2 \\
44.5 \\
27.1 \\
11.5\end{array}$ & $\begin{array}{r}+\quad 4.7 \\
+\quad 3.3 \\
-\quad .7 \\
-\quad .5 \\
+\quad 5.9 \\
+\quad 3.1 \\
+\quad .3\end{array}$ & $\begin{array}{r}1.26 \\
1.57 \\
1.09 \\
2.19 \\
.70 \\
.48 \\
.51\end{array}$ & $\begin{array}{l}3.68 \\
2.98 \\
2.57 \\
2.04 \\
1.31 \\
.80 \\
.60\end{array}$ & $\begin{array}{rr} & 2.42 \\
= & 1.41 \\
= & 1.48 \\
\pm & .15 \\
= & .61 \\
=\quad .32 \\
\quad .09\end{array}$ & $\begin{array}{l}.09 \\
.04 \\
.02 \\
.02 \\
.02 \\
.02 \\
.01\end{array}$ & $\begin{array}{l}.14 \\
.13 \\
.07 \\
.06 \\
.06 \\
.05 \\
.04\end{array}$ & $\begin{array}{l}=\quad .05 \\
=\quad .09 \\
=\quad .05 \\
=\quad .04 \\
=\quad .03 \\
=\quad .03\end{array}$ & $\begin{array}{l}.05 \\
.03 \\
.02 \\
.02 \\
.01 \\
.01 \\
-\end{array}$ \\
\hline $\begin{array}{l}\text { Jamuary } \\
\text { February } \\
\text { March } \\
\text { Apr1l } \\
\text { Nay } \\
\text { June } \\
\text { July } \\
\text { August } \\
\text { September } \\
\text { October } \\
\text { November } \\
\text { December } \\
\text { 1912 }\end{array}$ & $\begin{array}{r}-.6 \\
9.2 \\
31.2 \\
42.8 \\
58.0 \\
69.2 \\
67.8 \\
64.4 \\
55.9 \\
43.5 \\
17.2 \\
3.5 .6\end{array}$ & $\begin{array}{r}3.8 \\
8.1 \\
22.7 \\
40.6 \\
55.1 \\
64.4 \\
68.1 \\
66.1 \\
58.2 \\
44.5 \\
27.1 \\
11.5\end{array}$ & $\begin{array}{l}-4.4 \\
+1.1 \\
+\quad 8.5 \\
+2.2 \\
+2.9 \\
+4.8 \\
=1.7 \\
=2.7 \\
=1.0 \\
=9.9 \\
+4.1\end{array}$ & $\begin{array}{r}.92 \\
.73 \\
.34 \\
2.01 \\
4.01 \\
3.41 \\
2.58 \\
2.57 \\
2.44 \\
1.27 \\
.96 \\
.51\end{array}$ & $\begin{array}{r}.56 \\
.59 \\
.75 \\
1.72 \\
2.69 \\
3.68 \\
2.98 \\
2.57 \\
2.04 \\
1.31 \\
.80 \\
.60\end{array}$ & $\begin{array}{l}+\quad .36 \\
\pm \quad .14 \\
\pm \quad .41 \\
+\quad .29 \\
\pm \quad .32 \\
-\quad .27 \\
+\quad .40 \\
+\quad .40 \\
+\quad .04 \\
\pm \quad .09\end{array}$ & $\begin{array}{l}.01 \\
.01 \\
.03 \\
.08 \\
.07 \\
.08 \\
.03 \\
.02 \\
.02 \\
.02 \\
.02 \\
.02\end{array}$ & $\begin{array}{l}.03 \\
.03 \\
.09 \\
.28 \\
.18 \\
.14 \\
.13 \\
.07 \\
.06 \\
.06 \\
.05 \\
.04\end{array}$ & $\begin{array}{l}=\quad .02 \\
=\quad .02 \\
=\quad .06 \\
=\quad .21 \\
=\quad .06 \\
=\quad .10 \\
=\quad .05 \\
=\quad .04 \\
=\quad .04 \\
=\quad .02\end{array}$ & $\begin{array}{l}- \\
= \\
.04 \\
.04 \\
.02 \\
.01 \\
.01 \\
.01 \\
=\end{array}$ \\
\hline $\begin{array}{l}\text { January } \\
\text { Fobruary } \\
\text { March } \\
\text { April } \\
\text { May } \\
\text { Jume } \\
\text { July } \\
\text { August } \\
\text { September } \\
\text { October } \\
\text { November } \\
\text { December } \\
\text { I913 }\end{array}$ & $\begin{array}{l}-6.2 \\
11.0 \\
20.6 \\
46.0 \\
56.6 \\
63.0 \\
68.6 \\
64.4 \\
54.6 \\
46.0 \\
32.4 \\
17.6\end{array}$ & $\begin{array}{l}3.8 \\
8.1 \\
22.7 \\
40.6 \\
55.1 \\
64.4 \\
68.1 \\
66.1 \\
58.2 \\
44.5 \\
27.1 \\
11.5\end{array}$ & $\begin{array}{l}-10.0 \\
+\quad 2.9 \\
+2.1 \\
+5.4 \\
+1.5 \\
+1.4 \\
+\quad 1.5 \\
=3.6 \\
+1.5 \\
+5.3 \\
+6.1\end{array}$ & $\begin{array}{r}.32 \\
.22 \\
.38 \\
2.36 \\
4.02 \\
2.25 \\
3.82 \\
3.93 \\
3.87 \\
.52 \\
.14 \\
.62\end{array}$ & $\begin{array}{r}.56 \\
.59 \\
.75 \\
1.72 \\
2.69 \\
3.68 \\
2.98 \\
2.57 \\
2.04 \\
1.31 \\
.80 \\
.60\end{array}$ & $\begin{array}{l}-\quad .24 \\
=\quad .37 \\
\overline{+} \quad .37 \\
+\quad .64 \\
+1.33 \\
+1.43 \\
+\quad .84 \\
+1.36 \\
+1.83 \\
=\quad .79 \\
+\quad .66 \\
+\quad .02\end{array}$ & $\begin{array}{l}.01 \\
.01 \\
.08 \\
.08 \\
.05 \\
.03 \\
.03 \\
.04 \\
.06 \\
.03 \\
.02\end{array}$ & $\begin{array}{l}.03 \\
.03 \\
.09 \\
.29 \\
.18 \\
.14 \\
.13 \\
.07 \\
.06 \\
.06 \\
.05 \\
.04\end{array}$ & $\begin{array}{l}=\quad .02 \\
=\quad .03 \\
=\quad .08 \\
=\quad .21 \\
=\quad .09 \\
=\quad .10 \\
=\quad .04 \\
=\quad 02 \\
=\quad 0.02 \\
=\quad .02\end{array}$ & $\begin{array}{l}= \\
- \\
.04 \\
.04 \\
.04 \\
.02 \\
.02 \\
.02 \\
.03 \\
.\end{array}$ \\
\hline $\begin{array}{l}\text { January } \\
\text { Febmuary } \\
\text { March } \\
\text { April }\end{array}$ & $\begin{array}{r}1.0 \\
7.5 \\
19.0 \\
47.8\end{array}$ & $\begin{array}{r}3.8 \\
8.1 \\
22.7 \\
40.6\end{array}$ & $\begin{array}{r}-2.8 \\
-\quad 3.6 \\
-\quad 3.7 \\
+\quad 7.2\end{array}$ & $\begin{array}{r}.47 \\
.16 \\
.94 \\
1.01\end{array}$ & $\begin{array}{r}.56 \\
.50 \\
.75 \\
1.72\end{array}$ & $\begin{array}{l}-\quad .09 \\
\overline{-} \quad .43 \\
+\quad .29 \\
-\quad .71\end{array}$ & $\begin{array}{l}.01 \\
.01 \\
.01 \\
.31\end{array}$ & $\begin{array}{l}.03 \\
.03 \\
.09 \\
.29\end{array}$ & $\begin{array}{l}=\quad .02 \\
=\quad .02 \\
\overline{+} \quad .08 \\
\quad .02\end{array}$ & 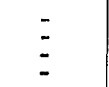 \\
\hline $\begin{array}{l}1929 \\
\text { June } \\
\text { JuIy } \\
\text { August } \\
\text { September } \\
\text { October } \\
\text { November } \\
\text { December }\end{array}$ & $\begin{array}{l}64.0 \\
71.5 \\
69.8 \\
54.8 \\
47.6 \\
24.8 \\
12.2\end{array}$ & $\begin{array}{l}64.4 \\
68.1 \\
66.1 \\
58.2 \\
44.5 \\
27.1 \\
11.5\end{array}$ & $\begin{array}{r}-\quad .4 \\
+\quad 3.4 \\
+\quad 3.7 \\
\quad 3.4 \\
+\quad 3.1 \\
+\quad 2.3\end{array}$ & $\begin{array}{l}1.15 \\
1.65 \\
1.10 \\
1.69 \\
2.63 \\
.78 \\
.81\end{array}$ & $\begin{array}{r}3.68 \\
2.98 \\
2.57 \\
2.04 \\
1.31 \\
.80 \\
.60\end{array}$ & $\begin{array}{r}2.53 \\
=1.33 \\
=1.47 \\
\overline{1} \quad .35 \\
\pm \quad 1.32 \\
+\quad .02\end{array}$ & $\begin{array}{l}.06 \\
.04 \\
.02 \\
.01 \\
.02 \\
.02 \\
.01\end{array}$ & $\begin{array}{l}.14 \\
.13 \\
.07 \\
.06 \\
.06 \\
.05 \\
.04\end{array}$ & $\begin{array}{l}=\quad .08 \\
=\quad .09 \\
=\quad .05 \\
=\quad .05 \\
=\quad .04 \\
=\quad .03\end{array}$ & $\begin{array}{l}.04 \\
.02 \\
.02 \\
.01 \\
.01 \\
.02 \\
.01\end{array}$ \\
\hline
\end{tabular}


Tablo 62.- Drought data for Rod River Basin above Grand Forks, N. Dak.-Continued

\begin{tabular}{|c|c|c|c|c|c|c|c|c|c|c|}
\hline \multirow[b]{2}{*}{ Month } & \multicolumn{3}{|c|}{$\begin{array}{c}\text { Temperature } \\
\text { at Moorhead, M1nn. }\left(0_{\mathrm{F}}\right)\end{array}$} & \multicolumn{3}{|c|}{$\begin{array}{l}\text { Precipitation } \\
\text { over the basin (inches) }\end{array}$} & \multicolumn{3}{|c|}{$\begin{array}{l}\text { Run-off } \\
\text { at Grand Forks (inches) }\end{array}$} & \multirow{2}{*}{$\begin{array}{l}\text { Estimated } \\
\text { ground- } \\
\text { nater } \\
\text { mun-off } \\
\text { (1nches) }\end{array}$} \\
\hline & For & Averago & Departure & $\begin{array}{l}\text { For } \\
\text { month }\end{array}$ & Average & Departur $\theta$ & $\begin{array}{l}\text { For } \\
\text { month }\end{array}$ & Average & Departure & \\
\hline \multicolumn{11}{|l|}{1930} \\
\hline $\begin{array}{l}\text { January } \\
\text { February }\end{array}$ & 0.3 & 3.8 & $=3.5$ & 0.32 & 0.56 & -0.24 & 0.01 & 0.03 & -0.02 & 0.01 \\
\hline March & 27.0 & 22.7 & $\begin{array}{r}+14.9 \\
+\quad 4.3\end{array}$ & $\begin{array}{r}1.48 \\
.26\end{array}$ & $\begin{array}{l}.59 \\
.75\end{array}$ & \pm .89 & .01 & .03 & $7: 09$ & .02 \\
\hline April & 46.3 & 40.6 & 5.7 & 1.20 & 1.72 & -.52 & .17 & .29 & -.12 & .05 \\
\hline May & 53.4 & 55.1 & 1.7 & 4.03 & 2.69 & +1.34 & .14 & .18 & .04 & .04 \\
\hline June & 65.0 & 64.4 & .6 & 2.26 & 3.68 & -1.42 & .05 & .14 & .09 & .04 \\
\hline JuIy & 73.6 & 68.1 & 5.5 & 1.45 & 2.98 & -1.53 & .05 & .13 & .10 & .02 \\
\hline Augus t & 72.2 & 66.1 & 6.1 & 1.08 & 2.57 & -1.49 & .01 & .07 & .06 & .01 \\
\hline Septernber & 58.8 & 58.2 & .6 & 1.07 & 2.04 & -.97 & .01 & .06 & .05 & .01 \\
\hline October & 43.6 & 44.5 & & 1.86 & 1.31 & +.55 & .01 & .06 & .05 & .01 \\
\hline November & 30.4 & 27.1 & $+\quad 3.3$ & 2.02 & .80 & +1.22 & .01 & .05 & -.04 & .01 \\
\hline \multirow{2}{*}{\multicolumn{9}{|c|}{1931}} & -.03 & .01 \\
\hline & & & +15.8 & .17 & & -.39 & .01 & .03 & & \\
\hline February & 26.2 & 8.1 & +18.1 & .31 & .59 & -.28 & .01 & .03 & & .01 \\
\hline March & 27.7 & 22.7 & $5: 0$ & .93 & .75 & +.18 & .02 & .09 & .07 & .01 \\
\hline ApriI & 44.6 & 40.6 & 4.0 & .53 & 1.72 & -1.19 & .05 & .29 & .24 & .02 \\
\hline May & 53.2 & 55.1 & 1.9 & 2.15 & 2.69 & -.54 & .03 & .18 & .15 & .02 \\
\hline June & 69.0 & 64.4 & 4.6 & 3.71 & 3.68 & +.03 & .02 & .14 & .12 & .01 \\
\hline July & 72.5 & 68.1 & 4.4 & 3.27 & 2.98 & +.29 & .01 & .13 & .12 & .01 \\
\hline August & 67.6 & 66.1 & 1.5 & 2.55 & 2.57 & -.02 & .01 & .07 & .06 & 0 \\
\hline September & 64.9 & 58.2 & 6.7 & 1.74 & 2.04 & -.30 & 0 & .06 & .06 & 0 \\
\hline october & 50.5 & 44.5 & 6.0 & 2.52 & 1.31 & +1.21 & .01 & .06 & .05 & 0 \\
\hline Novernber & 33.0 & 27.1 & 5.9 & 1.31 & .80 & +.51 & .01 & .05 & -.04 & 0 \\
\hline \multirow{2}{*}{\multicolumn{10}{|c|}{1932}} & 0 \\
\hline & & & & & & -.07 & & .03 & -.02 & \\
\hline February & 13.2 & 8.1 & 5.1 & .58 & .59 & $=.01$ & .01 & .03 & .02 & .01 \\
\hline March & 17.8 & 22.7 & 4.9 & .59 & .75 & $=.16$ & .05 & .09 & .04 & .01 \\
\hline April & 43.6 & 40.6 & 3.0 & 2.17 & 1.72 & +.45 & .17 & .29 & .12 & .02 \\
\hline May & 57.0 & 55.1 & 1.9 & 2.90 & 2.69 & +21 & .04 & .18 & .14 & .02 \\
\hline June & 68.9 & 64.4 & 4.5 & 2.35 & 3.68 & -1.33 & .02 & .14 & .12 & .01 \\
\hline Ju]y & 72.1 & 68.1 & 4.0 & 1.96 & 2.98 & -1.02 & .01 & .13 & .12 & .01 \\
\hline August & 70.7 & 66.1 & 4.6 & 2.42 & 2.57 & -.15 & 0 & .07 & .07 & 0 \\
\hline September & 58.8 & 58.2 & .6 & 1.30 & 2.04 & .74 & 0 & .06 & .06 & 0 \\
\hline October & 41.2 & 44.5 & 3.3 & 2.05 & $\begin{array}{l}1.31 \\
1.31\end{array}$ & +.74 & 0 & .06 & .06 & 0 \\
\hline November & 25.3 & 27.1 & 1.8 & .74 & .80 & .06 & 0 & .05 & .05 & 0 \\
\hline \multirow{2}{*}{\multicolumn{11}{|c|}{1933}} \\
\hline & & & & & & & & & & \\
\hline $\begin{array}{l}\text { January } \\
\text { February }\end{array}$ & $\begin{array}{r}11.9 \\
7.4\end{array}$ & $\begin{array}{l}3.8 \\
8.1\end{array}$ & $\begin{array}{l} \pm .1 \\
\pm \quad 0.7\end{array}$ & $\begin{array}{r}1.07 \\
.37\end{array}$ & $\begin{array}{l}.56 \\
.59\end{array}$ & \pm .51 & $\begin{array}{l}0 \\
0\end{array}$ & $\begin{array}{l}.03 \\
.03\end{array}$ & $=.03$ & $\begin{array}{l}0 \\
0\end{array}$ \\
\hline March & 28.0 & 22.7 & $\begin{array}{l}+\quad 5.3 \\
\end{array}$ & .84 & .75 & +.09 & .04 & .09 & $=.05$ & 0 \\
\hline April & 41.4 & 40.6 & 0.8 & 1.61 & 1.72 & .11 & .10 & .29 & .19 & .01 \\
\hline $\mathrm{May}$ & 56.8 & 55.1 & 1.7 & 3.40 & 2.69 & +.71 & .03 & .18 & .15 & .01 \\
\hline June & 72.8 & 64.4 & 8.4 & 2.28 & 3.68 & -1.40 & .02 & .14 & .12 & .01 \\
\hline July & 73.7 & 68.1 & 5.6 & 1.77 & $\begin{array}{l}2.08 \\
2.98\end{array}$ & $=1.21$ & $.0 I$ & .13 & .12 & $0^{\circ}$ \\
\hline August & 69.5 & 66.1 & 3.4 & 1.33 & 2.57 & -1.24 & $0^{.01}$ & .07 & .07 & 0 \\
\hline September & 63.2 & 58.2 & 5.0 & 1.30 & 2.04 & $=-.74$ & 0 & .06 & .06 & 0 \\
\hline octobs & 42.6 & 44.5 & 1.9 & .60 & 1.31 & $=.71$ & 0 & .06 & .06 & 0 \\
\hline Novernber & 25.4 & & -1.7 & .29 & .80 & +.09 & 0 & .05 & $=.05$ & 0 \\
\hline \multirow{2}{*}{\multicolumn{11}{|c|}{-400}} \\
\hline & 13.8 & 3.8 & +10.0 & .28 & .56 & -.28 & 0 & .03 & -.03 & \\
\hline February & 15.4 & & $\begin{array}{r}7 \quad 7.3 \\
+\quad 7.3\end{array}$ & .11 & .59 & $=.48$ & & .03 & $=.03$ & 0 \\
\hline March & 24.2 & 22.7 & +1.5 & .48 & .75 & $=.27$ & .02 & .09 & $=.07$ & 0 \\
\hline ApriI & 42.4 & 40.6 & +1.8 & (8) & 1.72 & $=.92$ & .07 & .29 & $=.22$ & .01 \\
\hline May & 63.6 & 55.1 & +8.5 & .91 & 2.69 & -1.78 & .02 & .18 & -.16 & .01 \\
\hline Jun & 66.2 & 64.4 & 1.8 & 3.96 & 3.68 & $+\quad .28$ & $.0 I$ & .14 & $=.13$ & $0^{* 01}$ \\
\hline JuI & 72.5 & 68.1 & 4.4 & 1.66 & 2.98 & -1.32 & .01 & .13 & $=.12$ & 0 \\
\hline August & 67.5 & 66.1 & 1.4 & 1.73 & 2.57 & -.84 & $0^{\circ}$ & .07 & $=.07$ & 0 \\
\hline September & 53.5 & 58.2 & 4.7 & 1.27 & $\begin{array}{l}2.04 \\
2.04\end{array}$ & $=.77$ & 0 & .06 & $=.06$ & 0 \\
\hline October & 49.6 & 44.5 & 5.1 & 2.08 & 1.31 & +.77 & 0 & .06 & $=.06$ & 0 \\
\hline November & 34.2 & $27 \cdot 1$ & +7.1 & .50 & .80 & -.30 & 0 & .05 & -.05 & 0 \\
\hline December & 11.0 & 11.5 & -.5 & .43 & .60 & - .17 & 0 & .04 & -.04 & 0 \\
\hline
\end{tabular}

Note.- Zero represents run-off less than $0.01 \mathrm{Inch}$. 
the end of 24 months the total accumulation nad reached 9.42 inches. During each growing season of the next 3 years, 1932, 1933, and 1934, the precipitation was deficient in amounts ranging from about 3 to 5 inches. During the drought of 1889-90 a deficiency in run-off of 1.45 inches had accumalated in 21 consecutive months; during the drought of 1910-13 a deficiency of 1.45 inches in 21 consecutive months and 1.94 inches in 34 months; and during the drought of 1929-31 a deficiency of 1.56 inches in 21 consecutive months and 1.88 inches in 31 months. The monthly mun-off subsequent to March 1930 has been continuously deficient up to the end of the record under consideration, December 1934. The ground-water flow, exclusive of frozen perlods, reached a minimum of practically zero during the drought of 1929-31. The temperature affecting the amount of transpiration (over $40^{\circ}$ ) was on the average during 1929-31 about $0.2^{\circ}$ a month lower than that during the period 1932-34, $1.2^{\circ}$ a month higher that that of the drought period of 1910-13, and $3.1^{\circ}$ a month higher than that of the drought period of $1889-90$.

Table 63 gives data for the Black River Basin for two outstanding drought periods, 1917-18 and 1930-31. During the earlier drought a deficiency of 4.10 inches in precipitation accumulated in 8 consecutive months, although in the second and sixth months the precipitation was slightly more than average. In the drought of 1930-31 a net deficiency of 5.55 inches in precipitation accumulated in 8 consecutive months, the fourth month having an excess of $0.85 \mathrm{inch}$, and by the end of 14 months the accumulated deficiency had reached 9.63 inches. During each growing season of the next 3 years, 1932, 1933, and 1934, the precipitation was deficient in amounts ranging from about 3 to 10 inches. Deficlency in run-off for the drought period of 1917-18 began 2 months earlier than deficiency in precipitation and by the end of 10 consecutive months amounted to 3.88 inches. The run-off during the drought period of 1930-31 was deficient for 16 consecutive months, accumulating a total deficiency in that time of 8.48 inches, and in a 10-month period simjlar to that of the drought of 1917-18 the deficiency in mun-off amounted to 6.85 inches. For the years 1932, 1933, and 1934 the maximum accumulation of deficiency in run-off amounted to 3.06 , 4.47, and 2.66 inches respectively. The temperature during the period 193031 that would affect the amount of transpiration (over $40^{\circ}$ ) was on the average about $4.5^{\circ}$ a month higher than that during the drought of 1917-18. The ground-water run-off, exclusive of months of freezing temperature, reached lower amounts in the later drought than in the earlier. 
Table 63.- Drought data for Black R1ver Basin above Neillsville, Wis.

\begin{tabular}{|c|c|c|c|c|c|c|c|c|c|c|}
\hline \multirow[b]{2}{*}{ Month } & \multicolumn{3}{|c|}{$\begin{array}{l}\text { Temperature } \\
\text { at Wausau, W1s. }\left({ }^{\circ} \mathrm{F} .\right)\end{array}$} & \multicolumn{3}{|c|}{$\begin{array}{l}\text { Precipitation } \\
\text { over the basin (inches) }\end{array}$} & \multicolumn{3}{|c|}{$\begin{array}{l}\text { Run-off } \\
\text { at Ne1lisville (Inches) }\end{array}$} & \multirow{2}{*}{$\begin{array}{l}\text { Estimated } \\
\text { ground- } \\
\text { water } \\
\text { run-off } \\
\text { (1nches) }\end{array}$} \\
\hline & $\begin{array}{l}\text { For } \\
\text { month }\end{array}$ & Average & Departure & $\begin{array}{l}\text { For } \\
\text { month }\end{array}$ & Average & Departure & $\begin{array}{l}\text { For } \\
\text { month }\end{array}$ & Average & Departure & \\
\hline $\begin{array}{l}1917 \\
\text { July } \\
\text { August } \\
\text { September } \\
\text { October } \\
\text { November } \\
\text { December } \\
1918\end{array}$ & $\begin{array}{l}68.4 \\
61.8 \\
56.0 \\
36.3 \\
34.8 \\
10.4\end{array}$ & $\begin{array}{l}68.4 \\
66.0 \\
58.9 \\
47.2 \\
32.2 \\
19.1\end{array}$ & $\begin{array}{r}0 \\
-4.2 \\
=2.9 \\
=10.8 \\
\pm \quad 2.6 \\
-8.7\end{array}$ & $\begin{array}{l}4.23 \\
5.30 \\
2.34 \\
2.86 \\
.23 \\
.55\end{array}$ & $\begin{array}{l}3.56 \\
3.54 \\
3.92 \\
2.41 \\
2.04 \\
.97\end{array}$ & $\begin{array}{r} \pm 0.67 \\
\pm \quad 1.76 \\
\pm \quad 1.58 \\
\pm \quad .45 \\
=\quad .81 \\
-\quad .42\end{array}$ & $\begin{array}{l}0.12 \\
.11 \\
.08 \\
.38 \\
.24 \\
.07\end{array}$ & $\begin{array}{r}0.35 \\
.39 \\
.46 \\
.49 \\
.66 \\
.20\end{array}$ & $\begin{array}{l}=\quad 0.23 \\
=\quad .28 \\
=\quad .38 \\
=\quad .42 \\
=\quad .13\end{array}$ & $\begin{array}{l}0.07 \\
.06 \\
.06 \\
.12 \\
.11 \\
.03\end{array}$ \\
\hline $\begin{array}{l}\text { Januery } \\
\text { February } \\
\text { March } \\
\text { April } \\
\text { May } \\
\text { June }\end{array}$ & $\begin{array}{r}4.0 \\
13.2 \\
34.2 \\
39.9 \\
56.9 \\
62.4\end{array}$ & $\begin{array}{l}14.2 \\
15.1 \\
28.0 \\
43.8 \\
55.2 \\
64.7\end{array}$ & $\begin{array}{l}-10.2 \\
=1.9 \\
\pm \quad 6.2 \\
\pm \quad 3.9 \\
\pm 1.7 \\
\pm 2.3\end{array}$ & $\begin{array}{l}1.12 \\
1.30 \\
1.34 \\
2.16 \\
7.68 \\
2.72\end{array}$ & $\begin{array}{l}1.23 \\
1.21 \\
1.58 \\
2.64 \\
3.47 \\
5.45\end{array}$ & $\begin{array}{l}\overline{ \pm} \quad .11 \\
\pm \quad .09 \\
\pm \quad .24 \\
\pm \quad 4.21 \\
\pm \\
2.73\end{array}$ & $\begin{array}{r}.01 \\
.01 \\
1.64 \\
1.13 \\
2.94 \\
1.57\end{array}$ & $\begin{array}{r}.15 \\
.18 \\
1.84 \\
2.95 \\
1.18 \\
1.31\end{array}$ & $\begin{array}{l}=\quad .14 \\
=\quad .17 \\
=\quad .20 \\
+\quad 1.82 \\
+\quad .26\end{array}$ & $\begin{array}{l}.01 \\
.01 \\
.19 \\
.32 \\
.18 \\
.08\end{array}$ \\
\hline $\begin{array}{l}1930 \\
\text { July } \\
\text { August } \\
\text { Septermber } \\
\text { October } \\
\text { November } \\
\text { December }\end{array}$ & $\begin{array}{l}71.4 \\
70.2 \\
60.8 \\
46.2 \\
36.4 \\
20.8\end{array}$ & $\begin{array}{l}68.4 \\
66.0 \\
58.9 \\
47.2 \\
32.2 \\
19.1\end{array}$ & $\begin{array}{l}+3.0 \\
+\quad 4.2 \\
+1.9 \\
+1.0 \\
+\quad 4.2 \\
+1.7\end{array}$ & $\begin{array}{l}2.09 \\
1.59 \\
3.11 \\
3.26 \\
1.80 \\
.35\end{array}$ & $\begin{array}{l}3.56 \\
3.54 \\
3.92 \\
2.41 \\
2.04 \\
.97\end{array}$ & $\begin{array}{l}1.47 \\
=1.95 \\
=\quad .81 \\
=\quad .84 \\
=\quad .62\end{array}$ & $\begin{array}{l}.29 \\
.05 \\
.03 \\
.25 \\
.22 \\
.09\end{array}$ & $\begin{array}{l}.35 \\
.39 \\
.46 \\
.49 \\
.66 \\
.20\end{array}$ & $\begin{array}{l}=\quad .06 \\
=\quad .34 \\
=\quad .24 \\
=\quad .44 \\
\end{array}$ & $\begin{array}{l}.11 \\
.02 \\
.02 \\
.09 \\
.08 \\
.07\end{array}$ \\
\hline $\begin{array}{l}1931 \\
\text { January } \\
\text { February } \\
\text { March } \\
\text { Apr11 } \\
\text { May } \\
\text { June } \\
\text { July } \\
\text { August } \\
\text { September } \\
\text { October } \\
\text { November } \\
\text { December }\end{array}$ & $\begin{array}{l}22.3 \\
27.0 \\
30.4 \\
45.7 \\
54.0 \\
68.8 \\
72.6 \\
66.8 \\
65.4 \\
51.9 \\
40.0 \\
28.0\end{array}$ & $\begin{array}{l}14.2 \\
15.1 \\
28.0 \\
43.8 \\
55.2 \\
64.7 \\
68.4 \\
66.0 \\
58.9 \\
47.2 \\
32.2 \\
19.1\end{array}$ & $\begin{array}{l}+8.1 \\
+11.9 \\
+2.04 \\
\pm 1.9 \\
\pm \quad 1.2 \\
\pm 4.1 \\
\pm 4.2 \\
\pm \quad .8 \\
+\quad 6.5 \\
+4.7 \\
+7.8 \\
+8.9\end{array}$ & $\begin{array}{r}.53 \\
.60 \\
1.46 \\
1.12 \\
1.40 \\
5.98 \\
2.25 \\
2.95 \\
5.76 \\
2.70 \\
4.70 \\
1.06\end{array}$ & $\begin{array}{l}1.23 \\
1.21 \\
1.58 \\
2.64 \\
3.47 \\
5.45 \\
3.56 \\
3.54 \\
3.92 \\
2.41 \\
2.04 \\
.97\end{array}$ & $\begin{array}{l}=\quad .70 \\
=\quad .61 \\
=\quad .52 \\
=2.07 \\
\pm \quad .53 \\
=1.31 \\
=1.59 \\
+\quad .84 \\
+\quad .29 \\
+\quad .06\end{array}$ & $\begin{array}{l}.10 \\
.06 \\
.19 \\
.65 \\
.22 \\
.76 \\
.11 \\
.02 \\
.13 \\
.20 \\
1.93 \\
.44\end{array}$ & $\begin{array}{r}.15 \\
.19 \\
1.84 \\
2.95 \\
1.18 \\
1.31 \\
.35 \\
.39 \\
.46 \\
.49 \\
.66 \\
.20\end{array}$ & $\begin{array}{l}=.05 \\
=\quad .12 \\
=\quad 1.65 \\
=2.30 \\
=\quad .96 \\
=\quad .24 \\
=\quad .37 \\
=\quad .33 \\
+\quad .29 \\
+\quad .24\end{array}$ & $\begin{array}{l}.05 \\
.04 \\
.09 \\
.21 \\
.14 \\
.07 \\
.05 \\
.02 \\
.05 \\
.10 \\
.14 \\
.25\end{array}$ \\
\hline $\begin{array}{l}1932 \\
\text { January } \\
\text { February } \\
\text { March } \\
\text { Apri1 } \\
\text { May } \\
\text { June } \\
\text { July } \\
\text { August } \\
\text { September } \\
\text { October } \\
\text { November } \\
\text { Decenber }\end{array}$ & $\begin{array}{l}21.3 \\
18.5 \\
21.6 \\
42.0 \\
55.3 \\
67.8 \\
70.5 \\
69.1 \\
58.0 \\
43.5 \\
28.1 \\
17.5\end{array}$ & $\begin{array}{l}14.2 \\
15.1 \\
28.0 \\
43.8 \\
55.2 \\
64.7 \\
68.4 \\
66.0 \\
58.9 \\
47.2 \\
32.2 \\
19.1\end{array}$ & 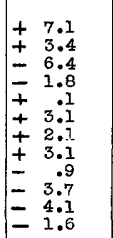 & $\begin{array}{l}2.64 \\
1.87 \\
.89 \\
2.32 \\
4.16 \\
3.86 \\
2.67 \\
3.74 \\
1.39 \\
1.08 \\
2.31 \\
2.34\end{array}$ & $\begin{array}{l}1.23 \\
1.21 \\
1.58 \\
2.64 \\
3.47 \\
5.45 \\
3.56 \\
3.54 \\
3.92 \\
2.41 \\
2.04 \\
.97\end{array}$ & $\begin{array}{rr}+ & 1.41 \\
\pm & .66 \\
\pm & .69 \\
\pm & .32 \\
\pm & 1.59 \\
= & .89 \\
\pm & .20 \\
& 2.53 \\
& 1.33 \\
+ & .27 \\
+ & 1.37\end{array}$ & $\begin{array}{r}.80 \\
.49 \\
1.92 \\
3.15 \\
1.29 \\
.22 \\
.11 \\
.07 \\
.05 \\
.05 \\
.10 \\
.22\end{array}$ & $\begin{array}{r}.15 \\
.18 \\
1.84 \\
2.95 \\
1.18 \\
1.31 \\
.35 \\
.39 \\
.46 \\
.49 \\
.66 \\
.20\end{array}$ & $\begin{array}{lr}+ & .65 \\
+ & .31 \\
+ & .08 \\
+ & .20 \\
\pm & .11 \\
= & 1.09 \\
= & .24 \\
& .32 \\
= & .41 \\
= & .54 \\
+\quad .02\end{array}$ & $\begin{array}{l}.24 \\
.25 \\
.28 \\
.29 \\
.23 \\
.07 \\
.04 \\
.03 \\
.04 \\
.02 \\
.04 \\
.02\end{array}$ \\
\hline $\begin{array}{l}1933 \\
\text { January } \\
\text { Fobruary } \\
\text { March } \\
\text { April } \\
\text { May } \\
\text { June } \\
\text { July } \\
\text { August } \\
\text { September } \\
\text { October } \\
\text { November } \\
\text { Decomber }\end{array}$ & $\begin{array}{l}23.6 \\
12.4 \\
27.5 \\
42.1 \\
57.2 \\
73.8 \\
73.7 \\
66.4 \\
63.1 \\
43.4 \\
29.2 \\
18.0\end{array}$ & $\begin{array}{l}14.2 \\
15.1 \\
28.0 \\
43.8 \\
55.2 \\
64.7 \\
68.4 \\
66.0 \\
58.9 \\
47.2 \\
32.2 \\
19.1\end{array}$ & 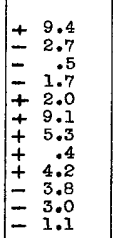 & $\begin{array}{l}1.88 \\
1.27 \\
.97 \\
3.23 \\
4.29 \\
2.44 \\
1.66 \\
1.76 \\
2.37 \\
1.89 \\
.63 \\
.98\end{array}$ & $\begin{array}{l}1.23 \\
1.21 \\
1.58 \\
2.64 \\
3.47 \\
5.45 \\
3.56 \\
3.54 \\
3.92 \\
2.41 \\
2.04 \\
.97\end{array}$ & $\begin{array}{l}+\quad .65 \\
\pm \quad .06 \\
\pm \quad .61 \\
\pm \quad .82 \\
\pm \quad 3.01 \\
=1.90 \\
=1.78 \\
=1.55 \\
=1.52 \\
+\quad .01\end{array}$ & $\begin{array}{r}.34 \\
.31 \\
1.63 \\
2.19 \\
1.04 \\
.32 \\
.02 \\
.02 \\
.01 \\
.03 \\
.05 \\
.05\end{array}$ & $\begin{array}{r}.15 \\
.18 \\
1.84 \\
2.95 \\
1.18 \\
1.31 \\
.35 \\
.39 \\
.46 \\
.49 \\
.66 \\
.20\end{array}$ & $\begin{array}{l} \pm .19 \\
\pm \quad .13 \\
=\quad .21 \\
=\quad .14 \\
=\quad .99 \\
=\quad .33 \\
=\quad .45 \\
=\quad .46 \\
=\quad .15\end{array}$ & $\begin{array}{l}.04 \\
.09 \\
.16 \\
.19 \\
.12 \\
.03 \\
.01 \\
.01 \\
.01 \\
.01 \\
.02 \\
.03\end{array}$ \\
\hline $\begin{array}{l}1934 \\
\text { January } \\
\text { February } \\
\text { March } \\
\text { Apr11 } \\
\text { May } \\
\text { June } \\
\text { July } \\
\text { August } \\
\text { September } \\
\text { October } \\
\text { November } \\
\text { December }\end{array}$ & $\begin{array}{l}22.4 \\
14.6 \\
27.0 \\
43.2 \\
64.3 \\
70.2 \\
74.3 \\
66.2 \\
58.4 \\
50.2 \\
37.5 \\
16.3\end{array}$ & $\begin{array}{l}14.2 \\
15.1 \\
28.0 \\
43.8 \\
55.2 \\
64.7 \\
68.4 \\
66.0 \\
58.9 \\
47.2 \\
32.2 \\
19.1\end{array}$ & $\begin{array}{lr} \pm & 8.2 \\
\pm & .5 \\
& 1.0 \\
\pm & .06 \\
\pm & 9.1 \\
\pm & 5.5 \\
\pm & 5.9 \\
\pm & .2 \\
\pm & .5 \\
\pm & 5.0 \\
\pm & -2.8\end{array}$ & $\begin{array}{l}1.30 \\
. .25 \\
1.78 \\
2.52 \\
1.03 \\
6.16 \\
1.98 \\
3.38 \\
8.10 \\
3.32 \\
4.86 \\
1.65\end{array}$ & $\begin{array}{l}1.23 \\
1.21 \\
1.58 \\
2.64 \\
3.47 \\
5.45 \\
3.56 \\
3.54 \\
3.92 \\
2.41 \\
2.04 \\
.97\end{array}$ & $\begin{array}{l} \pm \quad .07 \\
\pm \quad .96 \\
\pm \quad .12 \\
\pm 2.44 \\
\pm \quad .71 \\
\pm 1.58 \\
\mp \quad .16 \\
\pm \quad 4.18 \\
\pm \quad .91 \\
+\quad .82\end{array}$ & $\begin{array}{r}.10 \\
.06 \\
.23 \\
3.10 \\
.12 \\
.37 \\
.04 \\
.04 \\
2.02 \\
1.07 \\
2.66 \\
.50\end{array}$ & $\begin{array}{r}.15 \\
.18 \\
1.84 \\
2.95 \\
1.18 \\
1.31 \\
.35 \\
.39 \\
.46 \\
.49 \\
.66 \\
.20\end{array}$ & $\begin{array}{l}=.05 \\
=1.12 \\
\pm 1.61 \\
\pm 1.06 \\
=\quad .94 \\
=\quad .31 \\
\mp \quad .35 \\
\pm 1.56 \\
\pm \quad .58 \\
+\quad .00\end{array}$ & $\begin{array}{l}.04 \\
.04 \\
.04 \\
.10 \\
.09 \\
.03 \\
.03 \\
.01 \\
.04 \\
.10 \\
.17 \\
.22\end{array}$ \\
\hline
\end{tabular}


Table 64 gives data for the Rock River Basin for three outstandIng drought periods, 1918-19, 1930-31, and 1933-34. During the first drought a deficiency of 7.24 inches in precipitation accumulated in 8 consecutive months, and by the end of 15 months the accumulation had reached 7.94 Inches. In the second drought a deficiency of 7.37 inches in precipitation accumalated in a similar 8-month period, and by the end of 14 months the accumalation had reached 11.09 inches. During the drought of 1933-34 a deficiency of 7.48 inches in precipitation accumulated in 8 consecutive months and 13.11 inches by the end of 15 months. The mun-off during all three droughts was below normal for 16 consecutive months, a deficiency of 6.79 inches accumulating in 1933-34, 6.51 inches in 1930-31, and 4.25 inches in 1918-19. The temperature during drought of 1930-31 that would affect the amount of transpiration (over $40^{\circ}$ ) was on the average about $0.4^{\circ}$ a month higher than that of 1933-34 and $2.5^{\circ}$ higher than that of 1918-19. The flow from groundwater was less in the drought of 1933-34 than in that of the two earlier drought periods.

Table 65 gives data for the Skunk River Basin for three outstanding drought periods, 1917-18, 1930-31, and 1933-34. The three droughts were generally similar, the first accumulating a deficlency of 10.10 inches in prer cipitation in 10 consecutive months, the second a deficiency of 9.59 inches In 12 months, and the latest a deficiency of 18.80 inches in 15 months. The run-off during the drought of 1930-3I and 1933-34 was deficient for 14 and 19 consecutive months, accumulating a deficiency of 5.76 and 8.84 inches respectively. In the drought of 1917-18 there was an excessive amount of Inn-off during the IIth month, but the first 10 months accumulated a deficlency of 3.91 inches, and at the end of 14 months the accumulated deficlency was 4.92 inches. The greatest difference was in the temperature affecting the amount of transpiration (more than $40^{\circ}$ ), the earlier drought having temperatures about average and the last two droughts having temperatures averaging $3.5^{\circ}$ and $4.0^{\circ}$ a month respectively greater than the average. Table 66 gives data for the upper Mississippi River Basin for three outstanding drought perlods, 1894-96, 1910-11, and 1930-32. During the drought of 1894-96 a deficiency of 7.11 inches in precipitation accumilated in 4 consecutive months, and by the end of 22 months the accumulated deficiency had reached 13.88 inches. During the drought of 1910-11 a deficiency of 7.63 inches in precipitation accumulated in 5 consecutive months, and by the end of 16 months the accumulation amounted to 12.16 inches. In 
Table 64.- Drought data for Rock River Basin above Afton, Wis.

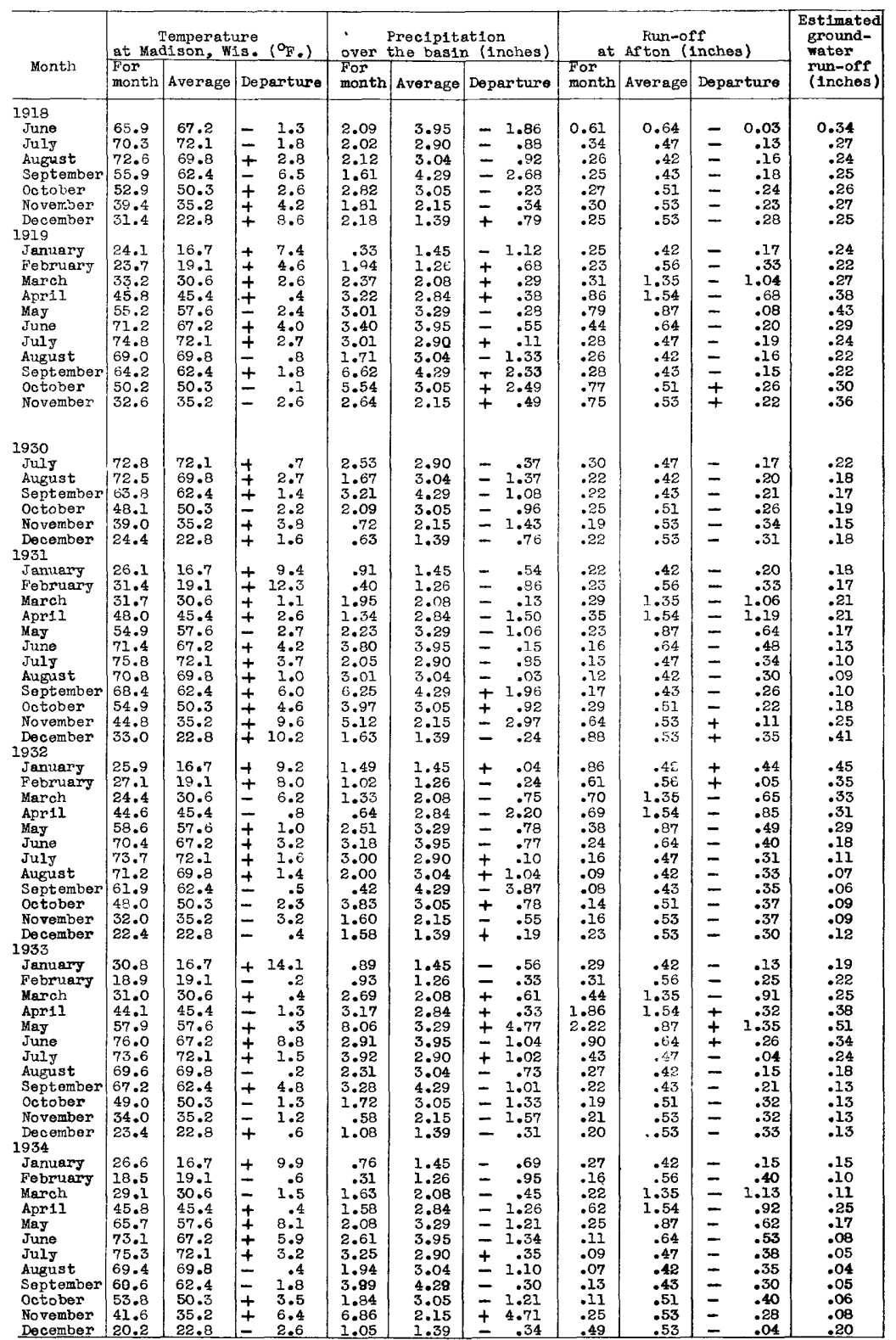


Table 65.- Drought data for Skunk River Basin above Augusta, Iowa

\begin{tabular}{|c|c|c|c|c|c|c|c|c|c|c|}
\hline \multirow[b]{2}{*}{ Month } & \multicolumn{3}{|c|}{$\begin{array}{l}\text { Temperature } \\
\text { at Davenport, Iowa }\left(\circ_{\mathrm{F}}\right)\end{array}$} & \multirow{2}{*}{\begin{tabular}{|l|} 
over \\
For \\
month
\end{tabular}} & \multicolumn{2}{|c|}{$\begin{array}{l}\text { Procipitation } \\
\text { the basin (inches) }\end{array}$} & \multicolumn{3}{|c|}{$\begin{array}{c}\text { Run-off } \\
\text { at Augusta (Inches) }\end{array}$} & \multirow{2}{*}{$\begin{array}{l}\text { Estimated } \\
\text { ground- } \\
\text { water } \\
\text { run-off } \\
\text { (inches) }\end{array}$} \\
\hline & \begin{tabular}{|l|}
$\begin{array}{l}\text { For } \\
\text { month }\end{array}$ \\
\end{tabular} & Average & Departure & & Average & Departure & $\begin{array}{l}\text { For } \\
\text { month }\end{array}$ & Average & Departur $\theta$ & \\
\hline \multicolumn{11}{|l|}{$\begin{array}{l}1917 \\
\text { July }\end{array}$} \\
\hline $\begin{array}{l}\text { July } \\
\text { August }\end{array}$ & $\begin{array}{l}75.8 \\
71.2\end{array}$ & $\begin{array}{l}75.3 \\
73.1\end{array}$ & $\begin{array}{l}+\quad 0.5 \\
-\quad 1.9\end{array}$ & 2.01 & 3.44 & $=\quad 1.43$ & 0.26 & 0.48 & -0.22 & 0.15 \\
\hline September & 63.7 & $\begin{array}{l}70.1 \\
65.6\end{array}$ & $\begin{array}{l}1.9 \\
-\quad 1.9\end{array}$ & $\begin{array}{l}2.01 \\
3.33\end{array}$ & $\begin{array}{l}3.78 \\
4.76\end{array}$ & $\begin{array}{l}1.77 \\
1.43\end{array}$ & $\begin{array}{l}.10 \\
.14\end{array}$ & $\begin{array}{r}.35 \\
49\end{array}$ & .25 & .07 \\
\hline october & 43.9 & 53.7 & -9.8 & 1.71 & 2.63 & $\begin{array}{r}1.40 \\
.92\end{array}$ & .04 & .48 & $=\quad .44$ & $\begin{array}{l}.05 \\
.04\end{array}$ \\
\hline $\begin{array}{l}\text { Novermber } \\
\text { Decomber }\end{array}$ & 42.2 & 39.0 & & .20 & 2.07 & -1.87 & .04 & .45 & $-.4 I$ & .03 \\
\hline $\begin{array}{l}1918 \\
\text { January }\end{array}$ & 18.2 & 27.1 & -8.9 & .68 & 1.21 & $-\quad .53$ & .03 & .34 & -.31 & .02 \\
\hline $\begin{array}{l}\text { January } \\
\text { February }\end{array}$ & $\begin{array}{l}10.0 \\
26.8\end{array}$ & $\begin{array}{l}21.8 \\
24.9\end{array}$ & $=\quad 21.8$ & 1.06 & 2.04 & +.02 & .0 .1 & .34 & .33 & .01 \\
\hline March & 44.8 & 36.1 & $\begin{array}{l}+\quad 1.9 \\
+\quad 8.7\end{array}$ & $\begin{array}{r}1.15 \\
.31\end{array}$ & $\begin{array}{l}1.10 \\
2.11\end{array}$ & $\pm \quad .05$ & .32 & .44 & -.12 & .06 \\
\hline April & 45.6 & 49.9 & $\simeq \quad 4.3$ & 2.83 & 3.25 & $\begin{array}{r}1.80 \\
.42\end{array}$ & .24 & .97 & $\begin{array}{l}-73 \\
=\quad 75\end{array}$ & .14 \\
\hline May & 66.2 & 61.3 & $+\quad 4.9$ & 7.20 & 3.48 & 3.72 & .1 .22 & .87 & $\begin{array}{l}=.75 \\
=\quad .04\end{array}$ & $\begin{array}{l}.09 \\
.08\end{array}$ \\
\hline June & 70.2 & 70.5 & $=.3$ & 6.93 & 5.18 & 1.75 & 2.24 & 1.08 & +1.16 & .28 \\
\hline $\begin{array}{l}\text { July } \\
\text { Augus }\end{array}$ & $\begin{array}{l}74.1 \\
76.8\end{array}$ & $\begin{array}{l}75.3 \\
73.1\end{array}$ & $\bar{\mp} \quad 1.2$ & $\begin{array}{l}2.70 \\
3.32\end{array}$ & 3.44 & $=\quad .74$ & .38 & .48 & -.10 & .17 \\
\hline September & 58.9 & 65.6 & $\begin{array}{l}3.7 \\
6.7\end{array}$ & $\begin{array}{l}3.32 \\
2.35\end{array}$ & $\begin{array}{l}3.78 \\
4.76\end{array}$ & $=\quad 2.46$ & .22 & .35 & .13 & .07 \\
\hline October & 56.1 & 53.7 & 2.4 & 3.00 & 2.63 & $\begin{array}{r}2.41 \\
+\quad .37\end{array}$ &. .05 & .49 & $\begin{array}{r}.31 \\
.43\end{array}$ & .07 \\
\hline November & $42 . \overline{2}$ & 39.0 & $\begin{array}{l}+3.2 \\
+\quad 1\end{array}$ & 2.02 & 2.07 & .05 & .07 & .45 & .38 & .04 \\
\hline $\begin{array}{l}\text { December } \\
1919\end{array}$ & 35.5 & 27.1 & +8.4 & 1.68 & 1.21 & .47 & .11 & .34 & .23 & .04 \\
\hline \multicolumn{11}{|l|}{$\begin{array}{l}1919 \\
\text { Januery }\end{array}$} \\
\hline $\begin{array}{l}\text { February } \\
\text { March }\end{array}$ & $\begin{array}{l}28.2 \\
40.0\end{array}$ & $\begin{array}{l}24.9 \\
36,9\end{array}$ & $\begin{array}{l}+\quad 3.3 \\
+3.9\end{array}$ & 2.56 & 1.10 & 2.46 & .23 & .44 & & .05 \\
\hline Apreli & $\begin{array}{l}40.0 \\
51.0\end{array}$ & $\begin{array}{l}36.1 \\
49.9\end{array}$ & $\begin{array}{r}+\quad 3.9 \\
+\quad 1.1\end{array}$ & $\begin{array}{r}2.75 \\
4.78\end{array}$ & 2.11 & .64 & 1.35 & .97 & .38 & .33 \\
\hline & & & & & & 1.53 & .98 & .87 & .11 & .43 \\
\hline \multicolumn{11}{|c|}{$=\quad 2.24$} \\
\hline $\begin{array}{l}\text { July } \\
\text { August }\end{array}$ & 78.6 & 75.3 & $+\quad 3.3$ & 1.20 & 3.44 & $-\quad 2.24$ & .26 & .48 & .22 & .17 \\
\hline $\begin{array}{l}\text { August } \\
\text { September }\end{array}$ & $\begin{array}{l}75.6 \\
68.9\end{array}$ & $\begin{array}{l}73.1 \\
65.6\end{array}$ & $\begin{array}{r}+\quad 2.5 \\
+3.3\end{array}$ & $\begin{array}{l}1.98 \\
2.50\end{array}$ & $\begin{array}{l}3.78 \\
4.76\end{array}$ & $=7.80$ & .06 & .35 & & .04 \\
\hline October & 52.2 & 53.7 & 1.5 & 2.22 & 2.63 & $=\quad 2.266$ & .03 & $\begin{array}{l}.49 \\
.48\end{array}$ & $\begin{array}{l}.46 \\
.42\end{array}$ & .02 \\
\hline November & 42.8 & 39.0 & +3.8 & 1.94 & 2.07 & .13 & .03 & .45 & $\begin{array}{l}.42 \\
.42\end{array}$ & .01 \\
\hline \multicolumn{11}{|l|}{$\begin{array}{l}\text { Decomber } \\
1931\end{array}$} \\
\hline $\begin{array}{l}\text { January } \\
\text { February }\end{array}$ & $\begin{array}{l}31.4 \\
36.8\end{array}$ & $\begin{array}{l}2.1 .8 \\
24.9\end{array}$ & +9.6 & .59 & 1.04 & .45 & .02 & .34 & - & \\
\hline $\begin{array}{l}\text { February } \\
\text { March }\end{array}$ & $\begin{array}{l}36.8 \\
36.2\end{array}$ & $\begin{array}{l}24.9 \\
36.1\end{array}$ & +1.1 .9 & .18 & 1.10 & .92 & .06 & .44 & & .01 \\
\hline Apr1I & $\begin{array}{l}30.2 \\
52.3\end{array}$ & $\begin{array}{l}49.1 \\
49.9\end{array}$ & $\begin{array}{l}+\quad .1 \\
+\quad 2.4\end{array}$ & $\begin{array}{l}2.45 \\
3.30\end{array}$ & $\begin{array}{l}2.11 \\
3.25\end{array}$ & .34 & .10 & .97 & .87 & .04 \\
\hline Kay & 58.4 & 61.3 & 2.9 & 3.08 & 3.18 & $\begin{array}{r}.05 \\
.40\end{array}$ & $\begin{array}{r}.48 \\
.18\end{array}$ & .87 & $\begin{array}{r}.39 \\
.63\end{array}$ & .11 \\
\hline June & 76.5 & 70.5 & 6.0 & 4.05 & 5.18 & $=1.13$ &. .12 & $\begin{array}{l}.75 \\
1.08\end{array}$ & $\begin{array}{l}.63 \\
.62\end{array}$ & .08 \\
\hline July & 90.2 & 75.3 & $+\quad 4.9$ & 3.61 & 3.44 & .17 & .27 & .48 & .21 & .05 \\
\hline $\begin{array}{l}\text { August } \\
\text { September }\end{array}$ & $\begin{array}{l}74.6 \\
72.4\end{array}$ & $\begin{array}{l}73.1 \\
65.6\end{array}$ & $\begin{array}{l}+1.5 \\
+\quad 6.8\end{array}$ & $\begin{array}{l}3.56 \\
7.21\end{array}$ & $\begin{array}{l}3.78 \\
4.76\end{array}$ & $\because 22$ & .07 & .35 & .28 & .02 \\
\hline October & 59.0 & 53.7 & 5.3 & 4.19 & $\begin{array}{l}2.70 \\
2.63\end{array}$ & $\begin{array}{l}2.45 \\
1.56\end{array}$ & $\begin{array}{l}.44 \\
.45\end{array}$ & $\begin{array}{r}-49 \\
-48\end{array}$ & .05 & .04 \\
\hline November & 48.8 & 39.0 & +9.8 & 5.96 & 2.07 & $\begin{array}{l}1 \\
3.80 \\
\end{array}$ & 1.75 & .48 & $+\quad .030$ & .1 \\
\hline \multicolumn{11}{|l|}{$\begin{array}{l}\text { December } \\
1938\end{array}$} \\
\hline $\begin{array}{l}\text { January } \\
\text { Fobruary }\end{array}$ & $\begin{array}{l}30.0 \\
34.0\end{array}$ & $\begin{array}{l}21.8 \\
24.9\end{array}$ & +8.2 & 1.56 & .04 & .52 & 2.02 & .34 & +1.68 & \\
\hline & & & \pm 9.1 & .75 & 2.10 & .35 & .73 & .44 & & $\begin{array}{r}.49 \\
.45\end{array}$ \\
\hline $\begin{array}{l}\text { March } \\
\text { April }\end{array}$ & $\begin{array}{l}29.7 \\
50.3\end{array}$ & $\begin{array}{l}36.1 \\
49.9\end{array}$ & $\begin{array}{r}6.4 \\
+\quad .4\end{array}$ & 1.53 & 2.1 & .58 & .90 & .97 & .07 & .52 \\
\hline $\begin{array}{l}\text { Aprill } \\
\text { May }\end{array}$ & 64.0 & 61.3 & $\begin{array}{l}+ \\
+\quad 2.7\end{array}$ & $\begin{array}{l}1.49 \\
4.03\end{array}$ & $\begin{array}{l}3.25 \\
3.48\end{array}$ & 1.76 & .48 & .87 & & .40 \\
\hline Jume & 74.2 & 70.5 & 3.7 & 6.95 & 5.18 & $\begin{array}{r}.55 \\
1.77\end{array}$ & $\begin{array}{r}.73 \\
1.14\end{array}$ & $\begin{array}{r}.75 \\
2.08\end{array}$ & $\begin{array}{l}.02 \\
.06\end{array}$ & $\begin{array}{l}.32 \\
.30\end{array}$ \\
\hline & $77 \cdot 4$ & 75.3 & 2.1 & 4.70 & 3.44 & 1.26 & 1.06 & .48 & & $\begin{array}{l}.30 \\
.31\end{array}$ \\
\hline August $t$ & $\begin{array}{l}73.8 \\
65.0\end{array}$ & $\begin{array}{l}73.1 \\
\text { is }\end{array}$ & $+\quad .7$ & 7.93 & 3.7 & 4.15 & 1.09 & .35 & .74 & .17 \\
\hline $\begin{array}{l}\text { September } \\
\text { October }\end{array}$ & $\begin{array}{l}65.0 \\
51.4\end{array}$ & $\begin{array}{l}85.6 \\
53.7\end{array}$ & $=\quad 2.6$ & $\begin{array}{l}1.45 \\
0.46\end{array}$ & $4 \cdot 7$ & 3.31 & .17 & .49 & & .16 \\
\hline November & 35.8 & 39.0 & $=3.2$ & $\begin{array}{l}2.40 \\
1.73\end{array}$ & $\begin{array}{l}2.6 \\
2.0\end{array}$ & .17 & .13 & .48 & .35 & $\begin{array}{l}.09 \\
.08\end{array}$ \\
\hline $\begin{array}{l}\text { December } \\
1933\end{array}$ & 26.4 & 27.1 & $-\quad .7$ & 2.83 & 1.21 & .04 & .93 & $\begin{array}{l}.45 \\
.34\end{array}$ & $\overline{+} \quad .59$ & .08 \\
\hline $\begin{array}{l}\text { January } \\
\text { February }\end{array}$ & 36.4 & 21.8 & +14.6 & 1.10 & 1.04 & .06 & .64 & .34 & & .19 \\
\hline & $\begin{array}{l}25.2 \\
37.4\end{array}$ & $\begin{array}{l}24.9 \\
36.1\end{array}$ & $\begin{array}{l}+3 \\
+\quad 1.3\end{array}$ & $\begin{array}{r}.35 \\
3.00\end{array}$ & 7.010 & & .20 & .44 & & \\
\hline Aprí & $\begin{array}{l}07.4 \\
49.6\end{array}$ & 49.9 & $\pm \quad 1.3$ & $\begin{array}{l}3.00 \\
1.30\end{array}$ & $\begin{array}{l}2.11 \\
3.25\end{array}$ & $\pm \quad .89$ & $\begin{array}{r}.24 \\
91\end{array}$ & .97 & .73 & .14 \\
\hline Mag & 62 & 61.3 & & 6.09 & 3.48 & $\begin{array}{l}1.90 \\
2.61\end{array}$ & 2.25 & .87 & $\begin{array}{l}+.04 \\
+1.50\end{array}$ & $\begin{array}{l}.32 \\
.46\end{array}$ \\
\hline & & 70.5 & 9.1 & 2.67 & 5.18 & 2.51 & .51 & 1.08 & .57 & .29 \\
\hline $\begin{array}{l}\text { July } \\
\text { August }\end{array}$ & $\begin{array}{l}77.6 \\
72.8\end{array}$ & $\begin{array}{l}75.3 \\
73.1\end{array}$ & $\begin{array}{l} \pm .3 \\
-\quad .3\end{array}$ & $\begin{array}{l}1.95 \\
3.20\end{array}$ & $\begin{array}{l}3.44 \\
3.78\end{array}$ & $\begin{array}{r}1.49 \\
.58\end{array}$ & .19 & .48 & & .09 \\
\hline September & 72.1 & 65.6 & 6.5 & 4.23 & 4.76 & $: .58$ & $\begin{array}{l}.16 \\
.17\end{array}$ & $\begin{array}{l}.35 \\
.49\end{array}$ & .19 & .05 \\
\hline October & 52.4 & 53.7 & 1.3 & 1.61 & 2.63 & 1.02 & .04 & .48 & .044 & .03 \\
\hline & & $39 \cdot 0$ & & .2 & 2.07 & 1.23 & .02 & .45 & .43 & .02 \\
\hline & & 27.1 & 2.9 & . 88 & 1.21 & $.33 \mid$ & .02 & .34 & .32 & .02 \\
\hline
\end{tabular}


Tablo 65.- Drought data for Skunk River Basin above Augusta, Iowa-Continued

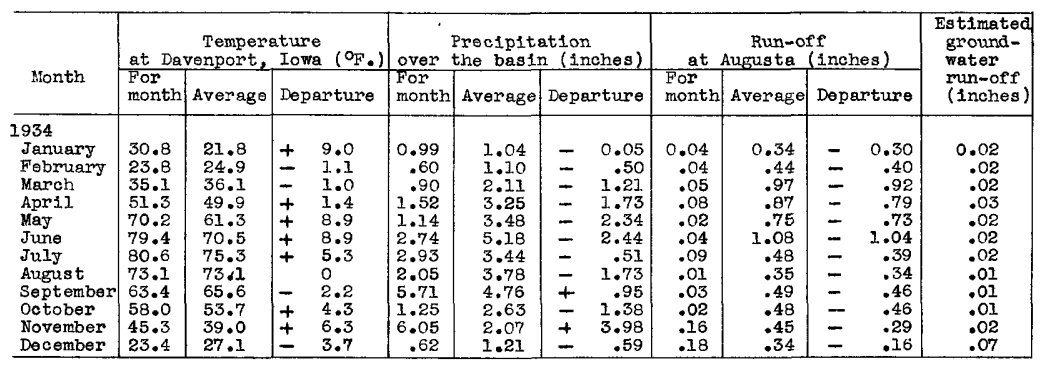


Table 66.- Drought data for Mississ1ppi River Basin above Keokuk, Iowa

\begin{tabular}{|c|c|c|c|c|c|c|c|c|c|}
\hline \multirow[b]{2}{*}{ Month } & \multicolumn{3}{|c|}{$\begin{array}{c}\text { Temperature* } \\
\left({ }^{\circ} \mathrm{F},\right)^{*}\end{array}$} & \multicolumn{3}{|c|}{$\begin{array}{l}\text { Precipitation } \\
\text { cver the basin (Inches) }\end{array}$} & \multicolumn{3}{|c|}{$\begin{array}{c}\text { Run-off } \\
\text { et Keoknk (Inches) }\end{array}$} \\
\hline & \begin{tabular}{l|} 
For \\
month
\end{tabular} & Average & Departure & For & Average & Departure & $\begin{array}{l}\text { For } \\
\text { month }\end{array}$ & Average & Departure \\
\hline $\begin{array}{l}1894 \\
\text { June } \\
\text { July } \\
\text { August } \\
\text { September } \\
\text { october } \\
\text { November } \\
\text { December } \\
1895\end{array}$ & $\begin{array}{l}70.9 \\
74.4 \\
71.5 \\
63.7 \\
50.0 \\
29.5 \\
28.6\end{array}$ & $\begin{array}{l}66.6 \\
61.44 \\
69.2 \\
61.5 \\
49.3 \\
34.0 \\
20.8\end{array}$ & $\begin{array}{l}+\quad 4.3 \\
+\quad 3.0 \\
+\quad 2.3 \\
+\quad 2.2 \\
+\quad 4.7 \\
+\quad 7.5 \\
+\quad 7.8\end{array}$ & $\begin{array}{l}2.70 \\
.67 \\
1.17 \\
3.17 \\
2.84 \\
1.15 \\
.89\end{array}$ & $\begin{array}{l}4.31 \\
3.61 \\
3.36 \\
3.54 \\
2.26 \\
1.50 \\
1.08\end{array}$ & $\begin{array}{l}1.61 \\
=\quad 2.94 \\
=\quad 2.19 \\
\overline{+} \quad .37 \\
=\quad .38 \\
-\quad .19\end{array}$ & $\begin{array}{r}0.91 \\
.33 \\
.20 \\
.25 \\
.23 \\
.27 \\
.23\end{array}$ & $\begin{array}{r}0.89 \\
.80 \\
.47 \\
.42 \\
.50 \\
.45 \\
.32\end{array}$ & $\begin{array}{lr} \pm & 0.02 \\
= & .47 \\
= & .27 \\
= & .17 \\
= & .27 \\
= & .18 \\
& .09\end{array}$ \\
\hline $\begin{array}{l}\text { Jamuary } \\
\text { February } \\
\text { March } \\
\text { Apri1 } \\
\text { May } \\
\text { June } \\
\text { July } \\
\text { August } \\
\text { September } \\
\text { October } \\
\text { Novembor } \\
\text { December }\end{array}$ & $\begin{array}{l}10.5 \\
13.9 \\
31.1 \\
50.7 \\
58.6 \\
67.5 \\
69.8 \\
70.6 \\
65.2 \\
44.8 \\
31.9 \\
23.3\end{array}$ & $\begin{array}{l}14.4 \\
17.7 \\
30.1 \\
45.2 \\
57.3 \\
66.6 \\
71.4 \\
69.4 \\
61.5 \\
49.3 \\
34.0 \\
20.8\end{array}$ & $\begin{array}{l}=3.9 \\
=\quad 3.8 \\
+\quad 1.0 \\
+\quad 5.5 \\
\pm \quad 1.3 \\
\pm \quad 1.9 \\
\pm \quad 1.6 \\
+\quad 3.4 \\
\pm \quad 4.5 \\
=\quad 2.1 \\
+\quad 2.5\end{array}$ & $\begin{array}{r}1.07 \\
.52 \\
.54 \\
1.56 \\
3.66 \\
3.50 \\
3.27 \\
2.70 \\
3.39 \\
.44 \\
1.55 \\
1.28\end{array}$ & $\begin{array}{l}1.03 \\
1.05 \\
1.60 \\
2.51 \\
3.62 \\
4.31 \\
3.61 \\
3.36 \\
3.54 \\
2.26 \\
1.50 \\
1.08\end{array}$ & $\begin{array}{lr} \pm & .04 \\
= & .53 \\
= & 1.06 \\
\pm & .95 \\
\pm & .04 \\
= & .81 \\
= & .66 \\
= & .15 \\
\pm & 1.82 \\
\pm & .05 \\
+ & .20\end{array}$ & $\begin{array}{l}.16 \\
.144 \\
.44 \\
.31 \\
.43 \\
.44 \\
.41 \\
.28 \\
.22 \\
.29 \\
.21 \\
.16\end{array}$ & $\begin{array}{r}.29 \\
.31 \\
.69 \\
1.02 \\
1.01 \\
.89 \\
.80 \\
.47 \\
.42 \\
.50 \\
.45 \\
.32\end{array}$ & $\begin{array}{l}z \\
z \\
z \\
z \\
z \\
z\end{array}$ \\
\hline $\begin{array}{l}1896 \\
\text { January } \\
\text { February } \\
\text { March } \\
\text { Apri1 } \\
\text { May } \\
\text { June } \\
\text { July } \\
\text { August } \\
\text { September } \\
\text { October } \\
\text { November } \\
\text { December }\end{array}$ & $\begin{array}{l}19.3 \\
23.3 \\
27.3 \\
49.3 \\
63.6 \\
68.0 \\
71.0 \\
70.0 \\
57.2 \\
46.1 \\
26.2 \\
25.7\end{array}$ & $\begin{array}{l}14.4 \\
17.7 \\
30.1 \\
45.2 \\
57.3 \\
66.6 \\
71.4 \\
69.22 \\
61.5 \\
49.3 \\
34.0 \\
20.8\end{array}$ & 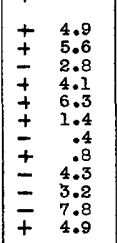 & $\begin{array}{r}.79 \\
.56 \\
1.51 \\
5.48 \\
5.33 \\
3.70 \\
3.37 \\
2.60 \\
3.63 \\
2.66 \\
2.50 \\
.69\end{array}$ & $\begin{array}{l}1.03 \\
1.05 \\
1.60 \\
2.51 \\
3.62 \\
4.31 \\
3.61 \\
3.36 \\
3.54 \\
2.26 \\
1.50 \\
1.08\end{array}$ & 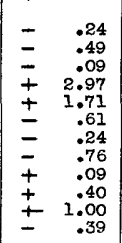 & $\begin{array}{r}.14 \\
.21 \\
.29 \\
.38 \\
1.20 \\
1.02 \\
.51 \\
.40 \\
.27 \\
.25 \\
.35 \\
.39\end{array}$ & $\begin{array}{r}.29 \\
.31 \\
.69 \\
1.02 \\
1.01 \\
.89 \\
.80 \\
.47 \\
.42 \\
.50 \\
.45 \\
.32\end{array}$ & $\begin{array}{l}= \\
= \\
\pm \\
\pm \\
= \\
=\end{array}$ \\
\hline $\begin{array}{l}1910 \\
\text { March } \\
\text { Apri1 } \\
\text { May } \\
\text { June } \\
\text { July } \\
\text { August } \\
\text { September } \\
\text { October } \\
\text { November } \\
\text { December }\end{array}$ & $\begin{array}{l}48.0 \\
49.2 \\
53.9 \\
69.5 \\
73.4 \\
69.4 \\
60.9 \\
53.3 \\
29.4 \\
19.5\end{array}$ & $\begin{array}{l}30.1 \\
45.2 \\
57.3 \\
66.6 \\
71.4 \\
69.2 \\
61.5 \\
49.3 \\
34.0 \\
20.8\end{array}$ & $\begin{array}{rr}+ & 17.9 \\
\pm & 4.0 \\
\pm & 3.4 \\
+ & 2.9 \\
+ & 2.0 \\
\pm & .2 \\
\pm \quad & .6 \\
\pm & 4.0 \\
\pm & 4.6 \\
- & 1.3\end{array}$ & $\begin{array}{l}.18 \\
2.20 \\
2.46 \\
1.36 \\
1.82 \\
3.11 \\
2.84 \\
.99 \\
.70 \\
.58\end{array}$ & $\begin{array}{l}1.60 \\
2.51 \\
3.62 \\
4.31 \\
3.61 \\
3.36 \\
3.54 \\
2.26 \\
1.50 \\
1.08\end{array}$ & 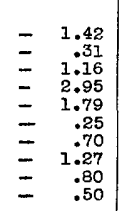 & $\begin{array}{l}.91 \\
.81 \\
.63 \\
.42 \\
.25 \\
.21 \\
.23 \\
.23 \\
.21 \\
.14\end{array}$ & $\begin{array}{r}.69 \\
1.02 \\
1.01 \\
.89 \\
.80 \\
.47 \\
.42 \\
.50 \\
.45 \\
.32\end{array}$ & $\begin{array}{l} \pm \\
= \\
= \\
= \\
=\end{array}$ \\
\hline $\begin{array}{l}1911 \\
\text { Jamuary } \\
\text { Februarry } \\
\text { March } \\
\text { April } \\
\text { May } \\
\text { June } \\
\text { July } \\
\text { August } \\
\text { September } \\
\text { October } \\
\text { November } \\
\text { December }\end{array}$ & $\begin{array}{l}15.9 \\
24.4 \\
37.11 \\
44.7 \\
62.3 \\
71.1 \\
71.6 \\
67.5 \\
60.8 \\
46.9 \\
26.2 \\
26.1\end{array}$ & $\begin{array}{l}14.4 \\
17.7 \\
30.1 \\
45.2 \\
57.3 \\
66.6 \\
71.4 \\
69.2 \\
61.5 \\
49.3 \\
34.0 \\
20.8\end{array}$ & 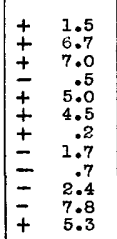 & $\begin{array}{l}.94 \\
1.68 \\
.90 \\
2.32 \\
3.90 \\
3.37 \\
3.69 \\
4.25 \\
4.98 \\
4.96 \\
. .76 \\
1.00\end{array}$ & $\begin{array}{l}1.03 \\
1.05 \\
1.60 \\
2.51 \\
3.62 \\
4.31 \\
3.61 \\
3.36 \\
3.54 \\
2.26 \\
1.50 \\
1.08\end{array}$ & $\begin{array}{lr}\overline{ \pm} & .09 \\
\pm & .63 \\
\pm & .70 \\
\pm & .19 \\
\pm & .98 \\
+ & .08 \\
\pm & .08 \\
\pm & 1.49 \\
\pm & 2.50 \\
+ & .50 \\
+ & .79\end{array}$ & $\begin{array}{l}.17 \\
.56 \\
.39 \\
.40 \\
.42 \\
.52 \\
.25 \\
.40 \\
.36 \\
.93 \\
.77 \\
.58\end{array}$ & $\begin{array}{r}.29 \\
.31 \\
.69 \\
1.02 \\
1.01 \\
.89 \\
.80 \\
.47 \\
.42 \\
.50 \\
.45 \\
.32\end{array}$ & $\begin{array}{l}.12 \\
.25 \\
.30 \\
.62 \\
.59 \\
.37 \\
.55 \\
.07 \\
.06 \\
.43 \\
.32 \\
.26\end{array}$ \\
\hline $\begin{array}{l}1930 \\
\text { July } \\
\text { August } \\
\text { September } \\
\text { October } \\
\text { November } \\
\text { December }\end{array}$ & $\begin{array}{l}74.0 \\
73.3 \\
62.7 \\
47.7 \\
37.3 \\
23.8\end{array}$ & $\begin{array}{l}71.4 \\
69.2 \\
61.5 \\
49.3 \\
34.0 \\
20.8\end{array}$ & $\begin{array}{ll}+ & 2.6 \\
\pm & 4.1 \\
\pm & 1.2 \\
\pm & 1.6 \\
\pm & 3.3 \\
\pm & 3.0\end{array}$ & $\begin{array}{l}2.41 \\
1.54 \\
3.27 \\
2.14 \\
1.97 \\
.45\end{array}$ & $\begin{array}{l}3.61 \\
3.36 \\
3.54 \\
2.26 \\
1.50 \\
1.08\end{array}$ & $\begin{array}{l}1.20 \\
=\quad .82 \\
=\quad .27 \\
\pm \quad .47 \\
. \quad .63\end{array}$ & $\begin{array}{l}.45 \\
.23 \\
.19 \\
.23 \\
.20 \\
.19\end{array}$ & $\begin{array}{l}.80 \\
.47 \\
.42 \\
.50 \\
.45 \\
.32\end{array}$ & $\begin{array}{l}.35 \\
.24 \\
.23 \\
.27 \\
.25 \\
.13\end{array}$ \\
\hline
\end{tabular}

table 11 .

* Stations used to compute average temperature over the basin are given in 
Table 66.- Drought data for Mississipp1, River Basin above Keokuk, Iowa-Continued

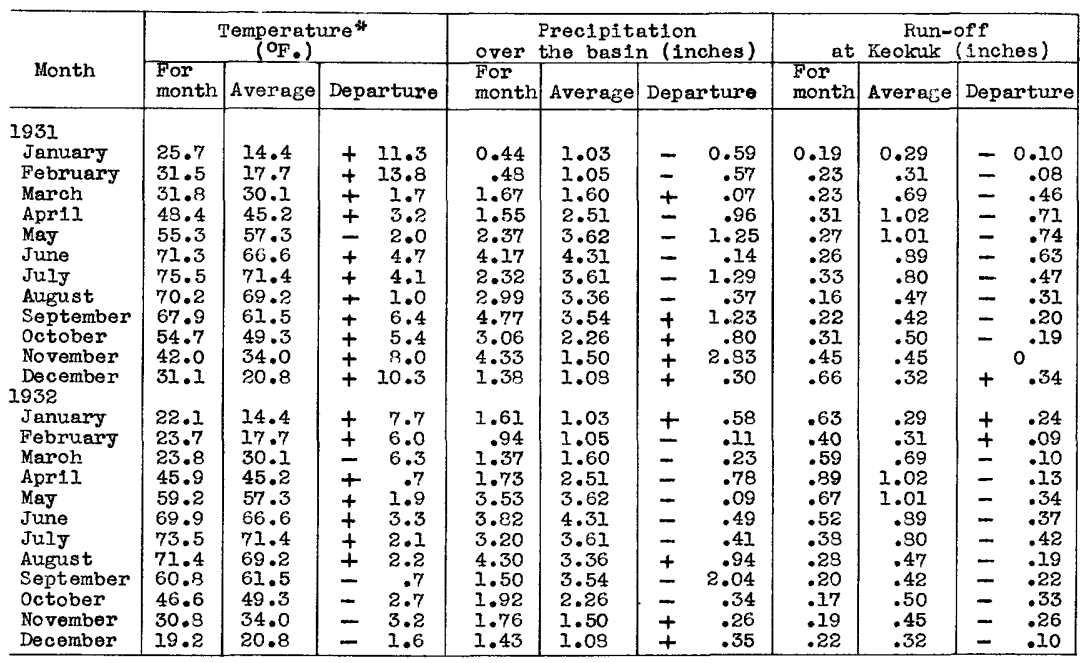

* Stations used to compute average temperature over the basin are given in table II. 
the drought of 1930-32 a deficiency of 3.64 inches accumulated in 4 consecutive months and a total of 8.67 inches in 14 months. The run-off during the first drought period was deficient for 22 consecutive months, the accumulated total being 6.42 inches, and by the end of 29 months the accumulated deficiency amounted to 6.96 inches. During the second drought a deficiency of 2.87 inches accumulated in 10 consecutive months, and at the end of 18 months the accumulation amounted to 5.18 inches. In the third drought a deficiency of 7.15 inches in run-of accumulated in 30 consecutive months. The temperature affecting the amount of transpiration (over $40^{\circ}$ ) during the drought of 1930-32 averaged about $0.6^{\circ}$ higher than in 1910-11 drought and about $0.7^{\circ}$ higher than in 1894-96.

\section{Ground-water levels}

The advisory comittee of the American Geophysical Union in a report to the Water Planning Committee, dated February 12, 1935, suggested, among other things, "a study of the laws governing the ground-water supply to streams and the relation of ground-water levels to ground-water flow. This is Important because ground water is the only source of supply to streams without surface storage during drought periods. Also in case of many crops, such as alfalfa, ground water is the principal source of moisture utilized by vegetation during drought periods when soil moisture is deficient."

In this connection a comparison of deficiencies in precipitation with decline of ground-water levels made in the Platte Valley in central Nebraska by Leland $K$. Wenzel, of the United States Geological Survey, is of interest. The results of this study are briefly outlined in the following statement prepared for the press, dated April 1, 1935. In connection with this statement it should be noted that water is pumped from wells for irrigation during the sumer in the area east of Kearney, and hence the water-level fluctuations shown in the accompanying figure are not wholly caused by natural conditions. The part of the Platte Valley where irrigation is practiced with water diverted from the Platte River is somewhat separated from the part of the valley east of Kearney by a restriction in the valley, and it is believed that the effect of surface-water irrigation west of Kearney on the fluctuations of the water table in the area to the east is negligible. 
"The water levels in about 100 wells in the Platte River Valley between Grand Island and Cozad, in central Nebraska, have been measured periodically since October 1930 by the United States Geological Survey in cooperation with the Conservation and Survey Division of the University of Nebraska. In October 1934 the water levels in these wells stood from 1 to 8 feet lower than in October 1930, thus indicating a general decline of the ground-water table throughout this part of the Platte Valley. It has been greatest in parts of the valley between Cozad and Kearney, ranging from 4 to 8 feet in an area north of Cozad and Lexington and from 3 to 4 feet in an area on the north side of the valley from Lexington to and beyond Kearney. This decline has been caused principaliy by submormal precipitation, together with the relatively small amount of surface water available for irrigation, and thus for seepage to the ground-water table, in the last 4 years. N. H. Derton, of the United States Geological Survey, made an Investigation in 1896 of the geology and ground-water conditions of southeastern Nebraska. The ground-water level in the vicinity of Lexington was then 20 to 22 feet below the land surface. At the present time it is only 7 to 10 feet below the land surface and hence is still from 10 to 15 feet above the level of 1896. The net rise since 1896 doubtless has been caused by seepage of water diverted from the Platte River for irrigation. In years when only comparatively little water flows in the irrigation ditches-as during the last 4 years--the seepage is small, and therefore rather large declines of the water teble occur. Rises of 1 to 4 feet of the water level in wells near Lexington were recorded in the fall of 1934, when surface water once more flowed in many of the canals near the city.

"East of Kearney the decline of the ground-water table has in general been less than west of Kearney. From Kearney to Shelton and south of Alda it has in general ranged from 2 to 3 feet, and in the vicinity of wood River it has been less than 2 feet. The decline east of Kearney was smaller chiefly because the water table had not been built up prior to 1930 to any great extent by surface-water irrigation and also, perhaps, because east of Kearney the ground-water level is sustained to a greater extent by underflow from the northwest. Such decline as occurred was due chiefly to subnormal precipitation but in small part to the considerable quantity of ground water that was pumped for irrigation.

"A special study was made of the fluctuation of the water levels In 20 observation wells between Grand Island and Kearney and their relation to the precipitation. The results are shown in the accompanying graphs 
(figure 88). One hydrograph shows the average water level at the end of successive 3-month periods from January 1931 to January 1935 in 14 wells In which the water levels stand more than 10 feet below the land surface. Another hyarograph similarly shows the average water levels in 6 wells with water levels less than 10 feet below the surface. The wells of the second group are in the same stretch of the Platte Valley as those of the first group but are nearer the river, where the water table is not far below the surface. A third graph shows the accumulative departure from normal precipitation as complied from the records at Grand Island and Keamey since January 1, 1931.

"The water levels in the wells of the second group in general rise and fall more than the water levels in the wells of the first group. This more active fluctuation is due to the following causes: Recharge from precipitation occurs more frequently where the water table is shallow and thus larger rises of the water level result. On the other hand, the roots of more plants draw water directly from the zone of saturation where the water table is shallow, and consequently larger declines of the water level occur in the growing season. Changes in the level of the Platte River cause similar changes in the water levels in wells close to the stream, but the river has small effect on the water levels in wells farther away. In the winter and spring of 1931, 1933, and 1934 the average rise was less than 1 inch in the wells with deeper water level but more than 1 foot in the wells with shallow water level. The decline of the water levels in the summer and fall was likewlse greatest in the shallow-water wells. Consequently in the last 4 years the net decline was nearly the same in each group.

"In the first half of 1932 there were rather large rises of the water levels in all the wells in the Platte Valley, as indicated by the hydrographs. The cause of this rise is apparent from the curve showing accumulative departure from normal precipitation. From october 1931 to April 1932 the average precipitation recorded at Grand Island and Kearney was slightly above normal, and consequently considerable water percolated into the ground and was added to the ground-water reservoir in this recharge perlod. As a result the water level did not reach as low a level 


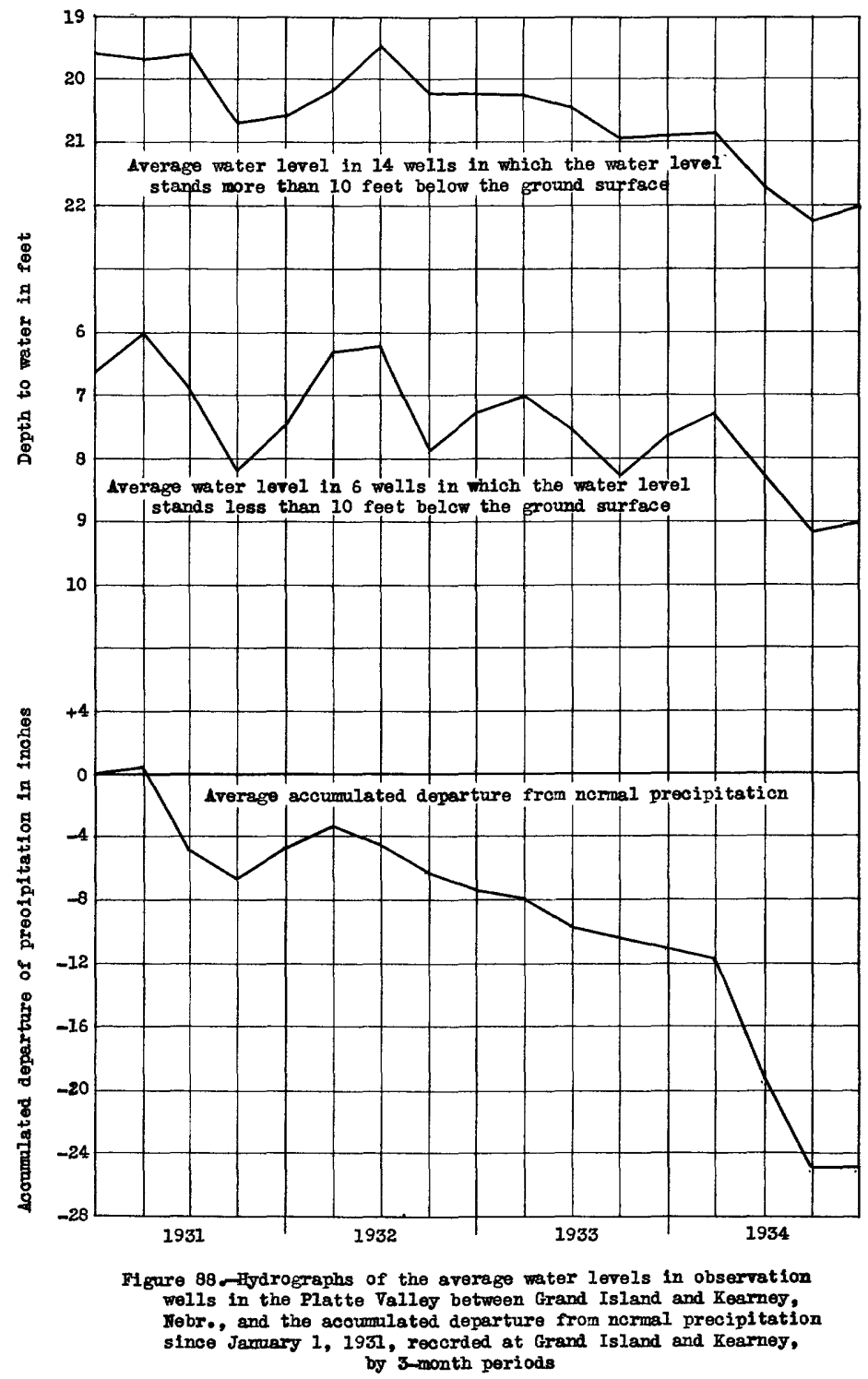


In 1932 as it did in 1931. Since July 1932 the precipitation has been about 22 inches below normal-a deficlency equivalent to almost one year's normal precipitation--and the water level in the valley has suffered annual net declines. It may reasonably be expected that future years of greater precipitation will again raise the ground-water levels."

\section{Comparison of graphs of minimum flow}

The comparison of the graph of minimum flow of the major basins studied should be of interest, especially if the relations between general ground-water conditions in the basins and the seepage flow therefrom are eventually determined. In figure 89 is plotted (plotted points are shown connected for purpose of illustration) for the period of record the annual minimam average daily discharge for 7 consecutive days, not including the frozen period, for the major basins studied, except for the Merrimack River Basin, for which anmual minimum monthly flows are plotted. The records have not been corrected for storage and no attempt has been made to determine the effect, if any, of storage operations or channel improvements on the mintmum flows.

Fram the records as they stard some general observations can be made. For the relatively short records for the Red, James, and Chattahoochoe Rivers, the trend in 7-day minimum flows seems to be somewhat downward. The longer time record for the Mississipp1 River above Keokuk shows a decided downward trend in 7-day minima since 1930, but in three years 1894, 1910, and 1925 - the minimum was almost as low as in 1930. The Lerrimack monthly minima have trended generally upward since 1911, with an early 1ow recorded in 1883. The Tennessee River minima have trended upward since 1925, when the minimum was the lowest for the period of record, although approached in the earlier years 1881, 1883, and 1904. Zero flow was recorded on the Neosho River in 1896, 1897, 1920, and 1934. $59550-35-18$ 


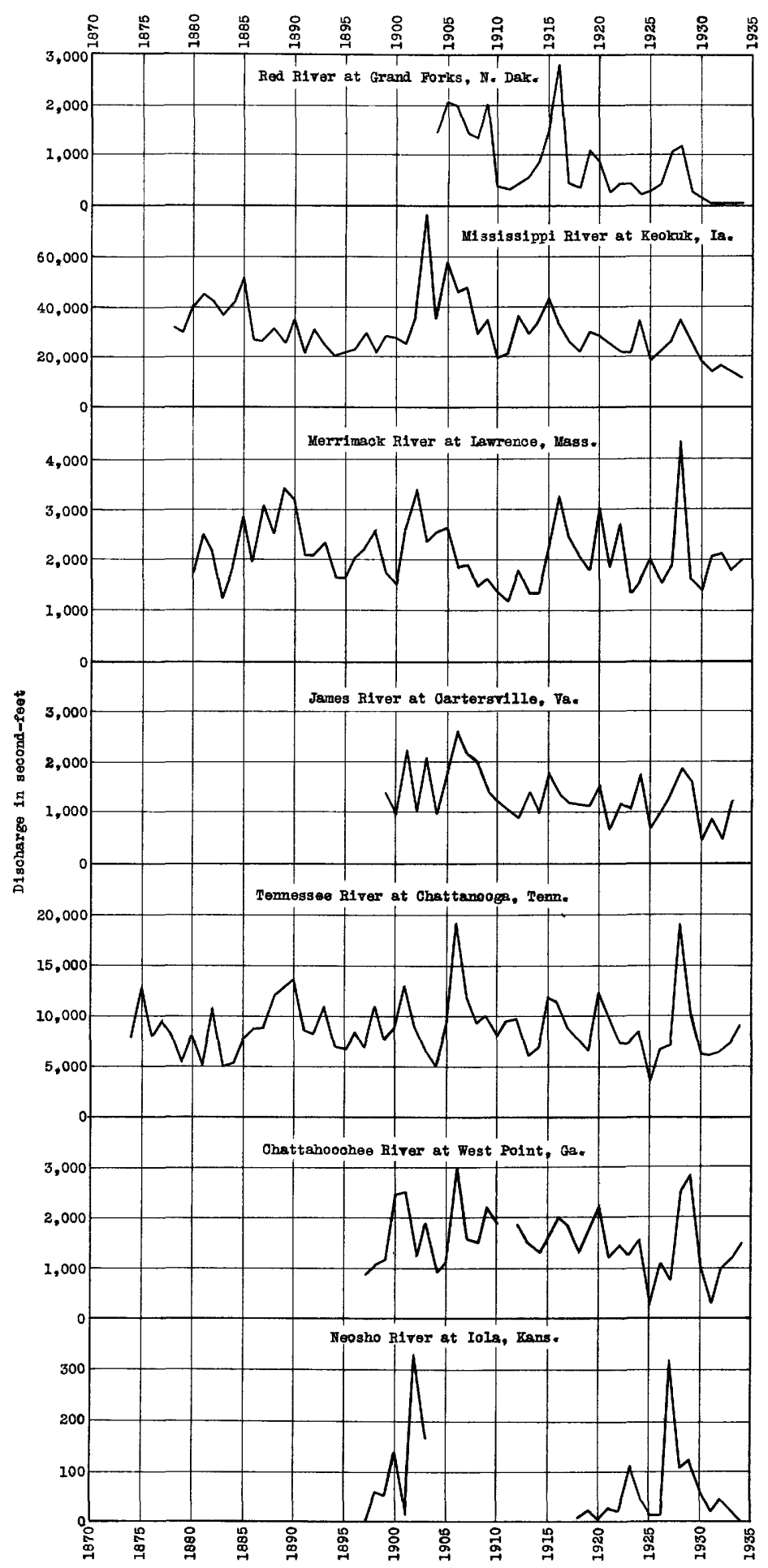




\section{APPENDIX}

\section{Report of Advisory Committee of Section of Hydrology of}

the American Geophysical Union to the Water-Planning

Committee of the National Resources Board

Gentlemen:

The Advisory Committee of the Section of Hydrology of the Amer1can Geophysical Union, which at jour request has maintained an advisory status with the Geological Survey with regard to studies of the relations of rainfall and run-off, has now in hand a progress report in this matter which, we understand, has been prepared for publication as a water-supply peper. *

The committee wishes to offer its commendation of the very useful work done by the engineers and hydrologists of the Geological Survey. The report is a record of progress made in exploratory studies of certain phases of the relations of rainfall and run-off and the factors that

affect these relations. It should be understood that this report is in no sense to be considered a record of completed, exhaustive research into the subject. Many parts of the report suggest pertinent questions concerning aspects of the data presented, which are not answered and not answerable at this time.

The proposed publication offers more or less simple representations and tentative analyses of basic hydrologic data and should be of value to those who seek knowledge of these subjects. The compliation will enable students of the subjects involved to have the benefit of the information collected, and its publication offers an opportunity for hydrologists, meteorologists, and others to review and criticize the methods used and the results obtained. One of the princlpal benefits hoped to be derived from the report is the stimulation of such review and criticism. Studies such as are here described, when supplemented by other similar studies or when carried to a point where defintte changes, trends, and relations can be disclosed and reasonably accurate conclusions drawn, should be of value in connection with the preparation of plans and measures

\footnotetext{
* Refers to this paper.- W. G. H.
} 
for the conservation of water resources. The cormittee cautions readers against the use of any of the material apart from its accompanying text. The Advisory Committee approves the publication of this material at this time. During the progress of the studies the committee has suggested items of study and also alternate methods of approach in many problems. It has recommended that some specific studies undertaken be abandoned, because the basic data available did not appear to be sufficiently complete or accurate for the purpose. It should be understood that in recommending publication of the material at this time the committee is not necessarilv committed to the approvel of the procedures used as the best methods for particular studies, nor in any way comitted to an approval of tentative conclusions which may appear to be expressed in the report.

Although rainfall and run-off are the most obvious and most widely observed factors of the hydrologic cycle, the records of reliable observation of these phenomena are comparatively short and afford a meager basis for satisfactory conclusions.

Few continuous records of precipitation and temperature and no records of stream flow are now available for any part of the United States for periods of 100 years or more.

The variations in precipitation, temperature, and run-off that are presented in the report cover a relatively short period of time, and no attempt has been made to extend the records by use of tree rings, lake levels, glacial changes, timber-line movements, or similar studies. No attempt has been made to determine whether the apparent changes are a part of long-time cyclic variations or are indications of permanent changes. The important thing is the fact that during a perlod of less than 100 jears changes of sufficient magnitude to affect human occupancy have apparently occurred in meteorologic and hydrologic conditions in certain parts of the United States. Whether any part of the changes noted may have resulted from man's occupancy is an open question. In one instance the data presented suggest that possibly conditions could be improved through man's efforts. The committee feels, however, that much more research will be needed before it can be definitely asserted that over the basins studied man's occupancy has caused measurable changes either in meteorologic conditions or stream flow. It is possible, however, that when the data presented are used in conjunction with other studies, or 
when the present studies are carried to completion, definite reasons can be disclosed for the various changes, and in that event it can be definitely determined whether or not over large areas man can reasonably undertake remedial measures.

The Advisory Committeo calls attention to the resolution of the American Geophysical. Union at its annual meeting in Washington on April. 25, 1935. This resolution points out the fact that the study of hydrologic phenomena and Its application to the conservation and utilization of water resources is a work that is divided among a number of different bureaus and departments of the Federal Government, and that at the present time there is no correlating authority or agency. for uniting in a systematic manner the work of these Federal agencies, and therefore the American Geophysical Union recommended and urged that there be established a permanent agency with authority to direct and correlate the work of all these separate agencies engaged in matters pertaining to the utilization of the nation's water resources.

The Advisory Committee endorses the aforesald resolution and furthermore recommends that in the event of further Investigations in the application of hydrology, all such future work be under the direction and supervision of such a centralized correlating agency, to be established; that such agency be vested with the necessary power and authority to Insure a correlated work; and that the aforesald correlating agency have authority to assign to the various bureaus and departments specific studies for which they may be best equipped.

In the attached supplementary notes the committee is indicating certain specific matters that might be restudied to advantage, and other methods of approach that for certain problems seem desirable.

This report was prepared and concurred in by a subcomittee consisting of Messrs. Horner, Horton, Heyer, and Sherman. The other members of the comittee, liessrs. PIckels, Towl, and Woermann, although cooperating in the studies, have not had opportunity to revlew the proposed watersupply paper in its present form of compliation.

Respectfully submitted.

ADVISORY COMMITTEE, ANERICAN GEOPHYSICAL UNION 


\section{Supplementary notes}

Work of the comittee

The seven members of the committee have maintained contact with the studies of the Geological Survey since their appointment in May 1934. To a considerable degree discussion of material between members of the Advisory Committee and between them and the active staff on this project of the Geological survey has been maintained by correspondence. During the first 6 months of the work the correspondence was supplemented by frequent conferences between Mr. Hoyt and others, on the one hend, and Messrs. Horner and Sherman, of the cormittee, on the other.

In order to expedite the work of the Advisory Committee, a subcommittee was formed, consisting of Messrs. Horner, Meyer, and Sherman, and to this subcomitteo was added Mr. R. E. Horton in January 1935. On January 18 three members of the subcommittee met with Mr. G. M. Matthes, chairman of the Committee of Flood Protection Data, for the discussion of certain material of common interest to the two committees; thereafter, a memorandum report sendered to the Water-Planning committee. On April 22, 1935, the four members of the subcomittee met with Mr. Hoyt and his assistants for a full-day session in Washington. At this time, the studies contained in the proposed water-supply paper were nearing completion. The material was analyzed in detail, and the members of the Advisory Committee offered definite suggestions as to policy, as to differences in procedure, and as to specific details or apparent defects in the basic data.

After the material had been assembled in final form, but prior to complete editing, the subcomnittee met in Chicago on June 12, 1935, and again reviewed the results of all the studies undertaken. This report of the Advisory Committee will be considered its finel report on the present exploratory studies, to be published as Water-Supply Paper 772.

\section{Detailed comments on matter contained}

in the water-supply paper

To amplify the statements on pages 19 and 20 it should be made clear that during the progress of the studies the Advisory Committee came to appreciate more and more the deficiencies of the fundamental data on which the studies undertaken had to be based. It had been hoped that 
exploratory studies in the various flelds might develop derived information of real present value, and that the results of the studies would permit tentative conclusions by both hydrologists and economists which would be useful in connection with present national planning. AIthough these hopes could not be fully realized, because of deficiencles in the fundamental data, the studies contained in the present report indicate flelds for further study for which present basic data may be considered reasonably adequate, and they alsc indicate desirable mcdifications in methods of collecting basic data. With respect to the last item, the Advisory Comittee calls attention to the report now being made to the Water-Planning Committee by a spectal comittee on standards and specifications for hydrologic data, with which some of the members of the Advisory Committee have been associated. Because the improvement and standardization in the collections, compliations, and publication of basic data are there discussed in detail and definite recommendations are made with regard to them the Advisory Conmittee refrains in general frcm further recommendation on these subjects herein.

With regard to the material on page 19 the Advisory Committee wishes to make clear its understanding that although the studies contained in the main report may not be considered "broad general studies", jet in many phases they deal with relations of mass values, such as rainfall, run-off, and temperature on annual, 5-year, and 10-year bases. At the committee's suggestion, seasonal values have been developed in certain of the studies. Tc the extent that mass values are involved, detailed fundamental relationships are obscured, and the comittee wishes at this point to call attention to the extreme benefit that would result from specific studies of the relations of rainfall and run-off with regard to smaller areas, high intensities, and short times of occurrence, such as definite storm periods. Owing to the greater simplicity of conditions and the possibility of their contrcl in part, studies of run-off from small drainage basins are better adapted to the determination of the underlying laws and principles of run-off phenomena than studies of larger drainage basins.

In the studies of natural phenomena, such as precipitation, temperature, and run-off, 10-year progressive averages have been used extensively in the report. The committee belleves that on the whole 5year moving averages, with the result plotted for the third year, give a 
better indication of trends than 10-year moving averages. If 10-yeax moving averages are used and are plotted on the tenth year they tend to obscure trends and make the moving averages appear in conflict with the annual averages. If 10-year averages are used it appears best to have the average value plotted as the middle point of the series instead of the end.

The material presented in table 1 ( $p, 21$ ) is af great interest. However, in view of studies presented in other sections of the report with regard to changes in precipitation by geographic provinces and by basins, table 1 and the statements on page 21 , appear to need further analysis and discussion. For example, figure 1 indicates a general dowmard trend of precipitation except in certain southern and west-central provinces and in a portion of the southwestern area. In view of the definite decrease in precipitation as indicated in figure $I$ and as shown more specifically in certain tables, there appears to be a necessity for harmonizing the two studies.

The study of precipitation trends by seasons in fifteen geographic areas is a presentation of material of the first importance and material that may be used by hydrologists for further analysis. The committee considers it unfortunate that these studies have of necessity had to be based to so great on extent upon precipitation data collected at the so-called "first order stations." At many of these stations the gage: have been subject to change in location and exposure and in particular, to more than one change in helght above the ground surface, generally to the roof of a higher building. On this account it is possible that the trend at some of these stations will indfcate a decreasing anmal precipitation, when as a matter of fact the data may be affected by decreased catch of gege.

Much of the work on trends of hydrologic data presented in the peper is based on annual values. The committee feels that although annual values are useful in various ways there are cextain respects in which such values alone are either inadequate or may be deceptive, and that in future studies, involving trends or changes in conditions, a seasonal basis should in general be used, with the data for a growing season presented separately from those for the remainder of the year. Aside from the obvious advantage of this plan in relation to agriculture, it segregates the surmer data which are less subject to basic emors than those for the winter season, and inasmuch as the greater part of the run-off for many 
drainage basins occurs in the winter season, such a segregation is necessary if the results are to be applied to sumer conditions.

The comittee particularly commends the study of trends and of relationships by basins and recommends that the future studies, insofar as possible, be carried out along dralnage-basin lines.

The comittee recommends that in future research relations between rainfall and rum-off should not be studied or expressed as ratios or percentages, but should be indicated by differences between rainfall and rum-off, or so-called "water Iosses", which are inaicative of what is called the "consumptive use" characteristic of the particular basins.

The report contains tabulations showing the segregation based on a 5-year annual average-for certain periods noted and obtained by subtracting from the total stream flow an estimated ground-water run-off obtained through a study of the plotted hydrograph of stream flow, in part by methods discussed in the report. Certain exceptions are made as to the straight-line methods used on the Miaml and Pomperaug Basins.

The comittee calls attention to the qualification as to the accuracy of the results obtained, contained on page 120 where it is stated: - It should be clearly recognized that the estimates given are subject to exror. Further refinements in the methods of determination and more exhaustive application of known factors may change the results materialiy." The comittee believes that the character of the material presented in subsequent tables is of such importance as to justify a further attempt to organize the technique of ground-water separation in accordance with the most scientific methods now possible, and it would suggest that the values presented in these tables be considered tentative only and that the studies on wich they are based should be renewed and revised at the earliest possible opportunity.

lany additional studies are in progress, and better methods for the separation of ground-water stream flow are being developed. Then these methods are applied to the records for which a separation of stream Plow was made in this report, material differences will undoubtedly be shown, but it is nevertheless appreciated that the existing information indicates striking differences in the characteristics of the various drainage basins listed, and for purposes of comparison the results are believed to be of value. 
In the opinion of the committee the methods used are not subject to error sufficient to invalidate their application to the separation of ground-water stream flow in the use of the unit-graph method.

The committee's statements with relation to the tables on pages 120-122 apply equally to tables on ground-water run-off on pages 246 and 247.

A considerable part of the ground-water flow included in the tabulated values is necessarily derlved from flow during the winter season. To the extent that values of winter flow are derived from estimates and not from measurements, the possible error in total annual quantity is increased. The development of winter depletion curves by the making of more extensive actual measurements on northern streams during periods when there is no surface mun-off is strongly recommended.

With regard to the statement on page 245, the committee 18 of the opinion that quantitative values of ground-water run-off which may eventualiy be developed by sclentific application of the best possible methods may vary from the values given on pages 246 and 247 , in some instances by more than 10 percent, and that the variation may be in elther direction.

The committee feels that the rork presented by Merr111 Bernard relating to the possibility of transposing flood producing storms by means of the unit hydrograph is a useful contribution in making flood estimates. In such applications it is necessary to be fully acqualnted with the geographic and meteorologic conditions of the areas involved. 


\section{REFERENCES}

The following list of references, largely American, to relations between rainfall and run-off and related subjects does not include articles on run-off of high intensity, such references being included in U. S. Geological Survey Water Supply Paper 771 .

1. Adams, F. D., Rainfall and run-off: Sclence, new ser., vol. 67, pp. 500-501, 1928 .

2. Auten, J. T., Porosity and water absorption of forest soils; Jour. Agr. Research, vol. 46, no. 1, June I, 1933.

3. Babb, C. C., Rainfall and river flow: Am. Soc. Civil Eng. Trans., vol. 28, p. 323, 1893. Curves giving monthly run-off in terms of percentage of annual mun-off; annual run-off computed as a percentage of annual precipitation.

4. Baker, D. M., and Conkling, Harold, Water supply and utilization, New York, John Wiley \& Sons, 1929. An outline of hydrology with reference to the arid section of the United States.

5. Baker, F. S., Some field experiments on evaporation from snow surfaces: Monthly Weather Rev., July 1917.

6. Barrows, H. K., Precipitation, mu-off, and altitude, Connecticut River: Am. Geophys. Union Trans. 14th meeting, p. 396, Nat. Research Council, 1933.

7. Barrows, H. K., Water-power engineering, 2d ed., New York, McGrawHill Book Co., 1934, Hydrology, pp. 38-123.

8. Bartell, F. O., and McCrory, S: H., First progress report on soilerosion experiments, North Carolina Experiment Station farm, West Ralelgh, Wake County, N. C., U. S. Dept. Agr., 1925. Experiments to show run-off and soil erosion.

9. Bates, C. G., and Henry, A. J., Forest and stream-flow experiment at Wagon Wheel Gap, Colo.: Monthly Weather Rev., Suppl. 30, 1928. For discussion, see Hoyt, W. G., and Troxell, H. C., Am. Soc. Civil Eng. Trans., vol. 99, pp. 1-94, 1934.

10. Belknap, J. B., Comparison of methods for determining the areal mean precipitation on drainage areas: New England Water Works Assoc. Jour., vol. 46, pp. 272-282, maps, 1932.

11. Bennett, C. S., Hydrological data from the Miani Conservancy District: Eng. News-Record, vol. 113, pp. 556-558, 11., 1934 ,

12. Bernard, M. M., Formulas for rainfall intensities of long duration, Am. Soc. Civil Eng., Trans.. vol. 96, P. 592, 1932.

13. Bernard, M.M., Approach to determinate stream flow: Am. Soc. Civil Eng. Proc., vol. 60, pp. 3-18, 1934. Discussion, vol. 60, pp. 436-438, 585-588, 764-765, 1037-1039, 1340-1351, 1934; vol. $61, \mathrm{pp} .84-88,1935$.

14. Bernard, M. M., A preliminary manual for the unit-hydrograph method (manuscript), U. S. Geol. Survey, August 1934.

15. Bigelow, F. H., Evaporation observations and formulae--a manual for observers in climatology and evaporation, U. S. Weather Bureau, 1909 . 
16. Blaney, H. F., and Taylor, C. A., Rainfall, penetration, and consumptive use: Californiá Dept. Public Works Water-Resources Bul1. 33, 1930.

17. Blaney, H. F., Consumptive use of water by native plants growing in molst areas in southern Californta: California iept. Public Works Water-Resources Bull. 44, pp. 1-26, 1933.

18. Boston Society of Civil Engineers, Report of committee on floods : Boston Soc. Clvil Eng. Jour., vol. 17, pp. 293-466, 1930.

18a. Bowman, Isalah, Our expanding and contracting deserts: Geog. Kev., January 1935, pp. 43-6I.

19. Briggs, I. J., Losses through transpiration; U.: S. Dept. Agr., Bur. Plant Industry, Bull. 230, 1912.

20. Briggs, L. J., and Shantz, H. L., Daily transplration during the normal growth perlod and its correlation with weather; Jour. Agr. Research. vol. 7, no. 4, Oct. 23, 1916.

21. Burchard, E. D., 1925 drought breaks all records in southern Appalachlans: Eng. News-Record, vol. 96, pp. 234-235, 1926. The average deficlency for 12 stations was 37 percent. A table shows monthly departure from normal rainfall at selected stations, and another shows comparison of monthly discharge of the French Broad River at Asheville for this period, with 16-Jear average.

22. Burgess, A. S., Safe yields of drannage areas in years of minimum rajnfall: Eng. News-Record, vol. 89, pp. 970-971, 1922. Presentation and discussion of minimum run-off in northeastern United States; mass curves to show safe yields.

23. Burr, E. W., Forests and stream flow, herrimac River: 62d Cong., lst sess., H. Doc. 9, 1911; 3ing. News, vol. 66, p. 100, i9li. No evidence of change in relation between rainfali and runoff from 2860 to 1910.

24. Cady, R. G., Fluctuations of water levels in Virginia wells: Am. Geophys. Union Trans. 13th meeting, p. 370, Nat. Research Counc11, 1932.

25. Chandler, E. F., What becomes of rainfall in North Dakota: North Dakota Univ. Quart. Jour., vol. 15, no. 2, p. 110, 1925.

26. Chittenden, H. M., Forests and reservolrs in their relation to stream flow, wh th special reference to navigable rivers: Am. Soc. Civil Eng. Trans., vol. 52, p. 245, 1003.

27. Church, J. E., Jr., Snow survey and stream mun-off forecast in Nevada for 19́23: Eng. News-Record, vol. 90, p. 1001, 1923.

28. Church, J. E., Jr., Precipitation and run-off at the Continental Dividé: Eng. News-Record, vol. 94, pp. 190-195, 1925.

29. Church, J. E., Jr., High density of snow accelerates its melting and run-off: Eng. News-Record, vol. 99, p. 553, 1927.

30. Church, J. E., Jr., Hydrology of snow: Am. Geophys. Union Trans. 13th meeting, p. 277, Nat. Research Counc11, 1932. Complete bibliography in Trans. 14th meeting, p. 342, 1933.

31. Collins, W. T., and Snyder, F. F., Run-off as a function of previous precipitation (thesis, 1932, Oh1o State University). Formulas for monthly run-off similar in character ta Hayford's formu-

31a. Condra, G. E., Relation of drought to water use in Nebraska: Nebraska Univ., Dept. Cons. and Survey Div., BulI. 6, 1934.

Conkling, Harold. See Baker, D. M.

32. Connor, A. B., DIckson, Clarlce, and Scoates, Factors influencing runoff and soll erosion: Texas Agr. Exper. Sta. Bull. 4ll, 1930. 
Cooley, L. E. See Johnston, T. T.

33. Crawford, E. J., Calculating run-off for water-power purposes with no rainfall records: Elec. World, vol. 76, pp. 1111-1112, 1920.

34. Cunningham, B., Rainfall and land drainage: Nature, vol. 105, p. 42, 1920.

35. Dole, R. B., and Stabler, Herman, Denudation: U. S. Geol. Survey Water-Supply Paper 234, pp. 78-93, 1909.

36. Eiffert, C. H., Problems in using Government data on rainfall and runof : Eng. News-Record, vol. 113, pp. 556-558, 1934.

37. Elliott, F. C., Results of run-off experiments with muck soil: Fing. and Contracting, vol. 55, pp. 363-365, abstracts, diagrams, 1921; Eng. News-Record, vol. 37, pp. 157-158, 192́1.

38. FitzGerald, Desmond, Evaporation from water surface: Am. Soc. Civil Eng. Trans., vol. 15, p. 581, 1886.

39. FitzGerald, Desmond, Rainfall, flow of streain, and storage: Am. Soc. Civil Eng. Trans., vol. 27, p. 253, 1892.

Flynt, F. L. See Horner, W. W.

Folse, J.A. See Hayford, J. F.

40. Forecasting snow run-off of Humboldt River, Nevada: Eng. News-Record, vol. 109, pp. 135-136, 1932. Contains bibliography.

41. Forests and rainfall: Nature, vol. 89, pp. 662-664, 1912. 42. Forests, climate, erosion, and inundations: Nature, vol. 127, pp. 524-

43. Forests in relation to climate and floods: Sci. Am., vol. 103, p. 334, 1910.

44. Forsling, C. L., Study of influence of herbaceous-plant cover on surface run-off and soil erosion, Wasatch Plateau: U. S. Dept. Agr. Tech. Bull. 220, 1931. For discussion see Stabler, Herman, Am. Soc. Civil Eng. Trans., vol. 99, pp. 80-86, 1934.

45. Frankenfield, H. C., Rainfall characteristics of the Mississippi River drainage basin: Am. Soc. Civil Eng. Trans., vol. 93, p. 6775 , 1929. Distribution and intensity of rainfail; averages for different basins.

46. Gannett, Henry, Map showing mean annuel run-off in the United States, U. S. Geol. Survey, 1908.

47. Girand, J., Weather records projected into the future: Civil Eng., vo1. 2, pp. 76-79, 1932.

48. Grover, N. G., Run-off characteristics of the Mississipp1 River arainage básin: Am. Soc. Civil Eng. Proc., vol. 53, pp. 2485$2491,1927$.

49. Grunsky, C. E., Rainfall and run-off near San Francisco: Am. Soc. Civil Eng. Trans., vol. 61, p. 496, 1908.

50. Grunsky, C. E., Kun-off from rainfall and other data: Am. Soc. Civil Eng. Trans., vol. 79, p. 1165, 1915.

51. Grunsky, C. E., Rainfall and run-off studies: Am. Soc. Civil Eng. Proc., vol. 47, pp. 203-242, map, 1921.

52. Grunsky, C. F., and Horton, R. E., Hydrology of the Great Lakes: Sanitary Dist. Chicago, Eng. Board of Reviev, Rept., pt. 3, app. $2,1927$. 
53. HaII, S, H., Stream flow and percolation water: Discussion of surface run-off and ground water mun-off: Inst. Water Engineers Trans., vol. 23, pp. 92-127, 1918.

54. Hal.1, S. I., The probable variations in yearly run-off as determined from a study of California streams: Am. Soc. Civil Eng. Trans., vol. 84, p. 191., 1921.

55. Harding, S. T., Changes in lake levels in Great Basin area: Civil Eng., vol. 5, no. 2, pp. 87-92, February 1935. Three hundred years of record studied to determine trend in avallable water supply.

56. Harrold, I. L., Relation of stream flow to ground-water levels; Am. Geophys. Union Trans. 1.5th meeting, pp. 414-416, Nat. Research Council, 1934.

57. Hayford, J. F., and Folse, J. A., A new method of estimating stream flow: Carnegle Inst. Washingt on Pub. 400, 1929. Most comprehensive study ever made to compute daily run-off.

58. Hazen, Allen, Storage to be provided in impounding reservoirs: Am. Soc. Civil Eng. Trans., vol. 77, p. 1539, 1914.

59. Hazen, Allen, Effect of elevation upon run-off from catchment areas: Eng. News-Record, vol. 89, pp. 62-64, map, 1922.

60. Horner, W. W., Rainfall and mun-off studies in St. Louis: sprinkling experiments at Washington University: Municipal and County Eng., vol. 63, pp. 176-180, 1922.

61. Horner, W. W., and Flynt, F. L., Relation between rainfall and munoff from small urban areas in St. Louls and Dallas, Tex.: Am. Soc. Civil Eng. Proc., vol. 60, pp. 1135-1178, 11., plans, 1934.

62. Horton, R. E., Evaporation from snow: Monthly Weather Rev., vol. 42, p. $99,1914$.

63. Horton, R. E., Rainfall and mun-off (discussion): Am. Soc. Civil Eng. Trans., vol. 77, p. 369, 1914.

64. Horton, R. E., Run-off from rainfalI and other data: Am. Soc. C1viI Eng. Trans., vol. 79, p. 1166, 1915.

65. Horton, R. E., Rational studies of rainfall data make possible better estimates of water yield: Eng. News-Record, vol. 79, pp. 211-213, 1917 .

66. Horton, R. E., Correlation of maximum rain characteristics for Iong and short time intervals: Konthly Weather Fev,, vol. 49, pp. 200202, 1921.

67. Horton, R. E., Determination of the mean precipitation on a drainage basin: New England Water Works Assoc. Jour., vol. 33, 1924.

68. Horton, R. E., in collaboration with Grunsky, C. E., Hydrology of the Great Lakes: Sanitary Dist. Chicago, Eng. Board of keview, Rept., pt. 3, app. 2, 1927. General treatise on rainfall, evaporation, and mun-off of Great Lakes basin.

69. Horton, R. E., Drainage-basin characteristics: Am. Geophys. Union Trans. 13th meeting, p. 350, Nat. Research Council, 1932.

70. Horton, R. E., Role of infiltration in the hydrologic cycle: Am. Geophys. Union Trans. J4th meeting, pp. 446-460, Nat. Research Council, 1933.

70a. Horton, R. E., Surface run-off phenomena, pt. I, Analysis of the hydrograph: Horton Hydrol. Lab. Pub. 101, Feb. 1, 1935.

71. Houk, I. E., Rainfal.], absorption, and run-off on small rural drainage areas: Eng. News-Record, vol. 82, pp. 875-876, 1919. 
72. Houk, I. E., Rainfall and run-off in the Miami Valley: Miami Conservancy Dist. Tech. Repts., pt. 8, 1921.

73. Houk, I. E., Relations between rainfall and Iun-off: Public Works, vol. 50, pp. 472-473, 1921 .

74. How rainfall is absorbed: Sc1. Am. Suppl., vol. 64, p. 265, 1907. Howson, I, R. See Thon, C. L.

75. Hoyt, J. C., Comparison between rainfall and run-off in the northeastern United States, with discussion: Am. Soc. Civil Eng. Trans., vol. 59, pp. 431-520, 1907.

76. Hoyt, J. C., Length of record necessary to determine run-off: Eng. News, vol. 59, pp. 459-60, 1908 .

77. Hoyt, W. G., The effects of 1 ce on stream flow: U. S. Geol. Survey Water-Supnly Páper 337, 1913.

78. Hoyt, W. G., Run-off from rainfall and other data (discussion): Am. Soc. Civ1l Eng. Trans., v01. 78, p. 1173, 1915.

79. Hoyt, W. G., Erosion - watershed protection: Civil Eng., vol. 4, pp. $81-84,1934$.

80. Hoyt, W. G., and Troxell, H. C., Forest cover and the water yield: Sclence, new ser., vol. 78, suppl., p. 6, 1933.

81. Hoyt, W. G., and Troxe11, H. C., Forests and stream flow: Am. Soc. Civil Eng. Trans., vol.99, p. 1, 1934.

82. Iwasaki, Tomihisi, A stream-flow study of the Tokyo water supply: Am. Water Works Assoc. Jour., vol. 26, pp. 163-175,1934.

83. Jarvis, C. S., Rainfall characteristics and their relation to solls and run-off: Am. Soc. Civil Eng. Trans., vol. 95, pp. 379449,1931 .

84. Johnston, T. T., and Cooley, I. E., Data pertaining to rainfall and stream flow: Western Soc. Eng. Jour., vol. 1, pp. 297-404, 1896. Daily rainfall and run-off on the Desplaines River at Riverside, III., 1886-1896.

85. Jones, E. H., Precipitation and run-off at the Continental Divide: Eng. News-Record, vol. 94, pp. 190-195, 1925.

86. Justin, J. D., Derivation of run-off from rainfall and other data: Am. Soc. C1vil Eng. Trans., vol. 77, p. 346, 1914. Expresses annual mun-off by an equation consisting of a coefficient (which varies with slope and mean annual temperature) mult1plied by the square of the annual rainfall.

87. Kincer, J. B., Is our climate changing? A study of Iong-time temperature trends: Monthly Weather Rev., vol. 61, no. 9, pp. 251$260,1933$.

88. Kincer, J. B., Study of weather records facts to reveal long range cjeles: Eng. News-Record, vol. 113, no. 2, pp. 46-47, 1934.

89. King, F. H., Principles and conditions of the movements of ground water: U. S. Geol. Survey 19th Ann. Rept., pt. 2, pp. 59-294, 1899 . Discusses rates of percolation.

90. King, F. H., The soil, New York Macmillan Co., 1908.

King, F. V. See simons, P. T.

91. Kulchling, Emil, Forests, reservolrs, and stream flow: Am. Soc. Civil Eng. Trans., vol. 73, p. 368, 1911. 
92. Lapworth, H., Relation of run-off to rainfall: Fingineering, vol. 112, p. 169,1921 .

92a. La Rue, E. C., Water power and control of Colorado River below Green River, Utah: U. S, Geol. Survey Water-Supply Paper 556, 1925.

93. Lee, C. H., Other elements than forestation which affect strean flow: Eng. News, vol. 64, pp. 155-156, 1910.

94. Lee, C. H., A study of seepage losses from streams in the Owens Valley, Calif.: Eng. liews, vol. 63, pp. 449-451, 1910.

95. Lee, C. H., An intensive study of the water resources of a part of owens Vailey, Calif.: U. S. Geol. Survey Water-Supply Paper 294, 1912.

96. Lee, C. H., Determination of the safe yield of underground reservoirs of the closed-basin type: Am. Soc. Civil Eng. Trans., vol. $78, \mathrm{p} .148,1915$.

97. Lee, C. H., Absorption and transpiration: Arr. Geophs. Union Trans. 13 th meeting, p. 288, Nat. Research Council, 1932. Contains reference to 41 papers on absorption, transpiration, and related subjects.

98. Lee, C. H., Absorption and transpiration: Am. Geophys. Union Trans. l4th meeting, p. 361, Nat. Research Council, 1933. Surmary of investigations then in progress.

99. Lippincott, J. B., Relation of rainfall to mun-off in Calffornia. Eng. News, vol. $47, \mathrm{p} .467,1902$.

100. Livingston, B. E., Transpiration from plant growth in relation to weight: Bot. Gaz., vol. 40, p. 31 .

101. Lowdermilk, W. C., Influence of forest litter on run-off, percolation, and erosion: Jour. Forestry, vol. 27, April 1930.

102. Lynch, H. B., Rainfall cycles historically deduced: Eng. Hews-Record, Sept. 17, 1931. Rainfall and stream run-off in southern California since 1769. By searching records of the Spanish or Mexican missions and various diaries Mr. Iynch has been able to go far back of the rainfall records that were begun in a scattering way about 1850 and have been kept in more orderly and extensive fashion since the establishment of the United States Signal Service and its successor, the Weather Bureau. The 162 jears of rainfall and mun-off in southern California have been plctured and valuable conclusions drawn fas commented on editorially, Fing. News-Record, Sept. 3, 1931, p. 358). Mr. Lynch's leading conclusion is: mhere has been no material change in the mean climatic conditions of southern California in the past 162 years."

103. Main, T. C., Water conservation in the Pras rie Provinces (advance proof), Eng. Inst. Canada, 1935.

104. McCarthy, E. F., Forest cover as a factor in flood control: Am. Soc. C1vil Eng. Proc., vol. 53, pp. 2511-2518, 1927.

105. McCarthy, E. F., Forest cover as a factor in flood control: Am. Soc. Civil Eng. Trans., vol. 93, p. 716,1929 . Forests delay runoff and prevent erosion and silting.

McCrory, S. H. See Bartell, F. 0 .

106. McEwen, G. F., our rainfall - how it is formed and what becomes of it: Sci. Monthly, vol. 31 , pp. 385-400, diagrams, 1930.

107. McGee, W J, Percolation and evaporation: U. S. Dept. Agr. Yearbook for 1911, Subsoil water of central United States, pp. 479-490.

McIntokh, R. P. See Bartell, M. J. 
108. Mchaughlin, W. W., Significant studies in hydrology on the Pacific coast: Am. Geophys. Unioh Trans. 12th meeting, pp. 202205, Nat. Research Council, 1931.

109. Mead, D. W., Notes on hyàrology, Chicago, Shea, Smith \& Co., 1904. Basis for an introductory study of the fundamental phenomena of hydrology.

110. Mead, D. W., Flow of streams and factors that modify it, with special reference to Wisconsin conditions: Wisconsin Univ. Bull. 425, 1911. Discussion of factors affecting stream flow, such as temperature, topography, geology, storage, and surface conditions. Hydrographs of rainfall and run-off for Wisconsin streams.

111. Mead, D. W., Hydrology, the fundamental basis of hydraulic engineering. McGraw-Hill Book Co., 1919. Discussion of the most important facts and principles of hydrology.

112. Meinzer, O. E., Bibliography and index of the publications of the United States Geological Survey relating to ground water: U. S. Geol. Survey Water-Supply Paper 427, 1920.

113. Meinzer, 0. E., Outline of ground-water hydrology, with definitions: U. S. Geol. Survey Water-Supply Paper 494, 1923.

114. Meinzer, O. E., Plants as indicators of ground water: U. S. Geol. Survey Water-Supply Faper 577, 1927.

115. Meinzer, O. E., and Stearns, N. D., A study of ground water in the Pomperaug Basin, Conn.: U.S. Geol. Survey Water-Supply Paper 597, pp. 73-146, 1929.

116. Meinzer, 0. E., The occurrence of ground water in the Unfted States, with a discussion of principles: U. S. Geol. Survey WaterSupply Paper 489, 1923.

117. Meinzer, 0. E., Outline of methods for estimating ground-water supplies: U. S. Geol. Survey Water-Supply Paper 638, pp. 99144, 1932. Numerous other reports discussing ground water in specific areas are given in Water-Supply Papers 256, 260 , $275,277,293,343,345,375,425,467,518,557,616,638$.

118. Merriam, C. F., Studies made in connection with reports of the Hydraulic Power Comittee of the Pennsjlvania Electric association, Harrisburg, Pa.: 1926, Relation between rainf ill and mun-off in Susquehanna Valley; 1928, Cyclic analyses of river flow; 1929, Comparative analysis of mun-off and rainfall of three areas; 1930 , The distribusion of run-off and rainfall in the Susquehanna Valley; 1934, Long-range forecasting.

119. Merriam, C.F., Inconsistencies in run-off records: Am. Geophys. Union Rept. Ifbson meeting, 1933.

120. Merriam, C. F., Forecasting water supply, a report of the National Hydraulic Power Committee: National Electric licht Assoc. Pub. 115.

121. Meyer, A. F., Computing run-off from rainfall and other data: Am. Soc. Civil Eng. Trans., vol. 79, p. 1056, 3915.

12?. Meyer, A. F., Elements of hydrology, New York, John wiley \& Sons, 1917; 2d ed., 1928. Physical bases and applications of the fundamental principles underlying the science of hydrology.

123. Miami Conservancy District, Storm rainfall of Eastern United States. Tech. Repts., pt. 5, 1917.

124. Mill, H. R., Forests and rainfall: Nature, vol. 99, pp. 445-446, 1917 .

125. Miller, E. R., Interpretation of rainfall clata by the method of correlation: Monthly Weather Rev., vol. 59, January 1931.

$59550-35-19$ 
126. Moore, B., Forests and precipitation: Science, new ser., vol. 70, pp. 141-142, 1929 .

127. Moore, W. L., The influence of forests on climate and on floods: Eng. News, vol. 63, pp. 245-249, 1910.

Nagler, F. A. See Woodward, S. M.

128. Newell, F. H., Results of stream measurements: U. S. Geol. Survey 14th Ann. Rept., pt. 2, pp. 89-155, 1894. Expresses the general relation between rainfall and run-off by two typical curves, one for streams in mountainous regions and the other for streams draining basins with broad valleys and gentle slopes.

129. Newell, F. H., The drought of 1930: Eng. News-Record, vol 106, pp. $237-239,1931$. Rainfail shortage show by isopluvial maps for June, July, and August 1930 and for the whole year. Tabulations of average rainfall by States, 1930. Discharge hydrograph of the Cumberland River at Nashvilie shows effect on streams.

Nickle, H. G. See Taylor, C. A.

130. Norton, R. A., Ramser, C. E., and Pickels, G. W., Run-off investigations in central Iilinois-final report, J. S. Dept. Agr., Bur. Public Roads, in cooperation wh Illinois Untv. Eng. Exper. Sta., 1931. Investigation respecting the relations existing between drainage-basin characteristics, rainfall, and run-off in twelve drainage districts near Urbana, Ili., in 1924-27.

131. Noyes, E. B., Fifty-year rainfall record, Norfolk, Va.: Kng. NewsRecord, vol. 87, p. 199, 1921. I table and diagram showing gradual decrease in ennual rainfall between 1871 and 1920; 10-year means decreased from 53.43 to 37.40 inches.

132. Parker, L. H., Simple ohart aids forecasting of run-off: Elec. World, vol. $95, \mathrm{p} .97,1930$.

133. Partridge, J. F., Forecasting annual run-off in the Klamath Basin: Am. Soc. Civil Eng. Proc., vol. 53, pp. 2511-2518, 1927.

134. Pennsylvania Hydraulic Power Committee, Reports on rainfall and runoff in the Susquehanna Valley, Elec. Assoc., 1928-30 (filed in Eng. Soc. Iibrary, 29 West' 39 th St., Ne'York).

135. Phillips, J., Rainfall interception by plants: Nature, vol. 118, pp. $387-388$, 1926; vo1. 121, pp. 354-355, 1928 .

Pickels, G. W. See Norton, R. A.

136. Pickels, G. W., Run-off investigations in centrel Illinois: Illinols Univ. Eng. Exper. Sta. Bul1. 232, pp. 1-131, 11., maps, 1931.

137. Pierce, C. H., New England rivers have similar run-off characteristics: Eng. News-Record, vol. 82, p. 577, 1919.

138. Predicting run-off by snow surveys: Elec. West, vo1. 70, pp. 149151 , $11 ., 1933$.

139. Prior, J. C., Run-off formulas and methods applied to selected Ohio strerms: Ohio State Univ. Fng. Exper. Sta. Bull. 49, 1929. Records and diagrams of rainfall and run-off on the Scloto and Miami Rivers, 1893-1927. A comparison of rainfall, runoff, and temperature. Application of the formulas of Meyer, Vermeule, Justin, and Grunsky for anmual run-off and comparison with the observed records of ohio streams.

140. Purton, A. B., Transpiration affects stream flow: Fing. News-Record, vol. 105, p. 662, 1930. 
141. Rafter, G. W., The relation of rainfall to run-off: U. S. Geol. Survey Water-Supply Paper 80, 1903. Curves showing general relation between rainfall and mu-off by storage, groming, and replenishing periods.

142. Rainfall and Infiltration: Canadion Eng., vol. 47, p. 580, 1924.

143. Ramser, C. E., Run-off from small agricultural areas in Tennessee: Jour. Agr. Research, 1927.

144. Ramser, C. E., Rational method of estimating run-off from small agricultural areas: Eng. and Contracting, vol. 67, pp. 429-431, 1928.

Ramser, C. E. See also Norton, R. A.

145. Relation of run-off to rainfall: Engineering, vol. 112, pp. 513-514, 1921.

146. Report of complttee on rainfall and run-off measurements: New England Water Works Assoc. Jour., vol. 35, pp. 151-183, map, 1921.

147. Report of the comnittee on run-off in New Fngland: Boston Soc. Civil Eng. Jour., vol. 9, pp. 163-212, 1922.

148. Run-off and erosion studied in tests in Malifornia: Eng. News-Record, vol. $110, \mathrm{p} .711,1933$.

149. Run-off equaled rainfall: Fng. News-Rocord, vol. 79, pp. 925-926, 1917.

150. Run-off from sewered areas; final report of committee: Boston Soc. C1vil Eng. Jour., vol. 1, pp. 291-382, 11., diagrams, 1914. Contains a bibliography, Abstract, Municipal Jour., vol. 37, pp. 73-74, 1914 .

151. Safford, A. T., Low rainfall in Nề England, 1832-40: Fing. News, p. 239, 1911. Comparisols with 10-year rainfalls of later dates.

152. Safford, A. T., Precipitation, evaporation, and man-off: Boston Soc. Civil Eng. Jour., vol. 5, pp. 406-414, 1918.

153. Saville, C. M., Some phases of southern New England hydrology: New England Water Works Assoc. Jour., vol. 47, p. 363, 1933. This paper is a study of long rainfali and mu-off records in southerm New England. The effect of length of record upon accuracy of estimates of probable values is well illustrated. Excerpts, Public Works, vol. 65, pp. 13-14, 1934. Discussion, New England Water Works Assoc. Jour., voi. 48, pp. 255-277, 1934.

154. Sayre, A. N., Selected list of papers on ground-water hydrology: Am. Geophys. Union Trans. 14th meeting, p. 377, Nat. Research Council, 1933.

155. Sherman, C. E., Ohio stream flow: Ohto Univ. Studies, vol. 1, no. 5, 1932.

156. Sherman, L. K., The relation of size and character of drainage basins : Am. Geophys, Uni on Trans, 13th meet1ng, p. 338, Nat. Kesearch Counc11, 1932 .

157. Sherman, L. K., Relation of hydrographs of run-off to size and character of drainage basins: Am. Geophys. Union Trans. 13th meeting, p. 332, Nat. Research Council, 1932.

158. Shermen, L. K., Stream flow from ralnfall by the unft-graph method: Eng. News-Record, v01. 108, pp. 501-505, 1932. Discussion by H. K. Barrows, C. S. Jarvis, C. E. Grunsky, R. E. Horton, Cecil Boling, and G. D. Clyde, vol. 109, pp. 223-226, 1932. Discussion by W. W. Horner, R. H. Gay, Thorndike Saville, and L. K. Sherman, vol. 109, pp. 255-259, 1932 . 
159. Sherman, L. K., Report of run-off committee: Am. Geophys. Union Trans. 14th meeting, p. 361, Nat. Research Counc1l, 1933.

160. Sherman, I. K., Hydraulics of surface run-off and stream flow (manuscript, 1934), filed in Eng. Soc. library, Now York, and librai'y of Am. Geophys. Union, Washington. A mathematical analysis of the unit-hydrograph method of analyzing stream flow.

161. Shreve, F., Rainfall, run-off, and soll molsture under desert cond1tions; based on the record of the desert laboratory, Tucson, Arlz., from 1905 to 1933: Assoc. Am. Geographers Annals, vol. 24, pp. 131-156, tables, dLagrams, 1934.

162. Sillimen, H. D., Run-off records for two sewerage areas show contrasts: Eng. Nows-Record, vol. 79, pp.925-926, 11., map, 1917 .

163. Simons, P. T., and King, F. V., Report on drainage arld prevention of overflow in the valiey of the Red River of the North: U. S. Dept. Agr., Bur. Public Roads, Bull. 1017, Mar. 31, 1922 .

164. Sleight, R. B., Evaporation from the surfaces of water and river-bed materials: Jour. Agr. Research, vol. 10, p. 209, 1917.

165. Slichter, C. S., Theorectical investigation of the motion of ground waters: U. S. Geol. Survey 19th Ann. Rept. pt. 2, p. 295, 1899. Discusses movement of water through sand.

166. Slichter, C. S., Evaporation from land and water surface: Eng. News, vol. 56, pp. 4-6, 1906 .

167. Smart, J. R., The unit-graph method of compliling mun-off applied to selected Ohio streams (thesis, 1933, Ohio State University).

168. Snow density in relation to run-off: Eng. News-Record, vol. 92, p. $234,1924$.

Snyder, F. F. See Collins, W. T.

169. Sonderegger, A. L., Water supply from rainfall on valley floors: Am. Soc. C1v11 Eng. Trans., vol. 94, p. 1242, 1930, Deterimination of rainfall penetration in southern California.

170. Sonderegger, A. L., Modffying the physlographical balance by conservation measures: Am. Soc. Civil Eng. Proc., vol. 59, p. 1543, 1933.

171. Stabler, Hermen, Rainfall, run-off, and erosion, grazing lands in Utah: Am. Soc. Civil Eng. Trans., vol. 99, pp.80-86, 1934.

172. Stabler, Herman, Sedimentation and silting: Eng. News-Record, vol. 60 , p. 649,1908 .

173. Stebbing, E. P., Influence of forests on rainfall, erosion, and inundation: Contemporary Rev., vol. 141, pp. 359-366, 1932.

174. Straub, I. G., Dynamics of streams, discussion and literature: Am. Geophys. Union Trans. 14th meeting, p. 379, Nat. Research Counc11, 1933.

175. Surface yield from a hydrographical basin: Engineering, vol. 117, pp. 193-195, 1924.

Taylor, C. A. See Blaney, H. F.

176. Taylor, C. A., and Nickle, H. G., Investigations in Mojave River area, and investigations in Coldwater Canjon: California Dept. Public Works Water Resources Bull. 44, pp. 74-121, 1933. D1scusses consumptive use of water by vegetation. 
177. Trylor, G. H., Investigations of absorption of precipitation and its penetration to the zone of saturation: Am. Geophys. Union Trans. 12th meeting, pp. 206-211, Nat. Research Counc11, 1931.

178. Terada, T., and others, on the effect of topography on the precipitation in Japan: Imp. Univ. Japan, Coll. Sc1., Jour., vol. 41, p. 24, diagrams, tables, 1919.

179. Thompson, D. G., Comnittee report on status of ground-water investigation: Am. Geophys. Union Trans. 14th meeting, p. 366, Nat. Research Counc1l, 1933.

179a. Thompson, D. G., Idem., 16th meeting, Nat. Research Counc1l, 1935.

180. Thompson, D. H., Hydrologlc conditions in the chalk at Compton, West Sussex: Inst. Water teng. Trans., vol. 26, pp. 228-261, 1921. Discussion of "depletion by underflow and replenishment by percolation; to ascertain the effect of ground-water storage and to compare each with rainfall."

181. Thon, C. L., and Howson, L. R., The yield of a Kentucky watershed: Western Soc. Eng. Jour., p. 643, September 1913. Study of a 26-year record.

182. Thornwaite, C. W., The climates of North America according to a new classification: Oklahoma Univ., reprint from Geog. Rev., vol. 21, 1931 .

183. Toumey, J. W., Relation of forests to stream flow: U. S. Dept. Agr. Yearbook for 1903, pp. 279-288, 1904.

184. Troxell, H. C., Ground-water supply and natural losses in the valley of Santa Ana RIver between R1 verside Narrows and the Orange County line: California Dept. Public Works Water Resources Bull. 44, pp. 147-172, 1933 .

Proxell, H. C. See also Hoyt, W. G.

185. United States Weather Bureau, Engineering aspects of the present drought: Eng. News-Record, vol. 105, pp. 259-261, 1930. Isopluvial map shows percentage of normal rainfali over the United States, March 1 to July 22, 1930, and another chart for July only. Table showing total rainfall in June and July 1930 and comparison with provious low years. Effect on ground-water conditions.

186. Veinmeyer, F. J., The disposal of molsture from aerated portions of solls: Am. Geophys. Union Trans. 13th meeting, p. 330, Nat. Research Counc1l, 1932.

187. Vermeule, C. C., Run-off formula for annual and monthly values: New Jersey Geol. Survey, vol. 3, pp. 1l-108, 1894; New Jersey Geol. Survey Ann. Rept. for 1899, pt. 1, pp. 13-318. Vermeule used a constant plus a percentage for the several months of the year and varied this relationship with mean annual temperatures.

187a. White, B. E., A determination of run-off in streams as a function of the rainfall (unpublished manuscript, Dec. 31, 1928).

188. White, W. N., A method of estimating ground-water supplies based on discherge by plants and evaporation from soll: U. S. Geol. Survey Water-Supply Paper 659, pp. 1-105, 1932.

189. Whitman, E. B., Stored water--how to get, preserve, and improve it: Eng. News-Record, vol. 105, pp. 416-419, 1930.

190. Wilkes, J., Sun spots and river mun-off records: Water Works, vol. 66 , pp. 264-265, 1927 . 
191. Young, A. A., Investigation in the Santa Ana River Valley and coastal plain: California Dept. Public Works Water Resources Bull. 44, pp. 26-72, 1933. Discusses consumption use of water by vegetation.

192. Zoch, R. T., on the relation between rainfall and stream flow: Monthly Weather Rev., vol. 62, no. 9, pp. 315-322, September 1934. First of a series of axticles dealing with the developient of the mathematical theory of the relation between rainfall, run-off, and stream flow. The application of the theory to flood forecasting. Relation between river stages, rain, evaporation, and soil capacity.

193. Zon, Raphael, Forests and water in the light of scientific investigation, U. S. Dept. Agr., Forest Service, 1927. 


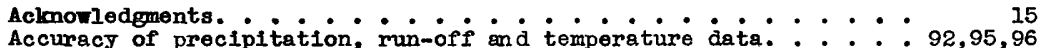

Administration . . . . . . . . . . . . . 12-14

Advisory Committé, American Geophysical Union, personnel: $:$ : $_{14}$

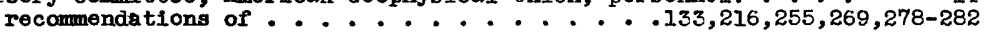

report to Fater Planning Comnittee........... 275-282

work of. . . . . . . . . . . . . . . . . . . . . . . 278

Advisory coordmation. : . . . . . . . . . . . . . 14,15

Alms of present study. . . . . . . . . . . . . . . . 19,20

Alin, A. L., work of ................. . . . . 13

American Geophysical Union. See Advisory Committee. * * * : ${ }_{12}$

Babb, c. c., clted: : : : : : : : : : : : : ${ }^{0} 16$

Berrows, Harlan H., member of Water Planning comittee . ${ }^{-} \cdot{ }_{11}$

Bernard, Merrill, cited. ............ 18,123,131,211,215

storm transposition. . . . . . . . . . . . . . . 218-244

work of. : : : : : : : : : : : : i3,218-244

Blbliography :.... 283-294

Black River Basin above Nolilsvilie, Wis., drought studies . . . 261,262

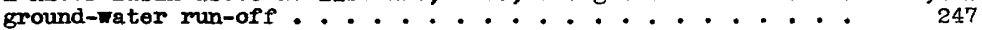

relations between temperature, precipitation, and

soll moisture. . . . . . . . . . . . . . . . 256

surface run-off.

Boston Society of Civil Engineers, cited............. 123,131

Bowker, J. Paul, work of : : : : : : : : : : : : : : 13,13

Chandler, E. F., clted . . . . . . . . . . . . . . . . 62

Channel storage. . . . . . . . . . . . . . . . . . 119

Chattahoocheo River Basin above West Point, Ga., basin description 91

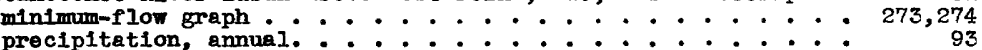

precipitation, annual.

rainfall and run-off relations: : : : : : : $: \dot{*}, 94,100,107,108-110$

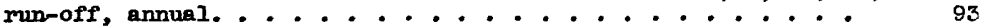

rum-off records, description of. . . . . . . . . . . : 91

run-off, ground-water. . . . . . . . . . . . . . 246

mun-off, surfece ....................... 121

temperature records, description of. . . . : . : : : : 92

temperature, mean annual ................. . . . 93

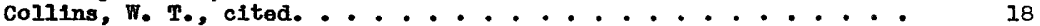

Colorado River at Loes Ferri, Ariz, figure showing run-off. : : 59

Condre, G. E., clted ........................ 248

Crocker, Herbert S., member of Water Planning Committee. : : : : 12,11

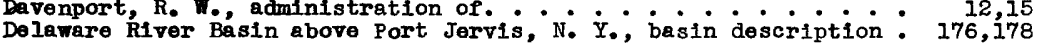

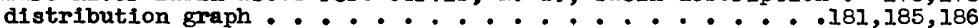

flood coefficients : : : : : : : : : : : : : $: 226,234$

flood hydrographs........................ 226,239

flood mun-off. ....................... . . . . . . . . . 237

map of basin . . . . . . . . . . . . . . . . . . . 182,238

precipitation, unit storms : . : : : : : : : 178-181

storm superposition. ................ . 235,237-239

surface mun-off from unit storms............... 181

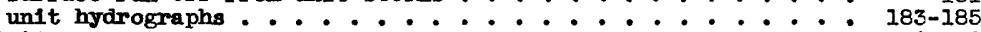

Depletion curves . . .

Distribution graphs, average for selected basins . . . . . . . 209,210

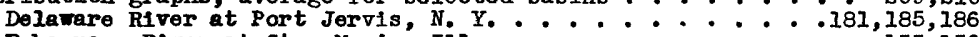
Rmbarrass River at Ste. Marle, Ill.............. . 155,156 French Broad River at Dandridge, Tenn. . . . . . . . . .190,195,196 Muskingrum River at Dresden, Ohio...:. : : : . . . 129,141,142

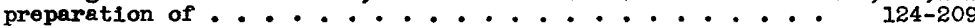


Red River at Denison, Tex.............. 207,208

Skunk River at Auguste, Iowa: : : : : : : : : : 163,164

Susquehanna River at Towanda, Pa............... 176,177

Wabash RIver at Iogansport, Ind................ 148,149

Drought studies. . . . . . . . . . . . . . . 255-274

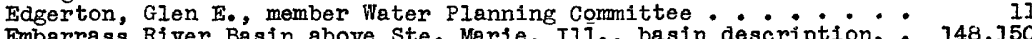

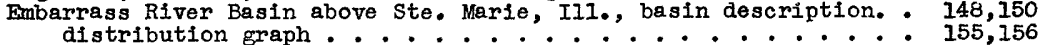

distribution graph : : : : : : : : : : : : : : : $: 155,156$

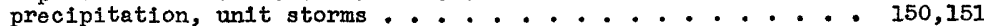

surface run-off from unit storms............... . . . 155

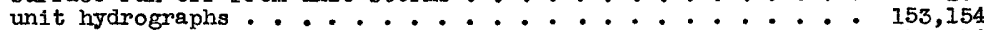

Engineers Corps, U. S. Army, cited .............. 211-214

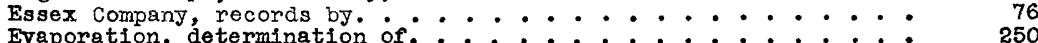

Skunk River Basin. . . . . . . . . . ........ 251-254

FItzGerald, Desmand, cited . . . . . . . . . . . . . . . 16

Flood bibliography, reference to Water-Supply Paper 771. . . . . 283

Flood coefficients and flood hydrographs ........... 218-229

Delaware River at Port Jervis, N. Y. . . . . . . . . . 226,234

determination of

Muskingum River at Dresden, Ohí............... 222

Red River at Dennison, Tex..................... 228

selected basins. . . . . . . . . . . . . . . . . . 2 229

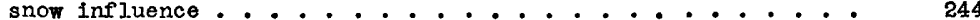

Skunk River at Augusta, Iowa : : : . : : : : : : 224,235

Susquehanna River at Towanda, Pa................ 225

Wabash River at Logansport, Ind. . . . . . . . . .223,234,235

Flood determination, Delaware River at Port Jervis, N. Y... . .235, 237-239

French Broad River at Dandridge, Tenn. . . . . . . . .237,240,24I

Skunk River at Augusta, Iowa ................ 24I,243

Wabash River at Logansport, Ind.: : : : : : : : $: 241,242$

Flood Protection Data Committee, American society of Civil

Engineers, personnel ................. 15

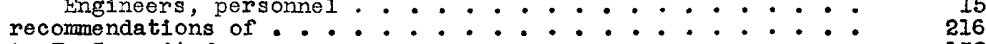

Flynt, F. I., cited. : : : : : : : : : 132

Foreword, Water Planning comittee . * . *........ . 9-1I

Fowler, Frederick H., member Flood Protection Data Comittee . $_{*}$ I5

French Broad River Bas in above Dandridge, Tenn., basin description 186,187

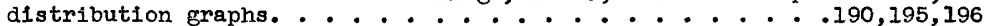

flood coefficients .................... . . . 227,234

flood hydrographs. . . . . . . . . . . . . . . . . . 227,240

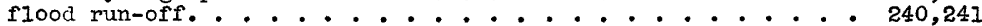

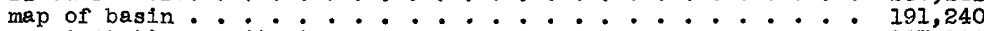

precipitation, unit storms : : : : : : : : : : $187-190$

storm superposition. ................237,240,241

surface run-off from unit storms............... 190

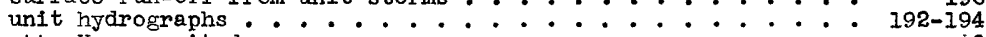

Gannett, Henry, cited. ................... . . . . . . . I6

Gay, Robert W., cited.................. 132

Grant, J. A., c1ted. . . . . . . . . . . . . . . 211

Graves, Henry S., member Water Planning Committe......... . II

Ground-water levels and accretion. . . . . . . . . . . 117,118

Ground-water levels, discussion of : : : : : : : : . : 257,258

Platte River Valley. . . . . . . . . . : . 269-273

Ground-water run-off comparison with rainfail. . . . . . . 257-266

quantitative analysis. . . . . . . . . . . . . . 245-247

Grover, N. C., administration of: : : : : : : : : : 12,15

Hall, Samuel, cited. ................... . . . 114

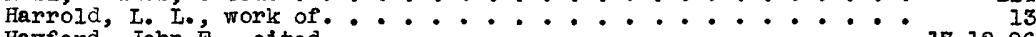

Hayford, John F., clted. : . . . . . . . : . : 17,18,96

Horner, Wesley w., chairman, Advisary committee.: : : : : . 14, 15, 277 clted. . . . . . . . . . . . . . . . . . . . 132

Horton, Robert E., member Advisory comittess: : : : : 14,15,277 cited. . . . . . . . . . . . 18,113,115,118

Houk, Ivan E., member Flood Protection Data committe. . . . .

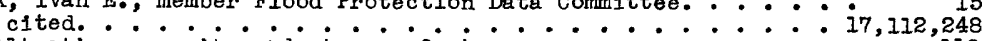

Infiltration capacity and storage factors. : : : : : : : 
IwasakI, Tomishisi, cited. * . . . . . . . . . . . 116

Iowa River Basin above Wapeilo, Iowa, ground-water run-off : : : $\quad 247$

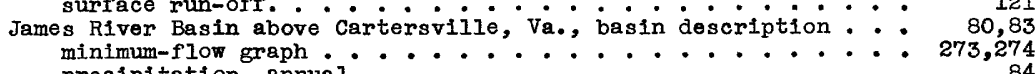

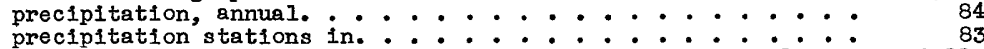
precipitation stations in.
rainfall and run-off relations : : : : : : : $84,85,100,105,108-110$ mun-off annual. . . . . . . . . . . . . . 84 run-off records, description of. . . . . . . . . . . . 83 run-off, ground-water. .................. 246 mun-off, surface ...................... . . . . 120

temperature records, description of............ 86 temperature, mean annual . . . : : : : : : . : . $\quad 84$

Johns, Dwight F., cited..................... 211

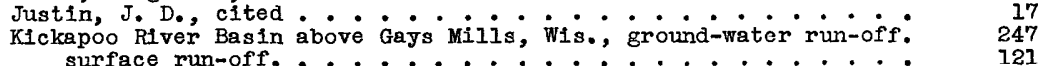

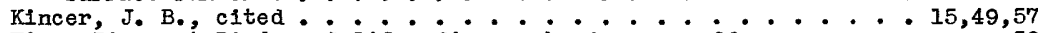

Kings River at Pledra, Calif., figure showing mun-off. . . . . . 59

Kitchin, C. E., work of. . ? . - . . . . . . . . . . 13

Kutz, C. W., member Flood Protection Data Committee. . . . . . . 15

La Crosse River Basin above West Salem, Wis., ground-water run-off 247

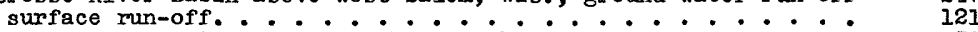

Lake Superior altitude, figure showing changes : : : . : 59

La Rue, E. C., clted........................ 58

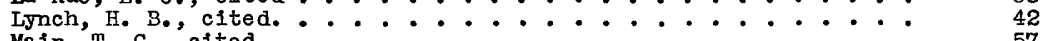

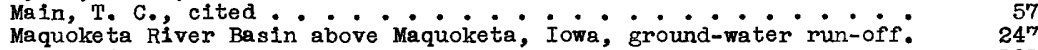

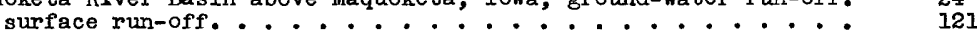

Markham, Edward M., member Water Planning Cormittee. . . . . . 11

Matthes, Gerard H., chairman, Flood Protection Data Committee. . - 15,278

Mead, D. W., cited ......................... 17,48

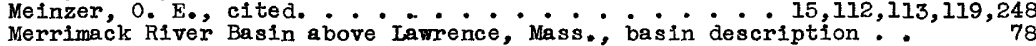

minimum-flow graph ....................: 273,274 precipitation, annual. ................ . . . 81 precipitation stations in. . . . . . . . . . . . . 79,80 rainfall and runoff relations: : : : : : $81,82,100,104,108-110$ run-off, annual. ................. 81 run-off records, description of. . . . . . . . . . . 78,79 run-off, ground-water. . . . .............. . .... 246 run-off, surface ..................... 120

temperature records, description of. . . . . . . . . $\quad 80$

temperature, mean annual . . . : : : : : : : : 81

Meteorologic factors, ground-water separation. . . . . . . . . 119

Mejer, A. F., member Advisory Committee............ . 14,15,277 cited. . . . . . . . . 17,119,248-251

Miami Conservincy District, cited. : : : : : : : :17,221,230

Miami River at Dayton, Ohio, ground-water run-off. . . . . . . . . 246 surface run-off. ................................... 121

Minne sota River Basin above Mankato, Minn., ground-water run-off: $\quad 247$ surface run-off. .................... 121

Mississippi River Basin above Keokuk, Iowa, basin description. : 65

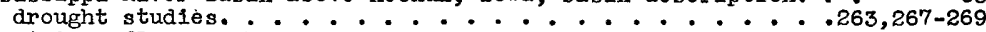
minimum-flow graph .................... . 273,274 precipitation, annual. . . . . . . . . . . . . . . . . 72 precipitation stations in. . . . . . . . . . . . rainfall and mun-off relations: : : : : $72,73,100,102,108-110$ run-off, annual. description of :

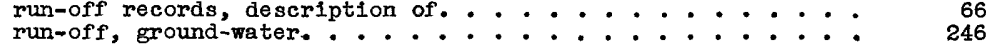
run-off, surface.:.: : : : : : : : : : 120 temperature records, description of: : : : : : : : : 71,74 temperature, mean annual .

Mississippl River Power Co., records by. . . . . . . . . . . 66 Mississippi valley Committee, cited. : : : . $10,11,12,14,15,16,19$ Muskingum River Basin above Dresden, ohio, basin description. . 134 distribution graphs. .................. 129,141,142

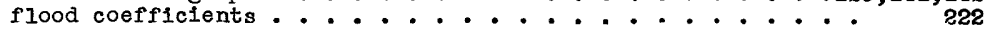


flood hydrographs. . . . . . . . . . . . . . . 222

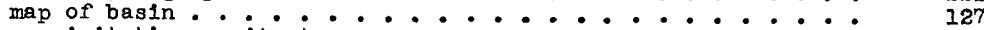

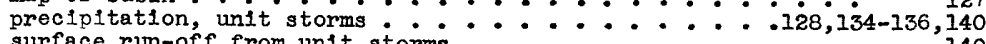

surface run-off from unit storms: : : : : : : : : 140

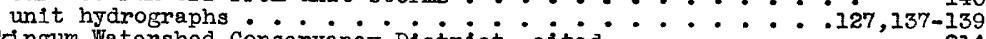

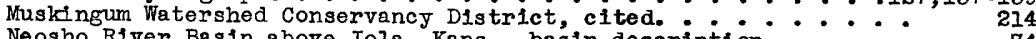

Neosho R1ver Basin above Iola, Kans., basin description.: : : ${ }^{214}$

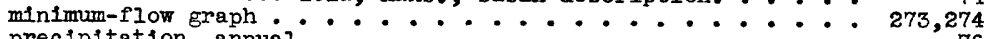

precipitation, annual : in: : : : : : : : : : : ${ }^{2}{ }^{7} 75$

precipltation stations in. rainfall and run-off relations:: : : : : : $76,77,100,103,108-110$

run-off, annual. . . . . . . . . . . . . . . . .

run-off records, description of: : : : : : : : : : 74,75

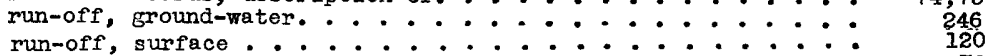

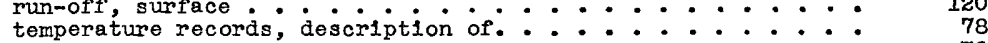

temperature, mean annual ................. 76

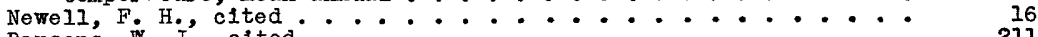

Parsons, W. J, clted.

Paul, D. M., work of ............................... 14

Pecatonica River Basin above Freeport, ili.; ground-rater run-off. 247

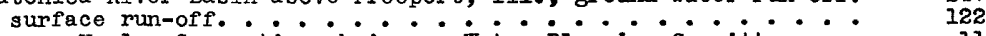

Persons, Harlow S., acting chairman, Water Planning Comittee. : : $\quad 11$ Flood Protection Data Committee, American Society

Civ11 Engineers. . . . . . . ......... 15

United States Goological Survej: : : : : : : : : $12-14$

Water Planning Committeo, Nationai Resources Board : . : . 11

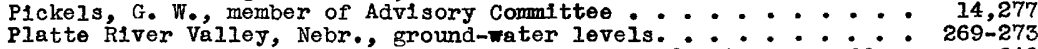

Pomperaug River at Bennett's Bridge, Conn., ground-water mun-off.: 246

surface run-off.

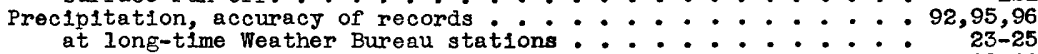

average monthly. . . . . . . : : : : : : 48,49

by basins. . . . . . . . . . . . . . . . . . 60-98

by geographic provinces. . . . . . . . . . . . . 22,33-43

changes, continental United States:

changes by bastns. . . . . . . . . . . . . . 96-98

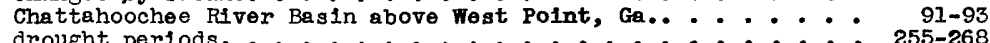

drought perlods.: : *: : : : : : : : : : : $255-268$

fall James River Basin above Cartersvilie, va...: : : : : : : : $45,47,48$

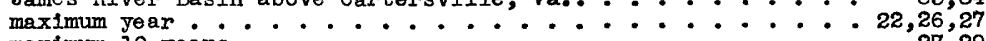

maximum 10 years ........................... 27-29

Merrimack River Basin above Iawrence, Mass... . . . . . 79-81

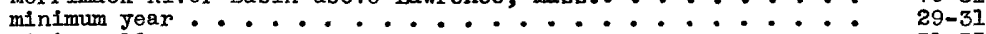

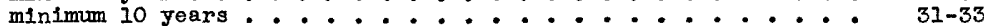

Miss1ss1pp1 RIver Basin above Keokuk, Iora . . . . . . . . 66-72

Neosho River Basin above Iola, Kans. . . . : .

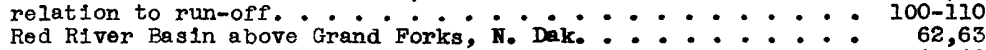

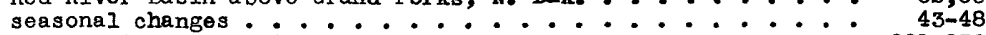

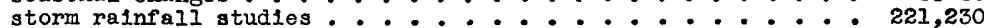

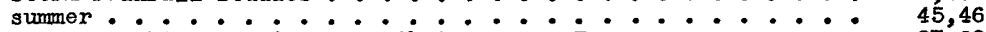

Tennessee River Basin above Chattanooga, Tenn. . . . . . . 87-89

untt storms. . . . . . . . ............. 128-204

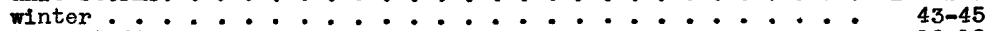

Previous studies: : : : : : : : : : : : : $16-19$

Rafter, George W., clted : . . . . . . . . . . 16,17

Rainfail. See Precipitation

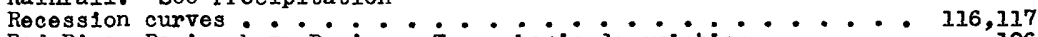

Red River Basin above Denison, Tex.; basin description: : : : 116

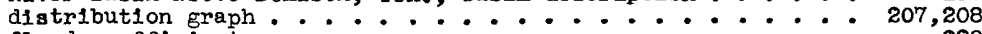

flood coefflcients: $:$ : : : : : : : : : : $\quad{ }^{2} 228$

flood hydrographs.

preclp1tation, unit storms : : : : : : : :

storm superposition. . . . . . . . . . 218-243 
surface run-off from unit storms............. 207

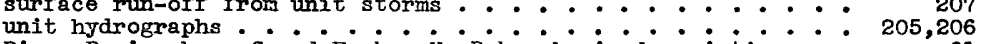

Red River Basin above Grand Forks, ${ }^{\circ}$ Dak., basin description.: ${ }_{61}$

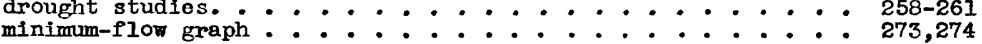

precipitation, annual.: : : : : : : : : : : : $\quad 63$

precipitation stations in. . . . . . . . . . . . 62

rainfall and run-off relations : : : : . : $63,64,100,101,108-110$

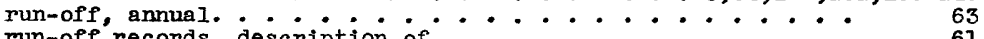

run-off records, description of. . . . . . . . . . . 61

run-off, ground-water. ................ 246

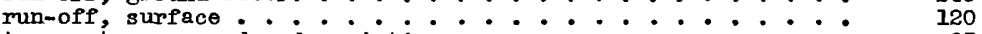

temperature records, description. . . . . . . . . 65

temperature, mean annual ................. . . . . 63

Relations between rainfall and run-off, all basins combined. . 108-110

Chat tahoochee River Basin. .........92-93,10C,107, 108-110

James River Basin. : . : : : : : : : : : : : : : :

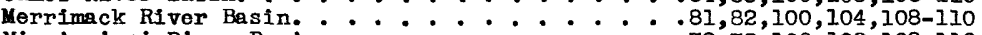

Mississippi River Basin.: : : : : : . $72,73,100,102,108-110$

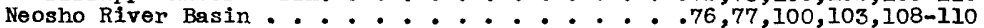

Red River Basin. . . . . . . . . . . . 63,64,100,101,108-110

Tennessee River Basin. . . . . * . . . 89,90,100,106,108-110

Rock River Basin jbove Afton, Wis., drought studies. . . . . 263,264

ground-water run-off .................. 247

relations between temperature, precipitation, and changes

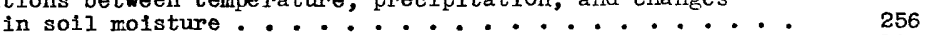

surface run-off. ..................... 121

Root River Basin above Houston, Minn., ground-water run-off. . . $\quad 247$

surface run-off. . . . . . . . . . . . . . . . 121

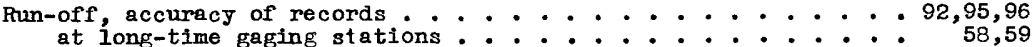

at long-time gaging stations : : : : : : : : : : : : : 58,59

changes by basins.

Chat tahoochee RIver Basin above West Point, Ga......... 93

drought periods. . . . . . . . . . . . . . . . 255-274

flood coefficient, development of.

floods from superposed storms. ............... 235-244

ground-water

James River Basin above Cartersvilie, Va............ 84

Merrimack River Basin above Lawrence, Mass... . . . . . . . . 81

Mississippi River Basin above Keokuk, Iowa . . . . . . . . 72

minimu-flor graphs,.................... 273,274

Neosho River Basin above Iola, Kans. . . . . . . . . 76

Red River Basin above Grand Forks, N. Dak. : : : : : : 63

relations to rainfall. . . . . . . . : : : : : 100-110

surface. . . . . . . . . . ....... 120-217

Tennessee River Basin above Chattanooga, Tenn. . . . . . $\quad 89$

unit-hydrograph analysis . . . . : : 123,124

San Gabriel River near Azuza, Calif., figure showing run-off . . . 59

Saville, Thorndike, administration of. . . . . . ..... 14,15

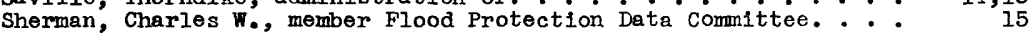

Sherman, L. K., member Advisory Committee. . . . . . . . . 14,15,277

clted. . . . . . . 18, $113,123,124,131,132,211,215,216$

Simons, P. T., cited : : : : : * : 61,62

Skunk River Básin above Augusta, Iowa, basin description : : : 155,157

distribution graphs. ..................... 163,164

drought studies. : : : : : : : : : $: 263,265,266$

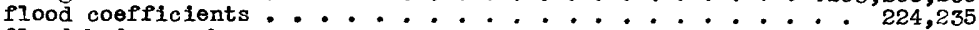

flood hydrographs. ....................... . . . 224,243

flood mun-ofe.

ground-water run-off ................. 247

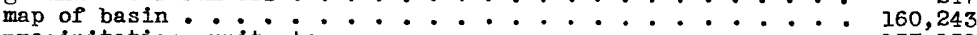

precipitation, unit storms : : : : : : $157-159$

relation between precipitation, temperature and soil-

molsture changes ................... 256

soil-moisture changes by months.: : : : : : : : $: 252-255$

storm superposition. . . . . . . . : . : 241,243

surface run-off. . . . . . . . . . . . . . . . . . 122

surface mun-off from unit storms .: : : : : : . : : : 159

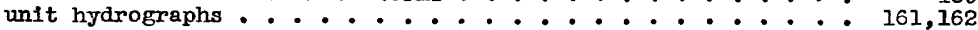


Smart, J. R., cited. . . . . . . . . . . . . . . 131

Snake RIver near Moran, Wyo., figure showing mun-off: . . . . $\quad 59$

Snow, influence on flood coefficients. : * : * : : : : : $\quad 244$

Snyder, Franklin F., cited . . . . . . . ......... 18

soil moisture, definition of : : : : : : : : : : : ${ }^{248}$

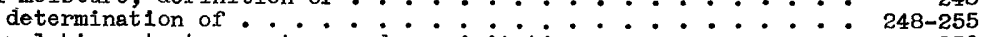

relations to temperature and precipitation. . . . . . . 256

Spokane RIver at Spokane, Wash., figure showing run-off. . . . . $\quad 59$

St. Croix River Basin above Rush City, Minn., ground-water run-off 247 surface run-off. ................... 121

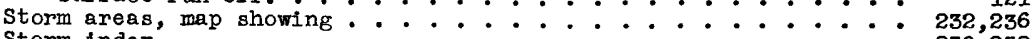

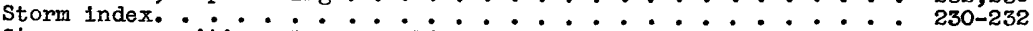

Storm superposition, Delaware River Basin above Port

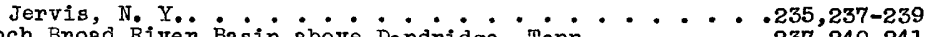

French Broad River Basin above Dandridge, Tenn.: : : : :237,240,241

Wabash River Basin over Logansport, Ind.....: $: 0^{\circ} 241,242$

Skunk River Basin above Augusta, Iowa. . : . : . . : $: 241,243$

Storm transposition. . . . . . . . . . ......... 230-244

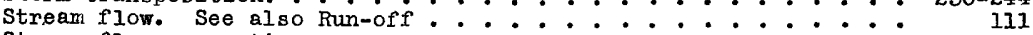

Stream-flow separation.................... ...111-119

channel storage. . . . . . . . . . . . . . . . . . . 119

depletion curves :

ground-water levels and accretions............. 1... 117,118

infiltration capacity and storage factors. . . . . . . . . 118

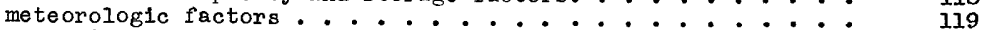

recession curves...........................116,117

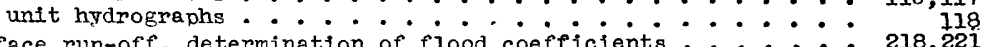

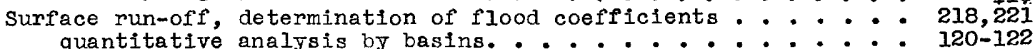
quantitative analysis by basins.: $:$ : : : : : : : : : : : : $120-122$
unit-hydrograph analysis of. $123-209$

usquehanna River Basin above Towanda, $\dot{\mathrm{Pa}}^{\circ}$, basin description.:- 163,165

development of a flood coefficient.............. 219-221

distribution graphs. . . . . . . : . : . : . 176,177

flood coefficients and flood hydrographs : . : . : 225

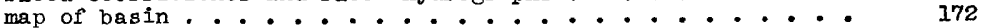

precipitation, unit storms : : : : : : : : : 165-171

surface run-off from unit storms .............. 176

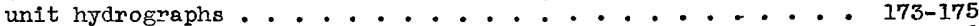

Temperature, accuracy of records:.................... 92,95,96

changes by basins. . . . . . . . . . . . . . . . $60-98$

changes over the United States............... 49-58

Chattahoochee River Basin above West Point, Ga......... 93

James River Basin above Cartersville, Va............ 84

Merrimack River Basin above Lawrence, Mass... . . . . . . . . 81

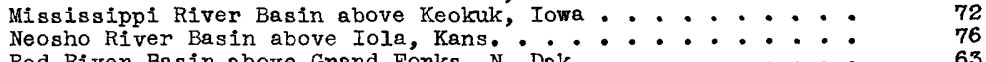

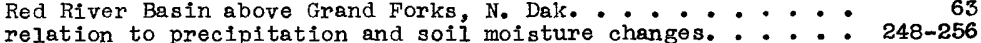

relation to precipitation and soil moisture changes.: $:$ : : 248-256

ennessee River Basin above Chattanooga, Tenn., basin description: 86

minimum-flow graph ...................... 273,274

preclpitation, annual. . . . . . . . . . . . . . 89

precipitation stations in.

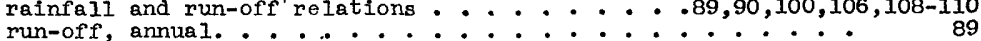

run-off records, description of: : : : : : : : : 86,87

mun-off, ground-water. . . . . . . . . . . . . . 246

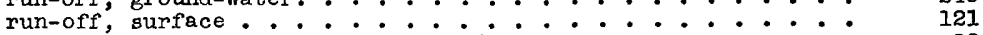

temperature records, description of............. 88

tomperature, mean annual . . . . . . . . . . . . 89

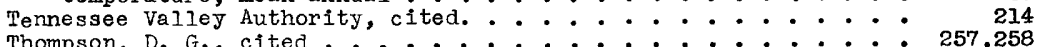

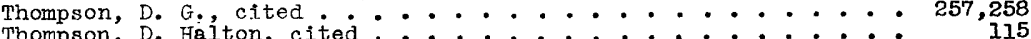

Towl, Roy, member Advisory Comittee : : : : : : : : : : : : 14,277

Transpiration, determination of. . . . . . . . . . . . . 251 Skunk River Basin. .................... 251-254

Unit hydrographs, analysis of surface run-off. . . . . . . . 123-209

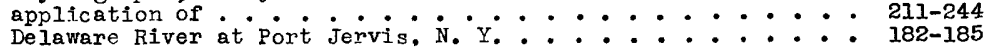


Embarrass River at Ste, Marie, Ill............... 153,154 French Broad River at Dandridge, Tenn. . . . . . . . . 192-194 Muskingum River at Dresden, Ohio........... . 127,137-139

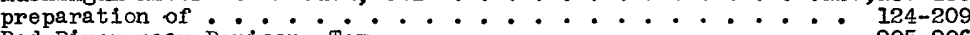
Red River near Denison, Tex. . . . . . . . . 205,206

Skunk River at Augusta, Iowa . . . . . . . . . . . . 161,162

Susquehanna River at Towanda, Pa............... 373-175

stream-flow separation ................... . . . . . . 118

Wabash River at Logansport, Ind. . . . . . . . . . . . 146,147

Vermeule, C. C., cited . . . . . . . . . . . . . . 16 16

Wabash River Basin above Logansport, Ind., basin description. . . I4I

distribution graphs. . . . . . . . . . . . . 148,149

flood coefficients.................223,234,235

flood hydrographs. . . . . . . . . . . . . . . . 223,242

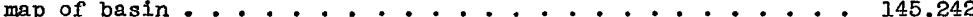

flood run-off. . . . . ............... 241,242

precipitation, unit storms . . . . . . . . . . . . . . .143,144

storm superposition.................... 241,242

surface run-off from unit storms.............. 148

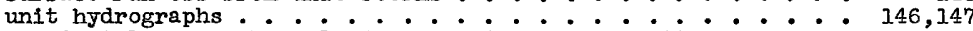

Walser, Daniel C., member Flood Protection Data Committee. $\dot{ }^{\circ} \cdot \dot{ }, 15$

Water Planning Committee, National Resources Board, cited.11,14,15,16,19,20

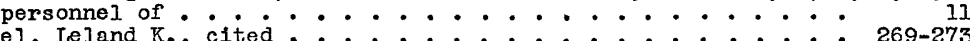

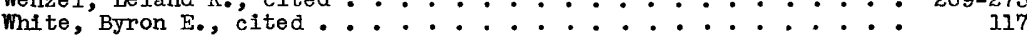

Willamette River at Albany, oreg., figure showing run-off: : : $\quad 59$

Woerman, J. W., member Advisory Committee. . . . . . . . . . 14,277

Woodward, Sherman W., administration of. . . . . . . . . . 14,15 member Water Planning Conmittee. . : : : : : : : : 11

Yellow River above Sprague, Wis., ground-water run-orf . . . : 247 surface run-off. . . . . . . . . . . . . . . . 122

Zumbro River above Zumbro Falis, Minn., ground-water run-off : : 247

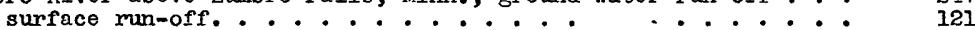

